\section{2) Wiadomości (3) Lekarskie \\ Czasopismo Polskiego Towarzystwa Lekarskiego}

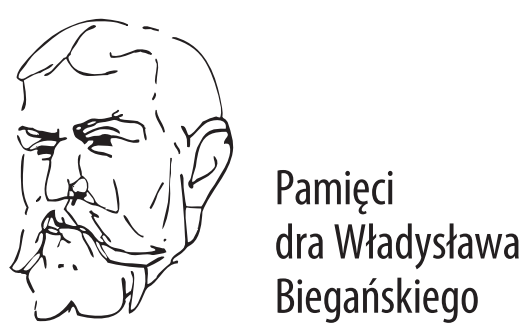

Rok założenia 1928 
Wiadomości Lekarskie is abstracted and indexed in: PubMed/Medline, EBSCO, SCOPUS, Index Copernicus, Polish Medical Library (GBL), Polish Ministry of Science and Higher Education.

Copyright: @ ALUNA Publishing.

Articles published on-line and available in open access are published under Creative Common Attribution-Non Commercial-No Derivatives 4.0 International (CC BY-NC-ND 4.0) allowing to download articles and share them with others as long as they credit the authors and the publisher, but without permission to change them in any way or use them commercially.

\section{Zasady prenumeraty miesięcznika Wiadomości Lekarskie na rok 2019}

Zamówienia na prenumeratę przyjmuje Wydawnictwo Aluna:

- e-mailem: prenumerata@wydawnictwo-aluna.pl - listownie na adres:

Wydawnictwo Aluna

ul. Z.M. Przesmyckiego 29, 05-510 Konstancin-Jeziorna

Prosimy o dokonywanie wpłat na numer rachunku Wydawnictwa: Credit Agricole Bank Polska S. A.: 82194010763010740700000000

Cena prenumeraty dwunastu kolejnych numerów: 240 zł/rok (w tym 5\% VAT)

Cena prenumeraty zagranicznej: 120 euro/rok.

Cena pojedynczego numeru - $30 \mathrm{zł}$ (w tym 5\% VAT) + koszt przesyłki.

Przed dokonaniem wpłaty prosimy o złożenie zamówienia. 


\section{4) Wiadomości . Lekarskie}

Editor in-Chief

Prof. Władysław Pierzchała

Deputy Editor in-Chief:

Prof. Aleksander Sieroń

Statistical Editor

Dr Lesia Rudenko
Polskie Towarzystwo Lekarskie:

Prof. Waldemar Kostewicz - President PTL

Prof. Jerzy Woy-Wojciechowski - Honorary President PTL

Prof. Tadeusz Petelenz

\section{International Editorial Board - in-Chief:}

Marek Rudnicki

Chicago, USA

\section{International Editorial Board - Members:}

Kris Bankiewicz
Christopher Bara
Krzysztof Bielecki
Zana Bumbuliene
Ryszarda Chazan
Stanislav Czudek
Jacek Dubiel
Zbigniew Gasior
Andrzej Gładysz
Nataliya Gutorova
Marek Hartleb
Roman Jaeschke
Andrzej Jakubowiak
Oleksandr Katrushov
Peter Konturek
Jerzy Korewicki
Jan Kotarski

Kris Bankiewicz

Zana Bumbuliene

Ryszarda Chazan

$\begin{aligned} \text { San Francisco, USA } & \text { George Krol } \\ \text { Hannover, Germany } & \text { Krzysztof Łabuzek } \\ \text { Warsaw, Poland } & \text { Henryk Majchrzak } \\ \text { Vilnius, Lithuania } & \text { Ewa Małecka-Tendera } \\ \text { Warsaw, Poland } & \text { Stella Nowicki } \\ \text { Ostrava, Czech Republic } & \text { Alfred Patyk } \\ \text { Cracow, Poland } & \text { Palmira Petrova } \\ \text { Katowice, Poland } & \text { Krystyna Pierzchała } \\ \text { Wroclaw, Poland } & \text { Tadeusz Płusa } \\ \text { Kharkiv, Ukraine } & \text { Waldemar Priebe } \\ \text { Katowice, Poland } & \text { Maria Siemionow } \\ \text { Hamilton, Canada } & \text { Vladyslav Smiianov } \\ \text { Chicago, USA } & \text { Tomasz Szczepański } \\ \text { Poltava, Ukraine } & \text { Andrzej Witek } \\ \text { Saalfeld, Germany } & \text { Zbigniew Wszolek } \\ \text { Warsaw, Poland } & \text { Vyacheslav Zhdan } \\ \text { Lublin, Poland } & \text { Jan Zejda }\end{aligned}$

San Francisco, USA George Krol

New York, USA

Katowice, Poland

Katowice, Poland

Katowice, Poland

Memphis, USA

Gottingen, Germany

Yakutsk, Russia

Katowice, Poland

Warsaw, Poland

Houston, USA

Chicago, USA

Sumy, Ukraine

Katowice, Poland

Katowice, Poland

Jacksonville, USA

Poltava, Ukraine

Katowice, Poland
Managing Editor:

Agnieszka Rosa

International Editor:

Lesia Rudenko

I.rudenko@wydawnictwo-aluna.pl

Distribution and Subscriptions:

BartoszGuterman prenumerata@wydawnictwo-aluna.pl
Graphic design / production:

Grzegorz Sztank

www.red-studio.eu
Publisher:

ALUNA Publishing

ul. Przesmyckiego 29, 05-510 Konstancin - Jeziorna www.aluna.waw.pl www.wiadomoscilekarskie.pl www.medlist.org 


\section{REGULAMIN PRZYJMOWANIA I OGŁASZANIA PRAC W WIADOMOŚCIACH LEKARSKICH}

1. Miesięcznik Wiadomości Lekarskie jest czasopismem Polskiego Towarzystwa Lekarskiego, ma charakter naukowo-edukacyjny. Zamieszczane są w nim prace oryginalne, kliniczne i doświadczalne oraz poglądowe w języku polskim lub angielskim oraz innych językach (za zgodą redakcji).

2. Publikacja pracy w Wiadomościach Lekarskich jest płatna. Od stycznia 2017 roku koszt opublikowania artykułu wynosi 1000 zł plus 23\%VAT. Jeżeli pierwszym autorem pracy jest członek Rady Naukowej czasopisma lub zespołu recenzentów - za druk nie pracy nie pobieramy opłaty, jeśli zaś jest kolejnym współautorem - opłata wynosi 500 zł plus 23\%VAT. Wydawca wystawia faktury. Opłatę należy uiścić po otrzymaniu pozytywnej recenzji, przed opublikowaniem pracy. Z opłaty za publikację zwolnieni są członkowie Polskiego Towarzystwa Lekarskiego z udokumentowaną opłatą za składki członkowskie za ostatnie 3 lata.

3. Prace zapisane w formacie DOC ( $z$ wyłączeniem rycin, które powinny stanowić osobne pliki) należy przesłać pocztą elektroniczną na adres redakcji: Agnieszka Rosa-amarosa@wp.pl.

4. Objętość prac oryginalnych - łącznie z rycinami i piśmiennictwem - nie może przekraczać 21600 znaków (12 stron maszynopisu), prac poglądowych - do 36000 znaków (20 stron).

5. Strona tytułowa powinna zawierać:

- tytuł w języku angielskim i polskim,

- pełne imiona i nazwiska autorów,

- afiliację autorów,

6. Praca oryginalna powinna mieć następującą strukturę: wstęp, cel pracy, materiał i metody, wyniki, dyskusja i wnioski, które nie mogą być streszczeniem pracy. Przy zastosowaniu skrótów konieczne jest podanie pełnego brzmienia terminu przy pierwszym użyciu. W pracach doświadczalnych, w których wykonano badania na ludziach lub zwierzętach, a także w badaniach klinicznych, należy umieścić informację o uzyskaniu zgody komisji etyki badań naukowych.

7. Streszczenia zarówno w języku polskim, jak i angielskim powinny zawierać 200250 stów. Streszczenia prac oryginalnych, klinicznych i doświadczalnych powinny posiadać następującą strukturę: cel, materiał i metody, wyniki wnioski. Nie należy używać skrótów w tytule ani w streszczeniu.

8. Słowa kluczowe (3-6) należy podawać w języku angielskim i polskim, zgodnie z katalogami MeSH (Medical Subject Headings Index Medicus http://www.nim. nih.gov.mesh/MBrower.html). Słowa kluczowe nie mogą być powtórzeniem tytułu pracy.

9. Materiał ilustracyjny - ryciny, wykresy, rysunki, fotografie, slajdy - powinien być opisany cyframi arabskimi i zapisany jako pliki JPG, TIFF lub EPS o rozdzielczości 300 DPI (nie w plikach tekstowych). Ich opisy należy przesłać w osobnym pliku. W tekście muszą znajdować się odniesienia do wszystkich rycin (w nawisach okrągłych).

10. Tabele - ich tytuły (nad tabelą) i treść - powinny być zapisane w programie Microsoft Word, ponumerowane cyframi rzymskimi. Wszystkie stopki dotyczące tabeli powinny znajdować się poniżej tekstu tabeli. W tekście pracy należy umieścić odniesienia do wszystkich tabel (w nawiasach okrągłych).

11. W wykazie piśmiennictwa ułożonym według kolejności cytowania należy uwzględnić wyłącznie te prace, na które autor powołuje się w tekście. W pracach oryginalnych nie powinno być więcej niż 30 pozycji, a w poglądowych nie więcej niż 40 pozycji. Każda pozycja powinna zawierać: nazwiska wszystkich autorów, pierwsze litery imion, tytuł pracy, skrót tytułu czasopisma (wg Index Medicus), rok, numer, stronę początkową i końcową. Przy pozycjach książkowych należy podać: nazwisko autora (autorów), pierwszą literę imienia, tytuł rozdziału, tytuł książki, wydawnictwo, miejsce i rok wydania. Dopuszcza się cytowanie stron internetowych z podaniem adresu URL i daty użycia artykułu oraz o ile to możliwe nazwisk autorów. Każda pozycja piśmiennictwa powinna mieć odwo- łanie w tekście pracy umieszczone w nawiasie kwadratowym, np. [1], [3-6]. Pozycje zapisuje się w sposób zaprezentowany w Załączniku nr 1 do niniejszego regulaminu.

12. Po piśmiennictwie należy podaćadres do korespondencji, nazwisko i imię pierwszego autora, adres, numer telefonu oraz adres e-mail.

13. Do pracy należy dołączyć oświadczenie podpisane przez wszystkich autorów określające udział poszzzególnych autorów w przygotowaniu pracy (np. koncepcja i projekt pracy, zbieranie danych i ich analiza, odpowiedzialność za analizę statystyczną, napisanie artykułu, krytyczna recenzja itd.), a także oświadczenie, że biorą oni odpowiedzialność za treść. Ponadto należy zaznaczyć, że praca nie była publikowana ani zgłaszana do druku w innym czasopiśmie.

14. Jednocześnie autorzy powinni podać do wiadomości wszelkie inne informacje mogące wskazywać na istnienie konfliktu interesów, takie jak:

- zależności finansowe (zatrudnienie, płatna ekspertyza, doradztwo, posiadanie akcji, honoraria),

- zależności osobiste,

- współzawodnictwo akademickie i inne mogące mieć wpływ na stronę merytoryczną pracy,

- sponsorowanie całości lub części badań na etapie projektowania, zbierania, analizy i interpretacji danych lub pisanie raportu.

Konflikt interesów ma miejsce wtedy, gdy przynajmniej jeden z autorów ma powiązania lub zależności finansowe z przemysłem bezpośrednie lub za pośrednictwem najblizszej rodziny. Jeśli praca dotyczy badań nad produktami częściowo lub całkowicie sponsorowanymi przez firmy, autorzy mają obowiązek ujawnić ten fakt w załączonym oświadczeniu.

15. Każda praca podlega weryfikacji w systemie antyplagiatowym (zapora ghostwriting).

16. Redakcja przestrzega zasad zawartych w Deklaracji Helsińskiej, a także w Interdisciplinary and Guidlines for the Use of Animals In Research, Testing and Education, wydanych przez New York Academy nof Sciencees' Adhoc Resarch. Wszystkie prace odnoszące się do zwierząt lub ludzi muszą być zgodne z zasadami etyki określanymi przez Komisję Etyczną.

17. Czasopismo recenzowane jest $w$ trybie podwójnej, ślepej recenzji. Nadesłane prace są oceniane przez dwóch niezależnych recenzentów, a następnie kwalifikowane do druku przez Redaktora Naczelnego. Recenzje mają charakter anonimowy. Krytyczne recenzje autorzy otrzymują wraz z prośbą o poprawienie pracy lub z decyzją o niezakwalifikowaniu jej do druku. Procedura recenzowania artykułów jest zgodna z zaleceniami Ministerstwa Nauki i Szkolnictwa Wyższego zawartymi w opracowaniu "Dobre praktyki w procedurach recenzyjnych w nauce" (Warszawa 2011) i szczegółowo została opisana na stronie http://www.nauka. gov.pl/g2/oryginal/2014_02/307f933b1a75d6705a4406d5452d6dbf.pdf

18. Redakcja zastrzega sobie prawo redagowania nadesłanych tekstów (dokonywania skrótów i poprawek). Prace są wysyłane do akceptacji autorów. Poprawki autorskie należy przesłać w terminie 3 dni od daty wysłania wiadomości e-mail (pocztą elektroniczną). Brak odpowiedzi w podanym terminie jest równoznaczny z akceptacją przez autora nadesłanego materiału

19. Przyjęcie pracy do druku oznacza przejęcie praw autorskich przez Redakcję Wiadomości Lekarskich.

20. Autorzy otrzymują nieodpłatnie plik PDF wydania, w którym znajduje się ich praca, a na życzenie - egzemplarz drukowany. Plik elektroniczny przeznaczony jest do indywidualnego użytku autora, bez prawa do rozpowszechniania bez zgody redakcji.

21. Prace przygotowane niezgodnie z regulaminem zostaną zwrócone autorom do poprawienia.

22. Redakcja nie odpowiada za treść zamieszzzanych reklam. 


\section{SPISTREŚCI}

\section{PRACE ORYGINALNE / ORIGINAL ARTICLES}

Volodymyr H. Hryn, Yuriy P. Kostylenko, Valentyna P. Bilash, Yana A. Tarasenko

FEATURES OF ANGIOARCHITECTURE OF THE ALBINO RATS STOMACH AND SMALL INTESTINE

CHARAKTERYSTKA UNACZYNIENIA ŻOŁADKA I JELITA CIENKIEGO U SZCZURÓW ALBINOSÓW

Rafał Słoniak, Tomasz Tittinger, Damian Szzzepański, Tadeusz Szymon Gaździk, Małgorzata Kulesa-Mrowiecka, Łukasz Kikowski

PRZYKURCZ MIEŚNIIA NAPREŻACZA POWIEZZI SZEROKIEJ UDA AZGIECIE STAWU KOLANOWEGO U BIEGACZY

CONTRACTION OF THE TENSOR FASCIAE LATAE MUSCLE OF THE FASCIA OF THE BROAD THIGH AND FLEXION OF THE KNEE JOINT IN THE RUNNERS

Kostyantyn V. Shevchenko, Galyna A. Yeroshenko, Olena S. Yakushko, Kateryna S. Kazakova, Denys R. Kramarenko

MORPHOMETRIC DESCRIPTION OF THE EXCHANGE SEGMENT OF MICROVASCULATURE OF RATS'SALIVARY GLANDS IN NORMAL CONDITIONS AND CHRONIC ETHANOL INTOXICATION

CHARAKTERYSTYKA MORFOMETRYCZNA SEGMENTU MIKROUNACZYNIENIA GRUCZOŁU ŚLINOWEGO SZCZURA W WARUNKACH PRAWIDŁOWYCH,

JAK I W WARUNKACH PRZEWLEKKEJ INTOKSYKACJI ETANOLEM

Artur Kotowski, Maja Kotowska, Aleksandra Warzyszyńska, Iwona Szymusik, Katarzyna Kosińska-Kaczyńska, Andrzej M. Fal

CERVICAL CANCER - CAUSES AND PREVENTION OF HPV INFECTIONS IN THE OPINIONS OF YOUNG POLISH WOMEN: A CROSS-SECTIONAL SURVEY

RAK SZYJKI MACICY - PRZYCZYNY ORAZ PROFILAKTYKA ZAKAZ̈EŃ HPV W OPINIACH MLODYCH POLEK: PRZEKROJOWE BADANIE ANKIETOWE

Maryne A. Georgiyants, Ganna V. Kolesnik, Olena V. Vysotska, Olha M. Yurchenko

THE INFLUENCE OFVARIOUS METHODS OF ANESTHESIA ON TIME OF POSTOPERATIVE RECOVERY OF PATIENTS'CONCIOUSNESS AFTER CURETTAGE OF UTERINE CAVITY

WPLYYW RÓŻNYCH METOD ZNIECZULENIA NA CZAS POWROTU ŚWIADOMOŚCI PO ZABIEGU U PACJENTEK PODDAWANYCH ŁYŻECZKOWANIU JAMY MACICY

Igor M. Vovchuk, Vitalij A. Katsal, Kateryna V. Khromykh, Victoria V. Balabueva, Maxim A. Hudz

CHOICE OF SURGICAL TACTICS AT THESTAGE OF PREOPERATIVE PREPARATION OF PATIENTS WITH BILLARY SEPSIS

WVBÓR POSTĘPOWANIA CHIRURGICZNEGO NA ETAPIE PRZEDOPERACYJNEGO PRZYGOTOWANIA U PACJENTÓWZ Z POSOCZNICA W NASTĘPSTWIEZAKAŻENIA DRÓG ŻÓLCIOWYCH

Yuriy M. Stepanov, Natalia Yu. Zavhorodnia, Victoria B. Yagmur, Olga Yu. Lukianenko, Elvira V. Zygalo

ASSOCIATION OF NONALCOHOLIC FATTY LIVER DISEASEWITH SMALL INTESTINE BACTERIAL OVERGROWTH IN OBESE CHILDREN

ZWIAZZEK NIEALKOHOLOWEJ STŁUSZCZENIOWEJ CHOROBY WATROBY ZZESPOŁEM ROZROSTU BAKTERYJNEGO JELITA CIENKIEGO U DZIECI Z OTYŁOŚCIA

Vadym A.Vizir, Olesia V. Nasonenko, OlexandrV. Demidenko, AntonS. Sadomov

PROLACTIN IN HYPERTENSIVE MEN WITH ANDROGEN DEFICIENCY: AN ÉMINENCE GRISE?

PROLAKTYNA U MEZŻCZYZN Z NADCIŚNIENIEM TETNICZYM I NIEDOBOREM ANDROGENÓW: SZARA EMINENCJA?

Victoria Erokhina, Olga Avilova

ULTRAMICROSCOPIC CHANGES OF RATS PARATHYROID GLANDS AND THYMUS AFTER SINGLE ADMINISTRATION OF CYCLOPHOSPHAMIDE AT THE DIFFERENT PERIODS OF OBSERVATION ULTRAMIKROSKOPOWE ZMIANYW PRZYTARCZYCACH I GRASICY U SZCZURÓW PO POJEDYNCZYM PODANIU CYKLOFOSFAMIDU W RÓŻNYCH OKRESACH OBSERWACJI

Magdalena Weber-Rajek, Agnieszka Radzimińska, Beata Pilarska, Mariusz Kozakiewicz, Aleksander Goch

OCENA POZIOMU KONCENTRACJ IRYZYNY U KOBIET ZWYSILKOWYM NIETRZYMANIEM MOCZU PO ZASTOSOWANIU ZEWNĘTRZNEJ NEUROSTYMULACJ MAGNETYCZNEJ

(EXTRACORPOREAL MAGNETIC INNERVATION - EXMI) - BADANIE PILOTAŻOWE

ASSESSMENT OF IRISIN CONCENTRATION IN WOMEN WITH STRESS URINARY INCONTINENCE AFTER USING EXRACORPOREAL MAGNETIC INNERVATION (EXMI) - PILOT STUDY

Oleksandr A. Nazarchuk, Ihor L. Chereshniuk, Halyna H. Nazarchuk

THE RESEARCH OF ANTIMICROBIAL EFFICACY OF ANTISEPTICS DECAMETHOXIN, MIRAMISTIN AND THEIR EFFECT ON NUCLEAR DNA FRAGMENTATION AND EPITHELIAL CELL CYCLE

ANALIZA AKTYWNOŚCI PRZECIWBAKTERYJNEJ DWÓCH ANTYSEPTYKÓW, DEKAMETOKSYNY I MIRAMISTYNY, ORAZ ICH WPLYWU NA FRAGMENTACJĘ JĄDROWEGO DNA ORAZCYKL KOMÓRKOWYŚRÓDBŁONKA

Oksana I. Afanasiuk, Valentyn I. Shmaliy, Yuliia Yu. Shushkovska

CLINICAL CHARACTERISTICS OF CARDIAC ARRHYTHMIAS IN PREGNANT WOMEN

CHARAKTERYSTKA ZABURZEŃ RYTMU SERCA U KOBIET W CIAZZZY

Tetiana S. Gruzieva, Liudmyla I. Galiienko, Iryna A. Holovanova, Victoria B. Zamkevich, Olena Ya. Antonyuk, Liudmyla V. Konovalova, Roman G. Dolynskyj, Anastasiia I. Zshyvotovska PREVALENCE OF BAD HABITS AMONG STUDENTS OF THE INSTITUTIONS OF HIGHER MEDICAL EDUCATION AND WAYS OF COUNTERACTION WYSTEPOWANIE ZLYYCH NAWYKÓW WŚRÓD STUDENTÓW UCZELNI WYŻSZYCH ORAZ METODY ZAPOBIEGANIA

Svitlana Zubchenko, Olena Sharikadze, Stepan Maruniak

ALLERGEN COMPONENT TESTING - A NEW ERA IN DIAGNOSTICS OF PATIENTS WITH POLLEN ALLERGY

BADANIE ELEMENTÓW SKŁADOWYCH ALERGENÓW - NOWA ERA W DIAGNOSTYCE PACJENTÓW Z ALERGIĄ PYŁKOWA

Inna S. Borisova, Dmitry 0. Stepansky

DETERMINATION OF POOR OUTCOME PROGNOSIS IN PATIENT WITH ACUTE LEUCEMIA WHICH WAS COMPLICATED BY PNEUMONIA

CZYNNIKI RYZYKA ZZEGO ROKOWANIA U PACJENTÓW Z OSTRA BIAŁACZKA POWIKLANA ZAPALENIEM PŁUC

OleksandrV. Avdeev, Roksana 0. Drevnitska, Alina B. Boykiv, Oksana Ya. Vydoinyk

CONDITION OF FAGOCYTOSIS OF EXPERIMENTAL ANIMALSWITH PERIODONTITIS DUE TO MODIFIED REACTIVITY

OCENA STOPNIA FAGOCYTOZY U ZWIERZAT EKSPERYMENTALNYCH Z CHOROBAMI PRZYZEBIA WYWOŁANYMI ZMODYFIKOWANA REAKTYWNOŚCIA

Nataliia 0. Gevkaliuk, Nataliya I. Sydliaruk, Larysa Ya. Posolenyk, Oksana Ya. Vydoinyk, Lesia I. Kuchyrka

THE STATE OF OXIDATIVE HOMEOSTASIS IN CHILDREN WITH INFLUENZA STOMATITIS

STAN HEMOSTAZY OKSYDACYJNEJ U DZIECI ZZAPALENIEM JAMY USTNEJ W PRZEBIEGU GRYPY 
Anastasiia A. Akhmedova, Oleksandr M. Ocheredko, Volodymyr P. Klimenyk

ASSESSMENT OF THE EFFECTIVENESS OF THE GASTROPATHY RISK REDUCTION PROGRAM IN PATIENTS WITH ARTERIAL HYPERTENSION

OCENA SKUTECZNOŚCI PROGRAMU ZMNIEJSZENIA RYZYKA ROZWOJU GASTROPATII U PACJENTÓW Z NADCIŚNIENIEM TĘTNICZYM

409

PRACE POGLADOWE / REVIEW ARTICLES

Vitalii M. Pashkov, Maryna V. Trotska, Oleksii S. Soloviov

RIGHT TO CHILD HEALTH IN CONTEXT OF NATURAL ENVIRONMENTAL SECURITY

PRAWO DO ZDROWIA W WIEKU DZIECIECCYM W KONTEKŚCIE BEZPIECZEŃSTWA ŚRODOWISKA NATURALNEGO

418

Magdalena Doręgowska, Monika Rudzińska-Bar

ZABURZENIA SNUW CHOROBIE PARKINSONA

SLEEP DISORDERS IN PARKINSON'S DISEASE

Nataliya B. Kuzniak, Roman R. Dmytrenko, Larysa Ya. Fedoniuk, Svitlana I. Boitsaniuk, Liudmyla V. Kuzniak, Andrii V. Yavorskyi, Stepan V. Tkachyk DEVELOPMENT OF THE INNER NASAL CAVITY IN ANIMALS IN PHYLO- AND ONTOGENESIS: FUNCTIONAL ANATOMIC SIGNIFICANCE IN THE DEVELOPMENT PERIOD

ROZWÓJ WEWNETRZNEJ JAMY NOSOWEJ U ZWIERZAT W FILO- I ONTOGENEZIE: CZYNNOŚCIOWE I ANATOMICZNE ZNACZENIE W OKRESIE ROZWOJOWYM

Ewa Gulczyńska, Ewa Peterson, Tomasz Radzik, Ludmiła Żylińska

BIOMARKERYWEWNĄTRZMACIIZNEGO ZAHAMOWANIA WZRASTANIA PłODU

BIOMARKERS OF INTRAUTERINE GROWTH RESTRICTION

Zhanetta A.Chornenka, Tetiana I. Domanchuk

INTEGRATED ESTIMATION OF THE DEMOGRAPHIC SITUATION IN UKRAINE - FORECAST FOR THE FUTURE

KOMPLEKSOWA OCENA SYTUACII DEMOGRAFICZNEJ NA UKRAINIE- PROGNOZA NA PRZYSZLOŚC

Alla M. Bilovol, Svitlana H. Tkachenko, Oleksandra A. Havryliuk, Alla A. Berehova, Yevheniia H. Tatuzian, Nataliia L. Kolhanova, Svitlana 0. Stetsenko LICHEN PLANUS AND COMORBID CONDITIONS (A REVIEW OF LITERATURE)

LISZAJ PLASKI I CHOROBY WSPÓ́ISTNIEJĄCE (PRZEGLĄD LITERATURY)

Magdalena Duda-Wiewiórka, Kazimierz Pityński WITAMINA D A PRAWID KOWA IZMIENIONA PATOLOGICZNIE BłONA ŚLUZOWA JAMY MACICY

VITAMIN D IN NORMAL AND PATHOLOGICALLY CHANGED ENDOMETRIUM

Hryhorii S. Krainyk, Svitlana M. Popova, Ella V.Vakulovych

PROBLEMS OF TRANSPLANTATION OF HUMAN ORGANS AND OTHER ANATOMICAL MATERIALS AND DIRECTIONS OF THEIR SOLUTION IN UKRAINE

PROBLEMY TRANSPLANTACJI LUDZKICH NARZADÓW I INNYCH MATERIAŁÓW ANATOMICZNYCH I KIERUNKU ROZWIAZZANIA TYCH PROBLEMÓW NA UKRAINIIE

Iryna S. Dankevych-Kharchyshyn, Olena M. Vynogradova, Natalia V. Malko, Roman M. Gnid, Andriana P. Skalat, Lidiya Y. Minko, Oleg I. Mrochko, Yurii L. Bandrivsky, Orysia 0. Bandrivska PERIODONTAL DISEASES AND ATHEROSCLEROSIS (LITERATURE REVIEW)

CHOROBY PRZYZEBIA A MIAŻDŻYCA (PRZEGLAD LITERATURY)

Valentyna I. Ilchenko, Liudmyla M. Sizova, Svitlana M. Tanianskaia, Inna N. Nesina, Kateryna V. Pikul

MODERN APPROACH TO THE PROBLEM OF PERTUSSIS

NOWOCZESNE PODEJŚCIE DO PROBLEMU KRZTUŚCA

Jan W. Pęksa, Piotr Jankowski, Danuta Czarnecka

KONTROLA CZYNNIKÓW RYZYKA SERCOWO-NACZYNIOWEGO U PACJENTÓW PO ZAWALESERCA

CONTROL OF CARDIOVASCULAR RISK FACTORS IN PATIENTS AFTER MYOCARDIAL INFARCTION

Olha I. Bezpalova, Valeriy A. Yusupov, Olha Ye. Avramova, Tetyana V. Krasiuk, Nataliia B. Larina

LEGAL PROTECTION OF INVENTIONS WITHIN MEDICAL PRACTICE IN UKRAINE

OCHRONA PRAWNA WYNALAZKÓW W MEDYCYNIE NA UKRAINIE

OPISY PRZYPADKU / CASE REPORTS

Jolanta Grabowska-Markowska, Iwona Pawłowska, Grzegorz Ziółkowski, Jadwiga Wójkowska-Mach

BAKTERIEMIA WYWOLANA PRZEZ OCHROBACTRUM ANTHROPI - NIETYPOWE POSTEPOWANIE

BACTERIA CAUSED BY OCHROBACTRUM ANTHROPI - UNUSUAL BEHAVIOR

Joanna Zajączowska, Jadwiga Korzeniowska

POWIKŁANIA LECZENIA IMMUNOSUPRESYJNEGO W PRZEBIEGU CIĘŻKIEJ POSTACI ATOPOWEGO ZAPALENIA SKÓRY - OPIS PRZYPADKL

COMPLICATIONS OF IMMUNOSOPRESSION TREATMENT IN HEAVY THERAPY FOR ATOPIC SKIN - CASE DISCUSSION

ORIGINAL ARTICLE / PRACA ORYGINALNA

Patryk Rzońca, Piotr Tomaka, Robert Gałązkowski

BURNS IN PRACTICE OF HELICOPTER EMERGENCY MEDICAL SERVICE IN POLAND. RETROSPECTIVE ANALYSIS

OPARZENIA CIALA W PRAKTYCE ZAŁÓG ŚMIGŁOWCOWEJ SŁUŻBY RATOWNICTWA MEDYCZNEGO W POLSCE. ANALIZA RETROSPEKTYWNA 
PRACA ORYGINALNA

ORIGINAL ARTICLE

\title{
FEATURES OF ANGIOARCHITECTURE OF THE ALBINO RATS STOMACH AND SMALL INTESTINE
}

\section{CHARAKTERYSTKA UNACZYNIENIA ŻOŁĄDKA I JELITA CIENKIEGO U SZCZURÓW ALBINOSÓW}

\author{
Volodymyr H. Hryn, Yuriy P. Kostylenko, Valentyna P. Bilash, Yana A. Tarasenko \\ UKRAINIAN MEDICAL STOMATOLOGICAL ACADEMY, POLTAVA, UKRAINE
}

\begin{abstract}
Introduction: The stomach and small intestine are important organs of the digestive system and, to date, they are the subject of research by morphologists, endocrinologists, immunologists, gastroenterologists, and other researchers.

The aim: The paper is aimed at the study and systematization of the features of angioarchitecture of the albino rats stomach and small intestine. Materials and methods: Thestudy based on the injection of the blood vasculature of abdominal organs of 20 albino male rats with $5 \%$ gelatin solution, colored with filtered blackink, was performed. The specimens were subject to photographing from different aspect angles in their original state, and then, after dehydration in alcohols with the transition to pure acetone, they were embedded in the epoxy. Photographing of the obtained specimens was made by a digital camera, as well as a binocular magnifier MBS-9, equipped with a digital photoattachment Sigeta DCM-9009.0MP. Results and conclusions: The results of injecting of blood vasculature of albino rats' gastrointestinal tract with ink mass clearly demonstrate the specific difference in the intraorganic angioarchitecture of its different regions, which depends entirely on their functional purpose in the digestive process. In the stomach, the highest concentration of blood microvessels is in its glandular part, which is explained by the increased nutrient needs of the secretory process of the gastric glands, while the mucous membrane of its fundus (pre-stomach) contains a scattered network of exchange microvessels that only promote the process of regeneration of the stratified squamous (partially keratinized) covering epithelium. In the small intestine, the typical principle of the organization of the microvasculature of its mucous membrane is somewhat modified in the duodenum, which is associated with the presence of mucous (Brunner's) glands in it, as well as in those sites (starting from the duodenum) where the group lymph nodes (Peyer's patches) are localized.
\end{abstract}

KEY WORDS: stomach, small intestine, angioarchitecture, albino rats

Wiad Lek 2019, 72, 3, 311-317

\section{INTRODUCTION}

The data on the anatomical and physiological features of the gastrointestinal tract of albino rats are reported in the publications of many authors who are engaged in experimental modeling of the pathological states of the digestive system [ 1 , 2]. According to the publications, generally, the digestive tract of humans and the laboratory animals have more similarities than differences. The latter include the absence of tonsils and the appendix in albino rats, though they have a relatively more developed cecal part of the large intestine, which is extremely extensive compared to the human one $[3,4,5,6,7,8,9,10,11]$.

However, all the data available in the literature on the morphological features of the gastrointestinal tract of albino rats cannot be considered sufficient, as the authors underestimate issues related to the peculiarities of its vascularization, and the available scarce data are not systematized, which determined the purpose of our studies.

\section{THE AIM}

The paper was aimed at the study and systematization of the features of the angioarchitecture of the albino rats stomach and small intestine.

\section{MATERIALS AND METHODS}

The study based on the injection of the blood vasculature of abdominal organs of 20 albino male rats with $5 \%$ gelatin solution, colored with filtered blackink, was performed in the mode of maintaining the temperature of the solution in the range of $37-40^{\circ} \mathrm{C}$. Euthanasia of rats was made under thiopentone anesthesia overdose $(75 \mathrm{mg} / \mathrm{kg}$ animal body weight intramuscularly in the upper third of the hip of the hind paw) $[12,13]$.

Before the experiment, all animals were kept in standard conditions of the experimental biological clinic (vivarium) at the Ukrainian Medical Stomatological Academy in compliance to the regulations on keeping experimental animals adopted by the European Parliament and Council Directive (2010/63 / EU), the Order of the Ministry of Education and Science, Youth and Sports of Ukraine as of 01.03.2012, No. 249 "On approval of the procedure for conducting tests, experiments on animals by research institutions" and "General ethical principles of experiments on animals", adopted by the V National Congress on Bioethics (Kiev, 2013) (Minutes No. 155 as of 26.04.2017 of meeting the Commission on Biomedical Ethics at Ukrainian Medical Stomatological Academy) $[14,15,16]$. 
Positive results were obtained only after preliminary washing of the entire blood vasculature with warm saline solution (with the addition of heparin injection solution of $5000 \mathrm{IU} / \mathrm{ml}$ ) through the cannulated distal abdominal aorta with the intersection of the common iliac vein, through which outflow of the displaced blood occurred until a colorless liquid appeared. Only after this procedure, the vessels were filled with a gelatinous mass through the same cannula until it outflowed from the iliac vein. Immediately after that, in order to prevent the injection mass from leaking out, a ligature was applied on the distal aorta and caudal vena cava, after which the animal's corpse was embedded first into cold water and then fixed in 10\% formalin solution for two days [17].

Subsequently, after washing in running water, the whole complex of internal organs was removed from the abdominal cavity of the animal and partitioned into sections, with the selection of those that corresponded to the objectives of the study. Initially, they were photographed from different aspect angles in their original state, and then, after dehydration in alcohols with the transition to pure acetone, they were embedded in epoxy resin $[18,19,20]$, facilitating the clearing of tissues and more expressive contrasting of injected blood vessels against their background. Photographing of the obtained specimens was made by a digital camera, as well as a binocular magnifier MBS-9, equipped with a digital photoattachment Sigeta DCM-900 9.0MP.

\section{RESULTS}

Out of all organs of the gastrointestinal tract of albino rats, the stomach is distinguished by the pronounced specificity of angioarchitecture, although, according to the general principle of the distribution of vessels, delivering the arterial and outflowing the venous blood, it is similar to the human stomach, which is supplied with blood (if not taking into account the short fundal arteries) with two pairs of branches (mainly) of the celiac trunk, of which one pair of oppositely directed arteries mutually anastomose along the small curvature, and the other pair along the large curvature. Thus, these longitudinal, oppositely located arterial arches mutually anastomose along the two external surfaces of the stomach through the encircling branches. At the same time, these inter-arterial anastomoses are accompanied by corresponding venous vessels, from which blood flows into the portal vein. In contrast, our findings show, that the stomach of albino rats is supplied with blood only by one arterial arch from its small curvature, from which the encircling branches are fan-shaped bifurcated, anastomosing mutually along the large curvature (Fig. 1). But the most remarkable feature of angioarchitecture of the albino rats stomach is the intramural (intraparietal) distribution of blood vessels, which are generally organized in stratification in the form of three networks, one of which, occupying an intermediate position in the submucosa, plays the role of blood distribution between two other blood networks. At the same time, one of them is represented by the microvasculature of the muscular layer, and the other belongs to the mucous membrane. Obviously, both of them are represented by a complex association of resistive (arterial), exchange (capillary) and capacitive (venous) microvessels, which are organized depending on the nature of tissue structures according to a modular principle, which implies the presence of bypass (preferred) blood flow in the microvascular modules [ 21, 22]. Due to the fact that the muscle membrane is more uniform in structural organization in the stomach wall, when filling its microvasculature, we get a homogeneous total density of its coloring on macropreparations, while the density of the injection mass in the blood vasculature of the mucous membrane is different depending on corresponding three sections of the stomach of albino rats (Fig. 2). These preparations clearly demonstrate that the greatest intensity of the total coloring of the injected blood vessels is shown in the middle part of the stomach wall, which belongs to its gastric region. It is quite obvious that it entirely depends on the dense concentration of the gastric glands in its mucous membrane, which require a more abundant network of exchange microvessels for their secretory activity. Compared to this, the two other regions of the stomach (pyloric and fundal) markedly show less density of injection coloring, and the fundus or the pre-stomach is the lightest.

This differentiation on the density of the injection mass in the stomach blood vasculature of the albino rats becomes more pronounced when the preparations are embedded into epoxy resin. Figure 3 shows two images of one half of the stomach, one of which (upper) shows its inside view, and the other (lower) shows it from the outside. It is noteworthy that its gastric (glandular) region is separated from the other two (pyloric and fundal regions) by two intensely colored transverse stripes, which are interconnected by strands of similar color intensity, the increased coloring density of which is caused by the folding of the mucous membrane.

Thus, on the basis of the above results of filling the blood vasculature of albino rats stomach with coloring mass, it can be concluded that, consequently, the highest activity of the metabolic processes is noted in its glandular region, and the lowest is in the mucous membrane of the fundal region, in which the scarce network of exchange microvessels provides only the process of regeneration of the stratified squamous epithelium.

More uniform and stereotypically organized angioarchitecture is characteristic of the small intestine, which is due to the ordered cluster principle of distribution in their mucous membrane of uniform structures, which are the intestinal villi and crypts. In their common blood vasculature, marked superficial vessels are noted that carry out blood delivery and distribution throughout the intestinal tube, and intramural networks, represented mainly by microvascular communications of the muscular and mucous membranes. Apparently, the superficial blood vasculature of the small intestine originated mainly from the branches of the superior mesenteric artery that are paired with the corresponding inflows of the portal vein, which arc-anastomosing in the mesentery. In albino rats, similar 


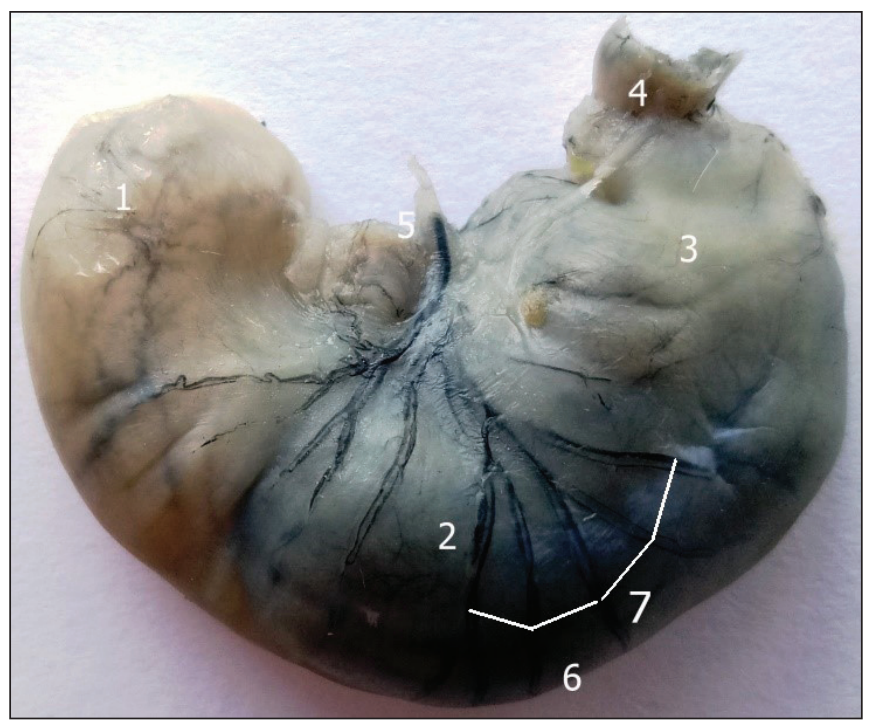

Figire 1. The outer surface of the albino rat stomach after injection of blood vessels with ink and gelatin.

1 - the fundus (pre-stomach); 2 - gastric (glandular) region; 3 - pyloric region; 4 - pyloric sphincter; 5 - small curvature of the stomach; 6 - large curvature of the stomach; 7 - encircling blood vessels.

to humans, these paired arcade chains are located along the line of attachment to the small intestine mesentery loops, from which, on a regular basis, along the whole length of the small intestine, the branches of the small intestine are divided into two surrounding ones, directed toward each other on the perimeter of the intestinal tube. The latter, meeting on the line opposite to the site of attachment to the small intestine mesentery, anastomose mutually. Considering this form of segmental loopback of blood delivery vessels (arteries) and its outflow (veins) in the small intestine, during preparation we dissect its individual segments along the mesentery line, after which they were spread out between two slide plates. Figure 4 shows the preparations of the duodenum, as well as the rest of the small intestine in the intermediate zone between Peyer's patches and in the site of localization of the latter. It is noteworthy that the most rigorous segmental order of distribution of encircling (circular) blood vessels is noted in the wall of the small intestine in its intermediate zones between the Peyer's patches, which is explained by the uniform nature of its structural organization. The above image clearly shows that the encircling arteries, accompanied by the venous vessels, having an opposite direction, gradually become thinner as a result of stepped branching, and their terminal branches in the zone opposite to the mesentery attachment site form extensive cross-anastomoses, which are seen more clearly after preparations embedment into the epoxy resin (Fig. 5). This image shows the extensive microvascular communications against the background of intestinal villi, which are formed by anastomoses between the arterial and venous vessels separately, among which the bypass blood flow pathways in the form of arteriole-venous anastomoses are found. This example shows the most typical picture of the

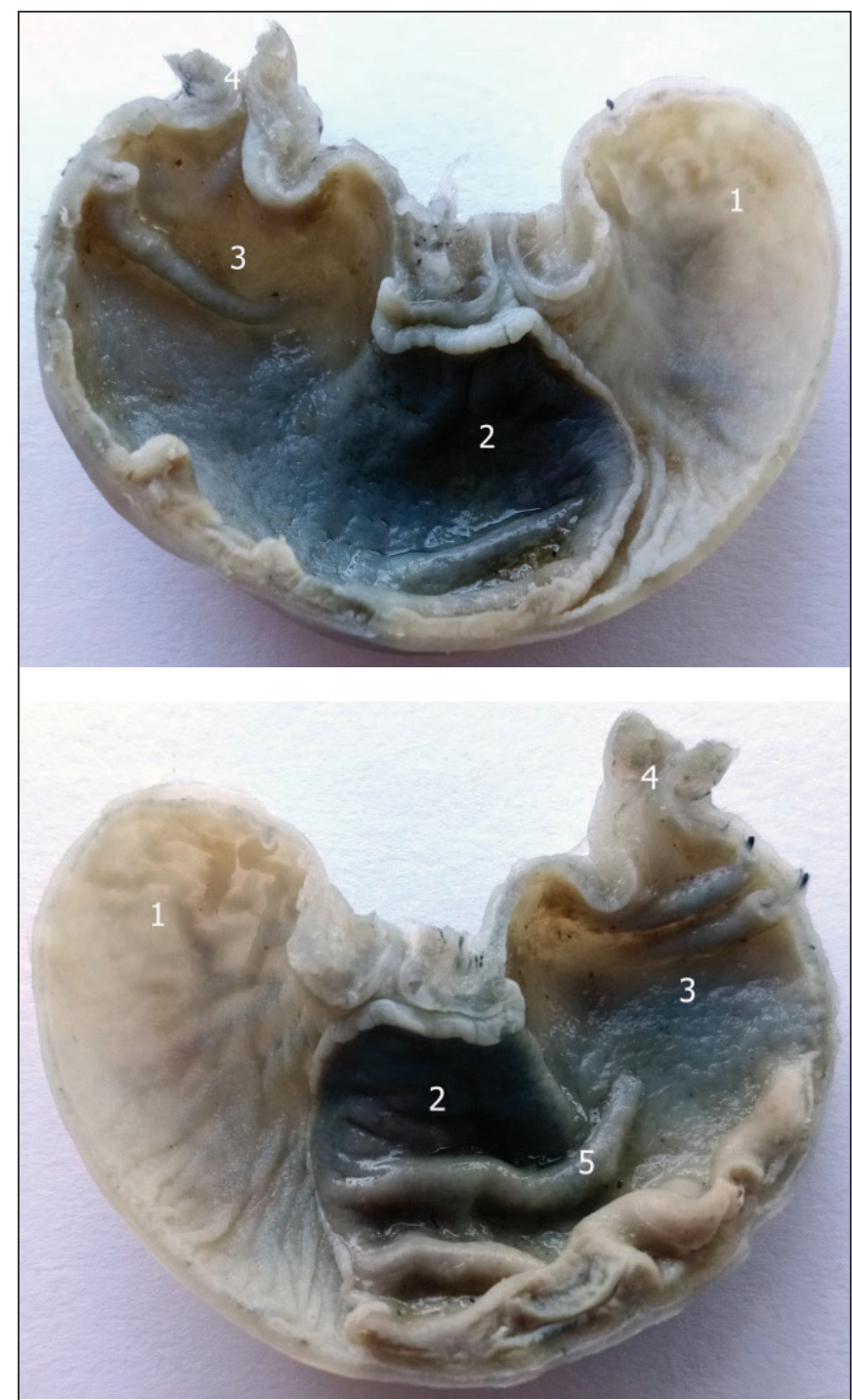

Figure 2. The inner surface of the albino rat stomach after injection of blood vessels with ink and gelatin.

1 - the fundus (pre-stomach); 2 - gastric (glandular) region; 3 - pyloric region; 4 - pyloric sphincter; 5 - folds of mucous membrane.

formation of a common network of the blood vasculature of the mucous membrane over the entire surface of the small intestine, to which blood is supplied by multiple, segmentary alternating along its entire length encircling arteries, which are accompanied by the venous vessels. It should be noted that at the level of the formation of the blood microvasculature between the arterial and venous vessels disintegration occurs.

This strictly ordered principle of the organization of the blood vasculature of the small intestine is somewhat disturbed in the duodenal wall and in those sites of the small intestine where Peyer's plaques are located. Figure $4 \mathrm{~A}$ shows that in the duodenal wall the encircling arteries paired with the corresponding veins do not have strict segmental regularity in their distribution along the length of the intestinal tube. In addition, more significantly, they give out more branches, which, in turn, form denser mi- 


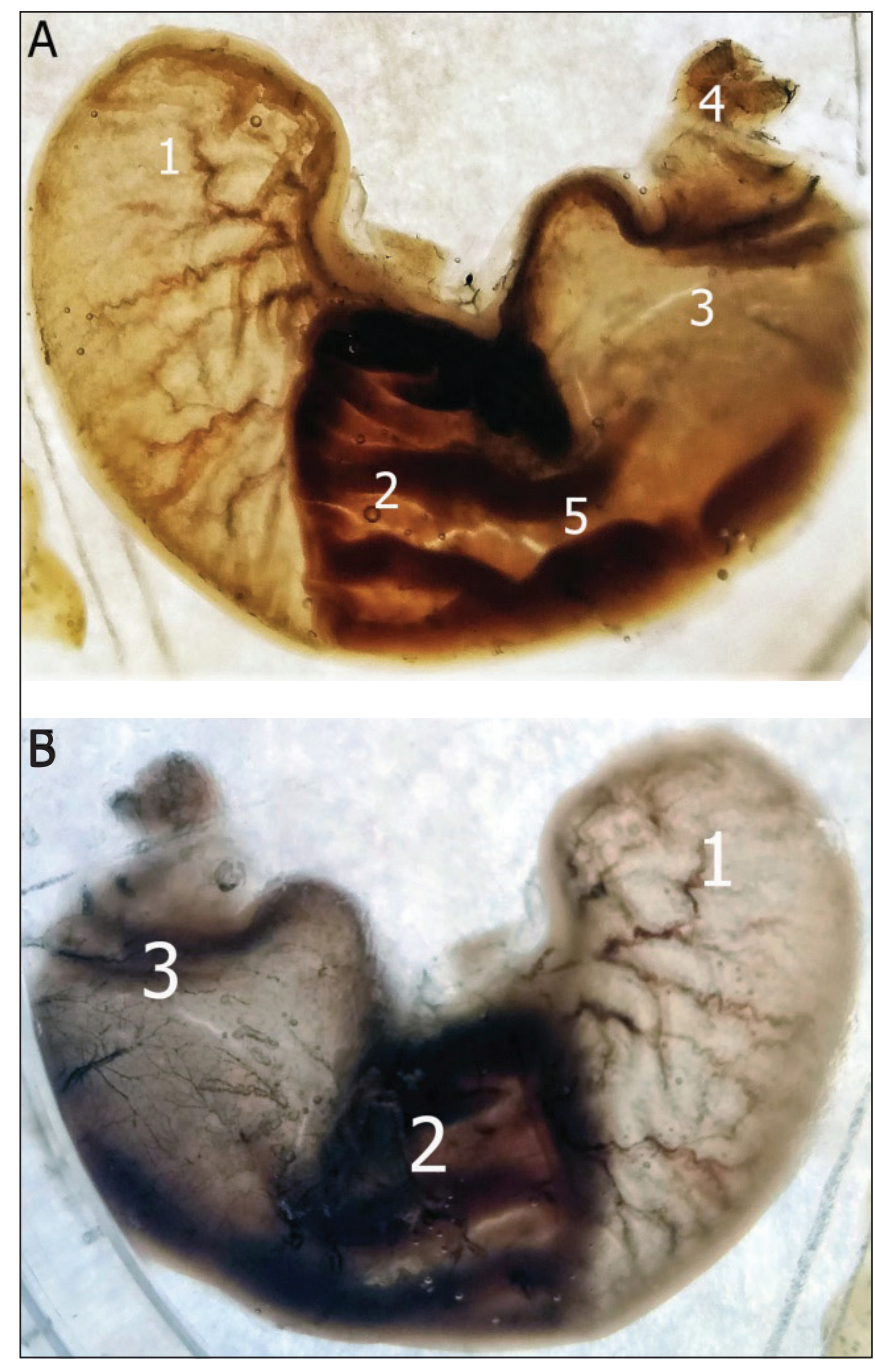

Figure 3. The albino rat stomach after injection of blood vessels with ink and gelatin, subsequently embedded into epoxy resin. A - inner surface; $B$ - outer surface.

1 - the fundus (pre-stomach); 2 - gastric (glandular) region; 3 - pyloric region; 4 - pyloric sphincter; 5 - folds of mucous membrane.

crovascular networks compared to the rest of the small intestine. This is due to the fact that, as we established, in the wall of the duodenum between the mucous and muscular membranes the acini of the mucous (Brunner's) glands are located.

As for those parts of the rest of the small intestine where Peyer's patches are located, their common angioarchitecture is subject to variability due to the inclusion of microvascular associations into the common blood vasculature, ensuring the trophism of these lymphoid masses.

\section{DISCUSSION}

The stomach and small intestine are important organs of the digestive system, and to date, they are the subject of research by morphologists, endocrinologists, immunologists, gastroenterologists, and other researchers. Publications report about the two-cavity stomach in all rodents, unlike
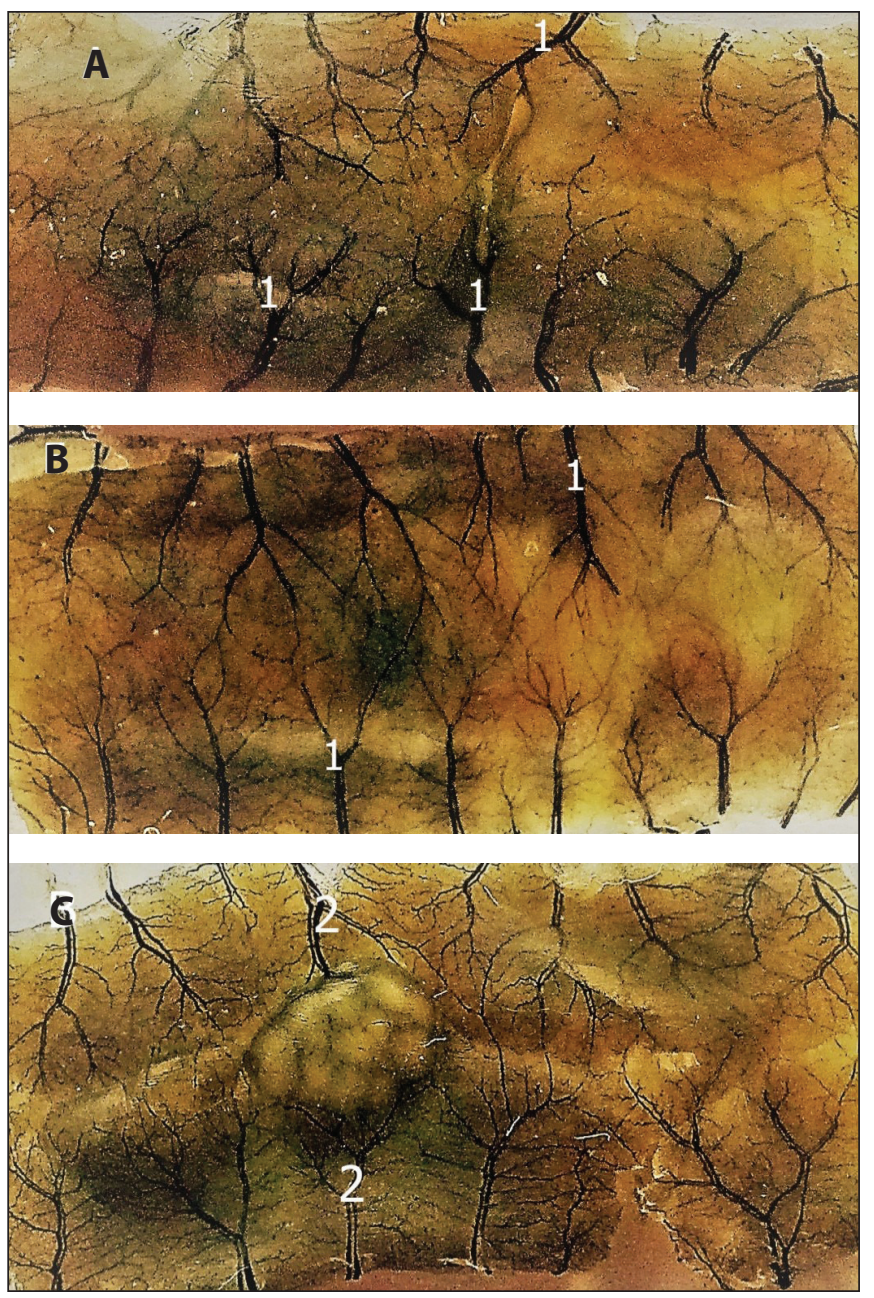

Figure 4. Preparations of different parts of albino rat small intestine. A - duodenum; B - part of the small intestine between the Peyer's patches; C - zone of localization of the Peyer's patches.

1 - segmentary encircling blood vessels; 2 - vessels ensured blood supply to Peyer's patch.

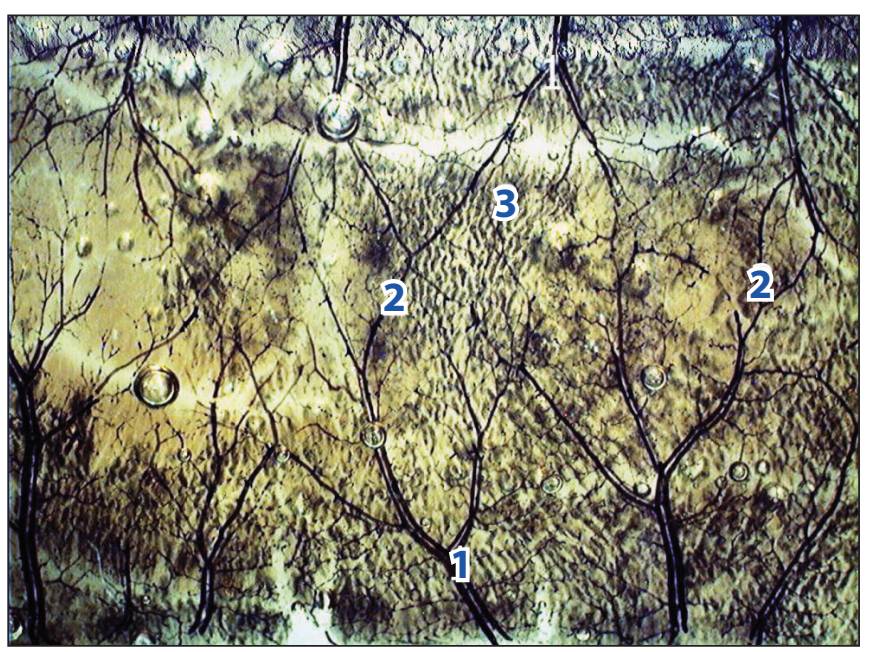

Figure 5. Blood vasculature of the small intestine in the intermediate zone between the Peyer's patches.

1 - arterial and venous, segmentary encircling vessels; 2 - their branches and anastomoses between them; 3 - intestinal villi. 
in human one. In rats, regardless of a mixed diet, though containing a large proportion of grain and solid foods, such division of the stomach into two regions is preserved. Consequently, the esophageal region or pre-stomach is distinguished as well as the rest of the major part, which is essentially comparable to the human stomach. These two regions are partially separated by a well-pronounced ridge. It is believed that the pre-stomach is intended mainly for bacterial digestion, whereas the rest of region performs an enzymatic digestion of foodstuff $[1,2,23,24,25]$.

The small intestine is the longest part of the digestive tract, intended to perform the major functions in the process of the consumption of nutrients by the body, which are mainly products of enzymatic hydrolysis of proteins, fats and polysaccharides. The final phase of this process is the absorption of these nutrients into the internal environment of the body. The conveyor nature of digestion in the small intestine is generally expressed in the well-known anatomical distinguishing of such parts as the duodenum, jejunum and ileum, the length of which in a human is approximately (separately) is $30 \mathrm{~cm}-2 \mathrm{~m}-3 \mathrm{~m}$, respectively. Evidently, the length of the rat small intestine is much smaller. However, the data reported in the literature are questionable. Thus, according to them, the length of the rat duodenum is comparable to that of a human one, and the rest of its small intestine is approximately equal to 1 meter. Consequently, the entire rat small intestine is only by $4-5$ times shorter than that of a human one. Obviously, in a limited volume of the rat abdomen of such a length, the digestive tube can fit if it is sufficiently thin [23]. Unfortunately, no data on its thickness have been found in the literature to date. It is known, the transverse size of the human small intestine varies in length from 2 to $3 \mathrm{~cm}[2,10]$.

Publications report $[9,24,26]$ that the thickness of the gastric mucosa varies from $2-3 \mathrm{~mm}$, dependent on its functional state. Its connective tissue lamina propria is covered with a simple high (columnar) secretory epithelium. Therefore, the entire epithelial layer of the gastric mucosa can normally be considered as a continuous glandular field, producing mucous secretion, with its thin layer covers the entire surface. This layer of mucus forms a protective barrier for the mucous membrane from the devastating effects of hydrochloric acid and pepsin.

The deepest layer of the gastric mucosa, bordering the submucosal layer, is myoplasty, consisting of bundles of smooth muscle cells located in all directions in the plane of the mucous membrane. Throughout its length, separate bundles are split off, which, penetrating the thickness of the mucous membrane, pass between the glands, ending in the basal membrane of their excretory ducts and covering epithelium. Due to the contractile activity of these smooth muscle structures, adaptive dynamic plasticity (change in thickness and shape) of the mucosa itself is carried out, as well as the enhanced secretion of the glands through the excretory ducts. Consequently, the gastric mucosa has its autonomous contractile system.

The mucous membrane of the human small intestine, preserving its general principle of the structure, has not only its own distinctive features, but also differs in certain morphological features in its various parts. A common anatomical feature for it is the presence of numerous transverse-ring folds throughout it, due to the loose submucosa and smooth muscle tone. But their number and degree of manifestation gradually decreases towards the distal part of the ileum. In the duodenum, the folding of the mucous membrane is somewhat different in that from the side of the medial wall of its descending part where a permanent longitudinal fold is located, which inferiorly becomes higher and ends with a large papilla. It opens with one common hole of the bile duct and pancreatic duct. A little superiorly, the second papilla of a smaller size is located, on which the accessory pancreatic duct opens.

The mucous membrane of the small intestine, in the straightened state, is distinguished by a dull, velvety appearance, due to the numerous tiny (about $1 \mathrm{~mm}$ long) finger- or foliate processes called the intestinal villi. [27].

The mucous membrane of the small intestine has a greatly developed local representation of the immune system in the form of intestinal lymphoepithelial clusters called lymphoid nodules. Mostly they are in the form of single nodules and their group clusters $[28,29]$.

The knowledge on the blood supply of the organs of abdominal cavity is crucial in the study of its state [30,31,32].

The features of the morphofunctional structure, the rheological properties of the blood, changes in the microvasculature in the vessels provide a comprehensive description of the effect of the chemical agent on the organ or system. The vascular bed is an important functional system that responds to various negative effects, both by the general reaction of its constituent structural components, and by the changes in the properties of the blood. This is explained by the fact that the vessels of the microvasculature are the first to be affected by the pathogenic agents and are the first to ensure the response of the organ or tissue to external influence [33].

The small intestine contains numerous vessels that form a large blood microvascular field, which is very sensitive to intoxication. It is also known that the endothelium, lining the blood capillaries of various organs, has its own characteristics, due to the specificity of the functioning of these organs. However, under the influence of various factors, the type of endothelium can locally change, which reflects a high level of adaptation processes [34].

\section{CONCLUSIONS}

The results of injecting of blood vasculature of albino rats gastrointestinal tract with ink mass clearly demonstrate the specific difference in the intraorganic angioarchitecture of its different regions, which depends entirely on their functional purpose in the digestive process.

In the stomach, the highest concentration of blood microvessels is in its glandular part, which is explained by the increased nutrient needs of the secretory process of the gastric glands, while the mucous membrane of its fundus (pre-stomach) contains a scattered network of exchange microvessels that 
only provides for the process of regeneration of the stratified squamous (partially keratinized) covering epithelium.

In the small intestine, the typical principle of the organization of the microvasculature of its mucous membrane is somewhat modified in the duodenum, which is associated with the presence of mucous (Brunner's) glands in it, as well as in those sites (starting from the duodenum) where the group lymph nodes (Peyer's patches) are localized. The latter, which are of primary interest in our research, will be discussed in detail in our subsequent publications.

\section{REFERENCES}

1. Tatarenko D. Pishchevaritel'naya sistema belykh krys: anatomofunktsional'nyye osobennosti i eksperimental'nyye raboty: monografiya [The digestive system of white rats: anatomical and functional features and experimental work: monograph]. Moskva: RUSAYNS; 2016, 90 p. (in Russian).

2. Makarova M, Ryibakova A, Guschin Ya i dr. Anatomo-fiziologicheskaya harakteristika pischevaritelnogo trakta u cheloveka i laboratornyih zhivotnyih [Anatomical and physiological characteristics of the digestive tract in humans and laboratory animals]. Mezhdunarodnyiy vestnik veterenarii. 2016;1:82-104. (in Russian).

3. Hryn V, Kostylenko Yu, Brovarnik Ya. Nekotoryye osobennosti anatomicheskogo stroyeniya tolstoy kishki belykh krys [Some features of the anatomical structure of the colon of white rats]. Visnik problem bíologíi í meditsini. 2018;4,2(147):265-270. (in Russian). doi:10.29254/2077-4214-2018-4-2-147-265-270

4. KostilenkoYu, HrynV. Izmenchivostformy slepoykishkiicherveobraznogo otrostka u lyudey zrelogo i preklonnogo vozrasta v predelah ogranichennoy vyiborki anatomicheskih preparatov [Variability of the shape of the caecum and the vermiform process in people of mature and advanced age within a limited sample of anatomical preparations]. Visnik morfologiyi. 2011;3(17):501-505. (in Russian).

5. Hryn V, Lavrenko A, Lavrenko D i dr. Topografiya i formy slepoy kishki s intaktnym appendiksom cheloveka [Topography and forms of the cecum with an intact human appendix]. Medical Teacher. 2017;12(2),39:14431449. (in Russian).

6. Hryn V. Forma slepoy kishki u lyudey preklonnogo vozrasta v otdalennyye sroki posle appendektomii [The form of the cecum in elderly people in the long-term after appendectomy]. Ukraißnns'kiy morfologíchniy al'manakh 2012;1(10):16-19. (in Russian).

7. Hryn V, Kostylenko Yu. Strukturno-funktsyonal'naya kharakterystyka cherveobraznoho otrostka lyudey v vozrastnom aspekte [Structural and functional characteristics of the vermiform process of people in the age aspect]. Svit medytsyny ta biolohiyi. 2012;2:103-106. (in Russian).

8. Hryn V. Osobennosty formy y mykroskopycheskoho stroenyya otdel'nykh chastey yleotsekal'noho otdela tolstoy kyshky y cherveobraznoho otrostka u plodov cheloveka [Features of the shape and microscopic structure of individual parts of the ileocecal region of the large intestine and the vermiform process in human fetuses]. Aktual'ni problemy suchasnoyi medytsyny: Visnyk Ukrayins'koyi medychnoyi stomatolohichnoyi akademiyi 2012;1-2(37-38),12:177-180. (in Russian).

9. Kostylenko Yu, Pryluts'kyy 0, Hryn V i dr. Anatomiya lyudyny (kurs lektsiy) [Human anatomy (course of lectures)]. Navchal'nyy posibnyk dlya studentiv stomatolohichnykh fakul'tetiv vyshchykh medychnykh navchal'nykh zakladiv Ukrayiny IV rivnya akredytatsiyi. Poltava; 2015, p. 59-82. (in Ukrainian).
10. Nozdrachev A, PolyakovE. Anatomiya kryisyi (Laboratornyie zhivotnyie) [Rat Anatomy (Laboratory animals)]. Pod red. akademika A.D. Nozdracheva. SPb.: Iz-vo «Lan»; 2001, 464 p. (in Russian).

11. Petrenko V. Forma i topografiya slepoy kishki u beloy krysy [The shape and topography of the caecum in the white rat]. Uspekhi sovremennogo yestestvoznaniya. 2012;1:8-11. (in Russian).

12. Bagry M, Dibrova V, Popadinets 0 i dr. Metodyky morfolohichnykh doslidzhen': Monohrafiya [Methods of morphological research: Monograph]. Vinnytsya: Nova knyha. 2016, 328 p. (in Ukrainian).

13. Vasyutina M, Smirnova S. Sravnitel'nyy analiz preparatov, ispol'zuyemykh dlya obshchey anestezii u krys [Comparative analysis of drugs used for general anesthesia in rats]. Vestnik novgorodskogo gosudarstvennogo universiteta 2015;86(1):41-43. (in Russian).

14. Direktiva 2010/63/EUYevropeyskogo parlamenta iSoveta ot 22 sentyabrya 2010 g. po zashchite zhivotnykh, ispol'zuyemykh dlya nauchnykh tseley [Directive 2010/63 / ElA of the European Parliament and of the Council of 22 September 2010 on the protection of animals used for scientific purposes]. Official Journal L. 20.10.2010;276:0033-0079. (in Russian).

15. Nakaz Ministerstva osvity i nauky, molodi ta sportu Ukrayiny № 249 vid 01.03.2012 r. [Order of the Ministry of Education and Science, Youth and Sports of Ukraine No. 249 dated 01.03.2012]. Ofitsiynyy visnyk Ukrayiny. 06.04.2012;24:82. (in Ukrainian).

16. Rybakova A, Makarova, M. Sanitarnyy kontrol'eksperimental'nykh klinik (vivariyev) v sootvetstvii s lokal'nymi i mezhdunarodnymi trebovaniyami [Sanitary control of experimental clinics (vivariums) in accordance with local and international requirements]. Mezhdunarodnyy vestnik veterinarii. 2015;4;81-89. (in Russian).

17. Gorbacheva A. Sravnitel'naya otsenka nekotorykh sposobov zalivki sosudistogo rusla mlekopitayushchikh [Comparative evaluation of some methods of filling the vascular bed of mammals]. Nauchnyy rezul'tat. Seriya «Fiziologiya». 2016;2(8):3-8. (in Russian).

18. Belokon S, Vitko Yu, Tkachenko P i dr. Optimizatsiya issledovaniya strukturnyih elementov biologicheskih tkaney na gistotopograficheskih shlifah [0ptimization of the study of the structural elements of biological tissues on histotopographic thin sections]. Kazan: Molodoy uchyonyiy. 2014,I,15(74):134-137. (in Russian).

19. Hryn V, Sherstiuk 0, Starchenko I i dr. vynakhidnyky; Vyshchyy derzhavnyy navchal'nyy zaklad Ukrayiny "Ukrayins'ka medychna stomatolohichna akademiya". Sposib kompleksnoho morfolohichnoho doslidzhennia chervopodibnykh vidrostkiv liudyny v epoksydnii smoli «Epon-812» [The method of complex morphological studies of the human vermiform processes in epoxy resin "Epon-812"]. Patent Ukainy № 112472. 2016 Hrud 26. (in Ukrainian).

20. Kostilenko Yu, Boyko I, Starchenko I i dr. Metod izgotovleniya gistologicheskih preparatov, ravnotsennyih polutonkim srezam bolshoy obzornoy poverhnosti, dlya mnogotselevyih morfologicheskih issledovaniy [Method for making histological preparations equivalent to semi-thin slices of a large viewing surface for multi-purpose morphological studies]. Morfologiya. 2007;132(6):77-82. (in Russian).

21. Bedenyuk0, Herasymyukl.Osoblyvostianhioarkhitektoniky shlunka shchuriv u normi [The features of the anhhoarhitectonics of the stomach of rats are normal]. Visnyk naukovykh doslidzhen'. 2015;4:121-124. (in Ukrainian).

22. Svintsitskaya N, Sherstyuk 0, Deynega T i dr. Klassicheskiye i sovremennyye predstavleniya o krovosnabzhenii intaktnogo zheludka cheloveka [Classic and modern ideas about the blood supply to an intact human stomach]. Aktual'ni problemy suchasnoyi medytsyny: Visnyk ukrayins'koyi medychnoyi stomatolohichnoyi akademiyi. 2009;42(28):256-261. (in Russian). 
23. Hryn V, Kostylenko Yu, Yushchenko Yu I dr. General comparative anatomy of human and white rat digestive systems: a bibliographic analysis. Wiadomości Lekarskie. 2018; tom LXXI, nr 8:1599-1602.

24. Kostylenko Yu. Anatomiya organov pischevaritelnoy sistemy: [uchebnoe posobie dlya studentov stomatologicheskih fakultetov meditsinskih vuzov] [Anatomy of the digestive system]. Poltava; 2003. (in Russian).

25. Petrenko V. Forma i topografiya zheludka u beloy kryisyi [The shape and topography of the stomach in a white rat]. Uspehi sovremennogo estestvoznaniya. 2012;4:227-229. (in Russian).

26. Cheraneva M. Morfologicheskie parametry slizistoj obolochki zheludka besporodnyh belyh krys, ispol'zuemyh v jeksperimente [Morphological parameters of the gastric mucosa of outbred white rats used in the experiment]. Uchenye zapiski kazanskoj gosudarstvennoj akademii veterinarnoj mediciny im. N.Je. Baumana. 2011;208:407-412. (in Russian).

27. Gusejnova S, Gusejnov T. Anatomija struktur slizistoj obolochki tonkoj kishki belyh krys [Anatomy of the structures of the mucous membrane of the small intestine of white rats]. Sovremennye naukoemkie tehnologii. 2010;8:140. (in Russian).

28. Hryn V. Planimetric correlations between Peyer's patches and the area of small intestine of white rats. Reports of morphology. 2018;2(24):66-72. doi: 10.31393/morphology-journal-2018-24(2)-10

29. Hryn V, Kostylenko Yu, Yushchenko Yu i dr. Comparative histological structure of the gastrointestinal mucosa in human and white rat: a bibliographic analysis. Wiadomości Lekarskie. 2018; tom LXXI, nr 7:1398-1403.

30. Koval'chuk N. Morfofunktsional'nyy stan hemomikrotsyrkulyatornoho rusla tonkoyi kyshky pislya stranhulyatsiyi v ranni terminy $z$ vrakhuvannyam vidstani vid neyi [Morphofunctional state of the hemomycocirculatory channel of the small intestine after strangulation at an early date, taking into account the distance from it]. Zdobutky klinichnoyi i eksperymental'noyi medytsyny. 2007;2:91-94. (in Ukrainian).
31. Hnatyuk M, Rybits'ka L, Hnatyuk R. Remodelyuvannya arteriy tovstoyi kyshky bilykh shchuriv pry toksychnomu koliti [Remodeling of colon arteries in white rats with toxic colitis]. Visnyk morfolohiyi. 2008;14(1):168-171. (in Ukrainian).

32. Shevchenko 0, Cherkasov V, Kuz'menko YU. Hemomikrotsyrkulyatorne ruslo slipoyi kyshky ta chervopodibnoho vidrostka lyudyny $v$ prenatal'nomu periodi ontohenezu [Hemomicrocirculatory bed of the caecum and the vermiform process of a human in the prenatal period of ontogenesis]. Klinichna anatomiya ta operatyvna khirurhiya. 2007;6(2):21-23. (in Ukrainian).

33. Vereshchaka V. Osoblyvosti systemnykh zmin hemomikrotsyrkulyatsiyi pry khronichnykh dermatozakh [Features of systemic changes in hemomicrocirculation in chronic dermatoses]. Fiziolohichnyy zhurnal. 2012;58(1):81-85. (in Ukrainian).

34. Yarema 0. Morfologicheskiye izmeneniya krovenosnykh sosudov tonkoy kishki pod vozdeystviyem khlorida alyuminiya [Morphological changes in the blood vessels of the small intestine under the influence of aluminum chloride]. Buletinul AŞM. Ştiințele vieții. Fiziologia şi Samocreatologia. 2013;1(319):40-45. (in Russian).

The paper has been written within the research scientific work, carried out at the Department of Human Anatomy of the Ukrainian Medical Stomatological Academy, entitled "Age-related aspects of the structural organization of the organs of the human immune system, glands of gastrointestinal and urogenital system in normal condition and pathology"; State registration number $0116 U 004192$.

\section{Authors' contributions:}

According to the order of the Authorship.

\section{Conflict of interest:}

The Authors declare no conflict of interest.

\author{
CORRESPONDING AUTHOR \\ Volodymyr Hryn \\ Department of Human Anatomy, \\ Ukrainian Medical Stomatological Academy \\ 23 Shevchenko str., 36011 Poltava, Ukraine \\ tel.: +380(66)8126497 \\ e-mail:vogrin034@gmail.com
}

Received: 15.11 .2018

Accepted: 22.02.2019 
PRACA ORYGINALNA

ORIGINAL ARTICLE

\title{
PRZYKURCZ MIĘŚNIA NAPRĘŻACZA POWIĘZI SZEROKIEJ UDA A ZGIĘCIE STAWU KOLANOWEGO U BIEGACZY
}

\author{
CONTRACTION OF THE TENSOR FASCIAE LATAE MUSCLE \\ OF THE FASCIA OF THE BROAD THIGH AND FLEXION \\ OF THE KNEE JOINT IN THE RUNNERS
}

\author{
Rafał Słoniak ${ }^{1,2}$, Tomasz Tittinger ${ }^{1}$, Damian Szczepański ${ }^{3}$, Tadeusz Szymon Gaździk4 ${ }^{4}$, Małgorzata Kulesa-Mrowiecka4, \\ Łukasz Kikowski ${ }^{5}$ \\ 'OŚRODEK REHABILITACJI, RZESZÓW, POLSKA \\ ²ODDZIAŁ NEUROLOGICZNY, NTM SZPITAL SPECJALISTYCZNY ŚW. RODZINY, RUDNA MAŁA, POLSKA \\ ${ }^{3}$ KATEDRA INFORMATYKI I AUTOMATYKI, POLITECHNIKA RZESZOWSKA, RZESZÓW, POLSKA \\ ${ }^{4}$ WYDZIAŁ NAUK O ZDROWIU INSTYTUT FIZJOTERAPII, COLLEGIUM MEDICUM, UNIWERSYTET JAGIELLOŃSKI, KRAKÓW, POLSKA \\ ${ }^{5}$ OŚRODEK PROFILAKTYKII REHABILITACJI CREATOR SP. Z 0.0. ŁÓDŹ, POLSKA
}

\section{STRESZCZENIE}

Wstęp: Zobrazowanie zakresów zgięcia kończyny wykrocznej podzzas wypadu w przód pozwoliło podzielić grupę badaną na dwie części. U większości badanych zgięcie początkowe przeważało nad końcowym. Badający skupili się na znalezieniu przyczyn przewagi zgięcia końcowego nad początkowym u $30 \%$ badanych.

Cel pracy: Analiza dynamicznego wykroku pod kontrolą systemu MVN Biomech w zakresie zgięcia stawu kolanowego kończyny wykrocznej w porównaniu do przygotowania do wykroku (zgięcie początkowe) i powrotu do pozycji wyjściowej (zgięcie końcowe).

Materiałi metody:Zbadano 18 praworęcznych biegaczy wieku 25-35 lat wyłonionych po zastosowaniu następujących kryteriów wyłączenia: wiotkość wielostawowa, choroby układowe, RZS, choroba zwyrodnieniowa stawów, niestabilność pourazowa. System MVN Biomech oceniał trójpłaszczyznowe ruchy stawów części wolnej kończyny dolnej i miednicy, a elastyczność mięśni podlegała ocenie fizjoterapeutycznej.

Wyniki:U $55 \%$ badanych dominował wzorzec, w którym zgięcie początkowe przewyższało o minimum $10^{\circ}$ zgięcie końcowe w obu kończynach (typ malejący). Badający skupili się na znalezieniu przyczyn mniejszej różnicy lub przewagi zgięcia końcowego obustronnie u 30\% badanych (typ mieszany). Porównanie wyników badania fizjoterapeutycznego i pomiarów MVN Biomech wykazało czynnościowe przykurcze mięśni naprężaczy powięzi szerokiej ud u 5 badanych z typem mieszanym (83\% badanych z typem mieszanym). Wnioski: Przykurcz mięśnia naprężacza powięzi szerokiej ograniczał wstępne zgięcie stawu kolanowego kończyny wykrocznej, a ponadto zwiększał obustronnie odwiedzenie stawów biodrowych podczas dynamicznego wykroku w typie mieszanym. Pozostałe mięśnie kończyn dolnych nie wykazują istotnych statystycznie różnic elastyczności w porównaniu do typu wykroku.

SŁOWA KLUCZOWE: naprężacza powięzi szerokiej, staw kolanowy, MVN Biomech

\section{ABSTRACT}

Introduction: The illustration of the ranges of bending the limb during the outflow allowed to divide the study group into two parts. In the majority of respondents, the initial flexion prevailed over the final one. The researchers focused on finding the reasons for the advantage of the final bend over the initial one in $30 \%$ of the subjects.

The aim: The analysis of the dynamic stride under the control of the MVN Biomech system in the bending of the knee joint of the lateral limb, comparing the preparation to the leg (initial bending) and its ending (final)

Materials and Methods: 18 right-handed 25 to 35 year old runners were selected after the following exclusion criteria were applied: polyarticular hypermobility, systemic diseases, Rheumatoid arthritis, osteoarthritis, post-traumatic instability. The MVN Biomech system assessed the three-dimensional movements of the joints of the free part of the lower limb and pelvis, and the flexibility of the muscles was subject to physiotherapeutic assessment.

Results: $\ln 55 \%$ of respondents dominated the pattern in which the initial flexion exceeded by min. $10^{\circ}$ final bend in both limbs (decreasing type). The researchers focused on finding the reasons for the smaller difference or the advantage of the final bending on both sides in $30 \%$ of respondents (mixed type). The comparison of physiotherapeutic examination results and measurements of MVN Biomech showed functional contractures of the tensor fasciae latea muscles in 5 subjects with a mixed type ( $83 \%$ of subjects with a mixed type).

Conclusions: Contraction of the tensor fasciae latae constrained the initial flexion of the knee joint of the lateral limb, and also increased bilateral visitation of the hip joints during the dynamic mixed-type twitch. The remaining muscles of the lower limbs show no statistically significant differences in elasticity compared to the type of the leg.

KEY WORDS: tensor fasciae latae muscle, knee joint, MVN Biomech 


\section{WSTĘP}

W czasie dynamicznego wykroku, staw kolanowy kończyny wykrocznej ulega trzykrotnemu zgięciu. Zgięcie 1 (wstępne) podczas fazy przeniesienia kończyny dolnej, zgięcie 2 (zasadnicze) wyhamowanie ruchu z obciążeniem kończyny wykrocznej oraz zgięcie 3 (końcowe) podczas powrotu do pozycji wyjściowej. Celem pracy była ocena ruchomości stawów kolanowych i biodrowych podczas asymetrycznego obniżania środka ciężkości z zastosowaniem system MVN Biomach oraz określenie stopnia przykurczu mięśni, które obustronnie zmniejszają zakres zgięcia początkowego stawu kolanowego w stosunku do końcowego za pomocą systemu MVN Biomech.

\section{HIPOTEZA}

Osobniczo zmienny zakres zgięcia stawu kolanowego przed wykrokiem (wstępny) w porównaniu do końcowego - podczas powrotu do pozycji wyjściowej zależy od braku elastyczności mięśnia naprężacza powięzi szerokiej kończyn dolnych.

\section{MATERIAtY I METODY}

W grupie praworęcznych biegaczy wieku 25-35 lat zastosowano następujące kryteria wyłączenia: wiotkość wielostawową, choroby układowe, RZS, chorobę zwyrodnieniową stawów, niestabilność pourazową. U 18 wyłonionych biegaczy (Tab. I) sprawdzono obustronnie w pozycji leżącej tyłem stopień rozciągnięcia mięśni kulszowo-goleniowych, biodrowo-lędźwiowych, naprężaczy powięzi szerokiej ud, czworogłowych ud w leżeniu przodem, a trójgłowe łydek w pozycji stojącej. Elastyczne mięśnie kulszowo-goleniowe umożliwiają bezbolesne zgięcie stawu biodrowego do $90^{\circ}$, z prostym stawem kolanowym (objaw Lasequ'a). Ujemny test Thomasa pozwolił na wykluczenie przykurczy mięśni biodrowo-lędźwiowych, które nie zginały stawu biodrowego badanej kończyny, podczas tyłopochylenia miednicy wywołanego maksymalnym zgięciem stawu biodrowego przeciwnej kończyny. Bezruch kolca biodrowego przedniego górnego podczas przywodzenia ipsilateralnej kończyny dolnej świadczy o braku przykurczu mięśnia naprężacza powięzi szerokiej uda. Elastyczny miesień czworogłowy uda umożliwia bezbolesne, maksymalne zgięcie stawu kolanowego podczas $15^{\circ}$ wyprostu stawu biodrowego i przy ustabilizowanym guzie kulszowym po tej samej stronie. Kontakt z podłożem guza piętowego kończyny zakrocznej przy $45^{\circ}$ wyproście ipsilateralnego stawu skokowego świadczy o braku czynnościowego przykurczu mięśnia trójgłowego łydki.

Następnie badani wykonali trzykrotny dynamiczny wypad pod kontrolą inercyjnych czujników MVN Biomech. Pojedynczy czujnik inercyjny IMU (inertial measure unit) to zintegrowane w jednej obudowie trzy elektroniczne urządzenia pomiarowe tj. akcelerometr, żyroskop oraz magnetometr. Aktualną orientację IMU oblicza się na podstawie chwilowego wskazu akcelerometru oraz żyroskopu. Magnetometr wykorzystywany jest to uniezależnienia się od rotacji IMU względem osi obrotu równoległej do wektora grawitacji. Dodatkowo w wyniku podwójnego zliczania wartości sygnału przyspieszenia w czasie, obliczana jest wartość przemieszczenia względem każdej z osi układu współrzędnych. Czujniki były umieszczone na tzw. segmentach, czyli na ścięgnach i brzuścach mięśni prostowników stawu skokowego, brzuścu mięśnia czworogłowego uda i kości krzyżowej za pomocą specjalnych opasekz rzepami. W punktach przecięcia segmentów (stawach) wyznaczono trójwymiarowy ruch odczytujący aktualną mobilność danego stawu, dając również informację o zakresie ruchów ROM - range of motion.

\section{WYNIKI}

Analiza wartości kątowych powyższych ruchów za pomocą systemu MVN Biomech u biegaczy potwierdziła maksymalny (około $100^{\circ}$ ) zakres zgięcia zasadniczego u wszystkich badanych. Porównanie zakresów zgięcia wstępnego i końcowego pozwoliło na podziałbadanych na dwie grupy. U większości badanych wystąpiła wyraźna, obustronna przewaga zgięcia wstępnego nad końcowym (typ malejący), a w pozostałej grupie zakres zgięcia końcowego był większy lub równy początkowemu (typ mieszany). Dwie osoby łączyły oba typy zgięcia (malejący w kończynach dominujących, a mieszany w kończynach przeciwnych.

Do 961 sekundy każdy badany wykonał trzy wykroki w przód. Podczas każdego wykroku staw kolanowy kończyny wykrocznej uległ opisanym trzem zgięciom

W typie malejącym w czasie badania zakresów zgięcia stawu kolanowego kończyny wykrocznej faza wstępna przewyższała fazę końcową u 10 osób (55\% badanych) obustronnie - zarówno w dominującej i niedominującej kończynie wykrocznej. Różnica zakresu zgięcia wynosiła minimum $10^{\circ}$ (Ryc. 1).

$\mathrm{W}$ typie mieszanym faza końcowa była większa lub równa fazie początkowej. Różnica między zakresami ruchu jest mniejsza niż $10^{\circ}$. Typ mieszany charakteryzował 6 mężczyzn (30\% badanych), u których występował zarówno w dominującej i niedominującej kończynie wykrocznej (Ryc. 2).

Dwóch badanych (11\%) miało różne wykroki w obu kończynach. W kończynie dominującej typ malejący, a w kończynie niedominującej mieszany.

Porównanie wyników badania fizjoterapeutycznego i pomiarów MVN Biomech wykazało czynnościowe przykurcze mięśni naprężaczy powięzi szerokiej ud u 5 badanych $\mathrm{z}$ typem mieszanym (83\% badanych z typem mieszanym) i asymetryczne różnice u 2 mężczyzn łączących oba typy

Tabela I. Charakterystyka grupy badanej.

\begin{tabular}{ccc}
\hline Liczba (N) & Średnia wieku & Odchylenie standardowe wieku (SD) \\
\hline 18 & 30,44 & 3,15 \\
\hline
\end{tabular}




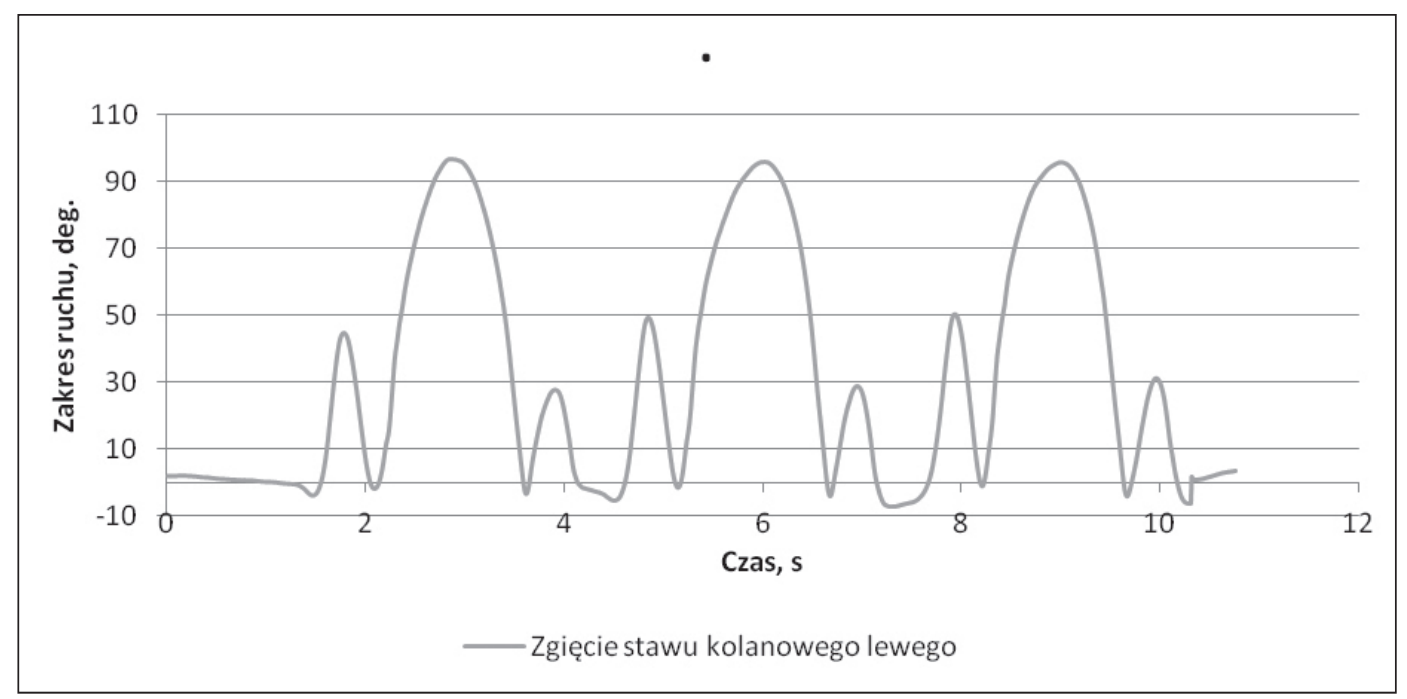

Ryc. 1. Trzy fazy zgięcia stawu kolanowego kończyny wykrocznej lewej podczas trzech prób wykroku. Typ malejący, w którym pierwsze zgięcie (ok. $50^{\circ}$ ) przeważa nad zgięciem trzecim (ok. $30^{\circ}$ ).

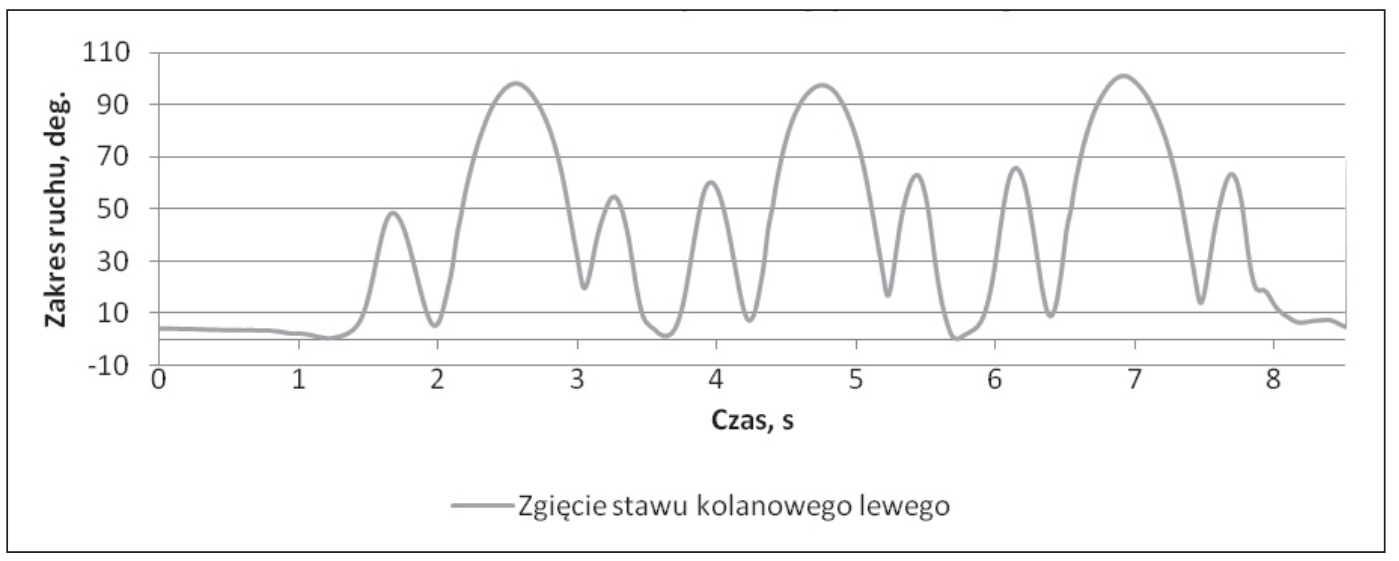

Ryc. 2. Trzy fazy zgięcia stawu kolanowego kończyny wykrocznej lewej podczas trzech prób wypadu. Typ mieszany, w którym zgięcie początkowe jest mniejsze, równe lub nieznacznie większe od zgięcia końcowego.

zgięcia (100\% badanych z typem malejącym po stronie dominującej, a mieszanym po stronie przeciwnej).

Analiza graficzna wykazuje wysokie wartości odwiedzenia podczas wypadu badanych z przykurczem mięśni naprężaczy powięzi szerokiej ud.

Przy odwiedzeniu w stawach biodrowych podczas wykroku prawą kończyną dolną w typie mieszanym lewy, zakroczny staw biodrowy osiąga $20^{\circ}$ odwiedzenie, kończyna wykroczna doszła do $13^{\circ}$. Powyższe zakresy odwiedzenia po obu stronach ciała, z przewagą odwiedzenia w kończynie zakrocznej, charakteryzują 4 biegaczy (66\% badanych o typie mieszanym). Widoczne są również 0,5 sekundowe przywiedzenia z zakrocznej kończynie dochodzace do $5^{\circ}$ charakteryzujące połowę badanych o typie mieszanym (3 osoby - 50\%) (Ryc. 3).

Przy przywiedzeniu i odwiedzenia w stawach biodrowych podczas wykroku lewą kończyną dolną w typie malejącym lewy staw biodrowy osiąga $10^{\circ}$ odwiedzenie, kończyna zakroczna dochodzi do $9^{\circ}$ przywiedzenia, trwającego do $2 \mathrm{~s}$. Przywiedzenie w stawie biodrowym kończyny zakrocznej (prawej) stwierdzono u 6 biegaczy (60\% badanych z typem malejącym), a u 20\% (2 biegaczy) przywiedzenie wystąpiło w lewej kończynie wykrocznej do $15^{\circ}$. Pojawiają się również krótkotrwałe (ok. $0,25 \mathrm{~s}$ ) epizody $4^{\circ}$ przywiedzenia kończyny wykrocznej, niewystępujące w typie mieszanym (Ryc. 4).

\section{DYSKUSJA}

Naprężacz powięzi szerokiej działa na staw kolanowy i biodrowy wzmacnia w swym działaniu pionowa postawę ciała. Mięsień ten zgina częściowo ugięty staw kolanowy, lecz jego działanie jest znacznie silniejsze na staw biodrowy, bierze udział w zginaniu biodra, obracana je do wewnątrz oraz silnie je odwodzi. Mięsień naprężacz powięzi szerokiej wraz z mięśniem pośladkowym średnim pełnią kluczową rolę $\mathrm{w}$ utrzymaniu równowagi oraz stabilizacji miednicy, jak i kontroli jej obrotu w początkowej fazie cyklu chodu [2]. Zwiększona dysproporcja pomiędzy mięśniami antagonistycznymi do agonistycznych może być przyczyną sytuacji, w której mięśnie antagonistyczne nie są w stanie wytworzyć wystarczającej siły, aby spowolnić działanie 


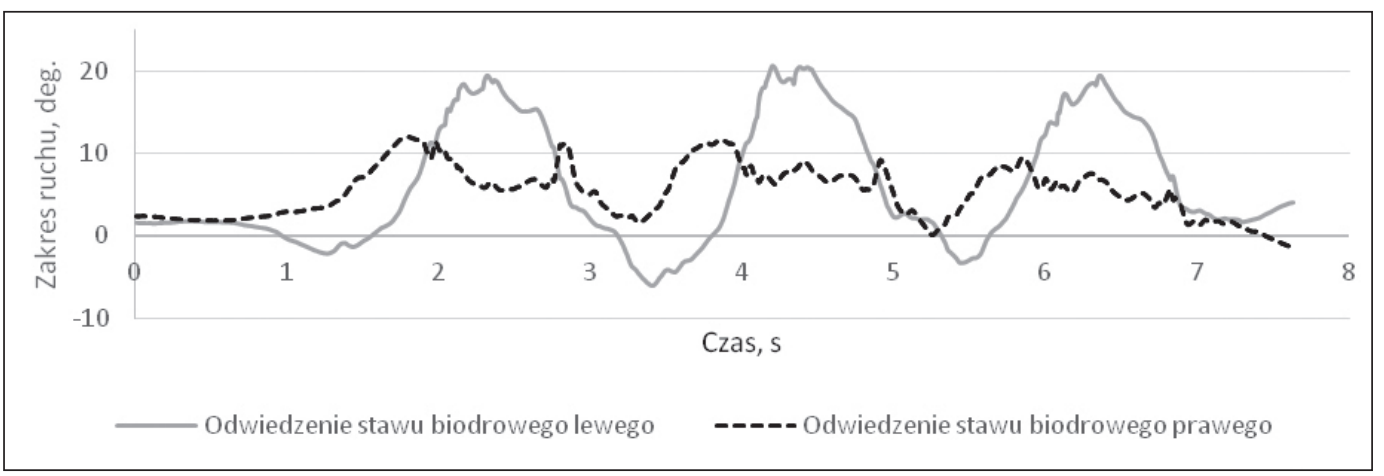

Ryc. 3. Odwiedzenie w stawach biodrowych podczas wykroku prawą kończyną dolną w typie mieszanym.

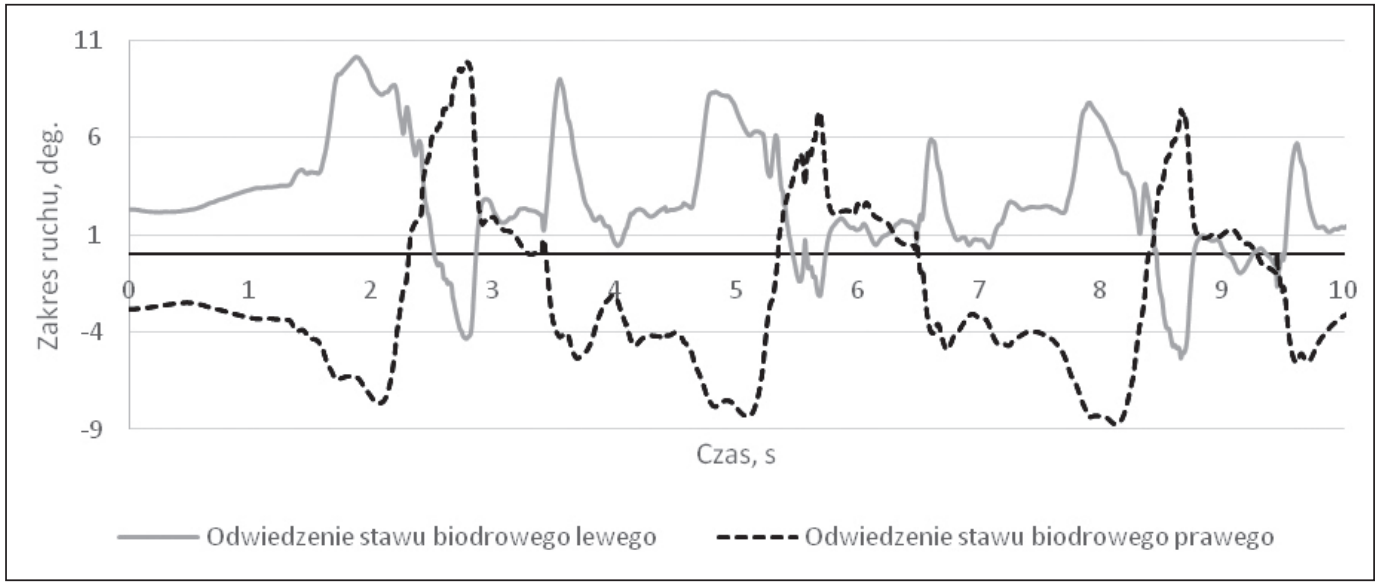

Ryc. 4. Przywiedzenie i odwiedzenie w stawach biodrowych podczas wykroku lewą kończyną dolną w typie malejącym.

agonistów w kierunku wykonywanego wzorca ruchowego. Zjawisko to jest przyczyną występowania nieprawidłowych wzorców ruchowych kończyny dolnej [3]. Niski poziom siły oraz zmniejszona elastyczność mięśni stabilizujących miednicę może być jedną z przyczyn przewlekłych dolegliwości bólowych odcinka lędźwiowego kręgosłupa. Wniosek ten ukazuje wpływ mięśnie miednicy na funkcję kończyny dolnej oraz tułowia [4]. Do prawidłowego wykonania wykroku potrzebna jest rotacja wewnętrzna oraz wyprost w stawie biodrowym. W przypadku niewystarczającej rotacji wewnętrznej nogi zakrocznej noga wykroczna wykona niekontrolowany ruch w kierunku koślawienia kolana [5]. Mięśniowo-powięziowa taśma boczna kończyny dolnej w sposób skoordynowany stabilizuje kończynę dolną oraz tułów w trakcie chodzenia oraz ruchów kończynami górnymi. Wykazuje działanie hamujące oraz stabilizujące dla ruchów skrętnych oraz bocznych tułowia [6].Zakres wykroku w trakcie fazy lądowania, jak i różnica wysokości, z jakiej jest wykonana czynność wykroku lub zeskoku, mają wpływ na występowanie niestabilności bocznej stawu kolanowego oraz stawu skokowego. Jeżeli zakres lub wysokość są zbyt małe, zjawisko niestabilności może nie wystąpić. Do największych wartości niestabilności bocznej w stawie kolanowym dochodzi w momencie kontaktu stopy z podłożem nogi wykrocznej biorącej udział w hamowaniu lądowania. Na szybkość uzyskania stabilizacji stawu kolanowego w tej czynności ma wpływ wydolność mięśnia czworogłowego uda [7].

\section{WNIOSKI}

Przykurcz mięśnia naprężacza powięzi szerokiej uda zmniejsza zakres zgięcia stawu kolanowego w fazie dynamicznego przeniesienia. Jednocześnie mięśnie te przy braku normy długości powodują zwiększenie czworoboku podparcia podczas wypadu, z uwagi na większe odwiedzenie w stawach biodrowych.

Badani bez przykurczu mięśnia naprężacza powięzi szerokiej ud charakteryzują się większym zgięciem początkowym stawu kolanowego kończyny wykrocznej w stosunku do końcowego oraz dwukrotnie dłuższym okresem przywiedzenia kończyny zakrocznej.

Pozostałe mięśnie kończyn dolnych nie wykazująistotnych statystycznie różnic elastyczności w porównaniu do typu wykroku.

\section{Konflikt interesów:}

Autorzy deklaruja brak konfliktu interesów.

\section{PIŚMIENNICTWO}

1. Bochenek A. Anatomia człowieka. vol 1. Warszawa: Wydawnictwo PZWL 1999. 860-862.

2. Gottschalk F. The functional anatomy of tensor fasciae latae and gluteus medius and minimus. Division of Orthopaedic Surgery and Department of Physical Therapy, University of Texas Southwestern Medical Center Dallas. 1989, 179-189.

3. Coombs R, Garbutt G. Development in the use of the hamstring/quadriceps ratio for the assessment of muscle balance. J Sports Sci Med. 2002;1:56-62. 
4. Bayramoglu M, Akman MN, KInç S, Çetin N, Yavuz N, Özker R. Isokinetic measurement of trunk muscle strength in women with chronic low-back pain. Am J Phys Med Rehabil. 2001;80:650-655

5. StarrettK. Becominga Supple Leopard"The Ultimate Guide to Resolving Pain, Preventing Injury, and Optimizing Athletic Performance. 2015;114-115.

6. Myers TW. Anatomy Trains: Myofascial Meridians for Manual and Movement Therapists. Edinburgh: Churchill Livingstone, 2009.

7. Orishimo KF, Kremenic IJ. Effect of fatigue on single-leg hop landing biomechanics. J Appl Biomech. 2006;22(4):245-54

\section{AUTOR KORESPONDUJĄCY}

Tomasz Tittinger

ul. Miłocińska 95/1, 35-506 Rzeszów, Polska

e-mail:biuro@fizjokursy.pl

Nadesłano: 25.01.2019

Zaakceptowano: 15.02.2019 
PRACA ORYGINALNA

ORIGINAL ARTICLE

\title{
MORPHOMETRIC DESCRIPTION OF THE EXCHANGE SEGMENT OF MICROVASCULATURE OF RATS' SALIVARY GLANDS IN NORMAL CONDITIONS AND CHRONIC ETHANOL INTOXICATION
}

\author{
CHARAKTERYSTYKA MORFOMETRYCZNA SEGMENTU \\ MIKROUNACZYNIENIA GRUCZOŁU ŚLINOWEGO SZCZURA \\ W WARUNKACH PRAWIDŁOWYCH, JAK I W WARUNKACH \\ PRZEWLEKŁEJ INTOKSYKACJI ETANOLEM
}

\author{
Kostyantyn V. Shevchenko, Galyna A. Yeroshenko, Olena S. Yakushko, Kateryna S. Kazakova, Denys R. Kramarenko \\ UKRAINIAN MEDICAL STOMATOLOGICAL ACADEMY, POLTAVA, UKRAINE
}

\begin{abstract}
Introduction: The state of the segments of the microvasculature, especially exchange one, has a significant effect on the organs' functions. The results of it's research can be objectified by morphometric method.

The aim: to determine the dynamics of changes in metric indices of the exchange segment of microvasculature of rats'submandibular glands in normal conditions and in chronic ethanol intoxication.

Materials and methods: 45 albino rats were involved into study. Intact group $(n=5)$ animals were administered with NaCl isotonic solution 4 times a day directly into the stomach. Experimental group $(n=40)$ animals were administered with $40^{\circ}$ ethanol 4 times a day directly into the stomach. Animals were sacrificed on $5,9,12$ and 30 days by overdose of thiopental anesthesia. Lobules of submandibular glands were embedded into epon-812 according to standard procedure.

Results: 0 n day 5 of the experiment the outer diameter of the capillary wall significantly reduced $(4,91 \pm 0,02 \mu \mathrm{m})$, that is $19,5 \%$ less than the values in controls $(p<0,05)$. On day 9 of the experiment it was $15,2 \%$ lower than the value of control group $(p>0,05)$. On day 30 of the experiment the outer capillary diameter was $8 \%$ lower compared to controls $(p<0,05)$.

Conclusions: The early observation showed vasodilatation, confirmed by the constriction of the outer diameter and lumen diameter, accompanied by the thickening of the vascular wall under the influence of chronic ethanol intoxication. The indices did not come to normal values by the 30 -th day of the experiment.
\end{abstract}

KEY WORDS: rats, salivary glands, capillaries, ethanol intoxication

Wiad Lek 2019, 72, 3, 323-326

\section{INTRODUCTION}

The oral cavity has a multi-component system of protection against environmental pathogenic factors. Apparently, the homeostasis of the oral cavity is determined by many factors, but, first of all, by the functional activity of the salivary glands, contributing to both the presence of dental pathology and somatic human health in general [1].

Saliva, which is the product of secretion of the salivary glands, is crucial in keeping the normal state of tissues and organs of the oral cavity. Functions of saliva are diverse [2]. It has been found that quantitative and qualitative changes in saliva greatly determine the resistance of teeth to dental caries [3].

The problem of alcoholism is considered to be relevant worldwide, and is ranking third in the mortality rate after cardiovascular diseases and cancer. The WHO's statistics reports about 140 million people suffering from chronic alcoholism worldwide, and more than half of them refuse to contact medical professionals for assistance $[4,5]$.

Salivary glands of almost all patients with alcohol abuse showed marked acinar hyperplasia, dilated ducts, granular and adipose dystrophy of the ductal epithelium. In some cases minor swelling and stromal fibrosis was detected [6].

The state of the segments of the microvasculature, especially exchange one, provided with full gas exchange between the blood, cells and vital substances, has a significant effect on the body.

Some publications report that experimental hyposalivation of both endogenic and exogenic nature shows stable dilatation of the exchange vessels of the microvasculature throughout the observation [7].

Morphometric method is beneficial for objective analysis of the resulting data in the structural elements after the effect of various endogenic and exogenic factors [8]. 

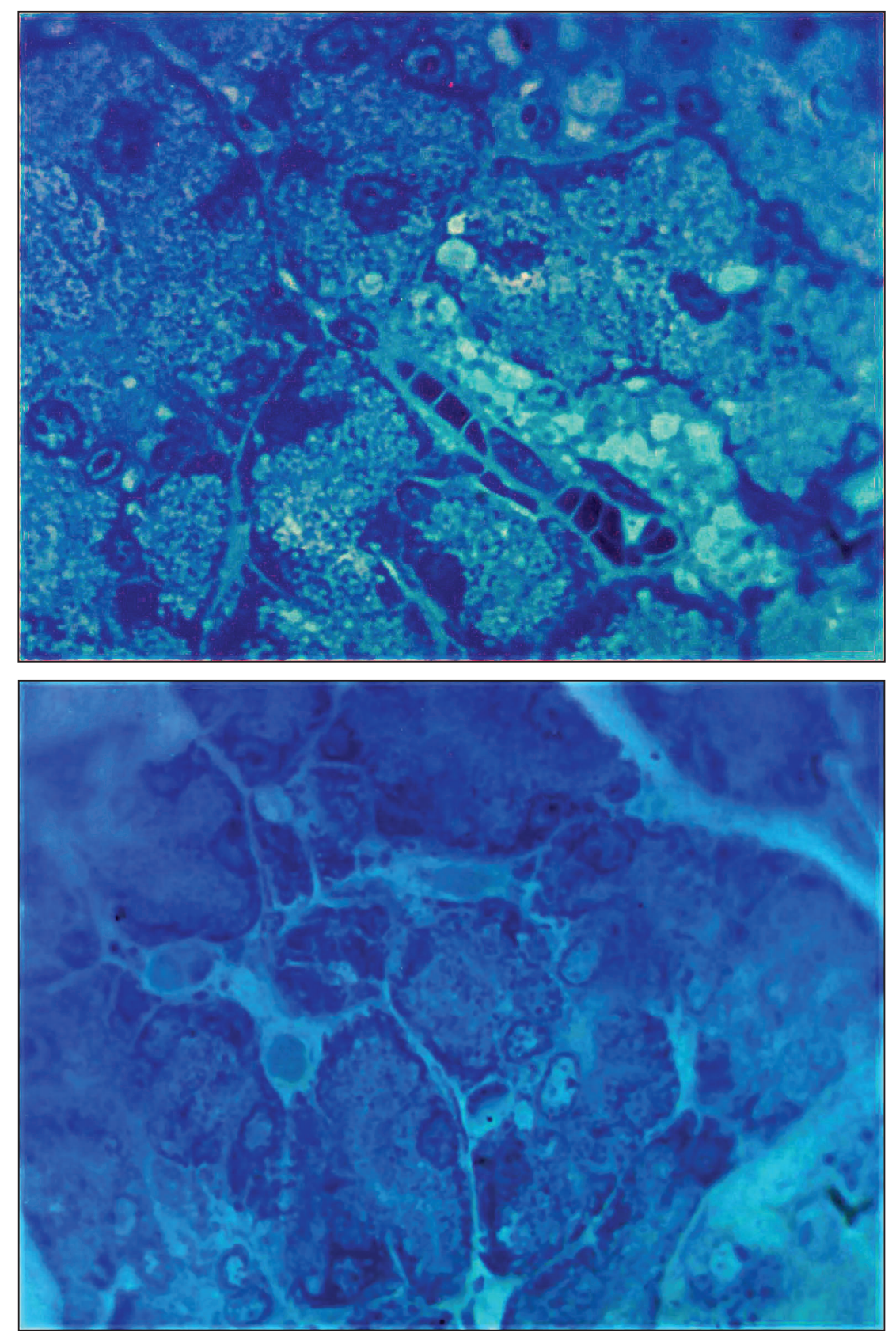

Fig. 1. Capillary in the lobule of rat's submandibular gland on day 5 of the experimental model of chronic ethanol intoxication. Methylene blue stain. $1000 \times$ magnification.

Fig. 2. Capillaries in the periacinar connective tissue of the rats' submandibular gland on day 30 of the experiment. Methylene blue stain. $1000 \times$ magnification.

\section{THE AIM}

The paper was aimed at the determining the dynamics of changes in metric indices of the exchange segment of microvasculature of rats' submandibular glands in normal conditions and in chronic ethanol intoxication.

\section{MATERIALS AND METHODS}

45 outbred albino rats were involved into study. Intact group $(n=5)$ animals were administered with $\mathrm{NaCl}$ isotonic solution 4 times a day directly into the stomach. Experimental group $(n=40)$ animals were administered with $12 \mathrm{mg} / \mathrm{kg} 40^{\circ}$ ethanol 4 times a day directly into the stomach [9].

The animals were sacrificed under $25 \mathrm{mg} / \mathrm{kg}$ thiopental anesthesia overdose in compliance with the scheduled time periods (on day 5, 9, 12 and 30). Lobules of submandibular glands were embedded into epon-812 according to standard procedure [10]. Semi-thin sections were stained with polychrome stain.

The average values of the outer diameter and diameter of capillary lumen were measured using the microscope with digital Biorex - 3 microphotohead with software, adapted to studies of such type. The thickness of the vascular wall was calculated according to the formula:

$$
\mathrm{T}_{\mathrm{vw}}=\mathrm{D}_{\mathrm{o}}-\mathrm{D}_{\mathrm{l}} / 2 \text {, }
$$

where $D_{0}^{\circ}$ is the outer diameter of the capillary wall,

$\mathrm{D}_{1}$ is the inner diameter of the capillary wall,

$\mathrm{T}_{\mathrm{vw}}$ is the thickness of the vascular wall of capillaries. Statistical processing of the morphometric data has been carried out using the Microsoft Excel [11].

Animal housing and experiments on them have been 
Table I. The average values of the capillary diameters of the microvasculature of the lobules of rats'submandibular gland $(\mu \mathrm{m})$

\begin{tabular}{cccc}
\hline Capillaries & $\mathbf{D}_{\mathrm{o}}$ & $\mathbf{D}_{\mathbf{1}}$ & $\mathbf{T}_{\mathrm{vw}}$ \\
\hline Control & $6,10 \pm 0,05$ & $4,16 \pm 0,02$ & 0,92 \\
\hline day $\mathbf{5}$ & $4,91 \pm 0,02^{*}$ & $3,64 \pm 0,02^{*}$ & 0,64 \\
\hline day $\mathbf{9}$ & $5,17 \pm 0,01^{*},{ }^{* *}$ & $3,80 \pm 0,02^{*},{ }^{* *}$ & 0,68 \\
\hline day $\mathbf{1 2}$ & $5,34 \pm 0,03^{*},{ }^{* *}$ & $3,87 \pm 0,01^{*},{ }^{* *}$ & 0,74 \\
\hline day $\mathbf{3 0}$ & $5,61 \pm 0,01^{*},{ }^{* *}$ & $3,99 \pm 0,02^{*},{ }^{* *}$ & 0,81 \\
\hline
\end{tabular}

Note: ${ }^{*}-p<0,05$ compared with controls; ${ }^{* *}-p<0,05$ compared with experimental group.

carried out in compliance with the "General Ethic Rules for Conducting Experiments on Animals", adopted by the I National Congress on Bioethics and the requirements of international principles of the "European Convention for the Protection of Vertebrate Animals Used for Experimental and Other Scientific Purposes"[12].

\section{RESULTS AND DISCUSSION}

The morphometric study has established that the average values of the outer diameter of the capillary wall of the lobules of submandibular gland was $6,10 \pm 0,05 \mu \mathrm{m}$; the inner diameter was $4,16 \pm 0,02 \mu \mathrm{m}$. The thickness of the vascular wall of capillaries was $0,92 \mu \mathrm{m}$ (Table I).

On day 5 of the experiment the outer diameter of the capillary wall significantly reduced $(4,91 \pm 0,02 \mu \mathrm{m})$, that is 19,5 $\%$ less than the values in controls $(\mathrm{p}<0,05)$; similarly, the diameter of the capillary lumen reduced by $12,5 \%$ (Fig. 1 ). Its average values were $3,64 \pm 0,02 \mu \mathrm{m}$, red blood cells in the lumens were deformed. The thickness of vascular wall was reduced by $30,4 \%(0,64 \mu \mathrm{m})$ (Table I).

On day 9 of the experiment the outer diameter of capillaries was enlarged by $5,3 \%(5,17 \pm 0,01 \mu \mathrm{m})$ compared to day 5 ; however, it was $15,2 \%$ lower than the value of control group ( $p>0,05)$. The lumen diameter was $3,80 \pm 0,02 \mu \mathrm{m}$, that was $4,4 \%$ higher the values on day 5 of the experiment but was $8,7 \%$ lower compared to controls ( $p>0,05)$. Similarly, the thickness of vascular wall was tending to change. It was $6,3 \%$ higher compared to day 5 of the experiment and $26,1 \%(0,68 \mu \mathrm{m})$ lower compared to controls (Table I).

On day 12 of the experiment the outer capillary diameter was $5,34 \pm 0,03 \mu \mathrm{m}$, that was $3,3 \%$ higher the values of the day 9 of the experiment, but was $12,5 \%$ lower compared to controls $(\mathrm{p}<0,05)$. The average values of the lumen diameter were $3,87 \pm 0,01 \mu \mathrm{m}$, that was $1,8 \%$ higher the values of the previous time period of experiment, but was $6,7 \%$ lower the values of controls $(\mathrm{p}<0,05)$. The thickness of the vascular wall was $8,8 \%$ higher compared to day 9 of the experiment and 19,6\% lower compared to controls ( $p$ $<0,05$ ) with the average values of $0,74 \mu \mathrm{m}$ (Table I).

On day 30 of the experiment the outer capillary diameter of the lobules of submundibular gland was 5,61 $\pm 0,01 \mu \mathrm{m}$, that was $5,1 \%$ higher the values of day 12 of the experiment but $8 \%$ lower compared to controls $(\mathrm{p}<0,05)$. The inner capillary diameter was 3,1 \% $(3,99 \pm 0,02 \mu \mathrm{m})$ higher the values of the previous time period of experiment, that was $4,1 \%$ lower the values of controls; loose placement of blood corpuscles was detected in the lumens (Fig.2). The thickness of the vascular wall was 9,5\% higher compared to day 12 and significantly $12 \%$ lower compared to controls $(\mathrm{p}<0,05)$ with the average values of $0,81 \mu \mathrm{m}$ (Table I).

The findings of our previous studies have shown the spasm of arterioles in the lobules of the rat's submandibular glands at the early stages of intoxication with ethanol, which is confirmed by the thinning of the vascular wall by $41.8 \%$. At the ninth day of the experiment, dilatation, manifested by the significant enlargement of the outer diameter and the diameter of the lumen was noted, as well as thinning of the vascular wall. The rates did not come to normal by the thirtieth day of the experiment [13].

It has been established that chronic ethanol intoxication leads to early detection of venous dilatation, which is confirmed by the significant enlargement of the outer diameter and diameter of the lumen along with thinning of the vascular wall. From the twelfth day of the experiment the metric values were tending to restore. The rates did not come to normal by the thirtieth day of the experiment [14]. Thus, the established changes in the exchange segment of the microvasculature are caused by the blood flow decrease from dilated arterioles on the one hand, and hyperhydration of the amorphous component of the intercellular substance of the connective tissue of the stroma of the rats' submandibular gland lobules on the other hand, at the early stages of the experiment. The findings of our study are in concordance with the findings of other researchers $[1,7]$, who studied the effect of ethanol and $1 \%$ methacrylic ester on the mucous membrane of the masticatory type. However, the authors established a more pronounced reaction of the exchange segment of the microvasculature of the glandular zone of hard palate and gums of rats due to direct exposure of the irritating factor to the surface. The submandibular glands are mediated indirectly by the bloodstream and, to a small extent, retrograde ethanol penetration through the duct system of the glands. The above reduces the manifestations of microcirculation disorders by an average of $10 \%$.

\section{CONCLUSIONS}

The morphometric study has established that chronic ethanol intoxication affects the exchange segment of the microvasculature of the lobules of submandibular gland. 
The early observation showed vasodilatation, confirmed by the constriction of the outer diameter and lumen diameter, accompanied by the thickening of the vascular wall. From day 9 of the experiment the metric values were tending to restore.

The indices did not come to normal values by the 30 -th day of the experiment.

\section{REFERENCES}

1. Yeroshenko GA, Shevchenko KV, Kazakova KS. Toksychnyi vplyv etanolu na slyzovi obolonky [Toxic effect of ethanol on mucous membranes]. World of Medicine and Biology. 2017;3(61):169-173. (in Ukrainian).

2. Débora Alejandra González, Martín Matías Barbieri van Haaster, Emmanuel Quinteros Villarruel. Histamine stimulates secretion of extracellular vesicles with nucleotidase activity in rat submandibular gland. Archives of Oral Biology. 2018;85:201-206.

3. Timofeev AA. Sekretornaya funktsiya slyunnykh zhelez u bolnykh s ostrymi odontogennymi vospalitelnymi zabolevaniyami chelyustey. [Secretory function of the salivary glands in patients with acute odontogenic inflammatory diseases of the jaws]. Sovremennaya stomatologiya. 2011;4:70-74. (in Russian).

4. Borisenko VV. Ehpidemiologiya ehpizodicheskih zloupotreblenij pri alkogol'noj zavisimosti s uchetom vliyaniya geliogeofizicheskih faktorov [Epidemiology of episodic abuse in alcohol dependence with the influence heliogeophysical factors]. World of Medicine and Biology. 2014;1(43):21-25. (in Russian).

5. Kazakov OA. Suchasnyi stan problemy pidlitkovoho alkoholizmu [Current state of problem of teenage alcoholism]. World of Medicine and Biology. 2017;2(60):63-65. (in Ukrainian).

6. Nepochatova ES, Ponomareva EA. Alkogol', ego vlijanie na organizm cheloveka. [Alcohol, its effect on the human body]. Alleja nauki. 2017;1(16):913-921. (in Russian).

7. Senchakovych YuV, Yeroshenko GA. Morfometrychna kharakterystyka lanok mikrotsyrkuliatornoho rusla pidnebinnykh zaloz shchuriv pry eksperymentalnii hiposalivatsii [Morphometric characteristics of the microcirculatory bed parts of the rat palatal glands at experimental hyposalivation]. Bulletin of Problems Biology and Medicine. 2014;3(112):275-278. (in Ukrainian).
8. Tsukanov DV, Yerochenko GA, Gasyuk NV et al. Morphometric characteristic of microcircular rate of salivary glands after administration of platiphillinum and proserinum. European International Journal of Science and Technology. 2014;3(8):29-34.

9. Ivanochko VM. Uljtrastrukturna orghanizacija reabsorbcijnogho bar'jeru nyrky pry khronichnij alkogholizaciji [Ultrastructural organization of the reabsorption barrier of the kidney at chronic alcoholization]. Tavricheskij mediko-biologicheskij vestnik. 2002;5(3):86-87. (in Ukrainian).

10. Karupu VYa. Jelektronnaja mikroskopija [Electron Microscopy]. Kiev: Vyshchaya shkola; 1984. 207 p. (in Russian).

11. Lapach SN, Chubenko AV, Babich PN. Statisticheskie metody v medikobiologicheskih issledovanijah s ispol'zovaniem Exel [Statistical methods in biomedical research using Excel]. Kiev: Morion; 2000.320 p. (in Russian)

12. European convention for the protection of vertebrate animals used for experimental an others scientific purposes/Strasbourg: Council of Europ, 1986. № 123.52p.

13. Yeroshenko GA, Shevchenko KV, Yakushko OS. Morphometric characteristics of rat salivary glands hemomicrovasculature capacity component under normal conditions and in ethanol chronic intoxication. World of Medicine and Biology. 2018;3 (65):149-152.

14. Silkina YuV, Volkov KS, Shevchenko KV. Morfometrychna kharakterystyka rezystyvnoi lanky hemomikrotsyrkuliatornoho rusla slynnykh zaloz shchuriv pry khronichnii intoksykatsii etanolom [Morphometric characteristics of the resistant link of salivary glands' hemomicrocircular rate of rats in chronic ethanol intoxication]. Morphologia. 2018;12(1):5154. (in Ukrainian).

The paper has been written within the research scientific work, entitled "Experimental and morphological study of the effect of transplantants of cryopreserved placenta and other exogenic factors on the morphofunctional state of several internal organs"; State registration number 0113 U006185.

Authors' contributions:

According to the order of the Authorship.

Conflict of interest:

The Authors declare no conflict of interest.

\section{CORRESPONDING AUTHOR Olena S. Yakushko}

Ukrainian Medical Stomatological Academy

23 Shevchenko str., 36011 Poltava, Ukraine

tel: +380662990448

e-mail: olena.yakushko@gmail.com

Received: 27.11 .2018

Accepted: 25.02.2019 
PRACA ORYGINALNA

ORIGINAL ARTICLE

\title{
CERVICAL CANCER - CAUSES AND PREVENTION OF HPV INFECTIONS IN THE OPINIONS OF YOUNG POLISH WOMEN: A CROSS-SECTIONAL SURVEY
}

\author{
RAK SZYJKI MACICY - PRZYCZYNY ORAZ PROFILAKTYKA \\ ZAKAŻEŃ HPV W OPINIACH MŁODYCH POLEK: \\ PRZEKROJOWE BADANIE ANKIETOWE
}

\author{
Artur Kotowski ${ }^{1}$, Maja Kotowska ${ }^{2}$, Aleksandra Warzyszyńska² ${ }^{2}$ Iwona Szymusik ${ }^{3}$, Katarzyna Kosińska-Kaczyńska ${ }^{3}$, \\ Andrzej M. Fal ${ }^{4}$ \\ 'MEMBER OF POLISH ASSOCIATION FOR GOOD CLINICAL PRACTICE GCPPL, WARSAW, POLAND \\ 2STUDENTS SCIENTIFIC CIRCLE, II FACULTY OF MEDICINE, WARSAW MEDICAL UNIVERSITY, WARSAW, POLAND \\ 3I CHAIR AND DEPARTMENT OF OBSTETRICS AND GYNECOLOGY, WARSAW MEDICAL UNIVERSITY, WARSAW, POLAND \\ ${ }^{4}$ CARDINAL STEFAN WYSZYŃSKI UNIVERSITY, WARSAW, POLAND
}

\begin{abstract}
Introduction: Cervical cancer is an important issue of gynecologic oncology. The awareness of this disease, the attitude towards HPV vaccination and cytological screening play an important role in decreasing morbidity and mortality due to cervical cancer.

The aim: To assess the various aspects of knowledge regarding cervical cancer, risk factors for this disease, the role of HPV infection and the attitude to primary (vaccination) and secondary (cytological screening) prevention among young women.

Materials and methods: The study was performed using CAWI method based on original questionnaire in electronic form. Online completing of the survey was voluntary and anonymous.

Results: The study was conducted in a group of 2058 women aged 19-33. In total 98.4\% of respondents came across the term "cervical cancer", $84.1 \%$ knew that cervical cancer could be prevented and the following were identified as the main risk factors: cervical cancer in closest relatives (85.3\%) and HPV infection (81.9\%). Although according to $82.0 \%$ of women HPV infection can be prevented by vaccination, only $18.4 \%$ of respondents were vaccinated. The main reason for non-vaccination was lack of knowledge about the availability of the vaccine (41.2\%) and high price (32.0\%). Of the unvaccinated people, $63.5 \%$ declare their will to be vaccinated in the future. Concerning secondary prevention, 98.6\% of the respondents admitted that they knew the term "cytological examination", $89.0 \%$ indicated that this examination detected the presence of pre-cancerous lesions, and according to $58.4 \%$ of respondents, this test should be performed after sexual initiation. Despite the fact that $80.5 \%$ of respondents confirmed the fact of beginning sexual activity (44.4\% of them had more than 1 partner), $17.1 \%$ of the respondents admitted that they didn't go to gynecologist yet. Approximately $84 \%$ of respondents believe that the amount of information on cervical cancer prophylaxis and HPV infections currently providing is insufficient.

Conclusions: The basic terms regarding primary (vaccination) and secondary (prophylactic tests) prevention of cervical cancer have been widely known. However, the knowledge about specific risk factors, sexual behaviors contributing to HPV infection and, consequently, the ability to self-identify as belonging to higher risk group is insufficient. It is justified to conduct educational activities regarding the assessment of risks related to cervical cancer addressed to young women. Together with education, HPV vaccination and secondary prevention programs require financial support.
\end{abstract}

KEY WORDS: cervical cancer, risk factors, prevention, HPV, vaccines, awareness

\section{STRESZCZENIE}

Wstęp: Rak szyjki macicy jest istotnym problemem ginekologii onkologicznej. Swiadomość choroby, nastawienie do szczepień przeciwko HPV oraz profilaktycznych badań cytologicznych, odgrywają istotną rolę w redukcji zachorowalności i śmiertelności z powodu tej choroby.

Cel pracy: 0cena poziomu wiedzy na temat raka szyjki macicy (RSM), czynników ryzyka tej choroby, w tym roli zakażenia wirusem HPV oraz stosunku do profilaktyki pierwotnej (szczepienia) i wtórnej (cytologiczne badania przesiewowe) wśród młodych Polek.

Materiały i metody: Badanie wykonano metodą CAWI (Computer Assisted Web Interview) wykorzystując autorską, 27-pytaniową ankietę kwestionariuszową w formie elektronicznej. Wypełnienie ankiety było dobrowolne, anonimowe, wykonane online.

Wyniki: Badanie przeprowadzono w okresie 11.2018-01.2019 w grupie 2058 kobiet w wieku 19-33 lata. Z ogółu badanych, 98,4\% respondentek zetknęła się z pojęciem rak szyjki macicy, 84,1\% wiedziała że można zapobiegać wystąpieniu RSM, a jako główne czynniki ryzyka wskazano: występowanie RSM u najblizszych krewnych (85,3\%) oraz zakażenie wirusem HPV (81,9\%). Pomimo, iż według 82,0\% kobiet można zapobiegać infekcji HPV poprzez szzzepienie, jedynie 18,4\% respondentek została zaszzzepiona, głównym powodem nieszczepienia był brak wiedzy o dostępności szzzepionki (41,2\%) oraz jej wysoka cena (32,0\%). Spośród osób niezaszzzepionych, 63,5\% deklaruje chęć zaszzzepienia się w przyszłości. W zakresie profilaktyki wtórnej, 98,6\% respondentek przyznało, że zna pojęcie badanie cytologiczne, 89,0\% wskazało, że badanie to wykrywa obecność zmian przednowotworowych i RSM, a według 58,4\% respondentek powinno być ono wykonane po inicjacji seksualnej. Pomimo iż 80,5\% badanych potwierdziło fakt 
rozpoczęcia współżycia płciowego (z czego 44,4\% zadeklarowało współżycie z $\geq 1$ partnerem seksualnym), 17,1\% respondentek przyznało, że nie było jeszcze u ginekologa. Około 84\% badanych uważa, że ilość informacji na temat profilaktyki RSM i zakażeń HPV docierająca obecnie jest niewystarczająca.

Wnioski: Podstawowe pojęcia z zakresu profilaktyki pierwotnej (szczepienia) i wtórnej (badania profilaktyczne) raka szyjki macicy okazały się powszechnie znane. Natomiast wiedza na temat poszczególnych czynników ryzyka raka szyjki macicy, zachowań seksualnych sprzyjających zakażeniu HPV i w konsekwencji umiejętność identyfikacji siebie w kontekście przynależności do grupy podwyższonego ryzyka jest niewystarczająca. Reasumując: zasadne jest prowadzenie działań edukacyjnych dotyczących oceny ryzyk związanych z RSM kierowanych do młodych kobiet. Równolegle z edukacją, w celu zwiększenia dostępności, wsparcia finansowego wymagają programy szczepień przeciwko HPV i profilaktyki wtórnej.

SŁOWA KLUCZOWE: rak szyjki macicy, czynniki ryzyka, profilaktyka, HPV, szczepienia, świadomość

Wiad Lek 2019, 72, 3, 327-335

\section{INTRODUCTION}

Cervical cancer is an important issue of gynecologic oncology. According to the GLOBOCAN report, 570,000 new cases of this type of cancer were reported worldwide in 2018 and the number of deaths exceeded 300,000 [1]. This problem is particularly conspicuous in African countries (incidence rate is $40 / 100,000$ and mortality rate is 20/100,000). Both indices are much lower in European countries, but there is a clear difference between the countries of Central and Eastern Europe and Western Europe (morbidity rate: $16 / 100,000$ vs. $6.8 / 100,000$, respectively and mortality rate $6.1 / 100,000$ vs. $2.1 / 100,000$, respectively).

Cervical cancer is currently the sixth most common (accounting for 4.0\%) malignant tumor among women. In recent years, there has been a steady, slow downward trend in the incidence of this cancer. According to the latest reports from the National Cancer Registry (NCR) in Poland, in 2010 there were 3078 new cases (morbidity rate: $10.3 / 100,000$ ) and 1,735 deaths (mortality rate: $5.1 / 100,000)$ reported [2].

Among the EU countries Poland is distinguished by a higher mortality rate due to cervical cancer, which results from the late diagnosis; app. $40 \%$ of patients are diagnosed in the advanced stage, and only $27 \%$ of women regularly performed cytological tests (Pap smears) [2]. The survival analysis indicates that as a country we have one of the lowest 5-year relative survival rates (app. 54.0\%) as compared to European countries (app. 67.0\%) [2]. In majority of cases, carcinogenesis in cervical cancer is associated with chronic human papilloma virus (HPV) infection [3]. Other risk factors include maintaining sexual contact with multiple partners and early age of beginning sexual activity, immune disorders and long-term smoking. Likely factors such as: long-term use of hormonal contraception, vaginitis (inflammation of the vagina), some sexually transmitted diseases (STDs) (e.g. chlamydiasis, trichomoniasis, infection of herpes simplex virus 2 [HSV2]) may accelerate the process of carcinogenesis [4]. An established way to reduce the risk of developing cervical cancer is anti-HPV vaccination, which should be done before sexual initiation. There are currently three vaccines available in the EU: 2-valent, 4 -valent or 9-valent vaccine that can be used as part of routine vaccinations for girls aged 11-12 and women up to 26 years of age, previously unvaccinated or those who have not completed the full, 3-dose vaccination schedule [5]. Unfortunately, the availability of vaccinations against $\mathrm{HPV}$ in Poland is hampered by the lack of funding in the childhood immunization programs, which is only partially compensated through preventive self-governmental programs.

In Poland, the subject of cervical cancer has been present in mass media for years. Since 2007, the annual edition of the European Cervical Cancer Prevention Week has been organized, a ministerial program of free-of-charge prophylactic tests is being conducted, there are also internet portals addressed to young women: www.hpvukobiet. net.pl, www.jestemprzytobie.pl, www.zaszczepsiewiedza. pl, www.koalicajacervicalcancer.pl and numerous groups in social media. Unfortunately, there is a lack of feedback from the addressees of educational messages, including the answer to the question to what extent available information meets information needs and how it translates into knowledge/awareness of cervical cancer. In Polish publications assessing knowledge and awareness of cervical cancer, the conclusions about the low level of knowledge and the lack of awareness of disease risk and the possibilities of prevention are mentioned [6-11].

This study aims to assess the level of knowledge about cervical cancer and to contribute to the understanding of young women's attitudes towards cervical cancer and disease prevention.

\section{THE AIM}

The aim of the study was to assess the level of knowledge of young women about cervical cancer and risk factors for the development of this disease, in particular the role of HPV and the possibility of prophylactic vaccination, as well as the assessment of knowledge and attitude of young women to cytological screening.

\section{MATERIALS AND METHODS}

The study was conducted using the CAWI (Computer Assisted Web Interview) based on original questionnaire, in which the respondents were asked to complete the survey in electronic form online. The questionnaire was prepared with use of Google Forms tool, placed between November 
Table I. Baseline characteristics of studied population.

\begin{tabular}{|c|c|}
\hline & $\begin{array}{l}\text { Studied group } \\
(\mathrm{N}=\mathbf{2 0 5 8 )}\end{array}$ \\
\hline \multicolumn{2}{|l|}{ Age } \\
\hline mean (SD) & $22.8(3.8)$ \\
\hline range & $19.0-33.0$ \\
\hline median & 22.0 \\
\hline \multicolumn{2}{|l|}{ Age (intervals) } \\
\hline $19-20$ & $763(37.1 \%)$ \\
\hline $21-24$ & $731(35.5 \%)$ \\
\hline 25 and above & $564(27.4 \%)$ \\
\hline \multicolumn{2}{|l|}{ Place of residence } \\
\hline countryside & 307 (14.9\%) \\
\hline city $<10,000$ & $102(5.0 \%)$ \\
\hline $10,000-100,000$ & $479(23.3 \%)$ \\
\hline$>100,000$ & $1170(56.8 \%)$ \\
\hline \multicolumn{2}{|l|}{ School/work } \\
\hline college & $1295(62.9 \%)$ \\
\hline work & $644(31.3 \%)$ \\
\hline other & $119(5.8 \%)$ \\
\hline \multicolumn{2}{|l|}{ Smoking } \\
\hline no & $1311(63.7 \%)$ \\
\hline occasionally & $499(24.2 \%)$ \\
\hline yes & $248(12.0 \%)$ \\
\hline \multicolumn{2}{|l|}{ Number of sexual partners } \\
\hline not yet sexually active & 402 (19.5\%) \\
\hline 1 & $742(36.1 \%)$ \\
\hline $2-3$ & $529(25.7 \%)$ \\
\hline $4-5$ & $186(9.0 \%)$ \\
\hline more than 5 & 199 (9.7\%) \\
\hline
\end{tabular}

2018 and January 2019 on popular discussion groups in one of social media platform. It contained 27 questions, which covered the following areas: knowledge, primary prevention - vaccinations, secondary prevention - screening based on cytological tests, sexual behavior description and expectations regarding information on cervical cancer and HPV prophylaxis. Closed questions were asked with a nominal scale (YES/NO/DON'T KNOW), multiple-choice semi-open questions and Likert scale questions from 1 to 10 points, where the value of " 1 " was the minimum level, and 10 points - the maximum level.

\section{STATISTICAL ANALYSIS}

All statistical calculations were carried out using the StatSo$\mathrm{ft}$ Inc. statistical package STATISTICA (2014) (data analysis software system), version 12.0, www.statsoft.com and the Excel spreadsheet. In case of the two related variables model, Student's t-test or the Wilcoxon matched-pairs signed-ranks test was used. Chi-square independence tests were used for qualitative variables. In order to determine the relationship, power and direction between variables, the correlation analysis was used by calculating the Pearson and/or Spearman correlation coefficients. In all calculations, $\mathrm{p}=0.05$ was assumed as the level of significance.

\section{RESULTS}

The study was conducted in a group of 2058 women aged 19-33. Baseline characteristics of the studied population in terms of age, place of residence, occupational situation (school/work), health-related behaviors (smoking) and sexual behaviors (number of sexual partners), are presented in Table I.

In the study population, almost all respondents (98.4\%; $\mathrm{n}=2025$ ) came across the term "cervical cancer", $81.9 \%$

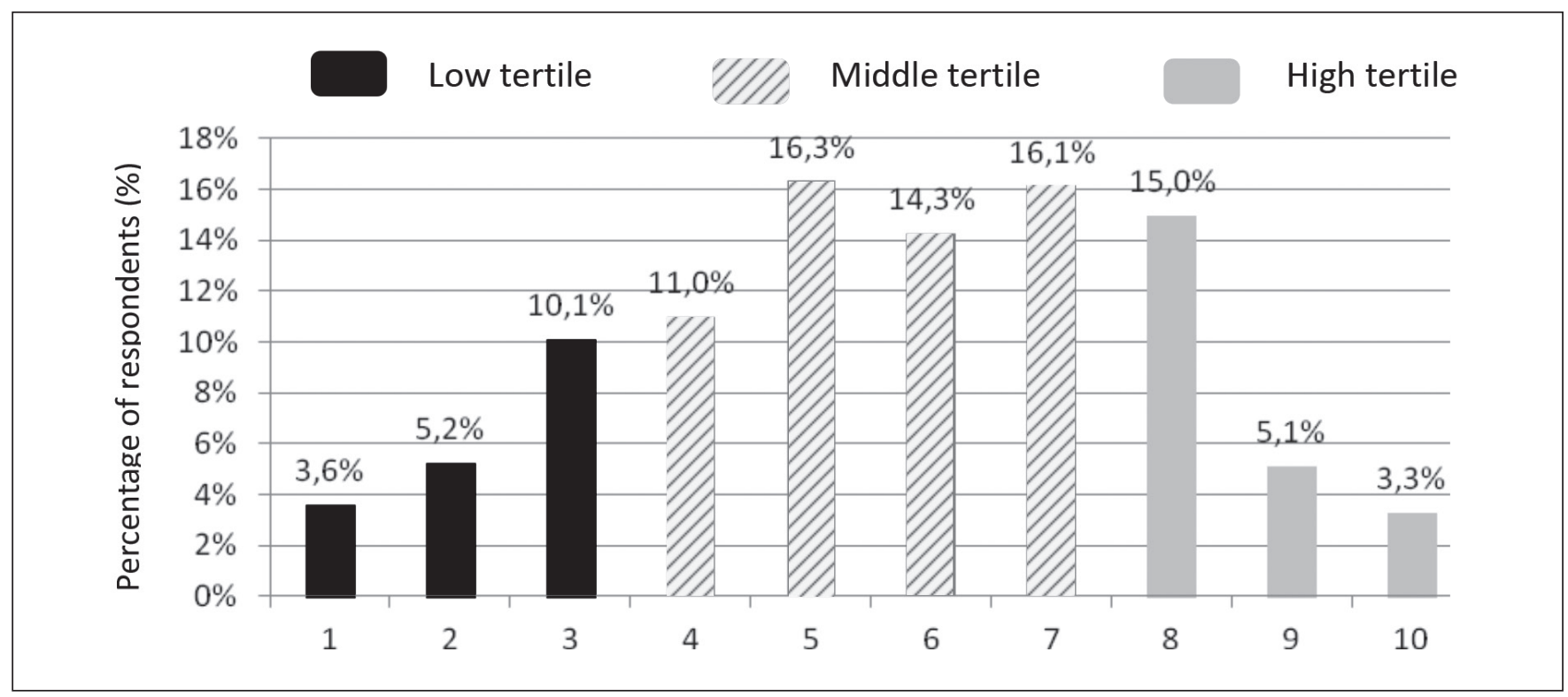

Fig. 1. Subjective respondents assessment of the level of own knowledge about cervical cancer on a scale of 1-10 points. 
Table II. Correlation between the answer to the question: "How would you rate your knowledge about the occurrence of cervical cancer" and the indicated risk factors.

\begin{tabular}{|c|c|c|c|}
\hline & $\begin{array}{l}\text { Answer: This is not } \\
\text { a risk factor }\end{array}$ & $\begin{array}{c}\text { Answer: This is a risk } \\
\text { factor }\end{array}$ & $P$-value \\
\hline Occurrence of cervical cancer in relatives & & & 0.0001 \\
\hline average level of knowledge in self-evaluation (SD) & $6.3(2.3)$ & $5.6(2.2)$ & \\
\hline median & 7.0 & 6.0 & \\
\hline Age $>\mathbf{5 0}$ years & & & 0.0114 \\
\hline average level of knowledge in self-evaluation (SD) & $5.6(2.3)$ & $5.8(2.1)$ & \\
\hline median & 6.0 & 6.0 & \\
\hline Alcohol consumption & & & 0.0001 \\
\hline average level of knowledge in self-evaluation (SD) & $5.6(2.2)$ & $6.4(2.2)$ & \\
\hline median & 6.0 & 7.0 & \\
\hline Smoking & & & 0.0001 \\
\hline average level of knowledge in self-evaluation (SD) & $5.5(2.2)$ & $6.0(2.2)$ & \\
\hline median & 5.0 & 6.0 & \\
\hline The use of hormonal contraception & & & 0.1094 \\
\hline average level of knowledge in self-evaluation (SD) & $5.6(2.2)$ & $5.8(2.2)$ & \\
\hline median & 6.0 & 6.0 & \\
\hline Early age of sexual initiation & & & 0.0100 \\
\hline average level of knowledge in self-evaluation (SD) & $5.3(2.1)$ & $6.8(2.0)$ & \\
\hline median & 5.0 & 7.0 & \\
\hline Many sex partners & & & 0.0100 \\
\hline average level of knowledge in self-evaluation (SD) & $5.0(2.1)$ & $6.4(2.1)$ & \\
\hline median & 5.0 & 7.0 & \\
\hline HPV infection & & & 0.0100 \\
\hline average level of knowledge in self-evaluation (SD) & $4.3(2.0)$ & $6.1(2.1)$ & \\
\hline median & 4.0 & 6.0 & \\
\hline HIV infection & & & 0.9627 \\
\hline average level of knowledge in self-evaluation (SD) & $5.7(2.2)$ & $5.7(2.4)$ & \\
\hline median & 6.0 & 6.0 & \\
\hline Recurrent genitourinary infections & & & 0.0001 \\
\hline average level of knowledge in self-evaluation (SD) & $5.8(2.2)$ & $5.4(2.2)$ & \\
\hline median & 6.0 & 5.0 & \\
\hline
\end{tabular}

$(\mathrm{n}=1685)$ indicated that the cause of cervical cancer may be HPV infection and $84.1 \%(n=1731)$ agreed with the statement that the occurrence of this disease can be prevented.

Participants of the study were asked to make a self-assessment of knowledge about cervical cancer on a scale of 1-10 points. In the whole study population, an average of 5.7 points (SD 2.2, median 6.0) was obtained, where $18.9 \%$ of the respondents indicated the level in the range of 1-3 points (lower tertile recognized by the authors as low level of knowledge), $57.7 \%$ in the range of $4-7$ points (middle tertile, considered as moderate level) and 23.3\% in the range $>8$ points (upper tertile, high level) (Fig. 1).

To the question: "What do you think may be a risk factor for cervical cancer?" the highest percentage of respondents indicated cervical cancer diagnosed in closest relatives
(85.3\%; $\mathrm{n}=1755)$ - not a significant risk factor and HPV infection $(77.7 \% ; n=1600)$. The early age of sexual initiation pointed out every fourth respondent. The distribution of responses in the whole studied population is shown in Fig. 2.

The relation between self-assessment of own knowledge about cervical cancer with the risk factors for the development of cervical cancer indicated by the respondents was analyzed. Respondents who indicated as a risk factor the occurrence of cervical cancer in close relatives and recurrent genitourinary infections - which in fact are not risk factors [4] - assessed their level of knowledge about cervical cancer statistically significantly lower compared to individuals who did not indicate these risk factors $(p=0.0001)$. On the other hand, women who indicated the following risk factors: HPV infection $(p=0.01)$, early 


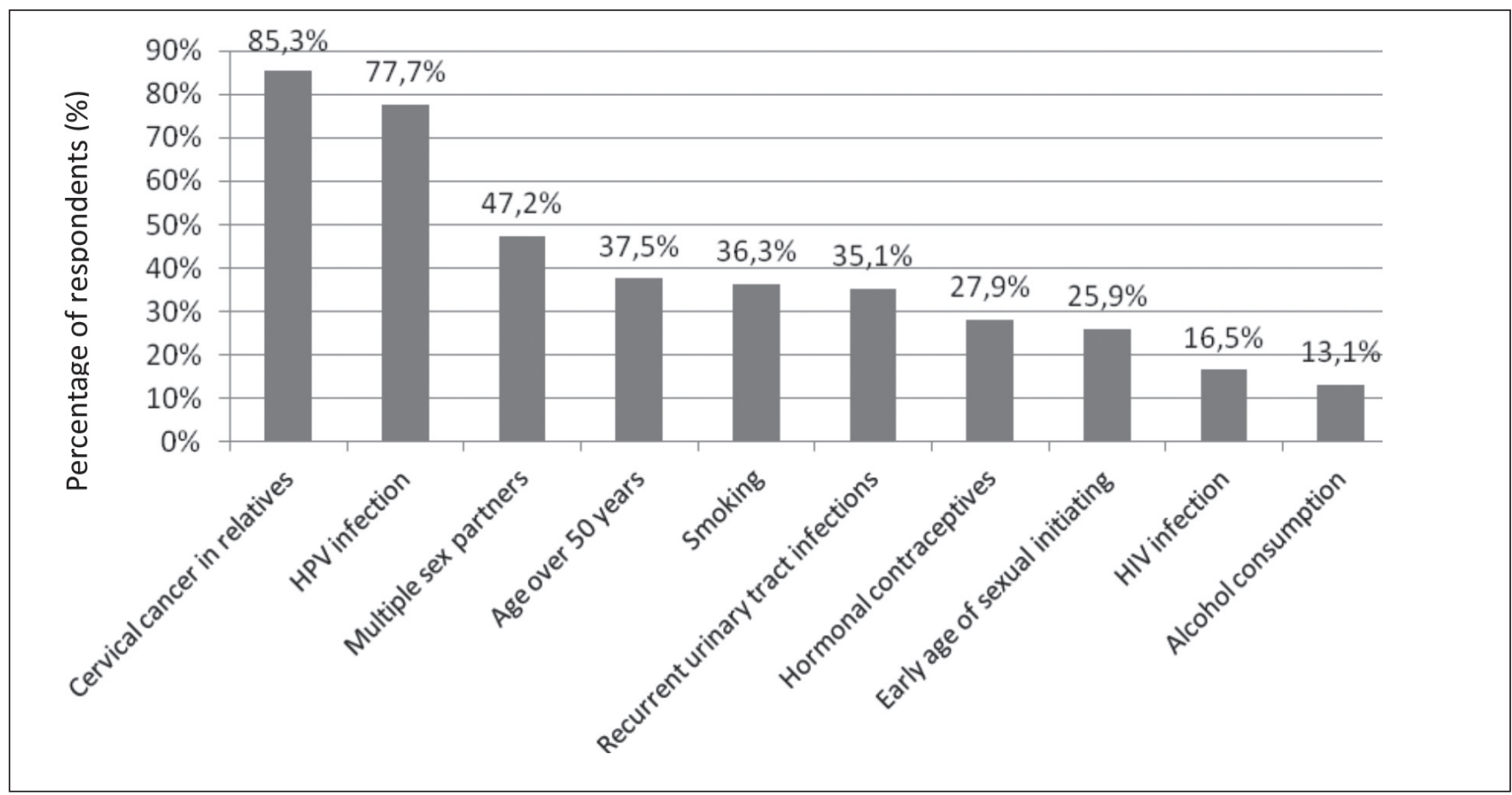

Fig. 2. Risk factors for cervical cancer identified by respondents in studied population.

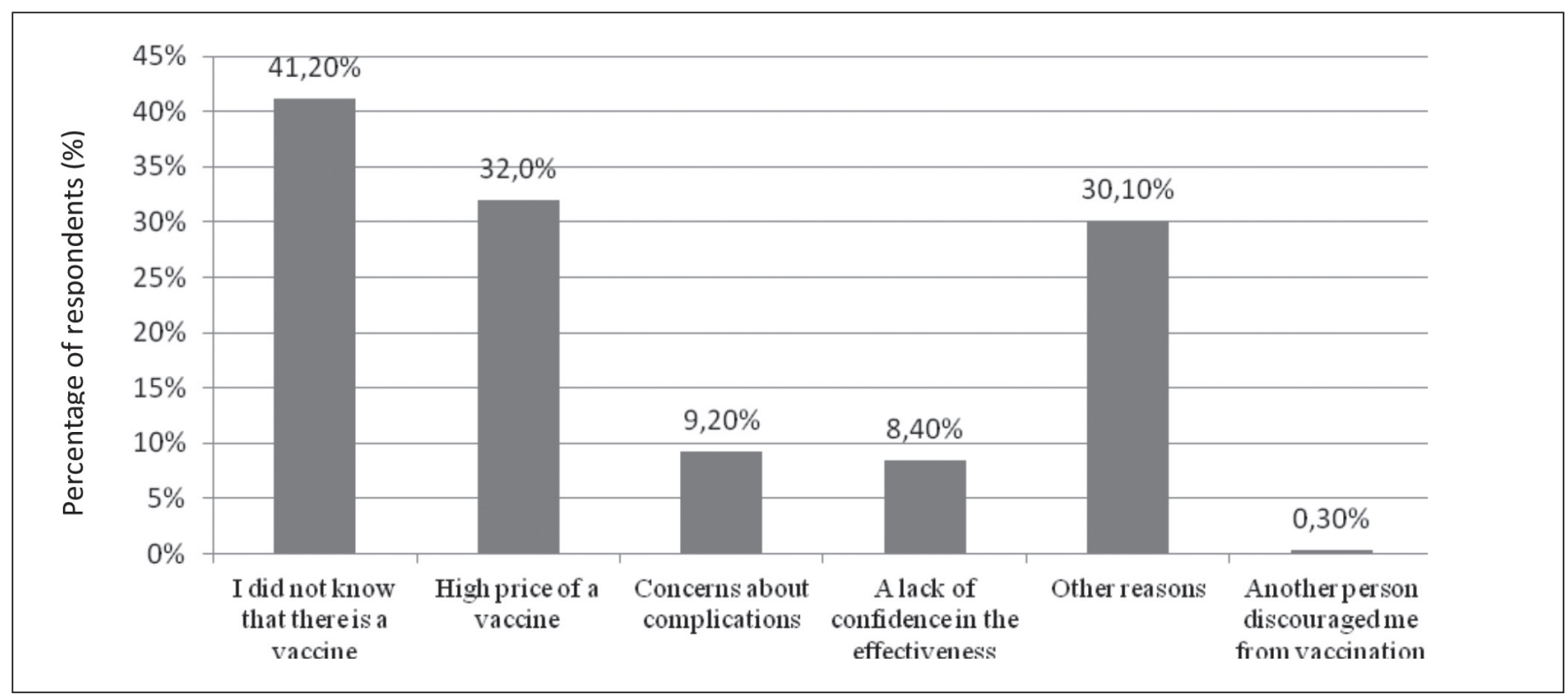

Fig. 3. Reasons for not-vaccinating against HPV.

sexual initiation $(p=0.01)$, many sexual partners $(p=0.01)$, age $>50$ years $(p=0.0114)$, alcohol consumption $(p=0.0001)$ and smoking $(\mathrm{p}=0.0001)$ assessed their level of knowledge about cervical cancer statistically significantly higher compared to individuals who did not indicate these risk factors (Table II).

There was no statistically significant correlation between the identification of cervical cancer risk factors and the age and place of residence of surveyed women.

Respondents $(n=430)$, who in the question about cervical cancer risk factors indicated all the following: HPV infection, early age of sexual initiation and many sexual partners, e.g. risk factors well known from the literature to correlate with cervical cancer [4] showed, that their average declared level of knowledge about cervical cancer is $7.1 / 10$ points (median 8.0$)$ and for other women $(n=1628)$ $5.3 / 10$ points (median 5.0) and this difference is statistically significant $(\mathrm{p}=0.0001)$.

When analyzing the level of awareness of cervical cancer risk factors in the study population, it turned out that only $15.7 \%(n=324)$ of women answered "yes" to the question: "Are you at higher risk of cervical cancer?", $55.9 \%(\mathrm{n}=1151)$ respondents answered "no", and $28.3 \%$ $(n=583)$ were unable to give a precise answer. In the group of women who declared having 4 and more sexual partners, i.e. in the individuals who should be included 
Table III. Comparative characteristics of women declaring/denying being at high risk of cervical cancer.

\begin{tabular}{cccc}
\hline & \multicolumn{3}{c}{ I am in a high-risk group } \\
\hline Number of sexual partners & $\begin{array}{c}\text { YES } \\
(\mathrm{N}=324)\end{array}$ & $\begin{array}{c}\text { DON'T KNOW } \\
(\mathrm{N}=583)\end{array}$ \\
\hline I didn't have intercourse yet & & & $1151)$ \\
\hline 1 & $39(9.7 \%)$ & $250(62.2 \%)$ & $206(27.8 \%)$ \\
\hline $2-3$ & $82(11.1 \%)$ & $454(61.2 \%)$ & $170(32.1 \%)$ \\
\hline $4-5$ & $87(16.4 \%)$ & $272(51.4 \%)$ & $46(24.7 \%)$ \\
\hline More than 5 & $46(24.7 \%)$ & $94(50.5 \%)$ & $48(24.1 \%)$ \\
\hline Have you been vaccinated against HPV? & $70(35.2 \%)$ & $81(40.7 \%)$ & $77(20.6 \%)$ \\
\hline yes & $59(15.8 \%)$ & $238(63.6 \%)$ & $389(27.8 \%)$ \\
\hline no & $223(15.9 \%)$ & $787(56.3 \%)$ & $112(42.9 \%)$ \\
\hline don't know & $32(12.3 \%)$ & $117(44.8 \%)$ & $5(20.8 \%)$ \\
\hline Do you smoke? & $10(41.7 \%)$ & $9(37.5 \%)$ & \\
\hline no & & & $337(25.7 \%)$ \\
\hline occasionally & $178(13.6 \%)$ & $156(31.3 \%)$ \\
\hline yes & $76(15.2 \%)$ & $98(60.7 \%)$ & $90(36.3 \%)$ \\
\hline
\end{tabular}

in the group of higher risk of cervical cancer $(n=385)$, the highest percentage were those who believed that they do not belong to this high risk group. Also among women non-vaccinated against HPV and smokers, the highest proportion were those believing they were not at high risk.

The characteristics of women in terms of self-assessment of belonging to cervical cancer risk group and selected risk factors are presented in Table III.

\section{PRIMARY PROPHYLAXIS - VACCINATIONS IN THE STUDIED POPULATION}

To the question: "Have you been vaccinated against HPV?", $18.2 \%(n=374)$ of respondents answered positively, while the negative answer was given by $68.0 \%(n=1399)$ of the respondents. The most common incentive/vaccination proposal came from parents $(58.8 \% ; n=220)$, pediatricians $(15.8 \% ; n=59)$, gynecologists $(6.2 \% ; n=23)$ and other people $(19.2 \% ; n=72)$.

Analysis of the declared level of knowledge among women vaccinated against HPV showed a statistically significant higher average in relation to the whole studied population $(6.3 / 10$ points vs $5.5 / 10$ points, $\mathrm{p}=0.0001)$. As the reason for not-vaccinating, the respondents showed the lack of knowledge about the existence/availability of the vaccine $(41.2 \% ; n=577)$ and its high price $(32.0 \% ; n=447)$. The distribution of responses in the studied population is shown in Fig. 3.

Interestingly, asking unvaccinated individuals $(\mathrm{n}=1399)$ "Would you vaccinate against HPV in the future?", 63.5\% $(n=1063)$ of respondents answered in the affirmative, expressing a willingness to vaccinate, only $7.0 \%$ responded negatively $(\mathrm{n}=118)$ and $29.5 \%(\mathrm{n}=493)$ women answered: "I do not know". People, who as the reason for not-vaccinating indicated a high price, were asked: "If you have not been vaccinated because of the high price of vaccination, what price would be acceptable for you?" In response to this question, women indicated PLN 256.6 as the average acceptable price for vaccination (SD PLN 196.0; median PLN 200.0). In the study group, only 8 women indicated the need for a full refund of vaccination as a condition for joining vaccinations.

\section{SECONDARY PROPHYLAXIS - CYTOLOGICALTESTS}

The main goal of prophylactic cytological examination according to the respondents is detection of pre-cancerous lesions and detection of vaginal inflammation (91.6\% and $48.5 \%$ respondents, respectively). The full structure of the answers to the question: "What does the cytological examination assess?" is shown in Fig. 4

In the whole analyzed population $17.1 \%(n=352)$ women indicated that they have not visited gynecologist yet, sporadic visits were declared by $19.0 \%(n=390)$ women, and visits once a year $29.4 \%(n=606)$ and more than once a year declared $34.5 \%(n=710)$ participants. To the question: "Did you have a Pap smear?" $62.4 \%$ of women answered in the affirmative, $36.3 \%$ responded negatively, while $1.3 \%$ were unsure of having this test. The vast majority of respondents $(58.4 \%)$ indicated that the first cytological examination should be performed after sexual initiation. The full structure of the answers to the question "When should the first cytological examination be performed?" is shown in Fig. 5. 


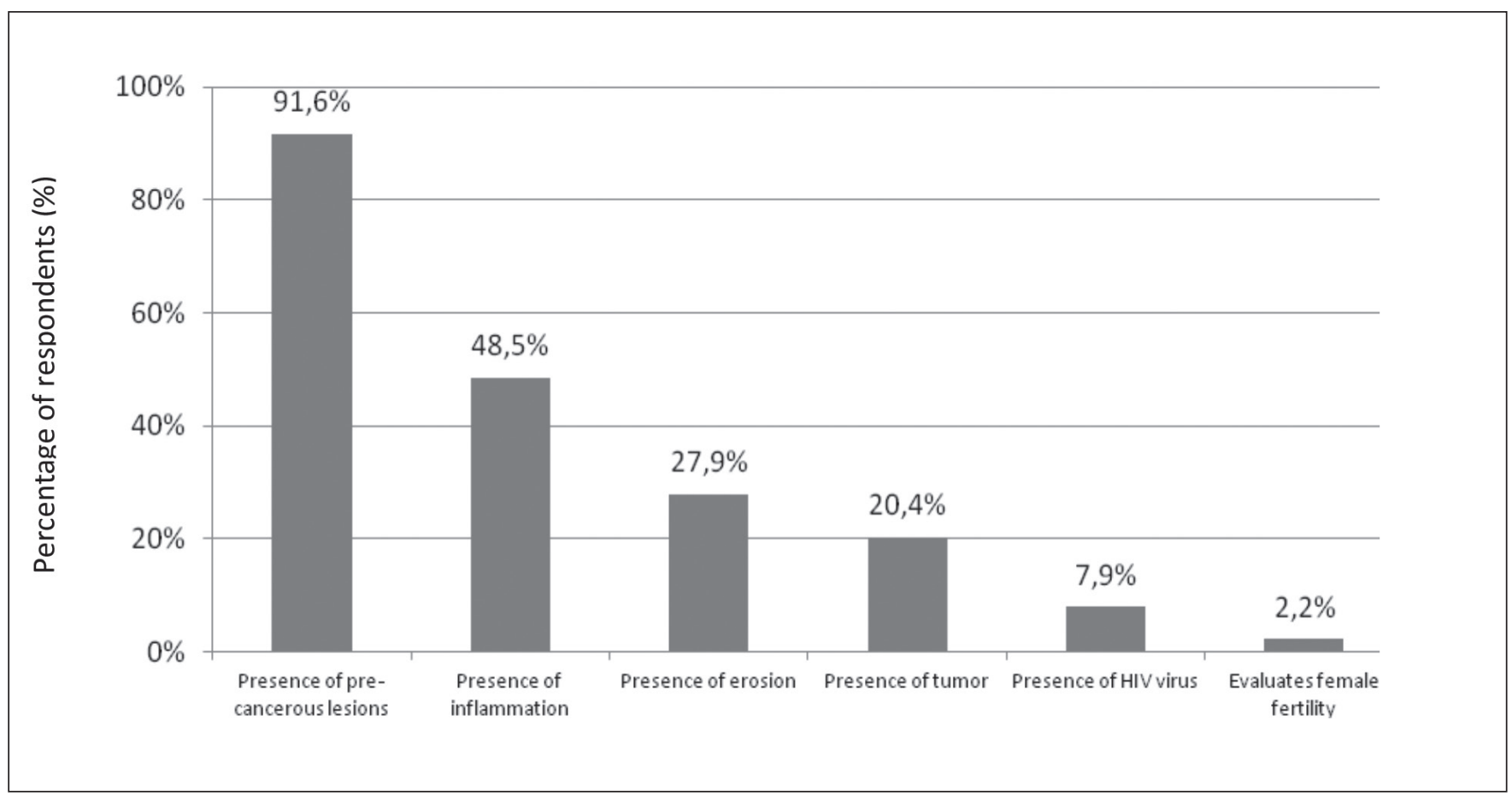

Fig. 4. The structure of the answers to the question: "What does the cytological examination assess?"

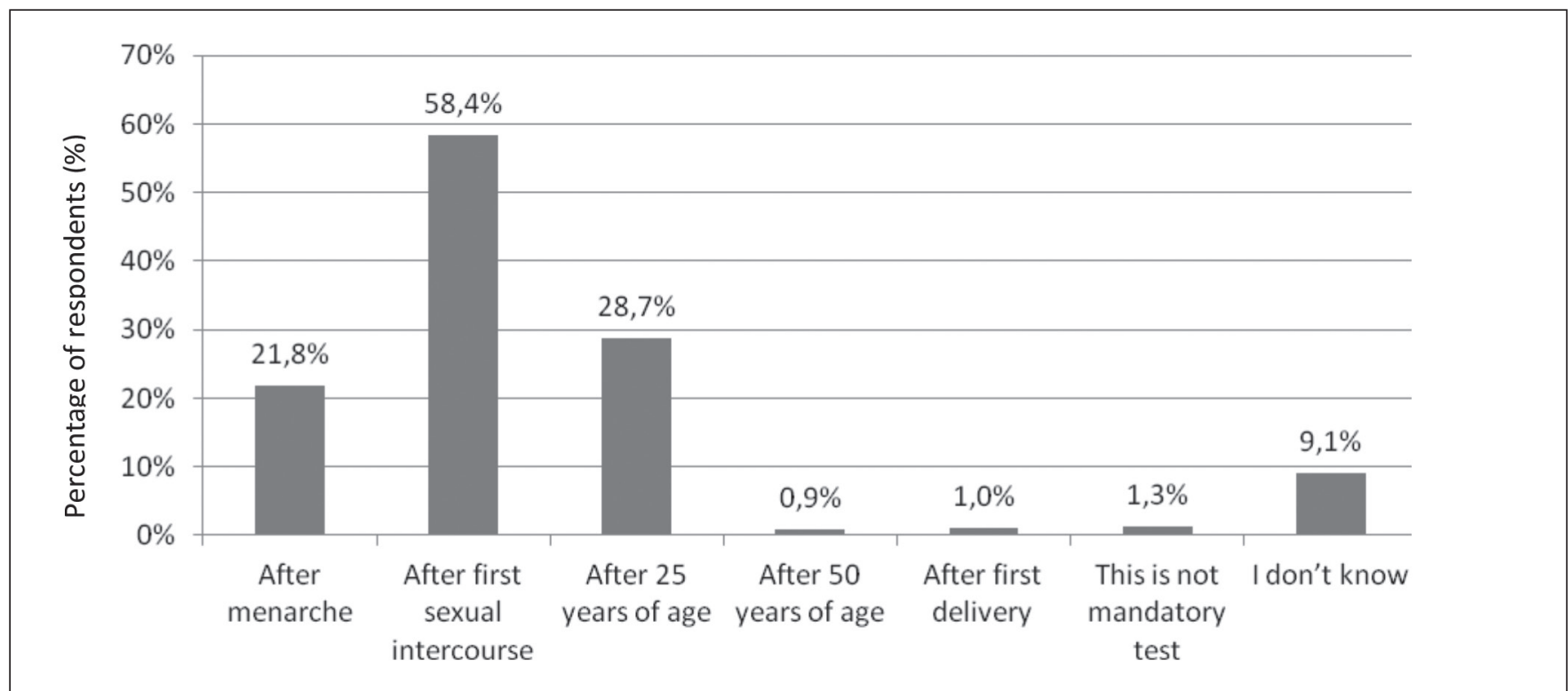

Fig. 5. The distribution of the answers to the question "When should the first cytological examination be performed?"

The analysis of the declared level of knowledge among women who have not yet visited the gynecologist $(n=352)$ showed a statistically significant lower average in relation to the population who had at least one gynecological visit $(\mathrm{n}=1706)(5.0 / 10$ points vs. $5.8 / 10$ points, $\mathrm{p}=0.0001)$.

In total $85.3 \%$ of the respondents answered that the amount of information on cervical cancer and HPV prophylaxis currently providing is insufficient.

\section{DISCUSSION}

In presented study, including one of the largest groups of young women in Poland [12-17] ever, in which the know- ledge of cervical cancer, risk factors as well as primary and secondary prevention was tested, the CAWI method was selected using a ready-made tool in the form of a Google form (https : //www.google.com/intl/pl/forms/). Thanks to the widespread access to the Internet, also in rural areas the online research is becoming a more and more popular research method. According to the CBOS report 2018, access to Internet in young people population ( $<34$ years) amounted to $96.0 \%$, while according to educational level it was $76.0 \%$ and $92.0 \%$ for individuals with secondary and higher education, respectively [18]. The distribution of respondents in presented study (14.9\% people were living in rural areas and $100 \%$ were $\leq 33$ years) confirms the lack 
of systemic bias of studied sample by limiting the scope of the research tool.

Poland is a country with a higher incidence $(+15 \%)$ and higher mortality $(+70 \%)$ due to cervical cancer compared to the average level in EU countries [2]. This is associated with a lower, compared to other countries, rates of early diagnosis of this disease due to lower awareness of young women about cervical cancer risk factors, lack of conviction about the need to participate in cytological screening and low rate of HPV vaccination [2,19-21]. These observations were confirmed in earlier studies (Sawaryn D 2011, Ulman-Włodarz I 2011, Cichońska M 2012, Pacewicz M 2012, Baran W 2013, Szykuła A 2013, Kalinowski P 2014, Mędrela-Kuder E 2014, Stefanek A 2014, Leszczyńska K 2015, Gawron Ż 2016, Sulima M 2016, Jankowska P 2017) [5-16,18,22].

In presented study, as many as $85.3 \%$ of respondents indicated the occurrence of cervical cancer in close relatives as a risk factor for the disease (for which a definite causal relationship with the development of cervical cancer was not described in the literature). At the same time, the well-recognized risk factors for this disease, such as HPV infection, many sexual partners and an early age of sexual initiation were significantly less frequently indicated, by $77.7 \%, 47.2 \%$ and $25.9 \%$ respondents, respectively. Higher rates in terms of a large number of sex partners (68.0\%) and early sexual initiation (52.0\%) as risk factors for cervical cancer were also reported by Sulima et al [22].

Among all respondents, 58.4\% indicated the time of sexual initiation as the recommended beginning of prophylactic $\mathrm{cy}$ tological tests. At the same time, approximately $17.0 \%$ of the surveyed women confirmed that they have had no visit in gynecologist yet, although $44.4 \%$ of the entire analyzed population admitted to having sex with two or more partners. The obtained result indicates a discrepancy between theoretical knowledge and behavior in practice and should be an important element of future educational campaigns. Preventive screening test is an extremely important instrument having a direct impact on the increase of detection of cervical cancer in the early stages and, as a consequence, increasing the chances for patient to be cured/ prolong life. In countries that successfully implemented preventive tests, a systematic decrease in mortality was observed. In Sweden in 1965, the incidence of cervical cancer was 20 per 100,000 women, while in 2012 it dropped to 6.5 per 100,000. The number of women reporting for Pap smears increased at the same time to $82 \%$ [23]. In the United Kingdom, a 74\% drop in the mortality rate due to cervical cancer has been noted over the past 40 years ( $24 \%$ in the last decade), among others because women have been persuaded to participate in the cervical cancer prevention program - participation in screening programs currently reaches up to $74 \%$ women [24].

In Poland, recognizing the legitimacy of population prophylaxis, in 2005 the Act introducing the National Program for Counteracting Cancer Diseases in 2006-2015 was adopted. In spite of information and education activities, media campaigns and personal invitations for testing, it failed to be successful in the form of decreasing morbidity and mortality rate due to cervical cancer $[25,26]$. The percentage of women qualifying for screening and participating in the program was $21-23 \%$ of which only approx. $7 \%$ applied thanks to the received personal invitation (complete data is unknown due to the lack of registers and participation of the private gynecological services market) [27]. Undoubtedly, it is necessary to thoroughly analyze the reasons for the lack of success of the Program in order to propose other, more effective tools leading to the increase of awareness and encouragement for preventive examinations.

Due to the prevalence of HPV, which is also the most common cause of sexually transmitted infections and the proven association between HPV infection and cervical cancer, WHO recommends prophylactic vaccination, which should be performed before sexual activity, preferably between 11 and 12 years of age. In Poland, vaccinations against the human papillomavirus (HPV) are included in the Protective Vaccine Program for 2019 in the category of "Recommended vaccinations", which means that they are not financed from the budget of the Ministry of Health [28]. Undoubtedly, high costs are a barrier to the generalization of vaccinations (in presented study $32 \%$ of respondents indicated the price as factor of not-vaccination against HPV), but other reasons indicated by the respondent included lack of knowledge about the existence of the vaccine (the highest percentage) (41.2\%) and lack of belief in effectiveness (8.4\%) as well as a risk of post-vaccination complications $(9.2 \%)$. The positive thing is that by asking unvaccinated persons about their willingness to vaccinate in the future, over $63.0 \%$ of respondents answered in the affirmative. An important factor contributing to higher vaccination rate is the increase in the awareness of parents, who according to our study in $58.8 \%$ cases encouraged their children to vaccinate. A similar recommendation was issued by Ganczak et al. highlighting the need to educate parents [29]. The average, acceptable pricelevel for all vaccinations indicated by respondents is approximately PLN 256.0. In terms of financing, free HPV vaccines offered by certain local governments within the framework of health promotion and preventive programs may be supportive.

Lack of awareness of the existence of vaccinations in the studied population is undoubtedly an important element of future educational activities. Evidence of the positive effect of educational activities was observed in many countries, including Denmark, where the level of HPV vaccination in 2018 was $73 \%$ [30]. It seems that a good channel to reach the target group could be social media, which is also confirmed by the wide participation of young women in our study, conducted via Internet.

\section{CONCLUSIONS}

1. Basic terms regarding cervical cancer, primary (vaccination) and secondary (prophylactic examinations) prevention have been well-known in the study population.

2. Knowledge about individual risk factors of cervical cancer and, consequently, the ability to identify oneself in the context of belonging to the group of higher risk is insufficient and requires improvement.

3. Due to the discrepancy between theoretical knowledge and behavior in practice, it is important to encourage women to implement appropriate pro-health attitudes, including performing regular cytological screening tests and participation in vaccination. 
4. HPV vaccination rate should be increased thanks to educational activities aimed at young women and parents of teenagers, informing about the availability of the vaccine and the benefits of its use, and by effectively reducing the price of vaccination and/or free access within health programs.

5. Due to the lack of information on cervical cancer and principles of prevention of this disease reported by the respondents, an educational campaign using social media should be considered.

\section{ACKNOWLEDGMENTS}

The authors acknowledge the medical writing assistance of Dariusz Stencel, MD, from DaFonte Dr Dariusz Stencel, during the development of this manuscript.

\section{REFERENCES}

1. Bray F, Ferlay J, Soerjomataram I et al. Global cancer statistics 2018: GLOBOCAN estimates of incidence and mortality worldwide for 36 cancers in 185 countries. CA Cancer J Clin. 2018, 68 (6): 394-424

2. Didkowska J, Wojciechowska U. Zachorowania i zgony na nowotwory złośliwe w Polsce. Krajowy Rejestr Nowotworów, Centrum Onkologii - Instytut im. Marii Skłodowskiej - Curie. Dostępne na stronie http:// onkologia.org.pl/k/epidemiologia/ accessed 2019.01.17

3. HPV-Szczepienia.Info http://szczepienia.pzh.gov.pl/szczepionki/hpv/ accessed 2019.01.17

4. Momenimovahed Z, Salehiniya H. Incidence, mortality and risk factors of cervical cancer in the world. Biomed Res Ther. 2017, 4 (12): 1795-1811

5. Petrosky E, Bocchini JA Jr, Hariri S et al. Centers for Disease Control and Prevention (CDC). Use of 9-valent human papillomavirus (HPV) vaccine: updated $\mathrm{HPV}$ vaccination recommendations of the advisory committee on immunization practices. MMWR Morb Mortal Wkly Rep. 2015 Mar 27; 64 (11): 300-4

6. Baran W, Kornacka K, Szela S. Ocena wiedzy kobiet z Podkarpacia na temat profilaktyki raka szyjki macicy. Przegląd Medyczny Uniwersytetu Rzeszowskiego i Narodowego Instytutu Leków. 2013, 311-318

7. Gawron Ż, Gajewska N, Gujska D et al. Education, Health and Sport. 2016, 6 (8): 41-53

8. Kalinowski P, Wala S. Wiedza o czynnikach ryzyka i metodach profilaktyki raka szyjki macicy wśród studentek szkół wyższych w Lublinie. Probl Hig Epidemiol. 2014, 95 (2): 460-464

9. Leszczyńska K, Franek G, Moskwa J et al. Wiedza kobiet na temat profilaktyki raka szyjki macicy. Zdrowie i Dobrostan. 2015,2

10. Mędrela-Kuder E. Poziom wiedzy z zakresu czynników ryzyka i profilaktyki raka szyjki macicy wśród studentek wybranych krakowskich uczelni. Pol. Przegląd Nauk o Zdrowiu. 2014; 1: 38

11. Ulman-Włodarz I, Nowosielski K, Romanik M et al. Świadomość profilaktyki raka szyjki macicy wśród kobiet zgłaszających się do poradni K. Ginekol Pol. 2011; 82 (1) :22-5

12. Cichońska M, Borek M, KrawczykW, Maciąg D. Wiedza kobiet w zakresie zapobiegania nowotworom piersi i raka szyjki macicy. Acta Scientifica Academiae Ostroviensis. 2012; 5-25

13. Jankowska P, Kikolska M, Kwiatkowska M et al. Poziom wiedzy na temat raka szyjki macicy wśród kobiet D0l: http://dx.doi.org/10.21784/ IwP.2017.002

14. Pacewicz M, Krajewska-KułakE, Krajewska-Ferishah K. Profilaktyka raka szyjki macicy - poziom wiedzy kobiet i mężczyzn. Medycyna Paliatywna. 2012; 4: 217-228
15. Sawaryn D, Wróbel A. Poziom wiedzy młodych dziewcząt na temat raka szyjki macicy. Medycyna Rodzinna. 2011, 2: 35-42

16. Szykuła A, Czarnecka J, Sienkiewicz Z et al. Wiedza studentek pielęgniarstwa na temat profilaktyki raka szyjki macicy. Piel Pol. 2013, 3 (49): 157-161

17. Stefanek A, Durka P. Poziom świadomości kobiet na temat profilaktyki raka szyjki macicy. Polski Przegląd Nauk o Zdrowiu. 2014, 1 (38)

18. CBOS Komunikat z badań Nr 62/2018 https://www.cbos.pl/SPISKOM. P0L/2018/K_062_18.PDF accessed 2019.01.17

19. Nowakowski A, Cybulski M, Śliwczyński A et al.The implementation of an organised cervical screening programme in Poland: an analysis of the adherence to European guidelines. BMC Cancer. 2015, 14; 15: 279

20. Anttila A, von Karsa L, Aasmaa A et al. Cervical cancer screening policies and coverage in Europe. Eur J Cancer. 2009; 45 (15): 2649-2658.

21. Döbrőssy L, Attila Kovács $A$, Budai A Inequalities in cervical screening practices in Europe Diversity and Equality in Health and Care. 2015; 12 (2): $48-53$

22. Sulima M, Lewicka M, Wiktor K et al. Ocena wiedzy kobiet na temat seksualnych czynników ryzyka raka szyjki macicy. Pomeranian J Life Sci. 2016; 62 (1):78-84

23. Wang J Effectiveness and equity of cervical cancer prevention: real-life evidence from organised programmes in Sweden https://openarchive. ki.se/xmlui/bitstream/handle/10616/46113/Thesis_Jiangrong_Wang. pdf accessed 2019.01.17

24. Cervical cancer statistics Cancer research UK https://www. cancerresearchuk.org/health-professional/cancer-statistics/statisticsby-cancer-type/cervical-cancer\#heading-Two accessed 2019.01.17

25. NIK o profilaktyce zdrowotnej w systemie ochrony zdrowia 24.05.2017 https://www.nik.gov.pl/aktualnosci/nik-0-profilaktyce-zdrowotnejw-systemie-ochrony-zdrowia.html accessed 2019.01.17

26. Nowakowski A, Wojciechowska U, Wieszczy Petal. Trends in cervical cancer incidence and mortality in Poland: is there an impact of the introduction of the organised screening? Eur J Epidemiol. 2017; 32 (6): 529-532

27. Nowakowski A, Cybulski M, Śliwczyński A et al. The implementation of an organised cervicalscreening programme in Poland: an analysis of the adherence to European guidelines. BMC Cancer. 2015, 15: 279

28. Dziennik Urzędowy MZz dn. 25.10. 2018 r. Poz. 104 https://gis.gov.pl/ wp-content/uploads/2018/01/akt.pdf accessed 2019.01.17

29. Ganczak M, Owsianka B, Korze M. Factors that predict parental willingness to have their children vaccinated against HPV in a country with low HPV vaccination coverage. Int. J. Environ. Res. Public Health. 2018, 15: 645

30. Lyngea E, Skorstengaardb M, Lübkerb CL, Thamsborgb L.HPV-vaccination impact in Denmark: is the vaccine working? Expert Review OfVaccines. 2018, 17, 9: 765-767

\section{Conflict of interest}

There is no conflict of interest

\author{
CORRESPONDING AUTHOR \\ Artur Kotowski \\ Member of Polish Association for Good Clinical Practice GCPPL, \\ Warsaw, Poland \\ e-mail:kotowski.a@gmail.com
}

Received: 30.01 .2019

Accepted: 25.02.2019 
PRACA ORYGINALNA

ORIGINAL ARTICLE

\title{
THE INFLUENCE OF VARIOUS METHODS OF ANESTHESIA ON TIME OF POSTOPERATIVE RECOVERY OF PATIENTS' CONCIOUSNESS AFTER CURETTAGE OF UTERINE CAVITY
}

\section{WPŁYW RÓŻNYCH METOD ZNIECZULENIA NA CZAS POWROTU ŚWIADOMOŚCI PO ZABIEGU U PACJENTEK PODDAWANYCH ŁYŻECZKOWANIU JAMY MACICY}

\author{
Maryne A. Georgiyants' ${ }^{1}$, Ganna V. Kolesnik², Olena V. Vysotska ${ }^{3}$, Olha M. Yurchenko ${ }^{4}$ \\ 'KHARKIV MEDICAL ACADEMY OF POSTGRADUATE EDUCATION, KHARKIV, UKRAINE \\ 2ACADEMY OF RECREATION TECHNOLOGIES AND LAW, LUTSK, UKRAINE \\ 3KHARKIV NATIONAL UNIVERSITY OF RADIOELECTRONICS, KHARKIV, UKRAINE \\ ${ }^{4}$ GRIGORIEV INSTITUTE FOR MEDICAL RADIOLOGY OF NATIONAL ACADEMY OF MEDICAL SCIENCE OF UKRAINE, KHARKIV, UKRAINE
}

\begin{abstract}
Introduction: Scientific information sources point to the significant effectiveness of curettage of uterine cavity (CUC) as a diagnostic and treatment mode of gynecologic oncology. Today the anesthesia service is able to satisfy virtually all the requirements of a surgeon and a female patient, however, some institutional factors, as for example postoperative recovery of consciousness, and factors influencing it, remain unaddressed.

The aim: to explore the possibilities of influence of different combinations and dosages of medical preparations used to provide monitored anesthesia care of CUC, to change the time of postoperative recovery of patient's consciousness.

Materials and methods: an interview of 96 patients by VAS, studies of cortisol, insulin and glucose levels in blood serum, measurements of time from the end of surgery to the awakening and complete recovery of consciousness and statistical processing of the results have been conducted.

Results: A combination of $50 \mathrm{mg}$ of dexketoprofen and half-dose drugs for narcosis can hasten the postoperative wake-up time by $38 \%$, while maintaining dosages can prolong by $37 \%$ on the contrary. There is a dose-dependent effect of drugs for narcosis on the time of full post-operative recovery of consciousness. The reduction of their dosages by half can reduce this time by almost $40 \%$.

Conclusions: the dosage modification of anesthetic drugs and their combinations may have a significant effect on the time of postoperative awaking and complete recovery of consciousness in female patients after CUC. As a result, it has a positive physiological, psychological and social effect.
\end{abstract}

KEY WORDS: outpatient gynecology, curettage of uterine cavity, time of postoperative recovery of the consciousness

Wiad Lek 2019, 72, 3, 336-342

\section{INTRODUCTION}

The growing speed of social and economic development $t$ poses a number of specific challenges to the healthcare industry. One of them is early recovery of proper qualities of life indicators of a patient after operative intervention. That is why the outpatient medicine becomes more and more popular. [1] These days in hospital environment of one day not only consulting assistance is provided but also diagnostic and treatment operative interventions are performed. Due to low injury rate, the possibility of rapid recovery after operative intervention and the absence of necessity for women to leave current affairs, the gynecology of one day has gained widespread popularity $[2 ; 3]$. Among the number of outpatient gynecological operations, the leading place is curettage of the uterine cavity (CUC) as one of the most effective diagnostic techniques of outpatient gynecology [4].
Scientists pay attention to a significant place of pathology of endometrium [5] and neoplasms of the uterine cavity among the total number of pathologies of the organs of the female genital sphere [6]. Information from the Center for Medical Statistics of the Ministry of Health of Ukraine shows that in 2017, under the conditions of local medical and preventive treatment facilities, almost 140,000 such interventions were conducted that were not related to termination of pregnancy [7].

The anesthetic achievement for a period of its history accounts for many variants of anesthesia, each element of which appeared and worked out in accordance with the requirements of a surgeon and a patient $[8 ; 9]$. Today, in the sphere of outpatient gynecology, anesthesia has reached the level where it can fully provide any anesthetic and surgical requirements during operational intervention. In everyday 
practice, with the objective of ensuring proper monitored anesthesia care of various combinations of antihistaminic and pro-kinetic preparations are used for narcosis, narcotic and non-narcotic analgesics, local anesthetic agents, etc. However, the depressive effect on the consciousness of certain product groups prolongs postoperative recovery of patients. The question of the time limits of such recovery of women after outpatient gynecological operations remains without due attention: the influence of combinations and dosages of anesthetic medical preparations on the duration of postoperative depression of consciousness, the influence on the life quality of women in the early postoperative period after outpatient operational interventions has not been studied yet.

As indicated by publications of world scientists, the study of the impact on the life quality of a significant number of medical and socio-medical factors in various fields of medical science $[10 ; 11]$. Particularly, in the field of gynecological surgery, the issues of changing the life quality under the influence of pain [12], psycho-physiological peculiarities of gynecological diseases, the therapy of which includes the surgical stage [13], etc. are currently considered.

Concerning postoperative recovery of consciousness, there are publications in which authors give the data of their studies of changes in the cognitive-intellectual sphere in the early postoperative period [14], self-identification of a person [15], depending on dosages of preparations used during anesthesia. The work of scientists from New Mexico (Yen $\mathrm{T}$ et al.) appears to be interesting. In their works they stated the practical achievements, gained under investigation of external shock therapy in sedation. A research was performed on the speed of postoperative recovery of consciousness and self-identification in time and space using different induction preparations [16].

It is necessary to operationalize the difference between such concepts as "awareness" and "consciousness". With the characteristics of the post-procedure and functional recoveries of CNS, depending on the need to perform one or another action relative to the patient, both concepts can be used. As for example Pasichnyk G.P. in his article uses the term "awareness" [17]. Analyzing it, we see that the data obtained during the BIS-monitoring and Aldrete scale characteristics were used to determine the moment of the possibility of restoring the physiology of the upper respiratory tract (tracheal extubation) and patient transfer to the postoperative department, in other words, the registration of the final autoregulation of the basic physiological characteristics of the organism. At this, the author points out that the termination of personal observation of the patient and transporting him to the postoperative department is already possible for the assessment on the Aldrete scale at least in 8 points (motion activity $\geq 1$ and consciousness $\geq 1$ point). The possibility of continuing, even not individual, but competent observation of the patient, separates the limits of the use of the terms "awareness" and "consciousness". Under the conditions of outpatient operational medicine, leaving the patient without competent observance is possible only if the consciousness is restored, that is, not only the basic physiological functions, such as hemodynamics, vascular tone, spontaneous breathing, etc., but also the full adequate restoration of self-identification as a personality, of his body in space and time, awareness and opportunity to formulate the purpose of life, correct implementation of elementary instructions of medical personnel, critical thinking. Only upon these conditions, the patient can be safely transferred to the general ward, and to stay not under the care of a physician. In such a case the patient transfer to a general ward is possible only after getting of 10 maximum possible Aldrete scale. Thus, the anesthesiologist can be sure that in the conditions of adequate post-operative analgesia the manifestation of the possible presence of an accentuation of personality traits of patient will not threaten life and health of him or people around. This question is especially important when working with the category of oncological patients with gynecological disorders. The somatopsychic aspect of oncological diseases can have a significant pathogenic effect on the structure of the individual, to destroy the established positive dominant, endanger the mental integrity of the individual and his mental health in general. Such an influence is especially important when taking into account the patients' life quality of gynecological hospital of one day. Staying of a patient under the care of a physician up to a total recovery of consciousness (not "awareness"!) is an important psychological factor with a sanology effect for both participants in the social relations of the "doctor-patient" system. The patient obtains calm and assurance in the necessity and urgency of providing medical care by a qualified medical worker in case of such need. The anesthesiologist, in his turn, has confidence in the impossibility of its occurrence after transfer to the general ward, the safety of leaving the patient without direct qualified supervision.

\section{JUSTIFICATION OF STUDY}

As is clear from the above mentioned, the period of postoperative recovery of consciousness has a significant influence on patients' life. Although, the outpatient anesthesiology of gynecologic hospitals of one day has not been investigated by the time characteristics of postoperative recovery of consciousness of patients after minor endo-uterine operational inventions. Possibility of influence and this factor is an important tool when working with such a specific cohort as women with oncological diseases. Specification of influential mechanisms on time of postoperative recovery of consciousness should give anesthesiologists practical recommendations for improving the life quality of patients of gynecological hospital of one day.

\section{THE AIM}

The objective of our work is to study the possibilities of influence of various combinations and dosages of medical preparations, used for anesthesia service of CUC, to change the time of postoperative recovery of patient's consciousness. 
Table I. Anthropometric and age characteristics $(\mathrm{M} \pm \mathrm{m})$

\begin{tabular}{cccc}
\hline Characteristic & Group I $(\mathbf{n = 3 2 )}$ & Group II ( $\mathbf{n = 3 2 )}$ & Group III ( $\mathbf{n = 3 2 )}$ \\
\hline Age & $41,6 \pm 1,45$ & $41,8 \pm 1,58$ & $44,8 \pm 1,15$ \\
\hline Height & $165,4 \pm 1,05$ & $166,5 \pm 1,14$ & $166,3 \pm 1,25$ \\
\hline Body weight & $71,8 \pm 2,43$ & $66,9 \pm 2,04$ & $68,8 \pm 2,41$ \\
\hline Body weight index & $26,3 \pm 0,95$ & $24,2 \pm 0,80$ & $24,3 \pm 1,19$ \\
\hline
\end{tabular}

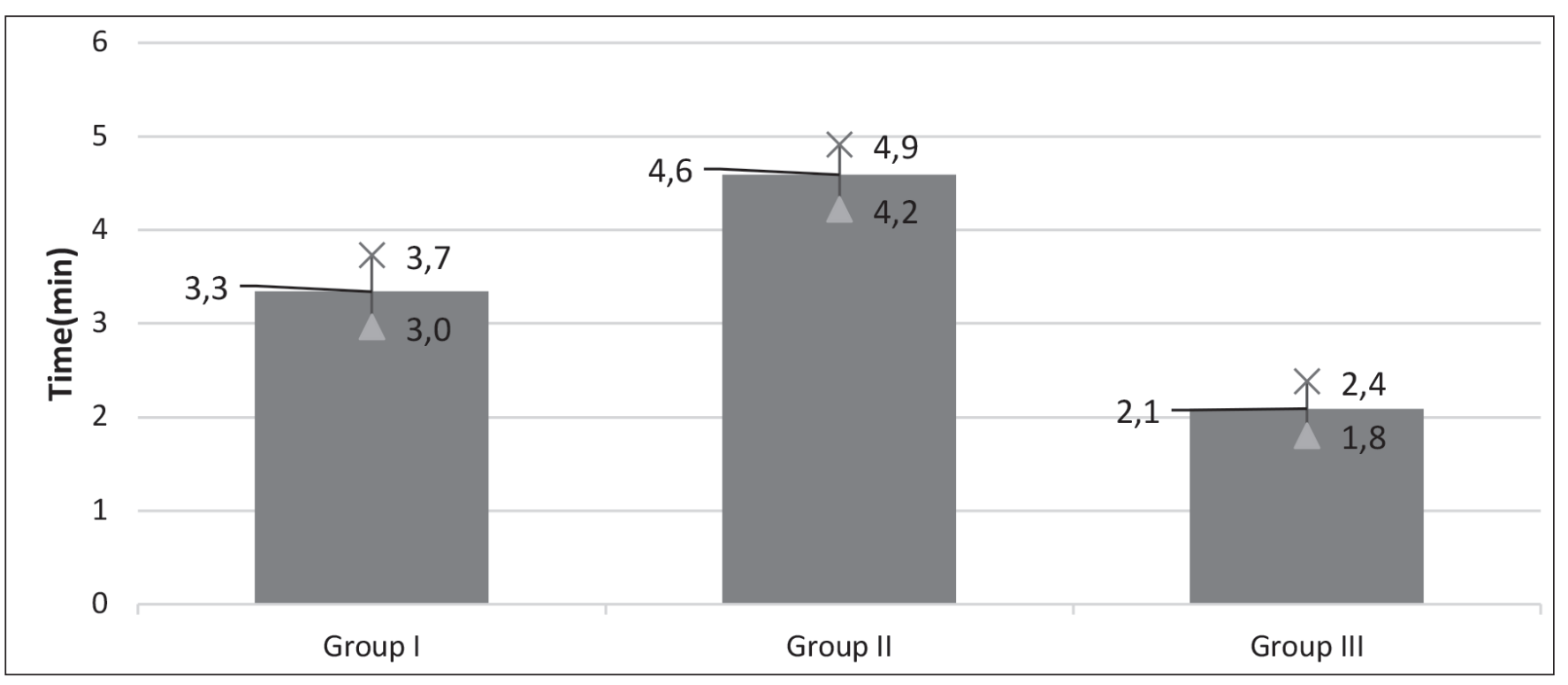

Fig. 1. Time of recovery of patient's consciousness after CUC in conditions of various kinds of anesthesia $(M \pm m)$; the differences are statistically significant between the indicators of all groups $(p<0,05)$.

\section{MATERIALS AND METHODS}

During 2017 on the basis of SI “Grigoriev's institute for medical radiology of National Academy of Medical Sciences of Ukraine", 96 female patients of working age with diagnostic and treatment purposes were maintained the curettage of uterine cavity. Women were included in the study after obtaining informed consent. Eligibility criteria have become: age of patients from 21 to 55 years; need for diagnosis of tumors or surgical removal of polyps in the uterine cavity and / or cervical canal; anesthetic risk for ASA I-II. Exclusionary criteria in their turn have become: the need for urgent intervention; severe accompanying pathology to a large extent exceeding the degree of surgical-anesthetic risk; chronic diseases in the stage of exacerbation; liver disease in violation of its metabolic functions. The intervention was carried out in hospital environment of one day. All women left the clinic on the operation day.

All women were randomly divided into III groups, 32 patients in each. The anthropometric and age characteristics of the group did not have statistically significant differences $(p>0,05)$ (Table I)

10 minutes prior to operational invention, all patients received intravenous preanesthetic medication, which consisted of atropine $0.01 \mathrm{mg} / \mathrm{kg}$, diphenhydramine hydrochloride $0.15 \mathrm{mg} / \mathrm{kg}$, and ondansetron $4 \mathrm{mg}$. The difference between the groups was the difference in medicamentous combinations and doses of anesthetic management. The group I is the observational group: anesthetic management consisted of a combination of propofol $2 \mathrm{mg} / \mathrm{kg}$, fentanyl $2 \mathrm{mg} / \mathrm{kg}$ and ketamine $2 \mathrm{mg} / \mathrm{kg}$;

In patients of the group II, the same combination was used for the anesthesia as for patients of the group I, but additionally, as a preanesthetic medication a preparation was inserted "on the table" from the group of non-steroidal anti-inflammatory agents (NSAIA), namely dexketoprofen at a dose of $50 \mathrm{mg}$. The medicamentous combination for the patients of group III was the same as of group II; however, the difference was the reduction of dosage for noninhalation narcosis (ketamine up to $1 \mathrm{mg} / \mathrm{kg}$ and fentanyl up to $1 \mathrm{mcg} / \mathrm{kg}$ ).

At the appearance of signs of awakening, such as mimic and motor activity, impression of respiratory movements, an additional infusion of propofol at a dose of $0.03 \mathrm{mg} / \mathrm{kg}$ was performed every 2 following minutes. The average duration of operational intervention was $7.00 \pm 0.308 \mathrm{~min}$. in the group I and up to $7.84 \pm 0.288 \mathrm{~min}$. in the group III. There are no statistically significant differences in the duration of the operation between the groups.

The time marking to awakening and complete recovery of consciousness began with the end of the operational intervention. The starting time of the awakening (the time of awakening) was recorded at the occurrence of arbitrary movements, mimic emotions and eye-opening. Complete recovery of consciousness was recorded when the patient received 10 points on the Aldrete scale. 
Table II. Time history of stress markers at the stages of the study under CUC (M $\pm \mathrm{m})$

\begin{tabular}{|c|c|c|c|}
\hline Characteristic & Groupl (n=32) & Group II $(n=32)$ & Group III (n=32) \\
\hline Cortisol 1 (nmol/l) & $456,7 \pm 13,42$ & $451,8 \pm 15,82$ & $446,0 \pm 11,07$ \\
\hline Cortisol 2 (nmol/l) & $488,4 \pm 14,14$ & $474,3 \pm 16,38$ & $472,5 \pm 11,55$ \\
\hline Cortisol 3 (nmol/l) & $534,5 \pm 15,27$ & $513,4 \pm 17,20$ & $509,3 \pm 12,02$ \\
\hline Insulin 1 (mcEd/l) & $10,0 \pm 0,38$ & $11,1 \pm 0,45$ & $10,5 \pm 0,45$ \\
\hline Insulin 2 (mcEd / I) & $8,2 \pm 0,36^{2,3}$ & $10,4 \pm 0,44$ & $9,5 \pm 0,41$ \\
\hline Insulin 3 (mcEd / I) & $4,6 \pm 0,23^{2,3}$ & $6,5 \pm 0,27$ & $5,9 \pm 0,25$ \\
\hline $\mathrm{C} / \mathrm{l} 1$ (nmol / mcEd) & $1,0 \pm 0,0$ & $1,0 \pm 0,0$ & $1,0 \pm 0,0$ \\
\hline $\mathrm{C} / \mathrm{l} 2(\mathrm{nmol} / \mathrm{mcEd})$ & $1,2 \pm 0,01^{2,3}$ & $1,16 \pm 0,01^{3}$ & $1,2 \pm 0,00$ \\
\hline $\mathrm{C} / \mathrm{l} 3(\mathrm{nmol} / \mathrm{mcEd})$ & $2,4 \pm 0,026^{2,3}$ & $2,0 \pm 0,01^{3}$ & $2,0 \pm 0,01$ \\
\hline Glucose 1 (mmol/l) & $4,7 \pm 0,17$ & $4,3 \pm 0,15$ & $4,5 \pm 0,19$ \\
\hline Glucose $2(\mathrm{mmol} / \mathrm{l})$ & $5,6 \pm 0,25$ & $5,4 \pm 0,30$ & $5,2 \pm 0,23$ \\
\hline Glucose $3(\mathrm{mmol} / \mathrm{l})$ & $8,1 \pm 0,38^{3}$ & $8,1 \pm 0,38$ & $6,9 \pm 0,32$ \\
\hline
\end{tabular}

Note: ${ }^{2}$ - the differences are statically significant $p<0,05$ between the following biochemical stress markers in comparison with the group II, ${ }^{3}-p<0,05$ in comparison with the group III $(p<0,05)$.

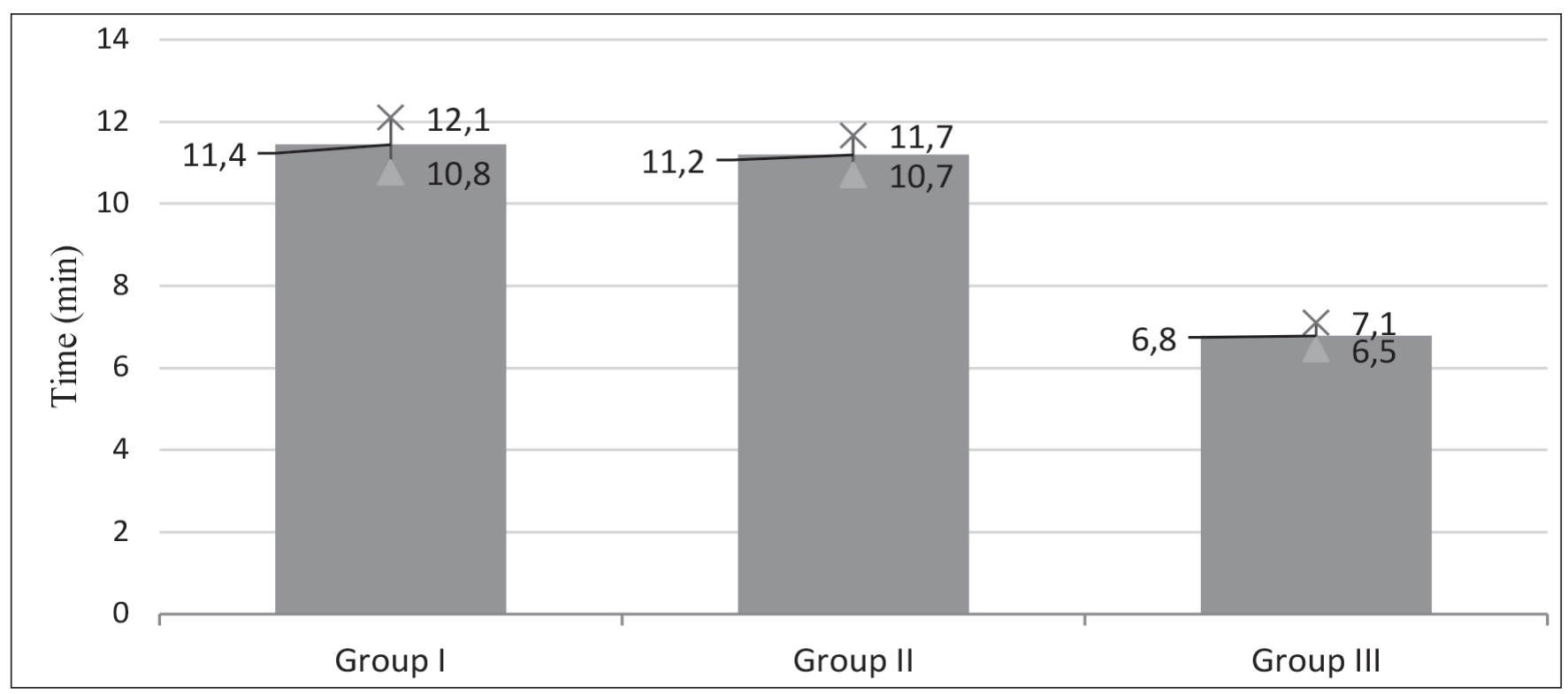

Fig. 2. Time of recovery of patient's consciousness after CUC in conditions of various kinds of anesthesia ( $M \pm m)$.

In order to control the proper level of analgesia, patients were offered inquiry on a VAS scale.

For the purpose of objectification of the pain level, the following stress markers were chosen: serum levels of cortisol, insulin, glucose. The determination of serum of cortisol and insulin was performed by ELISA technique with the sets of reagents "SSS-EIA-Steroid-Cortisol" and "Insulin-EIA-BEST", respectively.

The serum glucose level was measured by calorimetric method using the "Liquick Cor-GLUCOSE" diagnostic kit. Cortisol-insulin index $(\mathrm{C} / \mathrm{I})$, which was calculated mathematically by the formula 1 , was also studied.

Formula 1. Calculation formula $\mathrm{C} / \mathrm{I}$ is developed by Panin L. E. [18]

$C / I \mathrm{x}=$ Cx (cortisolinthestudyphase $) * 100 \% / C 1$ (cortisolpreoperatively) $C / I \mathrm{x}=\frac{C \mathrm{x}(\text { cortisolinthestudyphase }) * 100 \% / C 1(\text { cortisolpreoperatively })}{\text { Ix }(\text { insulininthestudyphase }) * 100 \% / I 1 \text { (insulinpreoperatively })}$
During the study, the pain level was monitored three times: for the first time, the survey and monitoring of laboratory parameters were performed prior to operation in the patient's presence in the ward (before she was transferred to the manipulation room in order to reduce the level of psycho-emotional stress, which theoretically could have an effect on the level of the laboratory parameters under study). The results of the first study were used in the following as control and are marked with the number" 1 ". The second checkpoint was the time of consciousness recovery and was designated as number " 2 ". For the third time the control of the pain level was carried out one hour after the second; marking - " 3 ”.

Statistical processing of results was performed using thr computer program for Windows the SPSS 19 (USA). The analysis of the studied parameters with regard to the nor- 
Table III. Survey findings of patients on VAS before and after the CUC under the conditions of various kinds of anesthesia ( $\mathrm{M} \pm \mathrm{m}$ )

\begin{tabular}{cccc}
\hline Characteristic & Group I $(\mathbf{n}=\mathbf{3 2})$ & Group II $(\mathbf{n}=\mathbf{3 2})$ & Group III ( $\mathbf{n = 3 2 )}$ \\
\hline VAS 1 (points) & $0,1 \pm 0,05$ & $0,1 \pm 0,05$ & $0,1 \pm 0,05$ \\
\hline VAS 2 (points) & $3,0 \pm 0,17$ & $2,7 \pm 0,15^{3}$ & $3,4 \pm 0,18$ \\
\hline VAS 3 (points) & $4,3 \pm 0,20$ & $4,1 \pm 0,20$ & $4,4 \pm 0,18$ \\
\hline
\end{tabular}

Note: ${ }^{3}$ - differences are statistically significant in comparison with the group III $(p<0,05)$.

mality of distribution was performed by the Shapiro-Wilk's test. Descriptive statistics for quantitative indicators were represented as average arithmetic and standard error of the mean $-\mathrm{M} \pm \mathrm{m}$. For the determination of distinctions between independent samples Student's test was used. The level $\mathrm{p}<0,05$ was considered as significant.

\section{RESULTS}

When investigating the timeframes of postoperative recovery of consciousness after curettage of uterine cavity, it was found that the average time of awakening in the observational group was $3.3 \pm 0.4 \mathrm{~min}$. When using dexketoprofen in combination with ketamine and fentanyl in full doses (group II), this time increased by $37 \%$ and amounted to $4.5 \pm 0.4 \mathrm{~min}$. Half dose reduction of ketamine to fentanyl (group III) led to a significant reduction in time of awakening (by 38\%) compared to the observational group, that is, it reached only $2.1 \pm 0.3 \mathrm{~min}$. (Fig. 1 )

The time for complete restoration of consciousness in the groups I and II was $11.4 \pm 0.7$ and $11.2 \pm 0.5 \mathrm{~min}-$ utes, respectively. Statistically significant differences between these groups were not detected ( $p>0.05)$. For patients of the group III, this time was considerably less than that in other study groups and lasted just over 6.5 minutes, which was about $60 \%$ of the time when complete consciousness was recovered in groups I and II (Figure 2).

Results of monitoring survey of biochemical stress factors are represented in the table II. Keeping watch over the growth of stress level with the course of time

Differences are statistically significant between biochemical markers of stress during runtime, namely by comparison of groups I and II, I and III, and $2^{\text {nd }}$ and $3^{\text {rd }}$ monitoring points $(\mathrm{p}<0,001)$.

Characteristics of survey findings by VAS is the following and is represented in the table III.

\section{DISCUSSION}

Before starting the discussion about time response characteristics of postoperative recovery of female patients of CUC, it is necessary to prove the analgesic effectiveness of all anesthetic techniques under investigation. Significant difference between C/I 2 indicators in all groups are explained by the effectiveness of dexketoprofen, as the preparation of intraoperative anesthesia of minor gynecological operational inter- ventions. This can be seen in the table II, in which the direct indicators of $\mathrm{C} / \mathrm{I}$ are described.

We see that $\mathrm{C} / \mathrm{I}$ in the group I is higher than the same indicator in groups II and III. The same picture can be seen by the example of insulin indicators. The difference between levels of insulin 2 in groups I and II, as well as in groups I and III (table II) testifies to the expediency of using dexketoprofen as part of the intravenous anesthesia of CUC as an additional one.

The subjective measurement of the pain syndrome level, presented by the results of the VAS scale, shows that all three of the investigated methods of CUC anesthesia are effective. VAS 2 indicators, shown in table III in all groups is less than mark " 4 ", which indicates a low level of early postsurgical pain syndrome that does not require additional anesthesia.

To the above mentioned data, it makes sense to remark on the indicators of VAS 2 and C/I 2, which in group III are greater than those of group II (table II and III). Their reliable statistical differences may indicate a decrease in the effectiveness of the analgesic component of anesthesia in group III. However, the numerical characteristic of the pain syndrome level for VAS in patients of group III is also less than 4 points, which proves the allowability of such a decrease.

In examining indicators $\mathrm{C} / \mathrm{I}$ and VAS indicators, obtained an hour after the recovery of consciousness, we observe an increase in the intensity of pain syndrome without a clear regularity of correlations of indicators of stress factors, which is explained by the full completion of the analgesic effect of preparations for narcosis. The conclusion is drawn on the expediency of considering the pain relief that occurs during this time period as postoperative, and the search for specific types of analgesia is appropriate for the struggle against pain in patients after the CUC.

V.G. Bayda and co-author (2008) argue that there is an influence of a combination of anesthetic group preparations on the tine of postoperative adaptation of patients of the one-day hospital [19]. However, their studies do not cover such a subtle aspect of this process as the time to recover consciousness after the end of operation. Such a time has been investigated in patients, who have undergone, although minimally invasive, but requiring complete hospitalization, operations [20].

In order to deepen knowledge on the time of postoperative recovery of consciousness in groups of ambulatory patients, the analysis of the data presented in fig. 1 has been carried out, which proves that the strengthening of the analgesic component of monitored 
anesthesia care, together with the preservation of the total dosage of ketamine and fentanyl, prolongs the recovery time of the patients. Currently, additional anesthesia, along with the dose reduction of anesthetic preparations, is able to accelerate the recovery time almost by a factor of two, which may be explained by a decrease in pain perception. Although NSAIDs do not have a direct influence on the perception and treatment of pain impulse with the central nervous system, however, the inhibition of the formation of prostaglandins synthesized from arachidonic acid by inhibition of cyclooxygenase in the tissues of the uterus under curettage of the uterine cavity reduces the sensitivity of the nociceptive receptors of the cerebral cortex to histamine and bradykinin. On the other hand, the inhibition of perception is relatively enhancing the effect of the hypnotic component of anesthesia. A significant difference in the recovery time of patients in group III (by almost 50\%) compared with groups I and II $(\mathrm{p}<0.05)$ indicates dose-dependent clinical efficacy in reduction of ketamine and fentanyl doses.

An authentic statistical difference between the temporal rates of awakening of patients of the groups I and II, which is shown in fig. 1 indicates the effectiveness of dexketoprofen as an additional analgesic preparation for minor gynecological operational interventions that can affect the time of postoperative recovery due to additional analgesic effect.

Regarding the time of complete recovery of consciousness (fig. 2), based on the lack of statistical significance between the groups I and II and its presence between groups I and II, as well as between II and III, we can assert that the possibility of influencing the investigated parameters by temporal pharmacodynamics dose-dependent effects of preparations for anesthesia without the effect of an additional analgesic component.

The obtained results indicate a significant effect of the combination of $50 \mathrm{mg}$ of dexketoprofen and half-doses of ketamine and fentanyl at the time of postoperative recovery of consciousness of patients after CUC. Such a combination may be used by practicing anesthesiologists for the purpose of life quality improvement of patients, that must undergo CUC under the conditions of gynecological hospital of one day, the correspondence of monitored anesthesia care of the CUC to the principles of the multimodal strategy of case management "Fast Track Surgery" and outpatient medicine in general.

Scientists should pay attention on the fact, that in the study only injectable preparations of anesthetic drugs were used. A rightful place in the outpatient anesthetic unit is occupied by inhalation anesthetics, the use of which, as is known, also provides a rapid postoperative recovery of consciousness. However, due to the high cost of these preparations and the absence of an institution on the basis of which the research was carried out on material and technical equipment for their use, the influence of the use of inhalation anesthetics during CUC for the duration of the postoperative recovery of consciousness of patients in the gynecological hospital was not carried out. This fact opens the door to the further study of this issue.

\section{CONCLUSIONS}

As a part of the study of time-response characteristics of postoperative recovery of consciousness of working age patients, which under the conditions of one-day hospital were made CUC, it was found that:

1. The anesthesia of female patients, which underwent CUC in 1 hour after recovery of consciousness must be considered in post operational context, to which the influence of intraoperative analgesia is smoothened over;

2. A combination of $50 \mathrm{mg}$ of dexketoprofen and preparations for narcosis in half-dose is able to speed up the time of postoperative awakening by $38 \%$ in comparison with classic medicamentous anesthetic combination, retaining the dosages - alternatively to increase by $37 \%$;

3. There is a dose-dependent influence of preparations for narcosis for the time of total postoperative recovery of consciousness; their under dosing when combined with dexketoprofen at a dose of $50 \mathrm{mg}$ is able to reduce this time almost by $40 \%$ and may be used by practicing anesthesiologists for the purpose of improvement of life quality of female patients, which were indicated the CUC under the conditions of gynecological hospital of one day, correspondence of monitored anesthesia care of CUC to the principals of multimodal strategy of interventional case management «Fast Track Surgery» and outpatient medicine in general.

\section{REFERENCES}

1. Szostek JH, Wieland ML, Post JA et al. Update in Outpatient General Internal Medicine: Practice-Changing Evidence Published in 2015. Am J Med. 2016; 129(8): e13-18. doi: 10.1016/j.amjmed.2016.03.004.

2. Clark TJ, Middleton L, Cooper NA et al. A randomised controlled trial of Outpatient versus inpatient Polyp Treatment (OPT) for abnormal uterine bleeding. Health Technol Assess. 2015; 19(61):1-194. doi: 10.3310/hta19610.

3. Policiano C, Pimenta M, Martins D et al. Outpatient versus inpatient cervix priming with Foley catheter: A randomized trial. Eur J Obstet Gynecol Reprod Biol. 2017; 210:1-6. doi: 10.1016/j.ejogrb.2016.11.026.

4. Rauf $R$, Shaheen A, Sadia $S$ et al. Outpatient endometrial biopsy with Pipelle vs diagnostic dilatation and curettage./ J Ayub Med Coll Abbottabad. 2014; 26(2): 145-148.

5. Tatarchuk TF, Kalugina LV, Tutchenko TN. Giperplasticheskie processy jendometrija: chto novogo? [Endometrial hyperplastic processes: what's new?]. Reproduktivnaja jendokrinologija. 2015; 5(25): 7-13. doi: 10.18370/2309-4117.2015.25.7-13. (In Russia)

6. Boljuh BA, Petrushenko VV, Tkach AA et al. Diagnostyka ta likuvannja zlojakisnyh novoutvoren': metodychni vkazivky dlja organizacii' samostijnoi' roboty studentiv [Diagnosis and treatment of malignant neoplasms: methodological guidelines for the organization of independent work of students]. Vinnycja:DP «Derzhavna kartografichna fabryka»; 2012, p. 196, 206. (In Ukraine)

7. Centr medychnoi' statystyky MOZ Ukrai'ny. Dovidnyk „Pokaznyky zdorov'ja naselennja ta vykorystannja resursiv ohorony zdorov'ja v Ukrai'ni za 2017 rik" [Directory "Health Indicators and Healthcare Resources in Ukraine for 2017"]. http://medstat.gov.ua/ukr/statdov. html. (In Ukraine) 
8. Limwatanapan N, Chalapati W, Songthamwat S et al. Lidocaine Spray Versus Paracervical Block During Loop Electrosurgical Excision Procedure: A Randomized Trial. J Low Genit Tract Dis. 2018; 22(1):38-41. doi: 10.1097/LGT.0000000000000365.

9. Quail J, Spence D Hannon M. Perioperative Gabapentin Improves Patient-Centered Outcomes After Inguinal Hernia Repair. Mil Med. 2017; 182(11):e2052-e2055. doi: 10.7205/MILMED-D-17-00107.

10. Alexiou KI, Roushias A, Varitimidis SE et al. Quality of life and psychological consequences in elderly patients after a hip fracture: a review. Clin Interv Aging. 2018; 13:143-150. doi: 10.2147/CIA.S150067.

11. Maillard J, Elia N, Haller CS et al. Preoperative and early postoperative quality of life after major surgery - a prospective observational study. Health Qual Life Outcomes. 2015;13:12. doi: 10.1186/s12955-014-0194-0.

12. Zechmeister JR, Pua TL, Boyd LR et al. A prospective comparison of postoperative pain and quality of life in robotic assisted vs conventional laparoscopic gynecologic surgery. Am J Obstet Gynecol. 2015; 212(2):e17. doi: 10.1016/j.ajog.2014.08.003.

13. Cosentino C,SgromoD,MerisioCetal.Psychophysiological Adjustmentto Ovarian Cancer: Preliminary Study on Italian Women Condition. Appl Psychophysiol Biofeedback. 2018; 43(2):161-168. doi: 10.1007/s10484-018-9395-3.

14. Mikuni I, Harada S, Yakushiji R et al. Effects of changing from sevoflurane to desflurane on the recovery profile after sevoflurane induction: a randomized controlled study. Can J Anaesth. 2016;63(3):290-297. doi: 10.1007/s12630-015-0514-9.

15. Seo JH, Goo EK, Song IA et al. Influence of a modified propofol equilibration rate constant $(\mathrm{k}(\mathrm{e} 0)$ ) on the effect-site concentration at loss and recovery of consciousness with the Marsh model. Anaesthesia.2013; 68(12):1232-1238. doi: 10.1111/anae.12419.
16. Yen T, Khafaja M, Lam N et al. Post-electroconvulsive therapy recovery and reorientation time with methohexital and ketamine: a randomized, longitudinal, crossover design trial. J ECT. 2015; 31(1):20-25. doi: 10.1097/YCT.0000000000000132.

17. Pasichnyk GP. Osoblyvosti pisljaoperacijnogo periodu ta intensyvnoi' terapii' u pacijentiv, prooperovanyh z pryvodu adenomy gipofiz [Features of postoperative period and intensive care in patients operated for pituitary adenoma]. Ukrai'ns'kyj medychnyj chasopys. 2015; 4(108):95-96. (In Ukraine)

18. Panin L.E. Biohimicheskie mehanizmy stressa [Biochemical mechanisms of stress]. Novosibirsk: Nauka, Sibirskoe otdelenie;1983, p. 240. (In Russia)

19. Bajda VG, Svintukovs'kyj MJu, Andrejeva MO et al. Anestezija pry «malyh» hirurgichnyh operacijah u stacionari odnogo dnja z tochky zoru i'i' komfortnosti [Anesthesia with «small» surgical operations in a hospital of one day in terms of its comfort]. Praktyka i dosvid. 2008; 2:44-51. (In Ukraine)

20. Krylov SV, Galushko OA, Nedashkivs'kyj SM et al. Porivnjal'na harakterystyka skladovyh bagatokomponentnoi' anestezii' pry laparoskopichnyh holecystektomijah [Comparative characteristics of components of multicomponent anesthesia in laparoscopic cholecystectomies]. Simejna medycyna. 2016; 3:61-65. (In Ukraine)

\section{Authors' contributions:}

According to the order of the Authorship.

\section{Conflict of interest:}

The Authors declare no conflict of interest.

\section{CORRESPONDING AUTHOR} Olha M. Yurchenko

Grigoriev Institute for medical Radiology of National Academy of Medical Science of Ukraine

Pushkinska str. 82, 61024 Kharkiv, Ukraine

tel: +380977978780

e-mail: olge.yurchenko@gmail.com

Received: 10.11 .2018

Accepted: 20.02.2019 
PRACA ORYGINALNA

ORIGINAL ARTICLE

\title{
CHOICE OF SURGICAL TACTICS AT THE STAGE OF PREOPERATIVE PREPARATION OF PATIENTS WITH BILIARY SEPSIS
}

\section{WYBÓR POSTĘPOWANIA CHIRURGICZNEGO NA ETAPIE PRZEDOPERACYJNEGO PRZYGOTOWANIA U PACJENTÓW Z POSOCZNICA W NASTĘPSTWIE ZAKAŻENIA DRÓG ŻÓŁCIOWYCH}

\author{
Igor M. Vovchuk, Vitalij A. Katsal, Kateryna V. Khromykh, Victoria V. Balabueva, Maxim A. Hudz \\ NATIONAL PYROGOV MEMORIAL MEDICAL UNIVERSITY, VINNYTSYA, UKRAINE
}

\begin{abstract}
ABSRTACT
Introduction: There is a problem of choosing the optimal method for eliminating choledocholithiasis in accordance with one The lack of satisfactory results from the use of existing methods of surgical correction explains the constant interest of specialists to this problem, requires the improvement of the commonly accepted and the search for new approaches to the treatment of this concomitant disease.

The aim: To substantiate the use of individual assessment at the stage of preoperative preparation for the purposeful differential tactic of surgical treatment of the biliary sepsis. Materials and methods: The basis of our research was the results of the analysis of treatment of 112 patients with biliary sepsis who were on treatment from 2010 to 2017 in the surgical clinic № 2 . An assessment of systemic inflammation performed according to the recommended criteria of the Chicago Interventional Conference on Intensive Care (USA, 1992). The systemic inflammatory response syndrome (SIRS) was determined in the presence of 2 or more symptoms: 1) t body $\left.>38^{\circ} \mathrm{Cor}<36^{\circ} \mathrm{C}, 2\right)$ heart rate $>90 /$ min; 3) breathing frequency $>20 / \mathrm{min}$; 4) white blood cell count $>12 \times 109 / \mathrm{l}$ or $<4 \times 109 /$; or $>10 \%$ immature forms (SOFA score 4, $27 \pm 0.6$ points).

Results: Based on the received pre-operative score, we proposed to optimize the differentiated selection of individualized surgical tactics, taking into account the available baseline conditions, to radically eliminate the cause of biliary sepsis and evaluate the measures of initial conservative therapy. In the course of work, anamnestic unit, clinical unit, laboratory-instrumental block used. The initial severity of the condition of each particular patient is calculate according to the received sum of points for each information block, which allows at the stage of preoperative preparation to standardize all patients in accordance with their score.

Conclusion: Thus, the ball assessment of the severity of the condition of patients allows us to determine not only the optimal tactics, the size and type of surgical correction, but also to determine the effectiveness of the selected composition of preoperative preparation and postoperative treatment, carrying out its dynamic assessment.
\end{abstract}

KEY WORDS: acute cholangitis, biliary sepsis

Wiad Lek 2019, 72, 3, 343-347

\section{INTRODUCTION}

Biliary sepsis (BS) - a set of systemic inflammatory reactions that occur in response to a local infectious process in the biliary tract [1].

According to modern ideas, there is a close pathogenetic relationship between mechanical jaundice (MJ), acute cholangitis (AC) and biliary sepsis (BS): under certain conditions, MJ can be complicated by the development of AC, which in some cases is transformed into BS. So, if GC is a localized pathological process, the basis of which is the inflammatory effect of the bile duct, then the BS is a systemic inflammatory reaction of the organism to the purulent process located in the bile ducts [2]. Accordingly, BS is a qualitatively new pathological state, is fundamentally different from GC and therefore requires special approaches to diagnosis and treatment. Thus, established that cholestasis and biliary tract infection are factors contributing to the transformation of $\mathrm{MJ}$ in $\mathrm{AC}$, but with the help of these factors, it is impossible to explain the existing differences in terms of the occurrence and severity of AC course in patients with $\mathrm{MJ}$ of different genesis. Among the factors of pathogenesis that contribute to the development of the BS, a special role is played by: - ischemia of the liver with MJ, which causes inhibition of the function of hepatocytes and RES cells (Kupffer cells, sinusoidal endothelium, Ito cells, Pit cells) that provide local immunity activity [5]. The phenomenon of enterogenous bacterial translocation, associated with the cessation of bile into the intestine, as well as damage to the membranes of the enterocytes of the mucous membrane, which determines the possibility of germs into the portal and further - systemic blood flow, which leads to the development of the syndrome of the systemic inflammatory response (SIRS). Reducing the portal blood flow with increasing MJ due to the partial effect of "dumping" blood leads to the generalization of infection and the development of SIRS. Biliary hypertension, which increases with $\mathrm{AC}$, as pressure from the secretory pressure of the bile is supplemented by the colonization of bile ducts 
by gas-forming bacteria, leads to stretching in the hepatic beams of the intercellular cracks and a breakthrough into the Disse space in the liver sinuses of infected bile. Cholangiovenous and cholangiolymphatic reflux, which arise in $\mathrm{AC}$ as a result of a sharp (over $300 \mathrm{~mm}$ water) increase in pressure in the bile ducts, accompanied by a massive release into the systemic circulation of mycorrhiza and endotoxins, enhances the development of SIRS. The significance of these factors in the pathogenesis of the BS is evident, but a number of issues concerning the characteristics of the development of the SIDS are unclear and require further resolution. Thus, extremely insufficiently studied mechanisms that determine the developmental time and the severity of bacteriocholia in progressive cholestasis in patients with MI, which is the cause of various types of diseases of the organs hepatopancreatoduodenal zone. Also little studied and interpreted contradictory ways of development of both portal and systemic bacteremia and endotoxemia in progressing AC [6].

Biliary sepsis (as a systemic inflammatory reaction in AC) has its own peculiarities that distinguish it from ordinary wart sepsis: often a lightning-fast, frequent development of liver abscesses, multiple organ failure syndrome, the presence of a pronounced secondary immunodeficiency, primarily due to inhibition of the reticuloendothelial system of the liver [4].

Interest in the BS is largely determine by the unsatisfactory results of treatment over the past 20 years, as evidenced by high numbers of lethality - from $11 \%$ to $64 \%$ in multiple organ failure by 3-4 systems, even with timely surgical procedures. At the same time, the largest percentage of deaths are given to emergency operations (33.0-60.0\%) due to severe concomitant pathology. When refusing surgical treatment, acute purulent cholangitis gives $100 \%$ lethality [7].

Preoperative preparation of the BS is limited to the most necessary and carried out for a short time, pursuing the main goal - stabilization of hemodynamics. Surgical treatment, initiated within 24 hours from the time of admission, yields the best results with a mortality rate of $17.0 \%$. Delay with operation up to 72 hours increases the mortality to $50.0 \%$. In order to prepare patients with BS, a preliminary decompression of the biliary system proposed. The implementation of the first stage of decompression operations dictated by the need for restoration of liver functions and the normalization of homeostasis, as the high mortality after radical operations in patients with BS, in many respects, is due to the discrepancy between the compensatory capacity of the liver and the weight of surgical intervention. Long-term obstructive cholestasis and ascending biliary infection a accompanied by severe disorganization of the structure and function of the liver, which leads to the fact that even a minimal trauma and anesthesia may appear as a trigger for the development of numerous complications: liver failure, peritonitis, and bleeding, leading to high lethality, even after palliative surgery - 30\% [3].

As an alternative to the surgical method of decompensation in the preparation of patients for radical surgical intervention used through the hematopoietic cholecystoholan- giostomy or through the hematopoietic papilloprotectomy. This procedure, in most observations, allows to achieve an adequate decompression of the biliary system and to gain time for the correction of concomitant pathology. To date, there are two main accesses to the biliary duct system, which allow for revision and rehabilitation of the common liver and bile ducts by minimally invasive methods. The first one - due to papillary access, combines endoscopic methods of audit and sanation of the common bile duct by means of the influence on the sphincter of Oddi:

1) ERCPG in conjunction with EPST;

2) ERCPG in conjunction with endoscopic balloon papillodication;

3) ERCPG in conjunction with nausea bleeding drainage or endoprosthesis (as a temporary measure for unsuccessful endoscopic extraction of stones).

The second - flow access, combines the methods of audit and sanation of the common bile duct through the hole in its wall during a laparoscopic operation or operation with minilaparotomic access, as well as in the postoperative period:

1) through the bladder duct,

2) by choledochotomy.

There is a problem of choosing the optimal method for eliminating choledocholithiasis in accordance with one The lack of satisfactory results from the use of existing methods of surgical correction explains the constant interest of specialists to this problem, requires the improvement of the commonly accepted and the search for new approaches to the treatment of this concomitant disease.

\section{THE AIM}

To substantiate the use of individual assessment at the stage of preoperative preparation for the purposeful differential tactic of surgical treatment of the BS.

\section{MATERIALS AND METHODS}

The basis of our research was the results of the analysis of treatment of 112 patients with BS who were on treatment from 2010 to 2017 in the surgical clinic № 2.

An assessment of systemic inflammation performed according to the recommended criteria of the Chicago Interventional Conference on Intensive Care (USA, 1992). The systemic inflammatory response syndrome (SIRS) was determined in the presence of 2 or more symptoms: 1) $\mathrm{t}$ body $>38^{\circ} \mathrm{C}$ or $<36^{\circ} \mathrm{C}$, 2) heart rate $>90 / \mathrm{min}$; 3) breathing frequency $>20$ / $\mathrm{min} ; 4$ ) white blood cell count $>$ $12 \times 109$ / 1 or $<4 \times 109$ / 1 ; or $>10 \%$ immature forms (SOFA score $4,27 \pm 0.6$ points).

\section{RESULTS AND DISCUSSION}

The method of ballroom individual assessment at the stage of preoperative preparation, which substantiates the purposeful selection of differentiated surgical tactics. Directly determines the method of its realization in accordance with 
Table I. Anamnestic block of the developed scale.

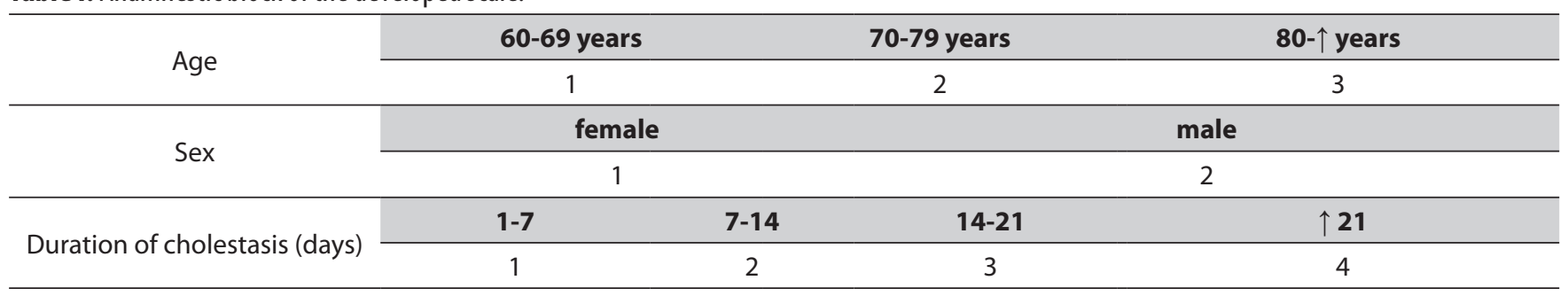

Table II. Clinical block of the developed scale.

\begin{tabular}{|c|c|c|c|}
\hline \multirow{2}{*}{ Fever ${ }^{\circ} \mathrm{C}$} & $37-37,9$ & $38-38,9$ & $39 \uparrow$ \\
\hline & 1 & 2 & 3 \\
\hline \multirow{2}{*}{ Diuresis ml } & $1000-700$ & $700-500$ & $300 \downarrow$ \\
\hline & 1 & 2 & 3 \\
\hline \multirow{2}{*}{ Liver cirrhosis } & compensation & subcompensation & decompensation \\
\hline & 1 & 2 & 3 \\
\hline \multirow{2}{*}{ Diabetes mellitus } & compensation & subcompensation & decompensation \\
\hline & 1 & 2 & 3 \\
\hline \multirow{2}{*}{ Heart failure } & HF I & HF II & HF III \\
\hline & 1 & 3 & 5 \\
\hline
\end{tabular}

Table III. Laboratory and instrumental block of the developed scale.

\begin{tabular}{|c|c|c|c|c|}
\hline \multirow{2}{*}{ Leukocytosis, 109} & $9-14,9$ & \multicolumn{2}{|c|}{$15-19,9$} & $20 \uparrow$ \\
\hline & 1 & \multicolumn{2}{|c|}{2} & 3 \\
\hline \multirow{2}{*}{ Bilirubinemia, $\mu \mathrm{mol} / \mathrm{L}$} & $50-99$ & 100-199 & 200-299 & $300 \uparrow$ \\
\hline & 1 & 2 & 3 & 4 \\
\hline \multirow{2}{*}{ Prothrombin index, \% } & $90-80$ & $79-60$ & $59-40$ & $\downarrow 39$ \\
\hline & 1 & 2 & 3 & 4 \\
\hline \multirow[t]{2}{*}{ USG criteria } & destructive cholecystitis & \multicolumn{2}{|c|}{$\begin{array}{c}\text { Diameter of TBT } \\
10-20 \mathrm{~mm}\end{array}$} & $\begin{array}{c}\text { Diameter of TBT } \\
\uparrow 20 \mathrm{~mm}\end{array}$ \\
\hline & 2 & \multicolumn{2}{|c|}{2} & 3 \\
\hline
\end{tabular}

the initial severity of the condition of patients with the BS in the form of a ball assessment according to the criteria of 3 blocks of primary information for a particular patient: 1) Anamnestic,

2) Clinical,

3) Laboratory and instrumental blocks.

The anamnestic information unit (Table I) consists of a ballroom assessment of the criteria: age (gradation at age intervals: 60-69, 70-79, over 80 years), sex (female, male), duration of jaundice (1-7, $7-14,14-21$, more than 21 days).

The clinical information block (Table II) consists of the following criteria: temperature (37-37.9, 38-38.9, over $\left.39^{\circ} \mathrm{C}\right)$, diuresis (1000-700, 700-500, less than $300 \mathrm{ml}$ per day), evaluation clinically significant concomitant somatic pathology (liver cirrhosis, diabetes in the stage of compensation, subcompensation, decompensation, heart failure - HF1, HF2 - 2A (2 bales), 2V (3 bales), HF3.

Laboratory-instrumental information unit (Table III) consists of the following criteria: the value of peripheral leukocytosis (9-14,9; 15-19,9; more than $\left.20 \times 10^{9} / 1\right)$; total bilirubin (50-99, 100-199, 200-299, more than 300 $\mu \mathrm{mol} / \mathrm{L}$ ) and the prothrombin index (90-80\%, 79-60\%, $59-40 \%$, less than 39\%), the results of the USG study (signs of destructive cholecystitis - increase in size, thickening and wall infiltration, inequality, fuzziness and double contour, positive ultrasound Murphy symptom, presence of echo changes in the parevasical zone, signs of degree and duration of jaundice per diameter TBT - 10-20mm, more than $20 \mathrm{~mm}$ ).

The initial severity of each individual patient hospitalized in the clinic will be calculate according to the amount received for each information block, which allowed us at the stage of preoperative preparation to standardize all patients according to their score in the following groups:

1) Low risk of postoperative complications (A) - 10-15 points;

2) Average risk of postoperative complications (B) - 16-25 points; 
3) High risk of postoperative complications (C) - 26-30 points;

4) Super-high risk of postoperative complications (D) - 31 points and above.

Based on the received pre-operative score, we proposed to optimize the differentiated selection of individualized surgical tactics, taking into account the available baseline conditions, to radically eliminate the cause of BS and evaluate the measures of initial conservative therapy.

In the course of work, anamnestic unit, clinical unit, laboratory-instrumental block used. The initial severity of the condition of each particular patient is calculate according to the received sum of points for each information block, which allows at the stage of preoperative preparation to standardize all patients in accordance with their score.

Based on the received preoperative score, one can optimize the differential choice of surgical tactics and preoperative preparation of patients with BS.

1) group A with low risk of postoperative complications (10-15 points) shows the implementation of a one-stage radical elimination of the causes of purulent cholangitis by surgical techniques (laparotomy, low-invasive - laparoscopic, endoscopic), based on the conditions of a separate surgical clinic, depending on its equipment, accumulated experience performing similar interventions and qualifications of the prepared surgical team;

2 ) in the groups of high-C (26-30 points) and ultra-high-D (31 balls and above) the risk of postoperative complications shows a unambiguous choice of the stage tactics of surgical treatment: at stage 1, low-traumatic palliative spontaneous dosage biliary decompression is performed by non-invasive technologies (endoscopic - stenting, EPST in addition to the displays by nocobiliary drainage), and already in 2 stages after stabilization of the functional state of the liver and reduction of the ball scoring of the initial severity of the condition of the patient with BS, to carry out radical treatment to eradication of biliary pathology invasive or traditional open methods depending on the conditions of surgical clinics;

3 ) group B in the average (16-25 points) of the risk of postoperative complications requires a dynamic assessment of the severity of the condition under the influence of initial preoperative conservative therapy. If in the monitoring process the score decreases, the patient may perform a one-stage radical elimination of the cause of the BS. If in the dynamics of the assessment does not change, then patients need unambiguous implementation of the stage tactics of biliary decompression with the predominant use of low-traumatic sparing dosage surgical techniques.

More rational method for treating of biliary sepsis is a surgical intervention from the mini-accessory in conjunction with supra-duodenal choledochotomy and the extraction of concrements by the Fogarty catheter and the Dormita basket, with the washing of the bile ducts with a warm solution of furatsillin it was known [3]. Unfortunately, there are currently not enough publications that would point to a differentiated approach to the treatment of cholangitis.
In this regard, it is promising to conduct research aimed at the selection of differentiated treatment in severe biliary sepsis against acute cholangitis with the use of mini-access.

Hawasli et al. note that in the acute blockade of the distal part of the common bile duct (acute biliary pancreatitis, acute obstructive cholangitis), the EPST is carried out as an emergency procedure. We have shown that all patients in accordance with the given scale may be divided into groups that would require urgent surgical intervention. It is also recommended to use different techniques and methods of surgical intervention, depending on the severity of the patient's condition.

A.M. Paganini, E. Lezoche argue that the stenosis of a large duodenal papilla shows EPST, which can be performed both before and after cholecystectomy. According to Y. Ochi, K. Mukawa et al. Endoscopic balloon dilatation is indicated for the treatment of cholelithiasis complicated by mechanical jaundice, with pronounced disturbances of the coagulogram (liver cirrhosis, coagulopathy, constant admission of anticoagulants), as well as in the narrow general bile duct containing small concrements. In all other situations, in the presence of appropriate equipment, removal of choledocholithiasis may occur intraoperatively during laparoscopic or with mini access to cholecystectomy.

We have recommended in patients with a low risk of postoperative complications provide an one-step radical elimination of the causes of purulent cholangitis by surgical techniques (laparotomy, noninvasive - laparoscopic, endoscopic). In a group of moderate risk of postoperative complications, recommended to conduct dynamic assessments of the severity of the condition. If the risk in the dynamics decreases, patients undergo one-step radical correction. If in the dynamics of the assessment does not change, then patients need unambiguous implementation of the stage tactics of biliary decompression with the predominant use of low-traumatic sparing dosage surgical techniques. In patients of the high-risk group, according to our data, we provide a step-by-step surgical treatment with the use of initially less traumatic palliative sparing metered biliary decompression with minimally invasive technologies is recommended, and after stabilization of the functional state of the liver, a radical elimination of biliary pathology by a minor invasive or traditional open method, depending on the conditions of the surgical clinic.

\section{CONCLUSIONS}

Thus, the ball assessment of the severity of the condition of patients allows us to determine not only the optimal tactics, the size and type of surgical correction, but also to determine the effectiveness of the selected composition of preoperative preparation and postoperative treatment, carrying out its dynamic assessment.

\section{REFERENCES}

1. Mattner J. Impact of microbes on the pathogenesis of primary biliary cirrhosis (PBC) and primary sclerosing cholangitis (PSC) Int J Mol Sci. 2016;17:1864. 10.3390/ijms17111864 
2. Tanaka A, Tazuma S, Okazaki K, Tsubouchi H, Inui K, Takikawa H. Nationwide survey for primary sclerosing cholangitis and IgG4related sclerosing cholangitis in Japan. J Hepatobiliary Pancreat Sci. 2014;21:43-50. 10.1002/jhbp.50.

3. Patel H, Gaduputi V, Chelimilla H, Makker J, Hashmi H, Irigela M, et al. Acute cholangitis: does the timing of ERCP alter outcomes? J Pancreas. 2016;17:504-509.

4. Kwan KEL, Shelat VG, Tan CH. Recurrent pyogenic cholangitis: a review of imaging findings and clinical management. Abdom Radiol (NY) 2017;42:46-56. 10.1007/s00261-016-0953-y.

5. Gornals JB, Consiglieri CF, Bergamino MA. Double pigtail for preventing ascending cholangitis after endoscopic ultrasonography-guided choledochoduodenostomy with lumen-apposing metal stent. Dig Endosc. 2016;28:100. 10.1111/den.12548.

6. Shenoy SM, Shenoy S, Gopal S, Tantry BV, Baliga S, Jain A. Clinicomicrobiological analysis of patients with cholangitis. Indian J Med Microbiol. 2014;32:157-160. 10.4103/0255-0857.129802.

7. Sun Z, Zhu Y, Zhu B, Xu G, Zhang N. Controversy and progress for treatment of acute cholangitis after Tokyo Guidelines (TG13) Biosci Trends. 2016;10:22-26. 10.5582/bst.2016.01033.

\section{Authors' contributions:}

According to the order of the Authorship.

\section{Conflict of interest:}

The Authors declare no conflict of interest.

\section{CORRESPONDING AUTHOR Kateryna Khromykh}

15 Saksaganskogo str., apt. 58

21032 Vinnytsya, Ukraine

e-mail:vovchukigor81@gmail.com

Received: 15.11 .2018

Accepted: 22.02.2019 
PRACA ORYGINALNA

ORIGINAL ARTICLE

\title{
ASSOCIATION OF NONALCOHOLIC FATTY LIVER DISEASE WITH SMALL INTESTINE BACTERIAL OVERGROWTH IN OBESE CHILDREN
}

\author{
ZWIAZZEK NIEALKOHOLOWEJ STŁUSZCZENIOWEJ CHOROBY \\ WĄTROBY Z ZESPOŁEM ROZROSTU BAKTERYJNEGO JELITA \\ CIENKIEGO U DZIECI Z OTYŁOŚCIĄ
}

\author{
Yuriy M. Stepanov, Natalia Yu. Zavhorodnia, Victoria B. Yagmur, Olga Yu. Lukianenko, Elvira V. Zygalo \\ STATE INSTITUTION «INSTITUTE OF GASTROENTEROLOGY OF THE NATIONAL ACADEMY OF MEDICAL SCIENCES OF UKRAINE», DNIPRO, UKRAINE
}

\begin{abstract}
Introduction: In recent years, NAFLD is considered as the key of the so-called metabolic inflammation, in which the intestinal microbiota plays an important role. The aim: To determine the effect of small intestine bacterial overgrowth on the liver structural and functional parameters in children with obesity and overweight. Materials and methods: The object of the study was 89 children with obesity/overweight. Depending on the presence of SIBO based on the results of the hydrogen breath test with glucose, the patients were divided into 2 groups: first (I) consisted of 31 children with SIBO, the second (II) included 58 children without SIBO. All the patients under study performed a general blood analysis and a biochemical blood test, immuno-enzyme test method with insulin level determination HOMA index calculation. For diagnostics of the liver steatosis, transient elastography with the CAP (controlled attenuation parameter) function was carried out using FibroScan ${ }^{\circledast} 502$ touch (Echosens, Paris, France). Results: According to fibroscan data, the presence of SIBO in obese children can lead to raise of CAP level; liver steatosis was diagnosed in 22 patients (70.9\%) of the 1st group and 24 patients (41.4\%) of the 2 group $(p<0,05)$. We found significant differences in the the ratio of neutrophils and lymphocytes (NLR) ( $p<0.05)$. The average glucose level and HOMA index were significantly higher in SIBO group $(p<0,05)$. The analysis of risk factors of SIBO showed that metabolic syndrome and NAFLD as the risk factors for SIBO development $(\mathrm{p}<0,05)$.

Conclusions: SIBO has an effect on the structural and functional characteristics of the liver resulting in higher insulin and glucose level, higher NLR level and greater prevalence of NAFLD.
\end{abstract}

KEY WORDS: nonalcoholic fatty liver disease, small intestine bacterial overgrowth, children, obesity

\section{INTRODUCTION}

Childhood obesity has become a worldwide epidemic nowadays. According to World Health Organization (WHO), overweight and obesity affect more than 42 million children under the age of 5 years. At the same time, the prevalence of the consequences of this problem is growing: every second child with severe obesity has manifestations of the metabolic syndrome (MS) $[1,2,3]$. The prevalence of non-alcoholic fatty liver disease (NAFLD), which is the hepatic manifestation of MS, reaches $5-18 \%$ in countries in Asia, 30\% in Europe, and its incidence in the child population is about $8-10 \%[4,5]$. It is known that in most cases the accumulation of fat in hepatocytes is a fairly benign condition, but in a certain number of patients (about 3-5\%) the pathological process leads to the development of non-alcoholic steatohepatitis (NASH) with the further formation of fibrosis and cirrhosis. The latter consequence is the formation of portal hypertension and hepatic-cell insufficiency. The cases of liver transplantation in children, the need for which was caused by the terminal stage of the NAFLD, have already been described [6].

In recent years, NAFLD is considered as the key component of the so-called metabolic inflammation, in which the intestinal microbiota plays an important role $[7,8]$. Microbiota is involved in regulation of the both inflammatory and anti-inflammatory homeostasis, and in the accumulation of triglycerides in the liver (Fig. 1).

Patients with obesity are characterized by a certain composition of microflora with a relatively low proportion of Bacteroidetes and a predominance of Firmicutes. The microbiota composition of people with steatohepatitis even without obesity also has a low proportion of Bacteroidetes, which can lead to the multiplication of other bacteria that are more effective in extracting and storing energy [9].

Firstly, the metabolites produced by microbiota-short-chain fatty acids-can act as energy storage form and modulate the signaling pathways of the host organism metabolism. Participation in the accumulation of lipids in 


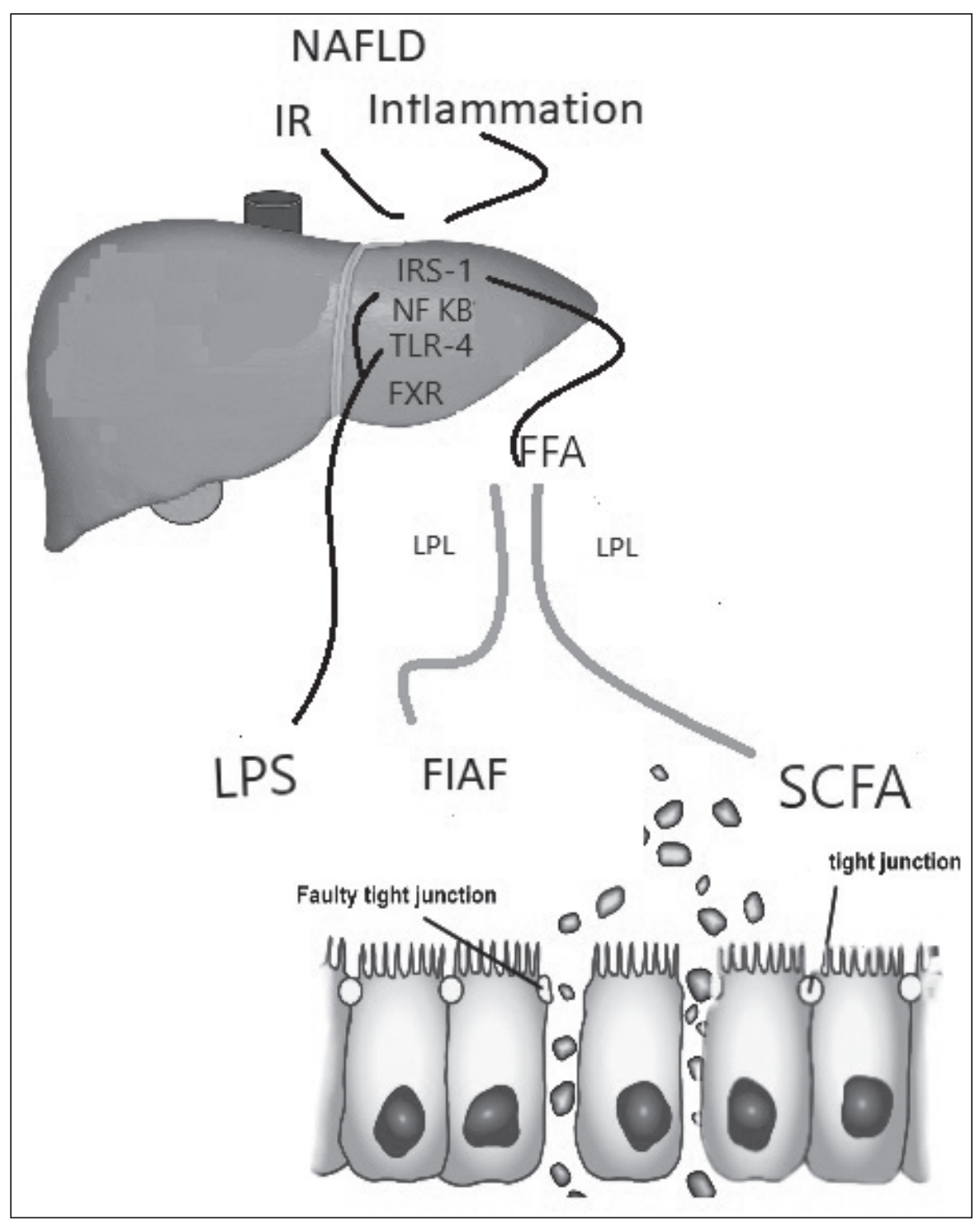

Fig.1. Complex association between NAFLD and intestinal dysbiosis. FFA, free fatty acid; NAFLD, nonalcoholic fatty liver disease; TLR, toll-like receptor; FIAF, Fasting-induced adipocyte factor; IRS: Insulin receptor substrate, LPS, Lipopolysaccharides; SCFA Short-chain fatty acid; IR insulin resistance. the liver occurs by enhancing the intestinal absorption of monosaccharides, thereby increasing hepatic lipogenesis and being suppressed by the fasting-induced adipocyte factor, resulting in the accumulation of triglycerides in adipocytes [10].

Secondly - the intestinal epithelium is a natural barrier to prevent the translocation of harmful bacteria and their elements into circulation. NASH patients are usually characterized by small intestine bacterial overgrowth (SIBO) which can damage intestinal joints and increase its permeability. SIBO also induces hepatic expression of the TLR-4 receptors and the release of IL-8, which stimulates the inflammatory response. Consequently, intestinal dysbiosis is the cause of increased secretion of lipopolysaccharides (LPS), the constituent components of the intestinal bacterial membranes, and inflammation caused by it during the development of NAFLD [11]. In support of the hypothesis on the influence of microflora in the NAFLD development, numerous experimental studies are available; it is showing that normalization of the microbiota helps to prevent the development of fatty liver disease $[12,13]$. It should be noted that, despite of numerous studies, the molecular mechanisms involved in this process in children and adolescents have not been fully determined yet.

\section{THE AIM}

To determine the effect of small intestine bacterial overgrowth on the liver structural and functional parameters in children with obesity and overweight.

\section{MATERIALS AND METHODS}

The object of the study was 89 children with obesity/overweight, who were on treatment at the Children's Gastroenterology Department of the State Institution "Institute of Gastroenterology of NAMS of Ukraine". Depending on the presence of SIBO based on the results of the hydrogen breath test with glucose, the patients were divided into 2 groups: first (I) consisted of 31 children with SIBO, the second (II) included 58 children without SIBO. The objective study, anthropometry with BMI calculation were conducted. 
Table I. Anthropometric indicators of study groups

\begin{tabular}{|c|c|c|c|}
\hline \multirow{2}{*}{ Parameters, units } & I group $(n=32)$ & II group ( $n=58$ ) & \multirow{2}{*}{$\mathbf{p}$} \\
\hline & $(M \pm m)$ & $(M \pm m)$ & \\
\hline Age, year & $12,8 \pm 2,5$ & $12,0 \pm 2,7$ & 0,2 \\
\hline Male gender, n (\%) & $22(68,75)$ & $25(43,1)$ & 0,2 \\
\hline BMI, kg / m2 & $25,5 \pm 3,5$ & $24,2 \pm 2,5$ & 0,2 \\
\hline Waist circumference, $\mathrm{cm}$ & $87,0 \pm 3,6$ & $81,1 \pm 3,2$ & 0,04 \\
\hline Thigh circumference, $\mathrm{cm}$ & $60,2 \pm 4,5$ & $56,9 \pm 8,5$ & 0,07 \\
\hline
\end{tabular}

Note. $p$ - significance of differences

Table II. Data of general blood analysis

\begin{tabular}{|c|c|c|c|}
\hline \multirow{2}{*}{ Parameters, units } & I group $(n=31)$ & II group $(n=58)$ & \multirow{2}{*}{$\mathbf{p}$} \\
\hline & $M \pm m$ & $M \pm m$ & \\
\hline hemoglobin, g / I & $140,2 \pm 11,7$ & $134,7 \pm 22,1$ & 0,0003 \\
\hline erythrocytes, $10^{12} / \mathrm{I}$ & $4,7 \pm 0,3$ & $5,7 \pm 8,7$ & 0,003 \\
\hline hematocrit, \% & $36,9 \pm 2,7$ & $35,9 \pm 2,9$ & 0,7 \\
\hline leukocytes, $10^{9} /$ I & $6,03 \pm 1,3$ & $6,1 \pm 1,5$ & 0,3 \\
\hline neutrophils / lymphocytes & $2,3 \pm 2,6$ & $1,5 \pm 0,7$ & 0,0003 \\
\hline platelets, $10^{9} / \mathrm{l}$ & $294,8 \pm 61,7$ & $311,6 \pm 88,8$ & 0,03 \\
\hline $\mathrm{ESR}, \mathrm{mm} / \mathrm{h}$ & $13,5 \pm 7,8$ & $11,8 \pm 6,7$ & 0,3 \\
\hline
\end{tabular}

Note. $\mathrm{p}$ - significance of differences

The presence of obesity / overweight was determined by the standard sigma deviations of BMI values for age and sex according to WHO recommendations [14]. The presence of abdominal obesity was diagnosed with a waist circumference (WC) of a patient that exceeded 90 percentiles for the corresponding age and sex according to the recommendations of the International Diabetic Federation (IDF) [15].

All the patients performed a general blood analysis and a biochemical blood test with the determination of the total protein, total bilirubin, ALT, AST, GGTP levels using the biochemical analyzer Stat Fax 1904 Plus, Awareness Technology (USA). The content of insulin in serum was determined by the immuno-enzyme test method with HOMA (Homeostasis model estimation) index calculation. A quantitative determination of the concentration of IL-6, IL-10, TNF- $\alpha$ in serum was carried out using ELISA.

Diagnosis of the small intestine bacterial overgrowth was performed according to the breath test with glucose loading with gas analyzer "Gastro" Gastrolyzer of Bedfont Scientific Ltd (UK). For diagnostics of the liver steatosis, transient elastography with the controlled attenuation parameter (CAP) measurement was carried out using FibroScan ${ }^{\circledR} 502$ touch (Echosens, Paris, France).

Diagnosis of NAFLD was established in case of liver steatosis being detected according to CAP level and exclusion of the secondary etiological factors of steatosis in children with overweight / obesity.

The statistical analysis was carried out using the Statistica program. Under normal distribution conditions, the data were presented as the mean (M) and standard deviation (m). The significance of differences between the groups was assessed using Student's t-test. The difference was considered reliable at a value of pless than 0.05 . In the absence of a normal distribution, the data was displayed using the median and quartiles, and the difference between the groups was estimated using the Mann-Whitney test. Analysis of risk factors was performed with calculation of odds ratio (OR).

\section{RESULTS}

\section{ANTHROPOMETRIC DATA}

Analyzing the anthropometric data, it was found that the abdominal type of obesity prevailed in children with SIBO - the waist circumference was higher in 1 group than in the second group $(\mathrm{p}=0.04)$ (Table I). Abdominal obesity was diagnosed in $16(51.6 \%)$ of the 1 group and in $25(43.1 \%)$ of the 2 group.

It should be noted that metabolic syndrome (according to IDF) was diagnosed in $6(19.3 \%)$ patients of SIBO group and $5(15.6 \%)$ patients of 2 group.

\section{BLOOD ANALYSIS}

The data of the general clinical analysis of the blood are presented in Table II.

Children of SIBO+ group had higher level of ESR in comparison with SIBO- group, but difference was not significant. As can be seen from the table, there were significant differences in the ratio of neutrophils to lymphocytes - in the group with bacterial overgrowth it was significantly higher $(\mathrm{p}<0.05)$. 
Table III. Parameters of carbohydrate metabolism in studied patients

\begin{tabular}{cccc}
\hline \multirow{2}{*}{ Parameters, units } & I group $(\mathbf{n = 3 1 )}$ & II group $(\mathbf{n}=\mathbf{5 8})$ & p \\
\cline { 2 - 3 } & $\mathrm{M} \pm \mathrm{m}$ & $\mathrm{M} \pm \mathrm{m}$ & 0,1 \\
\hline Insulin, $\mathrm{mU} / \mathrm{I}$ & $25,6 \pm 16,8$ & $24,3 \pm 22,1$ & 0,003 \\
\hline Glucose, $\mathrm{mmol} / \mathrm{I}$ & $4,9 \pm 0,8$ & $5,5 \pm 0,5$ & 0,04 \\
\hline HOMA1-IR & $6,7 \pm 0,8$ & $5,1 \pm 1,2$ & \\
\hline
\end{tabular}

Note. $p$ - significance of differences

Table. IV. Cytokine profile of the patients

\begin{tabular}{|c|c|c|c|c|c|c|}
\hline \multirow[b]{2}{*}{ Cytokines } & \multicolumn{2}{|c|}{ Mediana } & \multicolumn{2}{|c|}{ Min-max } & \multicolumn{2}{|c|}{$25 ; 75$} \\
\hline & $\begin{array}{l}\text { I group } \\
(\mathbf{n}=\mathbf{3 1})\end{array}$ & $\begin{array}{c}\text { II group } \\
(n=58)\end{array}$ & $\begin{array}{l}\text { I group } \\
(n=31)\end{array}$ & $\begin{array}{c}\text { II group } \\
(n=58)\end{array}$ & $\begin{array}{c}\text { I group } \\
(n=31)\end{array}$ & $\begin{array}{r}\text { II group } \\
(\mathbf{n}=58)\end{array}$ \\
\hline IL-6 & 1,3 & 1,2 & $0,1-560$ & $0,1-349,1$ & $0,3-3,0$ & $0,3-3,2$ \\
\hline IL-10 & 2,7 & 4,8 & $0,2-20,8$ & $0,1-310,0$ & $1,3-8,3$ & $1,5-9,4$ \\
\hline TNF-alpha & 0,8 & 0,5 & $0,1-320$ & $0,1-170,3$ & $0,2-2,0$ & $0,2-2,0$ \\
\hline
\end{tabular}

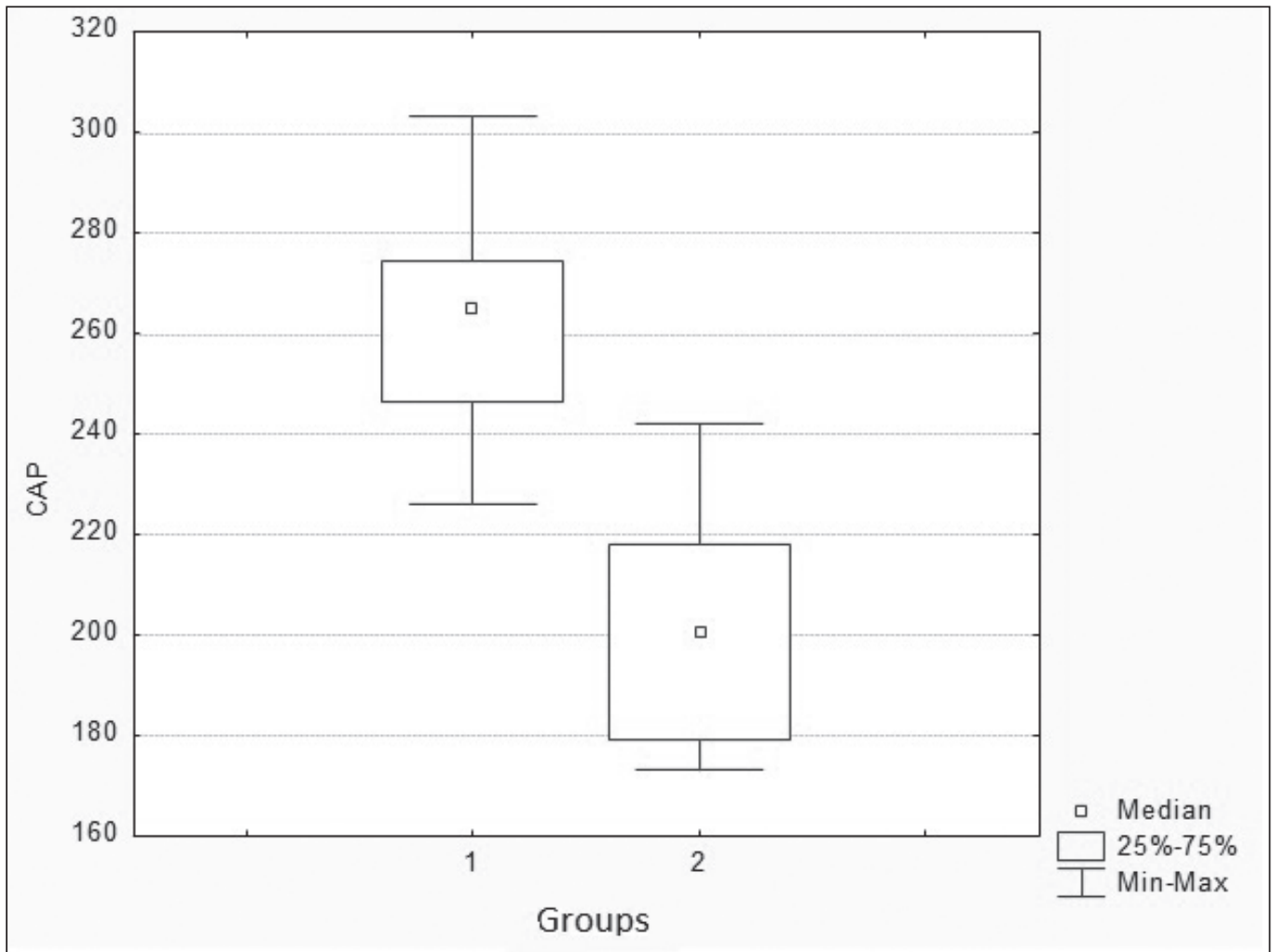

Fig. 2. CAP level distribution in studied group

\section{CARBOHYDRATE METABOLISM}

Interesting data were obtained by analyzing the carbohydrate metabolism parameters of patients (Table III). So, although the average glucose level did not go beyond the normal level, in the group without SIBO it was significantly higher, and conversely, insulin resistance (IR) was greater in the group with bacterial overgrowth.

Indices of the content of various cytokines (IL-6, IL-10 and TNF-alpha) are presented in Table IV.

It was found that the median level of IL-10 in patients in the 2 group was 1.8 times higher than in the 1 group (Tab. IV).

\section{FIBROSCAN DATA}

Significant differences were observed in the analysis of CAP level (Fig. 2).

According to fibroscan data, the presence of SIBO in obese children led to raise in CAP level (tab. V); liver steatosis was diagnosed in 22 patients $(70.9 \%)$ of the 1 st group and 24 patients $(41.4 \%)$ of the 2 nd group. In addition, different degrees of steatosis were observed. In SIBO group S1 degree was observed in 7 patients (22.6\%), S2 - in $9(29.0 \%)$ and S3 - in 6 patients (19.3\%), while in children without SIBO the maximum degree of steatosis was ob- 
Table V. Basic statistical indicators characterizing the structure of the liver

\begin{tabular}{ccccccc}
\hline & \multicolumn{2}{c}{$\mathbf{M} \pm \mathbf{m}$} & \multicolumn{2}{c}{ Median } & \multicolumn{2}{c}{ IQR (25\%-75\%) } \\
\cline { 2 - 7 } Parameters, units & $\begin{array}{c}\text { I group } \\
(\mathbf{n}=\mathbf{3 1})\end{array}$ & $\begin{array}{c}\text { II group } \\
(\mathbf{n = 5 8 )}\end{array}$ & $\begin{array}{c}\text { I group } \\
(\mathbf{n}=\mathbf{3 1})\end{array}$ & $\begin{array}{c}\text { II group } \\
(\mathbf{n}=\mathbf{5 8})\end{array}$ & $\begin{array}{c}\text { I group } \\
(\mathbf{n}=\mathbf{3 1})\end{array}$ & $\begin{array}{c}\text { II group } \\
(\mathbf{n}=58)\end{array}$ \\
\hline Liver stiffness $(\mathrm{kPa})$ & $4,6 \pm 1,3$ & $4,2 \pm 1,0$ & 4,2 & 4,0 & $3,6-5,1$ & $3,6-4,7$ \\
\hline CAP $\left(\mathrm{dB} / \mathrm{m}^{2}\right)$ & $262,7 \pm 20,1$ & $200,7 \pm 21,9$ & 265,0 & 200,5 & $246,5-274,5$ & $179-218$ \\
\hline
\end{tabular}

Table VI. Risk factors for SIBO

\begin{tabular}{ccccc}
\hline Factors, $\mathbf{n}(\mathbf{\%})$ & I group $(\mathbf{n = 3 1 )}$ & II group $(\mathbf{n = 5 8 )}$ & OR & $\mathbf{9 5 \% C l}$ \\
\hline Obesity & $18(58,1)$ & $30(51,7)$ & 1,29 & $0,54-3,11$ \\
\hline Overweight & $12(38,7)$ & $19(32,7)$ & 1,49 & $0,57-3,92$ \\
\hline Abdominal obesity & $16(51,6)$ & $25(43,1)$ & 1,40 & $0,58-3,37$ \\
\hline Hyperinsulinemia & $18(58,1)$ & $23(53,4)$ & 2,10 & $0,87-5,11$ \\
\hline NAFLD & $22(19,3)$ & $24(41,4)$ & 3,46 & $1,36-8,82$ \\
\hline Metabolic syndrome & $6(32,3)$ & $9(15,5)$ & 3,54 & $1,12-11,64$ \\
\hline
\end{tabular}

served in only $4(6.9 \%)$ patients, the 1 degree of steatosis in 9 patients (15.6\%); S2 - 11 patients (18.9\%).

Also we observed that liver stiffness showed a tend to be higher in SIBO+ children.

\section{RISK FACTORS}

The analysis of risk factors of SIBO was carried out, according to them it is possible to carry out metabolic syndrome and NAFLD as the risk factors for SIBO development (tab. VI).

\section{DISCUSSION}

Previous studies have already confirmed the relationship between the intestinal microflora and the development of fatty liver disease. It is known that metabolic profiles differ between children with and without obesity, as well as with and without NAFLD, and a significant contribution to these differences is made by the state of the entero-hepatic axis [15]. Intestinal microflora is involved in the development of obesity and MS by enhancing the interaction between the intestinal bacterial products and Toll-like receptors 4 (TLR4).

According to the studies in patients with nonalcoholic steatohepatitis (NASH) there are specific changes in the microflora and the amount of alcohol produced by Escherichia is increased. This results in intestinal wall intracellular connections disruption, the concentration in the portal blood of ethanol and other metabolic products of bacteria and their constituents - amino acids and lipopolysaccharides elevation [16].

Excessive reproduction and growth of microflora promote a cascade of reactions of oxidative stress, parenchymal inflammation and fibrogenesis. Thus, studies by Italian, American, Finnish scientists have shown that a high content of aromatic amino acids and branched chain amino acids in the plasma, as products of the vital activity of the intestinal microflora, is associated with the development of obesity-related MS. Metabolism is also disturbed by changes in the carnitine cycle, which leads to damage to the nucleotide, lysolipids, and activation of proinflammatory markers $[17,18,19,20]$.

The increase in lipopolysaccharide levels is associated with an increase in tumor necrosis factor-alpha (TNF- $\alpha$ ) gene expression in the hepatic tissue, which confirms the role of endotoxemia in the development of steatohepatitis [16]. It has been shown that SIBO with steatohepatitis is associated with an increase in hepatic expression of TLR4 and the release of interleukin- 6 and 8 (IL) -8 [9]. In our study, we did not find differences between the levels of the proinflammatory cytokines TNF, IL-6 and IL-10 in obese patients, depending on whether or not they had SIBO. Perhaps the fact is that previous studies were conducted in adults, and among our patients, the inadequate exposure of SIBO has not yet led to significant changes in these indicators.

Since the early 1970s, adipose tissue has been recognized as the link between inflammation and metabolism, demonstrating that endotoxin enhances the release of free fatty acids from visceral adipose tissue [8]. The identification of chronic release of cytokines such as TNF-alpha from adipose tissue has triggered a wave of studies showing that obesity presents a complex and integrated immune system of adipose tissue that includes both congenital and acquired components $[9,10]$. Within this network, multiple innate pathways of inflammatory signals such as inflammasomes, lysosomes, NF- $\kappa \mathrm{B}$, and JNK contribute to metabolic destruction [11-14]. These acute inflammatory signals cannot always counteract the metabolic adaptation to excessive nutrition and in fact may be required for an adequate response in adipose tissue. Proinflammatory cascades within adipocytes are required for adipogenesis and hypertrophy of adipocytes with a change in the highfat diet (HFD) (15). Within a short time, the HFD in mice induces IR regardless of inflammation and is characterized by NKT-mediated alternative activation of resident tissue 
macrophages of adipose tissue $[16,17]$. Thus, inflammatory responses in this context probably represent an adaptive response that allows the expansion of healthy adipose tissue and effective fat storage [18].

On the one hand, SIBO can induce the activation of blood leukocytes with the help of circulating LPS, on the other hand the metabolic inflammation in obesity stimulates the bone marrow for leukopoiesis [19]. In our study children with SIBO had higher level of ESR but the significance of differences wasn't sufficient, also we observed the higher neutrophil-to-lymphocyte ratio (NLR) level in SIBO group that indicates signs of more intensive inflammation in obese children with SIBO.

Several studies have demonstrated the importance of NLR as an indicator of subclinical inflammation in coronary artery disease. It has been shown that high levels of NLR could predict a risk of recurrence in patients with various malignancies [20]. The study of Mehmet Asil et al. showed that the neutrophil-to-lymphocyte ratio was higher in patients with steatohepatitis than in patients with simple steatosis and healthy controls. Taking into account that the difference between patients with simple steatosis and healthy controls was not statistically significant, the increased neutrophil-to-lymphocyte ratio in the patients with steatohepatitis can be attributed to a low level of systemic inflammation accompanying the hepatic inflammation [21]. Also it has been shown that neutrophil-to-lymphocyte ratio increases with increasing grade of non-alcoholic fatty liver disease in patients with type 2 diabetes, and may be a convenient marker to follow progression of non-alcoholic fatty liver disease [22]. We've calculated ratio of relative count and it was significantly higher in patients with SIBO, we suppose that this ratio also can be considered as inflammation index that can be useful in NAFLD patients.

We also found an increase in glucose and insulin levels in patients with SIBO that can be explained by the anabolic properties of microflora. Also it is known that the small intestine plays a key role in glucose regulation and diabetes pathogenesis. The central role of small intestinal motility on the development of SIBO was highlighted in a recent study; the authors concluded the primacy of altered small intestinal motility on the development of SIBO. SIBO is present in up to $40 \%$ of patients with diabetes with diarrhea [23].

One potential explanation for this effect might be the fact that the microbiotas of obese individuals have an increased capacity to breakdown non-digestible carbohydrates and produce short-chain fatty acids, which would be subsequently absorbed, metabolized to more complex lipids in the liver, and then stored in adipose tissue $[8,24,25]$.

Indeed, as we see association between NAFLD and SIBO can have bilateral character. Children with SIBO have inverse metabolic and functional liver profile and also NAFLD seem to be a risk factor for SIBO development in this group of patients.

The limitations of the study are due to the fact that the diagnosis of hepatic steatosis was not established on the basis of the "gold standard" - the morphological study of liver biopsy, but on the basis of the method of noninvasive diagnostics - transient elastography of the liver with determination of the CAP function. However, it should be noted that in most studies on the effect of SIBO on the course of NAFLD, the routine ultrasound was used as the basis for the diagnosis of steatosis, which is significantly inferior to fibroscan in sensitivity and specificity.

\section{CONCLUSIONS}

Thus, SIBO has an effect on the structural and functional characteristics of the liver resulting in higher insulin and glucose level, higher NLR level and greater prevalence of NAFLD. We can assume that NAFLD as far as MS are the risk factors for SIBO development in obese children.

\section{REFERENCES}

1. Cruz Martha L., Michael I. Goran. "The metabolic syndrome in children and adolescents." Current diabetes reports 4.1 (2004): 53-62.

2. Weiss R., Dziura J., Burgert T. S., Tamborlane W.V., et al. Obesity and the metabolic syndrome in children and adolescents. New England journal of medicine. 2004; 350(23):2362-2374.

3. Martino F., Pannarale G., Puddu P.E., et al. Is it possible a new definition of metabolic syndrome in childhood. Eur. Rev. Med. Pharmacol. Sci. 2015;19(22):4324-4331.

4. Anderson E. L., Howe L. D., Jones H. E., et al. The prevalence of nonalcoholic fatty liver disease in children and adolescents: a systematic review and meta-analysis. PloS one. 2015;10(10), [e0140908.https:// doi.org/10.1371/journal.pone.0140908 PMID: 26512983].

5. Fitzpatrick E., Hadzic N. Paediatric non-alcoholic fatty liver disease: An emerging threat. Paediatrics Today, 2015;11(1):1-9.

6. Doulberis M., Kotronis G., Gialamprinou D., et al. Non-alcoholic fatty liver disease: an update with special focus on the role of gut microbiota. Metabolism. 2017;71:182-197.

7. Ferolla S. M., Armiliato G. N., Couto C. A., et al. The role of intestinal bacteria overgrowth in obesity-related nonalcoholic fatty liver disease. Nutrients 2014;6(12): 5583-5599. doi:10.3390/nu6125583.

8. Bäckhed F., Ding H., Wang T., et al. The gut microbiota as an environmental factor that regulates fat storage. Proceedings of the national academy of sciences. 2004;101(44):15718-15723.

9. Ma J., Zhou Q., Li H. Gut microbiota and nonalcoholic fatty liver disease: insights on mechanisms and therapy. Nutrients. 2017; 9(10): 1124.

10. Everard A, Belzer C, Geurts L, et al. Cross-talk between Akker-mansia muciniphila and intestinal epithelium controls diet-induced obesity. Proc Natl Acad Sci USA. 2013;110(22):66-71

11. Nardone G, Compare D, Liguori E, et al. Protective effects of Lactobacillus paracasei F19 in arat model of oxidative and metabolic hepatic injury. Am J Physio IGastrointest Liver Physiol. 2010;299(3):69-76

12. Mercedes de Onis. World Health Organization Reference Curves / Mercedes de Onis.: http://ebook.ecog-obesity.eu/chapter-growthcharts-body-composition/world-health-organization-referencecurves/

13. Sir George Alberti, Paul Zimmet, et al. The IDF consensus definition of the metabolc syndrome in children and adolescents. International Diabetes Federation. 2007. p. 23

14. Order of the Ministry of Health of Ukraine dated January 29, 2013, №. $59^{\prime \prime} 0 \mathrm{n}$ approval of unified clinical protocols for medical care for children with digestive diseases" - Access mode (In Ukraine) 
15. Miccheli, A., Capuani, G., Marini, F., et al. Urinary (1)h-nmr-based metabolic profiling of children with NAFLD undergoing VSL\#3treatment. Int. J. Obes. 2015;39:1118-1125

16. Urinary Metabolomics in Pediatric Obesity and NAFLD Identifies Metabolic Pathways/Metabolites Related to Dietary Habits and GutLiver Axis Perturbations .. Jacopo Troisi, Luca Pierri, Annamaria Landolfi, Francesca Marciano, Antonella Bisogno, Federica Belmonte, Carmen Palladino , Salvatore Guercio Nuzio, Pietro Campiglia, and Pietro Vajro Nutrients 2017; 9: 485; doi:10.3390/nu9050485

17. Guercio Nuzio, S.; Di Stasi, M.; Pierri, L.; Troisi, J.; Poeta, M.; Bisogno, A.; Belmonte, F.; Tripodi, M. Di Salvio, D.; Massa, G.; et al. Multiple gut-liver axis abnormalities in children with obesitywith and without hepatic involvement. Pediatr. Obes. 2016

18. Paolella, G.; Vajro, P. Childhood obesity, breastfeeding, intestinal microbiota, and early exposure to antibiotics: What is the link? JAMA Pediatr. 2016;170:735-737

19. The initiation of metabolic inflammation in childhood obesity Kanakadurga Singer Carey N. Lumeng J Clin Invest.2017;127(1):65-73. doi:10.1172/JCl88882

20. Yilmaz, H., Yalcin, K. S., Namuslu, M., Celik, H. T., Sozen, M., Inan, 0., ... \& Kosar, A. (2015). Neutrophil-lymphocyte ratio (NLR) could be better predictor than C-reactive protein (CRP) for liver fibrosis in non-alcoholic steatohepatitis (NASH). Annals of Clinical \& Laboratory Science, 45(3), 278-286.
21. Asıl, M., \& Dertli, R. (2016). The Neutrophil-to-Lymphocyte Ratio as A Noninvasive Marker in Patients with Biopsy-Proven Non-Alcoholic Steatohepatitis. Istanbul Medical Journal, 17(4).

22. Kahraman NK, Kahraman C, Koçak FE et al. Predictive value of neutrophiltolymphocyte ratio in the severity of non-alcoholic fatty liver disease among type 2 diabetes patients. Acta Gastroenterol Belg. 2016;79(3):295-300.

23. Ouyang, X., Li, S., Foreman, R., Farber, J., Lin, L., Yin, J., \& Chen, J. D. Z. (2015). Hyperglycemia induced small intestinal dysrhythmias attributed to sympathovagal imbalance in normal and diabetic rats. Neurogastroenterology \& Motility, 27(3), 406-415.

24. N.Yu. Zavgorodnya, E. V. Zygalo, O.Yu. Lukianenko, S.A. Babii (2016). The role of the gut microbiota in the development of lipid and carbohydrate metabolism in the liver steatosis in children. "Child's Health», 8(76), P. 41-44.

25. Zavgorodnya N. Yu., Lukianenko 0. Yu., Konenko I.S. The state of pancreatobiliary system and intestinal microflora in children with nonalcoholic fatty liver disease (2016). Gastroenterology, 4(62), P. 37-32.

\section{Authors' contributions:}

According to the order of the Authorship.

\section{Conflict of interest:}

The Authors declare no conflict of interest.

\section{CORRESPONDING AUTHOR Natalia Zavhorodnia}

State Institution «Institute of Gastroenterology of the

National Academy of Medical Sciences of Ukraine»

Slobozhanckii st., 96, 49074 Dnipro, Ukraine

e-mail: nzavgorodni75@gmail.com

Received: 25.10 .2018

Accepted: 12.02 .2019 
PRACA ORYGINALNA

ORIGINAL ARTICLE

\title{
PROLACTIN IN HYPERTENSIVE MEN WITH ANDROGEN DEFICIENCY: AN ÉMINENCE GRISE?
}

\section{PROLAKTYNA U MĘŻCZYZN Z NADCIŚNIENIEM TĘTNICZYM I NIEDOBOREM ANDROGENÓW: SZARA EMINENCJA?}

\author{
Vadym A. Vizir, Olesia V. Nasonenko, Olexandr V. Demidenko, Anton S. Sadomov \\ DEPARTMENT OF INTERNAL DISEASES 2, ZAPORIZHZHIA STATE MEDICAL UNIVERSITY, ZAPORIZHZHIA, UKRAINE
}

\begin{abstract}
Introduction: Considering significant gap of convincing knowledge in the field of cardiovascular effects of prolactin and its role as a stress hormone in men precise investigations of these peculiarities has become necessary.

The aim of this study was to find out the relationship of prolactin concentration with parameters of arterial stiffness in hypertensive men with low testosterone. Materials and methods: In total 83 men were examined including 27 apparently healthy individuals as the control group. Physical examination, ABPM, non-invasive evaluation of arterial stiffness and central hemodynamics parameters, answering AMS questionnaire, evaluation of total testosterone and prolactin levels using ELISA were performed. Results: Initially 56 hypertensive patients were divided into 2 groups with regard to their total testosterone level: group 1 included 31 hypogonadal men, group 2 - 25 male patients who had their testosterone concentrations within the normal range. Prolactin levels appeared to be significantly higher in hypertensive men with lower testosterone, they had more unfavorable parameters of arterial stiffness and the difference between 1 and 2 group in terms of central aoSBP and aoPWV became statistically significant. Prolactin concentration was not related with RWTT and index Aix\% 75, a significant correlation was observed between prolactin and aoPWV. A strong correlation was found between prolactin concentration and psychological symptoms in AMS.

Conclusion: Our study suggests the positive association of prolactin concentration with psychological domain of andropause symptoms and worse parameters of arterial stiffness among hypertensive men with androgen deficiency.
\end{abstract}

KEY WORDS: hypertension, androgen deficiency, prolactin, arterial stiffness

Wiad Lek 2019, 72, 3, 357-361

\section{INTRODUCTION}

Prolactin is known as a multifunctional pituitary hormone presented by a non-glycosylated protein which contains a simple polypeptide chain of 198 amino acids. Prolactin is synthesized and secreted by lactotropic pituitary cells in diurnal rhythm, with its highest levels early in the morning. The expression of its receptor is present in most peripheral organs. The most prominent physiological role of prolactin is the maintenance of lactation, but the effect of this hormone also manifests itself in metabolic, osmotic and immunoregulatory mechanisms [1].

Experimental studies conducted even 30 years ago showed that prolactin has positive chronotropic and vasoconstrictor effects [2]. In subsequent years, some reports suggested a discrete role of prolactin in cardiovascular system depending on its concentration in the blood. High normal prolactin levels correlated with parameters associated with hypertension, while high or very high levels of prolactin (above reference values) might adversely affect endothelial function and perhaps other markers of atheromatosis [3]. The level of prolactin in the blood is higher in men with a significant increase of blood pressure (BP), while reducing of its concentration may benefit the BP control. According to Georgiopoulos et al., prolactin levels correlate with $\mathrm{BP}$ values, possibly by the mechanism of increasing of arterial stiffness, with no correlation with other traditional factors of cardiovascular risk. According to the evaluation of many surrogate markers, for example, endothelial and microcirculatory function, BMI, and the fact of existence of atherosclerotic plaques, there was no association between prolactin levels and atherosclerosis in women in early menopause, while men were not included into the study [4]. In studies of next years, prolactin receptors were discovered in atherosclerotic lesions of the coronary arteries [5], which further indicates the probable role of prolactin in atherosclerosis. A recent analysis of Georgiopoulos et al. showed that in women below 55 years of age prolactin is an independent predictor of changes in the pulse wave velocity (PWV) over time, and a high normal level of circulating prolactin suggests changes in hemodynamic parameters and deterioration of endothelial function in healthy postmenopausal women [6]. 
The given data for women disagree with the results obtained in the investigation of male population. It was noted by Corona et al. that in a large number of men who had been consulted about sexual dysfunction, the decrease in plasma level of prolactin was associated with a worse lipid profile and glycemic parameters, as well as a higher incidence of metabolic syndrome and erectile dysfunction [7]. According to the data of Reuwer et al. the systemic concentration of prolactin did not appear to be different in apparently healthy men from such women characterized by development of coronary artery disease during the observation period and those who did not suffer from cardiovascular diseases, patients with higher levels of prolactin did not show to have notably increased risk of CAD [5]. The association of daily fluctuations of circulating prolactin with decreased endothelial function in men with arterial hypertension was also described [8]. Subsequently, Haring et al. found an independent positive association of prolactin concentration with a higher 10-year cardiovascular and total mortality [9]. A similar result was obtained by Corona et al. - prolactin level was considered as an independent predictor of cardiovascular events in men with erectile dysfunction [10]. In spite of the previous data, later Therkelsen et al. using the information from the analysis of 4053 participants of the Framingham Study did not find any association of prolactin with certain cardiovascular risk factors [11].

Prolactin was also suggested to be a stress hormone which could alter BP level but its correlation with anxiety and depressive symptoms were clearly described mostly for female population [12]. Although the numerous studies show the negative impact of prolactin elevation in cardiovascular diseases (CVD), the global assessment of prolactin levels in patients with CVD, particularly in males, was not performed.

\section{THE AIM}

Since the previous studies were not gender-specific and did not describe in detail the characteristics of vascular remodelling depending on the level of circulating prolactin, the aim of this study was to find out the relationship of prolactin concentration with parameters of arterial stiffness in hypertensive men with low testosterone.

\section{MATERIALS AND METHODS}

To accomplish the aim of the study after obtaining written informed consent, 83 men were examined including 27 apparently healthy individuals who were included into the control group. All the study participants including the control group were comparable by age and anthropometric parameters, and were subjected to physical examination, daily blood pressure monitoring, non-invasive evaluation of arterial stiffness and central hemodynamics parameters using the BPLab VasoTens system. The following parameters were studied: the aortic pulse wave velocity (aoPWV), the reflected wave transit time (RWTT), function ( $\mathrm{dP} / \mathrm{dt})$, a ortic augmentation index (AIXao), Aix\% 75 (normalized for the heart rate of $75 \mathrm{bpm}$ ), ambulatory arterial stiffness index (AASI), central aortic systolic blood pressure (central aoSBP). Blood samples were obtained from study subjects in the morning hours (8 am-10 am). Levels of serum prolactin and total testosterone were assessed using a set of reagents "Accubind», USA. All the study participants filled in the AMS (Aging Male's Symptoms) questionnaire which is a 17-item self-report questionnaire for identifying middle-aged and older men with androgen deficiency. The results of the study were statistically analyzed using software packages Microsoft Excel 2016 and Statistica 6.0 (license number AXXR712D833214FAN5). The results were considered as statistically significant if $\mathrm{p}$-value was less than 0.05 . The data is presented as the median and interquartile interval.

\section{RESULTS}

Initially 56 hypertensive patients were divided into 2 groups with regard to their total testosterone (TT) level: group 1 included 31 hypogonadal men, while remaining 25 male patients had their TT concentrations within the normal range and were grouped together as the group 2 . The mean age of participants was $57.4 \pm 7.2,55.5 \pm 7.2$ and $53.1 \pm 8.0$ for group 1, group 2 and control subjects respectively. Statistically significant difference between group 1 and group 2 regarding office systolic $\mathrm{BP}$, office diastolic $\mathrm{BP}$ and heart rate was not found.

As it was mentioned before, all study participants were interviewed for symptoms of possible androgen deficiency using AMS questionnaire. According to calculations of total AMS score, patients' symptoms were evaluated in psychological, somatovegetative and sexual domains [13]. A total score was calculated based on Lickert scale for each question. Total AMS scores of 37-49 and >49 points which are classified as "moderate symptoms" and "severe symptoms" respectively, were peculiar for $90.3 \%$ of patients of 1 st group and $64 \%$ of patients of 2 nd group, besides the strongest correlation was seen between total testosterone level and sexual domain (Table I). In addition, a strong correlation was found between prolactin concentration and psychological symptoms. Somatic items did not correlate significantly with named hormones.

The main characteristics of study groups are shown in the Table I.

Seeing the contributing role of prolactin level in the development of predominantly psychological symptoms of androgen deficiency arises the need for the evaluation of its possible role in clinical settings with reference to the course of hypertension in these patients. Parameters of $24 \mathrm{~h}$ ABPM and indicators of arterial stiffness were assessed for this purpose.

The group of patients with low testosterone level were characterized by higher values of mean $24 \mathrm{~h} \mathrm{SBP}$ compared to men with normal testosterone level. It was also noticed that more patients of group 1 have non-favourable 
Table I. Characteristics of study groups.

\begin{tabular}{|c|c|c|c|}
\hline Parameters & $\begin{array}{c}\text { Group } 1 \text { (hypertensive men } \\
\text { with low TT) } \\
(n=31)\end{array}$ & $\begin{array}{c}\text { Group } 2 \text { (hypertensive men } \\
\text { with normal TT) } \\
(\mathrm{n}=25)\end{array}$ & $\begin{array}{l}\text { Control group } \\
\quad(n=27)\end{array}$ \\
\hline $\mathrm{TT}, \mathrm{ng} / \mathrm{mL}$ & $1.56[1.27 ; 1.82]^{*} \#$ & $3.08[2.55 ; 3.72]^{*}$ & $4.25[2.89 ; 4.83]$ \\
\hline Prolactin, $\mathrm{pg} / \mathrm{mL}$ & $12.62[10.55 ; 15.49]^{* \#}$ & $10.45[9.18 ; 12.61]$ & $10.26[5.11 ; 12.11]$ \\
\hline $\begin{array}{c}\text { AMS score: } \\
\text {-total score } \\
\text {-somatovegetative domain } \\
\text {-psychological domain } \\
\text {-sexual domain }\end{array}$ & $\begin{array}{c}41[38 ; 46]^{* \#} \\
7[4 ; 9] \\
13[9 ; 17]^{* \#} \\
13[8 ; 17]^{* \#}\end{array}$ & $\begin{array}{c}33[28 ; 37]^{*} \\
6[4 ; 8] \\
10[8 ; 13]^{*}\end{array}$ & $\begin{array}{c}28[22 ; 30]^{*} \# \\
5[4 ; 8] \\
9[7 ; 12]^{* \#}\end{array}$ \\
\hline
\end{tabular}

Note: * $-p<0.05$ compared to control group, \# - $p<0.05$ compared to group 2; TT - total testosterone, AMS - Aging Male's Symptoms Score

Table II. Parameters of central hemodynamics and arterial stiffness of study participants

\begin{tabular}{cccc}
\hline Parameters & $\begin{array}{c}\text { Group } \mathbf{1} \text { (hypertensive } \\
\text { men with low TT) }(\mathbf{n}=\mathbf{3 1})\end{array}$ & $\begin{array}{c}\text { Group } \mathbf{2} \text { (hypertensive men } \\
\text { with normal TT) } \mathbf{( n = 2 5 )}\end{array}$ & $\begin{array}{c}\text { Control group } \\
(\mathbf{n}=\mathbf{2 7})\end{array}$ \\
\hline Central aoSBP, mm Hg & $128[122 ; 134]^{* \#}$ & $124[121 ; 132]^{*}$ & $116[114 ; 119]$ \\
\hline aoPWV, $\mathrm{m} / \mathrm{s}$ & $11,2[9,1 ; 11,8]^{*}$ & $10,1[9,4 ; 10,6]^{*}$ & $8,1[7,6 ; 8,6]$ \\
\hline RWTT, ms & $128[126 ; 135]^{*}$ & $125[123 ; 137]^{*}$ & $118.5[106.3 ; 130.8]$ \\
\hline Aix \%75 & $-28.5[-36.8 ;-18.5]^{*}$ & $-27.5[-36.4 ;-19.0]$ & $-34[-37.5 ;-30.5]$ \\
\hline AASI & $145.5[129.8 ; 167.3]$ & $140.5[115.3 ; 165.8]$ & $135.5[119.3 ; 147.8]$ \\
\hline
\end{tabular}

Note: ${ }^{*}-p<0.05$ compared to control group, $\#-p<0.05$ compared to group 2

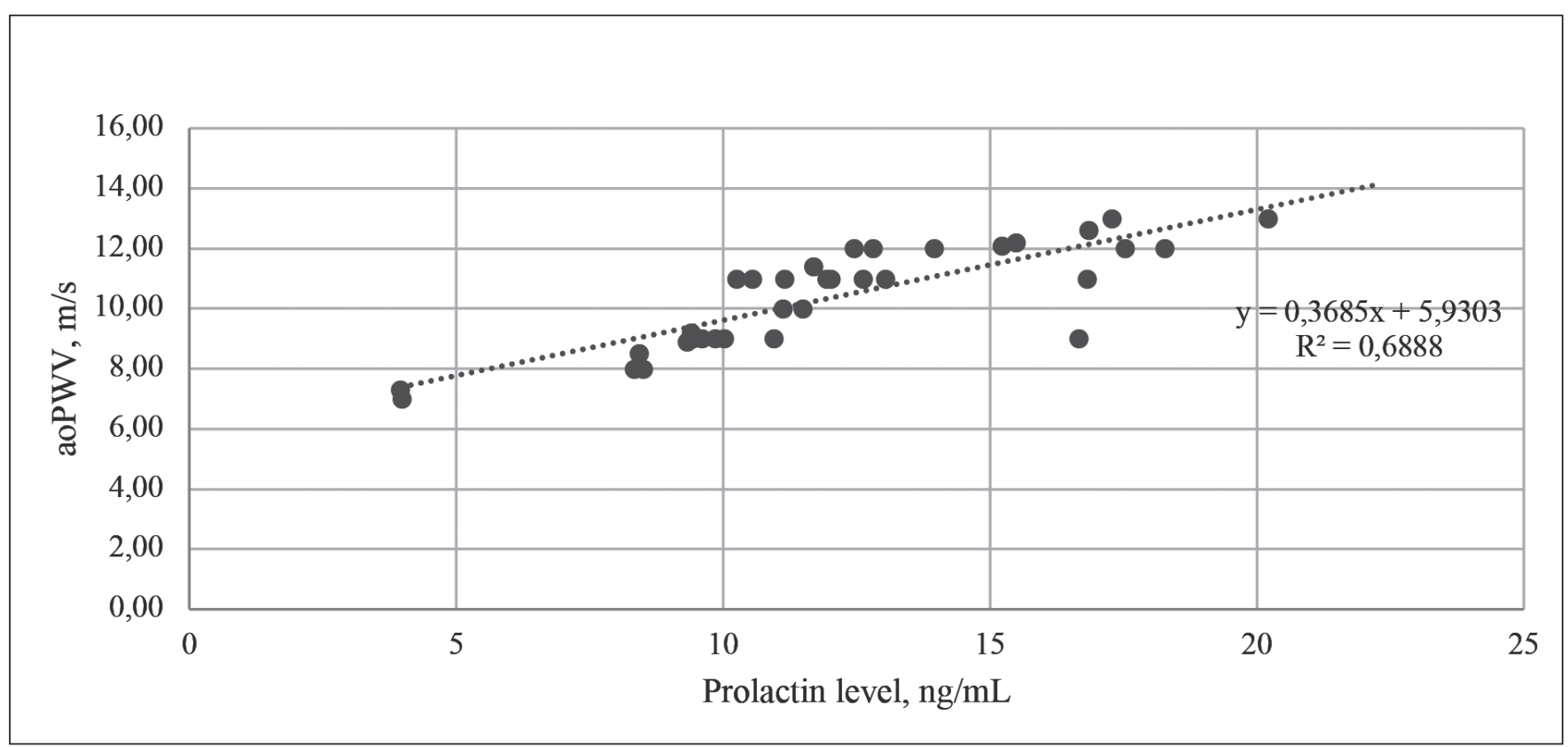

Figure 1. Correlation between prolactin level and aoPWV.

circadian pattern of BP ( $69 \%$ of non-dippers in 1 st group vs. $45 \%$ in $2 \mathrm{nd}$ ). The correlation of prolactin with these parameters turned out to be non-significant. Prolactin levels appeared to be significantly higher in hypertensive men with lower testosterone (median 12.62 [10.55; 15.49] versus $10.45[9.18 ; 12.61] \mathrm{ng} / \mathrm{mL}(\mathrm{P}=0.037)$ in group 2 and $10.26[5.11 ; 12.11] \mathrm{ng} / \mathrm{mL}(\mathrm{P}=0.0007)$ in control group $)$.
However, the correlation of prolactin with testosterone was insignificant $(\mathrm{P}=0.1)$.

In the matter of central aortic SBP, it appeared to be significantly higher in patients with lower values of total testosterone compared to those without androgen deficiency and control subjects. There were also notable differences in parameters of arterial stiffness (Table II). 
As demonstrated in Table II, men with low testosterone level who were also characterized by higher prolactin level had more unfavorable parameters of arterial stiffness and the difference between 1 and 2 group in terms of central aoSBP and aoPWV became statistically significant.

Further analysis showed that prolactin concentration was not related with RWTT ( $\mathrm{r}=0.172 ; \mathrm{P}=0.24$ and index Aix\% $75(\mathrm{r}=0.907 ; \mathrm{P}=0.87)$. In contrast, a significant correlation was observed between prolactin and aoPWV $(\mathrm{r}=0.87$; $\mathrm{P}=0.017$ ) (Figure 1).

\section{DISCUSSION}

The question about the consequential role of prolactin in processes of vascular remodelling in CVD has recently arisen and lead to the continuing of in-deep investigation of mechanisms of action of this hormone in the development of cardiovascular pathology. Most studies concentrate on prolactin level as a contributor to atherosclerosis in women in menopause, and the same data for men are not widely available. The notable finding of the current study is the demonstration of significant correlation of prolactin level with parameters of arterial stiffness, that is aoPWV and AASI, as well as with indicators of central hemodynamics (central aoSBP). Central BP is determined among others by stroke volume, peripheral resistance and arterial stiffness, emphasizing the role of the last as a key antecedent factor for BP elevation. Thereby, adverse cardiovascular effects of excess or upper boundary values of prolactin can be argued [4].

Several possible ways of the impact of prolactin levels in vascular remodelling were suggested, among them influence on vascular tone, mediation of low-grade inflammation and induction of smooth muscle cell proliferation are well described $[14,15]$.

Previous studies have described the association of prolactin with an increase in BP, especially among postmenopausal women $[4,16]$. Similar results have been shown in our study conducted among men.

Numerous studies conducted predominantly on male population have shown the regulating role of prolactin in acute psychological stress response but the type of hormonal reaction on stress in these studies are inconsistent. Our data correspond to the results received by Lennartsson et al., who demonstrated hormonal response to the general physiological stress activation with an increase in prolactin level. The present study revealed the correlation between the score of psychological domain in AMS questionnaire and prolactin concentration but these results are limited by the fact that the magnitude of psychological stress and levels of other stress hormones were not investigated so the correlations shown in our study cannot be used to assess the causality [17].

The probable mechanism of depressive disorders in hyperprolactinemia suggests the reduced ability of neurons in tubulofundibular region to produce dopamine and the excessive expression of prolactin receptors in the brain [18].

\section{CONCLUSIONS}

In conclusion, our study suggests the positive association of prolactin concentration with psychological domain of andropause symptoms and worse parameters of arterial stiffness among hypertensive men with androgen deficiency. These findings may be in use for further evaluation of prolactin as a predictor of poor prognosis of CVD.

\section{REFERENCES}

1. Ben-Jonathan N, Hugo E, Brandebourg T, LaPensee C. Focus on prolactin as a metabolic hormone. Trends in Endocrinology \& Metabolism. 2006;17(3):110-116. doi:10.1016/j.tem.2006.02.005

2. Manku M, Horrobin D, Zinner Het al. DOPAMINE ENHANCES THE ACTION OF PROLACTIN ON RAT BLOOD VESSELS. DOPAMINE EFFECTS ON PLASMA PROLACTIN. IMPLICATIONSFOR. Endocrinology. 1977;101(4):1343-1345. doi:10.1210/endo-101-4-1343.

3. Serri 0, Li L, Mamputu J, Beauchamp M, Maingrette F, Renier G. The influences of hyperprolactinemia and obesity on cardiovascular risk markers: effects of cabergoline therapy. Clin Endocrinol (0xf). 2006;0(0):060222010233005. doi:10.1111/j.1365-2265.2006.02469.x

4. Georgiopoulos G, Stamatelopoulos K, Lambrinoudaki I et al. Prolactin and Preclinical Atherosclerosis in Menopausal Women With Cardiovascular Risk Factors. Hypertension. 2009;54(1):98-105. doi:10.1161/hypertensionaha.109.132100.

5. Reuwer A, Twickler M, Hutten B et al. Prolactin Levels and the Risk of Future Coronary Artery Disease in Apparently Healthy Men and Women. Circulation: Cardiovascular Genetics. 2009;2(4):389-395 doi:10.1161/circgenetics.109.853572

6. Georgiopoulos G, Lambrinoudaki I, Athanasouli F et al. Prolactin as a predictor of endothelial dysfunction and arterial stiffness progression in menopause. J Hum Hypertens. 2017;31(8):520-524. doi:10.1038/ jhh.2017.15

7. Corona G, Maggi M. The role of testosterone in erectile dysfunction. Nature Reviews Urology. 2009;7(1):46-56. doi:10.1038/nrurol.2009.235D0l: 10.1161/CIRCGENETICS.109.853572 Circ Cardiovasc Genet. 2009;2:389395

8. Stamatelopoulos K, Georgiopoulos G, Sfikakis P et al. Pilot Study of Circulating Prolactin Levels and Endothelial Function in Men With Hypertension. Am J Hypertens. 2011;24(5):569-573. doi:10.1038/ ajh.2011.16 doi:10.1093/eurheartj/ehs23

9. Haring $\mathrm{R}$, Friedrich $\mathrm{N}$, Volzke $\mathrm{H}$ et al. Positive association of serum prolactin concentrations with all-cause and cardiovascular mortality. Eur Heart J. 2012;35(18):1215-1221. doi:10.1093/eurheartj/ehs233

10. Corona G, Rastrelli G, BoddiV et al. Prolactin levels independently predict major cardiovascular events in patients with erectile dysfunction. Int J Androl. 2010;34(3):217-224. doi:10.1111/j.1365-2605.2010.01076.x

11. Therkelsen K, Abraham T, Pedley A et al. Association Between Prolactin and Incidence of Cardiovascular Risk Factors in the Framingham Heart Study. J Am Heart Assoc. 2016;5(2). doi:10.1161/jaha.115.002640

12. Gomes J, Sousa A, Lima G. Hyperprolactinemia:EffectOn Mood?. European Psychiatry. 2015;30:714. doi:10.1016/s0924-9338(15)30564-2

13. Hellstrom W. Androgen Deficiency And Testosterone Replacement. New York: Humana Press; 2013.

14. Molinari C, Grossini E, Mary DA, Uberti F, Ghigo E, Ribichini F, Surico N, Vacca $G$. Prolactin induces regional vasoconstriction through the beta2adrenergic and nitric oxide mechanisms. Endocrinology. 2007;148: $4080-4090$. 
15. Montes de Oca P, Macotela Y, Nava G, Lo'pez-Barrera F, de la Escalera GM, Clapp C. Prolactin stimulates integrin-mediated adhesion of circulating mononuclear cells to endothelial cells. Lab Invest. 2005;85: 633- 642

16. Zhang L, Curhan GC, Forman JP (2010) Plasma prolactin level and risk of incident hypertension in postmenopausal women. J Hypertens 28(7):1400-1405.

17. Lennartsson A, Jonsdottir I. Prolactin in response to acute psychosocial stress in healthy men and women. Psychoneuroendocrinology. 2011;36(10):1530-1539. doi:10.1016/j.psyneuen.2011.04.007

18. Torner L. Actions of Prolactin in the Brain: From Physiological Adaptations to Stress and Neurogenesis to Psychopathology. Front Endocrinol (Lausanne). 2016;7. doi:10.3389/fendo.2016.00025

\section{Authors' contributions:}

According to the order of the Authorship.

\section{Conflict of interest:}

The Authors declare no conflict of interest.

\section{CORRESPONDING AUTHOR}

Olesia Nasonenko

Department of Internal Diseases 2,

Zaporizhzhia State Medical University,

9 Pryvokzalna str., 69000, Zaporizhzhia, Ukraine

e-mail: avnasonenko@gmail.com

Received: 29.11 .2018

Accepted: 21.02 .2019 
PRACA ORYGINALNA

ORIGINAL ARTICLE

\title{
ULTRAMICROSCOPIC CHANGES OF RATS PARATHYROID GLANDS AND THYMUS AFTER SINGLE ADMINISTRATION OF CYCLOPHOSPHAMIDE AT THE DIFFERENT PERIODS OF OBSERVATION
}

\author{
ULTRAMIKROSKOPOWE ZMIANY W PRZYTARCZYCACH \\ I GRASICY U SZCZURÓW PO POJEDYNCZYM PODANIU \\ CYKLOFOSFAMIDU W RÓŻNYCH OKRESACH OBSERWACJI
}

\author{
Victoria Erokhina', Olga Avilova² \\ 'DEPARTMENT OF HISTOLOGY, CYTOLOGY AND EMBRYOLOGY, KHARKIV NATIONAL MEDICAL UNIVERSITY, KHARKIV, UKRAINE \\ 2DEPARTMENT OF HUMAN ANATOMY, KHARKIV NATIONAL MEDICAL UNIVERSITY, KHARKIV, UKRAINE
}

\begin{abstract}
Introduction: Cyclophosphamide has wide spectrum usage as first-line drug in cancer chemotherapy that is why a detailed study of its effect on individual cell populations is of great interest for science and practice. The interaction of the nervous, immune and endocrine systems plays essential role in the homeostasis maintaining.

The aim: This study aimed to investigate the ultramicroscopic changes that occur in the parathyroid glands and thymus of male rats after cyclophosphamide administration. Materials and methods: Twenty-four WAG matured male rats were divided randomly into two groups. The first group served as control and was provided $0.9 \%$ soluble sodium chloride. The second group received cyclophosphamide in a dosage $200 \mathrm{mg} / \mathrm{kg}$ of body weight of animal by intramuscular single injection. All animals were sacrificed on the $7^{\text {th }}$ and $30^{\text {th }}$ day after injection. Parathyroid gland and thymus specimens were dissected out and processed for electron microscopy.

Results: The results showed that cyclophosphamide exposure caused marked ultramicroscopic changes in rats parathyroid glands and thymus. On the $7^{\text {th }}$ day after immunosuppression, the nuclei of parathyrocytes have deep wavy invaginations, amount of the organelles that participate in the protein synthesis is reduced to a minimum in the cytoplasm of the chief cells. Characteristic feature is the appearance of numerous plasma cells and active macrophages in thymus. There is a tendency to normalization of the parathyroid structure on the $30^{\text {th }}$ day after administration of cyclophosphamide and reduction of mitotic activity of lymphocytes in thymus, which points to the development of involution process. Conclusions: This data can be successfully extrapolated from experimental animals to humans.
\end{abstract}

KEY WORDS: Immunosuppression, Parathyroid glands, Thymus, Ultrastructure, Cyclophosphamide

Wiad Lek 2019, 72, 3, 362-367

\section{INTRODUCTION}

The concept of the parathyroid glands' structure has been formed during hundreds of years due to the development of microscopic technique and biological sciences [1]. Modern technologies have helped to obtain information about the ultramicroscopic structure of the parathyroid glands and their numerous compounds at different levels of the organization [2]. However, there are plenty of questions, the answers to which have not yet been found.

Parathyroid glands are aimed at sustaining one of the main components of the normal functioning of the body - calcium [3].The interaction of the nervous, immune and endocrine systems plays an essential role in the homeostasis maintaining [4].On the one hand, hormones affect the immune reaction rate; on the other hand, the activity of immunocompetent cells depends on the endocrine status of the organism [5].This is a reason to assume that the disturbance of one of the components of this complex status can lead to the imbalance of others. Moreover, the interaction between the immune system and bony tissue is beyond the doubt [6]. However, the morphogenetic influence of the immune system on the parathyroid glands has not been extensively studied yet. Therefore, in the case of treatment of patients with bone and joint pathology by immunotropic medications the effect of this group of drugs on the condition of the parathyroid glands must be taken into account.

Recent studies show that different types of immunotropic medicines have a significant role in the reducing endocrine diseases' risk factors. The parathyroid glands have a pronounced ability to rebuilding of their structure under the influence of various endogenous and exogenous factors $[7,8]$. However, the authors mostly focus on immunological and immunohistochemical studies of the parathyroid 
glands while the morphological aspects remain practically unexplored [9].

The thymus is a primary lymphoid organ that provides the microenvironment required for the development of T-lymphocytes. Many investigators have reported that thymus actively respond to a huge variety of exogenic and endogenic factors [10-12]. Therefore, one of the most promising directions in the problem solving of maintaining homeostasis is the study of the immune system due to the influence of immunotropic medications [13-14]. In the last few decades, chemotherapeutic drugs are widely used in healthcare settings as well as in the treatment community of cancers and other diseases. Unfortunately, acute and chronic dosing of chemotherapeutic agents is associated with numerous side effects. Cyclophosphamide has wide application as first-line drugs in cancer chemotherapy for various tumors that is why a detailed study of the drug's effect on individual cell populations and the timing of their recovery under various administration schemes is of vast interest for science and practice [15].

Proceeding from all above-mentioned electron microscopic study of the immune and endocrine system organs' structural features is essential for the development of new approaches for effective immunocorrection of the immune and endocrine systems [16-17].

\section{THE AIM}

This research aimed to investigate the ultramicroscopic changes that occur in the parathyroid glands and thymus of male rats after cyclophosphamide administration.

\section{MATERIALS AND METHODS}

\section{ANIMALS}

The following experimental work was conducted on 24 WAG matured male rats with initial body weight 180 $200 \mathrm{~g}$. White rats were used in the experiment because the structure of their organs of the immune and endocrine systems is not fundamentally different from those of humans. Keeping and manipulation of animals were carried out in compliance with national and world norms of bioethics $[18$, 19]. Experimental protocols were approved by the ethical committee of the Faculty of Medicine, Kharkiv National Medical University.

\section{EXPERIMENTAL DESIGN}

Rodents were randomly divided into two groups. The first group served as a control and was provided $0.9 \%$ soluble sodium chloride. The second group of animals received cyclophosphamide in a dosage $200 \mathrm{mg} / \mathrm{kg}$ of body weight of animal by intramuscular single injection. Rats used in the study were culled by cervical dislocation of the neck and tissue samples were collected on the $7^{\text {th }}$ and $30^{\text {th }}$ day after the injection. The parathyroid glands were extracted according to the original method, which has been described in detail in the patent[20]. The thymus was dissected with adjacent adipose and connective tissue in order to save its structure for further investigation.

\section{ELECTRON MICROSCOPY}

Materials for electron microscopy studies were further immersed in Karnovsky's fixative, postfixed in 1\% osmium tetraoxide for 1hour, dehydrated in an increasing ethanol series, infiltrated and embedded in EponAraldide resin. Ultrathin sections were cut with UMTP-4 ultramicrotome. The ultrathin sections were mounted on copper grids, double-stained with uranyl acetate and lead citrate and observed in EM-125 transmission electron microscope (TEM).

\section{RESULTS}

The parenchyma of the parathyroid glands of the control group of animals is represented mainly by chief cells, which contain numerous membrane-limited secretory granules as well as usual cytoplasmic organelles. Chief cells play an essential role in calcium homeostasis by releasing the appropriate amount of parathyroid hormone to maintain normal blood calcium levels. Chief parathyrocytes are organized as cords or clusters of cells supported by a loose connective tissue in which capillaries are embedded. Membrane interdigitations are well developed and form extensive complexes. Desmosomes also occur, but less frequently than interdigitation. In addition, the chief cells are classified into light cells and dark cells showing different functional phases of a single cell type. It is presumed that individual cells undergo periods of active secretion followed by periods of physiologic rest.

The cytoplasm of active chief cells in the parathyroid glands of the control group animals is finely granular and contains an abundant narrow rough endoplasmic reticulum, numerous dictyosomes of Golgi apparatus and occasional granules of glycogen, numerous secretory granules, and rare cilia. The nuclei are oval or spherical with occasional shallow invaginations. Inactive chief cells contain rare cisternas of rough endoplasmic reticulum and small Golgi apparatus, few secretory granules, and abundant glycogen. Lipid inclusions are membrane-limited and they are also prominent in many of inactive chief cells (Fig. 1).

The oxyphilic parathyrocytes derived from chief cells as aging or some metabolic derangements. They are observed either singly or in small groups between chief cells. Electron microscopy of the control series rats has shown that oxyphils are found in less number. The size of oxyphils is larger than size of chief cells. The cytoplasm of oxyphils is filled with numerous rod-shaped mitochondria. Organelles involved in protein synthesis are reduced to a minimum. Glycogen and lipid droplets are found in almost all cells, in some, there are single secretory granules.

On the $7^{\text {th }}$ day after immunosuppression, most of parathyrocytes have irregular shape, clear boundaries and well-defined intercellular contacts. Active chief cells are fewer than in rats of the control group. Some cells shrink and contain 


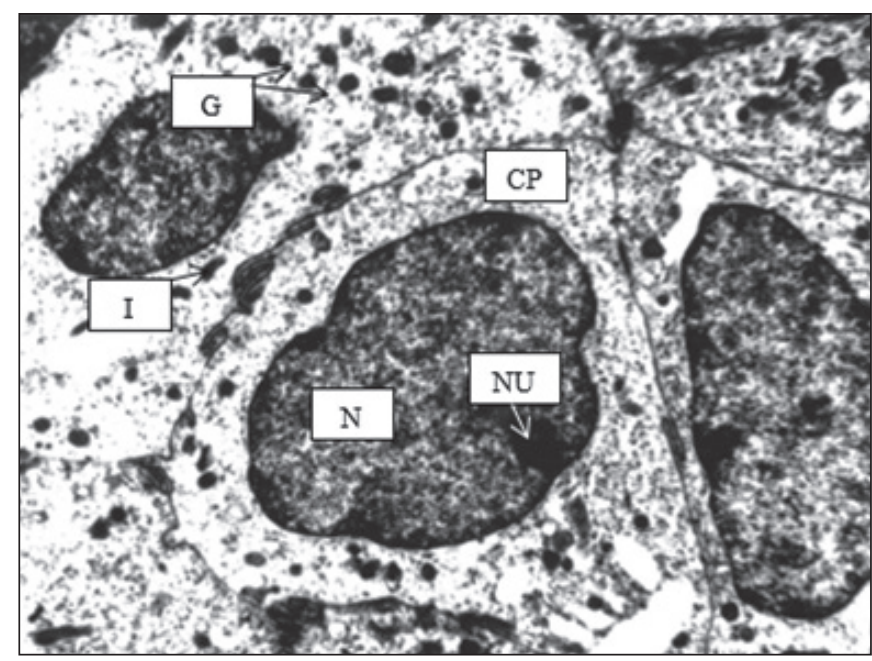

Fig. 1. Parathyroid gland of the control rat (7th day). TEM. Magnification $\mathrm{x} 8000$.

CP - chief parathyrocyte, $\mathrm{N}$ - nucleus, NU- nucleolus, I - interdigitation, $\mathrm{G}-$ secretory granules.

signs of apoptosis. The nuclei of chief parathyrocytes are shifted to the periphery. They are irregular in shape and contain deep wavy invaginations, chromatin condenses. The electronic density of the nuclei increases in comparison with the control group of rats. The chromatin is located in the form of clumps on the periphery of the nucleus.

The cytoplasm of the chief cells contains poorly developed organelles and infrequent secretory granules. The Golgi apparatus is small and relatively inconspicuous. There are numerous lipid droplets and lysosomes. The number of mitochondria increases; they have a beanshaped or oblong form with deep transverse cristae and an increased electronic density of their matrix. The capillaries are distended, slightly curved, and narrowed along the whole length. Additionally, some capillaries are marked with erythrocyte aggregations (Fig. 2).

Lastly, the oxyphills increase dramatically in number on the $7^{\text {th }}$ day after immunosuppression. General structure of the oxyphills has no significant changes in comparison with control rats.

On the $30^{\text {th }}$ day after the administration of cyclophosphamide to rats, the morphological pattern of the parathyroid glands at the ultramicroscopic level of the organization is different. At the same time, there is a tendency to normalization of the shape of cells and their nuclei. In the field of vision there are single dark cells. Some parathyrocytes have electronically dense nuclei with invaginations. The number of secretory granules in the cytoplasm is visually reduced in comparison with control animals. Lipid droplets of various electron densities are located on the periphery of parathyrocytes. There are single blood capillaries with a smaller diameter than in the slides of the control animals (Fig. 3).

The cellular composition of the cortex of the intact matured rats' thymus is represented by two main populations - lymphocytes and REC (reticuloepithelial cells). Lymphocytes of the control group animals' thymus have a regular

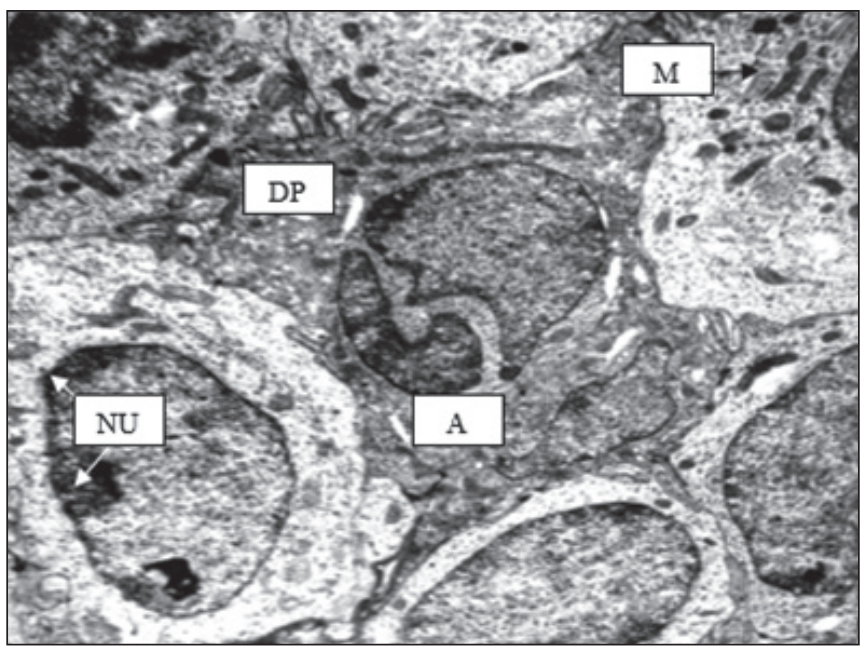

Fig. 2. Parathyroid gland of the experimental rat ( $7^{\text {th }}$ day). TEM. Magnification x8000.

DP - dark parathyrocyte, A - signs of apoptosis, NU- nucleolus, $\mathrm{M}$ - mitochondria.

rounded or slightly elongated shape with a smooth outer surface and characterized by high nuclear-cytoplasmic ratio. Small lymphocytes predominated in the inner layer of the thymus cortex. Their large, rounded nuclei are localized somewhat eccentrically, sometimes are invaginated, and have compact chromatin. The narrow electron-enlightened cytoplasm contains single spherical mitochondria and many free ribosomes.

Well-developed agranular endoplasmic reticulum is represented mainly by tubules and cisterns. The elements of the smooth endoplasmic reticulum are connected with the cisterns of the granular endoplasmic reticulum and the cell membrane. The mitochondrial matrix of lymphocytes is characterized by a significant electron-optical density. The lysosomal apparatus is represented by primary lysosomes, secondary lysosomes, and residual bodies.

The medium-sized lymphocytes were detected, the nuclei of some of them had 2 nucleoli. In the subcapsular zone of the thymus, lymphoblasts, the precursors of T lymphocytes, were detected. In subcapsular and, less, in the cortical zones are located mitotically dividing cells, a characteristic feature of which is the presence of dilated tubules of the endoplasmic reticulum near the plasmalemma (Fig. 4).

Within 7 days after the administration of cyclophosphamide, the ultrastructure of lymphocytes has a typical structure: chromatin in the form of lumps located along the periphery of the nucleus, a thin cytoplasm contains ribosomes and polysomes, sometimes there occur mitochondria.

Along with this, a large number of dark lymphocytes appear, representing a special pool of cells. They have smaller dimensions, vague boundaries, an electronically dense nucleus with condensed chromatin, a narrow cytoplasm rim around it with practically indistinguishable organelles.

Characteristic feature of the ultramicroscopic structure of the thymus after the application of cyclophosphamide is nu- 


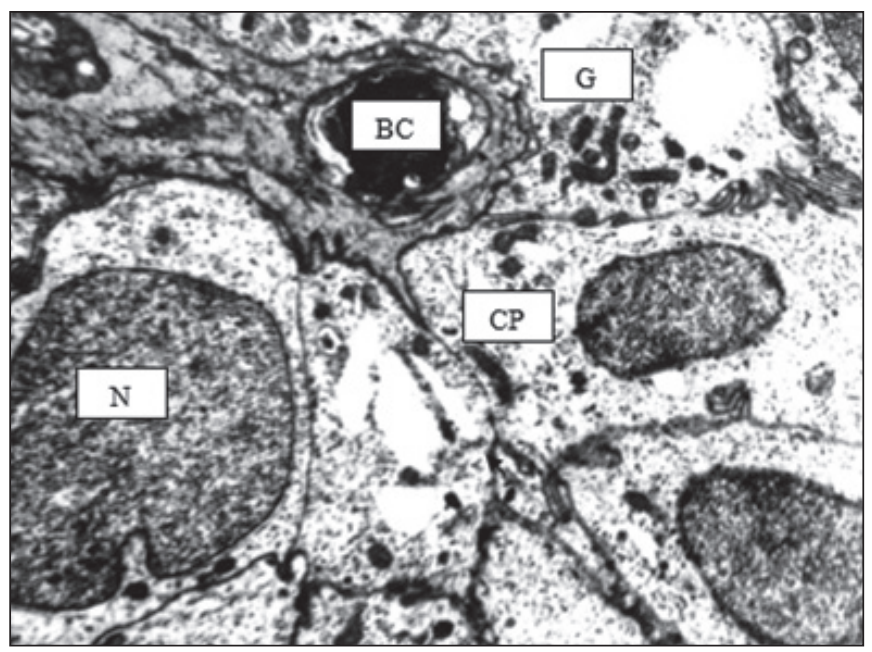

Fig. 3. Parathyroid gland of the experimental rat ( $30^{\text {th }}$ day). TEM. Magnification $\times 8000$.

CP - chief parathyrocyte, $\mathrm{N}$ - nucleus, $\mathrm{G}$ - secretory granules, $\mathrm{BC}$-blood capillary.

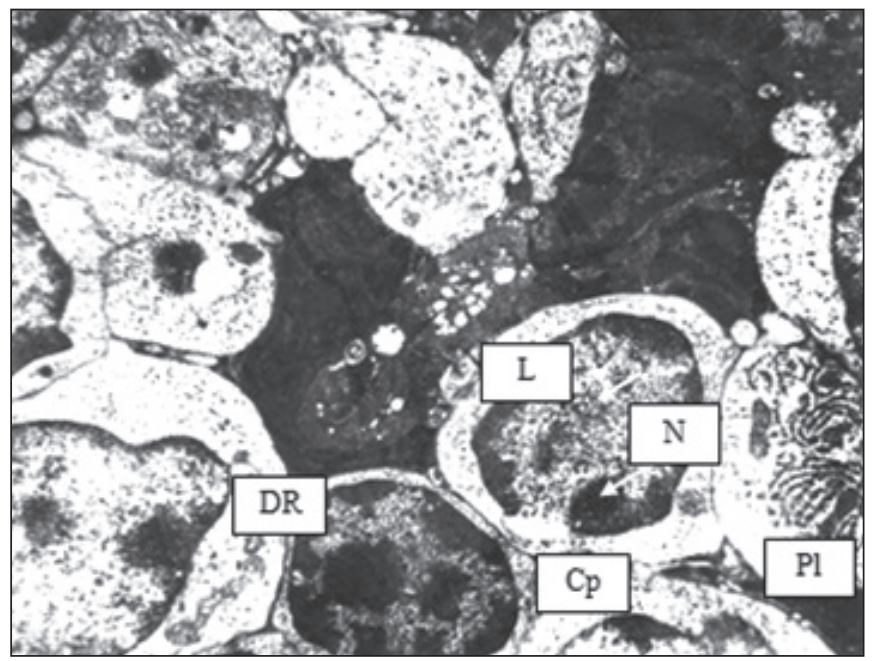

Fig. 5. Thymus cortex of the experimental rat ( $7^{\text {th }}$ day). TEM.

Magnification $\times 8000$.

L - lymphocyte, DR - dark lymphocyte, PI - plasma cell, N- nucleus, Cp-cytoplasm.

merous plasma cells, apparently migrating to the parenchyma of the organ from perivascular spaces. They have a rounded shape, large size, smooth contours. Nucleus of various sizes, irregular shape, invaginated, often located eccentrically, electronically dense, contain condensed chromatin. The cytoplasm is filled with dilated tubules of a granular endoplasmic reticulum with electronically dense contents. Only a light perinuclear region, poor in organelles, is preserved. Sometimes rounded mitochondria with destroyed cristae occur.

Many active macrophages are noted, as can be seen from the presence of secondary lysosomes and residual bodies in their cytoplasm. This picture is similar to electron microscopic changes in the structure of the thymus in involution, which indicates its active response to the use of an immunosuppressant (Fig. 5).

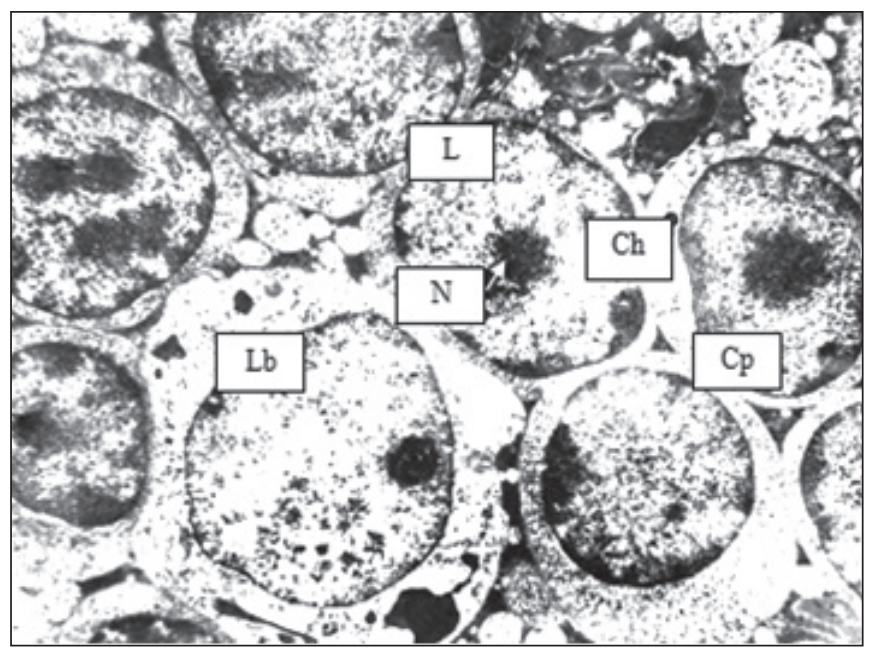

Fig. 4. Thymus cortex of the control rat $\left(7^{\text {th }}\right.$ day). TEM.

Magnification $x 8000$.

L- lymphocyte, Lb - lymphoblast, $\mathrm{N}$ - nucleus of the lymphocyte, Ch-chromatin, Cp - cytoplasm.

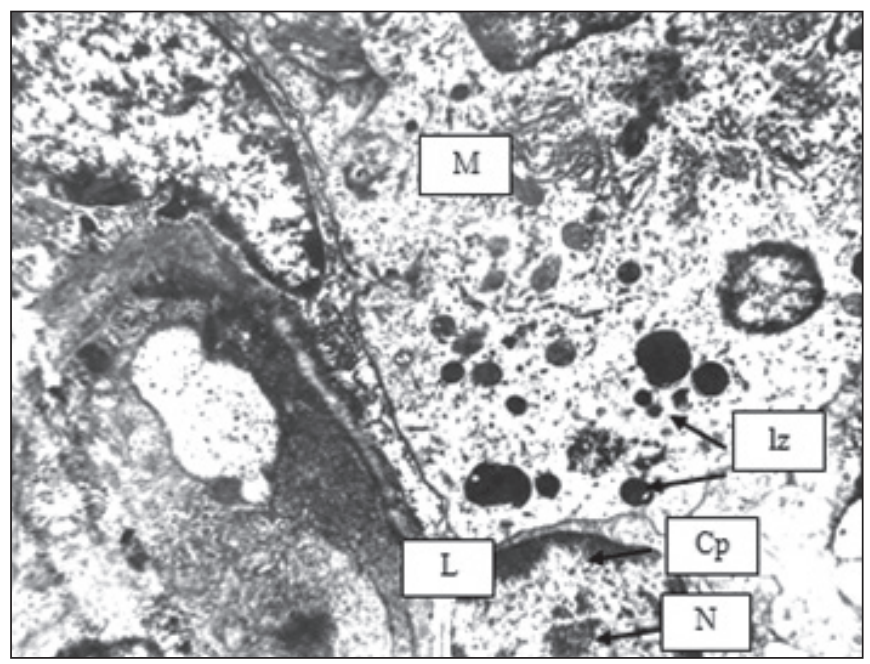

Fig. 6. Thymus cortex of the experimental rat ( $30^{\text {th }}$ day). TEM. Magnification x8000.

$\mathrm{L}$ - lymphocyte, $\mathrm{M}$ - macrophage, Iz - lyzosomes, $\mathrm{N}$ - nucleus, Cp - cytoplasm.

30 days after the administration of cyclophosphamide, the general features of the ultramicroscopic structure of the thymus are similar to those of the control group of animals. The presence of a large number of plasma cells is observed, the distinctive feature of which is the presence of dilated and deformed tubules of the granular endoplasmic reticulum filled with electron-dense contents, which indicates a disturbance of the metabolism of immunoglobulins with a shift towards intracellular accumulation. Distinctively seen their clock-face chromatin pattern where small dots symmetrically rim the nuclear membrane according to numbers on a clock.

Within eyeshot, the number of large macrophages increases, a large round or oval nucleus with a predominance of decondensed chromatin, numerous mitochondria, and lysosomes in 
the cytoplasm. Sometimes appear eosinophils and neutrophils of a typical structure. There is an increase in the number of connective tissue elements of the thymus stroma, in particular, collagen fibers, in comparison with the control group of animals (Fig. 6).

\section{DISCUSSION}

The principal change in the parathyroid glands of experimental rats compared to control animals of a similar age is the transformation of the population of active chief cells into inactive cells in less active stage of their secretory cycle. Ralph Y.C. reported that after the administration of methotrexatum active chief cells are fewer than in rats of the control group [21]. Moreover, cells were characterized by an electron-transparent cytoplasm which contained few organelles and secretory granules. A similar condition was reported by Toneto M. G. et al. [22]

Fournier C. et al. suggested that administration of high doses of cyclophosphamide is based on its ability to inhibit the proliferation of any metabolically active cells [15]. This allows us to explain the tendency to a decrease in all the organelles that are involved in protein synthesis. Kafetzis I. D. observed that the initial response (within 24 hours) to parathyroid suppression caused by heavy metals in rabbits was depletion of secretory granules, however, chronically stimulated chief cells had similar numbers of granules to cells in control rabbits [1].

Ge Q. and Zhao Y. were the first who discover that the administration of immunosuppressive drugs could lead to transformation of the nuclei and formation of the numerous invaginations of the nuclear envelope [21].

Avilova et. al. investigated the impact of xenobiotics on the thymus ultramicroscopic structure and revealed similar immunosuppressive effect as during administration of cyclophosphamide. Was observed thymocyte loss with more active process of involution due to activation of apoptosis and appearance of degenerative changes [10].

In research of Elmore S. [11] thymus has been shown to be a sensitive target organ following exposure to immunotoxicants and endogenous corticosteroids, and a decrease in size or weight is often one of the first noted measures of compound-induced effects with cortical lymphocytes being especially susceptible. Therefore, changes in thymus histopathology and architecture are considered to be of particular relevance for immunotoxicity screening.

\section{CONCLUSIONS}

1. The results showed that cyclophosphamide exposure caused marked ultramicroscopic changes in the rats' parathyroid glands and thymus. On the 7 th day after the administration of cyclophosphamide parenchyma of the parathyroid glands consists of mainly inactive chief cells. The nuclei of the parathyrocytes are shifted to the periphery and have deep wavy invaginations. Amount of the organelles that participate in the protein synthesis is reduced to a minimum. The outcome of thymus investigation allows to trace clearly the propensity to accidental involution development: there is a large number of dark lymphocytes, plasmocytes, macrophages.

2. There is a tendency to normalization of the shape of parathyrocytes and their nuclei on the $30^{\text {th }}$ day after the administration of cyclophosphamide to rats. In the field of vision, there are active dark chief cells, which may indicate the resumption of active synthesis of the parathormone. Reduction of lymphocytes mitotic activity, the presence of a large number of plasmocytes and macrophages with a characteristic structure, proliferation of connective tissue indicates the development of involutive processes in the thymus.

3. Investigating dynamic ultrastructural changes of parathyroid gland and thymus indicating intensive reactions of this organs to exogenous effects, cause huge interest in further study of their structure in immunostimulation, the results of which will be reflected in our future publications.

4. The results of a comprehensive evaluation of the morphological structure of rats' parathyroid glands and thymus at the ultramicroscopic level complement and extend the theoretical understanding of the interaction between endocrine and immune system. Revealed changes may be related to the generality of embryonic development of the parathyroid gland and thymus.

\section{REFERENCES}

1. Kafeyzis ID, Diamantopoulos A, Christakis I, Leoutsakos B. The history of the parathyroid glands. Hormones (Athens) 2011; 10(1): 80-84.

2. Toneto MG, Prill S, Debon LM et al. The history of the parathyroid surgery. Rev Col Bras Cir 2016; 43(3): 214-222.

3. DuBray La Perle KM, Dintzis SM. Endocrine System. In: Treuting PM, Dintzis SM, Montine KS (eds). Comparative anatomy and histology: a mouse, rat, and human atlas. 2018; 2nd Ed. London, Elsevier/Academic Press, pp 251-273.

4. Taub D. Neuroendocrine interactions in the immune system. Cell Immunol 2008; 252(1-2): 1-6.

5. Haddad J. The regulation of neuroimmune-endocrine interactions: Mechanisms, molecular pathways unraveled and the pivotal role of cytokines - A unsung putative bidirectional interdependence between the immune and neuroendocrine interfaces. Current Immunology Reviews 2008; 4(3): 134-158.

6. D'amelio P, Sassi F. Osteoimmunology: from mice to humans. Bonekey Rep 2016; 5: 802.

7. Arrangoiz R, Cordera F, Caba D et al. Parathyroid embryology, anatomy, and pathophysiology of primary hyperparathyroidism. International Journal of Otolaryngology and Head \& Neck Surgery IJOHNS 2017; 6(4): 39-58.

8. Shakeel S, Mubarak M. Proliferative lesions of parathyroid glands: an update for practicing pathologists. J Coll Physicians Surg Pak 2016; 26(1): 51-59.

9. Chen H, Senda T, Emura $S$ et al. An Update on the Structure of the Parathyroid Gland. The Open Anatomy Journal 2013; 5: 1-9.

10. Avilova 0 , Sheyan D, Marakushin D et al. Ultrustructural changes in the organs of the immune system under the influence of xenobiotics. Georgian medical news 2018; (6):132-7.

11. Elmore SA. Enhanced histopathology of the thymus. Toxicol Pathol 2006; 34(5): 656-665. 
12. Murray PJ, Wynn TA. Protective and pathogenic function of macrophage subsets. Nat Rev Immunol 2011; 11(11): 723-737.

13. Kim HJ, Alonzo ES, Dorothee $G$ et al. Selective depletion of eosinophils or neutrophils in mice impacts the efficiency of apoptotic cell clearance in the thymus. PLoS One 2010; 5(7): e11439.

14. Pearce G. Normal structure, function, and histology of the thymus. Toxicol Pathol 2006; 34(5): 504-514.

15. Fournier C, Clisant S, Amela EY et al. A dose-escalating phase I of imatinib mesylate with fixed dose of metronomic cyclophosphamide in targeted solid tumours. Br J Cancer 2013; 109(10): 2574-2578.

16. Aw D, Palmer DB. The origin and implication of thymic involution. Aging Dis 2011; 2(5): 437-443.

17. Mikusova R, MestanovaV, Polak Set al. What do we know about the structure of human thymic Hassall's corpuscles? A histochemical, immunohistochemical, and electron microscopic study. Ann Anat 2017; 211: 140-148.

18. Byk C. Bioethics, law and European integration. In: Fritz Jahr and European Roots of Bioethics. Proceedings of the 1st international conference; 2011 March 11-12; Rijeka Croatia. Department of Social Sciences and Medical Humanities University of Rijeka, Faculty of Medicine, pp 431-444.
19. Lolas F. Bioethics and animal research. A personal perspective and a note on the contribution of Fritz Jahr. Biol Res 2008; 41(1): 119-123.

20. Kaschenko SA, Tatarenko DP, Erokhina VV, Honcharova MV, Ivanov OS, Bobrysheva A0, inventors; Tatarenko DP, assignee. Modified method for thyroid preparation in rats. UA patent 81378. 2013 Jun 25.

21. Ge Q, Zhao Y. Evolution of thymus organogenesis. Dev Comp Immunol 2013; 39(1-2): 85-90.

Acknowledgments. The research was conducted on the basis of Kharkiv National Medical University. Hence, we are gratefully thankful for the technical support and to the spiritual guidance of the research unit.

Ethical consideration. Ethical issues in research have been completely observed by the authors.

\section{Authors' contributions:}

According to the order of the Authorship.

Conflict of interest:

The Authors declare no conflict of interest.

\section{CORRESPONDING AUTHOR}

\section{Victoria Erokhina}

Kharkiv National Medical University

Nauky Avenue, 4, 61022, Kharkiv, Ukraine

tel: +380961656483

e-mail: sha1936@rambler.ru

Received: 28.10.2018

Accepted: 11.02.2019 
PRACA ORYGINALNA

ORIGINAL ARTICLE

\title{
OCENA POZIOMU KONCENTRACJI IRYZYNY U KOBIET
}

Z WYSIŁKOWYM NIETRZYMANIEM MOCZU PO ZASTOSOWANIU ZEWNĘTRZNEJ NEUROSTYMULACJI MAGNETYCZNEJ (EXTRACORPOREAL MAGNETIC INNERVATION - EXMI) - BADANIE PILOTAŻOWE

\author{
ASSESSMENT OF IRISIN CONCENTRATION IN WOMEN \\ WITH STRESS URINARY INCONTINENCE AFTER USING \\ EXRACORPOREAL MAGNETIC INNERVATION (EXMI) \\ - PILOT STUDY
}

\author{
Magdalena Weber-Rajek', Agnieszka Radzimińska', Beata Pilarska², Mariusz Kozakiewicz', Aleksander Goch'1 \\ 'KATEDRA FIZJOTERAPII, WYDZIAŁ NAUK O ZDROWIU, COLLEGIUM MEDICUM W BYDGOSZCZY, UNIWERSYTET MIKOŁAJA KOPERNIKA W TORUNIU, \\ BYDGOSZCZ, POLSKA \\ 2KLINIKA UROLOGII, WYDZIAŁ NAUK OZDROWIU, COLLEGIUM MEDICUM W BYDGOSZCZY, UNIWERSYTET MIKOŁAJA KOPERNIKA WTORUNIU, BYDGOSZCZ, POLSKA \\ ${ }^{3}$ KATEDRA I ZAKŁAD CHEMII ŚRODKÓW SPOŻYWCZYCH, WYDZIAŁ NAUK O ZDROWIU, COLLEGIUM MEDICUM W BYDGOSZCZY, UNIWERSYTET MIKOŁAJA \\ KOPERNIKA W TORUNIU, BYDGOSZCZ, POLSKA
}

\section{STRESZCZENIE}

Wstęp: W Polsce nietrzymanie moczu (NTM) to dziewiąty co do częstości zgłaszany problem zdrowotny. Występuje on u 15,4\% kobiet powyżej 60. roku życia (dane Głównego Urzędu statystycznego z 2016 roku). Poszukiwanie optymalnych metod leczenia tego schorzenia oraz obiektywnych metod oceny skuteczności terapii stanowi wyzwanie dla interdyscyplinarnego zespołu specjalistów.

Cel pracy: 0cena koncentracji iryzyny u kobiet $z$ wysitkowym nietrzymaniem moczu po zastosowaniu zewnętrznej neurostymulacji magnetycznej (ExMI).

Materiały i metody: Do badań włączono 52 kobiety z wysiłkowym nietrzymaniem moczu, które przydzielono losowo do grupy eksperymentalnej $(n=28)$ i grupy kontrolnej (n=24). W grupie eksperymentalnej wykonano 12 zabiegów zewnętrznej neurostymulacji magnetycznej (ExMI). W obu grupach w ocenie początkowej i końcowej wykonano: ocenę poziomu koncentracji iryzyny oraz stopień nasilenia nietrzymania moczu przy użyciu The Revised Urinary Incontinence Scale (RUIS).

Wyniki: Po terapii w grupie eksperymentalnej wykazano istotny statystycznie wzrost koncentracji iryzyny oraz istotne statystycznie zmniejzzenie stopnia nasilenia nietrzymania moczu. Nie wykazano istotnej statystycznie korelacji między poziomem koncentracji iryzyny i stopniem nasilenia nietrzymania moczu. Wnioski: Istnieje potrzeba dalszych badań parametrów biochemicznych w ocenie dysfunkcji mięśni dna miednicy

SŁOWA KLUCZOWE: wysiłkowe nietrzymanie moczu, zewnętrzna elektrostymulacja magnetyczna, iryzyna

\begin{abstract}
Introduction: In Poland, urinary incontinence (UI) is the ninth in frequency of reported health problem, which occurs in $15.4 \%$ of women over 60 years of age (data of the Central Statistical Office of 2016). The search for optimal treatment methods for this disease and objective methods for assessing the effectiveness of therapy is a challenge for an interdisciplinary team of specialists.

The aim: To examine the effect of Extracorporeal Magnetic Innervation (ExMI) on the Irisin concentration in women with stress urinary incontinence.

Materials and methods: A total of 52 women were included in the analysis: 28 participants were allocated to the experimental group (EG) and 24 to the control group (CG). EG patients completed ExMI therapy, whereas no therapeutic intervention was applied to the CG. Irisin concentration, severity of urinary incontinence (RUIS) were measured in all women at the initial and final assessments.

Results: By comparing the initial and final assessment results we have been able to demonstrate a statistically significant differences in the measured variables in the EG. No statistically significant differences in the measured variables were reported for the $\mathrm{CG}$ at the initial and final assessments. No correlation was observed between the Irisin concentration results and severity of urinary incontinence in the $E G$ at the final assessment.

Conclusions: There is a need for further studies of biochemical parameters in the assessment of pelvic floor muscle dysfunction.
\end{abstract}

KEY WORDS: stress urinary incontinence, extracorporeal magnetic innervation, Irisin

Wiad Lek 2019, 72, 3, 368-373 


\section{WSTĘP}

W Polsce nietrzymanie moczu (NTM) to dziewiąty co do częstości zgłaszany problem zdrowotny występujący u 15,4\% kobiet powyżej 60. roku życia (dane Głównego Urzędu statystycznego z 2016 roku) [1]. Według WHO choroba, która dotyczy minimum $5 \%$ społeczeństwa nabywa status choroby społecznej [2]. Dane te jednoznacznie pokazują, że poszukiwanie optymalnych metod leczenia tego schorzenia oraz obiektywnych metod oceny skuteczności terapii stanowi wyzwanie dla interdyscyplinarnego zespołu specjalistów.

Etiopatogeneza nietrzymania moczu była przedmiotem badań wielu autorów. Według teorii integralnej przyczyną wysiłkowego nietrzymania moczu jest ubytek kolagenu i elastyny w ścianie pochwy lub/i niewydolność anatomicznych struktur otaczających pochwę, jak również związanych z nią mięśni, więzadeł i tkanki łącznej dna miednicy [3]. Badania wykazały również, że w mechanizmie trzymania moczu rolę odgrywa także mięsień dźwigacz odbytu. Przy wysiłku dochodzi do odruchowego skurczu okołocewkowych włókien tego mięśnia. Badania histopatologiczne przyśrodkowych pasm mięśnia dźwigacza odbytu wykazały, że zawierają one dwa typy włókien: włókna typu I (wolnokurczliwe) i włókna typu II (szybkokurczliwe). Przy wzroście ciśnień śródbrzusznych do zabezpieczenia cewki moczowej przed wyciekiem moczu wymagany jest udział włókien szybkokurczliwych [4]. Natomiast status biochemiczny tego mięśnia ulega zmianom, powodując wzrost liczby włókien wolnokurczliwych i jednocześnie zanik włókien szybkokurczliwych (niezbędnych do amortyzacji wzrostu ciśnień środbrzusznych). Pozwoliło to na wysunięcie teorii, że podstawowym mechanizmem powstawania wysiłkowego nietrzymania moczu (SUI stress urinary incontinence) u kobiet jest właśnie zanik lub upośledzenie funkcji włókien typu II dźwigacza odbytu [5]. Przemiana włókien mięśniowych typu II w typ I jest korzystnym, fizjologicznym mechanizmem adaptacji do wysiłku w innych mięśniach szkieletowych, jednakże gdy mechanizm ten występuje w otoczeniu cewki moczowej wywołuje efekt negatywny w postaci SUI. Wysiłkowe nietrzymanie moczu u kobiet związane jest również z niewydolnością aparatu więzadłowego podtrzymującego cewkę moczową (koncepcja „hamaka”) i/lub zwiotczeniem zwieracza cewki moczowej, które jest następstwem zmian w układzie mięśniowo-powięziowym dna miednicy [6, 7]. Wzmocnienie tego układu stanowi cel nadrzędny w terapii wysiłkowego nietrzymania moczu. Cel ten można osiągnąć za pomocą metod fizjoterapeutycznych, takich jak: ćwiczenia mięśni dna miednicy, elektrostymulację, biofeedback i zewnętrzną neurostymulację magnetyczną (ExMI - Extracorporeal Magnetic Innervation). ExMI jest to metoda wygodna, nieinwazyjna i bezbolesna. Pacjent siada w ubraniu na specjalnie skonstruowanym fotelu zabiegowym. W siedzisku fotela umieszczona jest głowica terapeutyczna, która wytwarza pole magnetyczne o wysokich wartościach indukcji elektromagnetycznej (2Tesle) oraz częstotliwość 10-50 Hz. Pole magnetyczne działa na włókna ruchowe nerwów sromowych i trzewnych.
Aktywacja pompy sodowo-potasowej i depolaryzacji neuronów ruchowych powodują torowanie impulsów w płytkach nerwowo-mięśniowych, które wyzwalają skurcz mięśni w unerwionym obszarze [8,9]. Mięśnie jako organ endokrynny podczas aktywności fizycznej wydzielają lokalne hormony tkankowe - miokininy, których aktywność wpływa na komunikację między tkankami i metabolizm organizmu. Jedna z tych miokinin - iryzyna (Ir), opisana po raz pierwszy w 2012 roku przez Boström i wsp. [10] jest fragmentem błony typu I zawierającej białko 5 domeny fibronektyny typu III (FNDC5 - fibronectin type III domain-containing protein 5). Ir jest wydzielana $\mathrm{z}$ mięśni szkieletowych w odpowiedzi na wysiłek fizyczny i indukuje brązowienie białej tkanki tłuszczowej oraz przemianę zmagazynowanej w mięśniach energii w energię cieplną, co w rezultacie powoduje zwiększone zużycie tlenu i większą dostawę energii [10-13].

\section{CEL BADAŃ}

Celem badań była ocena koncentracji iryzyny u kobiet z wysiłkowym nietrzymaniem moczu po zastosowaniu zewnętrznej neurostymulacji magnetycznej (ExMI).

\section{MATERIAŁY I METODY}

\section{PROJEKT BADANIA}

W okresie od marca do maja 2017, 71 kobiet $\mathrm{z}$ nietrzymaniem moczu zostało zakwalifikowanych do randomizowanych badań klinicznych z grupą kontrolną. Podziału na grupy dokonano za pomocą prostego, losowego wybierania kopert, które zawierały numer przydziału do grupy z wygenerowanej komputerowo tabeli liczb losowych. Na pierwszym etapie 16 kobiet zostało wykluczonych ( $14 \mathrm{z}$ nich nie spełniało kryteriów włączenia, a 2 odmówiły uczestnictwa). Następnie 55 kobiet zostało losowo przydzielonych do grupy eksperymentalnej (GE) i grupy kontrolnej (GK). Łącznie 3 uczestniczki nie skończyły badania: 2 kobiety wycofały się w trakcie 4-tygodniowej interwencji z GE, a 1 kobieta z GK nie pojawiła się na badaniach końcowych. W związku z tym 52 kobiety ukończyły badanie $(\mathrm{GE} n=28 ; \mathrm{GK} n=24)$. W celu zwiększenia jakości raportowania wykorzystano Consolidated Standards of Reporting Trials (CONSORT) (Ryc. 1) [14].

$\mathrm{U}$ wszystkich kobiet przed terapią przeprowadzono wywiad dotyczący okoliczności, w których dochodzi do gubienia moczu, występowania schorzeń współistniejących oraz wykluczono przeciwwskazania do terapii. Rodzaj nietrzymania moczu został potwierdzony za pomocą diagnozy lekarskiej oraz dodatkowo za pomocą The Questionnaire for Urinary Incontinence Diagnosis (QUID). QUID jest 6-punktowym kwestionariuszem dotyczącym objawów nietrzymania moczu, który został opracowany w celu zdiagnozowania rodzaju nietrzymania moczu. QUID ma akceptowalne cechy psychometryczne i jest powszechnie stosowany w badaniach klinicznych [15].

Kryteria włączenia do badań stanowiły: wiek 60 lat i powyżej, zdiagnozowane wysiłkowe nietrzymanie 


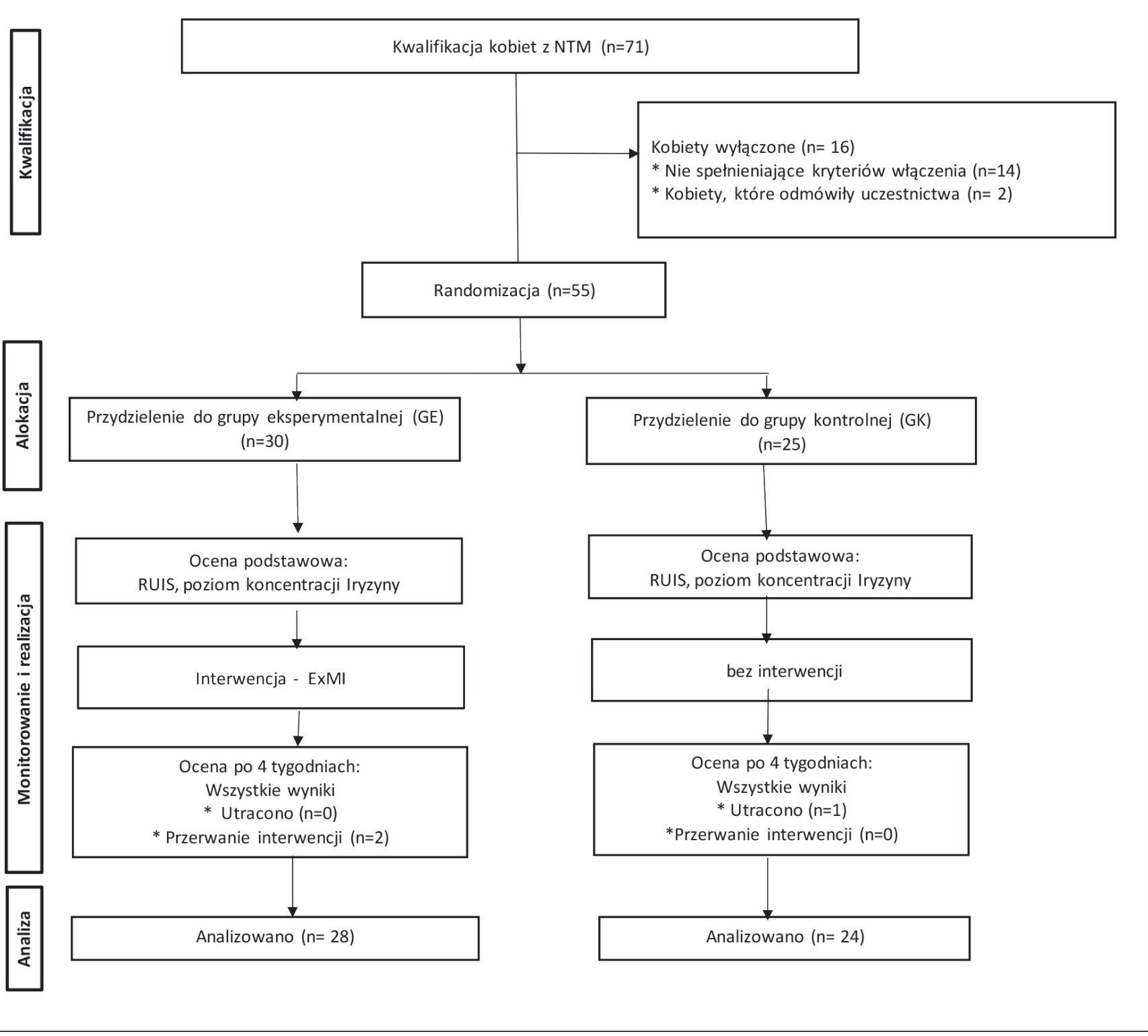

Ryc. 1. Schemat badania.

moczu oraz wykluczenie przeciwwskazań do terapii (utrudniony kontakt z pacjentem, czynny proces nowotworowy; gorączka; ostre stany zapalne; świeże złamania w obrębie miednicy; przebyte zabiegi chirurgiczne w obrębie miednicy; zaburzenie czucia w obrębie miednicy; guzy i mięśniaki macicy; obniżenie macicy 3. stopnia; hemoroidy; infekcje dróg moczowych lub rodnych; poważne osłabienie i/lub wada zwieracza cewki moczowej; zakrzepica żył głębokich; ostre infekcje; arytmia serca; rozrusznik serca; choroby neurologiczne). Natomiast kryteria wykluczenia $\mathrm{z}$ badań stanowiły: wiek poniżej 60 lat, zdiagnozowane naglące i mieszane nietrzymanie moczu; odbyte w ostatnich trzech miesiącach interwencje terapeutyczne w leczeniu nietrzymania moczu (ćwiczenia mięśni dna miednicy, magnetoterapia, elektrostymulacja, biofeedback) oraz występowanie wyżej wymienionych przeciwskazań.

\section{METODY OBIEKTYWIZACJI EFEKTÓW TERAPII}

U wszystkich kobiet przed terapią oraz bezpośrednio po jej zakończeniu dokonano:

1. Oceny stopnia nasilenia nietrzymania moczu, przy użyciu The Revised Urinary Incontinence Scale (RUIS). RUIS to walidowana, pięciostopniowa skala, którą można wykorzystać do oceny stopnia nasilenia nietrzymania moczu i monitorowania wyników leczenia. Wynik 0-3 - brak nietrzymania moczu; 4-8 - łagodne nietrzymanie moczu; 9-12 - umiarkowane nietrzymanie moczu, a wynik 13 lub powyżej - ciężkie nietrzymanie moczu [16].

2. Oceny poziomu koncentracji iryzyny.

Od każdej uczestniczki pobrano $6 \mathrm{ml}$ krwi na czczo $\mathrm{w}$ probówkach z lekiem przeciwzakrzepowym EDTA. Wykorzystany zestaw to test immunoenzymatyczny (ELISA) BIOVENDOR IRISIN ELISA nr kat.: RAG018R, Brno, Republika Czeska. Wykorzystany test jest 
Tabela I. Analiza porównawcza wszystkich badanych zmiennych w ocenie początkowej między GB I GK.

\begin{tabular}{ccccc}
\hline Zmienna & Statystyka & $\begin{array}{c}\text { GE } \\
(\mathbf{n = 2 8})\end{array}$ & $\begin{array}{c}\text { GK } \\
(\mathbf{n = 2 4 )}\end{array}$ & p value \\
\hline Koncentracja Iryzyny & $\mathrm{x}$ & 8,73 & 6,26 & 0,052 \\
$(\mu \mathrm{g} / \mathrm{ml})$ & $\mathrm{SD}$ & 1,76 & 2,05 & 0,051 \\
\hline RUIS & $\mathrm{x}$ & 9,64 & 7,79 & 2,10 \\
\hline
\end{tabular}

n - liczba obserwacji; $x$ - średnia; SD - odchylenie standardowe, p value - poziom istotności

Tabela II. Analiza porównawcza wszystkich badanych zmiennych w ocenie początkowej i końcowej w GE i GK.

\begin{tabular}{|c|c|c|c|c|c|c|c|}
\hline \multirow[b]{2}{*}{ Zmienna } & \multirow[b]{2}{*}{ Statystyka } & \multicolumn{2}{|c|}{ GE $(n=28)$} & \multicolumn{4}{|c|}{ GK $(n=24)$} \\
\hline & & $\begin{array}{c}\text { Ocena } \\
\text { początkowa }\end{array}$ & $\begin{array}{c}\text { Ocena } \\
\text { końcowa }\end{array}$ & p value & $\begin{array}{c}\text { Ocena } \\
\text { początkowa }\end{array}$ & Ocena końcowa & p value \\
\hline $\begin{array}{l}\text { Koncentracja } \\
\text { Iryzyny }\end{array}$ & $\mathrm{x}$ & 8,73 & 10,67 & \multirow[t]{2}{*}{$0,000^{*}$} & 6,26 & 6,66 & \multirow[t]{2}{*}{0,063} \\
\hline$(\mu \mathrm{g} / \mathrm{ml}$ & SD & 1,76 & 2,29 & & 2,05 & 2,28 & \\
\hline RUIS & $x$ & 9,64 & 7,53 & \multirow{2}{*}{$0,001^{*}$} & 7,79 & 8,35 & \multirow{2}{*}{0,234} \\
\hline (punkty) & SD & 4,09 & 3,56 & & 2,10 & 2,71 & \\
\hline
\end{tabular}

$\mathrm{n}$ - liczba obserwacji; $\mathrm{x}$ - średnia; SD - odchylenie standardowe, p value - poziom istotności; ${ }^{*}$ wyniki istotne statystycznie

testem kompetycyjnym, w którym oczyszczony antygen rywalizuje $\mathrm{z}$ antygenem $\mathrm{w}$ badanej próbce o wiązanie z przeciwciałem, które zostało unieruchomione w dołku płytki. Zestaw służy do ilościowego oznaczania iryzyny w ludzkim osoczu. Przeciwciało poliklonalne rozpoznające natywną iryzynę reaguje z szeregiem wcześniej określonych standardowych białek rekombinowanej iryzyny lub próbek w konkurencji na płytce powleczonej iryzyną. Następnie przeprowadza się reakcję barwną z substratem (TMB), w wyniku której powstaje niebieskie zabarwienie. Reakcję zatrzymuje się poprzez dodanie kwaśnego roztworu, w konsekwencji czego następuje zmiana barwy z niebieskiej na żółtą. Absorbancję zmierzono przy $450 \mathrm{~nm}$ w czytniku ELISA. Wygenerowano krzywą standardową, wykreślając średnią absorbancję otrzymaną dla każdego standardowego stężenia w stosunku do odpowiedniego stężenia iryzyny $(\mu \mathrm{g} / \mathrm{ml})$. Obliczanie stężeń próbek iryzyny przeprowadzono przez interpolację wzoru krzywej regresji 4-parametrowego równania logistycznego.

\section{METODA TERAPEUTYCZNA}

Pacjentki z GE poddane były terapii przez 4 tygodnie, z 3 sesjami w tygodniu po 15 minut. W terapii wykorzystano urządzenie NeoControl (Neotonus Inc., Marietta, GA, USA). Zastosowano następujące parametry pola elektromagnetycznego: 2.0 Tesla; $50 \mathrm{~Hz}$, “on" - 8 s, "of ”- 4 s; intensywność od $20 \%$ do $100 \%$. Intensywność stymulacji elektromagnetycznej była dostosowywana do maksymalnej wartości tolerowanej przez pacjentkę. W grupie kontrolnej nie prowadzono żadnej interwencji terapeutycznej.

\section{ANALIZA STATYSTYCZNA}

Analizę statystyczną zebranego materiału przeprowadzono w programie Statistica 10.0 firmy StatSoft. Do analizy zmiennych posłużono się zarówno testami parametrycznymi, jak i testami nieparametrycznymi. Wybór testu parametrycznego uwarunkowany był spełnieniem podstawowych jego założeń, tj. zgodności rozkładów badanych zmiennych $\mathrm{z}$ rozkładem normalnym, które zweryfikowano testem Shapiro-Wilka. Do oceny zmienności wewnątrzgrupowej w dwóch populacjach posłużono się testem t-Studenta dla zmiennych zależnych. Do oceny różnic między dwiema grupami posłużono się testem t-Studenta dla zmiennych niezależnych. Korelację między badanymi zmiennymi przeprowadzono przy użyciu współczynnika korelacji rang Spearmana. Za poziom istotności statystycznej przyjęto $\mathrm{p}<0,05$.

\section{WYNIKI}

W tabeli I przedstawiono statystyki opisowe i wyniki testu t-Studenta dla wszystkich badanych zmiennych w ocenie początkowej w GE i GK.

Porównując wartość p testu t-Studenta $\mathrm{z}$ poziomem istotności $\alpha=0,05$ wykazano brak istotnych statystycznie różnic między wynikami GE i GK w ocenie początkowej. Świadczy to o jednorodności badanych grup.

W tabeli II przedstawiono statystyki opisowe i wyniki testu t-Studenta dla porównania wyników wszystkich badanych zmiennych w ocenie początkowej i końcowej w GE i GK

Porównując wartość p testu t-Studenta z poziomem istotności $\alpha=0,05$ wykazano istotne statystycznie różnice we wszystkich badanych zmiennych w GE, natomiast nie 
Tabela III. Analiza porównawcza wszystkich badanych zmiennych w ocenie końcowej między GB i GK

\begin{tabular}{ccccc}
\hline Zmienna & Statystyka & $\begin{array}{c}\text { GE } \\
(\mathbf{n = 2 8})\end{array}$ & $\begin{array}{c}\text { GK } \\
(\mathbf{n = 2 4 )}\end{array}$ & p value \\
\hline Koncentracja Iryzyny & $\mathrm{x}$ & 10,67 & 6,66 & $0,000^{*}$ \\
$(\mu \mathrm{g} / \mathrm{ml})$ & $\mathrm{SD}$ & 2,29 & 2,28 & \\
\hline RUIS & $\mathrm{x}$ & 7,53 & 8,35 & 0,350 \\
(punkty) & SD & 3,56 & 2,71 &
\end{tabular}

$\mathrm{n}$ - liczba obserwacji; $\mathrm{x}$ - średnia; SD - odchylenie standardowe, p value - poziom istotności; * wyniki istotne statystycznie

wykazano istotnych statystycznie różnic we wszystkich badanych zmiennych w GK.W GE wykazano istotne statystycznie zwiększenie poziomu koncentracji iryzyny i zmniejszenie stopnia nasilenia moczu.

W tabeli III przedstawiono statystyki opisowe i wyniki testu t-Studenta dla wszystkich badanych zmiennych w ocenie końcowej w GE i GK.

Porównując wartość p testu t-Studenta $\mathrm{z}$ poziomem istotności $\alpha=0,05$ wykazano istotne statystycznie różnice w wynikach koncentracji iryzyny oraz nie wykazano istotnych statystycznie różnic w wynikach stopnia nasilenia nietrzymania moczu między GE i GK w ocenie końcowej.

$\mathrm{Na}$ ostatnim etapie badań w GE dokonano korelacji między wynikami koncentracji iryzyny i stopnia nasilenia nietrzymania moczu (RUIS) w ocenie końcowej. Nie wykazano korelacji istotnych statystycznie $(r=-0.007)$.

\section{DYSKUSJA}

Opublikowane przez Bostrom i wsp. w 2012 roku badania [10] rozpoczęły dyskusję nad czynnikami, które mają wpływ na ekspresję iryzyny. Dostępne badania pokazują, że do czynników tych należą: wiek $[17,18]$, rodzaj aktywności fizycznej i poziom wytrenowania [19-22], masa ciała [23, 24], jak również choroby wspólistniejące [25-28] Zgodnie z naszą wiedzą niniejsze badanie jest pierwszym, w którym oceniano ekspresję tej miokininy podczas aktywności mięśni dna miednicy. Wyniki pokazały istotny statystycznie wzrost koncentracji Ir po zastosowniu zewnętrznej neurostymulacji magnetycznej w grupie starszych kobiet z wysiłkowym nietrzymaniem moczu. Wykazano również zmniejszenie stopnia nietrzymania moczu ocenianego za pomocą The Revised Urinary Incontinence Scale. Korelacja wyników koncentracji Ir i stopnia nasilenia nietrzymania moczu w grupie eksperymentalnej w ocenie końcowej nie wykazała wyników istotnych statystycznie, jednak warto zwrócić uwagę na ujemny kierunek korelacji - wyższy stopień nietrzymania moczu wiązał się z niższym poziomem koncentracji iryzyny. Nasze badanie traktujemy jako badanie pilotażowe i planujemy jego kontynuację z uwzględnieniem dodatkowych zmiennych (parametry antropometryczne, choroby współistniejące). Przeprowadzone analizy są próbą odpowiedzi na pytanie, czy poziom koncentracji miokinin może stanowić marker wskazujący na dysfunkcję mięśni dna miednicy oraz być przydatny w obiektywizacji efektów terapii. We wcześniejszych ba- daniach podjęliśmy próbę oceny koncentracji miostatyny, uzyskując jej istotny spadek po zastosowaniu zarówno zewnętrznej neurostymulacji magnetycznej (ExMI) [29], jak i ćwiczeń mięśni dna miednicy (PFMT - pelvic floor musckle training) [30].

\section{WNIOSKI}

1. Wyniki przeprowadzonych badań wykazały istotny statystycznie wzrost koncentracji iryzyny i zmniejszenie stopnia nietrzymania moczu po zastosowaniu zewnętrznej neurostymulacji magnetycznej.

2. Istnieje potrzeba dalszych badań parametrów biochemicznych w ocenie dysfunkcji mięśni dna miednicy.

\section{PIŚMIENNICTWO}

1. Ludność w wieku 60 lat i więcej (struktura według płci i wieku, trwanie życia, umieralność, prognoza). Raport GUS, 19.02.2016; https://stat.gov. pl/fi les/gfx/ portalinformacyjny/pl/defaultaktualnosci/5468/24/1/1/ ludnosc_w_wieku_60._struktura_demografi czna_i_zdrowie.pdf [dostęp: 15.01.2019]

2. Adamczuk J, Kraczkowski JJ, Robak JM, Żurawska vel Dziurawiec K. Czy nietrzymanie moczu to choroba cywilizacyjna? Probl Hig Epidemiol. 2011;92(3):382-386.

3. Petros PE, Ulmsten U. An integral theory of female urinary incontinence. Experimental and clinical considerations. Acta Obstet Gynecol Scand Suppl 1990; 153:7-31.

4. Constantinou CE. Resting and stress urethral pressures as a clinical guide to the mechanism of continence. Clin Obstet Gynecol 1985;12(2):343-356.

5. Jóźwik M. Nowe koncepcje patogenezy nietrzymania moczu u kobiet. Praca habilitacyjna. AM Białystok 1999.

6. Petros P, Woodman P. The Integral Theory of continence. Int Urogynecol J. 2008; 19(1):35-40.

7. Jóźwik M, Jóźwik M, Adamkiewicz M, Szymanowski P, Jóźwik M. Budowa i czynności dna miednicy u kobiet - uaktualniony przegląd z podkreśleniem wpływu porodu drogami natury. Develop Per Med. 2013;17(1):18-30.

8. Galloway NT, El-Galley RE, Sand PK, Appell RA, Russell HW, Carlan SJ. Extracorporeal magnetic innervation therapy for stress urinary incontinence. Urology. 1999;53:1108-1111.

9. Galloway NT, El-Galley RE, Sand PK, Appell RA, Russell HW, Carlin SJ. Update on extracorporeal magnetic innervation (EXMI) therapy for stress urinary incontinence. Urology. 2000;56:82-86.

10. Boström P, Wu J, Jedrychowski MP et al. A PGC1-alpha-dependent myokine that drives brown-fat-like development of white fat and thermogenesis. Nature. 2012;481:463-468. 
11. Jedrychowski MP, Wrann CD, Paulo JA et al. Detection and Quantitation of Circulating Human Irisin by Tandem Mass Spectrometry. Cell Metab. 2015;22(4):734-740.

12. McMillan AC, White MD. Induction of thermogenesis in brown and beige adipose tissues: molecular markers, mild cold exposure and novel therapies. Curr Opin Endocrinol Diabetes Obes. 2015;22(5):347-352.

13. Erickson HP. Irisin and FNDC5 in retrospect: An exercise hormone or a transmembrane receptor? Adipocyte 2013;2(4):289-293.

14. Diallo S, Cour F, Josephson A et al. Evaluating single-incision slings in female stress urinary incontinence: the usefulness of the CONSORT statement criteria. Urology. 2012;80:535-541.

15. Bradley CS, Rahn DD, Nygaard IE et al. The questionnaire for urinary incontinence diagnosis (QUID): validity and responsiveness to change in women undergoing non-surgical therapies for treatment of stress predominant urinary incontinence. Neurourol Urodyn. 2010;29(5):727-734.

16. Sansoni J, Hawthorne G, Marosszeky N, Owen E, Marosszeky N. The Technical Manual for the Revised Incontinence and Patient Satisfaction Tools. Centre for Health Service Development, University of Wollongong, 2011.

17. Daskalopoulou SS, Cooke AB, Gomez YH et al. Plasma irisin levels progressively increase in response to increasing exercise workloads in young, healthy, active subjects. Eur J Endocrinol. 2014;171:343-352.

18. Miyamoto-Mikami E, Sato K, Kurihara T. Endurance Training-Induced Increase in Circulating Irisin Levels Is Associated with Reduction of Abdominal Visceral Fat in Middle-Aged and Older Adults. PLOS ONE 2015;10(3):e0120354.

19. Huh JY, Mougios V, Skraparlis A, Kabasakalis A, Mantzoros CS. Irisin in response to acute and chronic whole-body vibration exercise in humans. Metabolism 2014;63:918-921.

20. Kraemer RR, Shockett P, Webb ND, Shah U, Castracane VD. A transient elevated irisin blood concentration in response to prolonged, moderate aerobic exercise in young men and women. Send to Horm Metab Res. $2014 ; 46(2): 150-154$.
21. Loffler D, Muller U, Scheuermann K et al. Serum irisin levels are regulated by acute strenuous exercise. J Clin Endocrinol Metab. 2015;100:1289-1299.

22. Tsuchiya Y, Ando D, Takamatsu K, Goto K. Resistance exercise induces a greater irisin response than endurance exercise. Metabolism. 2015;64:1042-1050.

23. Stengel A, Hofmann T, Goebel-Stengel M, Elbelt U, Kobelt P, Klapp BF. Circulating levels of irisin in patients with anorexia nervosa and different stages of obesity-correlation with body mass index. Peptides. 2013; 39:125-130.

24. Pardo M, Crujeiras AB, Amil M et al. Association of irisin with fat mass, resting energy expenditure, and daily activity in conditions of extreme body mass index. Int J Endocrinol. 2014;2014:857270.

25. Moraes C, Leal V0, Marinho SM et al. Resistance exercise training does not affect plasma irisin levels of hemodialysis patients. Horm Metab Res. 2013;45:900-904.

26. Rana KS, Pararasa C, Afzal I et al. Plasma irisin is elevated in type 2 diabetes and is associated with increased E-selectin levels. Cardiovasc Diabetolog. 2017;16:147.

27. Sesti G, Andreozzi F, Fiorentino TV et al: High circulating irisin levels are associated with insulin resistance and vascular atherosclerosis in a cohort of nondiabetic adult subjects. Acta Diabetol. 2014;51(5):705-713.

28. Wen MS, Wang CY, Lin SL, Hung KC. Decrease in irisin in patients with chronic kidney disease. PLoS One. 2013;8(5):e64025.

29. Weber-Rajek M, Radzimińska A, Strączyńska A et al. A RandomizedControlled Trial Pilot Study Examining the Effect of Extracorporeal Magnetic Innervation (ExMI) in the Treatment of Stress Urinary Incontinence in Women. Clin Interv Aging. 2018;13:2473-2480.

30. Radzimińska A, Weber-Rajek M, Strączyńska A et al. The Impact of Pelvic Floor Muscle Training on the Myostatin Level and Severity of Urinary Incontinence in Elderly Women with Stress Urinary Incontinence - a Pilot Study. Clin Interv Aging. 2018;13:1893-1898.

\section{Konflikt interesów}

Autorze deklaruja brak konfliktu interesów.

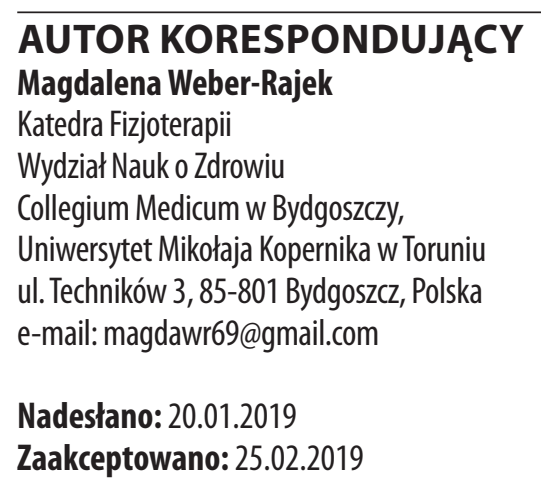


PRACA ORYGINALNA

ORIGINAL ARTICLE

\title{
THE RESEARCH OF ANTIMICROBIAL EFFICACY OF ANTISEPTICS DECAMETHOXIN, MIRAMISTIN AND THEIR EFFECT ON NUCLEAR DNA FRAGMENTATION AND EPITHELIAL CELL CYCLE
}

\author{
ANALIZA AKTYWNOŚCI PRZECIWBAKTERYJNEJ DWÓCH \\ ANTYSEPTYKÓW, DEKAMETOKSYNY I MIRAMISTYNY, \\ ORAZ ICH WPŁYWU NA FRAGMENTACJĘ JĄDROWEGO \\ DNA ORAZ CYKL KOMÓRKOWY ŚRÓDBŁONKA
}

\author{
Oleksandr A. Nazarchuk, Ihor L. Chereshniuk, Halyna H. Nazarchuk \\ NATIONAL PIROGOV MEMORIAL MEDICAL UNIVERSITY, VINNYTSYA, UKRAINE
}

\begin{abstract}
Introduction: Nowadays, the study of biological safety of modern cationic surface-active antiseptics with a wide antimicrobial spectrum has acquired particular importance. The aim was to study antimicrobial effectiveness of antiseptics decamethoxin, miramistin and their influence on nuclear DNA fragmentation and cellular cycle.

Materials and methods: A comparative microbiological study of antimicrobial efficacy and a cytometric study of the effect of decamethoxin $0,02 \%$ and miramistin $0,01 \%$ on the cellular cycle were carried out.

Antimicrobial activity of decamethoxin and miramistin was estimated by their minimal inhibitory and minimal microbicidal concentrations against opportunistic microorganisms using serial double dilution technique. Decamethoxin and miramistin cytotoxicity on anterior corneal epithelial cells, after their two-week daily instillation into the eyes of a Vistar line male rats was studied using flow cytometry. The parameters of epithelial cellular cycle, nuclear DNA fragmentation and apoptosis under the influence of antiseptics were registered.

Results: High antimicrobial effect of decamethoxin and miramistin against Gram-positive, Gram-negative bacteria with the significant advantages of decamethoxin were found $(p<0,001)$.

Decamethoxin caused minimal influence on anterior corneal epithelial cells, the insignificant decrease of their proliferation index, low increase of apoptosis $(0.68 \%)$, no difference of mitotic activity $(p>0.05)$. But the use of miramistin resulted in the significant increase of nuclear DNA fragmentation, decrease of proliferative activity $(p<0.05)$. Conclusions: Higher antimicrobial effect against a wide range of opportunistic pathogens is proved in decamethoxin $0,02 \%$ comparably to miramistin $0,01 \%$ ( $p<0,001)$. In prolonged antiseptic use of the first one there were found no cytotoxic and no pro-apoptotic effects on the epithelium $(p<0,05)$.
\end{abstract}

KEY WORDS: antiseptics, apoptosis, decamethoxin, decasan, flow-cytometry, miramistin, cytotoxicity

Wiad Lek 2019, 72, 3, 374-380

\section{INTRODUCTION}

Antiseptic drugs have gained a prominent place in medicine and pharmacy among the wide range of antimicrobial agents, having been used in medicine for a long period of time. Antiseptics are known to be chemicals and biological agents, which possess the ability to inhibit the reproduction of microorganisms (bacteriostatic action) and to kill them (bactericidal action), providing effective treatment of purulent-inflammatory diseases and the prevention of infectious complications. Antiseptics are medicines containing antimicrobials or their combination and they are permitted in accordance to the law for use in medical practice $[1,2]$.

Antiseptic drugs are well known to obtain high antimicrobial activity in non-toxic doses to the patient. Comparing the activity of antiseptics and antibiotics, it is necessary to note the higher antimicrobial effectiveness of antibiotics. But, at the same time, there is essential difference between the minimum effective concentration of the antibiotic in the organism that provides the antimicrobial action and the maximum concentration, which does not cause negative influence on the patient's organism. Such an indicator for antiseptics is known as the index of effectiveness of medicinal antiseptic drugs. It is known that skin, mucous membranes have a higher resistance to the damaging effects of chemicals and drugs in comparison with body tissues. Due to these properties, it is possible to use topical higher concentrations of antiseptic drugs, comparably to biosecurity antibiotic doses for internal organs cells $[1,3,4]$.

Antiseptics, which possess a wide spectrum of antibacterial, antifungal, antiviral action, and effectively eradicate resistant pathogens of infectious diseases, are acquired of 
particular importance. Detergents (surface-active substances) occupy an important place in antiseptics among the well-known assortment of antiseptic agents of different groups. Quaternary ammonium compounds (QACs), which during the last century were characterized by high antimicrobial efficacy in the fight against pathogens of infectious complications, are worthy of particular attention $[1,5]$. The high index of biocompatibility of antiseptics, containing quaternary nitrogen in its structure, opens up new perspectives of their in-depth comprehensive study and multi-vector application [6-9].

That is why, an in-depth study of the biological safety of modern QAC antiseptics with high microbicidal properties, is relevant too. Among them modern QAC antiseptic drug decamethoxin (DCM; 1,10-Decamethylene bis (N, N-dimethylmethoxycarbonylmethyl) ammonium dichloride) is known. Decamethoxin has been developed and introduced into medical practice by the Ukrainian scientists $[3,10,11]$.

Nowadays, many years of experience of the effective clinical use of this antiseptic have been accumulated. But, there is a need for in-depth study of DCM effect on the eukaryotic cell. There is still the lack of the knowledge of molecular mechanisms of the QAC effects on the fragmentation of the genetic material (nuclear DNA) and the cycle of epithelial cells. Therefore, these studies are important for broadening the perceptions about the properties of the agents, along with the study of the antimicrobial properties of antimicrobial agents on the basis of quaternary ammonium.

One of the contemporary research areas is the flow cytometry method, which, in contrast to the classical microbiological methods, can provide information on molecular changes at the level of the eukaryotic cell, assessing the cytotoxic properties of the drugs. This method is suitable for the analysis of drugs, including antiseptics, because it allows one to accurately determine the content of nuclear DNA in individual cells and the distribution of cells in accordance with the phases of the cell cycle $[12,13]$.

\section{THE AIM}

The aim of our research work was to study of antimicrobial effectiveness of modern antiseptic drugs as decamethoxin and miramistin, based on the QAC, and their influence on nuclear DNA fragmentation and cycle of eukaryotic cell.

\section{MATERIALS AND METHODS}

In the work, a comparative microbiological study of antimicrobial efficacy and a cytometric study of the effect on the cell and its cycle of surface-active antiseptic drugs based on DCM and miramistin (MR) produced by the pharmaceutical industry of Ukraine were carried out. In the research there was used the ready-made dosage form of an antiseptic based on DCM, containing decamethoxin $200 \mu \mathrm{g} / \mathrm{ml}$.

The other QAC antiseptic miramistin (Benzyldimethyl[3-myristoilamine)propyl]ammonium chloride monohydrate), containing miramistin $100 \mu \mathrm{g} / \mathrm{ml}$, was chosen as a comparison preparation. Both drugs for the experiment were purchased at the pharmacy network at our own expense.

The microbiological study of the antimicrobial activity of antiseptic drugs required determination of minimal inhibitory (MIC) and minimal microbicidal (MmCC) concentrations of DCM and MR against clinical strains of opportunistic isolates of microorganisms as Staphylococcus aureus $(\mathrm{n}=126)$, Enterococcus faecalis $(\mathrm{n}=18)$, Escherichia coli $(\mathrm{n}=89)$, Enterobacter spp. $(\mathrm{n}=39)$, Klebsiella pneumoniae $(\mathrm{n}=12)$, Acinetobacter baumannii $(\mathrm{n}=209)$, Pseudomonas aeruginosa $(\mathrm{n}=127)$, Proteus mirabilis $(\mathrm{n}=34)$, Candida albicans $(\mathrm{n}=35)$. There was used serial double dilution technique in accordance with standard methodological recommendations [14]. The analysis of antimicrobial effectiveness of ready-made dosage forms of an antiseptics DCM and MR, were carried out by means of comparison of indexes of antiseptic activity (IAA). In accordance with the well-known method, IAA, which indicates the efficacy of the drug, should be at least higher than " 4 ". This index was defined for both antiseptics in accordance with the well-known standard method by the ratio of the concentration of the active antiseptic substance in its officinal medicinal form to the MIC of the same drug for the relevant pathogen [4].

The effect of DCM and MR antiseptic drugs on nuclear DNA fragmentation and epithelial cell cycle was studied by flow cytometry in the experiment in vivo. Experimental studies were performed on male rats of the Vistar line, at the age of 3 months with a body weight of $150 \mathrm{~g}$, which were kept under standard vivarium conditions in National Pirogov Memorial Medical University, Vinnytsya. Animals were kept in the light mode: from 7:00 to 19:00 - light period (12 hours), from 19:00 to 7:00 - dark period (12 hours).

Corneal epithelial cells (CEC) were selected as a model of a single layer of epithelial cells in the whole organism for the research of in vivo cytotoxic action of drugs and their effects on the cell cycle. The use of CEC to study the effects of drugs, in particular antiseptics, on cell division according to phases of cell cycle and nuclear DNA fragmentation was based on the natural ability of the anterior epithelium of the cornea to complete the cycle of cell changes for 14 to 21 days, which in turn allowed us to investigate with the highest accuracy the smallest changes in the vital functions of individual cells of the whole organism, their proliferative activity and apoptotic death $[13,15]$.

Depending on the studied antiseptic drug, the animals were divided into two experimental groups per 10 animals in each there were used: DCM - in the main monitoring group and MR - in the comparison group. Both antiseptics were installed to the right of the rats' eyes 4 times a day for 14 days. In all rats, involved in the research, left eyes were intact ones.

To reduce the influence of the circadian rhythm on the parameters of the cellular cycle of the corneal anterior epithelium, the collection of material for the cytometric study was carried 
Table I. The characteristics of antimicrobial activity of antiseptic drugs, based on decamethoxin and miramistin

\begin{tabular}{|c|c|c|c|c|c|}
\hline \multirow{2}{*}{$\begin{array}{l}\text { Clinical isolates of } \\
\text { microorganisms }\end{array}$} & \multirow{2}{*}{ Number } & \multicolumn{2}{|c|}{ Decamethoxin $(0,02 \%)$} & \multicolumn{2}{|c|}{ Miramistin $(0,01 \%)$} \\
\hline & & $M I C *(\mu \mathrm{g} / \mathrm{ml})$ & $\mathrm{MCC}^{* *}(\mu \mathrm{g} / \mathrm{ml})$ & $M I C^{*}(\mu \mathrm{g} / \mathrm{ml})$ & $M C C^{* *}(\mu \mathrm{g} / \mathrm{ml})$ \\
\hline S.aureus & 126 & $1,76 \pm 0,12$ & $3,40 \pm 0,27$ & $3,32 \pm 0,21$ & $6,61 \pm 0,42$ \\
\hline E.faecalis & 18 & $1,50 \pm 0,19$ & $3,65 \pm 0,42$ & $5,03 \pm 0,75$ & $10,07 \pm 1,44$ \\
\hline E.coli & 89 & $4,15 \pm 0,29$ & $7,30 \pm 0,40$ & $8,75 \pm 0,63$ & $16,50 \pm 0,69$ \\
\hline A.baumannii & 209 & $27,92 \pm 1,58$ & $57,51 \pm 2,97$ & $41,93 \pm 2,16$ & $75,00 \pm 3,36$ \\
\hline P.aeruginosa & 127 & $48,99 \pm 3,41$ & $97,70 \pm 5,73$ & $65,51 \pm 3,22$ & $87,86 \pm 2,58$ \\
\hline P.mirabilis & 34 & $56,67 \pm 4,78$ & $88,33 \pm 3,93$ & $47,50 \pm 3,25$ & $91,67 \pm 3,46$ \\
\hline Enterobacter spp. & 39 & $10,70 \pm 0,99$ & $20,83 \pm 1,86$ & $12,51 \pm 1,42$ & $23,43 \pm 1,49$ \\
\hline K.pneumoniae & 12 & $11,06 \pm 1,44$ & $21,15 \pm 1,67$ & $14,11 \pm 2,40$ & $24,63 \pm 2,48$ \\
\hline C.albicans & 35 & $8,39 \pm 0,51$ & $15,36 \pm 0,90$ & $17,50 \pm 1,05$ & $28,57 \pm 1,50$ \\
\hline
\end{tabular}

*- minimal inhibitory concentrations; ${ }^{* *}$ - minimal cidal concentration.

out in the morning - from 10:00 to 11:00, and then the animals underwent euthanasia according to the ethical principles.

Under anaesthesia (10 mg/kg propofol intraperitoneally), under the control of the binocular microscope, a blade of a disposable microsurgical knife keratoma was used to collect the entire cornea of the CEC limited by limb. Subsequently, the preparation of samples of CEC cell suspensions for performing flow cytometric analyses was performed using a special kit CyStain DNA Step 2 (Partec, Germany). In each resulting sample of nucleic suspensions, 20.000 events were recorded at one and the same flow rate $(2 \mathrm{ml} / \mathrm{sec})$. Fluorescence control was performed using a special DNA standard of trout erythrocytes marked DAFI (Partec, Germany). During the flow cytometry of nuclear suspensions of PE on DNA histograms, a number of peaks were recorded. The first peak was placed in Channel 200 at 1024 channels for the most suitable for analysing the content of DNA on a linear scale, by adjusting the gain in the desired channel and scale [14]. To exclude unwanted alarm, the limit 20 was set. The analysis of the received DNA histograms was performed using multifunctional scientific-research flow-cytometer Partec Pas and analytical program FloMax (Partec, Germany).

The flow cytometry method allows to determine the percentage values of the cells that are in the phase of DNA synthesis (S-phase), as well as in the phases G0G1 (with DNA content $=2 \mathrm{~s}$, post-mitotic cell), G2 + M (tetraploid/ cells in which directly mitosis and there was a replication of DNA). The analysis of the special indices obtained during flow cytometry allowed to evaluate the proliferative activity of the cells under study and the peculiarities of their death by apoptosis under the influence of QAC antiseptic agents $[12,13,16,17]$. The statistical processing of the received CEC cell cycle parameters was performed separately for the right and left eyes using the Student's parametric t-criterion and the Man-Whitney nonparametric criterion [18].

\section{RESULTS}

The research of antimicrobial activity has demonstrated high bacteriostatic and bactericidal action of antimicrobial drugs based on DCM and MR against a wide range of opportunistic pathogens. As evidenced by the investigated relevant minimal microbicidal concentrations of DCM and MR, there was found high antimicrobial activity of both drugs against prominent Gram-positive microorganisms (S.aureus, E. faecalis). Predominantly, Enterobacteria (E.coli, Enterobacter spp., K.pneumoniae), as well as non-fermentative gram-negative representatives of the Acinetobacter genus, has been found to have high sensitivity to both of the studied antiseptic drugs (table I).

Also, DCM and MR have possessed effective fungistatic and fungicidal effects on yeast-like fungi of the genus Candida. Clinical isolates of Proteus spp. and Pseudomonas spp. were found to had obtained lower susceptibility to DCM and MR Corresponding high values of MCC of $\operatorname{DCM}(88,33 \pm 3,93 \mu \mathrm{g} / \mathrm{ml}$ and $97,70 \pm 5,73 \mu \mathrm{g} / \mathrm{ml})$ and $\mathrm{MR}$ $(91,67 \pm 3,46 \mu \mathrm{g} / \mathrm{ml}$ and $87,86 \pm 2,58 \mu \mathrm{g} / \mathrm{ml})$ indicated their low bactericidal properties against P.mirabilis and P.aeruginosa. The analysis of the antimicrobial activity of antiseptic agents DCM and MR, by an IAA, has demonstrated significant advantages of the dosage form containing the first one.

The IAA of DCM, was 6 times higher than the same criteria in MR-based antimicrobial agent against enterococci $(p<0,001)$; predominated 4 times IAA of MR against $S$. aureus $(\mathrm{p}<0,001), 4$ times - in the case of E.coli, $(\mathrm{p}<0,001), 3,3$ times - Acinetobacteria $(\mathrm{p}<0,001), 2,2$ times - in the case of Klebsiella $(\mathrm{p}<0,01), 2$ times higher - other Enterobacteria $(p<0,001)$. The advantages of 4 times higher antifungal effectiveness of DCM-based antiseptic was found against C.albicans (fig. $1 ; \mathrm{p}<0,001$ ).

Despite vivid resistance of Gram-negative pathogens as P.mirabilis and P.aeruginosa to DCM and MR, the sufficient activity of an antiseptic medicinal product containing $0,02 \%$ DCM has been established. According to the data of IAA, predominating criteria IAA, which exceeded minimum acceptable threshold and were respectively 1,8 and 2,8 higher than the same ones in antiseptic medicinal product containing $0,01 \%$ of $\mathrm{MR}(\mathrm{p}<0,001)$.

As a result of this study, the absence of objective changes in the eyes of rats was observed in the long-term use of DCM and MR. Following a cytometric study after two 


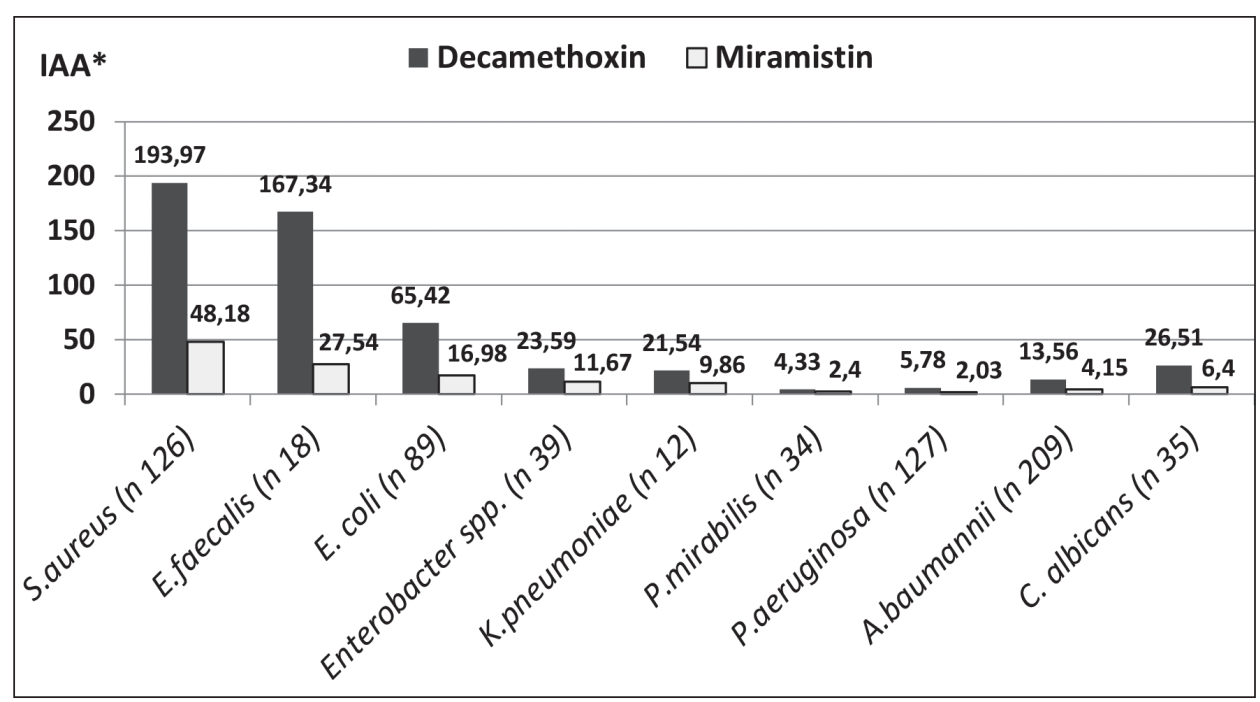

Fig. 1. Comparative characteristics of antimicrobial efficacy of decamethoxin and miramistin by the index of antiseptic activity (IAA*).
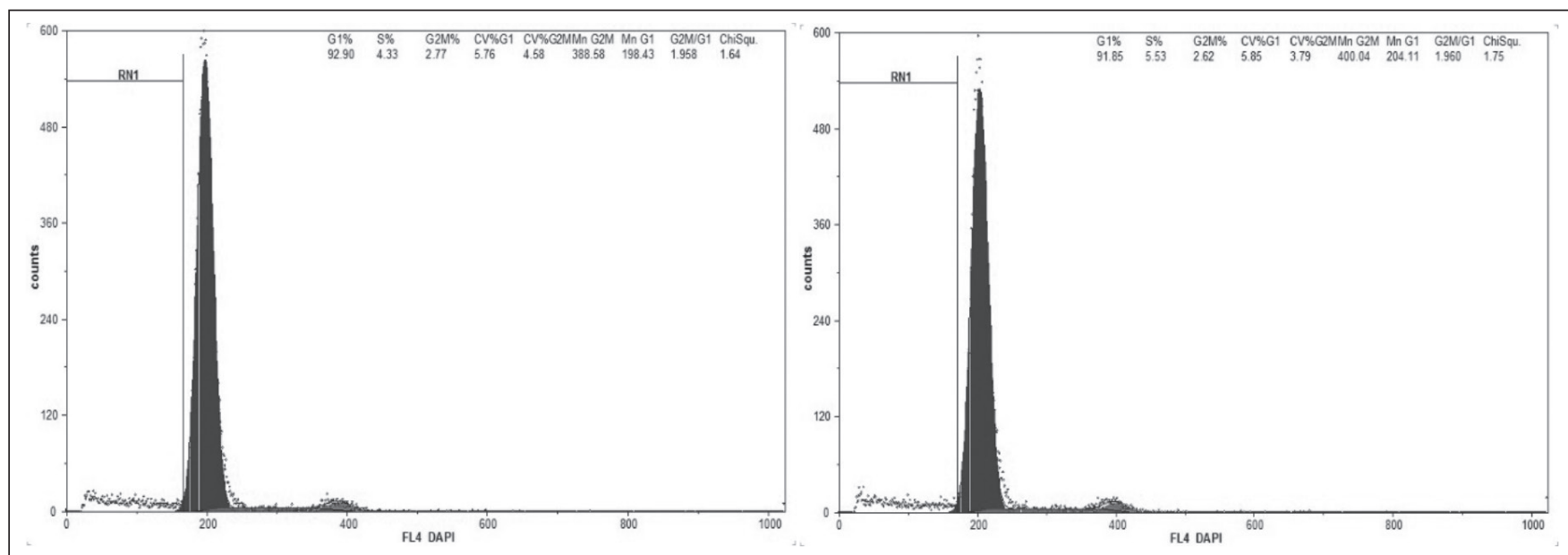

Fig.2.DNA-histogram of nuclei suspension of the corneal epithelium:a) the administration of DCM-based antiseptic for 14 days (OD); b) intact comparison eye (OS).

weeks of application of the antiseptic drugs, an evaluation of the distribution of cells in the phases of the cell cycle was performed. In the observation study group after daily instillations of DCM in conjunctival cavity for 14 days there were evaluated further criteria of the distribution of cells in the phases of the cell cycle as G0G1 $(93,13 \pm 0,99) \%$, S $(4,12 \pm 0,57) \%, \mathrm{G} 2+\mathrm{M}(2,75 \pm 0,43) \%$ (fig. $2 ; 3)$.

After the administration of antiseptic DCM, there has been found no significant difference between the percentages of CEC cells $(4,12 \pm 0,57) \%$, which were registered in their phase of DNA synthesis (S-phase) in comparison with the intact eye $(4,88 \pm 0,39) \%(p>0,05)$. After the course of DCM administration, the average values of the number of CEC cells present in the G0G1 phase, which characterized mitotic activity, did not differ from those of the G0G1 in the CEC of the eyes which did not receive antiseptic instillations $(p>0,05)$ The percentage rate of $\mathrm{G} 2+\mathrm{M}$ was lower by $1,04 \%$ when DCM having been used than in control eye. The observation demonstrated insignificant difference with this indicator of intact eyes. A detailed analysis of DNA-histograms has shown the complete acceptability of the variation coefficient $(\mathrm{CV})$, which was $(5,94 \pm 0,16) \%$ for G0G1 peak of CEC when DCM had been used. And CV did not differ from the same criterion in CEC of intact eyes $(5,87 \pm 0,15) \%$ ( $>>0,05$; fig.3).

The results of cytometric studies showed that that the index of proliferation of IP $(6,87 \pm 0,99 \%)$ in 1,3 times was lower under two-weekly daily every six hours instillation of DCM than in epithelial cells of CEC intact eyes. Under the 14 days influence of DCM on CEC cells, the minimal signal changes were recorded on DNA histograms that corresponded to nuclei of cells containing DNA $<2 \mathrm{sec}$ onds in the range of SUB-G0D1. An insignificant increase in the value of the apoptosis index (APO) of CEC cells treated with DCM for 14 days was found to be $0.68 \%$ in comparison with this indicator in the epithelial cells of the cornea of the intact eye. The difference was statistically insignificant ( $p>0.05)$, which seemed the absence of nuclear fragmentation of DNA in corneal epithelium with long-term use of DCM.

Under the experimental study of the daily installation of MR antiseptic for a two-week period the CEC cell cycle was characterized by a distribution of cells which differed slightly from those of intact cells. According to received data there was found the significant difference between 


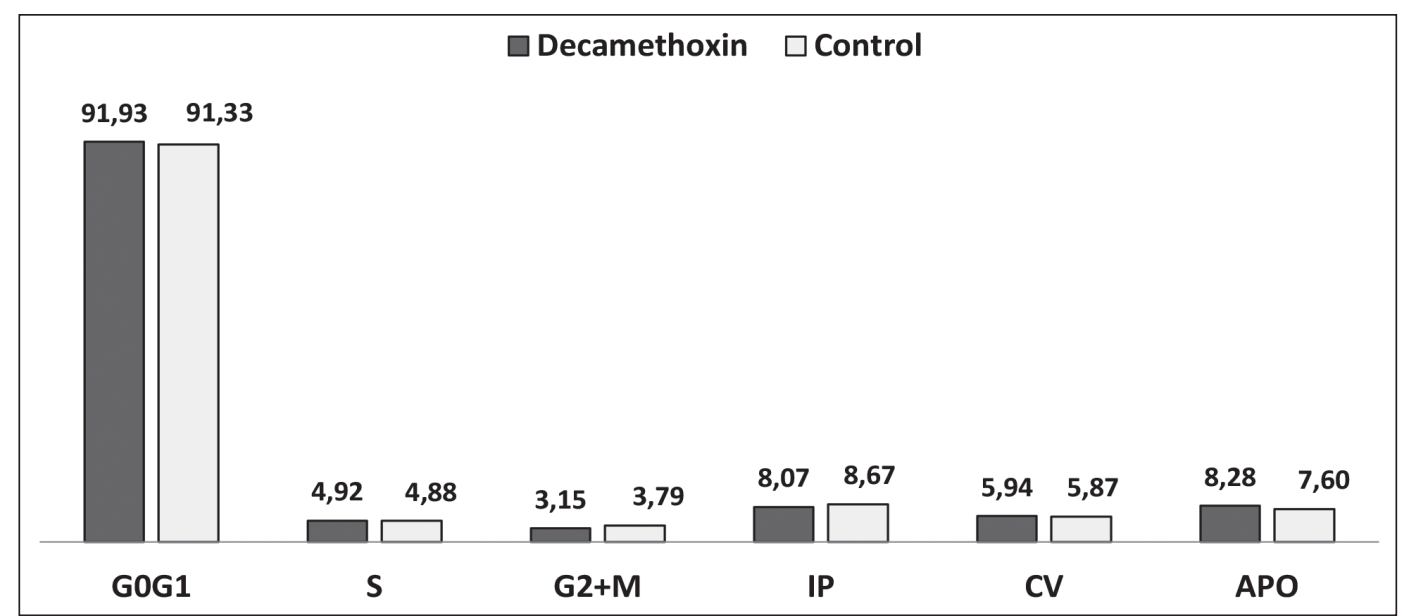

Fig. 3. The cytometric characteristics of the parameters of the cell cycle of CEC with in vivo long-term use of antiseptic decamethoxin in the experiment.

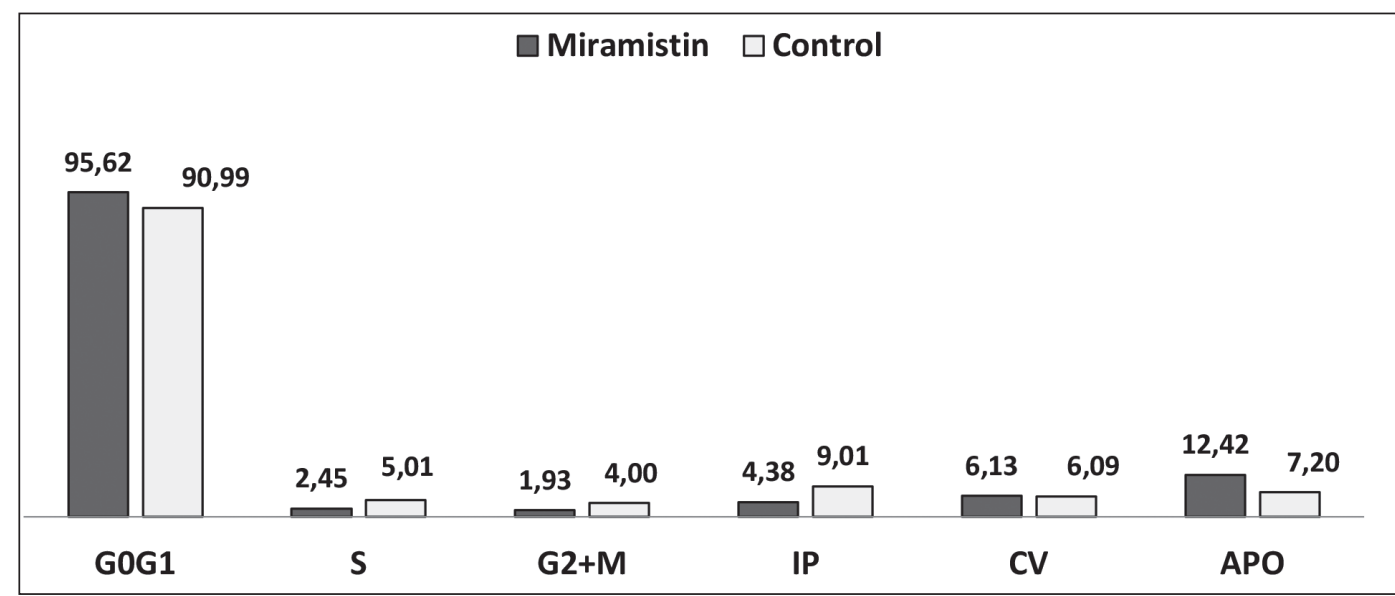

Fig. 4. The cytometric characteristics of the parameters of the cell cycle of CEC with in vivo long-term use of antiseptic miramistin in the experiment.

the values of the cell cycle phases G0G1 $(95,62 \pm 0,19) \%, S$ $(2,45 \pm 0,17) \%, \mathrm{G} 2+\mathrm{M}(1,93 \pm 0,04) \%$ of the experimental eyes and of comparison ones $(\mathrm{p}<0.05)$. The prolonged use of MR resulted in the significant increase of cells in the G0G1 phase $(4.63 \%)$ in comparison with intact ones and $3.69 \%$ compared to cells managed with DCM.

A comparative analysis of the G0G1 peak variation coefficients in the use of MR $(\mathrm{CV}=6.13 \pm 0.14 \%)$ and intact $\mathrm{CECs}(\mathrm{CV}=6.09 \pm 0.36 \%)$ showed valid $\mathrm{CV}$ values, and a lack of a significant difference between their values $(p>0.05)$ confirmed the proper quality of DNA-histograms in accordance with generally accepted requirements. In the use of MR during the S-phase of the epithelial cell cycle, suppression was found to be $2.55 \%$ of DNA synthesis in the nuclei of the CEC cells $(2.45$ $\pm 0.17 \%$ ), which was significantly lower than in intact epithelium ( $<<0,05$; fig. 4 ).

In the study group, after 14 days of MR administration on DNA histograms there were observed peaks, indicating a decrease in the percentage of cells in the $\mathrm{G} 2+\mathrm{M}$ phase in 2.1 times less than in intact CEC cells $(p<0,01)$. According to the obtained values of the interval SUB-G0G1 $(12,42 \pm 0,46) \%$, a significant increase in the level of DNA fragmentation in the nuclei of epithelial cells has been demonstrated, which was subjected to $5.22 \%$ daily MR exposure over a two-week period. At the same time, in intact cells, the level of nuclear DNA fragmentation did not exceed $(7.2 \pm 0.63) \%$, which was 1.73 times less than with this antiseptic. It was found, that the average values of the index of proliferation $(4.38 \pm 0.19)$ in the use of MR were significantly lower, than the proliferative activity of intact cells $(6.09 \pm 0.36 \%)$ only in 1.3 times ( $<<0,05$; fig. 4$)$.

After the application of the MR-based antiseptic drug solution, there was found no significant difference between the percentage content of CEC cells $(4,12 \pm 0,57) \%$ that were in the phase of DNA synthesis (S-phase) compared with the intact eye $(4.88 \pm 0.39) \%(\mathrm{p}>0,05)$.

\section{DISCUSSION}

QAC antiseptic agents contain a nitrogen atom, which is directly linked to four alkyl groups of varying complexity, which have a variable structure. The unique chemical structure, physical and chemical properties of the DCM realize its high therapeutic, prophylactic antimicrobial activity. Bioequivalence of DCM is significantly dependent on the 
presence in the composition of the molecule of L-menthol, which could be as of synthetic origin so as obtained by the biological extraction method from peppermint. [3,5, $10,11]$. The mechanism of antimicrobial effect of DCM and MR is realized by reducing the surface tension and violation of the permeability of the cell membrane of the microbial cell, transmembrane transport of molecules, osmotic balance ions, nitrogen and phosphorus exchange, activation of proteolytic enzymes, lysis and autolysis of microorganisms $[1,3]$.

A comparative study of the sensitivity of 689 clinical strains of opportunistic pathogenic microorganisms, causative agents of infectious complications in severely ill patients with surgical pathology, who were treated at the intensive care units showed a high sensitivity of Staphylococci and Enterococci to DCM and MR antiseptic drugs.

The high bacteriostatic and bactericidal effectiveness of these antiseptics against the Gram-negative representatives of enterobacteria (E.coli, Enterobacter spp., K.pneumoniae) and non-fermentative Gram-negative microorganisms as A.baumannii.

The advantages of the DCM-based antiseptic were found on the basis of the values of IAA, which exceeded 2-4 times the corresponding parameters of $M R(p<0,001)$. In spite of the high concentrations of DCM and MR, needed for ensuring bactericidal action against clinical strains of microorganisms P.mirabilis and P.aeruginosa, there were found relevant values of IAA of drug, containing $0,02 \%$ of DCM, to exceed the minimum allowable threshold, having proved its efficacy against mentioned pathogens. IAA of DCM also were 1,8-2,8 times higher than similar values of the antiseptic, containing $0,01 \% \mathrm{MR}(\mathrm{p}<0,001)$.

In the process of developing, manufacturing and investigation of antiseptic drugs for medical purposes, the issue of biocompatibility of a medicinal product always poses a challenge, leading to the need for modern research with quantitative and qualitative analysis of cell cycle performance through flow cytometry along with traditional microbiological, biochemical, pharmacological and pharmaceutical techniques.

The unique selective antimicrobial membran-directed action of QAC antiseptics has been proved due to many in vitro studies on protoplast and spheroplast cell-models. Besides of high biosafety, there was proved the cytotoxic effect and suppression of proliferation of fibroblasts in some QAC and cationic-active surfactant antiseptics (octenisept, polyhexamethylene biguanid, chlorhexidine digluconate) [19]. The ability of some of them (chlorhexidine digluconate) to stimulate apoptosis of cells, autolytic and necrotic cell death were proved [20].

According to the research data some scientists estimated in vitro cytotoxic effect of therapeutic antimicrobial concentrations of such cationic active detergents as cetylpyridinium chloride and miramistin on L929 fibroblast and keratinocyte cell line HaCaT. There is insufficient data on the cytotoxic action on human cells in vivo and the need for further research in the use of some QAC surface-active antiseptic agents [21].
According to the experimental data there was estimated absence of a significant difference between the number of epithelial cells in the phase of DNA synthesis after durable application of DCM and in the intact CEC ( $>00,05)$. This proved the absence of any negative effect of DCM antiseptic drug, with its prolonged use, on the state of proliferative activity of the cells of the anterior corneal epithelium.

There was found, that after the daily administration of an antiseptic DCM, the number of cells, capable for the synthesis of DNA during the S-phase, did not change and corresponded to the number of CEC cells in the inactive eye. At the same time, it was found that the number of epithelial cells, which did not lose the ability to synthesize DNA in the S-phase after prolonged use of an antiseptic based on MR, significantly had decreased in 2.04 times than in intact epithelium $(\mathrm{p}<0,05)$.

Flow-cytometric studies have shown that after long-term use of the DCM antiseptic drug, there was not found its side effect on the mitotic activity of CEC. This was proved, by insignificant difference between the number of postmithotic CEC cells after administration of DCM and isotonic sodium solution (intact eyes) respectively ( $p>0,05)$. After daily action of DCM for 14 days, the tetraploid cells, in which the replication of DNA had been finished and mitosis took place, were proved to have no significant difference from CEC cells, in which antiseptic had not been used $(p>0,05)$.

As a result of flow-cytometric analysis of apoptotic activity in CEC cell, there was proved a significant increase in 1.73 times of the rate of DNA fragmentation in the nucleus of epithelial cells, which had been undergone two-week everyday effect of miramistin $(p<0,05)$. Insignificant features of nuclear DNA fragmentation, registered in the nucleus of CEC cells, strictly affirmed that prolonged use of DCM-based antiseptic did not provide pro-apoptotic effect in the epithelium.

As a result of experimental imaging of the daily two-week exposure of the DCM-based and MR-based antiseptics into CEC cells, there was no significant difference in the proliferation index ( $p>0.05)$, when long duration of DCM administration had been used. This indicated no inhibitory effect of mentioned antiseptic agent on the proliferative activity of the epithelium. The minimal insignificant differences in the corresponding parameters of the cell cycle of the CEC have been experimentally determined by the equally strictly synchronized rate of proliferation and apoptotic death of the epithelial cells in intact eyes and eyes with two-weekly introduction of DCM.

\section{CONCLUSIONS}

1. The antiseptic drug, containing $0.02 \%$ decamethoxin, has high antimicrobial properties against a wide range of pathogens of infectious complications (S.aureus, E.faecalis, E.coli, Enterobacter spp., K.pneumoniae, A.baumannii, P.aeruginosa, P.mirabilis) as evidenced by the corresponding indexes of activity of antiseptics, which exceeded the minimum acceptable threshold, and also were $1.8-6$ times higher than similar indexes of antiseptic drug miramistin $(0.01 \% ; \mathrm{p}<0,001)$. 
2. The daily two-week use of an antiseptic drug decamethoxin $(0.02 \%)$ in vivo is does not affect the cytometric parameters of the cell cycle, in particular on the mitotic activity of the epithelium and the number of cells, capable to synthesize the DNA during the S-phase, while at the same time the antiseptic drug miramistin $(0.01 \%)$ reliably leads to the 2.04 times decrease of the number of epithelial cells and is accompanied by 1.73 times increase in the rate of nuclear DNA fragmentation $(\mathrm{p}<0,05)$.

3. Prolonged use of an antiseptic drug decamethoxin is characterized by a strictly synchronized rate of proliferation and apoptotic death of epithelial cells, which indicates the absence of cytometric signs of cytotoxic action and pro-apoptotic effects.

\section{REFERENCES}

1. McDonnell G., Russell AD. Antiseptics and Disinfectants: Activity, Action, and Resistance. Clinical microbiology reviews. 1999; 12 (1): 147-179.

2. Kramer A., Dissemond J., Kim S. et al. Consensus on wound antisepsis: update. Skin Pharmacology and Physiology. 2018; 31: 28-58. doi: 10.1159/000481545.

3. Paliy GK. Antiseptics in prophylaxis and treatment of infections. Zdorovya. Kyiv. 1997. (in Ukrainian).

4. Krasil'nikov AP, Adarchenko AA.. Klinicheskoe znachenie i metodologicheskie problemy opredelenija bakterial'noj chuvstvitel'nosti/ustojchivosti k antiseptikam [The clinical significance and methodological problems in determining bacterial sensitivity/ resistance to antiseptics]. Antibiotics and Chemotherapy. 1992; 37 (9): 39-44. (in Russia).

5. Paliy GK, Nazarchuk OA, BobyrVV et al. Оцінка антибактеріальних та протигрибкових властивостей сучасних антисептиків [Estimation of antibacterial and antifungal qualities of modern antiseptics]. Microbiology and biotechnology. 2015; 4: 67-74. (in Ukrainian).

6. Tischer M, Pradel G, Ohlsen K et al. Quaternary ammonium salts and their antimicrobial potential: targets or nonspecific interactions? Chem Med Chem. 2012; 7 (1): 22-31.

7. Rothenberger J, Krauss S, Tschumi C. et al. The effect of polyhexanide, octenidine dihydrochloride, and tea tree oil as topical antiseptic agents on in vivo microcirculation of the human skin: a noninvasive quantitative analysis. Wounds. 2016; 28(10): 328-333.

8. Kanazawa A, lkeda T, Endo T. A novel approach to mode of action of cationic biocides: morphological effect on antibacterial activity. Journal of Applied Bacteriology. 1995; 78: 55-60.

9. Minbiole KPC, Jennings MC, Ator LE. et al. From antimicrobial activity to mechanism of resistance: the multifaceted role of simple quaternary ammonium compounds in bacterial eradication. Tetrahedron. 2016;72 (25):3559-3566. doi:10.1016/j.tet.2016.01.014.

10. Mashkovskiy M. D. Lekarstvennye sredstva. Posobie dlja vrachej 15-e izdanie pererabotanoe, ispravlennoe i dopolnenoe [Remedies. The guideline for doctors. The 15th edition, underworked, checked and edited]. RIA "Novaya Volna": Publisher Umerenkov. Moscow. 2007. (in Russian).

11. Paliy HK., Nazarchuk OA, Honchar 00 et al. Doslidzhennia fizykokhimichnykh, antymikrobnykh vlastyvostei likarskoho preparatu "Dekametoksyn ${ }^{\oplus "}$ [The research of physical and chemical, antimicrobial qualities of "Decamethoxin ${ }^{\circledast \prime}$ remedy]. Medical and clinical chemistry. 2016; 18 (1): 36-44. (in Ukrainian).
12. Brotherick I. Basic DNA Measurement by Flow Cytomety. Guide_to_ flow_cytometry. 2005;16:99-106.

13. Voitkova, V.V. Study of apoptosis with use of flow cytometry (review of literature). (2010). Acta biomedica scientifica, 6 (76), 220-225.

14. Nekrasova L. S., Svita V. M., Glushkevich T. G.et al. (Ed.). Viznachennya chutlivosti mikroorganizmiv do antibakterial'nikh preparativ [The study of sensitivity of microorganisms to antibacterials: methodical recommendations]. MOZ Ukraini. Kiïv. 2007. Retrieved from: http: // mozdocs.kiev.ua. (in Ukrainian).

15. Haddad, A. Renewal of the rabbit corneal epithelium as investigated by autoradiography after intravitreal injection of $3 \mathrm{H}$-thymidine. Cornea. 2000; 19 (3): 378-383.

16. Khodakovskiy AA, Marynych LI., Bagauri OV. Features of the formation of the neurons' postperfusion damage - characteristic of "ischemia - reperfusion" model. New directions and perspectives of the development of modern cerebroprotective therapy of ischemic insult. "Postgraduate doctor" Journal. 2013; 3 (58): 69-76.

17. Waring P, Kos FJ, Mullbacher A. Apoptosis or programmed cell death. Medical Research Review. 2008; 11: 219-236.

18. STATISTICA:User guide. [Internet].2001.225 p. ftp://ftp.vt.tpu.ru/study/ Katsman/public/Statistica/Small\%20Book/ STATISTICA_Version6_ SmallBook.pdf.

19. Kolbenschlag J., Goertz O., Behr B.et al. Antiseptika in der Plastischen Chirurgie. [Skin Antiseptics in Plastic Surgery]. Handchirurgie Mikrochirurgie, plastic Chirurugie, 2012; 44(04): 254-258. doi: 10.1055/s-0032-1311577.

20. Karpiński, TM, Szkaradkiewicz. AK. Chlorhexidine - pharmacobiological activity and application. European Review for Medical and Pharmacological Sciences. 2015; 19: 1321-1326.

21. Fromm-Dornieden C, Rembe, JD, Schäfer N. Cetylpyridinium chloride and miramistin as antiseptic substances in chronic wound management - prospects and limitations. Journal of Medical Microbiology. 2015; 64 (4): 407-14. doi: 10.1099/jmm.0.000034.

"The research of multidirectional qualities of the remedy of decamethoxin "and its medicinal forms" Registration No 0115 U006000.

Authors' contributions:

According to the order of the Authorship.

Conflict of interest:

The Authors declare no conflict of interest.

\section{CORRESPONDING AUTHOR Oleksandr A. Nazarchuk}

National Pirogov Memorial Medical University

Pirogov Str. 56, 21018, Vinnytsya, Ukraine

tel: +380977293761

e-mail: nazarchukoa@gmail.com

Received: 19.11 .2018

Accepted: 07.02.2019 
PRACA ORYGINALNA

ORIGINAL ARTICLE

\title{
CLINICAL CHARACTERISTICS OF CARDIAC ARRHYTHMIAS IN PREGNANT WOMEN
}

\section{CHARAKTERYSTKA ZABURZEŃ RYTMU SERCA U KOBIET W CIAZŻY}

\author{
Oksana I. Afanasiuk, Valentyn I. Shmaliy, Yuliia Yu. Shushkovska \\ DEPARTMENT OF INTERNAL MEDICINE №3, NATIONAL PIROGOV MEMORIAL MEDICAL UNIVERSITY, VINNYTSYA, UKRAINE
}

\begin{abstract}
Introduction: Cardiac arrhythmia often occurs in the gestational period of pregnant women, contributing to the development of complications of pregnancy, childbirth and perinatal pathology, which requires a more thorough examination of pregnant women and antiarrhythmic treatment, which in turn increases the risk of complications pregnancy and childbirth. Many types of arrhythmias occur in women without structural damage to the cardiovascular system.

The aim is to study the occurrence of cardiac rhythm disturbances in healthy pregnant women, depending on the gestational age, the number of previous pregnancies, infectious diseases during pregnancy, and arrhythmia analysis, which required antiarrhythmic treatment. Materials and methods: Retrospectively 60 individual cards of pregnant women were studied. An ECG monitoring was performed to identify the arrhythmia.

Results: Among the arrhythmia were: supraventricular and ventricular extrasystoles, unstable paroxysmal tachycardia. All cases of arrhythmia were without lengthening QT interval. Sinus tachycardia was significantly more common in combination with anemia. Heart rhythm disorders are associated with emotional excitement. Conclusions: Most violations of the heart rate occurred in the second trimester of pregnancy. With concomitant anemia, sinus tachycardia is significantly more common, and sinus bradycardia is associated with an enlarged uterus in compression of the inferior vena cava. With the increase in the number of pregnancies, the risk of heart rhythm disturbances increases. However, the past infectious diseases of the bronchopulmonary system during pregnancy did not significantly affect the occurrence of rhythm disturbances. The appointment of antiarrhythmic drugs was observed in all pregnant women whose cards were included in the study.
\end{abstract}

KEY WORDS: cardiac rhythm disturbance, pregnancy

\section{INTRODUCTION}

Violation of the heart rhythm (VHR) is a violation of the frequency, rhythm and sequence of excitation and contraction of the heart. They are the most common complications from the cardiovascular system that occur during the gestational period and occur in $50 \%$ of pregnant women $[1,2]$. VHR can contribute to the development of other complications of pregnancy (malignant gestosis, miscarriage and fetal hypotrophy), complications of labor (violations of contractile activity of the uterus, bleeding) and perinatal pathology [3]. Many types of arrhythmias can occur in healthy women during pregnancy. In addition, the VHR require additional careful monitoring of the pregnant woman, the decision of the method of birth and the definition of obstetric tactics. The presence of VHR can contribute to an increase in maternal mortality. In addition, the spread of VHR significantly increases during pregnancy in healthy women, as well as with diseases of the cardiovascular system, compared with non-pregnant women [4]. According to some authors [3], arrhythmias are detected in $15.7 \%$ of pregnant women. It should be noted that $43 \%$ of them are functional arrhythmias that occur without organic damage of the heart. In addition, the occurrence of malignant gestosis, fetal hypotrophy is much more common in pregnant women with arrhythmias, even under the condition of inorganic origin $[3,5]$. Studies have been conducted that link the emergence of VHR with electrolyte disorders or as first manifestations of diseases that manifest themselves after pregnancy, which has become a provoking factor for them [4].

Physiological changes that occur during pregnancy, namely, an increase in the volume of fluid in the body by $40-50 \%$, leads to an increase in cardiac output and, consequently, mechanical overload of the woman's heart $[1,6]$, which in turn activates the ion channels and contributes to arrhythmias. Equally important in the mechanisms of arrhythmias is the physiological increase in the heart rate, contributes to the shortening of the intervals on the ECG, namely the intervals PQ and QT, which contribute to arrhythmogenesis $[7,8]$. It should be noted that the development of pregnancy is not accompanied by the emergence of specific changes in the structure of the heart, contributing to the emergence of the VHR [5]. However, in the study of literary sources, there is an insufficient number of publications that reflect an analysis of cardiac rhythm disturbances in pregnant women without cardiovascular damage, but VHR can be threatening to the fetus and mother. 


\section{THE AIM}

The aim is to study the occurrence of cardiac rhythm disturbances in healthy pregnant women, depending on the gestational age, when arrhythmias, the number of previous pregnancies, infectious diseases during pregnancy, hemoglobin parameters and arrhythmia analysis, which required antiarrhythmic treatment, were first recorded.

\section{MATERIALS AND METHODS}

Retrospectively 60 individual cards of pregnant women and women in childbirth of the Central Regional Clinical Hospital of Vinnitsa, Ukraine were analyzed. Criteria for inclusion in the study: cards of healthy pregnant women, who had identified any VHR. The criteria for exclusion from the study were: the presence of congenital or acquired heart defects, increased blood pressure, presence of VHR before pregnancy. The design of the study included estimating the gestational age when the VHR was first recorded, the number of previous pregnancies, infectious diseases during pregnancy, and hemoglobin. An electrocardiogram and ECG monitoring was performed to identify the VHR, the results of which were presented in an individual card or described during a doctor's appointment. All pregnant women underwent ultrasound examination of the heart to exclude structural changes. The average age of pregnant women was 17-36 years.

All pregnant women were prescribed antiarrhythmic drugs (beta-blockers, calcium channel antagonists, verapamil groups) due to poor subjective tolerability of the VHR. In one case, urgent measures were taken, such as cardioversion.

All the data obtained as a result of the study were processed using the SPSS software using variational statistics methods with the deduction of the mean $\mathrm{M}$, the standard deviation $S$, the average error of the average value $m$, the reliability criterion $t$, the reliability value $p$. Statistically significant differences were considered for $\mathrm{p}<0.05$. The investigated quantities are given in the form $(\mathrm{M} \pm \mathrm{m})$. Pair group comparisons were carried out by nonparametric Mann-Whitney methods.

\section{RESULTS AND DISCUSSION}

In the study of cards, it was found that 54 pregnant (90\%) VHR appeared in the second trimester of pregnancy and $5 \%$ pregnant had VHR in the third trimester, which may be due to the appearance of an increase in the standing of the diaphragm $[3,9]$, the appearance of active fetal movements that may increase as a result of the appearance of humoral-metabolic changes in the body of a woman or hypoxia of the fetus [10]. Important role in arrhythmogenesis is played emotional excitement which contributed to re-visit to the doctor $[9,11]$. Among the VHR were: supraventricular extrasystoles (SVE) in 51 (85.0\%), ventricular extrasystoles (VE), which in all cases were combined with SVE in 38 (63.33\%), unstable supraventricular paroxysmal tachycardia in all cases from the AV node in $11(18.33 \%)$ and unstable monomorphic ventricular paroxysmal tachy- cardia in 4 (6.66\%). The appearance of unstable paroxysmal tachycardias in healthy pregnant women did not affect the hemodynamic parameters. Their appearance can be explained by changes in the vegetative nervous system, which is confirmed by several other authors $[9,11]$. The predominant predominance of extraordinary contractions over paroxysmal tachycardia is confirmed by other studies $[1,10]$. Only 3 pregnant VHR appeared in the third trimester and this was a combined disorder in the form of SVE and VE. All cases of VHR were hemodynamically stable. In the study of the QT interval, normal indicators were noted, the occurrence of paroxysmal tachycardias was not associated with a lengthening of the QT interval.

Sinus tachycardia occurred in 52 pregnant women $(86.67 \%)$, sinus bradycardia in $8(13.33 \%)$, in which symptoms of the inferior vena cava (dizziness, nausea, lowering of blood pressure lying on the back) were noted. In pregnant women with sinus tachycardia, hemoglobin parameters were included in the study. It was found that 37 patients with sinus tachycardia $(61.66 \%)$ had grade I anemia $(\mathrm{p}<0.001)$. When comparing the heart rate in pregnant women with anemia and without it, $108 \pm 3,41$ and $96 \pm 2,32$ beats / $\min (\mathrm{p}<0,01)$ were revealed. Correction of hemoglobin level contributed to a decrease in the heart rate and improvement of the general condition of the pregnant woman, and also decreased the subjective feeling of palpitation and irregularities in the work of the heart. According to other authors [11], about $37 \%$ of cases of pregnancy in women with VHR took place against the background of anemia of 1-2 degrees. In 31 women (59.62\%) with sinus tachycardia, according to the data of individual cards, an ultrasound examination of the thyroid gland was performed. All indicators were in the normal range. The findings suggest that in pregnant women without cardiovascular diseases, various VHR appear that have stable hemodynamics, but are poorly tolerated and require antiarrhythmic drugs and more dynamic monitoring from a cardiologist. In this category of women, the occurrence of VHR can be associated with repeated pregnancy, later gestation and the development of anemia. The literature describes the changes in the electrical systole of the heart, electrolyte imbalance in pregnant women against the background of cardiovascular diseases. We noted that in healthy pregnant women, VHR is more associated with emotional instability and the occurrence of additional factors, such as anemia. The study of the vegetative status of healthy pregnant women can be considered in prospective studies with the development of preventive measures.

Pregnant women were also divided into 2 groups depending on the number of previous pregnancies: the first group (one or two pregnancies) 50 people, the second group (three or more pregnancies) - 10 people who had paroxysmal arrhythmias [11].

In addition, an analysis was made of the appearance of the VHR depending on the previous history of infectious diseases during pregnancy, which was included in the study. Two groups are formed: the first group includes pregnant women who have had infectious diseases of the bronchopulmonary system (acute respiratory viral 
diseases, bronchitis, pneumonia) during pregnancy, and the second group - without the transferred diseases. The number of women in the two groups was 18 and 42, respectively. VHR in the groups were found without significantly significant indicators, possibly due to small samples.

\section{CONCLUSIONS}

Thus, the vast majority of violation of the heart rhythm in healthy women appears in the second trimester of pregnancy, needs additional cardiologist consultation during this period. Most often there are supraventricular extrasystoles, sinus tachycardia. Sinus tachycardia significantly $(\mathrm{p}<0.001)$ occurs more often with concomitant anemia. When tachycardia occurs, it is additionally necessary to evaluate the level of hemoglobin, the correction of which helps to reduce the heart rate. Sinus bradycardia occurs at signs of constriction of the inferior vena cava with an enlarged uterus, which requires the training of a pregnant woman to change the position of the body during sleep. With an increase in the number of pregnancies a woman's risk of heart rhythm disorders increases. Accordingly, such women require more detailed examination and control by the cardiovascular system in most cases, the appointment of antiarrhythmic drugs. The past infectious diseases of the bronchopulmonary system during pregnancy do not significantly affect the onset of the violation of the heart rhythm.

\section{REFERENCES}

1. Shotan A., Ostrzega E., Mehra A. etc. Incidence of arrhythmias in normal pregnancy and relation to palpitations, dizziness, and syncope. The American Journal of Cardiology. 1997; 79 (8): 1061-1064. View at Publisher • View at Google Scholar • View at Scopus

2. Adamson D. L. Nelson-Piercy C. Managing palpitations and arrhythmias during pregnancy. Heart. 2007; 93 (12): 1630-1636. View at Publisher - View at Google Scholar • View at Scopus

3. Veropotvelyan P.N., Solomkina A.YU., Veropotvelyan N.P i dr. Beremennost'u patsiyentok s narusheniyem ritma serdtsa. [Pregnancy in patients with cardiac arrhythmias]. Woman's health. 2015; 6 (102): 66-70. (In Russian)

4. Dyadyk A.I., Bagriy A.E., Khomenko M.V.i dr. Sovremennyye podkhody k lecheniyu narusheniy ritma serdtsa pri beremennosti. Chast'1. [Modern approaches to the treatment of cardiac arrhythmias during pregnancy. Part I]. Ukrainian Cardiology Journal. 2003; 5: 131-137. (In Russian)

5. Dotsenko N.YA., Boyev S.S., Shekhunova I.A. i dr. Narusheniye ritma serdtsa u beremennykh: terapevticheskiye aspekty. [Disruption of heart rhythm in pregnant women: therapeutic aspects]. Therapia. 2015; 10 (102): 18-21. (In Russian)

6. Burkart T. A., Conti J. B. Cardiac arrhythmias during pregnancy. Current Treatment Options in Cardiovascular Medicine. 2010; vol. 12, no. 5: 457-471. View at Publisher • View at Google Scholar
7. Knotts R. J. Garan H. Cardiac arrhythmias in pregnancy. Seminars in Perinatology,. 2014; vol. 38, no. 5: 285-288. View at Publisher • View at Google Scholar

8. Soliman E. Z., Elsalam M. A., and Li Y. The relationship between high resting heart rate and ventricular arrhythmogenesis in patients referred to ambulatory $24 \mathrm{~h}$ electrocardiographic recording. Europace. 2010; vol. 12, no. 2: 261-265. View at Publisher • View at Google Scholar • View at Scopus

9. Boyko V.I., Sukharyev A.B., Nikityna I.M. Otsinka stanu ploda u vahitnykh $z$ arytmiyeyu sertsya [Assessment of the status of the fetus in pregnant women with cardiac arrhythmias]. J. Clin.Exp. Med. Res. 2015;3(1):7782. (In Ukrainian)

10. Chekashkina Ye. Ye., Nazarkina M. G., Leshchankina N. YU. i dr. Variabel'nost' serdechnogo ritma u beremennykh zhenshchin $\mathrm{s}$ zheludochkovoy ekstrasistoliyey. [Heart rate variability in pregnant women with ventricular extrasystoles]. Bulletin of Mordovia University. 2016; vol. 26(1): 122-133. (In Russian)

11. Kolomatskaya 0.Ye., Chesnikova A.I.. Narusheniya ritma serdtsa u beremennykh zhenshchin - aktual'nost' problemy i puti yeye resheniya. [Heart rhythm disturbances in pregnant women - the relevance of the problem and the ways to solve it]. Archive of internal medicine. 2016; 1(27): 49-53. (In Russian).

The work was performed within the framework of the research work Department of Internal Medicine 3, National Pirogov Memorial Medical University, Vinnytsya, Ukraine "Pathogenetic parallels between neurohumoral, metabolic and structural-functional disorders and the nature of the course of various cardiovascular diseases and comorbid conditions, optimization of pharmacological correction" (State registration number 0114U007197, scientific advisor - Grand PhD of Medical Sciences Valerii P. Ivanov)

Authors' contributions:

According to the order of the Authorship.

Conflict of interest:

The Authors declare no conflict of interest.

\author{
CORRESPONDING AUTHOR \\ Oksana I. Afanasiuk \\ Department of Internal Medicine №3 \\ National Pirogov Memorial Medical University \\ Zabolotnoho St., 8/15, 21037 Vinnytsya, Ukraine \\ tel: +380677669618 \\ e-mail: 0.afanasiuk@gmail.com
}

Received: 01.12.2018

Accepted: 27.02.2019 
PRACA ORYGINALNA

ORIGINAL ARTICLE

\title{
PREVALENCE OF BAD HABITS AMONG STUDENTS OF THE INSTITUTIONS OF HIGHER MEDICAL EDUCATION AND WAYS OF COUNTERACTION
}

\author{
WYSTĘPOWANIE ZŁYCH NAWYKÓW WŚRÓD STUDENTÓW \\ UCZELNI WYŻSZYCH ORAZ METODY ZAPOBIEGANIA
}

\author{
Tetiana S. Gruzieva', Liudmyla I. Galiienko', Iryna A. Holovanova², Victoria B. Zamkevich', Olena Ya. Antonyuk', \\ Liudmyla V. Konovalova' ${ }^{1}$, Roman G. Dolynskyj' ${ }^{1}$, Anastasiia I. Zshyvotovska² \\ 'NATIONAL BOGOMOLETS MEDICAL UNIVERSITY, KYIV, UKRAINE \\ ¿UKRAINIAN MEDICAL STOMATOLOGICAL ACADEMY, POLTAVA, UKRAINE
}

\begin{abstract}
Introduction: The relevance of scientific research is determined by the significant importance of lifestyle in preserving and strengthening the health of the population especially young people what determines the future of any society. Among the numerous youth lifestyle characteristics, particular attention is paid to behavioral factors, including the presence of bad habits. Data of scientific publications indicate a significant prevalence in student environment of tobacco-smoking, consumption of alcohol and other manifestations of unhealthy behavior, which are powerful factors of the risk of developing non-communicable diseases, injuries and other health disorders.

One of the most important tasks is the formation and establishment of a healthy lifestyle among medical students, because in the future they will not only treat patients, but also carry out professional activities for the prevention of diseases and risk factors for their development, correcting and overcoming already existing risk factors. Doctors must be conscious supporter of healthy lifestyle and serve as a role model for their patients.

The aim: To identify the features of prevalence of tobacco use, alcohol and energy drinks among medical students and justify ways of counteraction based on the results of own sociological research, scientific literature, WHO program and strategic documents.

Materials and methods: An anonymous questioning was covered 948 students of institutions of higher medical education including $34.5 \%$ of men and $65.5 \%$ women. It had been used bibliosemantic, sociological and medical-statistical methods.

The information base of the study included program and strategic documents of WHO, sources of scientific literature, data of own research. Statistical processing of the obtained results was carried out using generally accepted medical statistics methods using licensed programs (SPSS, STATA, Statistica 10.0 and MS Excel XP).

Results: The results of the study indicate a sufficient significant prevalence in the student environment of tobacco, alcohol and energy drinks. Third part of students consumes tobacco, of which 15.2 per 100 respondents are regular smokers with experience, 9.3 per 100 respondents smoked 10 or more cigarettes a day.

A new negative trend is the use of hookah by almost half of the interviewed students and consumption of electronic cigarettes ( 8.5 per 100 respondents), what must be taken into account when substantiating counteraction ways. Three quarters of the respondents consume alcohol. Despite the prevailing consumption of low-alcohol beverages and wine by respondents, every seventh of the respondents consumes strong drinks. The reason for the worrying is the fact that $13.6 \pm 4.7$ in 100 respondents combine the consuming of energy drinks with alcohol. By 4.9 per 100 students interviewed, energy drink increases the desire to drink alcohol.

Conclusions: The revealed connection between tobacco, alcohol and energy drinks consumption among medical students proves the need for an integrated approach to reduce the prevalence of risk factors in the context of a healthy lifestyle.
\end{abstract}

KEY WORDS: life-style, student youth, risk factors, unhealthy habits, healthy lifestyle, prevention

Wiad Lek 2019, 72, 3, 384-390

\section{INTRODUCTION}

The relevance of scientific research is determined by the significant importance of lifestyle in preserving and strengthening the health of the population especially young people what determines the future of any society.

Among the numerous youth lifestyle characteristics, particular attention is paid to behavioral factors, including the presence of bad habits [1-3].

It is proved that the consumption of tobacco and alcohol is a powerful risk factor for the development of non-infectious diseases, injuries, other health disorders. These risk factors make a significant contribution to the formation of the burden of illness, including disability and mortality, lead to significant economic costs in the healthcare system, which is a significant financial burden on families and communities [4-8].

Taking into account the stated in a number of strategic and program documents of the International and European regional level, priority is given to the issues of combating consumption of tobacco, harmful and dangerous consumption of alcohol [9]. 
Recently, a significant number of scientific publications indicate an increasing prevalence of a relatively new risk factor for the development of diseases, namely energy drinks. This is especially true for young people, among which the use of energy is becoming very popular.

Knowledge of the scale of the problem, features and trends in different groups of the population, the root causes of the choice of unhealthy behavior can justify the directions of counteraction with proven effectiveness. That is why studying the prevalence of leading factors in the development of youth health issues is extremely relevant in terms of an adequate response to existing challenges.

The relevance of this topic is substantially increased in relation to the environment of students of higher medical education institutions, who in the future will have to carry out professional activities to prevent diseases and risk factors for their development, to provide assistance in correcting and overcoming already existing risk factors. It is clear that they themselves should be a role model for their patients, so the formation and establishment of a healthy lifestyle among future physicians is an extremely important task.

Therefore, according to the WHO experts, the priority task of all countries of the world should be to improve preventive work in national health systems, to actively develop a healthy lifestyle and to have a responsible attitude towards their health in different groups of the population, starting with the youngest age.

This requires in-depth study of the peculiarities and trends of the prevalence of unhealthy habits among different contingents of the population, especially children and youth, monitoring and evaluation of these phenomena, formation of the principles of a healthy lifestyle, responsible attitude towards their health, prevention and correction of behavioral risk factors on an individual, group and population levels, advocacy, information and awareness raising among the population, advocacy and advancement of healthy lifestyle issues in all policies with the participation of the whole society using national approaches.

\section{THE AIM}

To study the prevalence of tobacco use, alcohol and energy drinks among medical students and justify ways to reduce the prevalence of harmful habits among future physicians based on the results of own research, data of scientific literature, taking into account the priorities of WHO program and strategic documents in the field of disease prevention and healthy lifestyle.

\section{MATERIALS AND METHODS}

The research was conducted on the basis of Bogomolets NMUwithin the framework of research work «Scientific substantiation of personnel support of public health service» (2017-2019). An anonymous questioning was covered 948 students of institutions of higher medical education, namely Bogomolets National Medical University, Kyiv and the Ukrainian Medical Dentistry Academy of the Ministry of Health of Ukraine, Poltava. 34.5\% of males and 65.5\% females were included in the set sample. By age distribution, the largest group was formed by students aged 20-25, whose proportion was $80,9 \%$, while respondents under 20 and over 25 accounted for $13.3 \%$ and $5.8 \%$, respectively.

The work uses a series of informative research methods based on the base of a systematic approach, including a bibliosemantic method - for studying world and domestic experience on the researched questions, sociological - to detect the prevalence of bad habits among students of the institutions of higher medical education, medical and statistical methods - for collecting, processing and analyzing the statistical information obtained during the study. The sociological research among medical students was conducted with use the questionnaire included 30 issues of closed and semi-closed type. to study the to study attitude of future doctors to smoking, use of alcohol and energy drinks.

The information base of the study included program and strategic documents of WHO, sources of scientific literature and data of own research.

Statistical processing of the obtained results was carried out using generally accepted medical statistics methods using licensed programs (SPSS, STATA, Statistica 10.0 and MS Excel XP).

\section{RESULTS AND DISCUSSION}

In the new European policy "Health-2020", the priority goal is to strengthen health for all and to reduce inequities in the context of health. At the same time, the focus is on the need to ensure universal coverage of public health services, primarily preventative, from birth and throughout whole life. Priority areas for action include investing in health at all stages of human life, empowerment of rights and opportunities of citizens, as well as solution of the most current problems of non-infectious and infectious diseases [9].

In this context, a critical role is played by the formation of a healthy lifestyle and the prevention of bad habits, starting at the earliest age as possible.

Advanced strategies for prevention and correction of various risk factors are outlined in strategic documents of the global, regional and national levels. Of particular interest are integrated strategies, in particular the Global Strategy for the prevention and protection from non-communicable diseases and the Global Plan of action for the prevention and protection from non- communicable diseases 2013-2020.

According to these documents, the European Action Plan for the Implementation of the European Strategy for the Prevention and Protection from Non-Communicable Diseases for 2012-2016 has been developed and approved by the World Health Organization (WHO) in the European Region. In addition, in the majority of countries, the Global Strategy for the Reducing of Harmful Alcohol Consumption is being implemented, the European Action Plan for the Reduction of Harmful Alcohol Consumption for 2012-2020 [10-13]. 


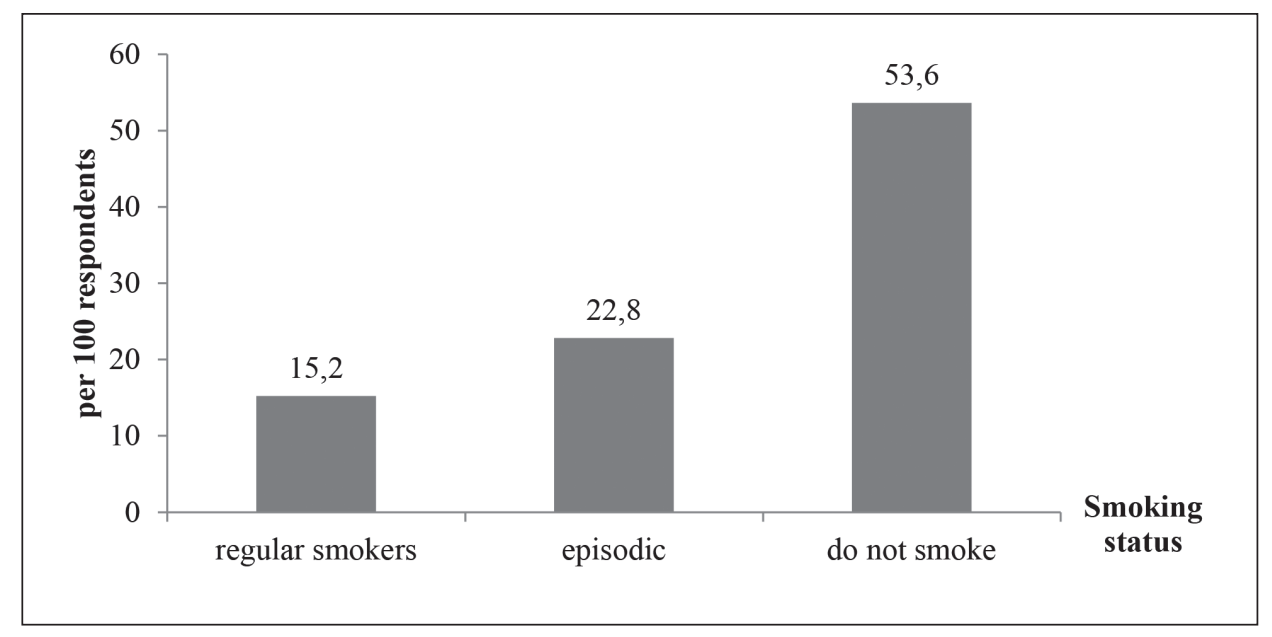

\section{㽗 a calming effect}

an example of friends

\section{: holding time in waiting \\ ather reasons}

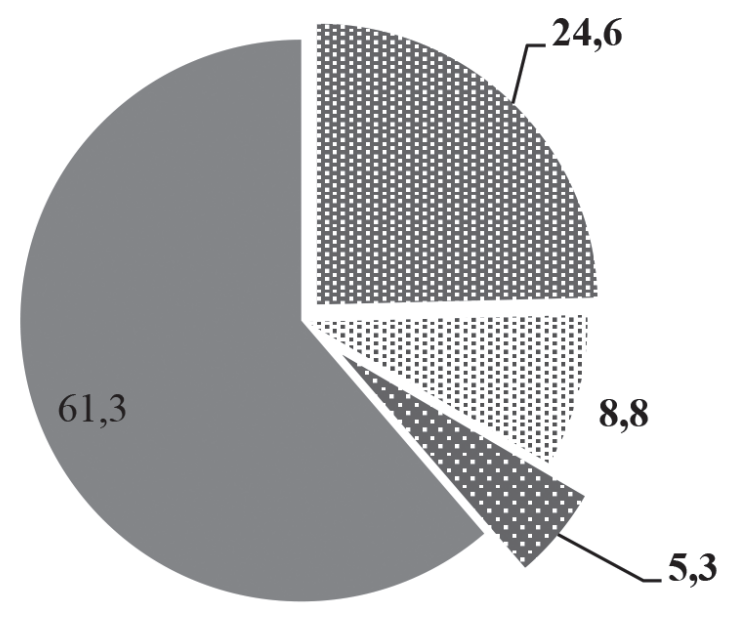

Fig. 1. Smoking status of students of institutions of higher medical education (per 100 respondents)
Fig. 2. Structure of causes of tobacco consumption by medical students (\%)
Implementation of strategic and program documents in the national context requires scientific support, with the identification of the features and trends of the phenomena to which the measures of influence are directed, their critical analysis, etc.

Analysis of the scientific literature showed a significant prevalence of harmful risk factors for the development of diseases in the population of Ukrainian youth, including students of higher educational institutions [14-18].

According to the results of the study of the prevalence of smoking, up to $40 \%$ of the polled young people recognized the presence of this bad habit. Moreover, the polynomial frequency was quite significant and amounted to 8 cigarettes a day [19].

Of particular concern is the variety of ways of tobacco consumption, in particular, the hookah smoking, which is relatively new for the Ukrainian youth population. This way of entering the body in addition to the total harm from nicotine, is also dangerous as a source of infectious pathogens. The results of a sociological survey showed that almost two thirds of the respondents smoked a hookah at least once in their life, at the same time $8 \%$ of respondents confirmed hookah smoking sporadically or regularly. The situation is complicated by the significant prevalence of alcohol consumption. Among those respondents, 35.9\% consumed alcoholic beverages at least once a week. At the same time, $13.7 \%$ of respondents indicated the consumption of strong alcoholic beverages, 9.1\% - wines, 7.7\% low-alcohol beverages [19].

An important characteristic of the formation of health of young people is often a low level of physical activity, which requires in-depth study and development and implementation of strategies aimed at overcoming hypodynamia and improving health [20].

Comprehensive research aimed at the prevention of non-communicable diseases among young people and students, it was found that regardless of the level of the institution and the profile of education, risk factors for 


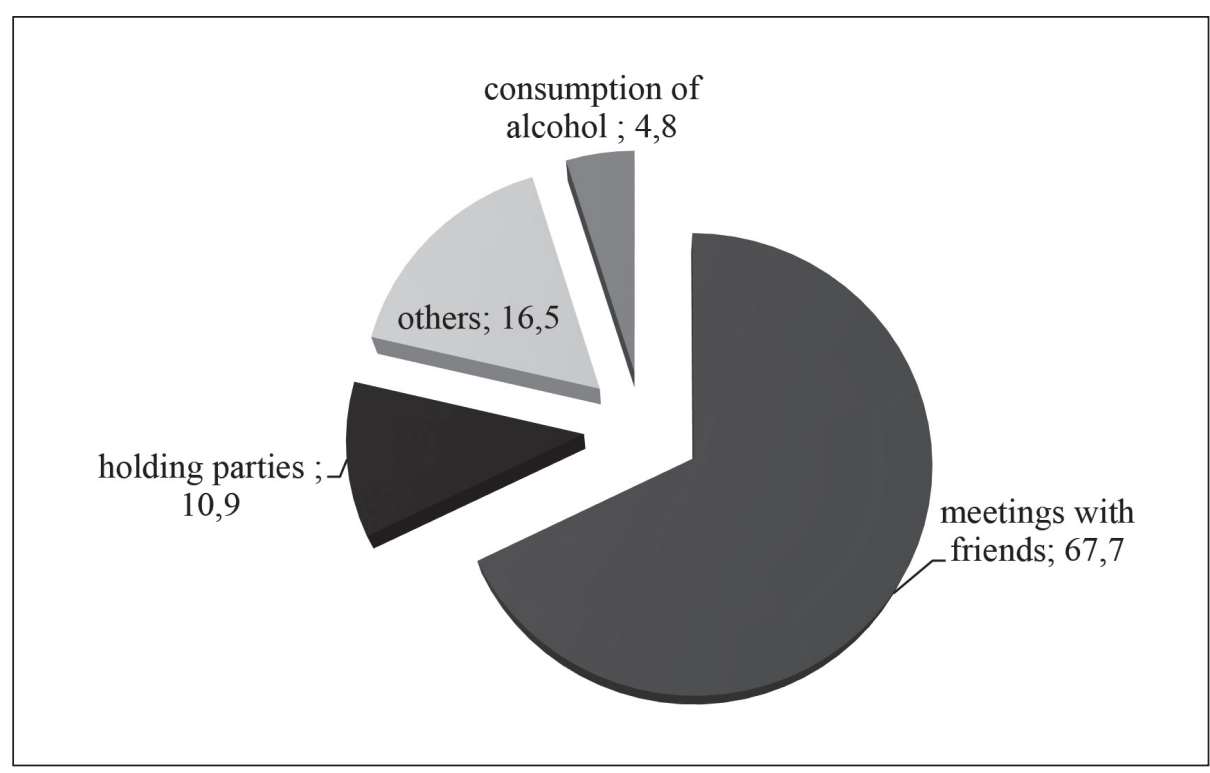

Fig. 3. Reasons for visiting places where alcoholic beverages are consumed, by students of institutions of higher medical education (per 100 respondents) ill-health are quite common. They lead to the development and progression of various non-communicable diseases.

In the course of the study, among the students of higher educational institutions of medical, technical and humanitarian areas, the established habit of drinking alcoholic beverages was detected, $5.4 \pm 1.2 \%$ of the respondents confirmed and smoking, which $26.8 \%$ of the respondents confirmed. The results of the study established the existing need to substantiate a set of measures to form the basis of a healthy lifestyle for students [21].

Researchers are unanimous in their opinion about the need to ensure the optimization of preventive activities in the integrated delivery of medical care. At the same time, emphasis is placed on preserving and strengthening the health of school and student youth for the prevention of numerous infectious and non-infectious diseases. This important and complex process depends on the timely identification of risk factors for the development of diseases, their correction, monitoring and evaluation of the health of young people and students, hardening and health promotion [22].

Preventive and health work requires a certain restructuring of the organization of the educational process in institutions of higher education, with the aim of leveling situations that adversely affect the health of students. In this context, the active involvement of specialists in the psychological and social services, the use of an intersectoral approach to solving the health problems of students are proposed [23].

The results of our sociological research on the prevalence of harmful habits among students of institutions of higher medical education showed that tobacco is used by $38.0 \pm$ 3.3 per 100 respondents. Regular smokers are $15.2 \pm 3.9$ per 100 respondents, periodic (episodic) $-22.8 \pm 3.7$. Some students pointed to isolated cases of tobacco consumption. At the same time, $53.6 \pm 2.9$ per 100 respondents indicated that they do not smoke and are indifferent to nicotine (Fig. 1).

Among the causes of smoking, $24.5 \pm 4.5$ per 100 interviewed students indicated a calming effect, $8.8 \pm 4.9$ - holding time in waiting, $5.3 \pm 5.0$ - an example of friends, $61.3 \pm 3.2$ - other reasons (Fig.2).

According to the intensity of tobacco consumption, respondents distributed as follows: $18.6 \pm 2.8$ per 100 respondents smoked up to 10 cigarettes a day, 8.3 - from 10 to 20 cigarettes, 1.0 - more than 20 cigarettes a day.

Among different ways of using tobacco, students preferred hookah, which was indicated by $48.0 \pm 4.0$ per 100 respondents. Traditionally, the using of cigarettes was high, which was confirmed by $39.6 \pm 4.3$ per 100 respondents. The using of electronic cigarettes was confirmed by $8.5 \pm$ 5.3 per 100 respondents. The combination of different ways of using tobacco was indicated by 3.9 per 100 respondents.

Smoking among students is often combined with alcohol use. Among students who smoke, 90,0 per 100 respondents drink alcohol, among those who do not smoke - 70,9, respectively. The calculation of the chi-square indicates the significance of this difference, since the calculated value (27.0) exceeds the table (9.6).

The results of the research of the prevalence of alcohol consumption among students of higher medical education institutions showed that it was used by $76.1 \pm 2.0$ per 100 respondents. Only less than a quarter of respondents $(23.9 \pm$ 3.7) indicated that they do not consume alcoholic beverages.

At the same time, visits to places where alcoholic beverages are consumed once a week have been confirmed by 24.5 \pm 3.6 per 100 respondents, twice a week $-16.4 \pm 3.8$, more than three times a week $-11.1 \pm 4.0$ In general, only less than half of respondents did not attend such institutions (48.0 \pm 3.0 per 100 respondents).

The most common reason for visiting places where alcoholic beverages are consumed, students called meetings with friends $-67.7+2.2$ per 100 respondents. Every tenth respondent indicated holding parties among the reasons for visiting such places $(10.9 \pm 4.0)$. One in six said that the reason for visiting drinking places was other. At the same time, 4.8 per 100 respondents indicated the main reason - the consumption of alcohol (Fig. 3). 
Almost half of the respondents confirmed the alcohol consumption at weekends ( $46.3 \pm 3.1$ per 100 respondents). Almost $18.5 \pm 3.8$ per 100 respondents were drinking on holidays. It is worrying that $11.2 \pm 4.0$ per 100 respondents indicated alcohol consumption during the week.

According to students, the main reasons for alcohol consumption are the satisfaction $(35.4 \pm 3.5$ per 100 respondents), alcohol consumption by friends (7.4 per 100), and solving existing problems (2.9 per 100 respondents).

Analysis of the models of alcohol consumption by medical students showed that the most frequent drinking is wine, as indicated by $43.1 \pm 3.2$ per 100 respondents, and beer, which confirmed $21.8 \pm 3.8$ per 100 respondents. At the same time, $14.8 \pm 3.9$ medical students called strong alcoholic beverages the most often for consumption. Attention is drawn to the negative fact that $29.4 \pm 3.6$ per 100 respondents mix of different alcoholic beverages when they are consumed.

When asked whether you drink more alcohol, in the company or alone, $76.2 \pm 2.2$ per 100 respondents indicated that they consume more alcohol in the company. However, $17.0 \pm 4.1$ per 100 respondents answered that it does not matter, and 2.9 per 100 respondents indicated that they consume more alcohol alone.

The vast majority of respondents, namely $61.1 \pm 2.9$ per 100 students, indicated that alcohol causes them a good mood. About a third part $(31.8 \pm 3.8)$ responded that drinking alcohol causes a lot of different mood. At the same time, 3.2 per 100 respondents pointed to aggression as a result of alcohol consumption, 3.6 per - to sadness.

Almost a third of the respondents $(32.3 \pm 3.7$ per 100) confirmed the fact that smoking was used during the consumption of alcoholic beverages. At the same time, $17.0 \pm 4.4$ respondents are convinced of the feasibility of combining of the alcohol consumption with smoking.

Studying differences in the frequency of smoking among students who consume alcohol and who do not consume showed that this difference is significant, as the calculated value of the chi-square (2.5 exceeds the table value (1.9).

The results of the study of the prevalence of energy drinks consumption among students of higher medical education institutions showed that they were consumed by $32.5 \pm$ 4.5 per 100 respondents. At the same time, 16.6 per 100 respondents indicated that they consume it once a week, 12.3 - twice a week, 3.6 - more than three times a week.

The vast majority of respondents indicated that they preferred to consume energy drinks during their study (24.8 \pm 4.5 per 100 students) and during physical work (6.7 per 100 respondents).

An analysis of the volume of consumption of energy drinks per day showed that energy drinks are consumed once a day by 16.2 per 100 people polled, twice by $3.6,3$ times or more -3.6 .

The volume of simultaneous consumption of energy drinks (during the disco, during the evening) was 1 bottle for $17.2 \pm 4.3$ per 100 students, 2 bottles - 3.6 per 100 students, 3 and more -3.6 per 100 students.

The purpose of the consumption of energy drinks is activation (18.9 \pm 4.7 per 100 respondents), increase of physical capacity (10.4), reception satisfaction of taste (9.0).

According to students, the key to choosing an energy drink is the brand, as was indicated by $17.5 \pm 5.5$ per 100 respondents, the taste, which was confirmed by $45.2 \pm 4.6$ per 100 respondents, ingredients of the energy drink, noted $35.8 \pm 4.9$ per 100 respondents respectively.

The result of cheering the body with energy drinks is an increase in concentration of attention, as indicated by 23.1 \pm 4.9 per 100 respondents, an increase in physical activity, which marked $22.7 \pm 4.9$ per 100 respondents, a decrease in the sense of hunger (5.0 per 100 of respondents). About a (18.3 \pm 4.8 per 100 respondents) confirmed the influence of the use of energy drinks on the mood.

After a short period after consuming of energy drinks, the respondents experienced improvement in physical activity (22.0 \pm 4.6 in 100 respondents), increased concentration (12.0 \pm 4.9 in 100 respondents), and internal calm (3.3 per 100 respondents). However, the next day after awakening, 9.4 per 100 respondents complained of stomach pain, 7.1 per 100 respondents - of internal anxiety.

The reason for the worrying is the fact that $13.6 \pm 4.7$ in 100 respondents combine the consuming of energy drinks with alcohol. By 4.9 per 100 students interviewed, energy drink increases the desire to drink alcohol.

The study of the differences in the frequency of energy drink consumption among students who drink alcohol and who do not drink showed that this difference is significant, because the calculated value of the chi-square -2.4 exceeds the table value (1.8).

The relationship established between the different factors of the risk of developing diseases, in particular between tobacco use, alcohol and energy drinks, has been established in the course of the research, which shows the need for an integrated approach to reduce their prevalence among the students and about the potential for positive results in terms of healthy lifestyle when reducing the prevalence of even one risk factor.

According to students, the effective ways of forming a healthy lifestyle and reducing unhealthy behavior are: information and education activities at the population level (63.7 per 100 respondents); more general coverage of prevention issues in the educational process in the institutions of higher medical education (70.5 per 100 of respondents), introduction of targeted lectures and trainings, master classes on the issue of correction and management of disease risk factors (83.4 per 100 respondents), holding of information campaigns (58.8 per 100 respondents), etc (Table I).

The generalization of the data obtained during the research, as well as the analysis of scientific literature and recommended international strategies by WHO, allowed them to be used for the preparation of information materials and for the holding of a number of information and educational events. In particular, the negative impact of smoking, dangerous and harmful consumption of alcohol, the consumption of energy drinks is highlighted for students of the Bogomolets National Medical University during the sessions of the Student Scientific Circle of the Department of Social 
PREVALENCE OF BAD HABITS AMONG STUDENTS OF THE INSTITUTIONS OF HIGHER MEDICAL EDUCATION AND WAYS...

Table I. Student assessment of ways of forming a healthy lifestyle and reducing unhealthy behavior (per 100 respondents)

\begin{tabular}{cc} 
Ways of forming a healthy lifestyle and reducing unhealthy behavior & $\mathbf{P} \pm \mathbf{m}$ \\
\hline Introduction of targeted lectures and trainings, master classes & $83,4 \pm 1,2$ \\
\hline $\begin{array}{c}\text { More general coverage of prevention issues in the educational process } \\
\text { in the institutions of higher medical education }\end{array}$ & $70,5 \pm 1,5$ \\
\hline Information and education activities at the population level & $63,7 \pm 1,6$ \\
\hline Holding of information campaigns & $58,7 \pm 1,6$ \\
\hline
\end{tabular}

Medicine and Public Health, during scientific conferences, information and educational events, etc.

During the meetings of the Student Scientific Circle of the Department of Social Medicine and Public Health to consider the issues of the influence of harmful factors on health and counteracting unhealthy behavior, interactive methods are widely used, including discussions, work in small groups, brainstorming, case study, business games.

Materials about the situation with the prevalence of risk factors in the student environment are covered in the abstracts of the IV International Congress of the Polish Society of Public Health, an article in the scientific journal was prepared.

Current experience has shown that informational and educational activities on correction of unhealthy behavior factors will contribute to the reduction and successful management of risk factors for diseases, as well as to the establishment of a healthy lifestyle for students.

\section{CONCLUSIONS}

The results of the study indicate a sufficient significant prevalence of manifestations of unhealthy behavior among students of institutions of higher medical education. This is indicated by the prevalence in the student environment of tobacco, alcohol and energy drinks.

The reason for the worrying is the fact that third part of students consumes tobacco, of which 15.2 per 100 respondents are regular smokers with experience, 9.3 per 100 respondents smoked 10 or more cigarettes a day. Along with the consumption of cigarettes, almost half of the interviewed students indicated the consumption of hookah, 8.5 per 100 respondents - the consumption of electronic cigarettes, which must be taken into account when substantiating counteraction ways.

Significant is the prevalence of alcohol consumption by students, as indicated by three quarters of the respondents. Despite the prevailing consumption of low-alcohol beverages and wine by respondents, every seventh of the respondents consumes strong drinks. At the same time, every fourth respondent mixes different drinks during consumption of alcohol. The negative consequences of using alcohol are the appearance in one third of respondents of aggression, sadness, or mixed mood. The prevalence of alcohol consumption is associated with tobacco consumption.

Relative to the new unfavorable health trend is the prevalence of energy drink consumption by students, which was confirmed by one third of the respondents. At the same time, respondents noted short-term effects in the form of increased work capacity, mood that passed the next day in anxiety, the appearance of pain in the stomach, etc. Each seventh of the respondents indicated a combination of alcohol and energy drinks.

The existing connection between tobacco, alcohol and energy drinks consumption proves the need for an integrated approach to reduce their prevalence among students and about the potential for achieving positive results in terms of healthy lifestyles.

The special aspects and causes of the prevalence of risk factors of illness and unhealthy behavior among student youth indicate the need for a complex approach to its prevention and reduction with the application of modern adequate methods, forms and methods.

\section{REFERENCES}

1. Global status report on non-communicable diseases 2014 “Attaining the nine global non-communicable diseases targets; a shared responsibility. Geneva: World Health Organization; 2014, 302 p.

2. Global Health Observatory Data Repository. World health statistics 2011 Geneva: World Health Organization; 2011.

3. Gruzeva T.S. Non-communicable diseases: the extent and trends of prevalence, control strategies /In: Gruzeva T.S., Dyachuk D.D., Zyukov A.L. et al. Annual report on the health status of the population, the sanitary and epidemic situation and the results of the health care system of Ukraine. Kyiv: Ministry of Health of Ukraine; 2016, p. 408-417.

4. WHO report on the global tobacco epidemic, 2017: monitoring tobacco use and prevention policies. Geneva:World Health Organization; 2017, $265 \mathrm{p}$.

5. Prevention and control of non-communicable diseases in the European Region: a progress report. Copenhagen:WHO Regional Office for Europe; 2014, $72 p$.

6. Maziak, W., Taleb ZB, Bahelah R. et al. The global epidemiology of waterpipe smoking. Tob. Control, 2015;24:i3-i12.

7. Tobacco control and the sustainable development goals. Copenhagen: WHO Regional Office for Europe; 2015, 7 p.

8. Report on the state of health care in Europe. 2015. Targets and a broader perspective - new frontiers in working with factual data. Copenhagen: WHO Regional Office for Europe; 2015, $157 \mathrm{p}$.

9. Health 2020. A European Regional Framework for Europe. Copenhagen: WHO Regional Office for Europe; 2013, 183 p.

10. Global Action Plan for the Prevention and Control of Non-communicable Diseases 2013-2020. Geneva: World Health Organization; 2013.

11. European action plan to reduce the harmful use of alcohol 2012-2020. Copenhagen: WHO Regional Office for Europe; 2012, 75 p.

12. Global strategy to reduce the harmful use of alcohol. Geneva: World Health Organization; 2010, $44 \mathrm{p}$. 
13. A package of measures to combat the tobacco epidemic. Geneva: World Health Organization; 2008, $41 \mathrm{p}$.

14. Krasovsky K.S., Andreeva T.I., Grigorenko A.A. et al. Dynamics of smoking prevalence in Ukraine. Bulletin of social hygiene and organization of health care in Ukraine. 2009;2:91-99.

15. Gruzieva 0. Prevalence survey from GHPSS survey. Ukrainian Scientific Medical Youth Journal. 2009;3:294-295.

16. Global Adult Tobacco Survey (GATS). $2010.160 \mathrm{p}$.

17. Kalinichenko D.0. Hygienic assessment of the quality and lifestyle of young people. Scientific Journal "ScienceRise: Medical Science». 2017;1:18.

18. Gruzeva T.S., Dufinets V.A. Zamkevich V.B., Marshal U.M. Alcohol use as a medical and social problem. East European Journal of Public Health. 2015;4(25):153-160.

19. Semigina T., Romanova N., Belyshev A. Self-assessment of youth health and lifestyle. Bulletin of the Ministry of Ukraine for Family, Youth and Sport. 2010;3:139-149.

20. Kensitska I. L. Characteristics of indicators of the physical condition of students. Scientific journal NPU named M.P. Dragomanov. Ser. № 15 "Scientific and pedagogical problems of physical culture. Physical Culture and sport". 2017;10(92):46-50.

21. Gruzieva T.S., Galiienko L.I., Pelyo I.M. et al. Health and lifestyle of students' youth: status, problems and ways of solution. Wiadomości Lekarskie. 2018;9:1731-1736.
22. Gruzieva T. S., Galiienko L. I. Sociological aspects of improvement of prevention of non-communicable diseases and formation of healthy life style of Ukraine population. Public Health Forum. 2017;3(42):199.

23. Romanova N.F. Formation of a healthy lifestyle as a modern strategy to counteract socially dangerous diseases among children and young people: monograph. In:Semigina T.V. Counteraction to socially dangerous diseases: study of Ukrainian experience. Kyiv: Pulsary; 2010, p. 39-48.

\section{Authors' contributions:}

According to the order of the Authorship.

\section{Conflict of interest:}

The Authors declare no conflict of interest

\section{CORRESPONDING AUTHOR \\ Tetiana S. Gruzeva}

National Bogomolets Medical University

Saksaganskogo St. 42/43, 01033 Kyiv, Ukraine

e-mail:gruzieva@ukr.net

Received: 10.12 .2018

Accepted: 28.02.2019 
PRACA ORYGINALNA

ORIGINAL ARTICLE

\title{
ALLERGEN COMPONENT TESTING - A NEW ERA IN DIAGNOSTICS OF PATIENTS WITH POLLEN ALLERGY
}

\section{BADANIE ELEMENTÓW SKŁADOWYCH ALERGENÓW - NOWA ERA W DIAGNOSTYCE PACJENTÓW Z ALERGIĄ PYŁKOWĄ}

\author{
Svitlana Zubchenko ${ }^{1}$, Olena Sharikadze ${ }^{2}$, Stepan Maruniak ${ }^{2}$ \\ 'DANYLO HALYTSKY LVIV NATIONAL MEDICAL UNIVERSITY, LVIV, UKRAINE \\ 25HUPYK NATIONAL MEDICAL ACADEMY OF POSTGRADUATED EDUCATION, KYIV, UKRAINE
}

\begin{abstract}
Introduction: Pollen allergy, also called hay fever or pollinosis, is referred to the most widespread allergic diseases. According to different sources, from 5 to $34 \%$ of the population in developed countries are likely to suffer from this condition. Moreover, the majority of patients are young people of working age

The aim: To demonstrate a practical decision of the choice of effective treatment tactics based on component testing in patients with pollen allergy.

Materials and methods: 126 patients with allergic rhinitis / conjunctivitis were randomly selected according to their primary visit during the first week in August of the current year. Among them, 53 (42.0\%) female and 73 (58.0\%) male, aged 22-47 years. General laboratory and instrumental investigations, skin prick test with allergen extracts (Diater, Spain), measurement of total serum and specific IgE by immunoenzymatic assay method using test system "Euroimmun" were performed. Immunofluorescent method ImmunoCap (Thermo Scientific, Uppsala, Swiss) was used to detect specific components of allergens. The material of investigation was blood serum.

Results: According to the results of skin prick-test, $50 \%$ of patients could receive allergen immunotherapy with two different extracts of allergens "Mixture of Weeds" and "Mixture of Grass". On molecular investigations, it was detected that this combination was not suitable for any patient ( $20 \%$ of individuals had genuine sensitization to allergens of grass pollen, including a marker of cross-reactive molecules, $30 \%$ of individuals were sensitized with genuine allergens of Artemisia and/or ambrosia).

Conclusions: Based on skin prick-test and molecular diagnostics, the doctor makes a completely different decision on the choice of extracts for allergen immunotherapy conduction. Component determination of a sensitized profile and high sensitivity of this method enables to reveal a genuine protein, which is the primary cause of allergy occurrence and administer etiotropic allergen-specific immunotherapy with the allergen, to which sensitization was detected.
\end{abstract}

KEY WORDS: component diagnostics, pollen allergy, allergen immunotherapy

Wiad Lek 2019, 72, 3, 391-394

\section{INTRODUCTION}

It has been over 20 years since the moment of the first concept of allergy diagnostics based on allergen components or component diagnostics (component-resolved diagnostics, CRD) [1]. Since then, the volume of knowledge in this area is constantly increasing, and the quality is improving. Allergy source is identified at a component level. Components of an allergen are proteins, which by their structure are very similar (homologous) and belong to the same protein family, though they have a completely different source. Implementation of component diagnostics into practice enables practical doctors to prognosticate possibility of occurrence of allergy symptoms, cross reactivity, determine the risks of acute conditions, to choose optimal eliminating measures, in particular diet in case of food allergy manifestations, as well as increase the efficacy of allergen immunotherapy (AIT) [2]. The Consensus on molecular diagnostics WAO-ARIA-GALEN, 2013 is the basic document to rely on during conduction of component investigations [3]. One of the evident examples, dictating necessity of conducting component investigations is allergy to plant pollen.
Pollen allergy, also called hay fever or pollinosis, is referred to the most widespread allergic diseases. According to different sources, from 5 to $34 \%$ of the population in developed countries are likely to suffer from this condition. Moreover, the majority of patients are young people of working age [4]. Thus, treatment of pollen allergy is among urgent problems of contemporary allergology. This type of allergopathy is referred to reactions of type I hypersensitivity, caused by the synthesis of specific immunoglobulins class $E$ in the body as a response to penetration of allergen molecules, which compose pollen of wind-pollinated plants. Since pollen usually lands on the mucosa of the eyes and airways, pollen allergy, as a rule, is manifested by conjunctivitis, rhinitis, sometimes in combination with the inflammation of Eustachian tubes - eustachitis, and allergic bronchial asthma. Much rarer, pollen allergens affect the skin (urticaria, Quincke's edema, atopic dermatitis), genitourinary system (allergic vulvitis, vulvovaginitis and very rarely - cystitis and nephritis), gastrointestinal tract (gastritis, colitis with diarrhea, vomiting, other signs of digestive disorders) etc. 
Worldwide, there are over 60 species of plants, pollen of which can sensitize the body. Throughout a year, three periods/seasons of exacerbations of allergic manifestations can be identified in the individuals, sensitized with pollen allergens. The first period - spring - is associated with blooming of wind-pollinated trees, among which are alder, hazel, willow, elm, aspen, poplar, birch. In the central regions, these trees blossom approximately from the second half of March to early May. Coniferous trees blossom almost at the same time. The second period - summer - is associated with blooming of meadow grasses and some weeds, for instance, dandelion, ambrosia, ryegrass, foxtail, fescue, timothy grass, saltwort, wheat-grass etc. These plants start blooming from the first week of June and to early July. The third period of pollinosis exacerbation is autumn, which is associated with weed blooming (mugwort, golden rod, orach etc.). It starts in the first weeks of September and lasts till late autumn. However, it should be remembered that pollination period of these plants can differ depending on a region, annual changes of climatic conditions, ecological problem etc. Most often, overlapping of pollination seasons is observed. Thus, diagnostics of a causative sensitizer based solely on calendars of pollination of wind-pollinated plants is relative. Another important fact is that due to a tiny size, allergenic pollen can be transmitted with wind for long distances and provoke sensitization in the regions where certain plant does not grow. Besides, according to scientific literature and our monitoring, patients with mono- or oligosensitization are quite rare, especially among adults, in whom polysensitization results in significant diagnostic difficulties [5].

Thus, component diagnostics for patients with pollen allergy is necessary, at the same time - structural approach is necessary during interpretation of the results of molecular investigation [6].

\section{THE AIM}

Thus, the aim of our research was to demonstrate a practical decision concerning the choice of effective treatment tactics based on component investigations in patients with pollen allergy.

\section{MATERIALS AND METHODS}

The investigation involved 126 the individuals, who lived in Lviv region, with allergic seasonal rhinitis / conjunctivitis, randomly selected after their first visit in the first week of August in the current year. Among them, 53 (42.0\%) female and 73( 58.0\%) male, aged $22-47$ years. The patients sought consultations of doctors-allergists in Lviv regional center of clinical immunology and allergology. After being informed, the patients consented. The diagnosis of allergy to pollen was based on case history, which indicated a seasonal peculiarity of clinical allergic signs and data of skin prick-tests with a standard panel, which contained extracts of allergenic pollen from local sources of allergens, including a mixture of weeds (Ambrosia artemisiifolia, Artemisia,
Atriplex cana, sunflower), mixture of grasses (Bromus, wheat-grass, rye, timothy grass), as well as extracts of Artemisia, ambrosia, timothy grass ("Immunolog", Ukraine). Physiological solution and $0.1 \%$ histamine solution were used as a negative and positive control, respectively. The results of skin prick-tests were estimated in 15 minutes according to European standards.

Total serum IgE was measured by enzyme immunoassay technique using test-system "Euroimmune" according to instructions of the manufacturer. Immuno CAP (Thermo Scientific, Uppsala, Swiss) was used for measuring the levels of specific antibodies IgE class, following instructions of the manufacturer. Five marker allergens of genuine sensitization to pollen of Artemisia (nArt v 1, rArt v 3), ambrosia ( $\mathrm{rAmb}$ a 1 ) and grasses ( $\mathrm{rPhl} \mathrm{p} 1, \mathrm{rPhl} \mathrm{p} 5$ ) were identified. Besides, two cross-reactive molecules of profilin $\mathrm{rPhl} p$ 12 and polcalcin $\mathrm{rPhl} \mathrm{p} 7$, which are responsible for cross reactions between pollens of different sources (including grasses and weeds), were determined [13]. Levels sIgE> $0.35 \mathrm{KU} / 1$ were considered positive.

The research was conducted following the $7^{\text {th }}$ review of the principles of Helsinki declaration on human rights (2013) (protocol of ethical commission № 6 20.06.2016 from Danylo Halytsky Lviv National Medical University).

\section{RESULTS AND DISCUSSION}

By the data of prick-tests, positive results of prick-testing to a mixture of weeds, Artemisia, ambrosia and a mixture of grass were found in 50\% of patients indicating co-sensitization to various sources of allergens. Monosensitization to allergens of weed pollen was revealed in $30 \%$ of patients, and monosensitization to pollen components of grasses was detected in $20 \%$ of individuals. It should be mentioned that prick-test to an extract of weed mixture was negative in $40 \%$ of patients with positive skin reaction to pollen extracts of Artemisia and ambrosia. Negative results of skin reaction to an extract of grass mixture were revealed in $10 \%$ of patients with high response $(++++)$ to pollen components of timothy grass.

Based on serological measuring of IgE to genuine components of Artemisia (Art v 1, Art v 3), ambrosia (Amb a 1) and timothy grass (Phl p 1, Phl p 5), the results obtained in these patients differed from the data of skin tests. Thus, simultaneous sensitization to pollen allergens of Artemisia, ambrosia and timothy grass, which was detected in $50 \%$ of patients in skin tests, was not confirmed at molecular level. Instead, sensitization to Artemisia and ambrosia was found in $20 \%$ of individuals, monosensitization to Artemisia in $30 \%$, and monosensitization to allergens of ambrosia pollen - in $20 \%$. In the majority $(70 \%)$ of patients with monosensitization to allergens of weed pollen, specific IgE to Art v 1 and/or Art v 3, and/or Amb a 1 were identified.

The results of our component investigation have regional peculiarities, which, first of all, depend on climatic and geographic conditions of a region. By our long-term monitoring, sensitization to Artemisia, which is common on the territory of Ukraine, is most often observed in 
patients sensitive to weed pollen. Due to geographic location of Western Ukraine, prevalence of sensitization to this weed is similar to a number of European countries. In particular, ambrosia pollen is a significant cause of allergy among residents of Germany, where sensitization to it constituted $23 \%(76,77)$. In reports from Italy, prevalence of sensitization to ambrosia is increasing annually and constitutes approximately $17.08 \%(78,79)$. Prevalence of sensitization to this pollen also increased in France (82). Particularly, in the north of France, ambrosia pollen is considered the third most common cause of pollinosis in children after grasses and plaintain, and the percentage of sensitized individuals reaches $21 \%$ (83). Concerning Poland, which borders on Western Ukraine, the research showed that sensitivity to ambrosia constituted $82.9 \%$ (91). In other investigation, conducted in Poland, sensitization to ambrosia was observed in $42 \%$ of individuals; in $71 \%$ of them, clinical symptoms appeared only after 20 years of age.

Thus, it has been established that the doctor makes completely different decisions on the choice of extracts for conduction of allergen-specific immunotherapy based on skin prick-test and molecular diagnostics. By the results of skin prick-test, $50 \%$ of patients could receive AIT with two different extracts of allergens "Mixture of weeds" and "Mixture of grasses". However, based on molecular investigations, it was found out that such combination was suitable for none of the patients (20\% of individuals suffered from genuine sensitization to allergens of grass pollen, including a marker of cross-reactive molecules, $30 \%$ were sensitive to genuine allergens of Artemisia and/or ambrosia). Since diagnostics based on skin prick-tests was less accurate than conducted molecular investigations for identification of exact sources of allergens, optimal choice of AIT tactics for such patients was elaborated based on molecular investigations. The tactics was as follows:

1. Patients with detected components of grass - Phl p 1/ Phl p 5 (+), Phl p 7/ Phl p $12( \pm)$ were recommended AIT with an extract of grass pollen;

2. Patients with detected components of ambrosia - Amb a 1 (+), Art v 1/Art v $3(-)$ were recommended AIT with an extract of ambrosia pollen;

3. Patients with detected major components of ambrosia pollen -Amb a $1(+)$ and Artemisia pollen - Art v 1/ Art v $3(+)$ were recommended AIT with extracts of ambrosia and Artemisia pollen;

4. Patients with detected components of Artemisia - Amb a $1(-)$, Art v $1 /$ Art v $3(+)$ were suggested AIT with an extract of Artemisia pollen;

5. Patients with detected only minor components of grasses - Phl p 1/ Phl p $12(+)$ were not recommended an extract of grass pollen.

Exact identification of causative sensitizers in patients with mono- or oligosensitization to pollen, without overlapping of pollination seasons, is achieved by means of traditional diagnostics using whole extracts of allergens. In most cases, patients are sensitized to major components of pollen (for example, Ole e 1, Bet v 1, Phl p 1, Phl p 5). However, this rule does not work in the areas with a high allergenic load, for example, in case of olive pollen in Mediterranean countries, where Ole el and Ole e 9 are usually considered minor allergens and can be the main sensitizers [7]. Thus, administering AIT in the areas with a high degree of sensitization to "minor allergens", molecular diagnostics can be very important, since commercial extracts for immunotherapy are standardized only for major allergens. Thus, patients, sensitized only to minor allergens, basically, will not be able to receive a sufficient amount of allergen for successful result of immunotherapy with the allergen. Even worse consequences are possible - side effects can occur in patients in case of high concentration of these minor allergens in the extract [8].

In recent clinical investigations, it has been shown that AIT with grass pollen extract with one allergen is safe and effective both in poly- and monosensitized patients [9]. It means that the allergen extract, used for AIT, is suitable for highly sensitized patients. CRD helps to obtain information about a patient's sensitization to choose an extract for AIT, which supports the concept of "therapy based on allergen components". Administration of AIT will be expedient if sensitization to species-specific allergens is confirmed, while in selective recognition of cross-reactive allergens, in particular, profilins or CCD - administration of CCD is doubtful [10]. Cross-reactive allergens are considered to have a limited clinical value and their qualitative amount in extracts is usually not estimated. In case of sensitization to "raw" extract (skin prick-tests and/or positive test for specific IgE), AIT administration is controversial if response to all components is negative, since extracts, most likely, will not contain sensitizing molecules.

Proving the importance of immunotherapy administration based on component diagnostics in three recent prospective investigations of adults and children it was shown that the results with the use of component investigations modified previously administered AIT in approximately half of patients [11, 12].

The data obtained by us confirm the results of our scientific literature on the correct choice of the extract for AIT on the basis of molecular research. Thus, according to the results of SPT - 50\% of patients in the study group could receive AIT with two different extracts of allergens "Mixture of weeds" and "Mixture of grasses". However, according to molecular studies, none of these patients had this combination ( $20 \%$ had true sensitization to grass pollen allergens, including cross-reactive molecule markers, $30 \%$ were sensitive to genuine allergens of artemisia and/ or ambrosia). Thus, in half of patients the correct choice of drug for AIT with the prediction of its high effectiveness was based on molecular studies.

\section{CONCLUSIONS}

1. Patients with pollen allergy, especially those polysensitized, require mandatory conduction of component allergy diagnostics for proper choice of treatment tactics, correction of therapy at the stage of patient monitoring and estimation of its efficacy.

2. Component identification of a sensitizing profile according to Consensus on molecular allergy diagnostics and high sensitivity of this method enables to detect a 
genuine protein, which is a primary cause of allergy occurrence and administer etiotropic allergen-specific immunotherapy with the allergen, to which sensitization was found out.

3. In the treatment of patients, it is important to use allergens standardized by activity and controlled for the presence of major components, which enables to achieve a maximally high effect of treatment.

\section{REFERENCES}

1. Valenta R, Lidholm J, Hayek B, et al. The recombinant allergen-based concept of component-resolved diagnostics and immunotherapy (CRD and (RIT). Clinical and Experimental Allergy, 1999, Vol. 29, pp. 896-904.

2. Sastre J. Molecular diagnosis in allergy. Clinical and Experimental Allergy, 2010, Vol. 40, pp. 1442-60.

3. Canonica GW, Ansotequi IJ, Pawankar R, et al. A WAO-ARIA-GA2LEN consensus document on molecular-based allergy diagnostics. World Allergy Organ Journal, 2013, Vol. 6, №. 1, pp. 13.

4. Stemeseder T, HemmerW, Hawranek T, Gadermaier G. Marker allergens of weed pollen - basic considerations and diagnostic benefits in the clinical routine: part 16 of the series molecular allergology. Allergo Journal International, 2014, Vol. 23, pp. 274-80.

5. Asam C, Hofer H, Wolf M, Aglas L, Wallner M. Tree pollen allergens - an update from a molecular perspective. Allergy, 2015, Vol. 70, №. 10, pp. 1201-11.

6. NiederbergerV. Allergen-specific immunotherapy. Immunology Letters, 2009, Vol. 122, pp. 131-3.

7. Wahl R, Roig J, Canejero A, Llamas E. In vitro investigation of crossreactivity between Olea europea L. (OE), Syringa vulgaris L. (SV) and Fraxinus excelsior L. (FE) pollens. Allergy, 1992, Vol. 47, pp. 58.

8. Panzner P, Vachová M, Vítovcová P, Brodská P, Vlas T. A comprehensive analysis of middle-European molecular sensitization profiles to pollen allergens. International Archives of Allergy and Immunology, 2014, Vol. 164, pp. 74-82.
9. Moverare R, Larsson H, Carlsson R, Holmquist I. Mugwort-sensitized individuals from North Europe, South Europe and North America show different IgE reactivity patterns. International Archives of Allergy and Immunology, 2011, Vol. 154, pp. 164-72.

10. Pichler U, Hauser M, Wolf $M$, et al. Pectate lyase pollen allergens: sensitization profiles and cross-reactivity pattern. Public Library of Science One, 2015, Vol. 10, pp. e0120038.

11. Lotran $A$, Espinazo M, Mareno F. Measurement of lgE to pollen allergen components helps in selecting patients for immunotherapy. An Allergy Asthma Journal, 2013, Vol. 11, pp. 293-7.

12. Sastre J, Landiwar ME, Ruiz-Garcia M, Andregrette-Rosigno MV, Maltillo I. How molecular diagnosis can change allergen-specific immunotherapy prescription in a complex pollen area. Allergy, 2012, Vol. 67, pp. 709-11.

13. Oberhuber C, Ma Y, Wopfner N, et al. Prevalence of lgE-binding to Art v 1 , Art v 4 and Amb a 1 in mugwort-allergic patients. International Archives of Allergy and Immunology, 2008, Vol. 145, pp. 94-101.

\section{Authors' contributions:}

According to the order of the Authorship.

\section{Conflict of interest:}

The Authors declare no conflict of interest

\section{CORRESPONDING AUTHOR}

\section{Svitlana Zubchenko}

Danylo Halytsky Lviv National Medical University

Kostya Levitskoso srt 68/7, 79010, Lviv, Ukraine

tel: +380676706643

e-mail: svitlana_zu@meta.ua

Received: 01.11.2018

Accepted: 26.02 .2019 
PRACA ORYGINALNA

ORIGINAL ARTICLE

\title{
DETERMINATION OF POOR OUTCOME PROGNOSIS IN PATIENT WITH ACUTE LEUCEMIA WHICH WAS COMPLICATED BY PNEUMONIA
}

\section{CZYNNIKI RYZYKA ZŁEGO ROKOWANIA U PACJENTÓW Z OSTRA BIAŁACZKĄ POWIKŁANĄ ZAPALENIEM PŁUC}

\author{
Inna S. Borisova, Dmitry 0. Stepansky \\ SE «DNIPROPETROVSK MEDICAL ACADEMY OF HEALTH MINISTRY OF UKRAINE», DNIPRO, UKRAINE
}

\begin{abstract}
Introduction: At the present stage, the medicine development is based on the principles of evidence-based medicine, which requires using of statistical methods and forecasting. Using statistical analysis and possibilities and mathematical forecasting emphasizes the probability of obtained data in scientific medical research. Identifying the factors that determine the survival of patients with acute leukemia and pneumonia causes the conduct of this study.

The aim: To create a mathematical model of poor outcome prognosis in patients with acute leukemia, which was complicated by pneumonia, to determine the treatment place and timely optimize the treatment.

Materials and methods: An electronic database of formalized disease history of 360 patients with acute leukemia and pneumonia was created. The data base contained data of objective survey and additional research methods. In our study we used non-parametric dispersion analysis of Kraskele-Wallis, correlation analysis with the calculation of Spierman's rank correlation coefficients, simple and multiple logistic regression analysis with the calculation of the odds ratio; ROC analysis. The significance level $p<0,05$ was considered statistically significant.

Results: It was determined that with the onset of the lethal outcome of patients with pneumonia, developed on the background of acute leukemia, the indicators of leukocytes, lymphocytes, neutrophils, platelets, erythrocytes, hemoglobin and immunity indexes (B(CD19+), $T(C D 4+), C D 4+/ C D 8+$, lgG). According to the results of our study, a mathematical model of prediction poor outcome in patients with acute leukemia, which was complicated by pneumonia, was created: $P P 0=\exp \left(-10,317+0,410^{*} B(C D 19+)-2,149^{*} \operatorname{lgG}\right)$ / $\left[1+\exp \left(-10,317+0,410^{*} B(C D 19+)-2,149^{*} \operatorname{lgG}\right)\right]$.

Conclusion: Using in clinical practice the proposed mathematical model of prediction poor outcome in patients with acute leukemia, which was complicated by pneumonia, will allow determining the treatment place and timely optimizing the treatment program.
\end{abstract}

KEY WORDS: acute leukemia, prognosis, pneumonia, poor outcome

Wiad Lek 2019, 72, 3, 395-400

\section{INTRODUCTION}

According to the International Agency for Research on Cancer (Lyon, France), more than 10 million patients with malignant neoplasms were registered in the world in 2000 , and the number of new cases is projected to reach 16 million in 2020 [1]. The problem of leukemia is one of the most urgent. Leukemia is about $8 \%$ of the total number of malignant tumors, and are among the six most common cancers. Every 3 minutes a new case of cancer is registered in the USA, and every 9 minutes one of the patients dies [2]. Up to 8 thousand new cases of oncohematological diseases are diagnosed annually in Ukraine. The index of morbidity per 100 thousand population at lymphogranulomatosis is 2,5; at MM - 1,6; at leukemia - 8,1 [3]. According to official data, the incidence of hemoblastosis in Ukraine during the last 20 years has increased from 14,7 (in 1991) to 18.9 per 100 thousand population (2014). The absolute number of newly diagnosed patients also increased $[4,5,6]$. The end of oncohematological diseases is often unfavorable. Timely diagnosis provides $2 / 3$ of success in overcoming illness. The situation with the treatment of acuteleukemia in adults remains unsatisfactory. The frequency of remissions abroad $-50-80 \%$, in Ukraine it does not exceed 20-40\% [7]. The using of integrated therapies allowed prolong the patients' lives with AL in remission, up to 3-5 years in 35-40\% of cases and to remove the terms of patients' disability with chronic blood and lymphoid tissue diseases [8]. At the same time, the survival prognosis of patients with AL became worst with infectious complications (IC), among them the leading role belongs to pneumonia [8]. It is proved that the course of AL is characterized by a high incidence of IC, which pneumonia is the main one. It occurs in 53\% of hospitalized in the hematological department [9]. Mortality in such cases is quite high and makes up 28\% [8]. Progressive increase of pneumonia poor outcome is determined even modern antibacterial drugs using. The mortality level of patients with AL and pneumonia reaches to $40 \%$ in the intensive care units [10]. 
Table I. Odds ratio clinical and laboratory parameters influence on mortality, depending on their threshold predictive value of the studied patients

\begin{tabular}{|c|c|c|c|c|c|}
\hline \multirow{2}{*}{$\begin{array}{c}\text { Indexes } \\
(1-\text { yes, } 0-\text { no) }\end{array}$} & \multirow{2}{*}{ OR } & \multirow{2}{*}{$95 \% \mathrm{Cl}$} & \multicolumn{2}{|c|}{ Patients proportion, (\%) } & \multirow{2}{*}{$p$} \\
\hline & & & Alive & Dead & \\
\hline Neutrophils $\leq 1,2410^{9} / \mathrm{I}$ & 10,20 & $5,52-18,83$ & 7,05 & 43,61 & $<0,001$ \\
\hline Pulse $>92$ per min. & 17,31 & $9,90-30,26$ & 10,57 & 67,18 & $<0,001$ \\
\hline Leukocytes $\leq 3,710^{9} / \mathrm{I}$ & 60,00 & $7,60-473,85$ & 28,57 & $96,0 \%$ & $<0,001$ \\
\hline Lymphocytes $\leq 18,9 \%$ & 9,90 & $4,51-21,76$ & 18,75 & 69,57 & $<0,001$ \\
\hline B CD19 $\leq 0,467 \mathrm{~g} / \mathrm{l}$ & 68,85 & $4,0-1185,95$ & 37,14 & 100,0 & $<0,001$ \\
\hline TCD19+ >58,13\% & 85,79 & $18,06-407,47$ & 14,46 & 93,55 & $<0,001$ \\
\hline CD4 $\leq 21,77 \%$ & 285,0 & $32,41-2506,38$ & 78,4 & 21,6 & $<0,001$ \\
\hline CD4 $\leq 0,71 \mathrm{~g} / \mathrm{l}$ & 28,80 & $6,14-134,98$ & 6,25 & 95,0 & $<0,001$ \\
\hline $\mathrm{CD} 4 / \mathrm{CD} 8 \leq 1,05$ & 437,0 & $46,23-4130,90$ & 4,17 & 95,0 & $<0,001$ \\
\hline $\lg G \leq 8,21 \mathrm{~g} / \mathrm{l}$ & 43,54 & $5,51-344,13$ & 30,38 & 95,0 & $<0,001$ \\
\hline $\mathrm{FA} \leq 22 \%$ & 14,44 & $4,19-49,75$ & 8,70 & 57,89 & $<0,001$ \\
\hline Creatinine $>94 \mathrm{mkmol} / \mathrm{l}$ & 3,84 & $2,44-6,03$ & 32,30 & 64,66 & $<0,001$ \\
\hline $\mathrm{HB} \leq 90 \mathrm{~g} / \mathrm{l}$ & 6,02 & $3,72-9,73$ & 33,48 & 75,19 & $<0,001$ \\
\hline Erythrocytes $\leq 1,9710^{12} / \mathrm{I}$ & 36,67 & $19,21-70,00$ & 6,61 & 72,18 & $<0,001$ \\
\hline $\mathrm{ESR}>33 \mathrm{~mm} / \mathrm{h}$ & 4,63 & $2,92-7,34$ & 31,86 & 68,42 & $<0,001$ \\
\hline Platelets $\leq 6010^{9} / \mathrm{I}$ & 8,50 & $5,15-14,03$ & 15,49 & 60,90 & $<0,001$ \\
\hline
\end{tabular}

At the present stage, the medicine development is based on the principles of evidence-based medicine, which requires using of statistical methods and forecasting. Using statistical analysis and possibilities and mathematical forecasting emphasizes the probability of obtained data in scientific medical research. Identifying the factors that determine the survival of patients with AL and pneumonia causes the conduct of this study.

\section{THE AIM}

To create a mathematical model for determine the forecast of pneumonia poor outcome in patients with acute leukemia in order to define patient's treatment place and timely optimize the treatment.

\section{MATERIALS AND METHODS}

The study was conducted in the hematological center of “City Multidisciplinary Clinical Hospital №4”, Dnipro (2012-2015 yrs). 360 patients with pneumonia developed on a background of AL were investigated. The patients were divided according to the American Thoracic Society recommendations 2007 [15]: the $1^{\text {st }}$ group consisted of 109 patients with mild and moderate severity of pneumonia, which developed shortly after hospitalization; the $2^{\text {nd }}$ group consisted of 65 patients with mild and moderate severity of pneumonia, which developed at any time, all patients have risk factors; the $3^{\text {rd }}$ group - 53 patients with severe pneumonia, which developed shortly after hospitalization, all patients have risk factors and patients with late pneumonia with severe course. In addition, we identified $4^{\text {th }}$ group - patients with pneumonia poor outcome. This group consisted of 133 patients.

Diagnosis of pneumonia and CL form were performed in accordance with generally accepted clinical, laboratory and morpho-immunohistochemical studies $[1,2,7,8,9,17]$.

General clinical methods included data of anamnesis, including anamnesis of oncohematological disease (form, stage of the disease, its first signs, duration, presence of B-symptoms, enlargement of liver, spleen, lymph nodes (LV), number of chemotherapy courses (CT), which preceded the IC of the broncho-pulmonary system, the presence of concomitant pathology, anamnesis of pneumonia (communiyu aquared pneumonia, nosocomial pneumonia (early, late)); the beginning, the presence of generally accepted clinical signs; data of pneumonia clinical picture and complaints (the presence, number and nature of sputum, the presence, number and type of dyspnea, the time when complaints began, temperature reaction dynamics); data of patient's physical examination, including in dynamics (data of percussion, auscultation); results of laboratory methods of research in dynamics ( complete blood count, biochemical blood test); general sputum analysis; chest $\mathrm{X}$-Ray in two projections and / or computed tomography (CT) of the lungs (if necessary in dynamics); to determine the probable pathogens of pneumonia - bacterioscopic and microbiological study of sputum and fluid of broncho-alveolar lavage (BAL); fibrobranchoscopy to obtain BAL fluid; immuno-enzymes study - to determine the parameters of cellular and humoral immunity.

All quantitative and qualitative (nominal) indices were entered into the electronic database of formalized disease histories like "object-sign" table. These data gradually and statistically processed using descriptive and analytical biostatistics methods implemented in software packages 
Table II. Forecast of pneumonia poor outcome in patients AL according to logistic regression analysis

\begin{tabular}{|c|c|c|c|c|}
\hline Prognostic Variables & $\begin{array}{l}\text { Regression } \\
\text { coefficient } \beta\end{array}$ & $\begin{array}{l}\text { Standard error of } \\
\text { coefficient } \beta\end{array}$ & Wald's $X^{2}$ & Wald's p-value $x^{2}$ \\
\hline Free member of the equation & $-10,317$ & & & \\
\hline $\mathrm{TCD} 19+\%\left(\mathrm{x}_{1}\right)$ & 0,410 & 0,162 & 6,429 & 0,011 \\
\hline $\lg G\left(x_{2}\right)$ & $-2,149$ & 0,944 & 5,189 & 0,023 \\
\hline Logistic equation & \multicolumn{4}{|c|}{$\begin{array}{l}y=\exp \left(-10,317+0,410^{*} x_{1}-2,149^{*} x_{2}\right) / \\
{\left[1+\exp \left(-10,317+0,410^{*} x_{1}-2,149^{*} x_{2}\right)\right]}\end{array}$} \\
\hline Xi-square & \multicolumn{4}{|c|}{$x^{2}=65,37(p<0,001)$} \\
\hline Percentage of concordance & \multicolumn{4}{|c|}{$93,67 \%$} \\
\hline Hosmer-Lemeshov Test & \multicolumn{4}{|c|}{$0,127(p=0,999)$} \\
\hline \multicolumn{5}{|c|}{ Forecasting operating characteristics according to ROC analysis } \\
\hline Sensitivity, \% & \multicolumn{4}{|c|}{100,0} \\
\hline Specificity, \% & \multicolumn{4}{|c|}{90,48} \\
\hline AUC & \multicolumn{4}{|c|}{0,991} \\
\hline $95 \% \mathrm{Cl}$ AUC & \multicolumn{4}{|c|}{$0,938-1,000$} \\
\hline $\mathrm{p}$ & \multicolumn{4}{|c|}{$<0,001$} \\
\hline Qualitative assessment of the model & \multicolumn{4}{|c|}{ excellent } \\
\hline
\end{tabular}

"STATISTICA 6.1" (StatSoftInc., Serial No. AGAR909E415822FA); Microsoft Excel (Office Home Business 2KB4Y-6H9DB-BM47K-749PV-PG3KT). Median (Me), as a measure of the central trend, was used to describe the quantitative indices; interquartile scale $((25 \%, 75 \%)$ - 25 and 75 percentiles respectively, Q1 and Q3 - first and third quartiles) to describe the sings variation., The nonparametric dispersion analysis of Kraskele-Wallis and a correlation analysis with the calculation of the Spirman rank correlation coefficients $(\rho)$ were used in statistical analysis of study results. Multiple comparisons were made with Bonferon and Hill. The statistically significant level was $\mathrm{p}<0,05(5 \%)[10]$.

\section{RESULTS}

Correlation between mortality and clinical, anamnestic, laboratory parameters shows the existence of probable connection between poor outcome forecast and 36 quantitative and qualitative sings.

The indicators with statistically significant, average and high correlation coefficients $(0,29<\rho<1,0)$ were selected for a more detailed analysis of which factors affect on poor outcome. The next step was - to analyze the effect of quantitative and nominal indicators on the mortality of patients with pneumonia and AL using a simple logistic regression analysis. Cutoff points were identified using the ROC analysis - the critical values of the clinical and laboratory results, which achieved the maximum predictive value of the indicator to predict the probability of pneumonia poor outcome [18].

Leukocytes, lymphocytes, neutrophils, platelets, erythrocytes, hemoglobin, B $(\mathrm{CD} 19+)(\mathrm{g} / \mathrm{l}), \mathrm{CD} 4+(\%)$, immunoregulatory index (CD4 + / CD $8+)$ and $\operatorname{IgG}(\mathrm{g} / \mathrm{l})$ showed the most prognostic ability to predict pneumonia lethal outcome in patients with AL (Tab. I).

The relationship between the signs "died" or "survived" analyzed using a logistic regression model with a step-bystep algorithm predictors inclusion $[13,14]$. The logistic equation used as the basis for developing the prediction model: $\mathrm{y}=\exp \left(\mathrm{b} 0+\mathrm{b} 1{ }^{\star} \mathrm{x} 1+\ldots+\mathrm{bn}{ }^{\star} \mathrm{xn}\right) /[1+\exp (\mathrm{b} 0$ $\left.\left.+\mathrm{b} 1{ }^{\star} \mathrm{x} 1+\ldots+\mathrm{bn}{ }^{\star} \mathrm{xn}\right)\right]^{(1)}$, where: $\mathrm{y}-$ the result (in our study - the prediction of pneumonia poor outcome (PPO); b0 - the free part of the regression equation; b1 - bn - regression coefficients; $\mathrm{x} 1$-xn - predictor variables.

If the calculated probability of pneumonia poor outcome will be less than 0,5 , we can assume that the event will not occur (the patient will not die); if probability more than 0,5 - the poor outcome of pneumonia is reliable.

We received the logistic regression equation parameters represented as a result of a step-by-step inclusion of independent variables. It's presented in tab. II (only meaningful factors are included in the table). For quantitative predictors, the index entered in the equation in units values, for binary 1 - factor is presented, 0 - is not.

We calculated the regression coefficient $\beta$ during logistic regression analysis, its error, and $\chi 2$ Wald statistics. Coefficient $\beta$ describes the change of the mortality risk due to risk factor change for the one unit. We estimated the predictive precision of the logistic regression equation using the $\mathrm{Hi}$ square $(\chi 2)$; percentage of concordant - the proportion of correctly reclassified observations (the closer this figure to $100 \%$, the higher model quality); Hosmer-Lemeshov's consent test and ROC-analysis. The evaluation of logistic regression equations using $\mathrm{Xi}$-square $(\chi 2)$ showed their precision, it was determined the statistically significant level $\chi^{2}(\mathrm{p}<0,001)$. The proportion of correct prediction for patients with AL membership of a particular group 
(survivor, died) was 93,67\%. This concordance indicator shows a high degree of consistency in the real distribution of mortalities and distribution based on the logistic regression equation. Overall consensus actual and estimated data based on Hosmer- Lemeshov test showed significant match, because $\mathrm{p}>0,05$ was for all equations. That allows us to take zero hypothesis regarding the consistency of the theoretical and actual results of the disease.

According to the ROC curve's shape and the area under it (AUC), we estimated the predictive precision of logistic regression equations. The area under the ROC curve shows the dependence between the numbers of correctly and incorrectly classified pneumonia poor outcome cases. The closer curve to the upper left corner and the bigger the area under the curve, the better its discriminatory power. When the AUC is 0.9 - 1 , the model's quality is considered "exellent"; 0,8 - 0,9 - "very good"; 0,7 - 0,8 - "good"; 0,6 0,7 - "average"; 0,5 - 0,6 - "unsatisfactory"; the value less than 0,5 indicates the model's unsuitable $[18,19]$.

Thus, it is determined that the proposed prognostic model - the logistic regression equation has excellent operational characteristics - sensitivity $100,0 \%$, specificity $90,48 \%$, area under the ROC curve $-0,991$ ( $\mathrm{p}<0.001$ ) (Table II, Fig. 1).

The constructed logistic models were acceptable relying on the criterion $\chi 2$; the percentage of concordation, the Hosmer-Lemeshov test and the ROC-analysis. The predicted values (y) in regression models will be always in ranges from 0 (survived) to 1 (died), regardless of regression coefficients or x-values. When calculated probability is less than 0,5 , we can supposed that event will not occur (the patient will not die); otherwise (probability more than $0,5)$ - the pneumonia poor outcome will be [19].

We propose a detailed scale for predicting the pneumonia poor outcome (PPO) in patients with AL based on all of the above calculations:

- up to 0,21 - very low probability of PPO ( $\mathrm{P}<5,24 \%)$;

- 0,22 - 0,42 - low probability of PPO $(5,24 \% \leq \mathrm{R}<25,08 \%)$;

- 0,43 - 0,55 - average probability of PPO $(25,08 \% \leq \mathrm{R}$ $<50,50 \%)$;

- 0,56 - 0,81 - high probability of PPO $(50,50 \% \leq \mathrm{R} \leq$ $90,45 \%)$;

- higher than 0.82 - very high probability of PPO (P> $90,45 \%)$.

\section{DISCUSSION}

Despite the presence of a sufficiently large number of prognostic and diagnostic scales, which are certainly useful for a physician, which solves the issue of choosing the treatment place, diagnosis, the severity of pneumonia, we can't consider this issue to be finally resolved, especially for certain categories of patients, in particular for patients with $\mathrm{AL}$ and pneumonia. Earlier the determination of the forecast mortality based on the analysis of leading symptoms and syndromes, but at present time it is possible to use the mathematical apparatus [17]. Quantitative analysis provides an opportunity to determine prognostic evaluation

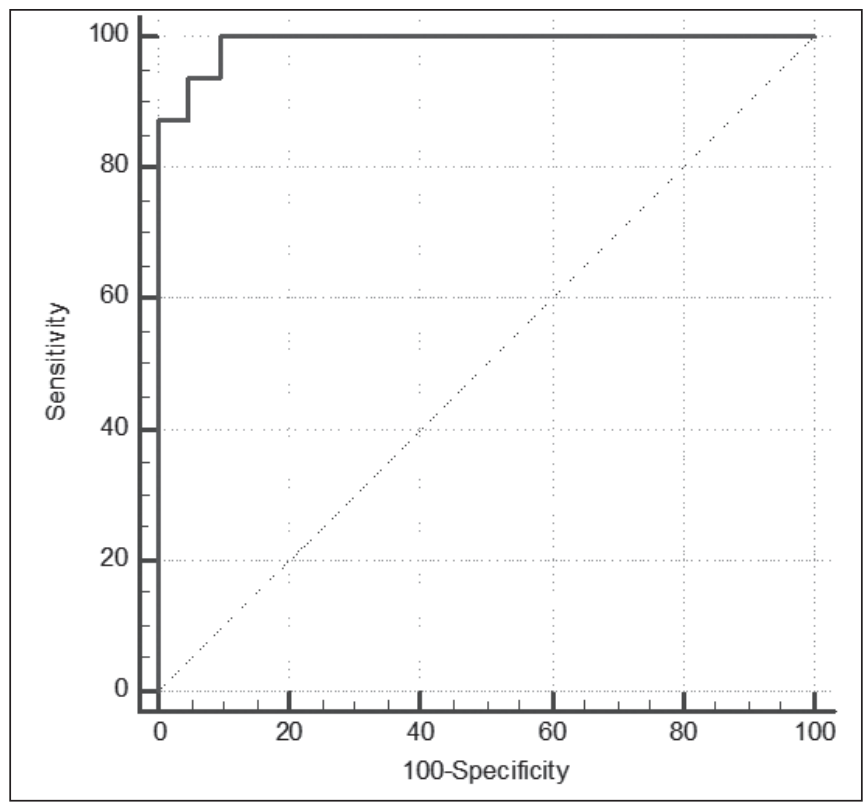

Fig.1.0perational characteristics of the forecasting pneumonia poor outcome logistic regression model in patients with AL according to ROC analysis.

criteria in numerical terms enriching and supporting the meaningful analysis, making it more evidence, excluding contradictory methods [17].

The study identified the factors predicting pneumonia poor outcome in patients with pneumonia, developed on the background of AL. The study proved that the predictors of the poor outcome were: leukocytes, lymphocytes, neutrophils, platelets, erythrocytes, hemoglobin, as well as immunity parameters: B $(\mathrm{CD} 19+)(\mathrm{G} / \mathrm{L}), \mathrm{CD} 4+(\%)$, immunoregulatory index (CD4 + / CD $8+)$ and $\operatorname{IgG}(\mathrm{g} / \mathrm{l})$. The logistical equation included two of the most influential indicators - B CD19 + (G/L) and IgG (g/l). It is known that the main effector cells-killers are T-lymphocytes. They provide recognition and destruction of cells that carry external antigens, in particular infectious agents [20]. The number of these cells is usually lowered in patients with acute leukemia. The function of B-lymphocytes with the phenotype $\mathrm{B}(\mathrm{CD} 19+)$ is the formation of complexes with antigenic receptors of B-lymphocytes and a decrease in the threshold of sensitivity of these receptors that stimulate the functional activity of T-killers [20]. Also, this phenotype, in terms of its quantitative reduction, characterizes the redistribution of lymphocytes to the inflammatory site. Therefore, it is clear that the quantitative decrease of $\mathrm{B}$ $(\mathrm{CD} 19+)$ is defined as a predictor of the poor outcome of such a severe IC, as pneumonia in patients with AL. The obtained data coincide with the data of other researchers, which determined the role of the indicator B (CD19+) for its increase - as a sign of a favorable forecast; for a decrease - as a sign of an unfavorable prognosis in patients with MM [21].

Using in clinical practice the obtained equation will allow to predict the pneumonia poor outcome in patient with chronic leukemia with a small number of parameters that 


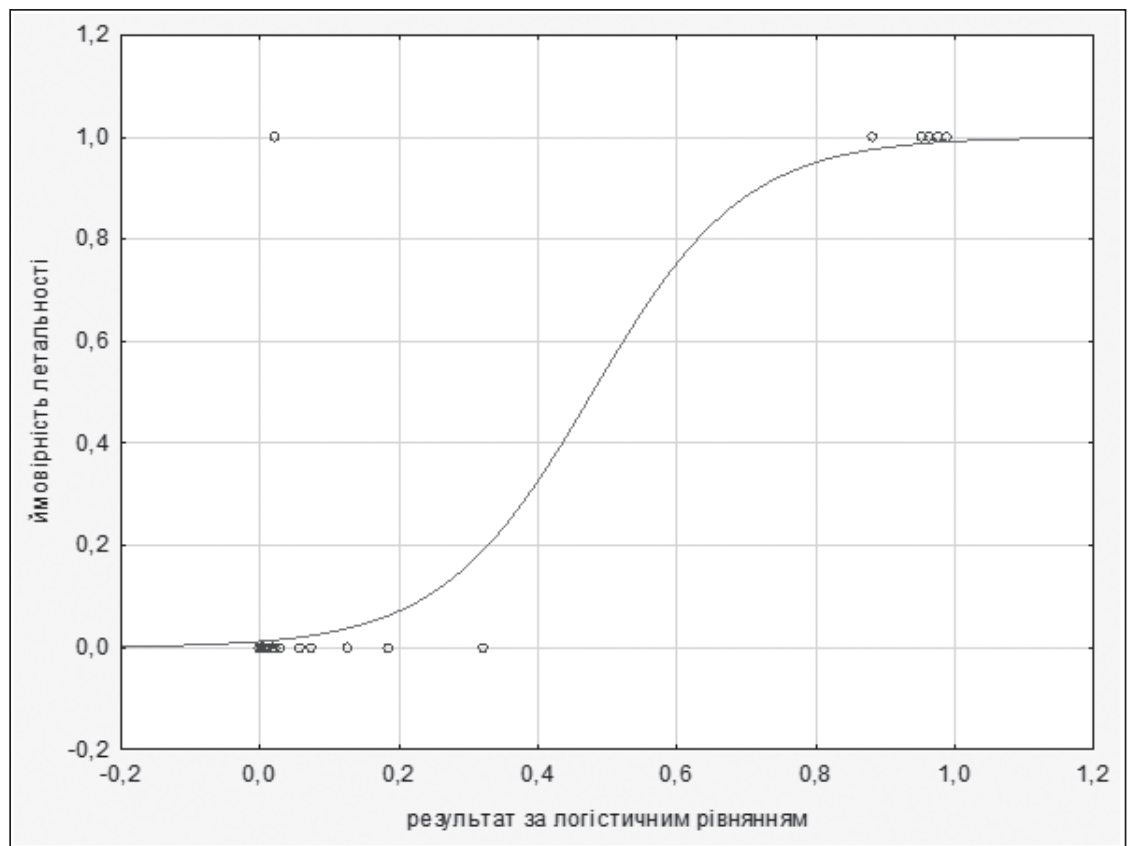

Fig. 2. Dependence on calculated logistic equation result the probability of pneumonia poor outcome in patient with acute leukemia. are available today in clinics with hematological profile. Determination the probability of PPO in patients with AL has a fundamental value for timely choice the treatment tactics: - 0,21 - 0,42 - low probability of PPO - it is possible to treat pneumonia in outpatient settings or in a therapy, hematologist consultation is necessary;

- 0,43 - 0,55 - average probability of PPO - treatment in therapy, hematologist consultation in dynamics of treatment;

- 0,56 - 0,81 - high probability of PPO - treatment in a hematological hospital, determination of immunity parameters in dynamics, consideration necessity of ABT modification;

- more than 0,82 - very high probability of PPO - treatment in the department of intensive care, optimization of ABT.

\section{CONCLUSIONS}

1. Results of our study prove that the forecast of pneumonia poor outcome in patients with acute leukemia is associated with: leukocytes, lymphocytes, neutrophils, platelets, erythrocytes, hemoglobin and immunity: B (CD19+) (G/L), T (CD4+) (\%), immunoregulatory index $(\mathrm{CD} 4+/ \mathrm{CD} 8+)$ and $\operatorname{IgG}(\mathrm{g} / \mathrm{l})$.

2. Mathematical modeling is a modern, necessary instrument in medical practice. A mathematical model for predicting the pneumonia poor outcome in patients with acute leukemia was created in our study: $\mathrm{PPO}=$ $\exp (-0.073-0.994$ * (leukocytes) $+4.842 *(\mathrm{P}$. aeroginosa $)) /[1+\exp (-0.073-0.994$ * (leukocytes) +4.842 * $(\mathrm{R}$. aeroginosa $)]$.

3. Using in clinical practice the proposed mathematical model of prediction pneumonia poor outcome in patients with acute leukemia will allow determining the treatment place and timely optimizing the treatment program. If the result of equality is $0,21-0,42-$ it is possible to treat pneumonia in outpatient settings or in a therapy, hematologist consultation is necessary; 0,43 0,55 - treatment in therapy, hematologist consultation in dynamics of treatment; $0,56-0,81$ - treatment in a hematological hospital, determination of immunity parameters in dynamics, consideration necessity of ABT modification; if result more than 0,82 - treatment in the department of intensive care, optimization of ABT.

\section{REFERENCES}

1. Ajiki W. Cancer incidence rates in Japan in 1999: Estimates based on data from 11 population-based cancer registries. Jpn. J. Clin. Oncol., 2004; 34:352-356.

2. Cancer Facts Figures. GA: American Cancer Society. 2017. Available from: https://www.cancer.org/research/cancer-facts-statistics/all-cancerfacts-figures/cancer-facts-figures-2017.html.

3. Sivkovych SO, Zinchenko VN, Zubryts'ka NV. State of medical care of patients with hematological malignancies in Kyïv. Lik. Sprava. 2012;8:134-40.

4. NovakVL, MasljakZV, MatlanVL. Oncohematology in Ukraine: problems of diagnosis and treatment. Oncology. 2006;8(2):163-170.

5. Cancer diseases in Ukraine 1993-2003. MOZ Ukraïni, AMN Ukraïni, Institut onkologiï. Kiiiv, 2004. 26 c. 18.

6. Incidence, mortality, indicators of the oncological service. Bjul $\mathrm{Nac}$ kancerreєstru Ukraïni. Kiiiv, 2016; (17).

7. Lazorishinec' VV, Slabkij G0, Jarosh NP, Chepelevs'ka LA, Shevchenko MV, Kutuza AS, ta in. Public administration of health care of Ukraine: [monograph]. Kiev; 2014.312 p.

8. Activities of the Ukrainian blood service establishments in 2016: reference book/ P. M. Perehrestenko, A. S. Timchenko, 0. I. Maligon - K.: TOV «Dia», 2017. $76 \mathrm{~s}$.

9. Orasch C, Klyasova G, Munoz P. Duration of antibacterial therapy in neutropenic patients. 4th European Conference on Infections in Leukaemia, Meeting, 8-10 September 2011. 2012. Available from: http://www.ebmt.org/Contents/Resources/Library/ECIL/Documents/ Forms/Allltems.aspx 
10. Heizmann WR, Kljucar $S$, Heizmann P. Infektionen bei schwerkranken Patienten. Berlin: Vademecum Infektiologie, 2003/2004; 179 p.

11. Mandell L.A.et al. Infectious Diseases Society of America. American Thoracic Society consensus quidelines on the management of community - acquired pneumonia in adults. Clin. Infect. Dis., 2007; 44:27- 72 .

12. Adaptovana klinichna nastanova, zasnovana na dokazah. Unifikovanij protokol nadannja medichnoï dopomogi doroslim hvorim na negospital'nu pnevmoniju. Vidannja oficijne. Kiiiv: Nac. akademija med. nauk Ukraïni; 2016. 107 s.

13. Negospital'na ta nozokomial'na (gospital'na) pnevmonija u doroslih osib: etiologija, patogenez, klasifikacija, diagnostika, antibakterial'na terapija: Nakaz MOZ Ukraïni «Pro zatverdzhennja klinichnih protokoliv nadannja medichnoï dopomogi za special'nistju «Pul'monologija» vid 19.03.2007 r. № 128. Kiïv: Veles; 2007. S. 105-146.

14. Pro zatverdzhennja protokoliv nadannja medichnoï dopomogi za special'nistju «Gematologija»: Nakaz MOZ Ukraïni vid 30.07.2010 r. № 647 iz dopovnennjami zgidno: Nakazu M0Z Ukraïni vid 30.01.2013 №72; Nakazu MOZ Ukraïni vid 02.11.2015 № 709; Nakazu MOZ Ukraïni vid 02.11.2015 № 711; Nakazu MOZ Ukraïni vid 02.11.2015 № 710; Nakazu MOZ Ukraïni vid 26.06.2014 № 433. Nakazu MOZ Ukraïni vid 02.11.2015 N 709; Nakazu MOZ Ukraïni vid 02.11.2015, Nakazu MOZ Ukraïni vid N 711 vid 02.11.2015, Nakazu MOZ Ukraïni vid 29.07.2016 N 797. Rezhim dostupu : http://document.ua./pro-zatverdzhennjaklinichnih-protokoliv-nadannja-medichnoyi-doc33137.html
15. Lang T.A. How to describe the statistics in medicine. Rukovodstvo dlja avtorov, redaktorov i recenzentov. Moskva: Prakticheskaja medicina, $2016.480 \mathrm{~s}$.

16. Leonov V. Logistic regression in medicine and biology. Rezhim dostupa: http://www.biometrica.tomsk.ru/logit_1.htm

17. Mil'chakov KS, Shebalkov MP. Scoring maps in medicine: review and analysis of publications. Vrach i informacionnye tehnologii. 2015;1:7179.

18. Rumjancev PO, Saenko VA. Statistical methods of analysis in clinical practice Part 2. Survival Analysis and Multidimensional Statistics. Problemy jendokrinologii. 2009;55(5):48 - 55.

19. Šimundić A-M. Measures of Diagnostic Accuracy: Basic Definitions. EJIFCC, 2009;19(4):203 - 211.

20. GabrielVirella, Marcel Dekker. Medical Immunology. Marcel Dekker Inc. 1998.651 p.

21. Peshikova MV. Clinical and immunological features of infectious complications in children with acute lymphoblastic leukemia and nonB-cell non-Hodgkin lymphomas receiving chemotherapy according to the protocol BFM-ALL-90 (M) [abstract]. Cheljabinsk; 2004. 24 s.

\section{Authors' contributions:}

According to the order of the Authorship.

Conflict of interest:

The Authors declare no conflict of interest.

\section{CORRESPONDING AUTHOR Inna S. Borisova}

SE "Dnipropetrovsk Medical Academy of Health Ministry of Ukraine" Soborna sq. 4, 49000 Dnipro, Ukraine e-mail: doctorinnaborisova1@gmail.com

Received: 08.11 .2018

Accepted: 21.02 .2019 
PRACA ORYGINALNA

ORIGINAL ARTICLE

\title{
CONDITION OF FAGOCYTOSIS OF EXPERIMENTAL ANIMALS WITH PERIODONTITIS DUE TO MODIFIED REACTIVITY
}

\author{
OCENA STOPNIA FAGOCYTOZY U ZWIERZĄT \\ EKSPERYMENTALNYCH Z CHOROBAMI PRZYZĘBIA \\ WYWOŁANYMI ZMODYFIKOWANĄ REAKTYWNOŚCIA
}

\author{
Oleksandr V. Avdeev, Roksana 0. Drevnitska, Alina B. Boykiv, Oksana Ya. Vydoinyk \\ STATE INSTITUTION OF HIGHER EDUCATION «I. HORBACHEVSKYTERNOPIL STATEMEDICAL UNIVERSITY OF THE PUBLIC HEALTH OF UKRAINE», TERNOPIL, UKRAINE
}

\begin{abstract}
Introduction: Taking into account the patho-immune mechanisms of formation of inflammatory process in periodontium, there is a necessity for in-depth study of the pathogenesis of periodontal diseases from the position of changes in the reactivity of the organism.

The aim: Carrying out a comparative estimation of phagocytic activity of leukocytes of animals with inflammation in periodontium with altered reactivity.

Materials and methods: Experiments were performed on 30 white rats: Group I - 10 white rats with hypoergic reaction; Group II - 10 white rats with hyperergic reaction; Group III - 10 white rats with normergic reaction - control group. Slaughter and blood sampling under thiopental anesthesia was performed 7 days after the beginning of the experiment. The percentage of phagocytic leukocytes - phagocytic index, phagocytic number were determined and the index of phagocytic activity was calculated.

Results: The phagocytic index (Fi,\%) decreased by 2,09 times $(p<0,05)$ at hypoergic, it increased by 1,37 times $(p<0,05)$ at hyperergic; the index of phagocytic activity (IFA) decreased by 1.96 times at hypoergic $(p<0.05)$; growth was 1.94 times $(p<0.05)$ in the hyperergic group of animals. In both experimental groups, the phagocyte number (Fu) increased by $6.25 \%$ and $41.7 \%$, with hypoergic and hyperergic, respectively.

Conclusions: Different directions of changes of the phagocytic activity were observed: increase of these parameters at hyperergic and decrease at hypoergic. An increase in phagocyte number was likely to indicate some autonomy of the process of phagocytosis and independence from the reactivity of the organism.
\end{abstract}

KEY WORDS: periodontitis, serum, phagocytic activity

Wiad Lek 2019, 72, 3, 401-404

\section{INTRODUCTION}

Diseases of periodontal tissues both of adults and children are the most common pathology in dentistry. Generalized periodontitis has not only different manifestations of the clinical picture of the disease of individual patients, but also in the dynamics of the pathological process in the periodontal disease of a particular patient [1]. The development of generalized periodontitis should be considered as the result of the interaction of the microbial factor and the patient's body. Currently, the influence of microbial, traumatic, immune, vascular and other local factors in the development of generalized periodontitis has been studied in various ways. The features of the course of the background of the concomitant pathology of the organism are studied. On the one hand, the course of the local inflammatory reaction depends on the immunobiological properties of the body of this patient, on the other - the inflammation center in the tissues of the periodontal affects the whole organism. There occurred the closed circle that worsens the reparation of damaged tissues and restoration of immune homeostasis [2].
The reasons for the lack of a steady effect after periodontitis treatment can be both dysbiotic phenomena in the oral cavity with a violation of the stability of normal microflora, and changes in the reactivity of the organism as a whole. This is facilitated by the growth of aggressiveness of the environment, the influence of stress factors, increase in the number of people with different types of immunodeficiency among the population, inappropriate use of antibiotics. It is possible that complex therapy of generalized periodontitis, which includes the use of antimicrobial agents with a wide spectrum of action, can contribute to total suppression of the indigenous microflora of the oral cavity and all parts of the immune defense [3].

Taking into account the patho-immune mechanisms of the formation of the inflammatory process in the periodontium, there is a necessity for in-depth study of the pathogenesis of periodontal diseases from the standpoint of changes in the reactivity of the organism. The study of the latter factor is devoted to a series of studies in which morphological features of the development of periodontal inflammatory diseases were studied when the body reactivity changed [4]. In the development of 
inflammatory reaction, an important component is the elimination of necrotic masses, which have all the signs of antigenicity and ensure the process of remodeling. The control over the implementation of these processes is carried out by the immune system. One of the initiators of such an organism's response is macrophages, which belong to bonded antigen-presenting cells. Taking into account ambiguous data from scientific sources, we conducted studies on immunological changes in the organism of experimental animals in response to altered reactivity, in particular, phagocytic activity of leukocytes, which may give an explanation of the triggering mechanisms of damage and, above all, to act purposeful therapeutic measures.

\section{THE AIM}

Carrying out a comparative estimation of phagocytic activity of leukocytes of animals with inflammation in a periodontium with altered reactivity.

\section{MATERIALS AND METHODS}

Experiments on animals were carried out in accordance with the European Convention for the Protection of Vertebrate Animals, which are used for experimental and scientific purposes (Strasbourg, 1986), norms of biomedical ethics and relevant laws of Ukraine. The Bioethics Commission of the I. Horbachevsky Ternopil State Medical University violations of these principles were not detected (Minutes No. 44 of January 15, 2018).

Experiments were conducted on 30 white non-linear male rats weighing 180-200 g, 5-6 months old, which were divided into three groups: Group I - 10 white rats with hypoergic reaction; Group II - 10 white rats with hyperergic reaction; The third group - 10 white rats with normergic reaction - control group, which received $1 \mathrm{ml}$ of saline solution intramuscularly. The modelling of the hypoergic reaction was carried out by intramuscular administration of the alkylating cytostatic cyclophosphamide (JSC “Kyivmedpreparat", Ukraine) within 7 days daily at the rate of $10 \mathrm{mg} / \mathrm{kg}$ [7]. The simulation of the hyperergic reaction was carried out by intramuscular administration of a immunostimulant of polysaccharide nature - pyrogenal (NIIEM named after M. F. Gamaleya RAMS, Russia) within 7 days daily at the rate of $10 \mathrm{mg} / \mathrm{kg}$ per animal in saline solution [8].

Slaughter and blood sampling under thiopental anesthesia was performed 7 days after the beginning of the experiment.

Determination of phagocytic activity of leukocytes is based on the ability of polymorphonuclear leukocytes and monocytes of peripheral blood to adsorb on its surface, absorb and digest microbial test culture. The following parameters were determined: the percentage of phagocytic leukocytes - the phagocytic index - the number of leukocytes from the hundred that showed phagocytic activity, the phagocytic number - the number of microbes absorbed by an average of one leukocyte and the index of phagocytic activity was calculated [9]. Quantitative indicators were processed by the method of variational statistics [10].

\section{RESULTS AND DISCUSSION}

Under the conditions of the changed reactivity of the organism, the inflammatory process in the periodontal tissues appeared, which was manifested by a decrease in the body weight of the animals, hyperemia, swelling, bleeding, gum erosion, a decrease in the height of the gingival papilla, destruction of the circular ligament, bulging of the root of the tooth, and, as our previous studies indicated $[4,11]$, the appearance of periodontal pockets: at hyperergia - from $110 \mathrm{~mm}$ to $550 \mathrm{~mm}$ (covered by the epithelium), with hypoergia - from $88 \mathrm{~mm}$ to $792 \mathrm{~mm}$ (with prevalence of necrosis) below the level of the enamel-cement border, which corresponds to the average degree of gravity bones of periodontitis. At the same time, the analysis of the results suggests that there are certain disorders in the functioning of the immune system of the animal organism.

Thus, evaluating the spectrum of indicators of non-specific protection in the blood of experimental animals with periodontitis, we are convinced that most of them differed significantly from the control (Table I).

The cells of the monocyte-phagocytic system are directly related to the development of the inflammatory process in the periodontal tissues. Substrates of this system play a key role in the implementation of a wide range of immune responses: from the activation of the pro-inflammatory cascade at the initial stages of its development, to the inclusion of anti-inflammatory mediator products systems. The evaluation of the condition of cells of the monocyte-phagocytic system, in particular segmental neutrophils of peripheral blood, showed that during hypoergia, the percentage of phagocytes cells decreased, i.e., the phagocytic index $(\mathrm{Fi}, \%)$ by 2.09 times $(\mathrm{p}<0.05)$, with hyperergia it increased by 1.37 times $(\mathrm{p}<0.05)$. The analysis of phagocytic activity of leukocytes showed a decrease in the index of phagocytic activity (IFA) with hypoergia in 1.96 times ( $p<0.05$ ). The growth of the above indicator of the hyperergic group of animals was 1.94 times ( $\mathrm{p}<0.05)$. However, both hypo- and hyperergic activity increased the absorbent activity of each phagocyte cell - phagocyte count $(\mathrm{Fu})$ of $6.25 \%$ and $41.7 \%$, at hypoergia and hyperergia, respectively.

Thus, discussing the results of the research, due to the indicator of phagocytic activity of leukocytes, our assumption that it changes with the change in the reactivity of the organism, was confirmed. The earlier carried out investigations of the state of phagocytosis in patients with localized and generalized juvenile periodontitis, chronic generalized periodontitis in comparison with healthy beings [6] indicates a low level of phagocytosis in patients with juvenile periodontitis ( $46 \%-53 \%$ of patients), only $6 \%$ of patients with generalized periodontitis had reduced 
Table I. Phagocytic activity of blood serum neutrophils of rats with different types of inflammatory reaction $(n=10, M \pm m)$

\begin{tabular}{cccc}
\hline Indicator & Hypoergic reactivity & Hyperergic reactivity & Control group \\
\hline Phagocytic index, $\mathrm{Fi},(\%)$ & $21,60 \pm 3,42^{*}$ & $61,70 \pm 2,17^{*}$ & $45,10 \pm 2,41$ \\
\hline Phagocyte number, Fu & $2,04 \pm 0,10$ & $2,72 \pm 0,17^{*}$ & $1,92 \pm 0,06$ \\
\hline Index of phagocytic activity, IFA & $44,10 \pm 7,86^{*}$ & $167,80 \pm 10,61^{*}$ & $86,60 \pm 5,17$ \\
\hline * - deviation of the index is reliably relative to the control group of animals, $\mathrm{p}<0,05$ &
\end{tabular}

phagocytosis. Phagocytosis has not changed since the initial periodontal treatment in all patients, suggesting that the reduction of phagocytosis can not be a temporary phenomenon associated with the state of periodontal. These results suggest that depressed phagocytic reaction of the patients may be due to defects in polymorphonuclear leukocytes. In our case, we explain this by changing the reactivity of the whole organism. There are other opinions [12], when the cause of the change in the state of phagocytosis is called the local flow of P. gingivalis to the function of polymorphonuclear leukocytes, which become depressed, which contributes to a greater risk of developing periodontitis in the future. The study of phagocytic activity of leukocytes made the authors [13] to make a conclusion that the presence of sodium fluoride contributed to a significant increase of the phagocytic index against Streptococcus oralis, Streptococcus mutans, Streptococcus sobrinus and Streptococcus sanguis. The authors explain this change by the susceptibility of bacteria, at the same time, do not exclude the direct activating effect of fluorides on polymorphonuclear leukocytes. These studies do not contradict our conclusions. In addition, investigations of the development of periodontitis with changes in body reactivity are original. We have independently developed experimental models of periodontitis, the pathogenesis of this disease can be studied, preclinical trials of new drugs and treatments can be conducted on their basis.

\section{CONCLUSIONS}

The development of periodontitis of moderate severity in the form of a hypoergic and hyperergic experimental model is accompanied by a marked violation in the monocyte-phagocytic system. Different directions of changes of the phagocytic index and index of phagocytic activity were observed: increase of these parameters at hyperergia and decrease at hypoergia. An increase in phagocyte number was likely to indicate some autonomy of the process of phagocytosis and independence from the reactivity of the organism.

The obtained results indicate the presence of various mechanisms of development of the inflammatory process in the periodontium. Accordingly, there is the question of determining the nature of the inflammatory process in a particular patient for conducting or not conducting correction of the state of the immune system or in the direction of immunosuppression, or immunostimulation.

\section{REFERENCES}

1. Leus P.A. Yevropeyskiye indikatory stomatologicheskogo zdorov'ya naseleniya [European Indicators of Dental Health of the Population]. Economics and Management in Dentistry (RF). 2012;3:50-54. (In Russian).

2. Avdeev 0. V. Kliniko-patohenetychni osnovy rozvytku ta likuvannya zapal'nykh ta dystrofichno-zapal'nykh zakhvoryuvan' parodonta pry rizniy reaktyvnosti orhanizmu [Clinical and pathogenetic basis of development and treatment of inflammatory and dystrophicinflammatory diseases of periodontal disease at different reactivity of an organism]: author's abstract of the dissertation for obtaining PHD in Medical Sciences: specialty 14.01.22“Dentistry". Lviv National Medical University named after D. Halytskiy. Lviv; 2013, p. 36. (In Ukrainian).

3. Levitskiy A.P., Nikolishin A.K., Stupak Ye.P. i dr. Disbioticheskiye aspekty patogeneza profilaktiki i lecheniya stomatologicheskikh zabolevaniy [Disbiotic aspects of pathogenesis of prophylaxis and treatment of dental diseases]. Problems of ecology and medicine. 2011;15(3-4) (Annex 1):105. (In Ukrainian).

4. Avdeev 0.V. Strukturni zminy parodonta shchuriv pry modelyuvanni hiporeaktyvnosti orhanizmu [Structural changes in periodontitis of rats in the modeling of hyporeactivity of the organism]. Clinical Dentistry. 2015;1:24-27. (In Ukrainian).

5. Phagocytosis - Past and Future. Edited by Manfred L. Karnovsky, Liana Bolis. Academic Press; 1982, P. 608.

6. Kimura S, Yonemura T, Hiraga T et al. Flow cytometric evaluation of phagocytosis by peripheral blood polymorphonuclear leucocytes in human periodontal diseases. Archives of Oral Biology. 1992;37(6):495-501.

7. Sposib modelyuvannya hipoerhichnoho parodontyta [Way of modeling of hypoergic periodontitis: branch innovation]. [0. V. Avdeev]. Register of sectorial innovations. Edition 36-37. Register. No. 438/37/12. K.: Ministry of Health, Ukrmedpatentinform, 2012. P. 321. (In Ukrainian).

8. Sposib modelyuvannya hipererhichnoho parodontyta [Way of modeling hyperergic periodontitis: branch innovation]. [0. V. Avdeev]. Register of sectorial innovations. Edition 36-37. Register. No. 437/37/12. K.: Ministry of Health, Ukrmedpatentinform, 2012. p. 320-321. (In Ukrainian).

9. Imunolohiya: pidruchnyk [Immunology: a textbook]. L.V.Kuznetsova, V.D. Babadzhan, N.V.Harchenko and others; by editing L.V. Kuznetsova, V.D. Babadzhan, N.V. Harchenko. Vinnytsya: LLC "Mercury Podillya"; 2013. p. 86-88. (In Ukrainian).

10. Trukhacheva N.V. Matematicheskaya statistika v mediko-biologicheskikh issledovaniyakh s primeneniyem paketa statistica [Mathematical statistics in medical-biological researches using the statistica package]. Moscow: Geotar-Media; 2012. P. 379. (In Russian).

11. Avdeev 0.V. Flohohennyy vplyv imunotropnoho preparatu na tkanyny parodonta v eksperymenti [Proinflammatory effect of immunotropic preparation on periodontal tissue in an experiment]. Bulletin of scientific research. 2010;3(60):104-106. (In Ukrainian). 
12. Wilton JMA, HurstTJ, ScottEE. Inhibition of polymorphonuclear leucocyte phagocytosis by Porphyromonas gingivalis culture products in patients with adult periodontitis. Archives of Oral Biology. 1993;38(4):285-289.

13. Gutiérrez J, Liébana J, Ruiz M et al. Action of sodium fluoride on phagocytosis by systemic polymorphonuclear leucocytes. Journal of Dentistry. 1994;22(5):279-282.

Initiative of the research work of the Chair of Pediatric Dentistry at the State Institution of Higher Education «I. Horbachevsky Ternopil State Medical University of the Public Health of Ukraine» "Study of metabolic homeostasis of the body in diseases of the oral cavity in people of different ages and optimization of their treatment and prevention" (state registration number 0116U004146).

\section{Authors' contributions:}

According to the order of the Authorship.

\section{Conflict of interest:}

The Authors declare no conflict of interest

\section{CORRESPONDING AUTHOR}

\section{Alexander V. Avdeev}

State Institution of Higher Education

«I. Horbachevsky Ternopil State Medical University

of the Public Health of Ukraine»

Maidan Voli, 1, 46001 Ternopil, Ukraine

tel .: +380978521694, +380663508440

e-mail:avalexandr@yahoo.com

Received: 30.11 .2018

Accepted: 14.02 .2019 
PRACA ORYGINALNA

ORIGINAL ARTICLE

\title{
THE STATE OF OXIDATIVE HOMEOSTASIS IN CHILDREN WITH INFLUENZA STOMATITIS
}

\section{STAN HEMOSTAZY OKSYDACYJNEJ U DZIECI Z ZAPALENIEM JAMY USTNEJ W PRZEBIEGU GRYPY}

\author{
Nataliia 0. Gevkaliuk, Nataliya I. Sydliaruk, Larysa Ya. Posolenyk, Oksana Ya. Vydoinyk, Lesia I. Kuchyrka \\ STATE INSTITUTION OF HIGHER EDUCATION “I. HORBACHEVSKY TERNOPIL STATE MEDICAL UNIVERSITY”, TERNOPIL, UKRAINE
}

\begin{abstract}
Introduction: The clinical course of acute respiratory viral infections was not sufficiently studied, specially the state of oxidative homeostasis in children with influenza stomatitis. This fact became the base for our study.

The aim: to characterize the state of oxidative-prooxidant system as one of the factors of non-specific resistance of children 'organism with influenza stomatitis.

Materials and methods: A survey was conducted on 384 children with acute respiratory viral infections aged from 6 months to 12 years, among them 318 had lesions of oral cavity. The mild form was diagnosed in 52 children, moderately severe - in 185, severe - in 81 children. The control group consisted of children without lesions of oral cavity (66 people). To analyze lipid peroxidation we used a spectrophotometric determination of diene conjugates. The ceruloplasmin activity and the transferrin saturation in blood plasma by iron were determined by $G$. Babenko's method.

Results: We found the intensification of lipid peroxidation: a significant increase of diene conjugates in serum up to $13.78 \%$, the level of which depended on the severity of disease. We also found the activity increase of ceruloplasmin in 1,8 times in patients with severe course of disease. The saturation of blood plasma transferrin by iron was significantly reduced - for $15.27 \%$ in patients with severe course of influenza stomatitis.

Conclusions: Changes in antioxidant system happend due to the activation of lipid peroxidation, and because of the inability to neutralize toxic metabolites in the children body the intoxication syndrome developed.
\end{abstract}

KEY WORDS: influenza stomatitis, antioxidant-prooxidant balance, oxidation homeostasis

Wiad Lek 2019, 72, 3, 405-408

\section{INTRODUCTION}

Infectious diseases have a leading role in morbidity ranking of people all over the world, due to its ' widespread distribution, multiorganic injuries, adverse effects. According to WHO [1], respiratory infections are one of the most widespread causes of child morbidity and mortality. Around 11-13 million people suffer from influenza and Upper respiratory tract infections (URTI) each year in Ukraine, that is $95 \%$ of all registered cases of infectious diseases [2, $3]$ and in the structure of child infections URTI occupies the first rank position [4]. In this regard, respiratory viral infections became one of the leading medical and social problems in world countries and have national importance in Ukraine $[5,6]$.

Whereas the leading role in pathogenesis of URTI has a general toxic, epileptotropic and vasopathic action of respiratory viruses, the rash on mucous membranes reflects the patterns of the infectious process in general [7, 8]. In patients with URTI, non-specific lesions of the oral mucous membrane are often developed in the form of catarrhal inflammation - an influenza stomatitis, which reflects local factors. Undoubtedly, increased susceptibility to respiratory viral infections has a close relationship with various functional mechanisms [9].

\section{THE AIM}

The aim: to characterize the state of oxidative-prooxidant system as one of the factors of non-specific resistance of children` organism with influenza stomatitis.

\section{MATERIALS AND METHODS}

We conducted a survey of 384 children with acute respiratory infections from 6 months to 12 years in order to study the clinical course of URTI, the identification of risk factors, and the severity of the course. From the total number of examined patients, 318 children had lesions of oral cavity, in which the mild form was diagnosed in 52 children, moderate-severe - in 185 children, severe - in 81 children. The control group consisted of children of corresponding age groups, patients with acute respiratory viral infections without lesion in the mouth (66 people). Formation of clinical groups of children with URTI was 
conducted after a parents` sign of Informed Agreement for patient and research conduction.

Taking into account the literature data $[10,11,12,13$, 14] about the role of free radical oxidation in the process of infectious inflammation, we studied the state of the prooxidant and antioxidant systems as one of the factors of nonspecific resistance in children with URTI. We used spectrophotometric determination of diene conjugates (DC) - intermediate products of free radical oxidation of erythrocyte phospholipids in blood serum using method of A. Riazeg in the modification of V. B. Gavrilova and M. N. Myshrokudna [15].

As an indicator of antioxidant activity in blood serum, we determined the activity of the copper-containing protein - ceruloplasmin (CP), which was determined with transferrin (TF) in blood plasma, taking into account its importance for normal processes of hematopoesis, iron transport and antioxidant defense, using the method of G. A. Babenko [16].

All the research methods which were used meet the requirements for examination of patients and conducting scientific researches meet the requirements of norms and principles of bioethics. In carrying out the work, the rules of patient safety, the rights and canons of human dignity, as well as the moral and ethical norms in accordance to the main conditions of the GSP (1996); European Convention on Human Rights and Biomedicine (dated 04.04.1997); a set of ethical principles regarding human experimentation developed for the medical community by the World Medical Association (WMA) - The Declaration of Helsinki (1964-2000); the Order of the Ministry of Health of Ukraine №281 dated November 1,2000; a code of ethics for scientists of Ukraine (2009) are followed and which is confirmed by the protocol of the Bioethics Commission of the I.Horbachevsky Ternopil State Medical University (protocol №21 dated January 8, 2014).

\section{RESULTS}

It is known that inflammation caused by respiratory viruses and microorganisms is an inducer of oxidative stress, which results in appearance of free radicals, whose excessive amount is limited by the antioxidant system $[8,18]$. Accumulation of lipid peroxidation toxic products causes a change in phospholipid structure of membranes, which can be analized as one of the possible adaptative mechanisms of the body in response to infectious and inflammatory process in patients with URTI.

According to our data all forms of URTI lead to the intensification of lipid peroxidation: the amount of DC in blood serum of children with URTI correlated with the increase of disease severity. In mild form of the disease the amount of DC was $1.51 \pm 0.02$ cond.units $/ \mathrm{ml}$ (in group of healthy children - $1.44 \pm 0.08$ cond.units $/ \mathrm{ml}$ ). There was an accumulation of DC in the blood serum in patients with URTI of moderate intensity, which was $1.580 \pm 0.002$ cond. units $/ \mathrm{ml}$. Significant intensification of lipid peroxidation activity occurred in patients with severe URTI, when the amount of DC significantly increased and was $1.670 \pm$ 0.001 cond.units $/ \mathrm{ml}$. Therefore we established reliable (P $<0.001$ ) increase in amount of DC in serum of all patients with acute respiratory infections, the severity of which depended on the severity of disease, which reflected the activity of inflammatory process.

Activation of lipid peroxidation process in children with acute influenza stomatitis leads to significant changes in antioxidant system (AS), activating the production of its components even in the mild form of the disease. Clinically, in patients with mild form of URTI, signs of general intoxication (headache, loss of appetite, sleep disturbance) and weakly expressed catarrhal phenomena in the form of rancid and coughing were weakly expressed. An increase in body temperature to $37.2^{\circ}-37.8^{\circ} \mathrm{C}$ was observed for not more than 2-3 days. The overall condition of patients was evaluated as satisfactory. While studying the antioxidant activity in serum, we found that activity of ceruloplasmin in patients with URTI of mild form is significantly higher $(\mathrm{P}<0.01)$ than in the control group and raises up to $48.19 \pm 0.81$ cond.units (in group of healthy children $37.16 \pm 0.52$ cond.units). Further activation of AS occurs in patients with severe URTI, when the activity of the CP is $59.85 \pm 0.55$ cond.units.

At the same time, all the signs of influenza intoxication were expressed in the examined children: body temperature increased to $39^{\circ} \mathrm{C}$ and was accompanied by dizziness, general weakness, chills, noise in the ears, pain in the eyeballs, myalgia and arthralgia, sweating, sleep disturbances; tracheitis was accompanied by an overhead dry cough. The effects of local factors reflect non-specific changes in oral cavity: catarrhal stomatitis, serous inflammation, manifested by hyperemia, swelling of the mucous membrane of gums, lips, cheeks, the appearance of impressions on the cheek's mucous membrane along the line of teeth contact, increase and bleeding of gums papillae. Nonspecific changes were due to the effect of taking medications, which led to a violation of the acid-base balance of the oral fluid, dysbiosis, local immunity, hypovitaminosis, which we confirmed in laboratory [19].

In children with severe course of pathological process, the activity of CP increased in 1.8 times compared to control and raised up to $67.23 \pm 1.50$ cond.units. In the clinical picture, this form of pathology dominated by symptoms of central nervous system intoxication, which was manifested by nausea, vomiting, nasal haemorrhage, seizures, delusions, short-term loss of consciousness, meningeal symptoms. The febrile reaction, which lasted 3-7 days, corresponded to the severe course of the disease. Sharp impairment of the general condition in which hyperthermic, neurotoxic syndromes occurred, was studied as severe course of disease. Catarrhal phenomena as coughing, congestion and mucous secretion from the nose, pain and sore throat, dry cough were present. Attention was drawn to hyperemia of the face, conjunctivitis, lacrimation, eye shine, moderate cianosis of the lips. The red lobe of the lips is covered with blisters and serous exudate or suffocated bloody crust. On the lips and nostrils often appeared 
herpes rashes. Local manifestations in the oral cavity were manifested by catarrhal stomatitis, dryness, multiple rashes on the mucous membrane of the mouth with a tendency to merge and the formation of extensive erosive surfaces.

It is known that important role in children susceptibility to infection, especially in early childhood when other mechanisms of protection are not yet completely formed [8, 9], plays a bacteriostatic effect of the transferrin (TF) [10, 12]. The study of TF saturation by iron, which is provided by the ferroxidase activity of the $\mathrm{CP}$, showed the following results. In the mild form of acute respiratory infections in children, the saturation of plasma TF was significantly lower in comparison with healthy children $-0.178 \pm 0.002$ cond. units. ( $0.190 \pm 0.002$ cond.units in the control group). In acute respiratory infections in the form of moderate-intensity saturation of blood TF was $0.165 \pm 0.003$ cond.units. The most significant decrease in saturation of blood TF $(\mathrm{P}<0.001)$ was in patients with severe URTI $-0.161 \pm 0.001$ cond.units.

\section{DISCUSSION}

It is known that in human body, the regulator of copper balance is ceruloplasmin - a protein with properties of enzymes specific to serum, which has protective, anti-infectious function in the form of antibodies and in the composition of the properdine-complementary system. Transferin, being a metalloprotein of blood, refers to factors that block free radical oxidation and, together with ceruloplasmin, forms a prooxidation-antioxidant buffer system of blood involved in the maintenance of oxidative homeostasis. Insufficiency of iron and iron-binding proteins has a secondary effect on the immune system and the function of leukocytes, which affects the mechanism of protection of the host from the invasion of microorganisms and viruses. As a result of infectious agent action, the child ' body undergoes changes that lead to a violation of metabolic processes, including the metabolism of trace elements, which result in the distortion of the stability and strength of organometallic compounds in biological fluids.

The dynamics of ceruloplasmin activity, the saturation of blood serum transferrin and the content of protein fractions are sensitive tests, which may indicate the morphological changes in mucous membrane of child oral cavity. This fact is partially confirmed by information from a number of authors $[10,20,21]$, which indicate that the complete elimination of morphological changes is accompanied by the normalization of protein metabolism.

\section{CONCLUSIONS}

Respiratory infections lead to increase of activity in one of the most powerful antioxidant enzymes - ceruloplasmin in blood serum, which stimulates the process of hematopoesis and regulates the blood function with the transferrin, on the background of significant decrease in the saturation of its iron. As a result of our clinical and laboratory studies, there was a disturbance in transportation of transferrin and ceruloplasmin in the body of children with viral influenza stomatitis, the depth of which depends on the severity and duration of the disease. As the severity of acute viral stomatitis increases, the lipid peroxidation activity increases, what is confirmed by the indexes of diene conjugates. Due to the lipid peroxidation activation, changes occur in the antioxidant system - the development of components of antioxidant protection of transferrin and ceruloplasmin. Because of the inability of detoxification systems to neutralize toxic metabolites in the body - an intoxication syndrome develops. Such changes in the functioning of the antioxidant defense system, in our opinion, are the manifestation of compensatory reactions and indicate a gradual increase in the level of catabolic processes with increasing severity of the disease, which must be taken into account when choosing the optimal method of treatment.

\section{REFERENCES}

1. WHO Library Cataloguing-in-Publication Data, The world health report 2008: primary health care now more than ever. -WHO. - 2008. - $152 \mathrm{p}$.

2. Dziublyk Y.V. Sovremennyie protivovirusnyie preparatyi [Modern antiviral drugs]. Zhurnal praktycheskoho vracha. 2003; 1:35-39. (In Ukrainian).

3. Osypova N.A., Yakubovskaia R.Y., Edeleva N.V. et al. Effektivnost tseruloplazmina v reanimatsionnoy onkologicheskoy klinike [Efficacy of ceruloplasmin in the resuscitation oncology clinic]. Likarska sprava. 2001; 5-6:140-145. (In Ukrainian).

4. Tatochenko V.K. Preparatyi dlya simptomaticheskogo lecheniya ostryih respiratornyih virusnyih infektsiy u detey [Medications for the symptomatic treatment of acute respiratory viral infections in children]. Vopr. sovremennoi pedyatryy. 2004; 3(4):112-114. (In Russian).

5. Kramarev S.A. Epidemiya gripu v Ukrayini [Influenza epidemic in Ukraine]. Nauk.-prakt. zhurn. dlia pediatriv «Z turbotoiu pro dytynu».2010; 1:9. (In Ukrainian).

6. Lukianova 0.M. Mediko-sotsialni aspekti zberezhennya zdorov'ya ditey, zabezpechennya yihnogo garmoniynogo flzichnogo ta intelektualnogo rozvytku [Medical and social aspects of maintaining the health of children, ensure their harmonious physical and intellectual development]. Zhurn. AMN Ukrainy. 2001; 3:408-415. (In Ukrainian).

7. Hemonov V.V., Mohylnyi M.A.Zaschitnyie svoystva poverhnostnyih sloev epiteliya slizistoy obolochki polosti rta [Protective properties of the surface layers of the epithelium of the oral mucosa]. Stomatolohyia.2006; 3:4-6. (In Russian).

8. Kazakova R.V. Izmeneniya slizistoy obolochki polosti rta pri infektsionnyih zabolevaniyah [Changes in the oral mucosa in infectious diseases]. In: Neiko N.V., Mateiko H.B. et al. Lvov: HalDent; 2009, p. (In Ukrainian).

9. Uchaikyn V.F. Retsidiviruyuschie respiratornyie infektsii u detey: primenenie immunomodulyatorov dlya lecheniya i profilaktiki [Recurrent respiratory infections in children: the use of immunomodulators for the treatment and prevention]. Pedyatryia. 2009; 1:127-132. (In Russian).

10. Vydyborets S.V. Transferin: KIInlchne znachennya ta laboratorna dlagnostika porushen [Transferrin: Clinical significance and laboratory diagnosis of disorders]. Lab. dyahnostyka. 2000;2:30-33. (In Ukrainian).

11. Holotiuk V.V. Mozhlivlst korektsIYi tseruloplazmlnom endogennoYi IntoksikatsIYi, scho zumovlena obstruktsIEyu obodovoYi kishki [Possibility of correction of ceruloplasmin endogenous intoxication caused by obstruction of the colon]. Onkolohiia. 2001; 4:286-289. (In Ukrainian). 
12. Zhavoronkov A.A., Kudryn A.V. Imunnyie funktsii transferina [Immune function of transferrin]. Hematoloh. y transfuzyoloh. 2002; 2:40-41. (In Russian).

13. Nahornyi 0.le. Vyvchennya stanu oksidantno-antioksidantnoyi sistemi u hvorih na urogenitalniy hlamidioz [Study of the state of the oxidantantioxidant system in patients with urogenital chlamydia]. Inf. khvoroby. 2002; 1:53-55. (In Ukrainian).

14. Shepelev A.P., Kornyenko Y.V., Shestopolov A.V. et al. Rol protsessov svobodnoradikalnogo okisleniya v patogeneze infektsionnyih bolezney [The role of free radical oxidation processes in the pathogenesis of infectious diseases]. Vopr. med. khymyy . 2001; 2: 110-116. (In Russian).

15. Havrylov V.B., Myshkhorudnaia M.N., Mazhul L.M. Analiz metoda opredeleniya produktov perikisnogo okislennya lipidov v slvorotke krovi po testu s tiobarbiturovoy kislotoy [Analysis of the method for determining the products of lipid peroxidation of lipids in the blood circulation test using thiobarbituric acid test]. Voprosy med. khymyy.1987; 1:118-122. (In Russian).

16. Babenko H.A. Viznachennya mlkroelementlv i metalofermentlv v klinicheskih laboratoriyah [Determination of trace elements and metal enzymes in clinical laboratories]. - Kyiv: Zdorovia, 1968, p. (In Ukrainian).

17. Znamenska T.K., Zhdanovych 0.I., Osynska L.F. et al. Stan perekisnogo oksilennya IIpldlv, antioksidantnoYi sistemi zahistu i klitynnyh memebran v novorozhdennyh vid materiv s ekstragenltalnoyu patologieju [Status of lipid peroxidation oxidation, antioxidant system of protection and cellular membranes in newborns from mothers with extragenital pathology]. Perynatolohiia ta pediatriia. 2001; 4:27-28. (In Ukrainian).

18. Chornovil A.V., Hrytsko R.lu., Birka Kh.lu. Zastosuvannya vitaminivantioksidantiv v infektologiyi [Application of vitamins-antioxidants in infectology]. Inf. khvoroby. 2001; 3:50-53. (In Ukrainian).
19. Gevkaliuk N.A., Sydliaruk N.I., Pynda M.Ya. et al. Sostoyanie nespetsificheskoy rezistentnosti slizistoy obolochki polosti rta pri grippoznom stomatite u detey v kontseptsii obschnosti MALT-sistemy [The state of nonspecific resistance of the oral mucosa with influenza stomatitis in children in the concept of generality of the MALT system]. Georgian Medical News. 2018; 7-8 (280-281):34-40. (In Russian).

20. Golovacheva E. G., Osydak L. V., Obraztsova E. V. et al. Produktsiya interferonov u detey s ostryimi respiratornyimi virusnyimi infektsiyami [Interferon production in children with acute respiratory viral infections]. Meditsinskaya immunologiya. 2009; 2-3: 205 - 214. (In Russian).

21. Boyko M.G. Farmakologichna korektsiya antioksidantnogo statusu u hvorih na hronichniy obstruktivniy bronhit [Pharmacological correction of antioxidant status in patients with chronic obstructive bronchitis]. Clinichna farmacija. 2001; 3:39-41. (In Ukrainian).

Inclusion of publication in planned scientific research work. Scientific work was done within plan of 2 research projects of I. Horbachevsky Ternopil State Medical University: «Formation of highly effective technologies, optimization of immune system of the human body against influenza and ARVI» (No. 0110U001824) and "Clinics, diagnosis, treatment of congenital malformations of the face, dental disease and periodontal disease» (No. 0109U002900). Authors worked on fragments of complex scientific works.

\section{Authors' contributions:}

According to the order of the Authorship.

Conflict of interest:

The Authors declare no conflict of interest

\section{CORRESPONDING AUTHOR Nataliia Gevkaliuk}

I. Horbachevsky Ternopil State Medical University

1 Majdan Voli, 46001 Ternopil, Ukraine

tel: +38 096-560-14-45

e-mail: gevkalyuk@tdmu.edu.ua

Received: 24.11.2018

Accepted: 15.02.2019 
PRACA ORYGINALNA

ORIGINAL ARTICLE

\title{
ASSESSMENT OF THE EFFECTIVENESS OF THE GASTROPATHY RISK REDUCTION PROGRAM IN PATIENTS WITH ARTERIAL HYPERTENSION
}

\author{
OCENA SKUTECZNOŚCI PROGRAMU ZMNIEJSZENIA RYZYKA \\ ROZWOJU GASTROPATII U PACJENTÓW Z NADCIŚNIENIEM \\ TĘTNICZYM
}

\author{
Anastasiia A. Akhmedova, Oleksandr M. Ocheredko, Volodymyr P. Klimenyk \\ NATIONAL PIROGOV MEMORIAL MEDICAL UNIVERSITY, VINNYTSYA, UKRAINE
}

\begin{abstract}
Introduction: For primary health care patients with concomitant morbidity are usual phenomena. Combination of gastropathy with arterial hypertension is increasingly being studied. However, the assessing of the medical and economic effectiveness of treatment of patients with concomitant morbidity still methodologically challenging. The issue aggravated by different cushion programs aimed to alleviate financial burden to indigent population. These cover non-expensive drugs with probable hazard to concomitant morbidity.

The aim: to evaluate the effectiveness of the gastropathy risk reduction program in patients with arterial hypertension (AH).

Materials and methods: data on 150 patients with AH collected by panel design with dynamic cohort traced up to 17 years. We have elaborated a program for the prevention of gastropathy in patients taking antihypertensive therapy. Program is based on regulations of the Ministry of Health of Ukraine, adapted clinical guidelines, and other official sources of information, since holistic prevention of gastropathy is not depicted in any source. Two main cohorts were distinguished: those in prevention program (PP) and patients with usual treatment. 6 built in cohorts (Group№0-№5) helped to diversify PP across groups of different severity. Event of interest was incidence or aggravation of gastropathy (gastroduodenitis mainly). We used Poisson model to study average treatment effect of PP on annual number of aggravations.

Results: The main effect of program participation is significant in a model of fixed effects $(\beta=-0.269 ; p=0.0156$ ), and even more supportive in the mixed model ( $\beta=-0.282$; $p=0.0097)$. Other components with a variable "PP participation", namely participation in the program given the group, participation in the program given GP duration, participation in the program given compliance, appeared to be nonsignificant, that suggest absence of substantial selection bias due to non-randomness of allocation. The greatest risk reduction due to program participation was in patients of Group0, that is, in patients with hypertension who do not receive antihypertensive therapy. In groups №1-№5 with more aggressive hypertension treatment the effects of program participation are obvious but less pronounced.

Conclusions: The elaborated program differentiates patients by groups and furthermore allows one to consider each patient characteristics, taking into account income, age, gender, progression of the disease, comorbidity, drugs the patient takes. The established program based on cooperation of patient, general practitioner, and gastroenterologist. We reduced selection bias due to possible randomness blemishes in allocation to the PP by control function method. The main effect of program participation is significant in a model of fixed effects ( $\beta=-0.269 ; p=0.0156)$, and even more supportive in the mixed model $(\beta=-0.282 ; p=0.0097)$.
\end{abstract}

KEY WORDS: program of prevention, risk, assessment of efficiency

Wiad Lek 2019, 72, 3, 409-417

\section{INTRODUCTION}

According to the World Health Organization, there is a rapid population aging throughout the world. In Ukraine, the proportion of people over 65 in 2016 was almost 16\% while by the United Nations scale, the old population considered with the proportion of people over 65 more than $7 \%$. Demographic changes caused by aging lead to a numerous consequences for society that have repercussion to all spheres of our lives. Delay in economic development, declining household incomes, lack of investment, reduction of consumer basket, employment problems, insufficient pension provision, tax increase, family composition, deterioration of living conditions, increased emigration movements, increased need for medical care and social services for the elderly, etc. Therefore, the modern concept of the health system goes along with "healthy aging" and requires comprehensive measures, both from the state and from the health care system. Among such measures should be the prevention of the incidence and exacerbations of chronic diseases.

According to the data of Health Ministry of Ukraine [1], circulatory system diseases occupy the first place in the structure of the morbidity prevalence in Ukraine. For example, in 2012 this indicator reached 31.48\% (58 385.70 per 100 thousand), in 2015 - 30,95\% (52 956.9 per 100 thousand), in 2016 - 30,67\% (52,970.4 per 100 thousand). 
At the same time, the third place was occupied by diseases of the digestive system: in 2012 - 9,74\% (18 058.10 per 100 thousand), in 2016 - 9,93\% (16 998.1 per 100 thousand) and 2016 - 9,74\% 16825.5 per 100 thousand).

With an increase in the life expectancy the probability of simultaneous existence of different diseases is increasing, which leads to a number of issues that are needed to be addressed. The problem of polymorbidity is one of the most difficult in medical practice. Mutual influence of diseases and medical pathomorphosis significantly change the clinical manifestation, the natural course of each, and the probabilities of complications. In addition, it causes deterioration in the quality of life, difficulties in the diagnostic and treatment. Prescribing the drug, it is necessary to keep in mind its possible positive or negative impact on the concomital pathology.

For primary health care patients with concomital morbidity are usual phenomena. Combination of gastropathy with arterial hypertension is increasingly pervasive. It is obvious that, with high blood pressure as conspicuous symptom, arterial hypertension is diverse and multifaceted. The diversity of the course of arterial hypertension and its combination with other diseases are among most common topics for research, still the assessment of effectiveness of combined pathologies treatment faces challenges on methodological ground [2].

\section{THE AIM}

The aim was to evaluate the effectiveness of the gastropathy risk reduction program in patients with arterial hypertension.

\section{MATERIALS AND METHODS}

Data on 150 patients with AH collected by panel design with dynamic cohort traced up to 17 years. Two main cohorts were distinguished: those in prevention program (PP) and patients with usual treatment. Event of interest was incidence or aggravation of gastropathy (gastroduodenitis mainly). We also discerned sub-cohorts: (i) patients with hypertension that did not receive antihypertensive therapy and without complaints related to the organs of the gastrointestinal tract (group 0), (ii) those treated with anticoagulants and (or) with antiaggregates (group 1), (iii) patients treated with non-steroidal anti-inflammatory drugs (group 2), (iv) patients with resistant $\mathrm{AH}$ (group 3), (v) patients on medications that reduce the tone of the lower esophageal sphincter (group 4), (vi) patients treated with antihypertensive drugs only.

In the course of the study, outpatient cards were retrospectively examined followed by prospective observation of patients. The main cohort included 100 patients of retirement age with arterial hypertension with different duration (at most 17 years) complicated by gastropathies originated in the course of antihypertensive therapy. The control cohort included 50 retirement age patients with arterial hypertension of varying duration (at most 17 years old) but without gastropathy developed. Data on the natural course of both diseases were collected with the assistance of attending physician.

\section{PROGRAM DESCRIPTION}

We have elaborated a program for the prevention of gastropathy in patients taking antihypertensive therapy. Program is based on regulations of the Ministry of Health of Ukraine, adapted clinical guidelines, and other official sources of information, since holistic prevention of gastropathy is not depicted in any source.

The program differentiates patients by groups and furthermore allows one to consider each patient characteristics, taking into account income, age, gender, progression of the disease, comorbidity, drugs the patient takes. The general principles are the same for all patients aimed to prevent the incidence and following exacerbations of gastropathy are balanced nutrition, normalization of body weight, active lifestyle, abstaining from bad habits, reduction of psycho-emotional overload.

The established program based on cooperation of patient, general practitioner, and gastroenterologist. The general approaches are complemented with particular activities identified under delineated groups of patients with essential hypertension. One of the prime goal is to achieve compliance.

We used mixed Poisson model to study average treatment effect of PP on annual number of aggravations. The statistical justification for the testing of the effectiveness of the prevention program (PP) based on the methods of eliciting "Average treatment effect" (ATE). These methods are called to correct the bias of treatment effects estimators primarily due to violation of the randomness of the program's assignment, in particular the bias imposed by self-selection.

\section{TREATMENT EFFECT ESTIMATION}

The general rule of the techniques is to take into account unobserved heterogeneity, which, in particular, leads to a biased test of the effectiveness of the treatment in case of its correlation with selection into treatment regiment, say, into main and control cohorts. If the PP performance indicator is $\mathbf{y}$, and the vector $\mathbf{w}$ contains PP components, we are interested in the effect $\mathbf{w}$ on $\mathbf{y}$ in the structural model

$$
\mathrm{E}(y \mid w, \mathrm{c})=\boldsymbol{a}+\boldsymbol{b} w
$$

where $\mathbf{a}$ and $\mathbf{b}$ may be confounded with both observed (covariates) and unobserved heterogeneity and $\mathrm{c}$ represents such heterogeneity.

b is not a constant because of the conditioning on unobserved heterogeneity, that is, we estimate the average (partial) treatment effect (ATE) averaged over the sample: $\mathbf{b} \equiv \mathrm{E}\left(\mathbf{b}_{\text {population }}\right) \approx \mathrm{E}\left(\mathbf{b}_{\text {sample }}\right)$.

In the presence of the set of covariates $\mathbf{x}$, which include, in particular, the components of the program, we can identify the average partial effect given $\mathbf{x}$ : $\mathrm{E}(\mathbf{b} \mid \mathbf{x})$. To validate the use of independent variables $\mathbf{x}$ as proxy variables to $\mathbf{c}$, it is necessary to fulfill 2 conditions of redundancy $\mathbf{x}$ and $\mathbf{c}$.

1. The vector $\mathbf{x}$ is redundant (or ignorable) given $\mathbf{w}$ and $\mathbf{c}$ $\mathrm{E}(y \mid w, c, x)=\mathrm{E}(y \mid w, \mathrm{c})=\boldsymbol{a}+\boldsymbol{b} w$

2. In the first two conditional moments of $\mathbf{w}, \mathbf{c}$ is redundant given $\mathbf{x}$ :

(i) $\mathrm{E}(w \mid \mathrm{c}, \mathrm{x})=\mathrm{E}(w \mid \mathbf{x})$;

(ii) $\operatorname{Var}(w \mid c, x)=\operatorname{Var}(w \mid \mathbf{x})$ 
As was demonstrated by Wooldridge, J.M. (2004, f.3.1) under these conditions ATE of $\mathbf{w}$ on $\mathbf{y}$ has unbiased estimator [3]:

$\operatorname{ATE}=\mathbf{E}\{[w-\mu(\mathbf{x})] y / \operatorname{Var}(\mathbf{x})\}$

with $\mu(\mathbf{x})$ and $\operatorname{Var}(\mathbf{x})$ are respectively the mean and the variance of vector $\mathbf{w}$.

There are several types of ATE appraisers (4) for meeting the conditions (2) and (3). We chose an evaluator based on the redundancy of the vector $\mathbf{w}$ given covariates $\mathbf{x}$ present due to the lack of reliable instrument variables. Analytical techniques are based on the proposals of Rosenbaum and Rubin (1983), known as ignorability of treatment conditioned on covariates $\mathbf{x}$, namely:

(a) $\mathrm{E}\left(\mathrm{y}_{0} \mid \mathrm{x}, w\right)=\mathrm{E}\left(\mathrm{y}_{0} \mid \mathrm{x}\right) ;$ (b) $\mathrm{E}\left(\mathrm{y}_{1} \mid \mathrm{x}, w\right)=\mathrm{E}\left(\mathrm{y}_{1} \mid \mathrm{x}\right)$

where $\mathbf{y}_{0}$ and $\mathbf{y}_{1}$ are the values of dependent variable (annual number of gastroduodenitis aggravations) in patients allocated to control and experimental (treatment) cohorts.

The idea (5) is straightforward: if there is sufficient information in the variable $\mathbf{x}$ about the allocation to PP, the expected values of dependent variable do not depend on the allocation status in the presence of $\mathbf{x}$. In other words, even if $\mathbf{y}_{0}$ and $\mathbf{y}_{1}$ are correlated with $\mathbf{w}$, this correlation is explained by $\mathbf{x}$, and, consequently, is not necessary in the presence of $\mathbf{x}$

An effective method for evaluating ATE given ignorability of treatment conditions (5) is a control function method [4]. By this method, the control functions of $\mathbf{x}(\mathbf{g}(\mathbf{x}))$ are added to the linear predictor $1, w$ to control the violation of the randomized allocation of the program, that is:

$\mathrm{E}(\mathrm{y} \mid \mathbf{x}, w)=\mu_{0}+\alpha w+\mathrm{g}_{0}(\mathbf{x})+w\left[\mathrm{~g}_{1}(\mathbf{x})-\mathrm{g}_{0}(\mathbf{x})\right]$

The coefficient $\alpha$ evaluates ATE. If the control functions are linear in $\mathrm{x}$, then the expression (6) is simplified to:

$\mathrm{E}(\mathrm{y} \mid \mathbf{x}, w)=\mu_{0}+\alpha w+\boldsymbol{\beta}_{0} \mathbf{x}+w[\mathbf{x}-\ddot{\mathbf{x}}] \theta$

with the normalization of the values of the covariates $\mathbf{x}$ by the means $\ddot{\mathbf{x}}$. Decentralization is important to ensure unbiased estimation of $\boldsymbol{\alpha}$ (ATE), which is confounded with w $\ddot{\mathbf{x}} \theta$ otherwise.

The type of model is determined by the nature of the effect measurement and the link function $\mathbf{y}=\mathbf{f}(\mathbf{w} \mid \theta, \mathbf{x})$. In the study the effectiveness of PP $\left(y_{i j}\right)$ is measured in annual number of gastroduodenitis aggravations in the patient $\mathbf{i}$ in the year $\mathbf{j}$, that calls for Poisson model with the dependent variable "annual number of exacerbations". The specification of the model depends on the organization of the data, which in the study for $\mathbf{N}$ patients have a panel structure:

$\begin{array}{ccccc}y_{11} & x_{111} & x_{112} & \cdots & x_{11 p} \\ y_{12} & x_{121} & x_{122} & \cdots & x_{12 p} \\ \cdots & \cdots & \cdots & \cdots & \cdots \\ y_{1 k} & x_{1 k 1} & x_{1 k 2} & \cdots & x_{1 k p} \\ \cdots & \cdots & \cdots & \cdots & \cdots \\ y_{N 1} & x_{N 11} & x_{N 12} & \cdots & x_{N 1 p} \\ y_{N 2} & x_{N 21} & x_{N 22} & \cdots & x_{N 2 p} \\ \cdots & \cdots & \cdots & \cdots & \cdots \\ y_{N l} & x_{N l 1} & x_{N l 2} & \cdots & x_{N l p}\end{array}$

where the first index indicates the patient's number, and the second denotes the year of observation; for predictors the third indicates the predictor number $(1, \ldots, p)$. So, the first patient is traced $\mathrm{k}$ years. Accordingly, the number of exacerbations of duodenitis is indicated by $\mathrm{y}_{11}, \ldots, \mathrm{y}_{1 k}$. In the first year, the values of $p$ predictors for the first patient are $\mathrm{x}_{111}, \ldots, \mathrm{x}_{11 p}$, while in the last year they are $\mathrm{x}_{1 k 1}, \ldots, \mathrm{x}_{1 k p}$.

Given the Poisson distribution of dependent variable we opted for log link function.

The basic equation of logistic regression for such a plan has the form:

\section{$\mathrm{y}_{\mathrm{it}} \sim \operatorname{Poisson}\left(\mu_{\mathrm{it}}\right)$}

$\mu_{\mathrm{it}}=\log \left(\mathrm{b}_{0}+\mathrm{b}_{1} \mathrm{x}_{1 \mathrm{it}}+\mathrm{b}_{2} \mathrm{x}_{2 \mathrm{it}}+\ldots+\mathrm{b}_{\mathrm{p}} \mathrm{x}_{\mathrm{pit}}\right)$

where $x_{i t}$ independent variables (factors of patient and aggravation episode),

$y_{i t}-$ the number of exacerbations of gastroduodenitis, observed in the patient $i$ in the period $t$.

$\log$ - function of natural logarithm,

$b_{j}-$ regression coefficient on $j$ variable.

Estimation of the model parameters was carried out by MCMC algorithms using Gibbs sampler realized in WinBUGs software.

The composition of predictor set was determined by their suggested effects on the incidence and aggravations of gastroduodenitis. Predictors organized as follows:

- patient characteristics: age, gender, marital status, smoking status, obesity, comorbidity load measured by Charleson index, PP allocation (participation) status, AH duration;

- patient by year data: annual income, occupation status, served by the social welfare status, stage and degree of hypertension, annual expenses for treatment of hypertension, annual number of AH related hospitalizations, annual size of reimbursement, annual costs of $\mathrm{AH}$ treatment, main drug for the treatment of hypertension, doctor's note of patient non-complaiance, GP related complaints;

- patient by year by exacerbation data: erosion presence, Hp presence.

In the hierarchical mixed model, we also included design elements such as: serial index (patients are organized in series by the place and time of inclusion in the study), physician 's code to make allowance for physician practice, patient's number.

\section{FIXED EFFECTS AND MIXED MODELS}

To measure risk shifts due to participating in the program, we have applied fixed effects and mixed models. The mixed model is padded out by three additional variables: the index of series, the number (code) of the district (doctor's code), the patient's number. The sample formed in series by time and place of inclusion in the study, presumably heterogeneous by composition, in particular by the ratios of patients with GP. Of course, accounting for such heterogeneity of the fragments of the general sample is desirable to accurate assessment of the risk of GP aggravation and its shift due to PP participation. It is hard-to-tackle with fixed effects model, since the series capture random effect nature (lack 


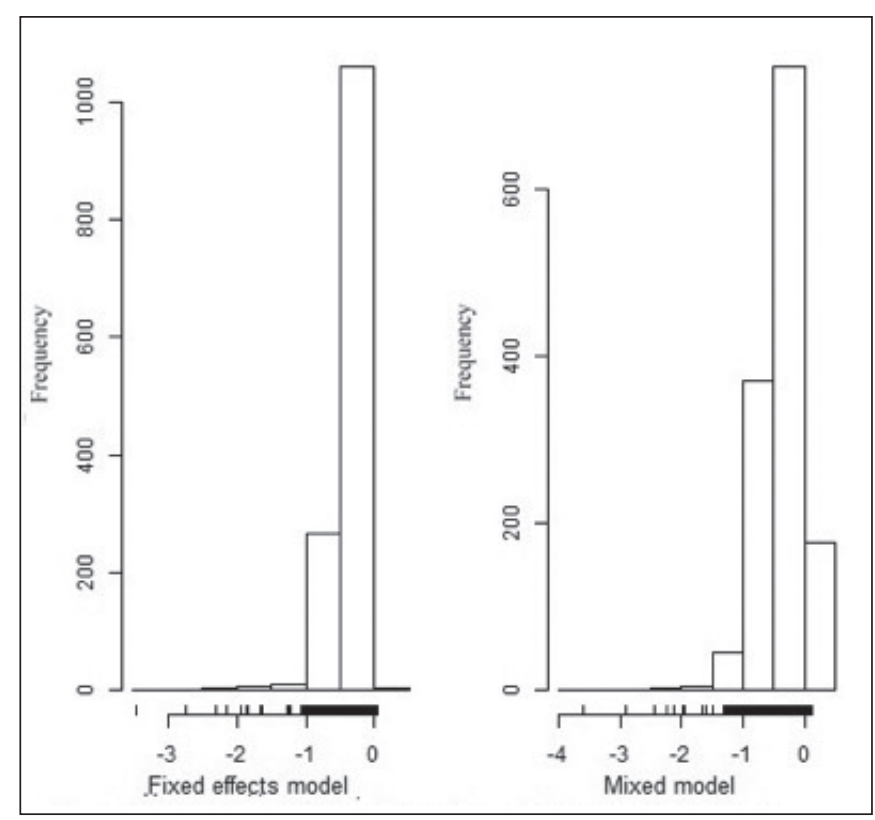

Fig 1. Histograms of distributions of expected risks reduction due to participation in program by fixed effects and mixed Poisson models

of clear sensible gradations or expected deviations from the mean, though so called pulling toward mean tendency is obvious). Analytically, for each series, its effect on the risk of GP is estimated, provided normal distribution with zero mean. That is, the random effects inclusion does not shift the expected risk, but modifies its value in each of the series. That is why the effect is estimated by the sigma parameter. The larger the sigma, the greater the risk deviations in individual series.

A similar logic of inclusion the site (physician) and the patient's personal effects as random. It is not possible to take into account the peculiarities of the individual medical practice and the patient's individual response to the proposed treatment otherwise. Therefore, we processed data both by the fixed effects model and by mixed model.

Randomized effects rendered by a complex covariance matrix structure with a clear hierarchical nesting effects, namely: the model's residuals are nested into the individual effects of patients due to panel data organization, the latter are nested into physician effects which in turn are nested into series.

\section{ATE IDENTIFICATION}

The identification of ATE is implemented in the linear predictor of the models as:

beta ${ }^{\star}$ Treatment + beta $1^{\star}$ Treatment ${ }^{\star}$ Group + beta $2^{\star}$ Treatment ${ }^{*}$ bi +

beta $3^{*}$ Treatment $^{*} \mathrm{AH}$ duration + beta $^{*}$ treatment ${ }^{*}$ Complaints $+\ldots$

where Treatment is participation in $\mathrm{PP}, \mathrm{b}_{\mathrm{i}}$ is individual patient $i$ effect, ... stands for other predictors.

The main parameter of ATE test is the beta coefficient, whose identification from the bias due to violation of the

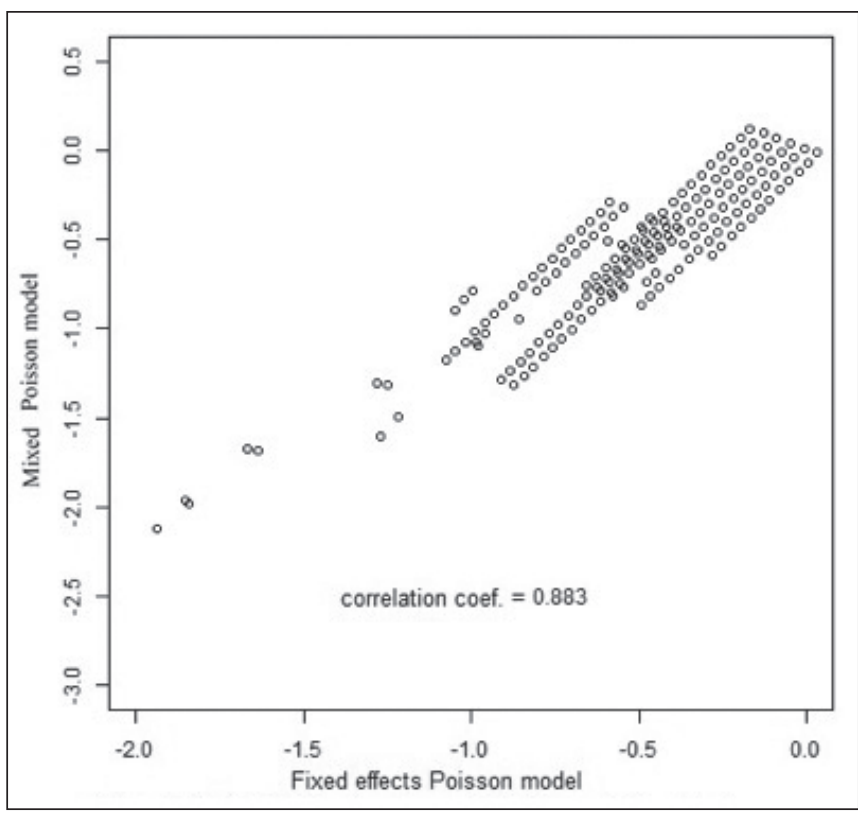

Fig 2. Biplot of estimates of expected risks reduction due to participation in program by fixed effects and mixed Poisson models

randomization of allocation into $\mathrm{PP}$ is ensured by including constituents of $\mathbf{w}[\mathbf{x}-\ddot{\mathbf{x}}] \theta$ in (7):

- component beta $2^{\star}$ Treatment ${ }^{\star}$ bi, bi expresses the individual effect of the patient, which is centered by assigning the function generating its prior values a normal law with zero mean $b[i] \sim d$ norm $(0$, tau $)$ in the text of the code. In fact, the individual patient effect absorbs all possible patient's characteristics not included into model (unobserved heterogeneity), thus providing a powerful proxy variable for unbiased test of ATE. Having beta2 insignificant indicates absence of substantial bias in the ATE estimation due to the randomness violation of the allocation to PP by unobserved patient's characteristic; - participation in the program, given sub-cohort (beta $1^{\star}$ Treatment ${ }^{*}$ Group), the positive effect shows smaller PP effect (compared to the standard program) in a given group against "healthiest" Group 0 used as reference;

- participation in the program, given AH duration (beta ${ }^{\star}$ Treatment ${ }^{*} \mathrm{AH}$ duration), the negative effect indicates the augment in gain due to participation in the program (compared with effect of the standard program) given progressed in time (presumably more serious and resistant to manage) $\mathrm{AH}$;

- participation in the program given complaints (beta $4^{*}$ treatment ${ }^{\star}$ Complaints), the positive effect of the effect indicates the additional gain due to participation in the program (compared with the standard program) in the presence of GP related complaints.

In addition to the important content, these effects are parts of $\mathbf{w}[\mathbf{x}-\ddot{\mathbf{x}}] \theta$ in (7) to identify the ATE effect.

\section{IMPLEMENTATION AND SOFTWARE}

The powerful modern driver for the implementation of hierarchical mixed models, which includes our model 


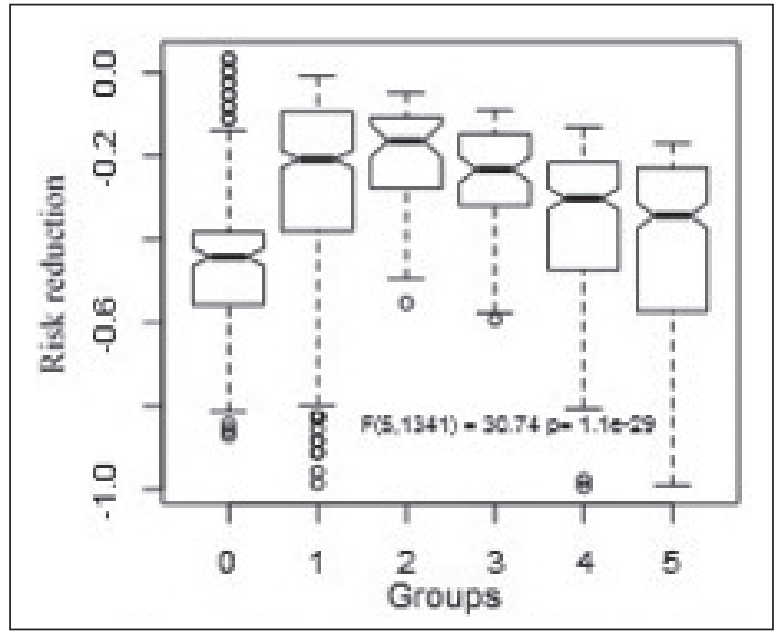

Fig 3. Box plots of distributions of risk reduction estimates due to program participation across groups

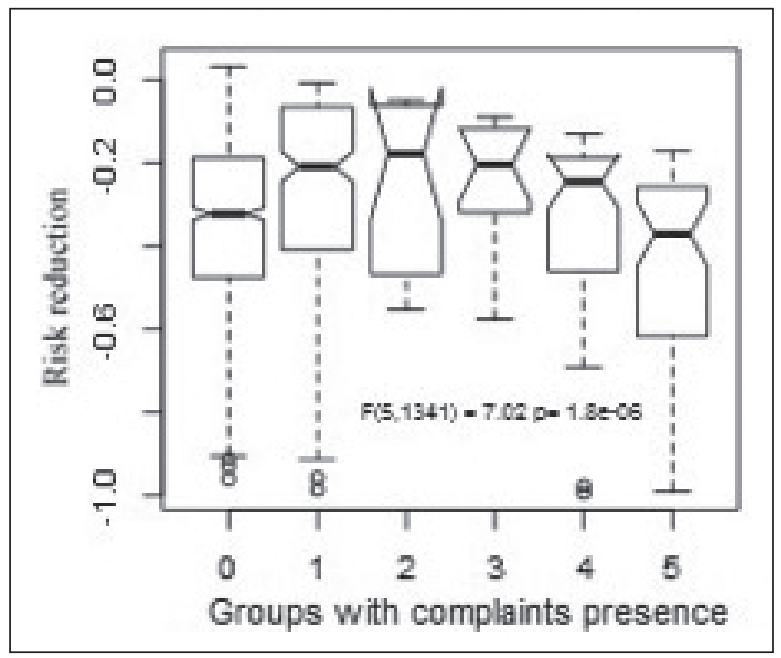

Fig 5. Box plots of distributions of risk reduction estimates due to program participation across $\mathrm{AH}$ grades

structure, are MCMC algorithms. We chose the most elaborate and powerful Gibbs sampler. The analytical program module is written in WinBUGS, which is the abbreviation for Bayesian inference using Gibbs (software). The processing of mixed model was carried out in the WinBUGS package version 1.4. Preliminary data preparation, as well as the study of convergence in the Markov chains, was carried out in the framework of the mathematical analytical system $\mathrm{R}$ version 3.1.0 on the basis of the CODA package. All of the above graphic images are also created in the $\mathrm{R}$ environment (GRAPHICS package). Fixed effect Poisson model was processed by GLM procedure.

\section{RESULTS AND DISCUSSION}

To evaluate the effectiveness of the proposed $\mathrm{PP}$ for patients with hypertension in terms of GP risk reduction, we first applied a simpler Poisson fixed effects model. To focus on

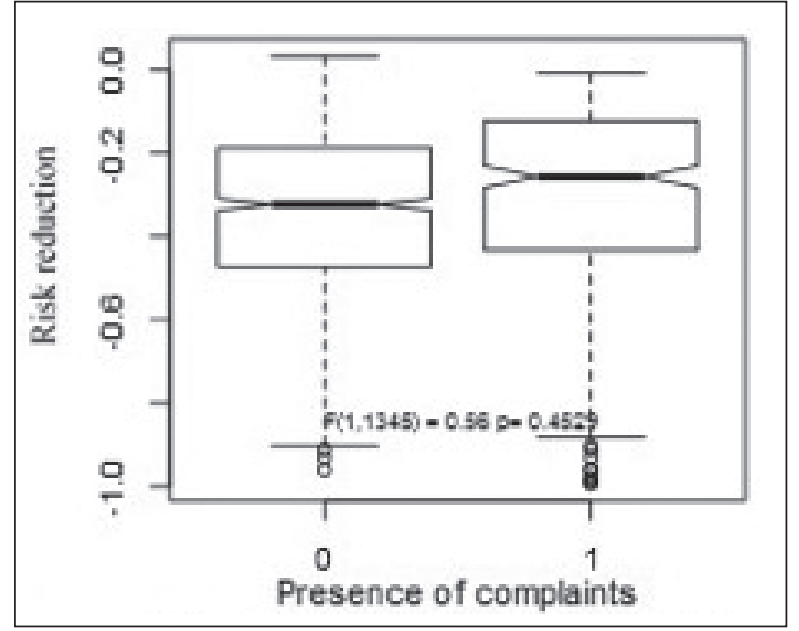

Fig 4. Box plots of distributions of risk reduction estimates due to program participation by complaints

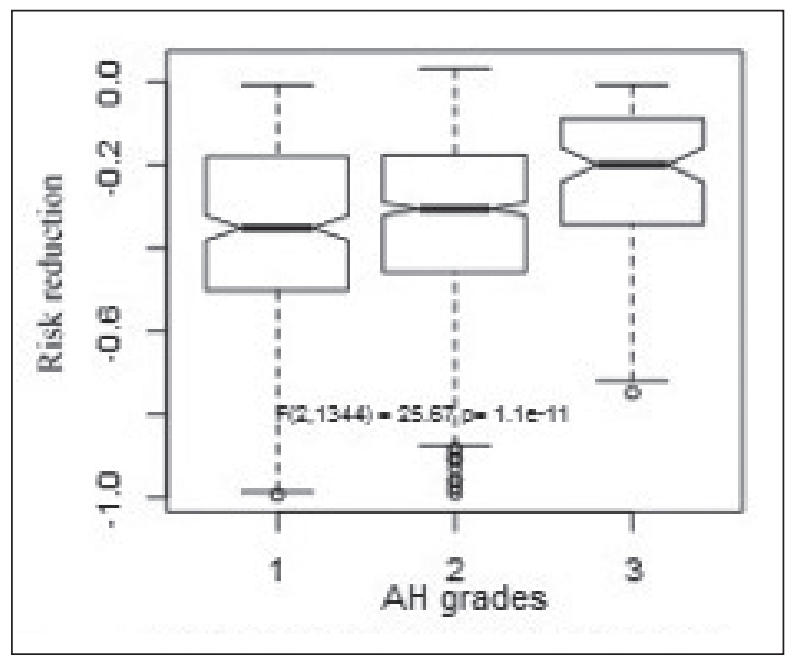

Fig 6. Box plots of distributions of risk reduction estimates due to program participation across groups with complaints

significant effects with meaningful interpretation, we used function STEP of the statistical system R. The procedure reduced the set of predictors from 27 to 16 without significant reduction of AIC (the value decreased from 1557.4 to 1540.3 ) with the difference $\Delta=17.1$, which defines the 0.895 area of hi-squared distribution $\chi^{2}(11)=17.1$, that is, $\mathrm{p}=$ 0.895 being insignificant. The estimations of a model with a reduced set of predictors are given in Table I.

\section{REGRESSION EFFECTS ESTIMATIONS}

In order to more accurately estimate ATE effect and increase the power of the test, we applied a mixed Poisson model with complete and reduced sets of predictors to study the robustness of the effects. Mixed model enabled to include the effects of design elements. Estimates of hierarchical mixed Poisson model with complete and selected set of predictors are shown in Tables I and II. 
Anastasiia A. Akhmedova et al.

Table I. Estimations of regressors effects on annual number of GP exacerbations in patients with AH by fixed effects and mixed Poisson models

\begin{tabular}{|c|c|c|c|c|c|c|}
\hline \multirow{2}{*}{ Predictors } & \multicolumn{3}{|c|}{ Poisson model } & \multicolumn{3}{|c|}{ mixed Poisson model } \\
\hline & $\boldsymbol{\beta}$ & $\mathbf{m}$ & $\mathbf{p}$ & $\boldsymbol{\beta}$ & m & $\mathbf{p}$ \\
\hline Constant & $-0,539$ & 0,269 & 0,04495 & $-3,752$ & 3,681 & 0,30810 \\
\hline Age & $-0,018$ & 0,051 & 0,71817 & 0,013 & 0,102 & 0,89926 \\
\hline Gender & 0,253 & 0,092 & 0,00572 & 0,122 & 0,162 & 0,45136 \\
\hline Marital status (Single) & $-0,238$ & 0,161 & 0,13947 & $-0,240$ & 0,245 & 0,32592 \\
\hline Occupation (Works) & $-0,070$ & 0,153 & 0,64780 & $-0,138$ & 0,257 & 0,59309 \\
\hline Served by the social welfare & $-0,014$ & 0,184 & 0,94089 & $-0,103$ & 0,315 & 0,74233 \\
\hline AH Stage & $-0,094$ & 0,209 & 0,65221 & $-0,650$ & 0,353 & 0,06582 \\
\hline AH Grade2 & 0,119 & 0,215 & 0,57879 & 0,284 & 0,368 & 0,44081 \\
\hline AH Grade3 & 0,692 & 0,468 & 0,13917 & 1,589 & 0,809 & 0,04957 \\
\hline Smoking (Smoke) & $-0,248$ & 0,183 & 0,17508 & $-0,023$ & 0,291 & 0,93568 \\
\hline Obesity (present) & $-0,241$ & 0,114 & 0,03411 & $-0,214$ & 0,198 & 0,27906 \\
\hline AH related expenses & 0,051 & 0,076 & 0,50271 & 0,068 & 0,099 & 0,49065 \\
\hline \# of AH related hospitalizations & $-0,040$ & 0,079 & 0,61318 & $-0,016$ & 0,106 & 0,88120 \\
\hline Reimbursement & 0,001 & 0,004 & 0,75372 & $-0,004$ & 0,005 & 0,40435 \\
\hline Income & 0,024 & 0,046 & 0,59789 & 0,017 & 0,061 & 0,78509 \\
\hline GP related complaints & 14,914 & 1,980 & 0,00000 & 10,640 & 2,039 & 0,00000 \\
\hline PP participant & 0,063 & 0,246 & 0,79892 & 0,231 & 0,349 & 0,50866 \\
\hline PP*bi & & & & 0,008 & 0,742 & 0,99921 \\
\hline Group (2-5 against 0 ) & $-2,596$ & 0,402 & 0,00000 & $-1,749$ & 0,422 & 0,00003 \\
\hline Compliance & 0,085 & 0,051 & 0,09480 & 0,095 & 0,073 & 0,19395 \\
\hline AH duration & $-0,018$ & 0,009 & 0,05443 & 0,007 & 0,012 & 0,55513 \\
\hline Complaints*Group1 & $-10,896$ & 1,618 & 0,00000 & $-7,146$ & 1,713 & 0,00003 \\
\hline Complaints*Group2 & $-7,799$ & 1,228 & 0,00000 & $-5,024$ & 1,315 & 0,00013 \\
\hline Complaints*Group3 & $-5,833$ & 0,854 & 0,00000 & $-3,951$ & 0,941 & 0,00003 \\
\hline Complaints*Group4 & $-3,250$ & 0,437 & 0,00000 & $-1,969$ & 0,507 & 0,00010 \\
\hline PP*Group & $-0,041$ & 0,060 & 0,49974 & $-0,064$ & 0,093 & 0,49430 \\
\hline PP*Complaints & $-0,418$ & 0,258 & 0,10527 & $-0,110$ & 0,341 & 0,74786 \\
\hline $\mathrm{PP} * \mathrm{AH}$ duration & $-0,029$ & 0,023 & 0,21556 & $-0,051$ & 0,031 & 0,10193 \\
\hline
\end{tabular}

None: Residuals st.dev. (sigma) $=0.514894$; Patients effects sigma $=0.53429 ;$

Physicians effects sigma $=0.09999 ;$ Subsample (series) effects sigma $=3.66673$;

AlCfixed $=1557.4, \mathrm{df}=27 ; \mathrm{AlC}$ ixed $=1421.2, \mathrm{df}=28$

There is no significant bias effect $\left(\mathrm{PP}^{\star} \mathrm{bi}\right)$ due to non-randomness of allocation into PP correlated with unobservable patients characteristics, $\beta=0,008 \pm 0,742 \mathrm{p}=0,999$ by the mixed model (Table II), which advocates the redundancy of the effect. Thus, the estimation of ATE effect is unbiased even in the absence of corrective control function. Thus, the randomness of allocation into PP is tenable. That is, allocation was independent of the unobserved characteristics of the natural course of the disease and the individual characteristics of the patient. Randomization of the allocation to treatments compared is a requirement of evidence-based medicine, in case of randomness violation there is a possibility of biased estimation of the treatment effect.

The main effect of ATE is significant in a model of fixed effects $(\beta=-0.269 ; p=0.0156)$, and even more supportive in the mixed model $(\beta=-0.282 ; \mathrm{p}=0.0097)$. Other components with a variable "PP participation", namely participation in the program given the group, participation in the program given GP duration, participation in the program given compliance, appeared to be nonsignificant and excluded from the reduced set of predictors. Insignificance of mentioned effects bear evidence on independency of allocation from these observed characteristics.

Effect of marital status indicates a substantial reduction in the risk of GP exacerbations in single patients. This may be explained by the opportunity to allocate the income, efforts and time to personal needs, health related needs in particular.

There is substantial increased risk of gastropathy exacerbation in patients with higher grades of hypertension as the consequence of more intensive treatment regimens. 
Table II. Estimations of selected regressors effects on annual number of GP exacerbations in patients with AH by fixed effects and mixed Poisson model

\begin{tabular}{ccccccc}
\hline Predictors* & \multicolumn{3}{c}{ Poisson model } & \multicolumn{2}{c}{ mixed Poisson model } \\
\cline { 2 - 7 } & $\boldsymbol{\beta}$ & $\mathbf{m}$ & $\mathbf{p}$ & $\boldsymbol{\beta}$ & $\mathbf{m}$ & $\mathbf{p}$ \\
\hline Constant & $-0,650$ & 0,162 & 0,00006 & $-1,224$ & 0,252 & 0,00000 \\
\hline Gender & 0,213 & 0,084 & 0,01117 & 0,167 & 0,162 & 0,30042 \\
\hline Marital status (Single) & $-0,258$ & 0,091 & 0,00474 & $-0,326$ & 0,178 & 0,06720 \\
\hline AH Grade2 & 0,234 & 0,092 & 0,01112 & 0,406 & 0,178 & 0,02288 \\
\hline AH Grade3 & 0,581 & 0,192 & 0,00247 & 0,344 & 0,389 & 0,37598 \\
\hline Smoking (Smoke) & $-0,295$ & 0,168 & 0,07965 & $-0,430$ & 0,273 & 0,11592 \\
\hline Obesity (present) & $-0,230$ & 0,107 & 0,03244 & $-0,239$ & 0,191 & 0,21018 \\
\hline PP participant & $-0,269$ & 0,111 & 0,01560 & $-0,282$ & 0,109 & 0,00970 \\
\hline Group (2-5 against 1) & $-2,499$ & 0,395 & 0,00000 & $-1,898$ & 0,415 & 0,00000 \\
\hline Compliance & 0,081 & 0,049 & 0,09806 & 0,098 & 0,074 & 0,18386 \\
\hline AH duration & $-0,021$ & 0,008 & 0,00674 & $-0,007$ & 0,011 & 0,52843 \\
\hline Complaints*Group1 & 4,000 & 0,380 & 0,00000 & 4,153 & 0,381 & 0,00000 \\
\hline Complaints*Group2 & 7,008 & 0,774 & 0,00000 & 6,371 & 0,805 & 0,00000 \\
\hline Complaints*Group3 & 8,823 & 1,163 & 0,00000 & 7,621 & 1,206 & 0,00000 \\
\hline Complaints*Group4 & 11,319 & 1,549 & 0,00000 & 9,725 & 1,587 & 0,00000 \\
\hline Complaints*Group5 & 14,472 & 1,939 & 0,00000 & 12,002 & 1,997 & 0,00000 \\
\hline
\end{tabular}

Note: Residuals st.dev. (sigma) $=0.281128$; Patients effects sigma $=0.53893$;

Physicians effects sigma $=0.06552 ;$ Subsample (series) effects sigma $=3.49836$;

$\mathrm{AlC}=1403.5, \mathrm{df}=16 ;$ AlCmixed $=1404.5, \mathrm{df}=18$

*Predictors chosen by $R$ function STEP

We obtained surprisingly insignificant effect of the compliance. The possible explanation is confounding compliance effect with PP effect for one of the improvement related to compliance support. PP effect captures the effect of compliance on GP exacerbations risk reduction. Assessing risk in groups 2-5, we see that they have significantly lower risk compared to group 1, which is due to the fact that the first group is the most resistant and difficult to treat, since this contingent experienced the longest treatment with drugs that increase the risk of gastropathy.

The "Complaints ${ }^{\star}$ Group" effect represents the set of contrasts with no complaints and Group0 as reference levels. Significant positive effects bear evidences on the marginal increase in risk due to presence of complaints in the groups 1-5 compared to that in Group0 patients. Since Group0 patients had no complaints by definition, in fact the contrasts "Complaints ${ }^{\star}$ Group 1" - "Complaints* Group 5" express the increased risk of joining complaints in groups (1-5). The estimates suggest a significant increase in the risk in the presence of complaints across all groups (1-5) with the largest increase in the $5^{\text {th }}$, the least severe group.

The analysis of the information values of the research design and its individual elements is given in Table III. In the fixed effects model it is not possible to estimate the components of variation because they are merged with the model residual term, inflating the residual variance and undermining power of study. The advantage of the mixed model is the ability to identify the variation structure and evaluate its components, formed by design elements.
Afterward residual component is small, its share does not exceed $2 \%$ in the total variance. The share of the variation across patients is slightly higher (up to $2.5 \%$ ). The low proportion of dispersion of physician individual effects suggests homogeneity of physicians practices. The greatest portion takes the series variance across subsamples. That is, a series of patients clump in time and locations is an important element of the design, having been accounted for it increases the power of statistical tests of hypotheses. In addition, the apparent dominance of the variances of the design elements over residual variance indicates improvement in information value of the mixed model over fixed effect counterpart.

\section{INDIVIDUAL EXPECTED RISK ESTIMATIONS}

The emphasis of the study is on the expected shifts in individual risks due to participation in the $\operatorname{PP}\left(\Delta \pi_{i}\right)$. The problem is that the patient can participate in one alternative only, and the risk for the other is a marginal expected value that was not directly observed. Given the panel design, we have $\Delta \pi_{i t}$ notation, that is, individual risks by the years of observation.

We evaluated $\Delta \boldsymbol{\pi}_{\mathrm{it}}$ both by the model of fixed effects and by the mix model. Histograms of distributions of the modeled values $\Delta \boldsymbol{\pi}_{\hat{\mathrm{t}}}$ are displayed (Figure 1) with the basic distribution statistics as follows: Table IV.

The two-sided criterion for the significance of the differences asserts the identity of the mean two distributions: $t$ $=1,14, \mathrm{df}=2522, \mathrm{p}=0,253$. 
Anastasiia A. Akhmedova et al.

Table III. Variances shares of design elements (components of covariance structure) estimated by mixed Poisson model under complete and selected sets of predictors (\%)

\begin{tabular}{ccc}
\hline Components of model covariance structure & Complete predictors set & Selected predictors set \\
\hline Residuals & 1,89 & 0,63 \\
\hline Individual effects of patients & 2,04 & 2,30 \\
\hline Individual effects of physicians & 0,07 & 0,03 \\
\hline Effects of subsamples & 96,00 & 97,04 \\
\hline
\end{tabular}

Table IV. Basic distribution statistics

\begin{tabular}{ccccccc}
\hline Model & Min & $\mathbf{0 , 2 5}$ & Median & Avg & $\mathbf{0 , 7 5}$ & Max \\
\hline Fixed & $-3,453$ & $-0,470$ & $-0,313$ & $-0,351$ & $-0,170$ & 0,034 \\
\hline Mixed & $-3,607$ & $-0,558$ & $-0,344$ & $-0,365$ & $-0,090$ & 0,125 \\
\hline
\end{tabular}

These findings support dominating effectiveness of participation in PP over usual treatment, since in fact all $\Delta \boldsymbol{\pi}_{\text {it }}$ are negative. However, the dispersion of the estimates $\Delta \boldsymbol{\pi}_{\mathrm{it}}$ based on the mixed model is significantly higher: $\mathrm{F}(1346$, $1346)=1.7021, \mathrm{p}<2,2 \mathrm{e}-16$ with a dispersion ratio of 1,7 , which is typical for the mixed formulations.

To visualize a joint distribution of estimates $\Delta \boldsymbol{\pi}_{\text {it }}$ for the two models, we demonstrate their biplot (Figure 2). Coincidence of the ranks, as well as the tight linear correlation ( $\mathrm{r}$ $=0.883$ ) are obvious. The difference is only in the scaling, with greater variation in the mix model estimates.

We also investigated the distributions of PP participation related individual risk shifts for important factors. Particularly, we were interested in the patterns across sub-cohorts (Group0-Group5).

The greatest PP related risk reduction was in patients of Group 0 , that is, in patients with hypertension who do not receive antihypertensive therapy (Figure 3). In groups №1-№5 the effects of program participation are obvious but less pronounced, especially in the first two groups as the most complicated. One-way ANOVA Fisher test shows a high significance of the demonstrated regularities: $\mathrm{F}(5,1341)=30.74$ with $\mathrm{p}=1.1 \mathrm{e}-29$.

The risk augmentation due to presence of complaints is another important issue to consider. However, there is no significant difference in distributions, since the notches of two box plots overlap (Figure 4). This is also evident from one-way ANOVA Fisher test: $F(1,1345)=0.56$ with $\mathrm{p}=0.4529$.

We observed distributions of risk reduction due to PP participation by presence of complaints across sub-cohorts Group0-Group5. Distribution pattern is alike to distribution across sub-cohorts.

We also studied the distributions of risk reduction due to PP participation across $\mathrm{AH}$ grades, since patients with higher grades subjected to more intensive $\mathrm{AH}$ therapy and, therefore, to a higher risk of induced exacerbations of GP which is confirmed by correspondent significant effects (Tables I and II) (Figure 5). The greatest risk reduction due to PP participation observed in patients with first grade of blood pressure, while the second and especially third degrees reduced the gain due to participation in the
PP, one-way ANOVA Fisher test suggests significance of findings: $\mathrm{F}(2.1344)=26.67$ with $\mathrm{p}=1.1 \mathrm{e}-11$ (Figure 6).

\section{CONCLUSIONS}

1. We have elaborated a program for the prevention of gastropathy in patients taking antihypertensive therapy. Program is based on regulations of the Ministry of Health of Ukraine, adapted clinical guidelines, and other official sources of information, since holistic prevention of gastropathy is not depicted in any source.

2. The program differentiates patients by groups and furthermore allows one to consider each patient characteristics, taking into account income, age, gender, progression of the disease, comorbidity, drugs the patient takes. The established program based on cooperation of patient, general practitioner, and gastroenterologist. The general approaches are complemented with particular activities identified under delineated groups of patients with essential hypertension. One of the prime goal is to achieve compliance.

3. Data on 150 patients with AH collected by panel design with dynamic cohort traced up to 17 years. Two main cohorts were distinguished: those in prevention program (PP) and patients with usual treatment. Event of interest was incidence or aggravation of gastropathy (gastroduodenitis mainly). The numbers of exacerbations weres analyzed by the Poisson regression. Model parameters were estimated by MCMC algorithms with the Gibbs sampler using WinBUGS.

4. The main effect of program participation is significant in a model of fixed effects $(\beta=-0.269 ; \mathrm{p}=0.0156)$, and even more supportive in the mixed model $(\beta=-0.282 ; \mathrm{p}$ $=0.0097)$. Other components with a variable "PP participation", namely participation in the program given the group, participation in the program given GP duration, participation in the program given compliance, appeared to be nonsignificant, that suggest absence of substantial selection bias due to non-randomness of allocation.

5. The greatest risk reduction due to program participation was in patients of Group0, that is, in patients with hypertension who do not receive antihypertensive therapy. In groups №1-№5 with more aggressive hypertension 
treatment the effects of program participation are obvious but less pronounced.

\section{REFERENCES}

1. Shchorichna dopovid pro stan zdorovia naselennia, sanitarnoepidemiologichnu sytuaciiu ta rezultaty diialnosti systemy ohorony zdorovia Ukrainy. 2016 rik. MOZ Ukrainy, DU «UISD MOZ Ukrainy». Kyiv, 2017 p.516. (In Ukraine)

2. Substantiation of the model of clinical and economic efficiency evaluation of prevention, treatment, and dispenserization of the patients with comorbidity. The example of patients with arterial hypertension and duodenitis AA Akhmedova, OM Ocheredko Wiadomosci lekarskie (Warsaw, Poland: 1960) 71 (3 pt 1), 479-484.
3. Wooldridge, J.M. (2004), "Estimating average partial effects under conditional moment independence assumptions", the Institute for fiscal studies, Department of economics, ucl cemmap working paper cwp03/04, 38p.

4. Wooldridge, J.M. (2012), "Control Function Methods in Econometrics», mimeo, Michigan State University Department of economics, East Lansing, Ml 48824-1038 p.45

\section{Authors' contributions:}

According to the order of the Authorship.

\section{Conflict of interest:}

The Authors declare no conflict of interest

\section{CORRESPONDING AUTHOR Anastasiia A. Akhmedova \\ National Pirogov Memorial Medical University \\ 56 Pirigova St., 21018 Vinnytsya, Ukraine \\ e-mail:vi270291aaa@gmail.com}

Received: 20.11.2018

Accepted: 12.02 .2019 
PRACA POGLĄDOWA

REVIEW ARTICLE

\title{
RIGHT TO CHILD HEALTH IN CONTEXT OF NATURAL ENVIRONMENTAL SECURITY
}

\section{PRAWO DO ZDROWIA W WIEKU DZIECIĘCYM W KONTEKŚCIE BEZPIECZEŃSTWA ŚRODOWISKA NATURALNEGO}

\author{
Vitalii M. Pashkov' ${ }^{1}$, Maryna V. Trotska', Oleksii S. Soloviov \\ 'DEPARTMENT OF CIVIL, COMMERCIAL AND ENVIRONMENTAL LAW POLTAVA'S INSTITUTE OF LAW YAROSLAV MUDRYI NATIONAL LAW UNIVERSITY, \\ POLTAVA, UKRAINE \\ 2DEPARTMENT OF MANAGEMENT AND ECONOMICS OF PHARMACY NATIONAL MEDICAL ACADEMY OF POSTGRADUATE EDUCATION NAMED \\ P.L.SHUPYK, KYIV, UKRAINE
}

\begin{abstract}
Introduction: From different points of view, health in general and child health, in particular, constitute the highest value which preserves a significant amount of resource potential. Child health is understood as his/her state consisting of a certain system of elements (physical, psychological, etc.) each of which, on the one hand, is characterized by its specificity, and on the other hand, is in a complementary relationship with each other. A process of child health formation is influenced by a large number of various elements (social, economic, etc.) and the natural environment is one of them. Its compliance with certain rules and standards that form its qualitative status affects life and health both directly and indirectly, therefore, determination of interdependence between the natural environmental conditions and child health is important for understanding a causal link between the specified categories.

The aim: To study provisions of international acts and other sources in order to clarify the concept of child health and a role of the natural environment of a proper quality in the process of its formation.

Materials and methods: the paper examines provisions of international acts, some scientists' conclusions and other sources. Different authors'scientific viewpoints are studied with scientific methods in the context of medical and legal components. Within the framework of the system approach, as well as analysis and synthesis, the concepts of safe natural environment, health in general and child health, in particular, as well as importance of a safe natural environment for child health are researched.

Review: The concept of health is complex and depends on various factors including proper natural environmental conditions. Presence of dangerous environmental factors affects occurrence of various children diseases. In the context of the natural environmental security, it is possible to indicate both general and individual natural resources. Their deterioration may affect its condition at large.

Conclusions: Ensuring child health, his/her proper physical, psychological and other development is impossible without guaranteeing natural environmental security. Consumption of high-quality natural resources, observance of norms and standards for the environmental security allows the human body to develop fully accumulating relevant resources and attracting them at the right time. Ensuring the natural environment of a proper quality guarantees a greater range of opportunities for a child in the process of forming, coming into being and maintaining his/her physical and psychological well-being, which is a prerequisite for exercising his/her other rights and proper fulfillment of his/her duties in the process of his/her transformation and transition to adulthood.
\end{abstract}

KEY WORDS: natural environment, safe natural environment, health, child health

Wiad Lek 2019, 72, 3, 418-424

\section{INTRODUCTION}

In order to achieve sustainable development, environmental protection shall constitute an integral part of the development process and cannot be considered in isolation from it (principle 4 of the Rio Declaration on Environment and Development [1]). Human beings are at the centre of concerns for sustainable development. They are entitled to a healthy and productive life in harmony with nature (principle 1 of the Rio Declaration on Environment and Development). Hence, one of the means of implementing the process of development is the environmental protec- tion in general and its natural components, in particular. Its proper qualitative conditions ensure productivity of human life and health. At the general theoretical level, the authors have stated their positions [2-6] with regard to the factors that may affect health in general and child health, in particular, in one way or another, but for comprehensive understanding of potential threats to a child's body, it is necessary to consider the specified issues using a systematic approach.

From longstanding to emerging hazards, environmental factors are a root cause of a significant burden of death, 
disease and disability. They range from poor water quality and access, vector-borne disease and air pollution to toxic chemical exposures, climate change and degraded urban environments $[7, \mathrm{p} .5]$. The natural environment security is essential for implementing human life activities in conditions which contribute to preservation of his/her health, or at least do not aggravate it. Such security is of great importance for formation, development and functioning of a child's body, which, by virtue of its immaturity, incompleteness and insecurity, is more sensitive to various negative aspects of the environment. Children are particularly vulnerable to many environmental threats, including a contaminated and unsafe physical environment. This heightened susceptibility derives primarily from the unique biological features that characterise the various stages of development from conception to adolescence. But it is not just the biology of growth and development that leads to the special impact of environmental threats on children: fetuses, infants, children and adolescents are also special in the way a variety of social and psychosocial factors influence their exposure as well as the consequent health effects $[8$, p. 18]. Let us define the essential characteristics of the outlined topics and find out possible threats to child health as a result of various changes of the natural environment, including those of dangerous nature.

Of all vulnerable populations, children are a unique section of the population with a particular susceptibility to environmental agents. Starting at the foetal stage, the close physiological relationship between a pregnant woman and the foetus she carries makes the foetus vulnerable to dangerous agents the mother has been exposed, especially those affecting development. Many toxic or allergenic agents present in maternal blood may also be present in mother's milk and a number are capable of crossing the placental barrier. This potential for transfer of environmental contaminants from the mother to the foetus and the neonate, further reinforces the need to protect pregnant and breastfeeding women from environmental contamination as a way to ensure a healthy start in children's life (para. 5.3 of the Communication from the Commission to the Council, the European Parliament and the European Economic and Social Committee - A European Environment and Health Strategy [9]).

The degradation of the environment, through air pollution, noise, chemicals, poor quality water and loss of natural areas, combined with lifestyle changes, may be contributing to substantial increases in rates of obesity, diabetes, diseases of the cardiovascular and nervous systems and cancer - all of which are major public health problems for Europe's population [10]. Reproductive and mental health problems are also on the rise. Asthma, allergies [11], and some types of cancer related to environmental pressures are of particular concern for children [12]. Polluted indoor and outdoor air, contaminated water, lack of adequate sanitation, toxic hazards, disease vectors, ultraviolet radiation, and degraded ecosystems are all important environmental risk factors for children, and in most cases for their mothers as well. Particularly in developing coun- tries, environmental hazards and pollution are a major contributor to childhood deaths, illnesses and disability from acute respiratory disease, diarrhoeal diseases, physical injuries, poisonings, insect-borne diseases and perinatal infections [13]. Consequently, influence of the natural environment on child health is both indirect and direct. From the moment of his/her conception, a process of a child bearing and giving birth by a mother, child health may potentially be negatively affected which is directly dependent on a mother's lifestyle. From the moment of birth, the environmental impact on child health becomes immediate, and, consequently, effects of such impact may vary, depending on different circumstances.

\section{THE AIM}

To study provisions of international acts and other sources in order to clarify the concept of child health and a role of the natural environment of a proper quality in the process of its formation.

\section{MATERIALS AND METHODS}

the paper examines provisions of international acts, some scientists' conclusions and other sources. Different authors' scientific viewpoints are studied with scientific methods in the context of medical and legal components. Within the framework of the system approach, as well as analysis and synthesis, the concepts of safe natural environment, health in general and child health, in particular, as well as importance of a safe natural environment for child health are researched.

\section{REVIEW AND DISCUSSION}

According to Art. 1 of the Convention on the Rights of the Child [14], a child means every human being below the age of eighteen years unless under the law applicable to the child, majority is attained earlier.

Consequently, a child is defined as a person who, by the general rule, as a result of his/her life, has not reached the appropriate stage of both physical and spiritual formation which is conditioned by his/her behaviour, perception and awareness of the world.

The protection of children from environmental health threats is based on international agreements designed to ensure that children grow up and live in an environment that is conducive to the highest attainable level of health [1]. In other words, at the international level, legal regulation of public health, in particular child health, concerning various threats to health, including those of ecological origin, is evidence of its importance and necessity directly for children since they are expected to form quantitative and qualitative potential of the adult population of the state. It also plays an important role in development and prosperity of the state itself. In particular, let us consider provisions of the relevant legal acts in order to study the specified issues. 
According to part 1 of Article 12 of the International Covenant on Economic, Social and Cultural Rights, the States Parties to the present Covenant recognize the right of everyone to the enjoyment of the highest attainable standard of physical and mental health. The steps to be taken by the States Parties to the present Covenant to achieve the full realization of this right shall include those necessary for: (a) The provision for the reduction of the stillbirth-rate and of infant mortality and for the healthy development of the child.

In its turn, according to part 2 of Article 6 of the Convention on the Rights of the Child, States Parties shall ensure to the maximum extent possible the survival and development of the child. In other words, one of the responsibilities of the States Parties is to ensure healthy development of children through maintaining an appropriate level of physical and mental health that cannot be implemented without taking care of security of the natural environment which may pose a potential threat. For example, in Estonia, one of the five strategic goals of the Strategy for Children and Families 2012-2020 [15] is defined as the rights of children are guaranteed and a functional child protection system is created in order to value each child and the kind of safe environment that supports the development and well-being of children. Their higher vulnerability is an important reason to take specific action for this population group when both assessing and managing risks. Furthermore, the economic impacts of environment-related childhood illnesses highlight the need to pay particular attention to children. This vulnerability and related economic impact has guided the focus on children throughout the Strategy and the choice of the specific pollutants to be addressed (para. 5.3 of the Communication from the Commission to the Council, the European Parliament and the European Economic and Social Committee - A European Environment and Health Strategy [9]).

According to part 1 of Article 24 of the Convention on the Rights of the Child, states Parties recognize the right of the child to the enjoyment of the highest attainable standard of health and to facilities for the treatment of illness and rehabilitation of health. States Parties shall pursue full implementation of this right and, in particular, shall take appropriate measures: (c) To combat disease and malnutrition, including within the framework of primary health care, through, inter alia, the application of readily available technology and through the provision of adequate nutritious foods and clean drinking-water, taking into consideration the dangers and risks of environmental pollution. Hence, the State Parties shall take all measures contributing to child health at most, including through elimination of a potential danger and risks of environmental pollution.

Furthermore, the 1997 Declaration of the Environmental Leaders of the Eight on Children's Environmental Health includes the following policy approaches, which may contribute to the development of policies aimed at the protection of children in Europe: - Preventing exposure is the most effective way of protecting children's health from environmental threats. Governments should therefore develop policies that seek to prevent childhood diseases by preventing exposures to environmental agents, on the basis of the precautionary principle. - National policies should take into account the specific exposure pathways and doseresponse characteristics of children when conducting environmental risk assessment and setting protective standards. - Research should be promoted in order to gain a better understanding of the particular exposure and sensitivities of infants and children to environmental hazards. Exchange of information on research results and the development of regulatory systems should also be promoted. - Awareness of the environment and health should be promoted, so as to enable [8, p. 13]. All these declarations and policy statements show that the commitment to a healthier and safer environment continues at the highest level. The awareness that children lie at the very heart of sustainable development makes the protection of their health and the promotion of their wellbeing a highly strategic issue. Europe has been at the forefront in recognising the fundamental rights of children and in establishing principles such as the right to selfdetermination, health and sustainable environment, and will continue to play a leading role in the further development and application of these principles [8, p. 15].

Consequently, when analyzing provisions of the legal grounds of the international character concerning the relationship between child health, natural environmental security and threats to it, and, therefore, and to child health, we can conclude that, on the one hand, a child is, by virtue of his/her state determined by his/her age, perception of the world, dependence on adults and other factors, is a special subject, that, in his/her formation, first of all, is vulnerable to various threats, and it is necessary to pay attention at this while forming the state policy. On the other hand, a lack of rational government decisions in the context of preventing and preserving a proper quality of the environment will also have an impact on child health both directly and indirectly.

According to dictionary sources, child health encompasses the physical, mental, emotional, and social well-being of children from infancy through adolescence [16]. Child health is a state of physical, mental, intellectual, social and emotional well-being and not merely the absence of disease or infirmity [17]. Health is influenced by a variety of factors, the main ones being genetic inheritance and the economic, social, psychological and physical environment. These factors interact in complex ways, which are specific for each disease and for specific individuals and population groups [8, p. 12]. That is, child health is determined through a system of appropriate conditions provided by a set of factors allowing not only to avoid diseases, but also promote development of a child at the spiritual, intellectual, emotional and other levels. The environment, in particular its natural component, is not least in this process of formation, coming into being and strengthening child health. A growing body of research suggests that increasing children's nature interactions can have positive benefits for their health-related quality of life (HRQOL); however, 
researchers have yet to examine how geographical context influences this relationship [18].

Pursuant to the Model Law on Environmental Protection [19] drafted under the auspices of the Council of Europe and adopted in 1994, along with such natural resources as air, outer space, water, soil, climate, fauna and flora in their interaction, the concept of "the environment" includes the values that form the surroundings created by man, as well as quality of life and conditions to the extent in which they have or may have an impact on human welfare and health. According to para. 2 of part 1 of the Environmental Protection Act 1990 [20], the «environment» consists of all, or any, of the following media, namely, the air, water and land; and the medium of air includes the air within buildings and the air within other natural or man-made structures above or below ground. With reference to vocabulary sources 'environment' means (a) fauna and flora; (b) soil, water, air, climate and landscape; and (c) cultural heritage and the built environment; (and includes occupational health and safety and projects' social effects in the non EU-countries) [21]. The EIB (European Investment Bank) uses the term 'natural' to refer to all those processes and components in the environment, which are spontaneously formed and not, or minimally, influenced by man [22]. Furthermore, at the general theoretical level, it is indicated that in an objective sense, "nature" as used here refers to physical features and processes of nonhuman origin that people ordinarily can perceive, including the "living nature" of flora and fauna, together with still and running water, qualities of air and weather, and the landscapes that comprise these and show the influence of geological processes. As such, "nature" overlaps substantially with "natural environment," an environment with little or no apparent evidence of human presence or intervention, and the two terms have been used interchangeably [23]. In other words, there are two concepts related to each other but having a slightly different meaning, though interrelated and interdependent.

Attribution of the role of the environment in the development of diseases, and the development of novel assessment approaches aimed at taking the inherent complexity and uncertainty of the environment and health interactions into account, remain a subject of intense debate [24-26]. Although the results of certain studies, which are often controversial and require in-depth research, show that interacting with nature is positively associated, for instance, with the mental health of children and teenagers [27]. Developing the scientific basis to protect child health will require a sustained effort by many disciplines. When data are insufficient, the development of a sound basis to deal with uncertainty may be equally or more challenging [8, p. 202].

The World Health Organisation (WHO) defines «environment and health» as including «both the direct pathological effects of chemicals, radiation and some biological agents, and the effects (often indirect) on health and well-being of the broad physical, psychological, social and aesthetic environment, which includes housing, urban development, land use and transport» [28]. Obviously, the specified elements are in a reciprocal relationship and understood in the context of child health, given that children have a unique vulnerability. They go through a succession of distinct developmental and learning phases e.g. the foetal, neonatal, school-age and pubertal phases. At each of these stages, a child is vulnerable and exposed to different agents: an adolescent may be more vulnerable to attacks on the reproductive system, while a baby is more vulnerable to dust at ground level. Children also face a potentially longer exposure to toxicants. In view of their life expectancy, children are the section of the population likeliest to endure exposure for the longest time (p. 5.3 Communication from the Commission to the Council, the European Parliament and the European Economic and Social Committee - A European Environment and Health Strategy [9]). Every person's right to a healthy environment is a good guiding goal for policies [8, p. 195].

Policies of the European Community concerning the environment are aimed at: - preserving, protecting and improving the quality of the environment, - protecting human health health (Art. 174 of Treaty establishing the European Community [29]). Article 174 of the Treaty provides that Community policy on the environment is to contribute to, inter alia, the preservation, protection and improvement of the quality of the environment, the protection of human health and the prudent and rational utilisation of natural resources and that it is to be based on the precautionary principle (part 1 of the enacting clause of Directive 2001/42/EC of 27 June 2001 on the assessment of the effects of certain plans and programmes on the environment). Moreover, in part 3 of Parma Declaration on Environment and Health, the main problems related to the environment and health determine: (b) the health risks to children and other vulnerable groups posed by poor environmental, working and living conditions (especially the lack of waterand sanitation) [30, p. 143].

A person's overall well-being is largely impacted by whether they live in an environment that supports their physical health. Included in national environment is drinking water quality, air quality and total toxic chemical pollution per square mile. It also encompasses how at risk a state's citizens are for chronic, long-term health effects due to pollution [31]. Understanding of the concept of impact assessment is quite important since it is regarded as the application of comprehensive and systematic foresight in policy-making - is a familiar approach in the environmental field. Many countries have legislation mandating practices such as environmental impact assessment, strategic environmental assessment and sustainability appraisal. These are routinely applied in the course of formulating and implementing policy at the local, national and supranational level [32]. WHO defines health impact assessment as "a combination of procedures, methods and tools by which a policy, programme or project may be judged as to its potential effects on the health of a population, and the distribution of those effects within the population" [33].

In its turn, a safe natural environment is characterized by 
a lack of hazards that can affect human health. Such hazards may have different sources of origin, both natural and others, which will be a prerequisite for a launch of negative processes in the natural environment and creation of potentially negative effects on human health. Since 2010, important new evidence has emerged, particularly with respect to the links between air pollution, endocrine disruptors, mercury, and climate change and several health outcomes, notably major noncommunicable diseases - including cardiovascular and respiratory diseases and cancer [30, p. 7]. Trends in exposures to environmental contaminants should be evaluated as part of a process to define the role of environmental contaminants in these and other childhood illnesses. For example, data on exposures to environmental contaminants associated with neurodevelopmental disorders in children, such as lead and mercury, should be considered in conjunction with the data on neurodevelopmental disorders in children [34].

In other words, any negative factors that can affect the natural environmental security represent a potential threat that can be reflected in their various manifestations and, above all, on child health. For example, in children under five years, up to $26 \%$ of all deaths could be prevented, if environmental risks were removed [35]. The prevalence of many childhood diseases varies by race/ethnicity and family income. For example, children of lower-income families and children of color are more likely to have had an asthma attack in the previous 12 months than are white children and/or children from higher-income families $[36,37]$. Better understanding of differences in the social distribution of environmental quality can be helpful for policy, since specific population groups, such as those on low incomes, children, and the elderly, may be more vulnerable - mostly due to their health, economic and educational status, access to health care, and lifestyle factors that affect their adaptation and coping capacities [38-40].

In the medical sense, the environment includes the surroundings, conditions or influences that affect an organism (Davis, 1989). Along these lines, Last (2001) defined the environment for the International Epidemiological Association as: "All that which is external to the human host. Can be divided into physical, biological, social, cultural, etc., any or all of which can influence health status of populations ...». According to this definition, the environment would include anything that is not genetic, although it could be argued that even genes are influenced by the environment in the short or long-term [41].

Consequently, sources of influence may have both natural and of different origins, which can affect human health. Analysing the latest data on the environment-disease nexus and the devastating impact of environmental hazards and risks on global health, backed up by expert opinion, this report covers more than 100 diseases and injuries. The analysis shows that $23 \%$ of global deaths (and $26 \%$ of deaths among children under five) are due to modifiable environmental factors [42]. WHO estimates that in developing countries $80 \%$ of illnesses and more than third of deaths are the result of drinking contaminated water. More startling is that approximately $60 \%$ of all infant mortality worldwide is linked to water-related infectious and parasitic diseases [43]. The growing recognition of the multiple factors behind major public health issues, such as obesity, cancer, mental illness, and other chronic diseases, as well as the ageing of the European population, have generated an increasing interest in the role of residential environments and access to green spaces. Still, the potential of using green space to promote health is not sufficiently exploited, and is occasionally considered as an 'extra', luxury detail in life [44]. Insufficient attention is paid to the natural potential that could be used to restore, preserve and improve child health. While public health experts have traditionally associated environmental health with the absence of contaminants, toxins, and pollution, they may have failed to consider an equally valid alternative - how the environment can improve human health in general and children's health specifically [45].

All human beings depend on the environment in which we live. A safe, clean, healthy and sustainable environment is integral to the full enjoyment of a wide range of human rights, including the rights to life, health, food, water and sanitation. Without a healthy environment, we are unable to fulfil our aspirations or even live at a level commensurate with minimum standards of human dignity [46]. When considering the above provisions in the context of ensuring a child's ability to exercise his/her right to health, we should state that it is not possible in the natural environment that is threatening him/her. A child's right to a safe environment is directly linked to the right to health. In a dangerous environment, health is quite difficult to maintain at the proper level and is very easy to lose. There is growing evidence that indicates direct exposure to nature is essential for children's physical and emotional health, improving their cognitive abilities and resistance to negative stresses and depression [45].

Without a healthy environment, we are unable to fulfil our aspirations or even live at a level commensurate with minimum standards of human dignity. At the same time, protecting human rights helps to protect the environment [46]. For instance, in the Gabcikovo-Nagymaros Case [47] (1997), Judge Weeramantry wrote that « $[\mathrm{t}]$ he protection of the environment is... a vital part of contemporary human rights doctrine, for it is a sine qua non for numerous human rights such as the right to health and the right to life itself... damage to the environment can impair and undermine all the human rights spoken of in the Universal Declaration and other human rights instruments» [48]. Among the various ways of restoring violated rights, first of all, we can talk about the judicial system which, using its levers, has an opportunity to restore the violated right and justice. "Environmental justice" is now a growing issue in Europe. It has at its heart the premise that the current disproportionate impacts of environmental hazards must be addressed, but it is also focusing on the availability and use of environmental resources [49]. However, implementation and enforcement are difficult [8, p. 195]. For example, Boyle [50] and several others note that a rights approach to environmental justice may be potentially problematic in practice. Often states in Europe and elsewhere have constitutions that maintain 
the 'right' to health and 'sufficient' environments. Some include procedural rights also. Yet articulation of these rights within current legal frameworks proves difficult [50]. One can distinguish its three directions: - national: the state of environmental injustice within Europe and European countries; - international: the extent to which Europe imposes injustice on other countries; - generational: the extent to which Europe imposes injustices on future generations, in Europe and globally [8, p. 192].

In other words, «ecological justice» is characterized by solving relevant issues, which, on the one hand, are related to pollution, and on the other hand, the proper use of natural resources. Each of the identified spheres affects human health, especially child health, in one way or another, either directly or indirectly. The degree of dissemination of the above-mentioned issues, legal regulation, ways of resolving and their consequences are spreading both geographically and temporally. In particular, it can relate to one, several states, and the entire planet. From the time viewpoint, the effects of such influence can be both short-term and longterm, those that may occur earlier or over a longer period of time.

\section{CONCLUSIONS}

Inevitably, all rights depend on the environmental security in general and the natural environmental security, in particular, but the right to health depends first and foremost. Ensuring the environmental security directly affects health of both adult population and children and is a guarantee of its preservation and improvement. Ensuring the natural environment of the proper quality guarantees a greater range of opportunities for a child in the process of forming, coming into being and maintaining his/her physical and psychological well-being, which is a prerequisite for exercising his/her other rights and proper fulfillment of his/her duties in the process of his/her transformation and transition to adulthood. Appropriate implementation of the measures aimed at improving and maintaining proper child health depends on proper ensuring the right to life, health and the natural environment. In its turn, appropriate legal regulation, both at the level of individual states and internationally, will allow to define limits of proper behaviour more clearly, understand results that can be obtained and ways to restore violated rights, should it turn out to be necessary.

\section{REFERENCES}

1. The Rio Declaration on Environment and Development, 1992. See at: https://www.un.org/documents/ga/conf151/aconf15126-1annex1. htm.

2. Vitalii Pashkov, Olena Batyhina, Maryna Trotska Legal Restraints of Pesticide Effect on Human Organism and Environment under International Legislation. Wiadomości Lekarskie 2017, vol. LXX, №. 2, czll, pp. 366-372.

3. Vitalii Pashkov, Olena Batyhina, Maryna Trotska Concept of Waste and Its Impact on Human Health. Wiadomości Lekarskie 2017, vol. 70, №. 5, pp. $964-969$.
4. Vitalii Pashkov, Olena Batyhina, Maryna Trotska International Legal Regulation of Impact of Occupational Injuries and Diseases on Agricultural Workers' Health. Wiadomości Lekarskie 2017, vol. 70, №. 5, pp. 953-958.

5. Gutorova N, Batyhina 0, Trotska M Legal protection of public health through control over genetically modified food. Wiadomości Lekarskie 2018, vol. 71, No. 2, pt 2, pp. 366-370.

6. Vitalii Pashkov, Harkusha Andrii, Gnedyk Yevgen. Rehabilitation tourism as a part of medical tourism. Acta Balnejligica, vol. LX, No. 1(151), 2018, pp. 48-53.

7. Health and environment : tools for effective decision-making : review of initial findings / the WHO-UNEP Health and Environment Linkages Initiative (HELI), 2004, $28 \mathrm{p}$.

8. Children's health and environment: A review of evidence $A$ joint report from the European Environment Agency and the WHO Regional Office for Europe / Edited by: Giorgio Tamburlini, Ondine S. von Ehrenstein, Roberto Bertollini. Luxembourg: Office for Official Publications of the European Communities, 2002, $225 \mathrm{p}$.

9. Communication from the Commission to the Council, the European Parliament and the European Economic and Social Committee - A European Environment and Health Strategy. See at: https://eur-lex.europa.eu/legal-content/EN/TXT/?qid=1531571768652 \&uri=CELEX:52003DC0338

10. Eugloreh, 2009. The Report on the Status of Health in the European Union.

11. GA2LEN 2010. Global Allergy and Asthma European Network. See at: www.ga2len.net.

12. Chapter 5: Environment, health and quality of life. See at: https://www. eea.europa.eu/soer/synthesis/synthesis/chapter5.xhtml.

13. The environment and health for children and their mothers. See at: http://www.who.int/ceh/publications/factsheets/fs284/en/.

14. Convention on the Rights of the Child of 20 November 1989. See at: https://www.ohchr.org/en/professionalinterest/pages/crc.aspx.

15. Strategy of children and families 2012-2020. See at: https://www. sm.ee/sites/default/files/content-editors/Ministeerium_kontaktid/ Valjaanded/lpa_kokkuvote_eng.pdf.

16. The free dictionary by farlex/Children's Health. See at: https://medicaldictionary.thefreedictionary.com/Children $\% 27 s+$ Health.

17. Child health - Definition. See at: http://www.azftf.gov/WhoWeAre/ Board/Documents/Program\%20Committee/Health/January\%20 13,\%202011\%20Meeting $\% 20-\% 20$ Health/07\%20Child $\% 20$ Health\%20Definition\%20Recommendation.pdf.

18. Suzanne Tillmann, Andrew F. Clark and Jason A. Gilliland Children and Nature: Linking Accessibility of Natural Environments and Children's Health-Related Quality of Life. See at: http://www.mdpi.com/16604601/15/6/1072/htm.

19. Brynchuk M. M. Ekologicheskoye pravo (pravo okruzhayushchey sredy): Uchebnik dlya vysshikh yuridicheskikh uchebnykh zavedeniy [Ecological Law (Environmental Law): Textbook for Higher Law Schools], Moscow, Yurist, 1998, $688 \mathrm{p}$.

20. Environmental Protection Act (United Kingdom), 1990 (Chapter 43). See at: https://www.ecolex.org/details/legislation/environmental-protectionact-1990-chapter-43-lex-faoc005515/?q=security+of+the+natural+ environment\&type=legislation\&xdate_min=\&xdate_max $=$.

21. EIB Environmental And Social Practices Handbook-2007, §201.

22. The EIB Statement of Environmental and Social Principles and Standards, 2009. See at: http://www.eib.org/attachments/strategies/ eib_statement_esps_en.pdf. 
23. Hartig, T.; Mitchell, R.; de Vries, S.; Frumkin, H. Nature and Health. Annu. Rev. Public Health 2014, 35, pp. 207-228.

24. Saracci, R.; Vineis, P., 2007. Disease proportions attributable to environment. Environmental Health 6: 38.

25. Knol, A.B.; Petersen, A.C.; van der Sluijs, J.P.; Lebret, E., 2009. Dealing with uncertainties in environmental burden of disease assessment, Environmental Health, 2009, 8: 21.

26. Briggs, D., Abellan, J.J., Fecht, D., 2008. Environmental inequity in England: Small area associations between socio-economic status and environmental pollution, Social Science and Medicine 67, pp. 1612-1629.

27. TillmannS., Tobin D., William AvisonW., GillilandJ. Mental health benefits of interactions with nature in children and teenagers: a systematic review. See at: https://jech.bmj.com/content/early/2018/06/27/jech2018-210436.

28. Environment and health. The European Charter and commentary. Copenhagen, WHO Regional Office for Europe, 1990 (WHO Regional Publications, European Series, № 35).

29. Treaty establishing the European Community (Consolidated version 2002). See at: https://eur-lex.europa.eu/legal-content/EN/ TXT/?uri=CELEX\%3A12002E\%2FTXT.

30. Improving environment and health in Europe: how far have we gotten? Copenhagen, WHO Regional Office for Europe, 2015, 152 p.

31. Natural Environment Rankings. See at:https://www.usnews.com/news/ best-states/rankings/quality-of-life/natural-environment.

32. Health and the environment in the WHO European region. Creating resilient communities and supportive environments, World Health Organization, 2013, 46 p.

33. Health impact assessment: main concepts and suggested approach. Gothenburg consensus paper, Brussels, WHO European Centre for Health Policy, 1999.

34. Tracey J. Woodruff, Daniel A. Axelrad; Amy D. Kyle; Onyemaechi Nweke; Gregory G. Miller; and Bradford J. Hurley Trends in Environmentally Related Childhood IIInesses. See at: https://pdfs.semanticscholar. org/34cf/446b569a4c4c786381f9ac9b72fffb79d676.pdf.

35. Public health and environment. See at: http://www.who.int/gho/phe/en/.

36. Woodruff T., Axelrad D., Kyle A., Nweke 0,, Miller G. America's Children and the Environment: Measures of Contaminants, Body Burdens, and IIInesses. Washington, DC: US Environmental Protection Agency, 2003 (Report No. EPA 240-R-03-001). See at: http://www.epa.gov/ envirohealth/children.

37. WoodruffT., Axelrad D., Kyle A. America's Children and the Environment: A First View of Available Measures. Washington, DC: US Environmental Protection Agency, 2000 (Report No. EPA 240-R-00-006).
38. EC, 2008. Addressing the social dimensions of environmental policy -a study on the linkages between environmental and social sustainability in Europe. Pye, S.; Skinner, I.; Meyer-Ohlendorf, N.; Leipprand, A.; Lucas, K.; Salmons, R.

39. Zuurbier, Moniek; Van den Hazel, Peter (eds); PINCHE project: Final reportWP4 Risk and Health Impact Assessment. Public Health Services Gelderland Midden, Arnhem, The Netherlands, 2005.

40. The Distributional Effects of Environmental Policy. Serret, Y.; Johnstone, N. (Eds.). Paris, OECD, 2006.

41. Prüss-Üstün, Annette,JWolf, CCorvalán, RBosandM Neira. Preventing disease through healthy environments. Towards an estimate of the environmental burden of disease, Paris, World Health Organization, 2016, $106 \mathrm{p}$.

42. Preventing disease through healthy environments: a global assessment of the burden of disease from environmental risks. See at: http://www. who.int/quantifying_ehimpacts/publications/preventing-disease/en/.

43. WHO and UNICEF. Global Water Supply and Sanitation Assessment 2000 Report. See at: http://www.who.int/water_sanitation_health/ Globalassessment/GlobalTOC.htm.

44. Environment and human health. Joint EEA-JRC report, 2003, №. 5, 112 p.

45. Martha Driessnack. Children and Nature Deficit Disorder. See at: https:// onlinelibrary.wiley.com/doi/full/10.1111/j.1744-6155.2009.00180.x.

46. Special Rapporteur on human rights and the environment (former Independent Expert on human rights and the environment). See at: https://www.ohchr.org/EN/Issues/Environment/SREnvironment/ Pages/SRenvironmentIndex.aspx.

47. Case Concerning the Gabcikovo-Nagymaros Project (Hungary-Slovakia) Judgment of 25 September 1997, B. ICJ/692 9210707575. See at: http:// www.icj-cij.org/files/case-related/92/092-19970925-JUD-01-00-EN.pdf.

48. Pevato, P. M. A Right to Environment in International Law: Current Status and Future Outlook, RECIEL, vol. 8 issue 3 (1999), at 315.

49. Stephens, C. et al., 2000. Our view. Act local, think global? Or act local, act global? How international environmental and social justice can be achieved if local governments reach out to each other, EG - Local Environment News, No. 4.

50. Boyle, A., 1996. The role of international human rights law in the protection of the environment, in Human rights approaches to environmental protection (edited by A. Boyle and M. Anderson), Oxford University Press/ Clarendon Press, 0xford, pp. 43-71.

\section{Authors' contributions:}

According to the order of the Authorship.

\section{Conflict of interest:}

The Authors declare no conflict of interest.

\section{CORRESPONDING AUTHOR Maryna V. Trotska}

Department of Civil, Commercial and Environmental Law, Poltava Law Institute of Yaroslav the Wise National Law University 6 Monastyrska str., 36000, Poltava, Ukraine

tel: +380954909415

e-mail: marinatrockaa@ukr.net

Received: 24.11.2018

Accepted: 15.02.2019 
PRACA POGLA¿DOWA

REVIEW ARTICLE

\title{
ZABURZENIA SNU W CHOROBIE PARKINSONA
}

\section{SLEEP DISORDERS IN PARKINSON'S DISEASE}

\author{
Magdalena Doręgowska, Monika Rudzińska-Bar \\ KATEDRA I KLINIKA NEUROLOGII, SLASKI UNIWERSYTET MEDYCZNY W KATOWICACH, KATOWICE, POLSKA
}

\begin{abstract}
STRESZCZENIE
Zaburzenia snu są częstą manifestacją pozaruchową w chorobie Parkinsona (PD - Parkinson `s disease). Są one zróżnicowane, dotyczą różnych faz snu, a także mogą występować w ciągu dnia. Korelują z szybszą progresją objawów ruchowych oraz pogorszeniem jakości życia pacjentów. W tym opracowaniu omówiono fizjologię snu, najczęściej występujące w przebiegu PD zaburzenia snu, takie jak: bezsenność, zaburzenia snu fazy REM (RBD-REM sleep behaviour disorder), nadmierna senność w ciągu dnia (EDS - excesive daytime sleepiness), obturacyjny bezdech senny (OSAS - obstructive sleep apnea syndrome). Przedstawiono ich przyczyny, manifestację kliniczną, także możliwości diagnostyki i leczenia. Zwrócono też uwagę na współwystępowanie różnych innych objawów pozaruchowych, takich jak: ból, depresja, czy nokturia i ich wzajemne korelacje.
\end{abstract}

SŁOWA KLUCZOWE: choroba Parkinsona, sen, zaburzenia snu, zaburzenia snu fazy REM, RBD, bezsenność, nadmierna senność w ciągu dnia, EDS

\begin{abstract}
Sleep disorder are common non-motor symptoms in Parkinson's disease (PD). They can be found in different sleep stages or appear during the daytime. They correlate with faster progression of motor problems and lower quality of a patient's life. Sleep physiology, different sleep dysfunction such as: RBD-REM sleep behavior disorder, EDS - excessive daytime sleepiness, insomnia, OSAS-obstructive sleep apnea syndrome, and their clinical manifestation have been presented in this review. Diagnostic and therapy possibilities have been summarized as well. Particular attention has also been paid to the coexistence of various non-motor symptoms such as pain, depression or nocturia, and their correlations with sleeping problems.
\end{abstract}

KEY WORDS: Parkinson's disease, PD, REM sleep behavior disorder, sleep, sleep disorders, excessive daytime sleepiness, EDS

\section{WSTĘP}

Sen jest niezbędnym elementem pozwalającym zachować równowagę homeostatyczną organizmów żywych. Umożliwia on konsolidację pamięci, stymulację układu odpornościowego, homeostazę energetyczną. Człowiek przesypia średnio $1 / 3$ życia. Zaburzenia snu występują często w populacji ludzkiej i obejmują ponad 80 jednostek chorobowych. Niejednokrotnie towarzyszą także chorobom neurodegeneracyjnym, które są coraz istotniejszym problemem w związku ze starzeniem się społeczeństwa. $\mathrm{W}$ przypadku choroby Parkinsona (PD - Parkinson disease) mogą wyprzedzać objawy ruchowe nawet o dekadę.

Częstość występowania zaburzeń snu w przebiegu PD szacuje się na 40 do nawet $90 \%$ chorych [1]. Może to być bezsenność nocna prowadząca do odwrócenia rytmu dobowego lub zaburzenia ruchowe związane ze snem, takie jak okresowe ruchy kończyn we śnie (PLMS - periodic limb movements of sleep) bądź zespół niespokojnych nóg (RLS - restless leg syndrome). Inną częstą parasomią występującą w PD są zaburzenia zachowania fazy snu REM (RBD-REM sleep behaviour disorder). Najczęstszymi przyczynami przerwania ciągłości snu u pacjentów z PD są objawy autonomiczne, takie jak: nocturia (79\%), zaburzenia ruchowe spowodowane nocnymi stanami off skutkującym trudnościami zmiany pozycji ciała podczas leżenia w łóżku $(65 \%)[2,3]$ lub też bolesne skurcze nóg (55\%) [4]. Nierzadko chorzy skarżą się na żywe sny lub koszmary senne, których występowanie łączy się z wysoką wieczorną dawką lewodopy. Pacjenci doświadczają także nadmiernej senności w ciągu dnia (EDS - excessive daytime sleepiness), która może być związana bezpośrednio z nocnymi zaburzeniami snu, terapią dopaminergiczną, ale także depresją $[2,5,6]$. Są to problemy niejednokrotnie niediagnozowane z powodu niewielkiej świadomości chorych, samotnego mieszkania, a także z powodu ograniczonego dostępu do specjalistów zajmujących się tymi dolegliwościami. Niemniej jednak, zaburzenia snu istotnie wpływają na jakość życia pacjentów [2], a ich nasilenie koreluje z szybszą progresją objawów oraz pogorszeniem procesów poznawczych $[7,6]$.

Niektórzy pacjenci z PD wykazują poprawę stanu motorycznego tuż po przebudzeniu rano, jeszcze przed zażyciem leku, które zazwyczaj trwa 1-3 godzin. Zjawisko to nazywane jest „benefitem snu” i jest zgłaszane przez 33-55\% pacjentów z PD; niemniej mechanizm leżący u jego podstaw pozostaje niejasny [8].

Prawidłowe różnicowanie i diagnostyka zaburzeń snu mogą mieć kluczowy wpływ na przebieg leczenia i poprawę jakości życia pacjentów. 


\section{FIZJOLOGIA SNU}

Sen to stan odmiennej świadomości, który charakteryzuje się: - przyjęciem charakterystycznej pozycji spoczynku;

- zaprzestaniem aktywności ruchowej;

- utratą świadomego kontaktu z otoczeniem;

- zmniejszoną reaktywnością na bodźce zewnętrzne;

- pełną odwracalnością, możliwością powrotu do pełnej świadomości pod wpływem adekwatnych bodźców, cyklicznie zmieniającą się aktywnością OUN.

Fizjologiczny sen jest niezbędny do prawidłowego funkcjonowania mózgu. Kluczowym ośrodkiem snu i czuwania jest podwzgórze. Neurony promujące sen zlokalizowane są w obszarze przedwzrokowym przedniego podwzgórza, natomiast odpowiadające za czuwanie w obszarze tylnym podwzgórza. Podstawowym ośrodkiem regulującym proces snu i czuwania jest jądro nadskrzyżowaniowe(SCN suprachiasmatic nucleus) mieszczące się w części bocznej podwzgórza. Jest ono określane jako wewnętrzny „zegar biologiczny”, a jego głównym egzogennym czynnikiem regulującym jest światło. SCN otrzymuje informację świetlną z drogi siatkówkowo-podwzgórzowej i wysyła sygnał do licznych połączeń neuronalnych w innych częściach podwzgórza oraz szyszynki, gdzie uwalniana jest melatonina. SCN posiada także receptory dla melatoniny, współdziałając w pętli sprzężenia zwrotnego z szyszynką. Intensywne wydzielania i wysokie stężenie melatoniny w nocy w istotny sposób wpływa na prawidłowy rytm dobowy.

Prawidłowy, fizjologiczny sen składa się z 4 faz:

NREM 1 - pierwsze stadium snu płytkiego, charakteryzuje się zmniejszeniem świadomości, zapisem EEG - występowanie fal alfa i thetha o amplitudzie nieprzekraczającej $75 \mu \mathrm{V}$ i częstotliwości 2-7 Hz;

NREM 2 - stadium 2 charakteryzuje się brakiem reaktywności na bodźce oraz występowanie serii fal podobnych do fal alfa, o częstotliwości $12-14 \mathrm{~Hz}$ i amplitudzie $50 \mu \mathrm{V}$ zwanych wrzecionami snu, a także ujemnych, fal ostrych, po których występuje fala dodatnia nazywana zespołem K;

NREM 3 - sen wolnofalowy, głęboki, charakteryzuje się występowaniem fal delta o amplitudzie powyżej $75 \mu \mathrm{V}$ i częstotliwości $2 \mathrm{~Hz}$;

REM - faza snu, w której występują szybkie ruchy gałek ocznych (Rapid Eye Movement). Na tym etapie snu występuje wysoka aktywność mózgu, w zapisie EEG dominują niskonapięciowe fale szybkie, trójkątne fale $(3-5 \mathrm{~Hz})$, tzw. zęby piły, pojawiają się marzenia senne, fizjologicznie tej fazie towarzyszy atonia mięśniowa.

Fazy te w ciągu życia osobniczego zmieniają swój stosunek trwania od dużej ilości snu NREM3 w dzieciństwie do jego skrócenia $\mathrm{z}$ biegiem lat, aż do istotnego spadku odsetka snu wolnofalowego na starość.

W prawidłowym, fizjologicznym śnie każdy cykl 4 faz trwa w przybliżeniu 90-100 minut. Zazwyczaj w ciągu nocy występuje od 4 do 6 takich cykli.

\section{BEZSENNOŚĆ}

Bezsenność to utrudnione zasypianie lub trudności w utrzymaniu snu występujące więcej niż 3 razy w ty- godniu i istotnie upośledzające funkcjonowanie w ciągu dnia. W PD zaburzenie to występuje bardzo często, według różnych autorów od 60 do $80 \%[5,9]$ pacjentów doświadcza bezsenności. Często współistnieje ona z innymi zaburzeniami snu, prowadząc do znacznego pogorszenia funkcjonowania w ciągu dnia.

W przypadku pacjentów z PD głównym problemem często nie jest samo zasypianie, a liczne przebudzenia nocne uniemożliwiające kontynuowanie snu. Przyczyną tych problemów może być nasilenie w ciągu nocy objawów ruchowych, np. bradykinezy lub sztywności mięśniowej, która utrudnia przyjęcie wygodnej pozycji ciała bądź też występowanie bolesnych dystonii stanu OFF. Ponadto ciągłość snu przerywają występujące w PD zaburzenia autonomiczne (nadmierne pocenie, nokturia). Niewątpliwie jednak kluczową rolę w etiologii bezsenności w PD należy przypisać pierwotnej degeneracji neuronów w centrach regulacji snu i czuwania. Niezaprzeczalny jest związek bezsenności z zaburzeniami depresyjnymi [10]. Ma on charakter dwukierunkowy - brak fizjologicznego snu może powodować rozdrażnienie, lęki i obniżenie nastroju. Z drugiej strony objawami zaburzeń afektywnych są problemy z zasypianiem, wczesne przebudzenia poranne, koszmary senne. Zaburzenia snu w PD mogą łączyć się również $\mathrm{z}$ terapią [10]. Leki pozwalające kontrolować nasilenie objawów ruchowych z grupy agonistów receptora dopaminergicznego mogą nasilać uczucie senności i konieczność drzemek w ciągu dnia, co skutkuje dezorganizacją prawidłowego snu nocny. Jest kilka skal przeznaczonych do oceny bezsenności wśród pacjentów z PD. Jedną z częściej używanych jest Parkinson's Disease Sleep Scale (PDSS) [11], a także SCOPA-sleep scale (Scale For Outcomes In Parkinson's Disease - Sleep Disturbances) [11]. Pomagają one uzyskać informację dotyczącą zaburzeń snu. Należy także brać pod uwage jakość snu opiekunów chorych, która przekłada się na ich późniejsze funkcjonowanie w ciągu dnia oraz na pielęgnację chorego.

\section{NADMIERNA SENNOŚĆ W CIĄGU DNIA}

Nadmierna senność w ciągu dnia (EDS - excesive daytime sleepiness) jest częstą manifestacją zaburzeń snu w PD, dotyczy ona według różnych badań $21-50 \%$ [5] pacjentów i nasila się wraz z progresją choroby $[12,13]$. Jej istotę stanowi niezdolność do utrzymania stanu czuwania w ciągu dnia i incydenty niezamierzonego zapadania w sen. Czynnikami ryzyka EDS w PD są: płeć męska, nasilenie objawów ruchowych, dłuższy czas trwania choroby oraz duża dawka leków dopaminergicznych. Skalą służącą do oceny nasilenia tej dolegliwości jest Epwhort Sleepness Scale (ESS) [11], która bada możliwość zapadnięcia w sen w różnych okolicznościach w ciągu dnia. Badanie polisomnograficzne pozwala na obiektywną ocenę upośledzenia snu w ciągu nocy, np. bezdech senny, RBD itd., wtórnie mogących powodować wyżej wymienione objawy. Poza powyższymi, opisuje się również inne czynniki nasilające objawy senności w ciągu dnia. Są nimi terapia dopaminergiczna (najczęściej połączenie lewodopy $\mathrm{z}$ agonistą receptora 
Tabela I. Kryteria RBD według International Classification of Sleep Disorders.

\begin{tabular}{|c|}
\hline A. Chory skarży się na nagłe zaburzenia zachowania w czasie snu powodujące uszkodzenie ciała \\
B. Ruchy ciała podczas snu są spowodowane marzeniami sennymi \\
C. Przynajmniej jedno z poniższych: \\
urazowe zachowanie podczas snu \\
bardzo żywe marzenia senne \\
zaburzenia zachowania podczas snu przerywają jego ciągłość \\
D. W badaniu polisomnograficznym jedna z poniższych cech: \\
nadmierna aktywność w EMG mięśni bródki (>30\% czasu fazy REM) \\
nadmierna aktywność w EMG mięśni bródki lub kończyn i jedno z poniższych: \\
masilone zrywania mięśniowe kończyn i ciała \\
złożone, gwałtowne, agresywne i energiczne zachowanie \\
brak wyładowań padaczkowych w EEG podczas obserwowanych zaburzeń snu \\
E. Objawy nie są związane z chorobami psychicznymi, ale neurologicznymi \\
Inne zaburzenia snu (np. zmory nocne, lunatykowanie) mogą występować, ale nie są przyczyną obserwowanych zaburzeń
\end{tabular}

dopaminergicznego), zaburzenia psychiczne: depresja, lęk, psychoza, objawy ruchowe, a także ból [13]. Nadmierna senność w ciągu dnia jest także łączona z utratą neuronów mających receptory dla oreksyny (hipokretyny) w podwzgórzu oraz obniżonymi wartościami oreksyny w PMR, podobnie jak w przypadku chorych na narkolepsję[14].

\section{ZABURZENIA ZACHOWANIA ZWIAZANE Z FAZA SNU REM}

Zaburzenia zachowania fazy snu REM (RBD-REM sleep behaviour disorder) $\mathrm{z}$ nieobecnością fizjologicznej atonii mięśniowej częściej dotyczą mężczyzn po 50. roku życia. W populacji powyżej 60. roku życia występują u 0,3-1,15\% osób. W połowie przypadków są one pierwszym z objawów PD lub innej synukleinopatii, jak: MSA (Multiple System Atrophy) czy DLB (Dementia with Lewy Bodies) i mogą wyprzedzać objawy ruchowe nawet o dekadę [1, 5, 15-18]. RBD występuje również w przebiegu tauopatiami - choroby Alzheimera czy PSP (Progresive Supranuclear Palsy) [19], choć ich związek z tymi chorobami jest o wiele rzadszy niż w przypadku synukleinopatii. RBD może współwystępować z subtelnymi prodromarnymi zwiastunami,będącymi biomarkerami wczesnej neurodegeneracji, takimi jak hyposmia i zaparcia (Tab. I) [20, 21].

Mechanizm powstawania RBD jest słabo poznany. Dotychczas, doświadczenia prowadzone na zwierzętach dowodzą obecności kluczowych neuronów kontrolujących fazę snu REM w ośrodkach mostowych: miejscu sinawym, jądrach bocznych nakrywki śródmózgowia, istocie szarej okołowodociągowej. Przejście snu NREM w sen REM reguluje system sprzężenia zwrotnego pomiędzy neuronami cholinergicznymi (REM-on cell) oraz noradrenergicznymi i serotoninergicznymi (REM-off). Neurony cholinergiczne leżą w jądrach konarowo-mostowym (PPN - tegmental pedunculopontine) i boczno-grzbietowym nakrywki (LTD - tegmental late- rodorsal) jako tzw. REM-on cell zapoczątkowują sen REM i wykazują zwiększoną aktywność w tym stadium, a neurony serotoninergiczne i noradrenergiczne, odpowiednio zlokalizowane w jądrach szwu (LR) i miejsca sinawego (LC), czyli tzw. REM-off cell, są wówczas nieaktywne. Dowodzi się ponadto, że neurony jądra boczno- -grzbietowego nakrywki (LTD) są odpowiedzialne pośrednio poprzez neurony wstawkowe rdzenia za atonię mięśni poprzecznie prążkowanych tułowia i kończyn podczas fazy REM. Neurony GABA-ergiczne i glicynowe działają hamująco na motoneurony w rdzeniu kręgowym. Redukują one także sygnały z neuronów noradrenergicznych i serotoninergicznych (neuronów „promujących pobudzenie”), co dodatkowo wzmacnia efekt zwiotczenia mięśni. U pacjentów z RBD hamujące neurony glutaminergiczne zlokalizowane w części grzbietowej mostu, neurony GABA-ergiczne jądra szwu ulegają degeneracji. Zmiany te prowadzą do utraty fizjologicznej atonii mięśni podczas snu fazy REM $[18,22]$. Dowiedziono, że u pacjentów z PD zmiany te pojawiają się przed neurodegeneracją w obrębie istoty czarnej. Jednak czas, który dzieli te patologie jest indywidualnie zmienny i waha się od kilku miesięcy nawet do dekad [22].

Obraz kliniczny RBD jest zróżnicowany. Podczas fazy snu REM, której towarzyszą marzenia senne, chorzy, u których brak jest fizjologicznej atonii mięśniowej, wykonują dużo gwałtownych ruchów. Treść marzeń sennych jest zazwyczaj bardzo realistyczna i nacechowana negatywnie. Pacjentom śni się, że są gonieni lub atakowani, biorą udział w kłótniach, bójkach. Poza gwałtownymi ruchami kończyn fazie snu REM mogą towarzyszyć również wokalizacje, płacz lub śmiech i inne dźwięki. W trakcie tych niekontrolowanych ruchów chorzy mogą doznać urazów tkanek miękkich, złamań, urazów głowy. Opisywano także urazy u partnerów dzielących łóżko z cierpiącymi na RBD. Po obudzeniu chorzy najczęściej nie pamiętają nocnych epizodów, często jednak wspominają nieprzyjemną treść snów [22].

\section{ZESPÓŁ NIESPOKOJNYCH NÓG}

Zespół niespokojnych nóg - RLS (restless legs syndrome), inaczej zespół Wittmaacka-Ekboma, to wrażenie zmęczenia i niepokoju nóg, któremu towarzyszą różnego rodzaju parestezje: mrowienie pod skórą lub palenie. Rzadko odczucia te dotyczą także kończyn górnych. Nasilają się wieczorem i w nocy. Charakterystyczną cechą zespołu jest jego ustępowanie lub znaczne złagodzenie pod wpływem ruchu [23]. Objawy RLS zwykle dotyczą kończyn dolnych i mają charakter obustronny. Mogą jednak być 
niesymetryczne i występować na przemian w kończynach. Rzadko występują objawy dotyczące tylko jednej strony ciała, zazwyczaj obejmują uda i podudzia. Choroba ta w około 7-15\% towarzyszy PD, co oznacza, że u tych chorych pojawia się dwukrotnie częściej niż w populacji ogólnej [6]. Nie dowiedziono jednak, że występowanie RLS wiąże się z wyższym ryzykiem zachorowania na PD (Tab. II) [3].

W zapisie polisomnograficznym w zespole niespokojnych nóg częste występowanie ruchów kończyn dolnych $\mathrm{z}$ następowym przebudzeniem (arousal) powoduje fragmentację profilu snu. Czas zasypiania jest wydłużony, podobnie jak czas czuwania w nocy oraz czas przejścia ze stanu snu do stanu czuwania. Wydłużone są fazy snu lekkiego NREM 1 i 2, z jednoczesnym skróceniem stadiów snu z powolnymi ruchami gałek ocznych i REM. Badanie EMG wykazuje okresowe ruchy kończyn dolnych i wywołane nimi krótkotrwałe przebudzenia.

\section{OBTURACYJNY BEZDECH SENNY}

Obturacyjny bezdech senny (OSAS - obstructive sleep apnea syndrome) był opisywany w kilku badaniach dotyczących zaburzeń snu w PD [24-26]. Zaburzenie to związane jest ze zwężeniem dróg oddechowych spowodowanych wiotkością i zapadaniem się podniebienia miękkiego w trakcie snu. Charakteryzuje się występowaniem chrapania, przerw w oddychaniu w trakcie snu powyżej 10 sekund, gwałtownymi wybudzeniami nocnymi, co natomiast skutkuje obniżeniem jakości snu, ciągłym poczuciem zmęczenia, nadmierną sennością w ciągu dnia, bólami głowy, problemami z koncentracją. Dolegliwość ta może dotyczyć około 2-4\% osób w populacji ogólnej [27]. Jej pojawieniu się sprzyjają: starszy wiek, otyłość, stan po zawale serca, udarze mózgu. Sugeruje się, że u pacjentów z PD OSAS może występować z większą częstotliwością niż w reszcie populacji, jednak nadal brakuje dużych badań potwierdzających tę hipotezę [28]. Autorzy opisujący większą częstotliwość występowania OSAS u pacjentów z PD podkreślają, że związek z tym może mieć upośledzenie ruchów ciała w trakcie snu, spowodowane nocnymi stanami OFF i spędzanie przez chorych większej ilości czasu w pozycji na wznak, która sprzyja zapadaniu się podniebienia miękkiego i występowania obturacyjnego bezdechy sennego [24]. Sugeruje się także, że OSAS może mieć istotnych wpływ nie tylko na jakość życia pacjentów, nadmierną senność w ciągu dnia czy zwiększeniem ryzyka chorób kardiologicznych, ale także sprzyjać deterioracji poznawczej pacjentów. Złotym standardem leczenia OSAS jest stosowanie urządzenia wywołującego stałe dodatnie ciśnienie w drogach oddechowych - CPAP (Continous Positive Airvay Pressure).

\section{DIAGNOSTYKA ZABURZEN SNU}

Diagnostyka zaburzeń snu opiera się przede wszystkim na dokładnym zebraniu wywiadu od pacjenta, a także w wielu przypadkach od partnera lub rodziny zamieszkującej wspólnie z chorym. Dużą czułość i specyficzność mają liczne kwestionariusze dotyczące zaburzeń snu np: PDSS (Parkinson's Disease Sleep Scale), Mayo Sleep Questionnaire, RBD1Q (REM Sleep Behavior Disorder Single-Question Screen ), RBDSQ (REM Sleep Behavior Disorder Screening Questionnaire). Mogą być one wykorzystane jako badanie przesiewowe.

Złotym standardem badań snu jest badanie polisomnograficzne, które pozwala ma monitorowanie licznych funkcji organizmu podczas snu i jest narzędziem umożliwiającym obiektywizację opisywanych dolegliwości.

Prawidłowa diagnostyka obejmuje również różnicowanie między innymi jednej z najtrudniejszych w rozpoznaniu parasomni, jaką jest RBD z innymi zaburzeniami mogącymi przebiegać podobnie (mimicking disorders), takimi jak: koszmary senne, somnambulizm, napady padaczkowe, zespół stresu pourazowego, psychozy, delirium. Znakomitą większość tego różnicowania można przeprowadzić posiłkując się badaniem polisomnograficznym.

\section{POLISOMNOGRAFIA}

Badanie polisomnograficzne jest zapisem fizjologicznych aktywności organizmu człowieka w czasie snu. Składa się ona z zapisu czynności bioelektrycznej mózgu: elektroencefalografii (EEG), czynności elektrycznej serca - elektrokardiografii (EKG), aktywności mięśniowej - elektromiografii (EMG), analizy ruchów gałek ocznych - elektrookulografii (EOG), zapisu czynności oddechowej oraz saturacji krwi.

$\mathrm{W}$ przypadku podejrzenia BRD najważniejszą częścią snu dla badającego jest faza snu REM, czyli tzw. sen paradoksalny. Jego nazwa pochodzi od występujących gromadnie szybkich ruchów gałek ocznych. Faza ta charakteryzuje się płaskim, nieregularnym rytmem fal o częstości 6-10Hz. i wyraźnym kształcie zębów piły. Często występują także ostre wyładowania o amplitudzie do $150 \mathrm{uV}$, przypominające kształtem iglice - są to tzw. iglice PGO (ponto-geniculo-occipital spikes) odpowiadające pobudzeniu przenoszącemu się z mostu do struktur układu wzrokowego, tj. do ciał kolankowatych bocznych i dalej do okolicy wzrokowej. Aktywacja tych obszarów jest uważana za przyczynę wzrokowej treści marzeń sennych.

Ruchy gałek ocznych są kontrolowane za pomocą elektrookulografii. Oko ludzkie stanowi dipole elektryczne. Rogówka to biegun dodatni, a siatkówka ujemny. Różnica potencjałów podczas ruchów gałek ocznych prowadzi do zmian potencjałów rejestrowanych za pomocą elektrod umieszczonych po bokach obu oczu. Ruch taki jest zwykle jednokierunkowy. Na podstawie EOG uzyskuje się informacje na temat ruchów gałek ocznych podczas zasypiania (ruchy wolne, wahadłowe) oraz ruchów podczas fazy REM (ruchy szybkie), a także ruchów powiek i mrugania.

Zapis elektromiograficzy EMG wykorzystuje jako miejsce najsilniej wyrażonej wartości atonii mięśniowej okolice podbródkowe i bródkę. Zapisu dokonuje się przy pomocy dwóch elektrod dwubiegunowych umieszczonych na obu brzuścach mięśnia bródkowego. W przypadku niecodziennego występowania zaburzeń zachowania w trakcie snu, podczas polisomnografii można wykazać brak atonii 
Tabela II. Kryteria RLS 2012 według International RLS Study Group (IRLSSG).

Kryteria RLS:
• Przymus wykonywania ruchów kończyn najczęściej z towarzyszącym nieprzyjemnym odczuciami w kończynach
$\cdot$ Objawy zaczynają się lub nasilają podczas spoczynku, bezruchu
• Objawy ustępują lub zmniejszają się podczas ruchu
• Objawy nasilają się lub tylko występują wieczorem lub w nocy
- Objawy nie mają związku z innymi chorobami, np. z bólem i obrzękiem nóg, skurczami mięśni

mięśni bródkowych. Elektrody EMG, jak również detektory akcelerometryczne umieszcza się także na kończynach górnych i dolnych.

W panelu badań polisomnograficznych wykorzystywane są również testy, służące obiektywnej ocenie konkretnych zaburzeń, jak np. nadmiernej senności w ciągu dnia.

\section{MULTIPLE SLEEP LATENCY TEST (MSLT)}

Badanie wykonywane w celu diagnozowania nadmiernej senności w trakcie dnia. Podczas badania MSLT pacjent co 2 godziny, pięciokrotnie w ciągu dnia ma możliwość położenia się do łóżka i odbycia 20-minutowej drzemki. Wykorzystując technikę badania polisomnograficznego, podczas każdej drzemki oznacza się czas do zaśnięcia. Średni czas do zaśnięcia (latencja snu) poniżej 5 minut świadczy o patologicznej senności. Średnia latencja snu powyżej 10 minut świadczy o braku nadmiernej senności.

\section{MAINTENANCE OF WAKEFULNESS TEST (MWT) - TEST UTRZYMANIA CZUWANIA}

Test utrzymania czuwania jest stosowany w medycynie snu do pomiaru jakości czuwania w ciągu dnia. Badanie umożliwia ocenę, czy osoba badana jest w stanie utrzymać czuwanie, mimo przebywania w monotonnych i sprzyjających zasypianiu warunkach. Badanie składa się z czterech 40-minutowych testów, które osoba badana spędza w wygodnym fotelu, znajdującym się w cichym i słabo oświetlonym pomieszczeniu.

\section{LECZENIE}

\section{ZABURZENIA NOCNE SPOWODOWANE ZABURZENIAMI SNU}

\section{BEZSENNOŚĆ}

Leczenie bezsenności w PD powinno koncentrować się na takiej modyfikacji terapii dopaminergicznej, która pozwoli wyeliminować problemy ruchowe pojawiające się w nocy: stany OFF lub bolesne dystonie wczesnego poranka, jednocześnie mając na uwadze ograniczenie drzemek w ciągu dnia. Prawidłowo dobrana terapia dopaminergiczna poprawia jakość snu u pacjentów z PD. Opisywano również poprawę jakości snu po zabiegach głębokiej stymulacji mózgu (DBS - deep brain stimulation), co ma najpewniej związek z poprawą stanu ruchowego [12, 29]. Pomocne może się także okazać zwiększenie dziennej aktywności ruchowej.
W cięższych przypadkach - przewlekłej bezsenności - proponowana jest terapia poznawczo-behawioralna. Leczenie benzodiazepinami stosowane jest najczęściej krótkotrwale. Niewskazane jest przewlekłe stosowanie takiej terapii, ponieważ wywołuje ona liczne niekorzystne efekty, jak poranna sedacja, zamroczenie, nasilenie niestabilności postawy oraz uzależnienie [30].

\section{ZABURZENIA ZACHOWANIA ZWIAZZANE Z FAZA SNU REM}

W leczeniu zaburzeń zachowania fazy REM rekomendowane jest stosowanie w pierwszej linii klonazepamu w dawce 0,25-2 mg/d, jednak może się ono łączyć z powikłaniami takimi jak: nadmierna sedacja, a także zwiększone ryzyko upadków. Klonazepam zwiększa całkowity czas snu, poprawia efektywność snu, wydłuża fazę NREM, a także zmniejsza liczbę wybudzeń. U pacjentów z PD, u których współwystępują RBD, zalecane jest zastosowanie melatoniny 3-12 $\mathrm{mg} / \mathrm{d}$. Melatonina redukuje epizody RBD i zmniejsza napięcie mięśniowe podczas fazy REM, jednak leczenie może być powikłane porannymi bólami głowy, sennośccią, halucynacjami, objawy te zwykle pojawiają się przy stosowaniu wysokich dawek [22].

\section{ZESPÓ NIESPOKOJNYCH NÓG}

W celu leczenia idiopatycznego syndromu niespokojnych nóg (RLS) rekomenduje się: zmianę stylu życia, wprowadzaniem higieny snu, aktywności fizycznej, kąpieli w ciepłej i zimnej wodzie naprzemiennie itd. W terapii farmakologicznej stosuje się w pierwszej kolejności agonistów dopaminy, np. pramipeksol 0,09-0,36 mg/d, ropinirol $0,25-4 \mathrm{mg} / \mathrm{d}$, alternatywnie stosować można leki przeciwpadaczkowe, np. pregabalinę 150-450 mg/d lub gabapentynę 900-2400 mg/d.

W przypadkach trudnych do leczenia można zastosować niskie dawki leków opioidowych [5] Wtórny RLS leczy się najczęściej przyczynowo, suplementując witaminy, żelazo lub lecząc chorobę podstawową.

\section{OBTURACYJNY BEZDECH SENNY}

Jak już wspomniano wcześniej złotym standem leczenia OSAS jest urządzenie wytwarzające dodatnie ciśnienie w drogach oddechowych CPAP [3]. Normalizuje ono oddychanie w godzinach snu, poprawia oksygenację krwi oraz architekturę snu (przywraca prawidłowe czasy faz REM/NREM), zmniejsza senność w ciągu dnia. Z zaleceń 
niefarmakologicznych proponuje się pacjentom kontrolę masy ciała, a także spanie na boku. W przypadkach trudności z obracaniem się w pozycji leżącej warto wdrożyć ćwiczenia fizjoterapeutyczne oraz zwiększyć leczenie dopaminergiczne w godzinach nocnych.

\section{ZABURZENIA DZIENNE SPOWODOWANE ZABURZENIAMI SNU}

\section{NADMIERNA SENNOŚĆ W CIĄGU DNIA}

Istotą leczenia EDS jest identyfikacja czynników zakłócających sen nocny i w miarę możliwości wyeliminowanie ich. Konieczna może być także redukcja dawek leków (o ile jest to możliwe) nasilających nadmierną senność, np. leków przeciwdepresyjnych, przeciwpsychotycznych lub nasennych. Równie ważnym czynnikiem jest edukacja pacjentów dotycząca prawidłowej higieny snu. Jak wspomniano wcześniej kombinacja leczenia lewodopą i agonistami dopaminy może nasilać objawy EDS, jednak dowiedziono, że sama selegilina, amantadyna i entakapon nie mają wpływu na EDS. Zastosowanie w leczeniu nadmiernej senności ma również środek stymulujący - modafinil [31] w dawce 100-400 mg/d.

\section{PODSUMOWANIE}

Zaburzenia snu są częstym objawem pozaruchowym w przebiegu PD. Ich diagnostyka i leczenie stanowi duże wyzwanie dla klinicystów, jest jednak bardzo istotnym elementem holistycznego spojrzenia na chorobę. Zaburzenia snu pogarszają jakość życia pacjentów, powodują szybszą progresją choroby i mogą powodować powikłania, np. złamania kości lub urazy głowy w przebiegu RBD, które znacznie pogarszają rokowanie pacjenta. Dostępny jest bogaty wachlarz możliwości terapeutycznych, zarówno farmakologicznych, jak i niefarmakologicznych, które można zastosować, tak aby istotnie poprawić komfort funkcjonowania pacjenta z PD, a także jego opiekunów. Istotne jest dalsze pogłębianie wiedzy na temat zaburzeń snu i kolejne badania kliniczne, ponieważ mimo wielkiego postępu, jaki z każdym rokiem dokonuje się w naukach medycznych, w wielu aspektach sen nadal pozostaje terra incognita.

\section{PIŚMIENNICTWO}

1. Zoccolella S, Savarese M, Lamberti P et al. Sleep disorders and the natural history of Parkinson's disease: The contribution of epidemiological studies. Sleep Med Rev. 2011;15(1):41-50. doi:10.1016/j.smrv.2010.02.004

2. Suzuki K, Miyamoto M, Miyamoto T et al. Parkinson's Disease and Sleep Wake Disturbances. Curr Neurol Neurosci Rep. 2015;15(3). doi:10.1007/ s11910-015-0525-5

3. Bhat $S$, Chokroverty S. Hypersomnia in Neurodegenerative Diseases. Sleep Med Clin. 2017;12(3):443-460. doi:10.1016/j.jsmc.2017.03.017

4. Lees AJ, Blackburn NA, Campbell VL. The nighttime problems of Parkinson's disease. Clin Neuropharmacol. 1988;11(6):512-519.

5. Videnovic A. Management of sleep disorders in Parkinson's disease and multiple system atrophy. Mov Disord. 2017;32(5):659-668. doi:10.1002/ mds.26918
6. Menza M, Dobkin RD, Marin H et al. NIH Public Access. 2011;25(Suppl 1):1-8. doi:10.1002/mds.22788.Sleep.

7. Vendette M, Gagnon JF, Décary A et al. REM sleep behavior disorder predicts cognitive impairment in Parkinson disease without dementia. Neurology 200; 69(19):1843-1849.

8. van Gilst MM, Bloem BR OS. "Sleep benefit" in Parkinson's disease: a systematic review. Park Relat Disord. 2013;19(7):654-659.

9. Svensson E, Beiske AG, Loge JH et al. Sleep problems in Parkinson's disease: a community-based study in Norway. BMC Neurol. 2012;12:71.

10. Thorpy MJ. Sleep disorders in Parkinson's disease. Clin Cornerstone.2004;6(1Suppl.1). doi:10.1016/S1098-3597(04)90013-0.

11. Kurtis MM, Balestrino R, Rodriguez-Blazquez C et al. A review of scales to evaluate sleep disturbances in movement disorders. Front Neurol. 2018;9:435. doi:10.3389/fneur.2018.00369

12. Albers JA, Chand P, Anch AM. Multifactorial sleep disturbance in Parkinson's disease. Sleep Med. 2017;35:41-48. doi:10.1016/j. sleep.2017.03.026

13. Salawu F, Olokoba A. Excessive daytime sleepiness and unintended sleep episodes associated with parkinson's disease. Oman Med J. 2015;30(1):3-10. doi:10.5001/omj.2015.02

14. Fronczek R, Overeem S, Lee SY et al. Hypocretin (orexin) loss in Parkinson's disease. Brain. 2007;130(Pt6):1577-1585. doi:10.1093/brain/awm090

15. Iranzo A, Molinuevo JL, Santamaría J et al. Rapid-eye-movement sleep behaviour disorder as an early marker for a neurodegenerative disorder: a descriptive study. Lancet Neurol. 2006;5(7):572-577. doi:10.1016/ S1474-4422(06)70476-8

16. Lerche S, Brockmann K, Wurster I et al. Reasons for mild parkinsonian signs - Which constellation may indicate neurodegeneration? Park Relat Disord. 2015;21(2):126-130. doi:10.1016/j.parkreldis.2014.11.018.

17. Al-Qassabi A, Fereshtehnejad SM, Postuma RB. Sleep Disturbances in the Prodromal Stage of Parkinson Disease. Curr Treat Options Neurol. 2017;19(6). doi:10.1007/s11940-017-0458-1.

18. Postuma RB. Predicting neurodegenerative disease in idiopathic rapid eye movement (REM) sleep behavior disorder: Conference proceedings, REM Sleep Behavior Symposium 2011. Sleep Biol Rhythms. 2013;11(Suppl.1):75-81. doi:10.1111/j.1479-8425.2012.00557.x.

19. Li M, Wang L, Liu JH, Zhan SQ. Relationships between Rapid Eye Movement Sleep Behavior Disorder and Neurodegenerative Diseases: Clinical Assessments, Biomarkers, and Treatment. Chin Med J (Engl). 2018;131(8):966-973. doi:10.4103/0366-6999.229886

20. Zhang J, Xu C-Y, Liu J. Meta-analysis on the prevalence of REM sleep behavior disorder symptoms in Parkinson's disease. BMC Neurol. 2017;17(1):23. doi:10.1186/s12883-017-0795-4

21. Fullard ME, Tran B, Xie SX et al. Olfactory impairment predicts cognitive decline in early Parkinson's disease. Parkinsonism Relat Disord. 2016;25:45-51. doi:10.1016/j.parkreldis.2016.02.013.

22. Rodriguez CL, Jaimchariyatam N, Budur K. Rapid Eye Movement Sleep Behavior Disorder: A Review of the Literature and Update on Current Concepts. Chest. 2017;152(3):650-662. doi:10.1016/j.chest.2017.03.015

23. Marelli S, Galbiati A, Rinaldi F et al. Restless legs syndrome/Willis Ekbom disease: New diagnostic criteria according to different nosology. Arch Ital Biol. 2015;153(2-3):184-193. doi:10.12871/0003982920152343

24. Cochen De Cock V, Benard-Serre N, Driss V et al. Supine sleep and obstructive sleep apnea syndrome in Parkinson's disease. Sleep Med. 2015;16(12):1497-1501. doi:10.1016/j.sleep.2014.09.014

25. Koo DL, Lee JY, Nam H. Difference in severity of sleep apnea in patients with rapid eye movement sleep behavior disorder with or without parkinsonism. Sleep Med. 2018:1-6. doi:10.1016/j.sleep.2018.05.042 
26. Crosta F,DesideriG, MariniC. Obstructive sleep apnea syndrome in Parkinson's disease and other parkinsonisms. Funct Neurol. 2017;32(3):137-141.

27. YoungT,PaltaM,DempseyJ,etal.Theoccurrence of sleep-disordered breathing among middle-aged adults. N Engl J Med. 1993;328(17):1230-1235

28. Sheu J-J, Lee H-C, Lin H-C et al. A 5-Year Follow-up Study on the Relationship between Obstructive Sleep Apnea and Parkinson Disease. J Clin Sleep Med. 2015;11(12):1403-1408. doi:10.5664/jcsm.5274

29. ArnulfI, Bejjani BP, Garma L et al. Improvement of sleep architecture in PD with subthalamic nucleus stimulation. Neurology. 2000;55:1732-1734.).
30. Chung S, Bohnen NI, Albin RL et al. Insomnia and sleepiness in Parkinson disease: Associations with symptoms and comorbidities. J Clin Sleep Med. 2013;9(11):1131-1137. doi:10.5664/jcsm.3150

31. St Louis EK, Boeve BF. REM Sleep Behavior Disorder: Diagnosis, Clinical Implications, and Future Directions. Mayo Clin Proc. 2017;92(11):17231736. doi:10.1016/j.mayocp.2017.09.007

\section{Konflikt interesów:}

Autorzy deklarują brak konfliktu interesów.

\author{
AUTOR KORESPONDUJĄCY \\ Magdalena Doręgowska \\ Klinika Neurologii Śląskiego Uniwersytetu Medycznego \\ ul. Medyków 14, 40-752 Katowice, Polska \\ tel. 512095403 \\ e-mail:magdalena.doregowska@med.sum.edu.pl
}

Nadesłano: 19.11.2018

Zaakceptowano: 25.02.2019 
PRACA POGLĄDOWA

REVIEW ARTICLE

\title{
DEVELOPMENT OF THE INNER NASAL CAVITY IN ANIMALS IN PHYLO- AND ONTOGENESIS: FUNCTIONAL ANATOMIC SIGNIFICANCE IN THE DEVELOPMENT PERIOD
}

\author{
ROZWÓJ WEWNĘTRZNEJ JAMY NOSOWEJ U ZWIERZĄT \\ W FILO- I ONTOGENEZIE: CZYNNOŚCIOWE I ANATOMICZNE \\ ZNACZENIE W OKRESIE ROZWOJOWYM
}

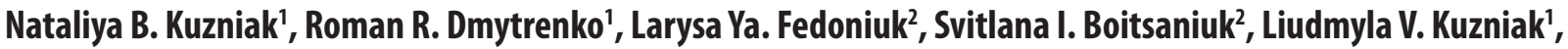 \\ Andrii V. Yavorskyi' ${ }^{1}$, Stepan V. Tkachyk ${ }^{1}$ \\ 'HSEE "BUKOVINIAN STATE MEDICAL UNIVERSITY", CHERNIVTSI, UKRAINE \\ 2. HORBACHEVSKY TERNOPIL STATE MEDICAL UNIVERSITY, TERNOPIL, UKRAINE
}

\begin{abstract}
Introduction: Main functions of the inner nose in humans are respiration and olfaction. Therefore, human needs a large surface of inhalable and exhalable air contact, warming and moistening. Importance of these organs in animals in phylogenesis before and after the secondary palate development can explain their anatomic and functional designation. The aim is to find out the functional significance of some anatomic formations of the inner nose and their development peculiarities in phylo-and ontogenesis.

Materials and methods: We used a comparative anatomy method where we compared well-known facts of different animals' development before and after secondary palate formation in phylo- and ontogenesis.

Review: Olfactory organ in lower vertebrates develops as canal with two openings through which as a result of water penetration the olfactory ability increases. Sinuses formation in animals happens after secondary palate formation. Secondary palate in embryo develops by second month of development, and sinuses' development begins on the 3-4 month. As a result, upper jaws and facial skull became stronger. Importance of mucous and lacrimal glands of the nose cavity and mucous glands of mouth received new functions of animal and vegetable food digestion.

Conclusions: development of the secondary palate in warm-blooded vertebrates changed (limited) functional applicability of the lacrimal gland and nasolacrimal canal, mucous glands of nose and vegetative innervation. Groups of lacrimal, mucous glands of nose and mouth are unified system of primary, neurosecretory reaction to environment.
\end{abstract}

KEY WORDS: nasolacrimal canal, paranasal sinuses, mucous membrane of nose and mouth, secondary palate in vertebral animals

Wiad Lek 2019, 72, 3, 432-435

\section{INTRODUCTION}

It is well-known that the main functions of the inner nose in humans are respiration and olfaction. To make their work successful and effective a human needs a large surface of the inhalable and exhalable air contact, air warming and moistening. It is known that smells are perceived only with the incoming air and their perception intensifies due to the sufficient moisturizing either of air or of the nose mucous membrane (for example, after rain). For this purpose we need a large surface of the nose mucous membrane supplied by a complicated configuration and numerous nasal sinuses and nasal passages. Among theories about possible functional significance of sinuses there exists an opinion about their role of skull mass reduction, resonance improvement, enlargement of the perceptive membrane, the inner nasal pressure regulation, and nasal cavity moisturizing by mucin. All these opinions are ana- tomically and physically grounded and complementary $[1$, 2]. Real functional significance of the paranasal sinuses is unknown. We can't clarify the necessity of tear inference through the nasolacrimal canal in the inferior nasal meatus and also vegetative innervations of the nerve vascular plexus of the nose submucous layer, while as a result of nerve irritation of pterygopalatine canal there is an increased mucous producing in the nasal cavity (Feil Syndrome). The importance of these organs in animals in phylogenesis before and after the secondary palate development can explain their anatomic and functional designation.

\section{THE AIM}

Of the research is to find out the functional significance of some anatomic formations of the inner nose and their development peculiarities in phylogenesis and ontogenesis. 


\section{MATERIALS AND METHODS}

In the research we used a method of comparative anatomy where we compared well-known facts of different animals' development before and after secondary palate formation in phylo- and ontogenesis. Undoubtedly, Haeckel biogenetic law cannot be absolute in such investigations, though morphogenesis with evident signs of recapitulation (concise reiteration of phylogenesis on ontogenesis) cannot be doubted [3]. Searching for the signs with important functional significance for ancestors and preserved in a modern human in a new way explains peculiarities of some pathological processes. And the way of cognition based on facts comparing and logic can be effective.

\section{REVIEW AND DISCUSSION}

Brain development and walking upright caused changes in the form of brain and facial skull in humans. Changes in the nutrition character and organization caused development of new functional peculiarities of nose and mouth cavity. Thus, the sense of smell in humans is quite decreased, and the ability of secreted chemical factors (pheromones) perception is lost. As a result of the olfactory zone decrease a human loses olfaction with age and because of being a high rung on the evolutionary ladder. Phylogenetically the olfactory organ development can be described this way. Thus, in invertebrates the olfactory organs are olfactory pits in different parts of the body covered by ciliary epithelium. Olfactory pits in the main end of the body first appeared in chordates.

In lower vertebrates an olfactory organ develops in the form of the double-layer thickening of ectoderm on the front end of the head which further form an olfactory pit opening outwards. Many fish have two disclosing openings: front and back. Thus, the olfactory organ develops as a canal with two openings through which as a result of water penetration the olfactory ability increases. Besides, there develop different pits to hold water in the canal.

In selahii (sharks and other cartilaginous fish) olfactory pits through a channel disclose with the mouth cavity; this way the disclosing olfactory pits with the mouth cavity (choana) develop.

To strengthen the olfactory function many vertebrates develop structures increasing the layer of the olfactory epithelium. It is achieved by development of the nasal folds and conchae in the nasal cavity, and also by the way of the supplementary bosom development the mucous membrane of which doesn't have olfactory cells. Thus, having first appeared as olfactory facilities paranasal sinuses lost this ability as a result of the habitat, nutrition and respiration character changes. Paranasal sinuses formation in animals happens after the secondary palate formation, which is proved by the human embryo development. Thus, the secondary palate in embryo develops by the second month of development, and sinuses' development begins on the 3-4 month.

An important condition of preserving effective olfaction is moist olfactory epithelium. Besides, moist mouth and nose cavities are important for effective food propulsion which is especially difficult with the undeveloped secondary palate. Thus, in land animals nose development complicates with the lacrimation, nasolacrimal canals, and mucous producing regulating by the vegetative nervous system.

In many amphibians and reptiles with the undeveloped secondary palate nasolacrimal and pterygopalatine canals (Vidian nerve) open to the nose cavity disclosing with the mouth cavity. Ontogenesis in the nasolacrimal canal in humans is widely investigated. The canal development starts on the early stages of embryogenesis. In the $7 \mathrm{~mm}$ embryos (5-6 week of the embryonic development) develops a cavity which presents the beginning of the nasal orbital furrow development, which is limited by an external and submandibular nasal outgrowth. In the area of the nasal-orbital fracture develops a thickened epithelial bundle in the upper end of which a tear-bag and lacrimal canals develop. On the $4^{\text {th }}$ month (11 week) of development in the thick nasolacrimo-ectodermal bundle develops an epithelial canal which is closed by a conjunctiva in the upper part, and in the lower part by an epithelium of the lateral side of the nose cavity. By the time of the eyelashes separating on the 5-7 months of the embryo's development happens an upper-membrane canalization, and a bit later a lower-membrane canalization. An abnormal resorption delay of the lower membrane may cause an inborn nasal lacrimal obstruction in newborn babies. Within a normal development the lower section of the canal is ended by the Gasner epicanthic fold. In the upper-section of the canal there are Rosenmuller and Krauser membranes, which regulate the incoming tear from lacrimal canals into a tear-bag. Physiological significance of these membranes is not investigated yet $[4,5]$. Nasolacrimal canal opens on the lateral side of the nose cavity in the front third of the inferior nasal meatus.

We may assume that these valves used to regulate the incoming tear in the nose and mouth cavity and used to be a barrier to the food while the secondary palate was absent. Practically, all glands of the jaw-facial area (lacrimal, salivary, nose and mouth mucous membrane glands) in humans and other animals are regulated by facial and trifacial nerves. [6,7]. Such complicated innervations are due to the anastomoses between them and also through vegetative ganglion including sympathetic and parasympathetic fibers (eyelash, pterygopalatine, ear, lower-jaw bundles). The innervations of the lacrimal gland are fulfilled by a lacrimal nerve including the anastomoses and temporal nerve. In the innervations of the lacrimal gland also takes part a facial nerve bundle - nervus intermedius (Wrisberg's nerve), in the structure of the Vidian nerve, which perforates the bone external orbital part connecting with the lacrimal gland and zygomatic region skin. When a person feels worried there appears an irritation of the sympathetic nervous system on the skin of zygomatic region (innervations zone n. zygomaticofacialis) appears a white $3 \mathrm{~mm}$ ischemia spot and dry sclera of the corresponding eye. Transmission these nerves through the bone of the external orbital side can be explained by peculiarities of 
the phylogenetic development of the facial skull. Due to Schmalhausen I.I. (1938), in the mammals (platypus, etc.) orbit is not completely developed and in the direction of malar and frontal bone is quite vast space displaced by soft tissues inside of which the nerves are placed. Such a comparison explains peculiarities of the anatomic face built.

The trifacial nerve system as well as the vegetative nervous system (pterygopalatine bundle, Vidian nerve) supply innervations of the nose mucous membrane in the result of which cells and submucous glands produce mucous covering the inner surface of the nose and paranasal sinuses. Daily from 0,5 to 0,7 liters of mucous are produced. Lacrimal glands normally produce $0,5-1,0 \mathrm{ml}$ of tears $[8,9]$. The exact amount of the tear coming in the mouth cavity is difficult to calculate, though we assume that it is quite big. For instance, many patients admit quick lacrimation while reading in bed which is connected with the change of the tear flow direction along the nasal lacrimal canal.

Disfunction (large increase) of the mucous production happens during the neuralgia of the Vidian nerve (Feil Syndrom). Intersection of this nerve (Golding-Wood surgery, 1961) decreases mucous production in the mouth cavity and causes xerophthalmus.

Of great interest is development of the mouth glands in vertebrates. In fish and water amphibians that live in water habitat there are no complicated mouth glands. They appear when animals go on land and serve for moistening the food and moisturizing the mouth-nasal cavity. Phylogenetically, mucous glands (unpaired paranasal gland in amphibians, sublingual, labial glands and also poison-producing glands of teeth in reptiles) appear first. Birds have glands in the palate and sublingual glands which are especially developed in the granivorous birds $[10,11]$. Development of the big salivary glands is typical for mammals and connected with the nutrition changes, secondary palate formation, intensive metabolic processes and energetic costs. Besides, glands start producing not only mucous but also serous which is helpful at the primary stage of digestion. Sublingual and submandibular glands are probably a rudiment of the reptiles' sublingual gland and the parotid gland, developed from buccal glands, is a new acquisition of mammals.

First animals with the secondary palate appeared in the middle of the Permian period. This last period of the Paleozoic era (280 million years ago) was characterized by a rapid fall of temperature and need to use new more effective energetic way of nutrition. At the same time giant equisetum and moss disappeared, forests stepped back to equator and many amphibians died (cold-blooded), who could not adapt to cooling down. Secondary palate is a haemogenetical structure, which means it has similarities in different species that do not have common origin. Independently it developed in crocodiles, turtles, mammals and some lizards, which is an example of convergent evolution. Secondary palate turned out to be very necessary to survive and played a crucial role in the development of the warm-blooded. With the development of the secondary palate upper jaws and facial skull became stronger; later masticatory teeth appeared. Importance of mucous and lacrimal glands limited to the nose cavity and serous and mucous glands of mouth received new functions of animal and vegetable food digestion.

In humans and animals with the secondary palate nasal lacrimal glands lost their initial applicability - the moisturizing agent in amphibians and reptiles. Probably it's the involution of the nasolacrimal meatus. In many cases meatus lower valve (Gasner membrane) after the child's birth closes the nasal lacrimal canal and may be a cause of the inborn obstruction. Humans phylogenetically and functionally preserved only the moisturizing function of the nose mucous membrane (from 1 to $10 \mathrm{ml}$ tears a day), though if it was the main function the opening of the canal would be in the upper nasal canal.

Glands innervations of the jaw-facial area are possible due to the tri-facial, facial, glossopharyngeal nerves, their anastomosis, and interrelation influencing the vegetative nervous system.

Trifacial nerve evidently has a prominent functional role, though facial nerve also including motor nerve, secretory, sensible fibres and plays role in developing aural sense, taste, mucous membrane secretion and saliva production.

In reticular bridge formation together with the nucleus of the facial nerve there is an upper salivary nucleus (nucleus salivatorius cranialis superior) which is a vegetative innervations center of the submandibular, sublingual and salivary glands. Salivary, submandibular and mucous glands of the nose are phylogenetically more ancient as provide nose and mouth cavity moisturizing within the absent secondary palate in amphibians and some reptiles which helps in food propulsion (insects, reptiles with dry surface). Position of the common nuclei which provide glands' functioning also presents such neuroformations' unity. Thus, in humans salivary and lacrimal glands secret is limited by the nose cavity after the secondary palate formation. This provides olfaction and moisturizing of the nose mucous membrane. Pathological processes development is much connected with the limitation of the nose cavity by a secondary palate. Such anatomic built is caused by inborn obstruction of the nasolacrimal canal, its inflammatory processes and development of rhinitis connected with neuritis and neuralgia.

Human salivary glands daily produce from 1,5 to 2 liters of saliva providing preparation and primary food digestion in the mouth cavity.

Thus, during phylogenesis nose and mouth cavity were anatomically and functionally separated. Though, if take into account common innervations, blood circulations and reaction to external distracters, in our opinion, such group of glands (lacrimal, mucous, salivary) can be a unified system of primary neurosecretory reaction while contacting with the environment.

\section{CONCLUSIONS}

1. The method of comparing phylo- and ontogenetical data is effective within the functional meaning of the human organs. 
2. Phylogenetically the earliest structures of the nose and mouth cavity in coldblooded which have only primary cavity (amphibians and reptiles) is nasolacrimal and Vidian canal, nose and mouth mucous glands, lacrimal and sublingual glands. They serve for moisturizing and swallowing the food (insects, reptiles, etc).

3. Ontogenetically nasolacrimal canal starts developing on the $1^{\text {st }}$ month of the embryonic development. Big salivary glands develop after the secondary palate development or simultaneously with it, which produce mucous secretion first two years after birth. Development of the perirhinal bosom begins on the $3-4^{\text {th }}$ month of the embryonic life, after the secondary palate development. Such ontogenetic sequence of nose, mouth and palate development is the same as in animals in phylogenesis.

4. Development of the secondary palate in warm-blooded vertebrates changed (limited) functional applicability of the lacrimal gland and nasolacrimal canal, mucous glands of nose and vegetative innervation.

5. Groups of lacrimal, mucous glands of nose and mouth, big salivary glands are a unified system of primary, neurosecretory reaction to an environment.

\section{REFERENCES}

1. Dzhalibov D, Gasy`mov D, Panaxiyan V. Patologiya LOR-organiv pry` vrodzheny`x zuboshhelepny`x anomaliyax. [Dzhalibov D., Gasimov D., Panakhiyan V. Pathology of otolaryngology organs in congenital dento and mandibular anomalies]. Zhurnal LOR-zaxvoryuvan` [LOR-diseases Journal]. 2013 2: 54-56. (In Ukraine).

2. Panahiyan V. Sistema profilaktiki i rannego vyiyavleniya vrozhdyonnyih porokov i nasledstvennyih zabolevaniy v otolaringologii. [Panakhiyan V. The system of prevention and early identification of congenital malformations and hereditary diseases in otolaryngology]. Zhurnal LOR-zaxvoryuvan` [LOR-diseases Journal]. 2010.6:32-36. (In Ukraine).

3. Soldatov I. Lektsii po otolaringologii. [Soldatov I. Lectures on otolaryngology]. M.: Medicine; 1990, p. 23-72. (In Russia).

4. GardnerK, Sekretyi otolaringologii [GardnerK, Secrets of Otolaryngology]. M.: Binom; 2001, p. 136-142. (In Russia).
5. Shmalgauzen I. Osnovyi sravnitelnoy anatomii. [Schmalhausen I. Basics of comparative anatomy]. M.:Uchmedgiz; 1938, p. 17-29, 55-67. (In Russia).

6. Malanchuk V, Chepurny 'j J. Travmaty' chni poshkodzhennya orbity` i sl’ozovy` vidny'x shlyaxiv [MalanchukV, ChepurnijY. Traumatic damage of the orbit and lacrimal ducts]. Belaya Tserkov:2014, p. 38-50. (In Ukraine).

7. Dortzbach R. Ophtalmic plastic surgery. NY: Raven Press; 1994, p.10-34.

8. Pautov N. Sravnitelnaya anatomiya i embriologiya naruzhnogo nosa i nosovoy polosti [Pautov N. Comparative anatomy and embryology of the external nose and nasal cavity]. Omsk: dissertation of medical sciences; 1923, p.13. (In Russia).

9. Severtsov A. Morfologicheskie zakonomernosti evolyutsii [Severtsov A. Morphological patterns of evolution]. M.: Academy of Sciences of the USSR; 1939, p. 98-128, 234-246. (In Russia).

10. Romer A, Parson T. Anatomiya pozvonochnyih [Romer A, Parson T. Anatomy of vertebrates]. M.: Mir; 1992, p. 67-120. (In Russia).

11. Keroll R. Paleontologiya i evolyutsiya pozvonochnyih [Paleontology and the evolution of vertebrates]. M.: Mir; 1993, p. 67-143. (In Russia).

The work is a fragment of inter-department al scientific research work of he Department of Human Anatomy named after M.G. Turkevichand The Department of Anatomy, Topographic Anatomy and Operative Surgery of the Higher State Education al Institution of Ukraine "Bukovinian State Medical University" "Patterns of perinatal anatomy and embryo-typography. Determination of gender-age characteristics of the structure and topographic-anatomical interrelation so for gans and structuresin human ontogenesis" (state registration number 0110U003078) and "Gender-age patterns of anatomy and topography-anatomical interrelation so for gans and structuresin human ontogenesis. Peculiarities of age and gender embryo-typography" (state registration number 0105U002927).

Authors' contributions:

According to the order of the Authorship.

Conflict of interest:

The Authors declare no conflict of interest

\author{
CORRESPONDING AUTHOR \\ Larysa Y. Fedoniuk \\ I. Horbachevsky State Medical University \\ Valova street 9, 46000, Ternopil, Ukraine \\ tel: +380673999143 \\ e-mail: Fedonyuk22Larisa@gmail.com
}

Received: 25.12 .2018

Accepted: 28.02.2019 
PRACA POGLĄDOWA

REVIEW ARTICLE

\title{
BIOMARKERY WEWNĄTRZMACICZNEGO ZAHAMOWANIA WZRASTANIA PŁODU
}

\section{BIOMARKERS OF INTRAUTERINE GROWTH RESTRICTION}

\author{
Ewa Gulczyńska' ${ }^{2}$ Ewa Peterson ${ }^{1}$, Tomasz Radzik' ${ }^{1}$ Ludmiła Żylińska ${ }^{1}$ \\ 'ZAKŁAD NEUROCHEMII MOLEKULARNEJ, UNIWERSYTET MEDYCZNYW ŁODZI, ŁÓDŹ, POLSKA \\ ${ }^{2}$ KLINIKA NEONATOLOGII, INSTYTUT CENTRUM ZDROWIA MATKI POLKI W ŁODZI, ŁÓDŹ, POLSKA
}

\begin{abstract}
STRESZCZENIE
Wewnątrzmaciczne zahamowanie wzrastania płodu (IUGR - intrauterine growth restriction) jest poważnym problemem klinicznym dotykającym około 10\% wszystkich ciąż, a także do 15\% ciąż bliźniaczych jednokosmówkowych. Jest to schorzenie, któremu towarzyszy zdecydowanie podwyższona umieralność okołoporodowa oraz zwiększona śmiertelność płodów. Przyczyny IUGR są bardzo liczne, a obejmują etiologię matczyną, płodową oraz środowiskową. Wielce istotnym jest fakt, że IUGR niesie za sobą liczne negatywne następstwa zarówno zaraz po urodzeniu, jak i w późniejszym okresie życia. Mimo prowadzonych od wielu lat badań klinicznych, brak jest miarodajnego algorytmu pozwalającego na rozpoznanie choroby we wczesnym stadium, zaś brak odpowiedniej terapii zwiększa ryzyko nieprawidłowości w rozwoju płodu. W niniejszej pracy przedstawiono najnowsze dane dotyczące poszukiwania potencjalnych biomarkerów, których oznaczanie w trakcie trwania ciąży oraz po urodzeniu we krwi pępowinowej zwiększyłoby precyzję diagnostyki, profilaktykę i skuteczność leczenia.
\end{abstract}

SŁOWA KLUCZOWE: wewnątrzmaciczne zahamowanie wzrastania płodu (IUGR), ciąża, biomarkery, miRNA

\begin{abstract}
Intrauterine growth restriction (IUGR) is a serious clinical problem affecting about 10\% of all pregnancies, and even up to $15 \%$ of all monochorionic twin pregnancies. This disorder is accompanied by strongly increased perinatal mortality. IUGR has multiple causes including maternal, fetal, placental, and environmental factors. Importantly, IUGR is associated with a number of negative effects exerted just after the birth, as well as during the later years of life. Despite multiple clinical trials conducted for many years, there is no reliable algorithm to diagnose the disease at an early stage, and lack of efficient therapy increases the risk of abnormal fetus development. In this short review, we present recent progress on potential IUGR biomarkers that could be determined during pregnancy and in the umbilical blood after delivery to provide more accurate diagnosis, prophylaxis and efficient treatment.
\end{abstract}

KEYWORDS: intrauterine growth restriction (IUGR), pregnancy, biomarkers, miRNA

Wiad Lek 2019, 72, 3, 436-441

\section{WSTĘP}

Wewnątrzmaciczne zahamowanie wzrastania płodu (IUGR - intrauterine growth restriction) jest istotnym problemem klinicznym i społecznym, dotyka bowiem około 10-15\% ciąż $[1,2]$. Śmiertelność okołoporodowa noworodków z IUGR jest około 12-krotnie wyższa w porównaniu do dzieci z prawidłową masą urodzeniową. Ten patologiczny stan występuje, gdy płód nie wykorzystuje genetycznie uwarunkowanego potencjału wzrastania. Rozwój płodu jest procesem kompleksowym, kontrolowanym przez wiele czynników pochodzących od matki, łożyska oraz płodu [3]. Z klinicznego punktu widzenia IUGR można podzielić na proporcjonalny, gdy wszystkie wymiary noworodka są równomiernie zmniejszone oraz nieproporcjonalny, gdy obwód głowy i długość płodu odpowiada wiekowi ciąży, natomiast masa ciała jest znacznie obniżona.
Powszechnie stosowaną metodą diagnostyczną IUGR są badania ultrasonograficzne przeprowadzane w trakcie ciąży. Istotną wskazówką są badania wykonane w 11-14 tygodniu ciąży, bowiem pomiar długości ciemieniowo-siedzeniowej (CRL - crown rump lenght) pozwala oszacować wiek płodu z dokładnością do 4-7 dni [4]. W kolejnych badaniach USG w II i III trymestrze ciąży można ocenić tempo wzrastania płodu, bazując na wieku płodu określonym w pierwszym badaniu ultrasonograficznym. Przydatnym także jest pomiar obwodu brzucha płodu (AC - abdominal circumference), gdyż koreluje on z wielkością wątroby, której wzrost w przypadku IUGR jest upośledzony [2].

Wieloletnie obserwacje wskazują, że występowanie IUGR w życiu płodowym niesie za sobą konsekwencje w późniejszych latach życia. Zaobserwowano, że u dzieci urodzonych 
z IUGR częściej występuje otyłość, nadciśnienie, cukrzyca typu II, choroby układu sercowo-naczyniowego i osteoporoza. Jedną z przyczyn jest działanie heterogennych czynników na DNA płodu, zaś zaburzenia metabolizmu na tym etapie rozwoju powodują w następstwie nieprawidłowe działanie i rozwój narządów wewnętrznych [4]. Standardowo stosowane prenatalne procedury diagnostyczne IUGR zostały wyczerpująco opisane w publikacjach z $2010 \mathrm{r}$ i 2015 r [5,6]. Niewątpliwym utrudnieniem w diagnostyce IUGR jest wieloczynnikowość jego przyczyn [3, 7-9], stąd, wraz z rozwojem coraz nowocześniejszych technik badawczych, rośnie liczba nowych narzędzi diagnostycznych. Niniejsza praca przedstawia zaktualizowane informacje obejmujące identyfikację potencjalnie użytecznych biomarkerów IUGR.

\section{BIOMARKERY ŁOŻYSKOWE}

W mechanizmie powstawania IUGR często istotną rolę odgrywa nieprawidłowa czynność łożyska, związana z takimi czynnikami, jak hipoinsulinemia, kwasica metaboliczna czy niedotlenienie prowadzące do stresu oksydacyjnego. Jego skutkiem jest wzrost w łożysku i krwi pępowinowej stężenia malondialdehydu (MDA) oraz aktywności oksydazy ksantynowej [10]. W IUGR obserwuje się także zwiększoną aktywność enzymów, takich jak deaminaza adenozynowa, dysmutaza ponadtlenkowa, peroksydaza glutationowa, natomiast spada aktywność katalazy oraz poziom antyoksydantów [11]. Bezpośrednim skutkiem niedotlenienia jest wzrost poziomu leptyny w łożysku, związany ze zwiększoną ekspresją genu leptyny oraz intensywnej syntezy tego białka w komórkach trofoblastu. Leptyna stymuluje syntezę transformującego czynnika wzrostu $\beta$ (TGF $\beta$ - transforming growth factor $\beta$ ), pełniącego kluczową rolę w procesach proliferacji, różnicowana, migracji, a także w apoptozie [12]. Zaburzenia w sygnalizacji indukowanej przez TGF prowadzą do nieprawidłowego metabolizmu sfingolipidów, co wiąże się ze zwiększoną śmiercią komórek trofoblastu, charakterystyczną dla IUGR [13].

W 2015 roku opublikowano badania, w których dowiedziono, że jakość budowy łożyska związana jest $\mathrm{z}$ funkcjonowaniem jednego $\mathrm{z}$ ważniejszych szlaków sygnalizacyjnych JAK-STAT [14]. Jest to ścieżka sygnałowa, za pomocą której wiele receptorów błonowych przekazuje swoje sygnały do wnętrza komórek. Szlak ten działa poprzez aktywację kaskady kinaz MAP.W jego skład wchodzą kinazy z rodziny JAK (JAK1, JAK2, JAK3 i Tyk2) oraz fosforylowane przez nie białka STAT, będące funkcjonalnymi czynnikami transkrypcyjnymi (STAT1, STAT2, STAT3, STAT4, STAT5a, STAT5b i STAT6). Ekspresja STAT3, STAT2 i STAT5b w przypadku występowania wewnątrzmacicznego zahamowania wzrastania płodu była znacząco niższa niż w ciąży niepowikłanej. Najistotniejsze różnice odnotowano względem ekspresji STAT3. Genowi temu przypisuje się także ważną rolę w prawidłowym rozwoju łożyska. Zbyt mała ekspresja STAT3 może powodować hamowanie proliferacji, przedwczesne różnicowanie i apop- tozę komórek łożyska. Dodatkową interesującą obserwacją było następcze upośledzenie transportu aminokwasów do płodu związane z aktywnością SNAT2 (sodium-dependent neutral aminoacid transporter-2). Białko to transportuje glutaminę, glicynę, prolinę i alaninę, zatem jego dysfunkcja może znacząco zmieniać całkowitą pulę (zarówno ilość, jak i skład) dostępnych aminokwasów, niezbędnych do rozwoju komórek płodu.

W wielu ciążach powikłanych IUGR wykazano wzmożoną ekspresję łożyskowego genu PHLDA2 (pleckstrin homology-like domain family A member 2) odpowiedzialnego za wzrost łożyska [15]. W badaniu przeprowadzonym na grupie ciężarnych ze stwierdzonym IUGR wykryto korelację między wzmożoną ekspresją PHLDA2 a częstością występowania tego schorzenia. Ponadto najwyższa ekspresja genu PHLDA2 występowała w najcięższych przypadkach IUGR. Drugim istotnym odkryciem było stwierdzenie, że w surowicy krwi ciężarnej stężenie ludzkiego laktogenu łożyskowego było odwrotnie proporcjonalne do stopnia ekspresji PHLDA2. Choć po skontrolowaniu masy urodzeniowej noworodków zależność ta nie osiągała istotności statystycznej, autorzy sugerują, że wzmożona ekspresja PHLDA2 może prowadzić zarówno do IUGR, jak i do zmniejszenia wydzielania laktogenu łożyskowego.

Krytycznym etapem rozwoju płodu jest proces angiogenezy, natomiast ciąże powikłane IUGR często charakteryzują się nieprawidłowym przebiegiem tworzenia naczyń. Zaburzona równowaga między czynnikami pro- i anty-angiogennymi oraz ich receptorami skutkuje nieprawidłowym rozwojem łożyska. W związku z tym dochodzi do zmiany poziomów czynników antyangiogennych, między innymi takich jak rozpuszczalna fms-podobna kinaza tyrozynowa-1 (sFlt1 - soluble fms-like tyrosine kinase-1), która wiąże czynnik wzrostu śródbłonka naczyniowego oraz łożyskowy czynnik wzrostu, tym samym modyfikując intensywność wzrostu naczyń krwionośnych [16]. Obniżeniu ulegają natomiast ilości czynników pro-angiogennych, takich jak neuropilina-1. Jest to transbłonowa glikoproteina, pełniącą funkcję koreceptora dla semaforyn, które z kolei odgrywają istotną rolę w rozwoju układu nerwowego. Obserwuje się także niską aktywność łożyskowego czynnika wzrostu (PlGF - placental growth factor), który w sposób nierozerwalny łączony jest $\mathrm{z}$ procesem angiogenezy, w szczególności w okresie rozwoju embrionalnego [17]. Biomarkery łożyskowe, takie jak PIGF obecny w krążeniu matczynym, mogą stać się dodatkowym narzędziem do identyfikacji IUGR. Prace pilotażowe prowadzone do tej pory sugerują, że niskie poziomy PlGF mogą charakteryzować ciąże powikłane IUGR związane ze znaczną patologią łożyska.

Ważną ścieżkę sygnalizacyjną w angiogenezie stanowi rodzina czynników wzrostu i receptorów czynnika wzrostu śródbłonka naczyniowego (VEGF - vascular endothelial growth factor) [18]. Jest on również silnym czynnikiem mitotycznym i chemotaktycznym dla komórek śródbłonka, stymulując tworzenie nowych naczyń, zwiększając przepuszczalność już istniejących, a także biorąc udział w przebudowie macierzy zewnątrzkomórkowej [19]. 
Zwiększona aktywność genu VEGF-A w ludzkim łożysku wiąże się z wczesnym początkiem IUGR i jest uważana za wtórną odpowiedź na stan hipoksji w macicy, powszechny w niewydolności łożyska [20].

Kolejnym potencjalnym markerem łożyskowym wydaje się być czynnik transkrypcyjny p45 NF-E2 (nuclear factor erythroid derived 2), którego aktywność drastycznie spada w ciążach powikłanych IUGR [21]. Analizę mechanizmu tej regulacji przeprowadzono na modelu mysim, w którym całkowicie wyłączono gen p45 NF-E2, co spowodowało znaczne zmiany niedokrwienne łożyska. W efekcie, dużo częściej występowało zahamowanie wzrastania płodu. Wydaje się więc, że oznaczanie p45 NFE2 mogłoby stanowić bardzo ważny element wczesnego wykrywania IUGR.

Istotną rolę w prawidłowym rozwoju łożyska pełnią także białka szoku cieplnego (HSP - heat shock proteins), funkcjonujące jako białka opiekuńcze regulujące prawidłowe formowanie białek [10,22]. Zmniejszona ekspresja dwóch z nich, HSP-27 oraz HSP-70 skutkuje aktywacją enzymu kaspazy-3, prowadząc do apoptozy komórek łożyska.

\section{BIOMARKERY MATCZYNE}

Identyfikacja biomarkerów, które byłyby charakterystyczne jedynie dla IUGR jest zadaniem dość trudnym, bowiem jak wykazało wiele badań, etiologia schorzeń, takich jak wczesny lub późny stan przedrzucawkowy i IUGR wydaje się mieć wspólne podłoże i wiele parametrów ulega takim samym zmianom. Zaobserwowano m. in., że we krwi matek wzrastało stężenie sFlt1, a także markerów stanów zapalnych - wysoce wrażliwego białka C-reaktywnego (hsCRP - high-sensitivity C-reactive protein) i interleukiny 6 (Il-6), natomiast stężenie PlGF było niższe niż w grupie kontrolnej [23]. Znacząco wyższy był także stosunek sFlt-1 do PIGF. Oznaczanie tych parametrów może więc stanowić ważne kryterium przesiewowe, pomocne podczas wstępnego diagnozowania IUGR.

Jednym z powszechnie stosowanych badań jest oznaczanie poziomu podjednostki $\beta$ ludzkiej gonadotropiny kosmówkowej ( $\beta$-hCG) we krwi ciężarnej. Jej stężenie poza zakresem normy dla wieku ciążowego może świadczyć o komplikacjach w późniejszym okresie rozwoju płodu. Obniżone stężenie $\beta$-hCG między 11 a 14 tygodniem trwania ciąży wiąże się z większym ryzykiem poronienia. Z kolei wartości powyżej normy obserwowane w drugim trymestrze zwiększają ryzyko wystąpienia nieprawidłowości u płodu, w tym IUGR [24].

Kolejnym genem, którego przydatność diagnostyczną analizowano jest DLK1 (delta like non-canonical notch ligand 1), kodujący białko regulujące procesy różnicowania niektórych komórek, w tym adipocytów. U kobiet w zaawansowanej ciąży wzrasta ekspresja genu DLK1, zaś białko to osiąga wysokie stężenie w krążeniu matki podczas późnej ciąży. Więcej światła na funkcję DLK1 rzuciły badania przeprowadzone w 2016 roku na mysim modelu z usuniętym genem pokazując, że to płód jest źródłem matczynego krążącego DLK1 [25].Wzrost zapotrzebowa- nia metabolicznego matki z uwagi na rozwijający się płód nasila utlenianie kwasów tłuszczowych i występuje zdecydowanie szybsza reakcja na stany deficytu kalorycznego, natomiast w przypadku braku DLK1 matczyna odpowiedź na stan głodzenia była upośledzona. Stwierdzono także, że poziom DLK1 w krążeniu matczynym koreluje z rozwojem masy embrionalnej u myszy. Dlatego też pomiar stężenia DLK1 we krwi matki mógłby być cennym wskaźnikiem przy diagnozowaniu zaburzeń związanych z predykcją słabego wzrastania wewnątrzmacicznego.

Do zestawu markerów IUGR może dołączyć pentraksyna 3 (PTX3) odgrywająca zasadniczą rolę w regulacji płodności, odporności wrodzonej i przede wszystkim w procesach zapalnych [26]. Mechanizm działania tego białka ostrej fazy nie jest do końca poznany, jednak stwierdzono znaczny wzrost stężenia PTX3 we krwi u kobiet w III trymestrze ciąży powikłanej IUGR. PTX3 produkowane jest przez wiele komórek, w tym komórki nabłonka i śródbłonka, fibroblasty, monocyty, leukocyty, makrofagi i komórki dendrytyczne, co zwiększa jego przydatność w ocenie progresji IUGR.

\section{BIOMARKERY U NOWORODKÓW Z IUGR}

W prawidłowym rozwoju tkanek płodu ważną funkcję pełnią insulinopodobne czynniki wzrostu IGF-I i IGF-II (IGF - insulin-like growth factor) [27]. Zaobserwowano, że delecja ludzkiego genu IFG-I wiązała się z silnym upośledzeniem wewnątrzmacicznego wzrastania, zatem oznaczanie jego poziomu we krwi mogłoby być przydatnym, wspomagającym kryterium diagnostycznym. IGF mogą wiązać się z 6 specyficznymi białkami (IGFBP - IGF binding protein), które funkcjonują jako inhibitory aktywności IGF. Za zniesienie tej inhibicji odpowiadają m. in. dwie proteazy ADAM 12 degradująca IGFBP-3 i IGFBP-5 oraz PAPP-A degradująca IGFBP-3 i IGFBP-4, co skutkuje odblokowaniem aktywności IGF. Oba enzymy produkowane przez komórki trofoblastu podczas ciąży uwalniane są do krwi płodowej, przechodzą do łożyska, a następnie do krążenia matki. Ich stężenie we krwi matki wydaje się odzwierciedlać wartości obecne we krwi płodu [28]. Obniżone ilości ADAM12 i PAPP-A mogą wskazywać na upośledzenie wzrastania płodu. Interesującą obserwacją było stwierdzenie, że jeśli redukcja ilości ADAM12 lub PAPP-A występowała między 10 a 14 tygodniem ciąży, niższa była także masa urodzeniowa. To sugeruje, że właśnie te tygodnie ciąży decydują o prawidłowej lub nie masie urodzeniowej.

IUGR wiąże się z ogólnym ryzykiem opóźnienia neurorozwojowego [29]. Ciekawym potencjalnym kandydatem diagnostycznym jest białko S100B należące do bogatej rodziny kwaśnych białek S100 wiążących wapń [30]. Występuje w cytoplazmie komórek wyściółki splotu naczyniówkowego astrocytów i oligodendrocytów, z których jest aktywnie uwalniane. S100B bierze udział w regulacji metabolizmu komórek centralnego układu nerwowego, ich proliferacji oraz $\mathrm{w}$ wewnątrzkomórkowym przekazywaniu sygnałów [31]. W stężeniach nanomolarnych 


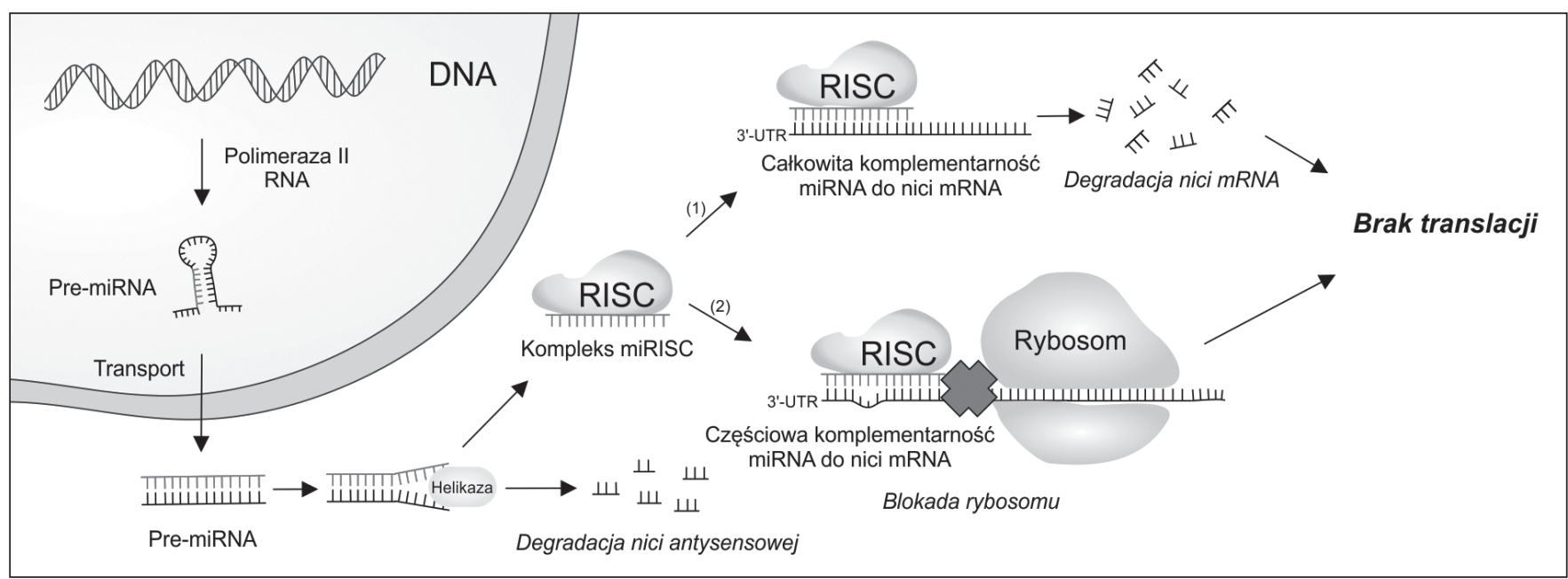

Ryc. 1. Schemat działania mikroRNA.

MikroRNA (miRNA) powstają w jądrze komórkowym w procesie transkrypcji przeprowadzanej przez polimerazę RNA II (lub III), a następnie na skutek szeregu modyfikacji tworzy się pre-miRNA. Po przetransportowaniu do cytoplazmy i kolejnych modyfikacjach powstają dwuniciowe struktury posiadające 18-25 nukleotydów. Jedna nić (antysensowa) ulega degradacji, natomiast druga nić (wiodąca) tworzy tzw. kompleks RISC (RNA-induced silencig complex). Dalsze działanie, w zależności od stopnia komplementarności kompleksu miRNA/RISC i docelowych transkryptów, może zachodzić poprzez dwie drogi: 1. przy wysokim stopniu komplementarności następuje degradacja transkryptu, 2. częściowa komplementarność powoduje blokowanie funkcji rybosomów. W obu przypadkach zahamowany jest proces translacji.

pobudza wzrost i różnicowanie neuronów i astrocytów, zmniejszając uszkodzenia wywołane stresem, natomiast w stężeniach mikromolarnych działa już niekorzystnie, stymulując apoptozę neuronów, produkcję czynników prozapalnych oraz wydzielanie czynnika martwicy guza TNF- $\alpha$ (tumor necrosis factor $\alpha$ ) przez komórki mikrogleju. Wykazano, że ilość białka S100B wzrasta u noworodków z IUGR, u których zdiagnozowano nieprawidłowe przepływy w badaniu ultrasonograficznym metodą Dopplera bądź krwawienie dokomorowe. Ponadto, zaobserwowano także zwiększony poziom enolazy specyficznej dla tkanki nerwowej (NSE - neuron-specific enolase) [32,33]. Badania prospektywne wykazały obecność podwyższonych stężeń białka S100B oraz neuronalnej enolazy u pacjentów z IUGR w wieku 2 lat, co korelowało z gorszymi wynikami rozwoju układu nerwowego [34]. Choć oba parametry znalazły już zastosowanie w biochemicznej diagnostyce poudarowych uszkodzeń mózgu, mogą także być wysoce skuteczne w rozpoznawaniu IUGR.

\section{MIKRORNA JAKO NOWE NARZĘDZIE W DIAGNOSTYCE IUGR}

Jednym $\mathrm{z}$ najnowszych, obiecujących narzędzi $\mathrm{w}$ diagnostyce IUGR wydaje się być oznaczanie mikroRNA, małych, 18-25 nukleotydowych niekodujących cząsteczek, które pełnią ważną rolę pozytywnych lub negatywnych regulatorów procesów posttranskrypcyjnych, $\mathrm{w}$ tym modyfikacji epigenetycznych. Odkrycie miRNA w 1993 r. zapoczątkowało nowy etap poznawania regulacji ekspresji genów [35]. Dotychczas opisano około 1900 różnych miRNA, z czego duża część występuje w łożysku [36]. Poprzez zwiększoną degradację mRNA lub blokowanie translacji zmieniają poziom ekspresji białek i w warunkach fizjologicznych kontrolują prawidłowy rozwój i funkcjonowanie komórek i tkanek (Ryc.1) [37]. Szczególnie dynamicznie te procesy zachodzą w czasie ciąży, natomiast wiele badań wykazało, że nieprawidłowa ekspresja miRNA wiąże się z ciążą patologiczną.

Charakterystyczny dla miRNA jest fakt, że w pierwszym trymestrze ciąży zwiększona jest ekspresja tej grupy cząsteczek, które związane są z kancerogenezą, angiogenezą oraz z procesami antyapoptycznymi, natomiast $\mathrm{w}$ trzecim trymestrze ciąży najbardziej aktywna jest ta grupa, która reguluje procesy różnicowania i antynowotworowe. Interesującą z punktu klinicznego jest obserwacja, że w surowicy matki występują znaczne ilości miRNA związanych $\mathrm{z}$ łożyskiem, których profil zmienia się $\mathrm{w}$ trakcie trwania ciąży, a co szczególnie istotne, ich poziom wykazuje wysoką stabilność [38]. Stąd też pojawia się coraz większa liczba prac oraz duże nadzieje wiązane $z$ opracowaniem wieloelementowych zestawów testowych identyfikujących te grupy miRNA, które pozwolą na wczesną diagnostykę IUGR. Dodatkowym atrybutem miRNA jest występowanie ich we wszystkich płynach ustrojowych (m.in. osocze, płyn mózgowo-rdzeniowy, ślina, siara, mleko, mocz), co szczególnie istotne może być podczas badań prowadzonych na noworodkach z małą masą urodzeniową.

Interesujących danych dostarczyło retrospektywne badanie we krwi matczynej zależności między profilem ekspresji grupy miRNA związanej z chorobami sercowo-naczyniowymi i mózgowo-naczyniowymi a IUGR [39]. I tak, wykazano, że następował statystycznie istotny spadek 6 rodzajów miRNA (100-5p, 125b-5p, 146a-5p, 199a-5p, 221-3p, 574-3p), a kolejne trzy wykazywały tendencję spadkową (17-5p, 103-3p, 195-5p). Przy zastosowaniu mi- 
kromacierzy stwierdzono, że miRNA-10b, miRNA-363 oraz miRNA-149 zaangażowane są w proces rozwoju łożyska, zaś ich wysoka ekspresja występuje w IUGR [40]. Zablokowanie tych cząsteczek z zastosowaniem sekwencji antysensowych spowodowało znaczący wzrost ekspresji genów kodujących czynnik transkrypcyjny regulujący angiogenezę (KLF-4), transportery neutralnych aminokwasów (SNAT1 i SNAT2) oraz transporter leucyny (LAT2). Zmiany te bezpośrednio związane są z odpowiednim przepływem krwi w łożysku oraz dostarczaniem niezbędnych substancji odżywczych dla płodu.

\section{PODSUMOWANIE}

Bieżąca diagnostyka na podstawie oceny ogólnoklinicznej jest niewystarczająca, przede wszystkim ze względu na wieloczynnikowe podłoże IUGR. Brak prostych testów diagnostycznych krwi jest największą przeszkodą w rozwijaniu skutecznej terapii tego schorzenia. Na przestrzeni ostatnich lat ukazało się szereg prac, w których poszukiwano specyficznych markerów mogących wzbogacić paletę czynników diagnostycznych IUGR [41-43]. Co ciekawe, niektóre z nich oznaczane są podczas diagnozowania wielu innych chorób, zaś dopiero niedawno wykazano ich potencjalną przydatność także w ocenie IUGR.

Próby identyfikacji wczesnych biomarkerów oznaczanych we krwi kobiet z podejrzeniem IUGR, jak również dalsza analiza wybranych parametrów w łożysku, krwi matki oraz krwi pępowinowej zwiększyłaby istotnie zarówno precyzję diagnostyki, profilaktykę, jak i skuteczność leczenia. Równie ważnym wydaje się możliwość uzyskania narzędzi prognostycznych dla ewentualnych późniejszych następstw u pacjentów z IUGR. Rozwój nowych technik analitycznych, wykorzystujących także metody biologii molekularnej, stwarza realną możliwość wczesnego wykrywania stanów patologicznych, jednocześnie znacznie ograniczając inwazyjność czy bolesność badania, a zwiększając efektywność diagnostyczną.

Praca powstała $w$ trakcie realizacji tematów nr 502-03/6086-02/502-64-112 oraz 503/6-086-02/503-01 Uniwersytetu Medycznego $w$ Łodzi.

\section{PIŚMIENNICTWO}

1. Groom KM, Poppe KK, North RA, McCowan LM. Small-for-gestationalage infants classified by customized or population birth weight centiles: impact of gestational age at delivery. Am J Obstet Gynecol. 2007;197(3):239.e1-5.

2. Dall'Asta A, Brunelli V, Prefumo F, Frusca T, Lees CC. Early onset fetal growth restriction. Matern Health Neonatol Perinatol. 2017;18;3:2.

3. Rodriguez A, Tuuli MG, Odibo A0.First-, Second-, and Third-Trimester Screening for Preeclampsia and Intrauterine Growth Restriction. Clin Lab Med. 2016;36(2):331-51.

4. Barker DJP. Adult consequences of fetal growth restriction. Clin Obstet Gynecol. 2006;49:270 -283.

5. Jasińska EA, Wasiluk A. Wewnątrzmaciczne ograniczenie wzrastania płodu (IUGR) jako problem kliniczny. Perinat Neonat Gin. 2010;3(4): 255-261.
6. Radon-Pokracka M, Huras H, Jach R. Intrauterine growth restriction diagnosis and treatment. Przegl Lek. 2015;72:376-382.

7. Sharma D, ShastriS, Sharma P. Intrauterine growth restriction: antenatal and postnatal aspects. Clin Med Insights Pediatr. 2016;10:67-83.

8. Roifman M, Choufani S, Turinsky AL et al. Genome-wide placental DNA methylation analysis of severely growth-discordant monochorionic twins reveals novel epigenetic targets for intrauterine growth restriction. Clin Epigenetics. 2016;8:70.

9. Bernstein IM, Horbar JD, Badger GJ et al. Morbidity and mortality among very-low-birth-weight neonates with intrauterine growth restriction. Am J Obstet Gynecol. 2000;182:198-206.

10. Gurugubelli Krishna R, Vishnu Bhat B. Molecular mechanisms of intrauterine growth restriction. J Matern Fetal Neonatal Med. 2018;31(19): 2634-2640.

11. Biri A, Bozkurt N, Turp A, Kavutcu M, Himmetoglu 0, Durak I. Role of oxidative stress in intrauterine growth restriction. Gynecol Obstet Invest. 2007;64(4):187-92.

12. Tzschoppe A, Struwe E, RascherW et al. Intrauterine growth restriction (IUGR) is associated with increased leptin synthesis and binding capability in neonates. Clin Endocrinol (0xf). 2011;74(4):459-466.

13. Chauvin S, Yinon Y, Xu J et al. Aberrant TGF $\beta$ signalling contributes to dysregulation of sphingolipid metabolism in intrauterine growth restriction. J Clin Endocrinol Metab. 2015;100(7): E986-E996.

14. Borg AJ, Yong HEJ, Lappas M et al. Decreased STAT3 in human idiopathic fetal growth restriction contributes to trophoblast dysfunction. Reproduction. 2015;149:523-532.

15. Janssen AB, Tunster $S J$, Heazell AEP et al. Placental PHLDA2 expression is increased in cases of fetal growth restriction following reduced fetal movements. BMC Med Genet. 2016;17.

16. Palmer KR, Kaitu'u-Lino TJ, Cannon P et al. Maternal plasma concentrations of the placental specific sFLT-1 variant, sFLT-1 e15a, in fetal growth restriction and preeclampsia. J Matern Neonatal Med. 2017;30:635-639.

17. Benton SJ, McCowan LM, Heazell AEP et al. Placental growth factor as a marker of fetal growth restriction caused by placental dysfunction. Placenta. 2016;42:1-8.

18. Koczy-Baron E, Kasperska-Zając A. The role of vascular endothelial growth factor in inflammatory processes. Postepy Hig Med Dosw. 2014;68:57-65.

19. Zamarian ACP, Araujo Júnior E, Daher S et al. Evaluation of biochemical markers combined with uterine artery Doppler parameters in fetuses with growth restriction: a case-control study. Arch Gynecol Obstet. 2016;294:715-723.

20. Szentpeteri I, Rab A, Kornya L et al. Gene expression patterns of vascular endothelial growth factor (VEGF-A) in human placenta from pregnancies with intrauterine growth restriction. J Matern Fetal Neonatal Med. 2013;26:984-989.

21. Kohli S, Hoffmann J, Lochmann F et al. p45 NF-E2 regulates syncytiotrophoblast differentiation by post-translational GCM1 modifications in human intrauterine growth restriction. Cell Death Dis. 2017;8.

22. Hromadnikova I, Dvorakova L, Kotlabova K et al. Circulating heat shock protein mRNA profile in gestational hypertension, pre-eclampsia \& foetal growth restriction. Indian J Med Res. 2016;144(2):229-237.

23. Kwiatkowski S, Dołęgowska B, Kwiatkowska E, Rzepka R, Torbè A, BednarekJędrzejekM.ACommon Profile ofDisordered AngiogenicFactorProduction and the Exacerbation of Inflammation in Early Preedlampsia, Late Preedlampsia, and Intrauterine Growth Restriction. PLoS One. 2016;11(10): e0165060. 
24. Sirikunalai P, Wanapirak C, Sirichotiyakul S et al. Associations between maternal serum free beta human chorionic gonadotropin $(\beta-h C G)$ levels and adverse pregnancy outcomes. J Obstet Gynaecol. 2016;36(2):178-182.

25. Cleaton MAM, Dent CL, Howard M et al. Fetus-derived DLK1 is required for maternal metabolic adaptations to pregnancy and is associated with fetal growth restriction. Nat Genet. 2016;48:1473-1480.

26. Ibrahim MI, Ammar EM, Ramy A et al. The association between pentraxin 3 in maternal circulation and pathological intrauterine fetal growth restriction. Eur J Obstet Gynecol Reprod Biol. 2015;185:1-8.

27. Cowans NJ, Spencer K. First-trimester ADAM12 and PAPP-A as markers for intrauterine fetal growth restriction through their roles in the insulinlike growth factor system. Prenat Diagn. 2007;27(3):264-71.

28. Kasimis C, Evangelinakis N, Rotas M, Georgitsi M, Pelekanos N, Kassanos D. Predictive value of biochemical marker ADAM-12 at first trimester of pregnancy for hypertension and intrauterine growth restriction. Clin Exp Obstet Gynecol. 2016;43(1):43-47.

29. Najjar S, Pearlman DM, Alper K et al. Neuroinflammation and psychiatric illness. J Neuroinflammation. 2013;10(1).

30. Schroeter ML, Sacher J, Steiner J et al. Serum S100B represents a new biomarker for mood disorders. Curr Drug Targets. 2013;14:1237-1248.

31. Steiner J, Bogerts B, Schroeter ML et al. S100B protein in neurodegenerative disorders. Clin Chem Lab Med. 2011;49:409-424.

32. Velipaşaoğlu M, Yurdakök M, Özyüncü Ö, Portakal 0, Deren Ö. Neural injury markers to predict neonatal complications in intrauterine growth restriction. J Obstet Gynaecol. (Lahore) 2015;35:555-560.

33. Mazarico $E$, Llurba $E$, Cumplido $R$ et al. Neural injury markers in intrauterine growth restriction and their relation to perinatal outcomes. Pediatr Res. 2017;82:452-457.

34. Mazarico E, Llurba E, Cabero L et al. Associations between neural injury markers of intrauterine growth-restricted infants and neurodevelopmentat 2 years of age. J Matern Neonatal Med. 2018:1-11.
35. Lee RC, Feinbaum RL, Ambros V. The C. elegans heterochronic gene lin-4 encodes small RNAs with antisense complementarity to lin-14. Cell. 1993;3;75(5):843-854.

36. Chiofalo $B$, Laganà AS, Vaiarelli $A$ et al. Do miRNAs Play a Role in Fetal Growth Restriction? A Fresh Look to a Busy Corner. Biomed Res Int. 2017;2017:6073167.

37. O'Brien J, Hayder H, Zayed Y, Peng C. Overview of MicroRNA Biogenesis, Mechanisms of Actions, and Circulation. Front Endocrinol (Lausanne). 2018;3;9:402.

38. Cai M, Kolluru GK, Ahmed A. Small Molecule, Big Prospects: MicroRNA in Pregnancy and Its Complications. J Pregnancy. 2017;2017:6972732.

39. Hromadnikoval, Kotlabova K, Hympanova L, KroftaL.Gestational hypertension, preeclampsia and intrauterine growth restriction induce dysregulation of cardiovascular and cerebrovascular disease associated microRNAs in maternal whole peripheral blood. Thromb Res. 2016;137:126-40.

40. Thamotharan $S$, Chu A, Kempf $K$ et al. Differential microRNA expression in human placentas of term intra-uterine growth restriction that regulates target genes mediating angiogenesis and amino acid transport. PLOS One. 2017;12.

41. Cetin I, Mandò C, Calabrese S. Maternal predictors of intrauterine growth restriction. Curr Opin Clin Nutr Metab Care. 2013;16(3):310-9.

42. Sotiriadis $A$, Figueras $F$, Eleftheriades $M$ et al. First-trimester and combined first- and second-trimester prediction of small-forgestational age and late fetal growth restriction. Ultrasound Obstet Gynecol. 2019;53(1):55-61.

43. Spencer R, Ambler G, Brodszki J et al. EVERREST prospective study: a 6 -year prospective study to define the clinical and biological characteristics of pregnancies affected by severe early onset fetal growth restriction. BMC Pregnancy Childbirth. 2017;23;17(1):43.

Konflikt interesów:

Autorzy deklarują brak konfliktu intresów

\author{
AUTOR KORESPONDUJĄCY \\ Ludmiła Żylińska \\ Zakład Neurochemii Molekularnej \\ Uniwersytet Medyczny \\ ul Mazowiecka 6/8, 92-215 Łódź, Polska \\ tel: 422725680 \\ faks: 422725679 \\ e-mail: ludmila.zylinska@umed.lodz.pl
}

Nadesłano: 23.07.2018

Zaakceptowano: 20.02.2019 
PRACA POGLĄDOWA

REVIEW ARTICLE

\title{
INTEGRATED ESTIMATION OF THE DEMOGRAPHIC SITUATION IN UKRAINE - FORECAST FOR THE FUTURE
}

\author{
KOMPLEKSOWA OCENA SYTUACJIDEMOGRAFICZNEJ \\ NA UKRAINIE - PROGNOZA NA PRZYSZŁOŚĆ
}

\author{
Zhanetta A.Chornenka, Tetiana I. Domanchuk \\ HIGHER STATE EDUCATIONAL ESTABLISHMENT OF UKRAINE «BUKOVINIAN STATE MEDICAL UNIVERSITY», CHERNIVTSI, UKRAINE
}

\begin{abstract}
Introduction: The demographic situation in the country is largely due to the state of the economy and reflects the medical and social conditions of the population, which in turn testify to the state of the economy, the health care system, education, culture, and other factors.

The aim: Analysis and comparison of the demographic situation in Ukraine with the EU countries, forecast for the future.

Materials and methods: The statistical materials of the Center for Medical Statistics of the Ministry of Health of Ukraine 2012-2016 were processed. A medical-statistical analysis of the system's performance indicators for the five components carried out; an assessment of the performance of the health system according to the WHO approach with certain modifications used.

Review: Having analyzed the statistics of the last years in Ukraine, the birth rate in 2017 decreased as compared to 2016, in January-April 2017 there was a natural decrease in the population, while migration processes in Ukraine exceeded immigration beyond its borders. In connection with the antiterrorist operation in the east of the country and the beginning of active hostilities in the region, the population was significantly reduced to 43 million people. Life expectancy has also changed, and today the average life expectancy in Ukraine is 71 years (66 years are men, 75 are women).

Conclusions: It is necessary to concentrate efforts on solving current problems - economic birth control, adequate social protection of families with children and the elderly, promoting a healthy lifestyle, ensuring the availability of quality medical care and education, which in turn will ensure an increase in the duration of a full active life.
\end{abstract}

KEY WORDS: demographic situation, demographic crisis, mortality, fertility, integral evaluation of indicators, average expected life expectancy

Wiad Lek 2019, 72, 3, 442-446

\section{INTRODUCTION}

The population of the country is a component of the state, a pledge of security, the basis of social development in general. According to the Ministry of Health, the demographic situation in Ukraine is deteriorating every year, depopulation occurs, and, consequently, the production forces are reduced quantitatively.

In conditions of stable unhurried development, the main method of foreseeing a relatively near future is extrapolation of existing trends. In the era of reforms, forecasts become extremely difficult, although the demand for them is dramatically increasing. What will happen in a year, ten, and fifty? We are trying to detail what kind of changes will occur in the demographic situation of the country because of a radical change in the social and economic situation.

In recent decades, most countries in the world are trying to assess and strengthen their health systems to increase the positive impact on public health. The starting point for improving the health system at various levels is the assessment of its current state, the analysis of effectiveness and effectiveness. The report of the World Health Organization (WHO) proposed measures and methodology for compar- ative evaluation of health systems. These measures reflect progress in achieving the three fundamental goals of health systems: 1) improving the health status of the population (both in terms of level and social equity); 2) observing the principle of equity in the allocation of financial resources, providing protection against financial risk; 3) increasing the sensitivity of the system to the expectations of the population in matters not related to health.

However, the need for an evaluation of activities to determine the extent to which the various links and the overall system is reaching the end results is rapidly growing because of the need to meet the population's needs for affordable medical care in conditions of limited funding and lack of resources. Therefore, the development of a system of balanced indicators that allow us to comprehensively evaluate the effectiveness of the health care system and further optimize medical care is extremely urgent in modern conditions.

The main reason for the aggravation of the demographic crisis in Ukraine is a decrease to the critical level of the birth rate. Only half of the population necessary for reproduction provided bythe current demographic state indicates. To 
Table I. The main demographic indicators for Ukraine

\begin{tabular}{|c|c|c|c|c|c|c|}
\hline № & Demographic index & 2012 & 2013 & 2014 & 2015 & 2016 \\
\hline \multirow[t]{3}{*}{1.} & $\begin{array}{c}\text { Number of } \\
\text { of the population (yew): } \\
\text { - Total }\end{array}$ & 45633 & 45553 & 45426 & 42929 & 42760 \\
\hline & - men & 20976 & 20962 & 20918 & 19787 & 19717 \\
\hline & - women & 24476 & 24409 & 24327 & 22971 & 22872 \\
\hline 2. & Demographic burden per 1000 persons & 421 & 425 & 432 & 443 & 452 \\
\hline 3. & Number of live births (yew) & 520705 & 503657 & 465882 & 411781 & 379089 \\
\hline 4. & Number of deceased (yew) & 663139 & 662368 & 465882 & 594796 & 583642 \\
\hline 5. & Natural increase & -142434 & -158711 & -66414 & -183015 & -186612 \\
\hline \multirow{3}{*}{6.} & Average life expectancy: & 71,15 & 71,37 & 71,37 & 71,38 & 70,33 \\
\hline & - men & 66,11 & 66,34 & 66,25 & 66,37 & 64,56 \\
\hline & - women & 76,02 & 76,22 & 76,37 & 76,25 & 76,11 \\
\hline \multirow{2}{*}{7.} & $\begin{array}{l}\text { Mortality of children under one year: } \\
\text { - boys }\end{array}$ & 2496 & 2309 & 2124 & 1896 & 1689 \\
\hline & - girls & 1875 & 1721 & 1532 & 1422 & 1311 \\
\hline 8. & Maternal mortality & 65 & 68 & 71 & 62 & 59 \\
\hline \multirow{3}{*}{9.} & $\begin{array}{l}\text { Migration movement of the population: } \\
\qquad \text { - arrived }\end{array}$ & 726226 & 675942 & 542506 & 533278 & 51178 \\
\hline & - retired & 664382 & 644029 & 519914 & 519045 & 52469 \\
\hline & - migration increase & 61844 & 31913 & 22592 & 14233 & 10643 \\
\hline
\end{tabular}

date, Ukraine has already crossed the border of the decline in the birth rate, which is the irreversible destruction of the country's demographic potential, which leads to a loss of conditions for the restoration of the population. The process of reducing fertility caused in modern conditions is of a global nature and by a number of economic, social, and biological causes.

Comparison of statistical indicators with other countries shows that according to the main indicators of natural changes in the population - fertility, mortality, natural increase - Ukraine is not only after the countries of the West, but also the republics of the former USSR. In terms of fertility, it occupies the penultimate place among them and the countries of Europe, the death rate of the population is the second among the countries of the continent, according to the level of child mortality, its indicators are among the top ten indicators for European countries, by the expected life expectancy (67 years) - one hundred and ninth place In the world, when in 1994 occupied the eighty seventh place.

\section{THE AIM}

The aim of writing the article was to analyze the current state of the demographic situation in Ukraine and the factors influencing it, comparing the demographic situation of our country with the EU countries and considering a conceptual forecast for the future.

\section{MATERIALS AND METHODS}

In our work, the statistical materials of the Center for Medical Statistics of the Ministry of Health of Ukraine 2012-2016 were processed; literary and scientific sources analyzed in accordance with the methods for evaluating the performance of health systems.

Accordingly, for the purpose of research it is necessary to solve the following tasks:

- study of existing methods for assessing the performance of the health care system, an analysis of their compliance with modern requirements and information support capabilities for determining a set of performance indicators; - study of a set of indicators of the effectiveness of the health care system in Ukraine on the preservation and promotion of health;

- investigating factors that hamper the development of the health care system and the rationale for improving the performance of the future health care system.

To calculate the performance indicators of the national system, we used statistical information and data from a number of studies. The medical-statistical analysis carried out of the system's effectiveness indicators in five components: the level of health, the scale of health inequalities, and the degree of sensitivity of the system to the expectations of the population, the fairness of the burden of spending on health and the structural effectiveness of the system.

For the calculations, the evaluation of the health system 
performance used according to the WHO approach with certain modifications, additions and clarifications, based on the capabilities and needs of the national health system.

The main demographic indicators for Ukraine presented for the last 5 years in Table I.

\section{REVIEW}

The state of the Ukrainian health systemcan be characterized as a crisis, based on its most important result of activity - public health indicators, , primarily due to the high level of overall mortality (16.3 per 1000 population) and low life expectancy at birth. The demographic crisis has observed around the worldin recent decades. Annual population decline occurs in many countries. Governments of some countries, taking into account such a negative trend, are pursuing an appropriate migration policy, seeking compensation for losses from migrants. However, the indigenous population in them is declining. This is practically all European states, as well as the United States, Russia, Japan and a number of other countries.

The reason for the population decline in the world was a significant decline in the birth rate, which began in the 1950 s and 1960s. Now the population continues to grow only in the states of Africa and Asia (the highest rates are in India and China), which is caused by the traditions that still exist, as well as the poverty and illiteracy of a significant part of the people.

The first national All-Ukrainian Population Census took place in Ukraine on December 5, 2001 (the previous one held in 1989). According to this census, the population of Ukraine was 48 million 457000 people. This figure was significantly less than in 1989 - 51 million 452 thousand people. These data indicate the continuation of a rapid fall in the birth rate in Ukraine. During the period between the two censuses, the total population of Ukraine decreased by 3291.2 thousand people, or by 6.3\%. The largest population in Ukraine was recorded in early 1993 - 52244.1 thousand people. Since that time and until December 5, 2001, demographic losses amounted to 3,787.0 thousand people; $72 \%$ of these losses is a natural decline in the population. According to the census, from 1989 to 2001, part of the urban residents almost did not change, more than two thirds of the population of Ukraine lives in urban areas.

Although in recent years the rates of maternal and child mortality in Ukraine have improved due to the introduction of modern perinatal technologies, in particular obstetric care with the participation of family members, the demadication of childbirth, etc., the expected life expectancy is lower than that registered in the early 90s and is 70.33 years (men - 64.56, women - 76.11). All this takes place against the background of a significant improvement in health and a reduction in the mortality rate in most of the developed countries of the world and leads to a significant gap in the magnitude of life expectancy in Ukraine and European countries (Table II).

If we analyze in more detail the statistics of recent years in Ukraine, the birth rate in January-April 2017, according to the State Statistics Service, was 116,907 children, while in the same period in 2016 this figure was 128530 children. In January-April 2017, there was a natural decrease in the population by 85,387 people, whereas in January-April 2016 this figure was 74,379 people. At the same time, the number of those who came to the country exceeded the number of those who left the country for 2612 people in January-April this year, for the same period in 2016, when this figure was 6,256 people.

The population of Ukraine at the end of 2016 was 42 million 584.5 thousand people, which, according to the State Statistics Service of Ukraine, 176 thousand people less than it was at the end of 2015. In the spring of 2014, after the annexation of the Crimea and the formation of an anti-terrorist operation zone in the east of the country in connection with the beginning of active military operations in the region, the population of Ukraine adjusted and significantly reduced to 43 million from 45 million people. In the future, this indicator decreases from month to month.

The life expectancy has also changed; today the average life expectancy in Ukraine is 71 years (66 years - men, 75 women). According to this indicator, Ukraine ranks 52nd among the countries of the world. The overall mortality rate has increased in all areas, especially in agricultural areas, where the share of elderly people in the population is twice that in cities. To make the population the same as in 1991, it is necessary to raise the birth rate to 2.2-2.3 children per both parents. Today, this figure in Ukraine is almost half, what it was in 1990 and is 1.1 children per family. Coming out of this population decreases annually by almost 350 thousand people.

In demographic terms, Ukraine has become one of the worst countries in the world. First of all, it is caused by an ineffective policy towards the least protected segments of the population. The decrease in the birth rate led to the fact that today about $30 \%$ of the population is people who get retired (people more than 65). For 14 million retirees there are 18 million working people, of which only 7 million are in the material sphere of production. If this trend continues, then there is a real threat that by 2025 the population of Ukraine will decrease to 25-30 million. Under such circumstances, population preservation should be the main demographic strategy of the state today.

\section{DISCUSSION}

The demographic situation in Ukraine is characterized not only by depopulation it has acquired the properties of an acute demographic crisis, the main signs of which are unfavorable changes not only in quantity but also in the health of the population[8]. A modern demographic situation can be defined as a crisis situation precisely because depopulation is accompanied by a significant deterioration in people's health, which is manifested in a decrease in the average life expectancy.The tendency of significant deterioration in the health of children and adolescents is progressing [10]. The problem of improving the health of the population today has become a problem of its elementary preservation. 
Table II. Expected duration of life in Ukraine and some EU countries.

\begin{tabular}{ccccc}
\hline \multirow{2}{*}{ Country } & Populationsize (million) & \multicolumn{3}{c}{ Average life expectancy } \\
\cline { 3 - 5 } & & men & women & Total fertility rate \\
\hline Ukraine & 42,8 & 66,2 & 76,4 & 1,50 \\
\hline Austria & 8,7 & 79,1 & 84,0 & 1,47 \\
\hline Italy & 60,7 & 80,7 & 85,6 & 1,37 \\
\hline Germany & 82,2 & 78,7 & 83,6 & 1,47 \\
\hline Poland & 38,0 & 73,7 & 81,7 & 1,32 \\
\hline Romania & 19,8 & 71,4 & 78,7 & 1,52 \\
\hline Slovakia & 5,4 & 73,3 & 80,5 & 1,37 \\
\hline Hungary & 9,8 & 72,3 & 79,4 & 1,44 \\
\hline France & 66,7 & 79,5 & 86,0 & 2,01 \\
\hline Czech Republic & 10,6 & 75,8 & 82,0 & 1,53 \\
\hline
\end{tabular}

Radioactive and technogenic pollution of the atmosphere, soils, and reservoirs in most areas leads to mutations and damage to genes. The consequence of this is a decrease in the birth rate, an increase in deformity among newborns, the spread of hereditary diseases and the like. Ecological safety of the population remains catastrophic. Atmospheric pollution adversely affects every third inhabitant of Ukraine, and 28\% in general breathe air, dangerous to life. According to the Ministry of Health of Ukraine for 2017 , cardiovascular diseases cause almost $67 \%$ of all deaths of Ukrainians [9].The prevalence of diseases among the population over the past 10 years has grown by $38 \%$.

There are prerequisites for reducing morbidity and disability, some increase in life expectancy, which, however, do not lead to fundamental changes in the quality of health, to a transition from a rather backward to a more modern model of health. This option is possible with a significant increase in living standards, improving the environmental situation, when viewing the ideology of the Ukrainian health care system and increasing its funding by $40-50 \%$.

In order to solve the critical demographic situation in the country, in our opinion, are: encouraging the population to create two- and three-child families through propaganda and material incentives; prohibition of abortion; transfer of state attention to two- and three-child families, and not to large families, as the main regulator of the demographic situation; improvement of the economic state of the state, since the impoverishment of the majority of the population adversely affects the demographic situation; decrease in the death rate of newborns (now the birth rate in Ukraine and Japan is almost the same - 11.5 children per 1000 inhabitants, but in Japan, the death rate of children is $6.2 \%$ per 1000 inhabitants, and in Ukraine - 13.4\%) [7].

In addition, demographic problems require the development of a scientifically based comprehensive program to overcome the demographic crisis that would cover not only the issues of simple reproduction of the population, but also its development in a broad social context [2]. It is necessary to develop a modern ideology of the demographic development of Ukraine, it is necessary to strengthen scientific developments in the field of demographic and gender studies, and their financial support.

In matters of family policy and fertility, the main goal is the formation of a system of personal and public values aimed at creating a family with two children, strengthening and enhancing its educational potential as the main environment for the reproduction of the population [6]. The objects of direct attention of the state should be young families and families with children.In the field of improving health, reducing mortality and increasing the life expectancy of the population, measures are needed to improve the quality of life, prevent harmful and dangerous production factors, improve the sanitary, epidemiological, and environmental situation, reform the health care system, and stimulate positive changes in people's behavior and way of life.

\section{CONCLUSIONS}

Thus, in modern conditions, when the population of Ukraine continues to be in a state of uncertainty, the evaluation of effectiveness plays a significant role in the progressive development of the health care system, because an undeveloped, unjustified economic strategy at the state level will lead to an even greater demographic crisis.

In order to improve the demographic situation, the state needs to direct socio-economic policies to address the most acute problems: stimulating fertility, increasing medical care, enhancing protection and remuneration, improving living conditions and introducing a healthy lifestyle, and creating a broad network of state and non-government social services.

\section{REFERENCES}

1. Teitelbaum MS. Political demography: Powerful trends under-attended by demographic science. Popul Stud (Camb). 2015;69 Suppl 1:87-95.

2. Blue L, Espenshade TJ. Population momentum across the demographic transition. Popul Dev Rev. 2011;37(4):721-47.

3. Nolin DA, Ziker JP. Reproductive Responsesto Economic Uncertainty: Fertility Declinein Post-Soviet Ust'-Avam, Siberia. HumNat. 2016 Dec;27(4):351-371. 
4. Sobotka T.Post-transitional fertility: the role of child bearing post ponementin fuelling the shift to low and unstable fertility levels. J BiosocSci. 2017 Nov;49(S1):20-45.

5. Rodin J. Fertility intention sand risk management: exploring the fertility decline in Eastern Europeduring transition. Ambio. 2011 Mar;40(2):221-30.

6. Romaniuk P, Szromek AR. The evolution of the health system out comes in Central and Eastern Europe and the irassociation with social, economic and political factors: ananalysis of 25 years of transition. BMC Health ServRes. 2016 Mar 17:16:95.

7. BohdanovychV. Shliakhy podolannia demohrafichnoi kryzy v umovakh sotsialno-ekonomichnykh transformatsii. Visn. Natsionalnoi akademii derzhavnoho upravlinniapry Prezydentovi Ukrainy. 2006;4:207-214.

8. Demohrafichna sytuatsiia [Elektronnyi resurs]. Rezhym dostupu: http:// myukraine.info/uk/country/people/demography

9. Demograficheskaya situatsiya v Ukraine [Elektronnyiy resurs]. - Rezhim dostupu: https:/ /economistua.com/demograficheskaya-situatsiya-vukraine

10. Dity, zhinky ta simia v Ukraini: statystychnyi zbirnyk. K.: Derzhavnyi komitet statystyky Ukrainy. 2000:362
"The study of the processes of socially important pathology and substantiation of its prevention», 0115U002766, Higher State Educational Establishment of Ukraine "Bukovinian State Medical University», Department of Social Medicine and Public Health, 01/2015 - 12/2019.

Authors' contributions:

According to the order of the Authorship.

\section{Conflict of interest:}

The Authors declare no conflict of interest.

\section{CORRESPONDING AUTHOR}

Zhanetta A. Chornenka

Department of Social Medicine and Public Health,

Higher State Educational Establishment of Ukraine

«Bukovinian State Medical University»

Theatralna sq., 2, 58002. Chernivtsi, Ukraine

tel: +380505606077

e-mail:0zo@bsmu.edu.ua

Received: 11.11 .2018

Accepted: 15.02.2019 
PRACA POGLADDOWA

REVIEW ARTICLE

\title{
LICHEN PLANUS AND COMORBID CONDITIONS (A REVIEW OF LITERATURE)
}

\section{LISZAJ PŁASKI II CHOROBY WSPÓŁISTNIEJĄCE (PRZEGLĄD LITERATURY)}

\author{
Alla M. Bilovol', Svitlana H. Tkachenko', Oleksandra A. Havryliuk' ${ }^{1,2}$, Alla A. Berehova', Yevheniia H. Tatuzian', \\ Nataliia L. Kolhanova', Svitlana 0. Stetsenko' \\ 'KHARKIV NATIONAL MEDICAL UNIVERSITY, KHARKIV, UKRAINE \\ 2STATE ESTABLISHMENT «INSTITUTE OF DERMATOLOGY AND VENEREOLOGY OF NATIONAL ACADEMY OF MEDICAL SCIENCES OF UKRAINE», KHARKIV, UKRAINE
}

\begin{abstract}
Introduction: The studying of the comorbidity of skin diseases is a priority scientific direction in modern dermatology. Comorbid conditions aggravate the course of the underlying disease, reduce the effectiveness of diagnosis and treatment can lead to chronization of the process, disability of patients. Understanding of the commonality of pathogenesis and the mutually complicating nature of comorbidity makes a possible to prescribe individual rational treatment.

The aim of the study was search and analysis of the data of review, experimental and clinical scientific and medical publications on the issues of the comorbidity of LP. Materials and methods: an analysis of the studying of the scientific and medical literature was shown. Searching was carried out through the PubMed/MEDLINE portal from the databases of the National Center Biotechnology Information, U. S. National Library of Medicine, National Institute for Health and Clinical Excellence, as well as the portals «Scientific Electronic Library eLIBRARY.RU», «Russian Science Citation Index (RSCI)» and «Index Copernicus».

Conclusions: The main global trends of comorbidity of $L P$ are determined. The results of these studies can form the basis for updating of clinical guidelines for the management of patients with $L P$ at the international and local levels.
\end{abstract}

KEY WORDS: comorbid conditions, lichen ruber planus, rational treatment

Wiad Lek 2019, 72, 3, 447-451

\section{INTRODUCTION}

The studying of the comorbidity of skin diseases is a priority scientific direction in modern dermatology. Understanding of the commonality of pathogenetic aspects, clinical alertness and timely diagnosis of comorbid conditions allow to conduct individual rational treatment aimed at the treatment of dermatosis associated with comorbid disorders. It is known that comorbid conditions are exactly aggravate the course of the underlying disease lead to chronization of the process, disability of patients, reduce the effectiveness of diagnosis and treatment, which leads to increased economic costs of the health care system as well as premature death of the working population. [1,2]. Nowadays the dermatologist works in close cooperation with the therapist, cardiologist, rheumatologist, endocrinologist and oncologist, which is the key to improving and/ or preserving the quality of life of patients suffering from combined pathology. Previously, the interest of scientists studying the associations of dermatoses was focused on atopic dermatitis and psoriasis and the interest of researchers has shifted towards rare dermatoses now. A number of studies on the LP comorbidity have been published, which demonstrate a new perspective on this problem.

\section{THE AIM}

The aim of the work was search and analysis of the data of review, experimental and clinical scientific and medical publications on the issues of the comorbidity of LP over the past five years.

\section{MATERIALS AND METHODS}

Searching was carried out through the PubMed/MEDLINE portal from the databases of the National Center Biotechnology Information, U. S. National Library of Medicine, National Institute for Health and Clinical Excellence, as well as the portals «Scientific Electronic Library eLIBRARY. RU», «Russian Science Citation Index (RSCI)» and «Index Copernicus».

\section{REVIEW AND DISCUSSION}

The LP is a chronic inflammatory immuno-dependent dermatosis of unknown etiology with a specific type of cell-mediated skin reactivity and a pronounced autoimmune mechanism in the bullous clinical form [3]. LP affects $0.2-4 \%$ of the general population as a whole, mostly women (63-67\%). Comorbid conditions of LP can be the result of both its transformation, including malignant and 
iatrogenic medication effects $[4,5,6]$. The combinations of dermatosis with various somatic diseases of the gastrointestinal tract, cardiovascular, endocrine systems and hemostasis, as well as rheumatological diseases have been noted in the previous scientific and analytical reviews. The specific lesions of the epithelium of the uterus, bladder, digestive tract, which indicates a possible systemness of the pathological process in LP have been described. It was felt, that LP can be combined with a group of dermatoses having a number of common pathogenetic aspects, such as impaired keratinization, immune response, metabolism, endothelial function. There are such dermatosis as psoriasis, vitiligo, discoid lupus erythematosus, morphea, lichen scleroatrophica, pemphigus vulgaris, bullous pemphigoid, keratoses, keratoacanthoma, squamous cell carcinoma. [7, $8,9,10]$.

The viral hepatitis $\mathrm{C}$ is one of the most well-known association of LP, and its comorbidity with the oral LP (OLP) is considered a postulate. The HCV seropositivity has been recorded in $16 \%$ of patients with LP and in 6 times more frequently with oral form of dermatosis in compare with control group. [11]. However, in 2017, a group of Indian scientists has published the results of a survey of 84 patients with a histopathologically verified diagnosis of lichen planus. The patients have been examined for the presence of hepatitis $\mathrm{B}$ and $\mathrm{C}$, in all 84 cases the results have been negative. The revealed zero comorbidity allowed the authors to conclude that screening patients with LP on viral hepatitis $\mathrm{B}$ and $\mathrm{C}$ is unjustified, at least in the Indian population. [12]. The comorbidity of LP with chronic active hepatitis, biliary cirrhosis, and dyslipidemia have been also noted in earlier single studies. Some associations have been confirmed later by more extensive researches. Thus, a meta-analysis of 7 observational studies with a total of 5242 subjects revealed an association of LP with dyslipidemia, which occurred 1.74 times more often than in the control group. At the same time, lipid metabolism disorders were manifested by an increase in the level of triglycerides, low-density lipoproteins, total cholesterol and a decrease in the level of high-density lipoproteins. [13]. According to the authors, it is necessary to screen lipid metabolism parameters when establishing the diagnosis of LP. Concomitant hyperlipidemia may also worsen the prognosis for recovery in LP patients. The epidemiological study conducted in Singapore demonstrated that patients who suffer on LP associated with hyperlipidemia and / or diabetes mellitus showed a significantly lower degree of improvement after treatment compared with a group of patients without such comorbidities. $[9,13]$.

A high degree of comorbidity of the OLP with pathology of the gastrointestinal tract and the hepatobiliary system (76.5\%), disorders of the nervous system (70.5\%), cardiovascular system $(61.8 \%)$ was found in a small core study (47 patients) by a group of scientists from the Ural Scientific Research Institute of Dermatology and Immunopathology. The dermatosis was less associated with endocrine pathology $(44.1 \%)$, chronic viral diseases (38.2\%) and diseases of the genitourinary system (34.5\%). Moreover, the po- ly-systemic comorbid pathology was most often recorded in patients with erosive-ulcerative form of LP [14].

In recent years, new data on comorbid associations of LP with autoimmune diseases have been appeared. There was no statistically significant difference in the combination of the OLP and autoimmune diseases, since the identified association of $7 \%$ did not significantly differ from the same indicator of the control group (4\%) [15]. The cutaneous form of the LP (CLP) has demonstrated such an association in an recent extensive study of Thai scientists. A study of 12,427 patients suffering from LP has shown a reliable association of dermatosis with systemic lupus erythematosus (multivariate odds ratio (mOR) was 2.87) with Sjogren's syndrome $(\mathrm{mOR}=3.75)$ with dermatomyositis $(\mathrm{mOR}=6.34)$ with vitiligo $(\mathrm{mOR}=2.01)$, with alopecia areata $(\mathrm{mOR}=2.82)$. The identified associations, according to the authors, need further study and researching of the mechanisms underlying them, as well as analyzing the role of autoimmunity in the etiology of LP. [16].

A study of the comorbidity of LP with scleroatrophic lichen has been also conducted. The authors evaluated the histopathological characteristics of vulvar biopsies of 31 patients (mean age 69.5 years) with the vulvar form of the LP and the current scleroatrophic lichen of the vulva preceding or simultaneous, and also described the clinical features of the comorbidity of these conditions. 30 samples demonstrated a pathological picture of erosive LP, moreover, 22 samples with elements localized on the inner surface of the labia minor and 8 ones localized on the mucous membrane of the vaginal opening. The overlay of scleroatrophic lichen on the LP was detected in 3 (10 $\%)$ patients. The most significant pathological marker of the identified association was the pattern of regeneration of the basal layer characteristic of the LP. According to the authors, the combination of genital lichen planus and scleroatrophic lichen is not rare. However, the association of these dermatoses is not sufficiently diagnosed due to the lack of a characteristic histopathological picture, pathomorphologic errors in the case of the "overlap syndrome" of lichens, as well as different localization of foci of various dermatoses requiring multiple biopsies. The authors of the study revealed a pattern of lichen-comorbid lesions on the vulva, in which the LP is localized on the inner surface of the labia minor and the vaginal opening with scleroatrophic lichen foci on its periphery. Some crucial pathomorphological and clinical signs showing LP and scleroatrophic lichen association in vulva area was also noted. This research gave no answers about frequency of comorbidity of genital LP and scleroatrophic lichen, however, the proposed tools help to identify better such combinations. [17].

Chinese scientists Li D., Chen Q., Hua H. and co-authors researched 11 electronic databases of clinical studies which were published before August 2016. These researches were devoted to the problem of association of OLP and thyroid pathology. Eight researches were taken for the survey, four of them with case-control was included in the final meta-analysis. According to Newcastle-Ottawa scale, the 
average score of four researches was 6.5 , chance coefficient (CC) was 2.1 (confidence interval 95\%). This was indicated a statistically significant difference in the prevalence of thyroid pathology in patients with OLP compared the control group. Two publications were showed a higher reliable correlation between OLP and hypothyroidism $(\mathrm{CC}=1.83)$. The author's meta-analysis was demonstrated a significantly higher prevalence of thyroid disease among patients with OLP compared the control group, that indicates the need for screening such patients in order to identify thyroid pathology. However, more studies are required to confirm the results because of little amount of surveys involved in meta-analysis [18].

Another study was included 215 patients with OLP showed significantly high percentage of thyroid diseases, especially hypothyroidism, and authors assumed the comorbidity of these conditions [19]. The results of another research, published in 2017, were confirmed a possible connection between the severity of the OLP and serum autoantibodies titer to thyroperoxidase and thyroid pathology. A significant positive correlation between the serum levels of IL-8 and autoantibodies to thyroperoxidase was revealed. A significant increase of autoantibodies to thyroperoxidase level in blood of patients with the erosive form of OLP was detected. This can be an indicator of previously unrevealed thyroid pathology in these patients [20]. In a recent study of 549 patients suffering from thyroid diseases, the clinical manifestations of OLP were detected almost 3 times more often than in the control group. The need to inform endocrinologists about the possible association between oral mucosa lesion in LP and thyroid disorders was indicated [21].

It should be noted that the endocrine associations of LP are not limited to the pathology of the thyroid gland. A recent study by Indian dermatologists was detected $33(33 \%)$ patients with diabetes of 100 patients with LP and it was confirmed by high fasting blood glucose level. Authors emphasized the need to screen blood analysis among people with lichen planus to control glucose level [22]. Authors indicated the need for screening a blood glucose test in patients with LP [22]. Comorbidity of LP and diabetes mellitus lowers clinical efficacy of dermatosis treatment, slowing recovery. The authors suggested that the inflammatory nature of components of metabolic syndrome plays a significant role in the pathogenesis of LP. Particularly, hyperglycemia inhibits the proliferation of keratinocytes and fibroblasts, causes endothelial cell apoptosis and reduces vasodilation by blocking the synthesis of nitric oxide. Furthermore, the final glycation products activate the NF- $\kappa \mathrm{B}$ signaling pathway, resulting in the release of pro-inflammatory cytokines and intracellular oxidative stress $[9,22]$.

In our opinion, a study devoted to the study of psychosomatic disorders associated with LP is quite interesting as well. In a prospective clinical study of 93 patients with predominantly CLP (58 women, 35 men; mean age - 47.6 years) the authors identified following data: psychogenic manifestations of the skin process in $28(30.1 \%)$ patients; nosogenic reactions, which were qualified as an adaptation disorder - in 56 (60.2\%) of them, recurrent depression - in $9(9.7 \%)$, while stress as a trigger rarely was objective and significant. Depressive nosogeny, a greater extent, depended on the prevalence and severity of the skin process and were accompanied by anxiety-hypochondriac depressive reaction with decreased mood, irritability, tearfulness, sleep disorders, psychosomatic hyperesthesia phenomena contributing to the amplification of itch. Sociophobic reactions and reactions with the phenomena of hypochondria of beauty were mainly recorded in cases of localization of lesions in open areas of the body with moderate and minor severity of dermatosis. Recurrent depressions accompanied in all cases the classical course of the LP and manifested in depression, anguish, anxiety, and thoughts of hopelessness and feeling of own inferiority [23].

Iranian scientists studied the connection between OLP with psychological stress appearance. The authors studied 45 scientific papers for the period from 1985 to 2014, identified in the main bases for the following search subjects: "oral red lichen planus", "stress", "anxiety", "depression", "psychological disorder". Only 10 works met the necessary requirements. In these studies they used questionnaire methods for assessing stress, evaluating genetic polymorphism at the DNA level, studying the level of hormones in the human body, and the effect of drug therapy of mental disorders on patients suffering from OLP. The criteria for inclusion in the study were clinical and histopathological confirmation of OLP, exclusion criteria - the uncertainty of the diagnosis, inadequate number of subjects in the experimental and control groups, discrepancy (mismatch) in sex and age between the main and control groups. The results of the meta-analysis showed that a higher level of stress was noted in patients suffering from the OLP. The reduction of psychological stress and the well-being of patients are important and must be considered during the treatment of LP [24].

In a comparative study conducted at Oral Medicine Clinical Services (OMCS) of the University of Washington, psychosomatic disorders were studied in patients with LP and oral lichenoid rash compared with healthy persons and with patients suffering from myofascial pain. The diagnoses were confirmed clinically and pathomorphologically. The SCL-90R and VAS tools were used to evaluate pain. From January 2011 to March 2017, scientists examined 112 patients with OLP, 40 patients with oral lichenoid rashes, 185 patients with myofascial pain and 90 healthy persons according to the inclusion/exclusion criteria. The study revealed the absence of a significant difference in the assessment of the SCL-90R scale results in patients with OLP and the control group however, there was a tendency to develop moderate and severe degree, compared with control group.

In patients with OLP, on average, higher rates of depression were observed compared with control, though the differences were not significant. High and moderate pain-related somatization was detected in $36 \%$ of patients with OLP and $28 \%$ ones with oral lichenoid rashes com- 
pared with $23 \%$ in the control group, while moderately severe somatization without pain was significantly higher in the OLP group than in control. The results of the studies showed the need for psychosocial examination and assessment of the patient's status with OLP, as well as the rationality of including psychotherapy in a comprehensive treatment plan for this condition that can help improve the prognosis and quality of life [25].

Keeping in mind a long course of treatment for LP and often empirical therapeutic approaches, the understanding of the psychosomatic associations of LP is an important point in the interaction of the patient and the dermatologist and the key to successful therapy.

In the context of the psychosomatic nature of the LP, a group of Indian scientists carried out a psychometric assessment of the patient's status with OLP compared the control group. The patients with LP showed significantly higher incidence of comorbid mental disorders (depression, anxiety and stress) compared with the control. The authors expressed the opinion that a psychiatric assessment can be entered into standard protocols for the treatment of OLP [26].

\section{CONCLUSIONS}

Analysis of the data of scientific and medical literature over the recent years has shown that the problem of comorbidity of LP remains the focus of the scientific interests of dermatologists of the international community. Most studies deal with the study of endocrine, psychosomatic and internal comorbidity. The results of the Indian study were detected zero comorbidity of LP and viral hepatitis B and C, although previously the association of hepatitis $C$ and LP was considered a postulate and HVC serological screening was recommended by standard protocols for the management of patients with LP. Current regional Indian guidelines may call into question the need for this test. There were convincing results about the association of the ORP and thyroid pathology. Considering widespread thyroid disorders in Ukraine, there is a need to inform endocrinologists and dentists about the need for mutual cooperation and screening of these patients in order to identify thyroid pathology. The previous hypotheses about comorbidity of LP with components of metabolic syndrome - diabetes mellitus and dyslipidemia were confirmed as well, their negative impact on the effectiveness of treatment of dermatosis was revealed and a screening examination of lipid metabolism indicators was recommended when managing patients with LRP. A large proportion of psychosomatic disorders identified in patients with CLP and OLP may initiate the introduction of psychiatric evaluation into standard protocols for the treatment of patients with LP.

\section{REFERENCES}

1. Abrahamovich 0.0., Faiura 0.P., Abrahamovich U.0. Komorbidnist: suchasniy pohliad na problemu; klasifikatsiia (povidomlennia pershe). [Comorbidity: a modern view at the problem; classification (message first)]. Lvivskyi Clinichnyi Visnyk. 2015;4(12):56-64.
2. Bardellini E., Amadori F., Flocchini P. et al. Clinicopathological features and malignant transformation of oral lichen planus: a 12-years retrospective study. Acta Odontol Scand 2013;71:834-840.

3. Slesarenko N.A., Utts S.R., Artemina Ye.M., et al. Komorbidnost pri krasnom ploskom lishaie. [Comorbidity at lichen ruber planus]. Clinicheskaia Dermatologiia i Venerologiia. 2014;5:4-10.

4. Gorouhi F., Davari P., Fazel N. Cutaneous and mucosal lichen planus: comprehensive review of clinical subtypes, risk factors, diagnosis and prognosis. Scientific World Journal 2014;Vol.2014:1-22.

5. Crincoli V., Di Bisceglie MB, Scivetti M. et al. Oral lichen planus: update on etiopathogenesis, diagnosis and treatment. Immunopharmacol Immunotoxicol. 2011;33:11-20.

6. Farhi D., Dupin N. Pathophysiology, etiologic factors and clinical management of oral lichen planus, part l: fact and controversies. Clin Dermatol. 2010;28:100-108.

7. Yusupova L.A, Ilyasova E.Yi. Krasnii ploskii lishai: sovremenniie patoheneticheskiie aspekti I metodi terapii. [Lichen ruber planus: modern pathogenetic aspects and methods of therapy]. Practicheskaia medicina. 2013;1-4(73):14-6.

8. Lu R., Zeng X., Han Q. et al. Overexpression and selectively regulatory roles of IL-23/IL-17 axis in the lesions of oral lichen planus. Mediators Inflamm. 2014;306(5):441-6. doi: 10.1007/s00403-013-1429-3.

9. Yew W.Y., Lai Y.Ch., Chan R. Lichen Planus Epidemiology Study. Annals Academy of Medicine. 2016;45(11):516-9.

10. Wagner G., Rose C., Sachse MM., Clinical variants of lichen planus. Dtsch Dermatol Ges. 2013;11:309-319.

11. Alaizari N.A., Al-Maweri S.A., Al-Shamiri H.M. et al. Hepatitis C virus infections in oral lichen planus: a systematic review and metaanalysis. Aust Dent J. 2016;61(3):282-7.

12. Sajini L., Anjaneyan G., Jagadeesan S. et al. Zero prevalence of hepatitis B and hepatitis C infections in clinicopathologically proven lichen planus cases: a cross sectional study at a tertiary care centre in South India. International Journal of Research in Dermatology. 2017;3(3):351-4.

13. Lai Y.C., Yew Y.W., Schwartz R.A. Lichen planus and dyslipidemia: a systematic review and meta-analysis of observational studies. Int J Dermatol. 2016;55(5):295-304.

14. Zhovtyak P.B., Grygoryev S.S., Letayeva O.V. Struktura komorbidnoi patologii u patsiientov s raslichnimi formami krasnoho ploskoho lishaia slisistoi obolochki rta [The structure of comorbid pathology in patients with various forms of lichen ruber planus of oral mucosa]. Sovremenniye problemy nauki i obrasovaniya. 2015;4. URL: http://www.scienceeducation.ru/ru/article/view?id=20732.

15. López-Jornet P., Parra-Perez F., Pons-Fuster A. Association of autoimmune diseases with oral lichen planus: a cross-sectional, clinical study. J. Eur. Acad. Dermatol.Venereol. 2014;28(7):895-9. doi: 10.1111/ jdv. 12202.

16. Chung P.I., Hwang C.Y., Chen Y.J. et al. Autoimmune comorbid diseases associated with lichen planus: a nationwide case-control study. J. Eur. Acad. Dermatol. Venereol. 2015;29(8):1570-5.doi: 10.1111/jdv.12939.

17. Day T., Moore S., Bohl T. G. et al. Comorbid Lichen Planus and Sclerosus. Journal of Lower Genital Tract Disease. 2017;21:204-208.

18. Li D., Li J., Li C. et al. The Association of Thyroid Disease and Oral Lichen Planus: A Literature Review and Meta-analysis. Front. Endocrinol. 2017;8:310. doi: 10.3389/fend0.2017.00310.

19. Garcia-Pola M.J., Llorente-Pendás S., Seoane-Romero J.M. et al. Thyroid Disease and Oral Lichen Planus as Comorbidity: A Prospective Case-Control Study. Dermatology. 2016;232(2):214-9.doi: $10.1159 / 000442438$. 
20. Alikhani M., Ghalaiani P., Askariyan E. et al. Association between the clinical severity of oral lichen planus and anti-TPO level in thyroid patients. Braz. Oral Res. 2017;31(10):1-6.

21. Arduino P.G, Karimi D., Tirone F. et al. Evidence of earlier thyroid dysfunction in newly diagnosed oral lichen planus patients: a hint for endocrinologists. Endocrine Connections. 2017;6:726-30.

22. Varma K., Shukla P. Association of diabetes mellitus in patients with Lichen Planus. Indian Journal of Clinical and Experimental Dermatology. 2017;3(1):14-6.

23. Dorozhenok I.U., Snarskaya E.S., Shenberg V.G. Krasnii ploskii lishai I assotsiirovanniie psihosomaticheskiie rasstroistva. [Lichen ruber planus and associated psychosomatic disorders]. Vestnik dermatologii i venerologii. 2016;4:27-32.

24. Agha-Hosseini F., Moosavi M.S., Sadrzadeh M.S., et al. Assessment of the relationship between stress and oral lichen planus: a review of literature. Journal of Islamic Dental Association of Iran. 2016;28 (2):78-85.

25. Malhotra R. Anxiety, Depression and Somatization in Patients with Oral Lichen Planus. Abstract for the degree of Master of Science in Dentistry. University of Washington, 2017. Washington: 2017, p.65.

26. Kalkur C., Sattur A.P., Guttal K.S. Role of Depression, Anxiety and Stress in Patients with Oral Lichen Planus: A Pilot Study. Indian J Dermatol. 2015;60(5):445-9. doi:10.4103/0019-5154.159625.

\section{Authors' contributions:}

According to the order of the Authorship.

\section{Conflict of interest:}

The Authors declare no conflict of interest.

\section{CORRESPONDING AUTHOR Oleksandra Havryliuk}

7/9 Chernyshevska str., 61057 Kharkiv, Ukraine tel: +38097 9782452

e-mail:alex_h2817@hotmail.com

Received: 10.12 .2018

Accepted: 25.02.2019 
PRACA POGLĄDOWA

REVIEW ARTICLE

\title{
WITAMINA D A PRAWIDŁOWA I ZMIENIONA PATOLOGICZNIE BŁONA ŚLUZOWA JAMY MACICY
}

\section{VITAMIN D IN NORMAL AND PATHOLOGICALLY CHANGED ENDOMETRIUM}

\author{
Magdalena Duda-Wiewiórka, Kazimierz Pityński \\ KLINIKA GINEKOLOGIII I ONKOLOGII COLLEGIUM MEDIUM, UNIWERSYTET JAGIELOŃSKI, KRAKÓW, POLSKA
}

\begin{abstract}
STRESZCZENIE
Istnieje coraz więcej naukowych dowodów na znaczącą rolę witaminy D (VD) w rozwoju stanów patologicznych endometrium. VD ma wpływ nie tylko na homeostazę wapnia, ale moduluje także działanie wielu genów zaangażowanych w podział komórkowy, reakcje immunologiczne i syntezę białek. Najnowsze odkrycia dowodzą, że VD działa wielokierunkowo, a jej powszechny niedobór ma związek przyczynowy z patogenezą wielu chorób ginekologicznych, także nowotworowych. Istnieje klika mechanizmów oddziaływania VD na endometrium. Odkrycie, iż większość tkanek posiada receptory dla VD, było przełomowe w zrozumieniu jej roli w wielu chorobach, także w mechanizmie rozwoju nowotworu, ale nie wyjaśniono do tej pory, w jakim stopniu zaburzony jest, prowadzący do rozwoju zmian patologicznych, metabolizm VD w eutopowym endometrium.
\end{abstract}

SŁOWA KLUCZOWE: witamina D, VDR, endometrium, rak endometrium

\begin{abstract}
More and more evidence from research confirms the significance of vitamin $D(V D)$ in the development of endometrial pathologies. Apart from the well known role of VD in regulation of calcium levels, VD acts as modulator to many genes involved in cell growth, immunological functions and protein synthesis. The newest research shows that VD acts multidirectionally and its common deficiency has a causal link to the pathogenesis of many gynecological and cancerous conditions. It is postulated that VD affects the endometrium via various mechanisms. The discovery that most tissues have $V D$ receptors was ground-breaking in understanding its role in various medical conditions, including the neoplasmal development mechanism, but the degree, to which the VD metabolism in the eutopic endometrium during pathological conditions is impaired, has not yet been explained.
\end{abstract}

KEY WORDS: vitamin D, VDR, endometrium; endometrial cancer

Wiad Lek 2019, 72, 3, 452-456

\section{WSTĘP}

Witamina D została odkryta w latach dwudziestych ubiegłego stulecia przez McColuma. Aktualnie znajduje się w centrum zainteresowania specjalistów i naukowców z wielu dziedzin medycyny. Ostatnie lata przyniosły wręcz eksplozję liczby publikacji dotyczących witaminy D oraz jej roli w patogenezie wielu chorób, m.in. ginekologicznych, położniczych i nowotworowych. Jest to szczególnie istotne w kontekście jej powszechnego niedoboru u kobiet $\mathrm{w}$ różnych grupach wiekowych. Ta grupa rozpuszczalnych w tłuszczach, steroidowych związków organicznych, przez dziesięciolecia klasyfikowana była jako witamina, jednak obecnie uważa się, że jest aktywnym hormonem, ważnym czynnikiem transkrypcyjnym, regulującym ekspresję wielu genów. Oprócz dobrze poznanej roli witaminy w procesie regulacji wapnia, najnowsze odkrycia dowodzą, że działa wielokierunkowo, potwierdzają również istotny jej wpływ na zachowanie prawidłowych funkcji endometrium. Badania molekularne dotyczące nieprawidłowych rozrostów endometrium nie były do tej pory prowadzone i zakres wiedzy na ten temat jest bardzo ograniczony.

\section{BIOSYNTEZA I METABOLIZM WITAMINY D}

Odpowiedź biologiczna na podanie witaminy $\mathrm{D}$ jest odroczona w czasie. Wynika to $\mathrm{z}$ faktu, że jest ona nieaktywna i w pierwszej kolejności musi ulec metabolizmowi, aby powstały jej aktywne metabolity. Witamina D3 (cholekalcyferol), powstaje z 7-dehydrocholesterolu obecnego w skórze pod wpływem promieniowania UVB, jest również przyswajalna z pożywieniem w postaci witaminy D2 (ergokarcyferolu) lub witaminy D3. Obie postacie ulegają dwustopniowej aktywacji do 25-hydroksywitaminy D3 (kalcydiol, 25(OH)D), z udziałem 25-hydroksylaz, CYP2R1 i CYP 27A1 - enzymów wątrobowych zawierających cytochrom P450 i kolejno do 1a, 25(OH)D2, z udziałem CYP27B1 i 1a-hydroksylazy - enzymu występującego w nerkach, ale także w innych tkankach [1]. W biologicznych działaniach witaminy D pośredniczy głównie receptor VD (VDR). Odkrycie, iż większość tkanek posiada receptory dla VD, było przełomowe w zrozumieniu jej roli w wielu chorobach, także w mechanizmie rozwoju nowotworu [2]. Po związaniu VD z VDR powstaje heterodimeryczny kompleks z recep- 
Tabela I. Zasady suplementacji i leczenia witaminą D - nowelizacja $2018 \mathrm{r}$.

\begin{tabular}{cc}
\hline Zapotrzebowanie & Stężenie witaminy D (ng/ml) \\
\hline Niedobór ciężki & $10-20$ \\
\hline Niedobór znaczny & $>10-20$ \\
\hline Stężenie suboptymalne & $>20-30$ \\
\hline Stężenie optymalne & $>30-50$ \\
\hline
\end{tabular}

torem retinoidu $\mathrm{X}$ (RXR), który oddziałuje $\mathrm{z}$ regionami DNA zwanymi elementami odpowiedzi VD. Elementy te aktywują koaktywatory zdolne do regulowania transkrypcji docelowych genów zaangażowanych nie tylko w homeostazę wapniowo-fosforanową, ale także w proliferację, różnicowanie i odpowiedź immunologiczną komórek [3, 4]. Co więcej, najnowsze badania sugerują, że działanie VD może odbywać się również poprzez szlaki niezależne od regionów genomowych [5]. VDR ulega ekspresji w różnych narządach i tkankach, w tym w szkielecie, układzie odpornościowym, przytarczycach i tkankach układu rozrodczego [2]. Badania pokazały, że w endometrium podczas cyklu menstruacyjnego zróżnicowanej ekspresji oprócz VDR ulegają również liczne enzymy uczestniczące w metabolizmie VD [6].

\section{KRYTERIA I PRZYCZYNY NIEDOBORU WITAMINY D U KOBIET}

Za docelowe stężenie uznano stężenie kalcydiolu (25(OH)D) w surowicy wynoszące 30-50 ng/ml (75-125nmol/1). Chociaż kalcytriol stanowi aktywną biologicznie formę witaminy D, jego stężenie we krwi nie koreluje ze stanem rzeczywistego zaopatrzenia organizmu w tę witaminę i stanowi jedynie $0,1 \%$ stężenia kalcydiolu. Dlatego też to kalcydiol (25(OH)D) został uznany za najlepszy wskaźnik zasobów witaminy D w organizmie, ze względu na długi okres półtrwania, stabilność, duże stężenie w surowicy i zwiększone powinowactwo do białek wiążących we krwi [7]. Niedobór witaminy D jest powszechny, a Polska należy do krajów, w których nasłonecznienie, szczególnie w okresie jesienno-zimowym, jest niewystarczające do utrzymania prawidłowego jej stężenia.

Przyczyny niedoboru witaminy D:

- obniżona synteza w skórze (szerokość geograficzna, stopień zachmurzenia i zanieczyszczenia powietrza, stosowanie kremów z filtrami UVB, wiek, kolor skóry);

- zmniejszona podaż w diecie lub zwiększone zapotrzebowanie (dieta uboga w nabiał i tłuste ryby, stosowanie diet redukcyjnych, okresy zwiększonego zapotrzebowania - intensywny wzrost u dzieci, ciąża, okres karmienia piersią);

- upośledzone wchłanianie z przewodu pokarmowego w przebiegu zespołów złego wchłaniania, mukowiscydozy, po operacjach bariatrycznych i w stanach zapalnych jelit;

- choroby towarzyszące: otyłość, cukrzyca, choroby układu sercowo-naczyniowego, sarkoidoza, gruźlica, choroby autoimmunologiczne, choroby przytarczyc, przewlekłe choroby wątroby i nerek;
- choroby dziedziczne: krzywica hipofosfatemiczna oraz krzywica typu 1;

- przewlekłe stosowanie niektórych leków (przeciwdrgawkowe, izoniazyd, rimfapicyna, leki antyretrowirusowe, steroidy, barbiturany) [7].

Zasady suplementacji i leczenia witaminą $\mathrm{D}$ przedstawiono w tabeli I.

\section{WITAMINA D W PRAWIDŁOWYM ENDOMETRIUM}

Podczas cyklu menstruacyjnego endometrium ulega proliferacji, różnicowaniu i ostatecznie złuszczaniu. Wszystkie te zdarzenia są regulowane przez zmiany w poziomie hormonów steroidowych, głównie estrogenu i progesteronu. VD jako hormon steroidowy, może odgrywać bezpośrednią rolę podczas modyfikacji, którym endometrium podlega przez cały cykl menstruacyjny [8]. Po raz pierwszy obecność receptora VDR w błonie śluzowej macicy potwierdzili Vienonen i wsp. [9]. Używając metody real-time PCR badali oni wzorzec różnych jądrowych czynników transkrypcyjnych, także ekspresję VDR, w prawidłowej błonie śluzowej macicy. Próbki zostały pobrane od trzech kobiet przed menopauzą (38-50 lat), u których przeprowadzono histerektomię. Stwierdzili znaczne różnice $\mathrm{w}$ poziomach ekspresji receptora u poszczególnych osób, ale nie wykazali różnić w zależności od fazy cyklu [9]. Kolejne badania przynosiły różne rezultaty oceny ekspresji VDR w fizjologicznym endometrium w fazie proliferacyjnej i sekrecyjnej, czego przyczyn należy upatrywać w różnych modelach i technikach badań, różnorodności dobieranych pacjentek [10-12]. Jedną z głównych funkcji endometrium jest zapewnienie odpowiednich warunków do utrzymania ciąży, a zmiany w endometrium są w tym procesie niezbędne. Proces decydualizacji wiąże się z przekształceniem komórek zrębowych endometrium w wyspecjalizowane komórki wydzielnicze, które zapewniają odżywczą i ochronną matrycę niezbędną do implantacji zarodka i prawidłowego rozwoju łożyska [13]. Badania pokazały, że w endometrium podczas cyklu menstruacyjnego zróżnicowanej ekspresji oprócz VDR ulegają również liczne enzymy uczestniczące w metabolizmie VD $[6,11]$. Co więcej odnotowano, że ekspresja zarówno VDR, jak i enzymów uczestniczących w metabolizmie VD ulegała zwiększeniu podczas ciąży, co niewątpliwie związane było z zapewnieniem większego zapotrzebowania na wapń w tym okresie [14]. Szczególną uwagę zwraca się na błonę śluzową macicy u kobiet z problemem niepłodności, a także poddawanych technikom wspomaganego rozrodu 
(ART - assisted reproductive technology). W zespole policystycznych jajników (PCOS) suplementacja witaminą D była związana $\mathrm{z}$ poprawą grubości endometrium, ale nie prawdopodobieństwem ciąży. Niestety nie zaproponowano molekularnego mechanizmu wyjaśniającego to zjawisko [15]. Chociaż wykazano, że różne szlaki hormonalne, takie jak szlaki sygnałowe insuliny i hormonu tarczycy są rozregulowane w endometrium u pacjentek poddawanych ART, to hormonalna stymulacja nie wydaje się zmieniać szlaku hormonalnego witaminy D, przynajmniej pod względem ekspresji jej receptora (VDR) [16]. Od kilku lat niedobór witaminy $\mathrm{D}$ jest obiektem zainteresowania specjalistów od IVF i nadal niewyjaśnione pozostaje, na który element - czy endometrium, czy oocyt - niedobór ten ma większy wpływ. W jednym z pierwszych badań próbujących rozstrzygnąć tę kwestię został potwierdzony związek pomiędzy stężeniem witaminy D w surowicy krwi, u pacjentek po zapłodnieniu in vitro a wynikami tego zapłodnienia. Wskaźnik ciąż, w których urodziły się żywe dzieci, był niższy u kobiet $\mathrm{z}$ niedoborem witaminy $\mathrm{D}$ w porównaniu z pacjentkami z suplementacją nią [17]. W innych badaniach nie potwierdzono tej zależności [18, 19]. Na tym etapie nie ma więc wystarczających dowodów, aby potwierdzić, że poziom witaminy D ma istotny wpływ na błonę śluzową macicy u kobiet po przebytym IVF, natomiast wyniki badań niewątpliwie pokazują istotny związek VD z zachowaniem prawidłowych funkcji endometrium.

\section{WITAMINA D A ENDOMETRIOZA}

Gruczolistność zewnętrzna, czyli obecność komórek gruczołowych i zrębu endometrium poza jamą macicy, nadal sprawia wiele problemów diagnostyczno-terapeutycznych. Od lat poszukuje się mechanizmów, które zapobiegają implantacji „zagubionych komórek”. Odporność komórkowa i humoralna wydaje się mieć decydujące znaczenie w tej chorobie. Ektopowe endometrium wykazuje funkcjonalnie podobieństwo do eutopowej błony śluzowej macicy [20]. Ekspresja receptora VDR i enzymów uczestniczących $\mathrm{w}$ metabolizmie witaminy $\mathrm{D}, \mathrm{w}$ endometriozie, po raz pierwszy została wykazana w 2007 r. przez Agic i wsp [21]. Porównali oni endometrium pobrane od kobiet $z$ endometriozą z grupą zdrowych pacjentek. Zauważyli zwiększoną ekspresję VDR i enzymów (24-hydroksylazy, 25-hydroksylazy i 1 $\alpha$-hydroksylazy) w tkance pobranej od pacjentek z endometriozą, w stosunku do grupy kontrolnej. Niestety autorzy nie badali ekspresji VDR w ektopowym endometrium [21]. Kwestia wymaga dalszych szczegółowych wyjaśnień. Dowody genetyczne sugerują, że polimorfizmy w genie VDR, mogą być związane z większą wrażliwością na choroby, takie jak rak czy zapalenie kości i stawów [22]. Możliwość tę zaczęto rozważać również w endometriozie. Badaniu poddano kobiety $z$ niepłodnością powiązaną z endometriozą, niepłodnością idiopatyczną oraz kobiety zdrowe, jednak nie wykazano żadnej różnicy w występowaniu różnych polimorfizmów genu receptora witaminy $\mathrm{D}$, badanych pod kątem RFLP (restriction fragment gene polymorphisms) $[23,24]$. Biorąc pod uwagę odwrotną korelację pomiędzy poziomami witaminy $\mathrm{D}$ a rozwojem nowotworu[21, 25] oraz fakt, że endometrioza jest chorobą o „podobnych” komórkowych i cechach złośliwości, w ostatnich latach zbadano potencjalny antyproliferacyjny i przeciwzapalny wpływ witaminy D na leczenie endometriozy. W badania przeprowadzonych głównie na komórkach zrębu, potwierdzono te mechanizmy, stwierdzając obniżenie poziomów mRNA dla interleukin - IL-1B, IL-8, czynnika martwicy nowotworu TNF- $\alpha$, metaloprotrinazy MMP-2 i MMP-9, a także zmniejszenie syntezy DNA, ale bez wpływu na apoptozę $[26,27]$. Do tej pory regresje ognisk endometriozy, po leczeniu witaminą D i agonistami VDR, opisywano głównie przy użyciu modeli zwierzęcych 28, 29]. Badania dotyczyły tylko kilku funkcji komórkowych, leżących u podstawy rozwoju endometriozy, a bardzo niewiele danych dotyczy wpływu na inwazję, adhezję, apoptozę oraz procesy zapalne w tej właśnie chorobie. W celu wyjaśnienia rzeczywistego mechanizmu działania witaminy D w endometriozie konieczne są dalsze badania, przeprowadzone przy użyciu różnych modeli, a próby kliniczne z zastosowaniem witaminy i jej agonistów byłyby pomocne w ocenie możliwych korzyści terapeutycznych.

\section{WITAMINA D A ROZROSTY ENDOMETRIUM I RAK ENDOMETRIUM}

Rozrosty endometrium należą do najczęstszych zmian patologicznych występujących w jamie macicy. Mogą współistnieć lub prowadzić do rozwoju raka endometrium. Rak ten jest piątym co do częstości występowania złośliwym nowotworem u kobiet. Szacuje się, że nieleczony rozrost atypowy w około 25-39\% ulega progresji do raka, a kobiety z niskim poziomem witaminy D są czterokrotnie bardziej narażone na jego rozwój. Do czynników ryzyka raka endometrium należą m.in. starszy wiek, otyłość, cukrzyca, niepłodność i jej leczenie, brak potomstwa, a na uwagę zasługuje fakt, że czynniki te, same w sobie związane są z niedoborem witaminy $D$ $[7,30,31]$. Zauważono, że witamina D działa antykancerogennie i znacznie zmniejsza częstość występowania chorób nowotworowych u osób, u których jej poziom w surowicy krwi jest nie mniejszy niż 30 ng/ml [32]. W kontekście raka endometrialnego badania pokazały kilka istotnych faktów świadczących o znaczeniu VD. Przykładowo, w badaniach tkanek ludzkich objętych rakiem endometrium wykazano podwyższony poziom ekspresji mRNA 24-hydroksylazy. Enzym 24-hydroksylazy jest odpowiedzialny za katabolizm VD i, hipotetycznie, jego wzrost może zmniejszyć działanie komórkowe kalcytriolu [21]. Ponadto, wykazano również związek pomiędzy zwiększonym poziomem mRNA 24-hydroksylazy i złym rokowaniem w zaawansowanych stadiach raka trzonu macicy $[33,34]$. W innych badaniach, prowadzonych na hodowlach komórkowych $\mathrm{z}$ rakiem endometrium zaobserwowano, że VD działa jako czynnik antyproliferacyjny i antyapoptotyczny $[35,36]$. Leczenie kalcytriolem powodowało zatrzymanie cyklu komórkowego w komórkach raka trzonu macicy, hamując niektóre regulatory progresji cyklu komórkowego, takie jak cyklina D1 i D3 i zwiększając ekspresję p27, dobrze znanego inhibitora cyklu 
komórkowego [37]. W jeszcze innych badaniach wykazano, że VD może indukować programowaną śmierć komórki w komórkach raka trzonu macicy poprzez aktywację kluczowych czynników wewnętrznej ścieżki apoptotycznej (takich jak kaspaza-3 i kaspaza-9) oraz poprzez zaburzenie równowagi między czynnikami proapoptotycznymi i czynnikami związanymi z przeżyciem komórek (takimi jak BAX, BCL-xL i Bcl2) [36, 37]. Wreszcie, VD jest równie uznawana za czynnik o właściwościach przeciwzapalnych, a zapalenie jest powszechnie uważane za czynnik ryzyka rozwoju raka [38]. W kilku badaniach wykazano zmniejszenie ryzyka raka trzonu macicy związane ze stosowaniem leków przeciwzapalnych $[39,40]$. Dowodów na temat przeciwzapalnego działania VD dostarczono dzięki badaniom raka endometrium, w których zaobserwowano, że VD powodowała supresję NF-kB, kluczowego czynnika transkrypcyjnego biorącego udział w odpowiedziach zapalnych i wrodzonej odpowiedzi obronnej organizmu. Supresja NF-kB była związana ze zmniejszoną ekspresją cytokin i chemokin zapalnych (takich jak CXCL1 iCXCL2k) zaangażowanych w procesy związane z przerzutami [41]. Wyniki wyżej opisanych badań dowodzą plejotropowego działania VD w raku błony śluzowej macicy, a także możliwości terapeutycznych z zastosowaniem VD. Przypuszcza się również, że witamina ta uwrażliwia komórki nowotworowe na cytotoksyczne działanie cytostatyków i dzięki temu leczenie raka tradycyjnymi metodami w połączeniu z suplementacją kalcitriolem skutkuje lepszymi efektami terapeutycznymi, $\mathrm{w}$ porównaniu z podawaniem pacjentowi samej chemioterapii [42]. Jak wynika $\mathrm{z}$ badań, VD może modyfikować ekspresję licznych białek (do tej pory oszacowano 300 różnych białek, których ekspresja była modyfikowana przez VD) zaangażowanych w różnicowanie komórek, w regulację transkrypcji oraz naprawę DNA [37]. Chociaż wyniki badań mocno podkreślają rolę VD jako inhibitora progresji raka endometrium, to należy uwzględnić fakt, że są to póki co badania prowadzone głównie na unieśmiertelnionych liniach komórkowych raka endometrium. Co więcej, brakuje szczegółowych danych na temat roli VD w rozwoju nieprawidłowego rozrostu endometrium prowadzącego do powstania raka endometrium, zwłaszcza brak danych na temat dokładnych mechanizmów molekularnych. Biorąc pod uwagę wspomnianą już wcześniej, odwrotną korelację między poziomami VD a rozwojem raka oraz fakt, że stany przedrakowe związane z zaburzonym rozrostem endometrium są stanami patologicznymi, ważne jest dokładne poznanie mechanizmów antyproliferacyjnego i przeciwzapalnego działanie VD w leczeniu nieprawidłowych rozrostów endometrium.

\section{PODSUMOWANIE}

Najnowsze doniesienia naukowe podkreślają plejotropowe działanie witaminy D i ugruntowują jej ważną pozycję w patomechanizmie licznych stanów chorobowych. Rola witaminy $\mathrm{D}$ w płodności została dokładnie poznana, jednak wiedza na temat skutków niedoboru VD w fizjologii endometrium jest na dzień dzisiejszy jeszcze bardzo ograniczona. Nie wyjaśniono do tej pory, w jakim stopniu zaburzony jest metabolizm VD w eutopowym endometrium w przebiegu stanów patologicznych. Brakującym elementem są przede wszystkim mechanizmy molekularne, które powinny być szczegółowo poznane, aby w pełni móc wnioskować o udziale VD w stanach patologicznych endometrium. Postuluje się, że VD oddziałuje na endometrium poprzez kilka mechanizmów. Jednakże postawienie ostatecznych wniosków na temat wpływu VD jest bardzo ograniczone z uwagi na brakujące dane na temat wpływu VD na apoptozę, adhezję i inwazję na różnych etapach rozwoju endometrium. Ponad to, dotychczasowe badania koncentrowały się również głównie na jednym metabolicie witaminy $\mathrm{D}, 25$-hydroksywitaminie D, a jak wiadomo istnieją liczne metabolity, określane wręcz jako metabolom VD. Na podstawie dotychczas przedstawionych wyników badań wydaje się, że szlaki sygnałowe, w których pośredniczy VDR, są zaburzone $\mathrm{w}$ stanach patologicznych endometrium; niemniej jednak wyniki są niejednoznaczne. Dlatego potrzebne są dalsze badania potwierdzające znaczenie VD w patologii endometrium, w kontekście przede wszystkim profilaktyki i leczenia endometriozy, stanów przedrakowych czy raka endometrium.

\section{PIŚMIENNICTWO}

1. Bikle DD. Vitamin D Metabolism, Mechanism of Action, and Clinical Applications. Chem Biol. 2014;21(3):319-329. doi:10.1016/j. chembiol.2013.12.016

2. Grzechocinska B, Dabrowski FA, Cyganek A, Wielgos M. The role of vitamin $D$ in impaired fertility treatment. Neuro Endocrinol Lett. 2013;34(8):756-762.

3. Hansen CM, Binderup L, Hamberg KJ, Carlberg C. Vitamin D and cancer: effects of 1,25(OH)2D3 and its analogs on growth control and tumorigenesis. Front Biosci. 2001;6:D820-48.

4. Cantorna MT, Mahon BD. D-hormone and the immune system. J Rheumatol Suppl. 2005;76:11-20.

5. Hii C, Ferrante A. The Non-Genomic Actions of Vitamin D. Nutrients. 2016;8(3):135. doi:10.3390/nu8030135

6. Becker S, Cordes T, Diesing D, Diedrich K, Friedrich M. Expression of 25 hydroxyvitamin D3-1a-hydroxylase in human endometrial tissue. J Steroid Biochem Mol Biol. 2007;103(3-5):771-775. doi:10.1016/j. jsbmb.2006.12.075

7. Strawa-Zakościelna K, Lenart-Lipińska M, Szafraniec A et al. Niedobór witaminy D w świetle najnowszych zaleceń. Forum Poloż Ginekol. 2014;17.

8. Yoshizawa T, Handa Y, Uematsu Y et al. Mice lacking the vitamin D receptor exhibit impaired bone formation, uterine hypoplasia and growth retardation after weaning. Nat Genet. 1997;16(4):391-396. doi:10.1038/ng0897-391

9. Vienonen A, Miettinen S, Bläuer M et al. Expression of Nuclear Receptors and Cofacotrs in Human Endometrium and Myometrium. J Soc Gynecol Investig. 2004;11(2):104-112. doi:10.1016/j.jsgi.2003.09.003

10. Zelenko Z, Aghajanova L, Irwin JC, Giudice LC. Nuclear Receptor, Coregulator Signaling, and Chromatin Remodeling Pathways Suggest Involvement of the Epigenome in the Steroid Hormone Response of Endometrium and Abnormalities in Endometriosis. Reprod Sci. 2012;19(2):152-162. doi:10.1177/1933719111415546

11. Vigano P, Lattuada D, Mangioni $S$ et al. Cycling and early pregnant endometrium as a site of regulated expression of the vitamin D system. J Mol Endocrinol.2006;36(3):415-424. doi:10.1677/jme.1.01946. 
12. Bergadà L, Pallares J,Arcidiacono MV etal. Role of local bioactivation ofvitamin Dby CYP27A1 and CYP2R1 in the control of cell growth in normal endometrium and endometrial carcinoma. Lab Investig. 2014;94(6):608-622. doi:10.1038/ labinvest.2014.57

13. Gellersen B, Brosens JJ. Cyclic Decidualization of the Human Endometrium in ReproductiveHealthand Failure. EndocrRev.2014;35(6):851-905.doi:10.1210/ er.2014-1045.

14. Salazar-Martinez E, Lazcano-Ponce E, Sanchez-Zamorano LM, Gonzalez-Lira $G$, Escudero-de los Rios P, Hernandez-Avila M. Dietary factors and endometrial cancer risk. Results of a case-control study in Mexico. Int J Gynecol Cancer. 2005;15(5):938-945. doi:10.1111/j.1525-1438.2005.00253.x.

15. Asadi M, Matin N, Frootan M, Mohamadpour J, Qorbani M, Tanha FD. Vitamin $D$ improves endometrial thickness in PCOS women who need intrauterine insemination:arandomized double-blind placebo-controlled trial. Arch Gynecol Obstet. 2014;289(4):865-870. doi:10.1007/s00404-013-3055-x.

16. DettiL,UhlmannRA,FletcherNM,DiamondMP,SaedGM.Endometrial signaling pathways during ovarian stimulation for assisted reproduction technology. Fertil Steril. 2013;100(3):889-894. doi:10.1016/j.fertnstert.2013.05.027

17. RudickBJ,Ingles SA, ChungK, StanczykFZ, Paulson RJ, Bendikson KA. Influence of vitamin D levels on in vitro fertilization outcomes in donor-recipient cycles. Fertil Steril. 2014;101(2):447-452. doi:10.1016/j.fertnstert.2013.10.008

18. Fabris A, Pacheco A, Cruz M, Puente JM, Fatemi H, Garcia-Velasco JA. Impact of circulating levels of total and bioavailable serum vitamin $D$ on pregnancy rate in egg donation recipients. Fertil Steril.2014;102(6):1608-1612. doi:10.1016/j. fertnstert.2014.08.030

19. Franasiak JM, Molinaro TA, Dubell EK et al. Vitamin D levels do not affect IVF outcomes following the transfer of euploid blastocysts. Am J Obstet Gynecol. 2015;212(3):315.e1-315.e6. doi:10.1016/j.ajog.2014.09.029

20. RadowickiS,Szyło K. Endometrioza Diagnostykai Leczenie.Wrocław: Elservier, Urban \& Partner, 2013.

21. AgicA,HongXuH,AltgassenCetal.RelativeExpression of 1,25-Dihydroxyvitamin D3 Receptor, Vitamin D 1a-Hydroxylase, Vitamin D24-Hydroxylase, andVitamin D 25-Hydroxylase in Endometriosis and Gynecologic Cancers. Reprod Sci. 2007;14(5):486-497. doi:10.1177/1933719107304565

22. Valdivielso JM, Fernandez E. Vitamin D receptor polymorphisms and diseases. Clin Chim Acta. 2006;371(1-2):1-12. doi:10.1016/j.cca.2006.02.016

23. Szczepańska M, Mostowska A,Wirstlein P,Skrzypczak J, Misztal M, Jagodziński PP. Polymorphic variants in vitamin D signaling pathway genes and the risk of endometriosis-associated infertility. Mol Med Rep. 2015;12(5):7109-7115. doi:10.3892/mmr.2015.4309

24. Vilarino FL, Bianco B, Lerner TG et al. Analysis of vitamin D receptor gene polymorphisms in women with and without endometriosis. Hum Immunol. 2011;72(4):359-363. doi:10.1016/j.humimm.2011.01.006

25. Guyton KZ, KenslerTW, Posner GH. Vitamin D and vitamin D analogs as cancer chemopreventive agents. Nutr Rev. 2003;61(7):227-238.

26. Miyashita M, Koga K, lzumi G et al. Effects of 1,25-Dihydroxy Vitamin D3 on Endometriosis.JClin Endocrinol Metab.2016;101(6):2371-2379.doi:10.1210/ jc.2016-1515

27. DelbandiAA,MahmoudiM,Shervin A,ZarnaniAH.1,25-DihydroxyVitamin D3 Modulates Endometriosis-Related Features of Human Endometriotic Stromal Cells. Am J Reprod Immunol. 2016;75(4):461-473. doi:10.1111/aji.12463

28. Abbas MA, Taha M0, Disi AM, Shomaf M. Regression of endometrial implants treated with vitamin D3 in a rat model of endometriosis. Eur J Pharmacol. 2013;715(1-3):72-75. doi:10.1016/j.ejphar.2013.06.016

29. Mariani M, Vigan P, Gentilini D et al. The selective vitamin D receptor agonist, elocalcitol, reduces endometriosis development in a mouse model by inhibiting peritoneal inflammation. Hum Reprod. 2012;27(7):2010-2019. doi:10.1093/ humrep/des 150
30. Sobstyl M, Tkaczuk-Wach J, Jakiel G. Krwawienia z dróg rodnych w okresie pomenopauzalnym. Przegl Menopauz. 2010;5:349-352.

31. Morice P, Leary A, Creutzberg C, Abu-Rustum N, Darai E. Endometrial cancer. Lancet. 2016;387(10023):1094-1108. doi:10.1016/S0140-6736(15)00130-0

32. Garland CF, Garland FC, Gorham ED et al. The role of vitamin D in cancer prevention. Am J Public Health. 2006;96(2):252-261. doi:10.2105/ AJPH.2004.045260

33. Cross HS, Bises G, Lechner D, Manhardt T, Kállay E. The Vitamin D endocrine system of the gut - Its possible role in colorectal cancer prevention. J Steroid Biochem Mol Biol. 2005;97(1-2):121-128. doi:10.1016/J.JSBMB.2005.06.005

34. Anderson MG, Nakane M, Ruan X, Kroeger PE, Wu-Wong JR. Expression of VDR and CYP24A1 mRNA in human tumors. Cancer Chemother Pharmacol. 2006;57(2):234-240. doi:10.1007/s00280-005-0059-7

35. Nguyen H, Ivanova VS, Kavandi L, Rodriguez GC, Maxwell GL, Syed V. Progesterone and 1,25-Dihydroxyvitamin D3 Inhibit Endometrial Cancer Cell Growth by Upregulating Semaphorin 3B and Semaphorin 3F. Mol Cancer Res. 2011;9(11):1479-1492. doi:10.1158/1541-7786.MCR-11-0213

36. Kim TH, Park J, Lee JS, Lee HH. Effects of 1alpha, 25-dihydroxyvitamin D 3 on programmed cell death of Ishikawa endometrial cancer cells through ezrin phosphorylation. J Obstet Gynaecol. 2017;37(4):503-509. doi:10.1080/0144 3615.2016.1271777

37. Lee LR, Teng P-N, Nguyen H et al. Progesterone Enhances Calcitriol Antitumor Activity by Upregulating Vitamin D Receptor Expression and Promoting Apoptosis in Endometrial Cancer Cells. Cancer Prev Res. 2013;6(7):731-743. doi:10.1158/1940-6207.CAPR-12-0493

38. Modugno F, Ness RB, Chen C, Weiss NS. Inflammation and Endometrial Cancer: A Hypothesis. Cancer Epidemiol Biomarkers Prev. 2005;14(12):2840-2847. doi:10.1158/1055-9965.EPI-05-0493

39. Verdoodt F, Friis S, Dehlendorff C, Albieri V, Kjaer SK. Non-steroidal antiinflammatory drug use and risk of endometrial cancer: Asystematic reviewand meta-analysis of observational studies. Gynecol Oncol. 2016;140(2):352-358. doi:10.1016/j.ygyno.2015.12.009

40. Neill AS, Nagle CM, Protani MM, etal. Aspirin, nonsteroidal anti-inflammatory drugs, paracetamol and risk of endometrial cancer: A case-control study, systematic review and meta-analysis. Int J Cancer. 2013;132(5):1146-1155. doi:10.1002/ijc.27717

41. Kavandi L, Collier MA, Nguyen H, SyedV. Progesterone and calcitriol attenuate inflammatory cytokines CXCL1 and CXCL2 in ovarian and endometrial cancer cells. J Cell Biochem. 2012;113(10):3143-3152. doi:10.1002/jcb.24191

42. Trump DL. Calcitriol and cancer therapy: A missed opportunity. Bone Reports. 2018;9:110-119. doi:10.1016/j.bonr.2018.06.002

\section{Konflikt interesów}

Autorzy deklarują brak konfliktu interesów.

\author{
AUTOR KORESPONDUJĄCY \\ Magdalena Duda-Wiewiórka \\ Klinika Ginekologii i Onkologii \\ Collegium Medium, \\ Uniwersytet Jagieloński, Kraków, Polska \\ e-mail: kundzi@poczta.onet.pl
}

Nadesłano: 12.02.2019

Zaakceptowano: 03.03.2019 
PRACA POGLADDOWA

REVIEW ARTICLE

\title{
PROBLEMS OF TRANSPLANTATION OF HUMAN ORGANS AND OTHER ANATOMICAL MATERIALS AND DIRECTIONS OF THEIR SOLUTION IN UKRAINE
}

\author{
PROBLEMY TRANSPLANTACJI LUDZKICH NARZĄDÓW \\ I INNYCH MATERIAŁÓW ANATOMICZNYCH I KIERUNKU \\ ROZWIAZZANIA TYCH PROBLEMÓW NA UKRAINIE
}

\author{
Hryhorii S. Krainyk', Svitlana M. Popova'², Ella V. Vakulovych ${ }^{2}$ \\ ${ }^{1}$ YAROSLAV MUDRYI NATIONAL LAW UNIVERSITY, KHARKIV, UKRAINE \\ ${ }^{2}$ KHARKIV NATIONAL UNIVERSITY OF INTERNAL AFFAIRS, KHARKIV, UKRAINE
}

\begin{abstract}
Introduction: The focus of the work is the importance of transplantation of human organs and other anatomical materials as the method of treating and a way of saving people's lives and it also attaches particular importance to solving issues of transplantations in Ukraine.

The aim: To find out the problems of human organ transplantation and other anatomical materials and determine the directions of their solutions in Ukraine.

Materials and methods: The assessment and analysis of domestic and foreign experience has been developed. In addition, data collected from Ukrainian and international organizations and the results of scientific research by scientists are used in the work.

Review and conclusions: Investigating the legislation of Ukraine in the part of transplantation of human organs and other anatomical materials, conclusions were made on the necessity of its improvement, in particular, Article 16 of the Law of Ukraine «0n the application of transplantation of anatomical materials to a person» dated by May 17 , 2018, is proposed to be worded as follows: «Any adult may give written consent or disagreement to become a donor of anatomical materials in case of his death. In the absence of such a statement of disagreement with the transplantation of his organs or other anatomical materials, consent of relatives or others is not required. In this case, the deceased person is deemed to have given consent to the transplantation of his organs or other anatomical materials».

It is proposed to make changes and significant additions to Art. 17 of the Law of Ukraine «0n the application of transplantation of anatomical materials to a person» of May 17 , 2018 regarding the creation of the Unified State Register of persons in need of transplantation, as well as to consolidate the procedure for its administration. In the context of urgent transformations, the necessity to significantly increase state funding for the provision of medical services, raise the awareness and informality of citizens about transplantation, as well as to change their misconceptions about this issue are sometimes put forward.
\end{abstract}

KEY WORDS: transplantation, presumption of consent for transplantation, donor

Wiad Lek 2019, 72, 3, 457-461

\section{INTRODUCTION}

Nowadays changes seem to be underway in Ukraine leading to transformations in state-political, socio-economic and legal spheres. The construction of the rule of law and civil society requires new challenges to address the fundamental problems of legal culture [1, p. 13]. Legal culture manifests itself in the accumulated legal values that belong to the spiritual culture, has a practical orientation along with the culture of management and consists of interconnected elements [1, p. 17].

According to O.I. Bugera's opinion, the current legal existence of Ukrainian society is marked by two opposing tendencies: the commitment to the standards of a democratic standard based on the rule of law and on the other hand, the existence of legal illiteracy, old misconceptions and still remaining legal nihilism [2, p. 193].
Transplantology has saved thousands of lives and is a common treatment for a number of pathologies, moreover, sometimes it remains the last chance for saving human lives. Taking this into consideration, transplantology can be called the phenomenon of the twentieth century. Therefore, the society has realized the importance of transplantation as a method of treatment and saving human lives and now it's beginning to turn from undue criticism to thorough philosophical and legal analysis, searching for optimal solution of problems existing in the sphere of transplatology [3, p. 17].

In certain countries (for example: India, USA, Russia, Spain, Republic of Poland, etc.) the presumption of consent for transplantation is present into force, which means that every adult citizen of the state automatically becomes a posthumous donor if during his life he did not express 
disagreement with the transplantation. The positive experience of these countries is based on the researches in the sphere of psychology that claims that mostly young people do not think at all that they can die (but it happens mostly by the car accidents, on the work place or they are riddled with firearms), so they don't thinks what will happen to their organs, and therefore do not write the wills and do not give instructions to their relatives about the use of their organs after death. As for the relatives of the dead person - they are primarily concerned with the burial issues and do not think that the bodies or tissues of their deceased relatives can save someone's life. Data from medicine shows that often transplantation is the only chance to save lives. Certain organs can be transplanted within a few hours.

\section{THE AIM}

Searching for solutions to improve legislative regulations in the sphere of transplantation in order to save people's lives.

\section{MATERIALS AND METHODS}

The experience of foreign countries has been used in the research. Additionally, we used data from domestic and foreign international organizations, results of scientific researches and the reports of Global Financial Integrity.

It is impossible to change situation without modifying the provisions to the national legislation pertaining to the article 16 of Law of Ukraine «On the Transplantation of Human Organs and Other Anatomical Materials» of May 17, 2018.

\section{REVIEW AND DISCUSSION}

Transplantation as a method of treating or the most severe diseases or injuries of a human being, it is used in cases where elimination of danger to life or restoration of health of the patient is impossible with other methods of treatment, of there is no alternative treatment. Transplantation - is a special method of treatment, consisting in transplanting the recipient of an organ or other anatomical material taken from a person or animal (Article 1 of the Law of Ukraine «On the Transplantation of Human Organs and Other Anatomical Materials» of May 17, 2018 [4]. In the scientific literature [5] on improving the human right to transplantation, the improvement of the editorship of art. 143 or 144 of the Criminal Code of Ukraine [6] or to consolidate the presumption of consent for transplantation, without specifying specific regulations.

A crucial area of concern is the lack of registry of people in Ukraine who is in need of transplantation, the information is not available on the official Web-site of the Ministry of Health of Ukraine [7]. Proposals to establish the registry were made in literature [8, p. 703] and they are worthy of support, as this will enable us to find out the real needs of people in transplantation and provide more effective assistance. There is no exact data on persons requiring transplant on the World Health Organization web-site [9].
In addition, it seems necessary to launch an on-line queue for people in need of transplantation in Ukraine. We suggest placing it on the official Web-site of the Ministry of Health of Ukraine. This measure will allow you to control the speed of the queue, as well as its fairness (to prevent other people from getting out of order) and it also will enable those in need of transplantation to decide whether to wait for transplantation in Ukraine or to go abroad.

It is necessary to make changes and significant additions to Art. 17 of the Law of Ukraine «On the Transplantation of Human Organs and Other Anatomical Materials» of May 17, 2018 concerning the creation of the Unified State Register of Transplants, as well as the consolidation of the order of its administration.

Consider the provisions of the Law of Ukraine of July 16, 1999 in Art. 16 contains the provision that a person must always consent to transplantation (this is a presumption of non-consent on transplantation) [10]. This law will expire in January 2019. Instead, the provisions of the new law of May 17, 2018, too, do not significantly change the situation with transplantation, since from Art. 16 [4]. Also, the provisions of the presumption of non-consent on transplantation, which does not meet the needs of Ukrainian society. In accordance with the first paragraph of Article. 16 of the Law of Ukraine «On the Transplantation of Human Organs and Other Anatomical Materials», "In the absence of such an application, anatomical materials in a deceased adult capable person may be taken with the consent of the spouses or relatives living with him until death. Anatomical materials may be taken with the consent of their legal representatives in deceased minors, disabled, or incapacitated persons». In the paragraph of the sixth, article 16 the objection is the following sentence: «In the deceased adult legal person whose application for donation is absent, as well as in minors, disabled and incapacitated persons, the taking of anatomical materials is not allowed, unless it is received or impossible to obtain the consent of the persons specified in part one of this articles» [4], since it significantly restricts the removal of anatomical materials to save the lives of others.

In other words, Ukraine still has a presumption of non-consent on transplantation, which deprives citizens of Ukraine of the right to transplant, and therefore often deprives the right to life, health and normal existence. Also, the will of the minors is limited (since even if there is an application for consent to transplantation, anatomical materials can be taken only «with the consent of their legal representatives»). This, in turn, raises another problem: the presence of permanent, so-called, transplantologic queues - records where there are people in need of transplant, in the absence of donors. And the very presumption of non-consent on transplantation does not contribute to the salvation of such people, since with the large presence of "potential donors» real, that is, those who give their bodies, there are only those who in their lives gave their consent to such transplantation, as well as those, whose relatives have given such consent, and living people who sacrifice part or body to save the life of another. Existing 
practice shows that people can die while awaiting for such a donor for years.

According to the Art. 3 of the Constitution of Ukraine, the Human being, his or her life and health, honor and dignity, inviolability are recognized in Ukraine as a highest social value. According to the Art. 8 of the Constitution of Ukraine, the Constitution of Ukraine has the highest legal force. Laws and other normative-legal acts are adopted on the basis of the Constitution of Ukraine and must comply with it [11]. As we see, the priority in our state is human life itself. The guarantee of the basic rights and freedoms of man and citizen and, above all, the right to life, is one of the indicators of civilization of the state. However, the provisions of Art. 16 of the Law of Ukraine «On the application of transplantation of anatomical materials to a person» is not directly, but indirectly contrary to Art. 3 of the Constitution of Ukraine, because the disagreement on transplantation existing in the law, firstly, deprives medical workers of precious time, and even when consent for transplantation is provided by the relatives of the deceased - time, unfortunately, will not allow a transplant to be carried out as it is possible during just a few hours; secondly, people do not write a will with the indication of the possibility of transplanting their organs for various reasons: some do not know that otherwise because of dissent or long reflection of their relatives it will become impossible in the long run, others do not want to sniff, others do not want to pay a notary money for the will of the will, the fourth is afraid of abuses in this area, etc. Existing wording of Art. 16 of the Law of Ukraine «On Transplantation of Organs and Other Human Anatomical Materials» promotes the removal of organs and tissues in humans by coercion or deception, trade in organs or tissues, since the demand for organs far exceeds the supply.

One of the few arguments for supporters of the presumption of non-consent on transplantation is the prevention of the image of religious feelings of relatives or relatives of the deceased. At the same time, Art. 35 of the Constitution of Ukraine contains the provision that «The Church and religious organizations in Ukraine are separated from the state, and the school is from the church. No religion can be recognized by the state as obligatory. No one can be freed from his duties to the state or refuse to execute laws on the grounds of religious beliefs» [11]. That is, opposed to preventing the image of religious feelings of relatives or close persons of the deceased and the right of another person to life. Obviously, the benefit should be the right to life of a person in need of transplantation. It does not in fact affect the ability of a person to be buried, cremated or otherwise honored, without encroachment on her religious feelings or feelings of their relatives.

The presence in the modern world of a large number of spectacular and dangerous factors, the possibility of injuries and injuries that occur at almost every step. Car accidents, acts of terrorism, consequences of hereditary or genetic diseases, ordinary domestic injuries, which can lead to lethal consequences without the need for emergency intervention, the presence of a large number of wounded servicemen as a result of military conflicts, which is now very relevant in our country, is not a complete list of that that every day endangers a person.

Still here a very strong statement remains on medical services (its level of development allows you to successfully carry out transplantation, save thousands of lives) and the right (to realize the possibilities of medicine). At the present stage, the possibilities of medicine have reached such a level that it is not difficult to replace even such a human body as the heart that stopped. In the leading countries of the world, such as, the United States, there is the so-called presumption of consent for transplantation, that is, the possibility to select, if necessary, in the deceased person organs or materials suitable for transplantation without its consent or without objection to it, which in turn allows you to save one, and sometimes a few lives. That is, if there is a death of a young person, say after a car accident, and it is possible to use her organs or tissues to save one, two, three or more people, why not do it? As you can see, the experience and good practice of transplantation in the United States seem more rational and very convincing. The death of one person makes it possible to save several others, to reduce the queues for transplantation (and in the long term - to eliminate these queues) and the corruption of this sphere, which at the moment is very important.

Therefore, in order to improve the implementation of the human right to organ transplantation in Ukraine, the first paragraph of Art. 16 of the Law of Ukraine should be worded as follows: «Every adult legal person can give written consent or disagreement to become an donor of anatomical materials in case of his death. In the absence of such a statement, in the case of deceased adults or minors, anatomical materials for transplantation may be taken regardless of the consent of the spouse or relatives living with her until death. Regardless of the existence of such a statement, in the case of deprived persons with limited capacity or incapacity, anatomical materials for transplantation may be taken regardless of the consent of their legal representatives».

Presence of a presumption of consent for transplantation in our legislation (Article 16 of the Law of Ukraine «On the Transplantation of Human Organs and Other Anatomical Materials») could have a positive impact not only on the development of medicine in our country, but also to save a large number of lives. The proposed changes to the legislation do not require additional financing from the budget, could reduce the number of crimes related to illegal transplantation, since the lack of donors is the main reason for their existence.

Currently, there are only five transplantation centers in Ukraine that carry out kidney, liver and heart transplantation operations (interestingly, over the past twenty years only 8 heart transplants have been performed in Ukraine, 1000-1500 if necessary), for comparison, Spain has 47 million population of more than 40 transplantation centers, the average number of transplants ranges from 98-115 transplants per year [12]. 
A.V. Musiyenko recommends the adoption of standards regulating organ transplantation in accordance with the Guidelines developed by the World Health Organization and the World Medical Association to organize bilateral and regional cooperation on the basis of the development of common standards, guided by the conventions and recommendations adopted by the Council of Europe, and also bring national laws and standards in line with these general principles [13, p. 17].

Some Ukrainian citizens are afraid of transplantation through mass media reports of «black transplantologists». However, there are positive examples in Ukraine the STB channel clearly explained in a number of reports why the presumption of consent for transplantation is important and that without it the register of patients requiring organ transplantation is inevitably threatened with death, whereas their bodies are no longer needed for death.

If we keep the law of Ukraine «On the application of transplantation of anatomical materials to a person» of May 17, 2018 that way, then hundreds of Ukrainian citizens may die while awaiting for the vital assistance. Amendments to the law do not require additional funds from the state and local budgets. It is also free to create a registry of people in need of transplantation as well as running the on-line queue of people in need on the official Web site of the Ministry of Health of Ukraine. It will save people's lives, furthermore, these steps are in accordance with the requirements of Art. 3 of the Constitution of Ukraine, which states that the human being is recognized as the highest social value.

Consequently, the discussion is whether to continue to spend millions of UAH on transplant operations abroad in the absence of the necessary organs and other human anatomical materials in Ukraine, or to save hundreds of lives, while still saving budgetary funds and reducing the level of illegal transplantation.

\section{CONCLUSIONS}

1. The need to review the legislation of Ukraine in the part of transplantation and the requirement of the implementation of significant improvements in order to prevent such problems as: the absence of presumption of consent, considerable underinvestment in medical services, the lack of citizen's knowledge and their misconceptions in the transplantation area.

2. Article 16 of the Law of Ukraine «On the application of transplantation of anatomical materials to a person» of May 17, 2018, is proposed to be worded as follows: «Every adult legal person can give written consent or disagreement to become an donor of anatomical materials in case of his death. In the absence of a statement of disagreement with the transplant, consent from relatives or others is not required. In this case, the deceased person is deemed to have given consent to the transplantation of anatomical materials».

3. It is necessary to make changes and significant additions to Art. 17 of the Law of Ukraine «On the application of transplantation of anatomical materials to a person» of May 17, 2018 concerning the creation of the Unified State Register of Transplants, as well as the consolidation of the order of its administration.

4. National legislation should take into account the standards governing the organ and tissue transplantation, in accordance with the Guidelines developed by the World Health Organization, to organize bilateral and regional cooperation on the basis of the development of common standards, guided by the conventions and recommendations adopted Council of Europe, as well as bring national laws and standards in line with these general principles.

\section{REFERENCES}

1. Egorov 0.P. Pravova kul'tura: ponyattya, elementy ta rivni [Legal Culture: Concept, Elements and Levels]. Pravnychyy visnyk Universytetu «KROK». 2011. Issue. 9, 13-18.

2. Bugera 0.I. Pidvyshchennya rivnya pravovoyi kul'tury suspil'stva iz vykorystannyam mozhlyvostey merezhi Internet [Increasing the level of the legal culture of society using the possibilities of the Internet]. Aktual'ni problemy vitchyznyanoyi yurysprudentsiyi. 2018. №. 1, 193-196. Available at: http://apnl.dnu.in.ua/1_2018/1_2018. pdf\#page $=193$.

3. PashkovV. M., Golovanova I. A., Noha P. P. Principle of serviceability and gratuitousness in transplantation? Wiadomosci Lekarskie. 2016, tom LXIX, nr 3 (cz. II), 565-568.

4. Pro zastosuvannya transplantatsiyi anatomichnykh materialiv lyudyni: Zakon Ukrayiny vid 17 travnya, 2018 № 2427-VIII [0n the application of transplantation of anatomical materials to a person. Law of Ukraine. May 17, 2018, №. 2427-VIII]. Available at: http://zakon3.rada.gov.ua/ laws/show/2427-19.

5. HrynchakS.V. Transplantatsiya za kryminal'nym pravom [Transplantation under criminal law]. Velyka ukrayins'ka yurydychna entsyklopediya : u 20 t. / Nats. akad. prav. nauk Ukrayiny, In-t derzhavy i prava im. V.M. Korets'koho, Nats. yuryd. un-t im. Yaroslava Mudroho; redkol. V.YA. Tatsiy ta in. Kharkiv: Pravo, 2017. Kryminal'ne pravo, 967-969.

6. Kryminal'nyy kodeks Ukrayiny vid 05 kvitnya 2001 r. № 2341-III [The Criminal Code of Ukraine of April 5, 2001 № 2341-III]. Vidomosti Verkhovnoi Rady Ukrayiny. 2001. № 25-26. St. 131.

7. Ministerstvo okhorony zdorov"ya Ukrayiny [Ministry of Health of Ukraine]. Available at: http://moz.gov.ua/.

8. Krainyk H. S., Sachuk B. P. Problematyka rozvytku transplantatsiyi v Ukrayini [Problematics of development of transplantation in Ukraine]. Young scientist April 2018. № 4 (56), 700-703.

9. Vsesvitnya orhanizatsiya okhorony zdorov'ya [World Health Organization]. Available at: http://www.who.int/en/.

10. Pro transplantatsiyu orhaniv ta inshykh anatomichnykh materialiv lyudyni : Zakon Ukrayiny vid 16 lypnya 1999 r. № 1007-XIV [About transplantation of organs and other anatomical materials to a person: Law of Ukraine dated July 16, 1999 No. 1007-XIV]. VidomostiVerkhovnoi Rady Ukrayiny. 1999. № 41. St. 377.

11. Konstytutsiya Ukrayiny vid 28 chervnya 1996 r. № 254k/96-VR [The Constitution of Ukraine of June 28, 1996]. Vidomosti Verkhovnoi Rady Ukrayiny. 1996. № 30. St. 141.

12. Krainyk H. S., Sachuk B. P. Problematyka rozvytku transplantatsiyi v Ukrayini [Problematics of development of transplantation in Ukraine]. Young scientist April 2018. № 4 (56), 700-703. 
13. Musiyenko A. V.Zapobihannya zlochynam u sferi transplantatsiyi orhaniv ta tkanyn lyudyny [Prevention of crimes in the field of transplantation of organs and tissues of the person]: avtoref.. dys. ... k.yu.n.: 12.00.08. Kyyiv : Kyyivs'kyy natsional'nyy universytet imeni Tarasa Shevchenka, 2002.20 p.

\section{Authors' contributions:}

According to the order of the Authorship.

Conflict of interest:

The Authors declare no conflict of interest.

\section{CORRESPONDING AUTHOR}

Hryhorii Krainyk

Yaroslav Mudryi National Law University

77, Pushkinska St., 61024 Kharkiv, Ukraine

tel: +380502602452

e-mail: vip.kraynik@ukr.net

Received: 03.10 .2018

Accepted: 28.02.2019 
PRACA POGLADOWA

REVIEW ARTICLE

\title{
PERIODONTAL DISEASES AND ATHEROSCLEROSIS (LITERATURE REVIEW)
}

\section{CHOROBY PRZYZĘBIA A MIAŻDŻYCA (PRZEGLĄD LITERATURY)}

\author{
Iryna S. Dankevych-Kharchyshyn', Olena M. Vynogradova', Natalia V. Malko', Roman M. Gnid', Andriana P. Skalat', \\ Lidiya Y. Minko', Oleg I. Mrochko', Yurij L. Bandrivsky², Orysia 0. Bandrivska² \\ 'DANYLO HALYTSKY LVIV NATIONAL MEDICAL UNIVERSITY, LVIV, UKRAINE \\ 2. HORBACHEVSKY TERNOPIL STATE MEDICAL UNIVERSITY, TERNOPIL, UKRAINE
}

\begin{abstract}
Introduction: The relationship between periodontal diseases and atherosclerosis is addressed in this article. Both these diseases have an inflammatory basis. Because periodontal disease is a risk factor for developing atherosclerotic vascular disease, diagnosis of the former is important. Particular attention must be paid to patients who have periodontal disease with other risk factors for atherosclerotic vascular disease. Recommendations managing these patients have been made included.

The aim: The paper is aimed at familiarization of broad medical public with the presence of the relationship between diseases of periodontal tissues and atherosclerosis. Materials and methods: A thorough comprehensive analysis and generalization of scientific achievements elucidated in the fundamental and periodical publications, relating to diseases of the periodontal tissues and atherosclerosis, has been carried out.

Review: The article consists of many researchers regarding the prevalence and intensity of periodontal tissue diseases in people of all ages. Problems associated with the state of periodontal tissues in people under study as dentists and general practitioners. Proven role in the pathogenesis of inflammatory diseases of the periodontal tissues in people with atherosclerosis. In the modern concept of the etiology and pathogenesis of periodontal diseases in people is extremely important role for the immune system and resistance to periodontal bacterial invasion. Analyzed common changes important for pathogenesis of periodontal tissue diseases and atherosclerosis.

Conclusions: Consequently, recent studies have shown a clear, directly proportional relationship between periodontal tissue diseases and atherosclerosis, but mechanisms for their development and interaction are not fully disclosed.
\end{abstract}

KEY WORDS: periodontal disease, atherosclerosis, dentistry

Wiad Lek 2019, 72, 3, 462-465

\section{INTRODUCTION}

More than a hundred years ago, the relationship between infections in the oral cavity, tooth extraction and cardiovascular diseases (infective endocarditis) [1] was established, which led in the middle of the twentieth century in the practice of medicine to the appointment of antibiotics for the prevention of endocarditis in invasive stomatological interventions [2]. After 1950, the theory of the development of infections associated with infections of the tooth-jaw system is expanding, and it is also given an etiological role in a number of other anatomical areas far removed from the oral cavity. In the last two decades, infections of the oral cavity as the cause of systemic disease, with a special emphasis on periodontal disease and their possible association with atherosclerotic vascular diseases, were again the focus of attention. $[3,4]$.

\section{THE AIM}

The aim of this review is to familiarize the broad sections of the medical community with the link between periodontal tissue diseases and atherosclerosis.

\section{MATERIALS AND METHODS}

A thorough comprehensive analysis and generalization of scientific research concerning the main and periodical publications related to periodontal tissue diseases in the context of atherosclerosis has been carried out.

\section{REVIEW AND DISCUSSION}

Periodontal disease is a serious problem of the present. [5]. They have a high prevalence, reduce the quality of life and chewing, have a negative effect on aesthetics, lead to disability and loss of teeth, are the cause of most cases of complete loss of teeth and are chronic diseases with potential negative consequences for health in general, promote the development of atherosclerotic vascular diseases [6]. Disease of periodontal tissues can be prevented by introducing preventive measures, for example, maintaining proper oral hygiene, brushing teeth, dental floss and regular professional hygiene of the oral cavity (by cleaning ultrasound of the roots of teeth and teeth with subsequent brushing polishing).

Periodontal disease is a group of diseases that arise from the accumulation of plaque, with or without the 
development of the inflammatory process, the destruction of periodontium, including the gums itself, periodontal ligament and alveolar bone. Clinically, furrow of the gums deepens, forming a pocket, disrupting the attachment of gums to the root surface, while the biofilm on the surface of the teeth migrates apical, attaching connective tissue and appears alveolar bone loss, gingival recession [7].

Different microorganisms colonize the dental plaque above and below the edge of the gum, to form over and under gums layers of dental plaque. The over gums plaque is primarily populated Streptococcus Sanguis, Streptococcus oralis, Streptococcus mutans, Actinomyces naeslundii i Actinomyces odontolyticus. Next joing, the secondary colonizers, such as the Fusobacterium nucleatum, and soon form conglomeration, consisting of millions of gram-positive, gram-negative bacteria and cocci, which form a biofilm.

Over time, the microflora of the area of the attached gums goes from predominantly gram-positive to primary gram-negative, which includes a large number of obligate, anaerobic, gram-negative microbes, for example Porphyromonas gingivalis, Tannerella Forsythia, Treponema denticola, Selenomonas noxia, Campylobacter rectus, microarrophils Aggregatibacter (formerly Actinobacillus) Actinomycetemcomitans, Prevotella intermedia, and spirochetes [7]. In addition, Chlamydophila pneumoniae, Mycoplasma, Helicobacter pylori, Candida species, Epstein-Bar virus, cytomegalovirus, herpesviruses, amebi, methane-forming prokaryotic microbes (methanogens classified as arheium) are found in periodontal pockets.

Bacterial-endothelial cell interactions occur in periodontal pockets, creating and exchanging signals between microorganisms and adjacent cells of the immune system. Proinflammatory cytokines, as well as chemokines, are released, attracting dendritic cells, T-lymphocytes, B-lymphocytes, macrophages and neutrophils, which are involved the innate and acquired immune responses and the inflammatory process [3]. Some microorganisms are likely to be involved in periodontal diseases, for example Porphyromonas gingivalis, Aggregatibacter (formerly Actinobacillus) actinomycetemcomitans and Prevotella intermedia, are attracted and assimilated by receptor-mediated endocytosis in the epithelium cells lining the ashen furrow. Thus, endotoxin (e.g., lipopolysaccharide) produces microorganisms, for example, Porphyromonas gingivalis, protected from the immune system and can multiply within the cells, and maybe may circulate systemically through the bloodstream, causing a generalized immune response $[2,4]$.

Cardiovascular diseases, the basis of which is atherosclerosis, is the most common cause of morbidity and mortality of the adult population in the whole world [8]. Atherosclerotic vascular disease can lead to coronary heart disease (stable angina and acute coronary syndrome), coronary artery disease (impaired cerebrovascular flow, or stroke and transient ischemic attacks) and peripheral vascular disease.

The process of atherosclerosis begins with lipid capture in the subendothelial layer of the arterial wall, followed by the production of biologically active substances: malonic dialdehyde (MDA) - modified low density lipoprotein (MDALDL), which stimulate vascular cells to form inflammatory molecules, thus involving monocytes and T-cells into the intima layer of the arterial wall [9]. Circulatory monocytes also join the vascular endothelium and are differentiated into macrophages which are absorbed by lipoproteins (xanthomas (foamy)) cells. They accumulate in the form of fatty streaks that develop into more complex fibro-fatty plaques. Monocytes and T cells are attached to the surface of the endothelial cells indirectly through chemical mediators, including ICAM-1 intercellular adhesion molecules (ICAM-1), endothelial-leukocyte adhesive molecules of the first type (ELAM-1), and vascular endothelium adhesion molecules (VCAM-1 ) [10]. Foam cells eventually die, leaving necrotic, rich in lipoproteins of the nucleus in the arterial wall, which can calcify. At the same time, smooth muscle cells in the arterial wall migrate to the intima layer (Tunica intima) and multiply. Atherosclerotic plaques are places of chronic inflammation.

Violations of cerebral circulation and acute coronary syndrome, which are the main adverse cardiovascular factors, arise in people who develop atherosclerotic plaques in the major and coronary arteries. These diseases occur when the fibrous membrane unstable ruptures the atherosclerotic plaque, causing tissue baring under the intima of vessels, as well as partial or complete blockage of the vessel due to aggregation of platelets and the formation of blood clots in situ.

Numerous epidemiological and invasive studies confirm the link between clinically diagnosed periodontal disease and coronary heart disease. A recent review (published in 2012) was performed by the American Heart Association (AHA) working group. They conducted an electronic search for literature on the relationship between periodontal disease and cardiovascular disease (with the exception of infectious endocarditis), Behcet's syndrome, Stevens-Johnson syndrome and Sjogren's syndrome. A total of 537 articles were analyzed in dental / periodontological (61\%) and medical (39\%) journals [11]. A survey on the prevalence of cardiovascular diseases and periodontal disease, anatomy, pathophysiology and microbiology of periodontal diseases, risk factors and pathogenetic mechanisms for cardiovascular diseases and periodontal disease, both indirect and direct development mechanism, and actual data on interactions are published. The relationship between cardiovascular disease and periodontal disease. It was concluded that "periodontal disease is associated with atherosclerosis, regardless of somatic pathology», but there was no evidence of causation and that for this reason, «statements that imply a causal relationship between periodontal diseases and specific cases of vascular atherosclerotic diseases are unfounded »[11].

A consensus statement from the European Federation of Periodontology and the American Academy of Periodontology (EFP / AAP) was published in 2013 [12]. The results of biological, epidemiological and first data obtained after invasive studies were published. Longitudinal studies have been conducted to evaluate the incidence of cardiovascular 
disease, in which statistically significant risk factors for the development of atherosclerotic vascular disease, independent of the established cardiovascular risk factors, were in individuals with periodontal disease. Given the high prevalence of periodontal disease, this risk factor is considered important from the point of view of overall health.

Only moderate evidence was found that the treatment of periodontal diseases reduces CRP and improves the function of the endothelium. No data on the effect on the lipid profile were found, but biomarkers of coagulant activity and endothelial cellular activity, as well as arterial pressure and subclinical atherosclerosis, are improved from periodontal therapy. The working group came to the conclusion that: 1) there are significant epidemiological data that periodontitis is an increased risk for the development of cardiovascular disease;

2) while in vitro tests on animals and clinical studies confirm the interaction and biological mechanism, the presently available invasive tests are not reliable to draw further conclusions. Necessary well thought out invasive trials on the effects of treatment of periodontal tissue diseases on the prevention of atherosclerotic vascular diseases with clear clinical results «[7].

Other authors also systematically reviewed epidemiological data on the relationship between periodontal disease and atherosclerotic vascular disease [13]. All types of longitudinal tests were studied in the English and German-speaking countries. The researchers included only those studies that used as criteria for evaluating periodontal probing, clinical loss of connection and / or radiological evaluation of alveolar bone tissue loss. To compare the risk of developing atherosclerotic vascular disease in people with periodontal disease and those who do not suffer from periodontal disease, studies have been analyzed that evaluated patients who suffered the first signs of coronary heart disease (coronary heart disease, stable angina pectoris, acute coronary syndrome, death), who had cases of cerebrovascular diseases transient ischemic attacks, acute cerebrovascular disorders and peripheral vascular diseases. Only those studies that assessed the degree of relative risk and were monitored for the assessment of the mixed effects of age and sex were included in the evaluation of the relationship between periodontal disease and atherosclerotic vascular disease. A total of 12 studies ( 6 for coronary heart disease, 3 for cardiovascular exacerbations, 2 for coronary heart disease and cardiovascular exacerbations, 1 for peripheral vascular disease) were selected for this review. It was concluded that there is evidence of an increased risk of atherosclerotic vascular disease in patients with periodontal tissue diseases compared to patients without periodontal disease, but these data can not be applied to all population groups.

Inflammation can be as a component of pathobiology of atherogenesis, and a trigger for rupture of the plaque. In addition, inflammation is inherent in the pathogenesis of periodontal diseases. Inflammation can rarely be considered as a localized process, as the occurrence of inflammation mediators in the system environment occurs when the inflammatory process occurs somewhere in the body. Therefore, it is possible that the inflammatory processes affect each other when present at the same time.

Several markers can be used to evaluate systemic inflammation. The inflammatory response is characteristic of the acute phase, as evidenced by an increase in the level of C-reactive protein (CRP) or highly susceptible CRP (hs CRP) associated with many chronic diseases and is part of the Framingham risk scale used to predict mortality from cardiovascular diseases or myocardial infarction [14]. However, it is unknown whether this acute phase protein will be only a marker of the inflammatory process, because it participates in the pathophysiology of atherogenesis [13]. It is present in newly formed ateromatous plaques and it is localized in conjunction with the activated complement. The US Preventive Measures Team concluded from a systematic review that there is strong evidence that CRP is associated with coronary heart disease but there is not enough evidence to support the idea that CRP should be targeted for therapy [15]. A number of studies have shown that in individuals without atherosclerotic vascular disease in the history of a single, planned determination of CRP can predict future vascular problems, including acute coronary syndromes, cardiovascular attacks, peripheral vascular disease, and sudden cardiac death. Thus, CRP is an independent marker for future cardiovascular disease and adds information for prediction.

Another inflammatory biomarker that is consistently linked to cardiovascular risk is myeloperoxidase (MPO), an enzyme that is expressed in leukocytes and is associated with both inflammation and oxidative stress. Both processes play an important role in the pathobiology of coronary heart disease.

The metalloproteinases are involved in the dissolution of the fibrous membrane of the atheromatous plaque, which leads to the development of the most frequent cardiovascular diseases, and indicators of many other markers are elevated in cardiovascular diseases, but not to the same extent as in CRP, for example, lipoprotein-associated phospholipase A2, tissue inhibitors of matrix metalloproteinase, fibrinogen, interleukin 6 [IL-6], soluble molecules of intercellular adhesion type 1, macrophageal cytokine-1 inhibitors and soluble form of CD40 molecule ligand [15]. In diseases of the periodontal, the systemic markers of inflammation, including CRP, tumor necrosis factor (TNF-a), IL-1, IL-6 and IL-8, are elevated. Consequently, periodontal disease, as well as chronic infections, contribute to an increase in chronic inflammatory agents due to the systemic spread of inflammatory mediators released by local tissue destruction, the immune-inflammatory response to parodonotopathogens, as well as the systematic proliferation of these pathogenic microorganisms and their products. This may contribute to both the development of atherosclerosis and the discontinuity of plaques in patients with periodontal disease. Epidemiological studies of the role of periodontal disease as an independent risk factor for atherosclerotic vascular disease were reviewed by authoritative organizations such as the American Heart 
Association (AHA) and the European Federation of Periodontology (EFP) / American Academy of Periodontology (AAP), as well as by other authors $[11,12,16]$. The authors who conducted the study came to the conclusion that there is evident evidence of the relationship between these two diseases, but this statement is not valid for all groups of the population. Although the available research findings show the tendency of periodontal interventions for systemic inflammation and some markers of atherosclerotic vascular disease and endothelial function, this is not consistent with all of our studies. In addition, transient inflammation and endothelium abnormalities were seen after the exacerbation of periodontal disease. Because in our knowledge of the relationship between diseases of periodontal tissues and atherosclerotic vascular diseases there are significant problems, more fundamental, epidemiological, invasive studies are needed.

Due to concern about this health problem, all health care professionals need to know that periodontal disease is a risk factor for the development of atherosclerotic vascular diseases, and prophylaxis, diagnosis, and treatment of periodontal diseases are of paramount importance. In addition, patients with periodontal disease who have other risk factors for development of atherosclerotic vascular disease, such as hypertension, obesity, smoking, dyslipidaemia, diabetes mellitus or burdened family diagnosis that have not been visited by their doctor for the past 12 months should be recommended do it. Patients prone to periodontal disease with atherosclerotic vascular diseases associated with lifestyle features, should be advised in dental clinics on these issues within the framework of a comprehensive, periodontal treatment plan. They should be given recommendations, preferably together with doctors of other specialties, for example, programs to combat smoking and obesity. The treatment of patients with periodontal diseases that are prone to the risk of developing infectious endocarditis before dental procedures should be considered in accordance with existing recommendations [2]. The above measures and approaches, which are carried out in cooperation with representatives of all medical specialties, help to support the maximum dental and general health of the patient.

\section{CONCLUSIONS}

Consequently, recent studies have shown a clear, directly proportional association between periodontal tissue diseases and atherosclerosis, but the mechanisms for their development and interaction are not fully disclosed.

\section{REFERENCES}

1. Grudyanov, A.I. \& Fomenko, E.V. . Etiologiya i patogenez vospalitelnyih zabolevaniy parodonta. Moscow : MIA; 2010: 34s

2. Zabolotnyi, T.D., Borysenko, A.V. Pupin, T.I. Zapalni zakhvoriuvannia parodonta . Lviv : HalDent 2013: $78 \mathrm{~s}$.

3. Bandrivskyi Yu. L., Bandrivska N. N., Vinohradova 0. M. Osoblyvosti HLA - antyheniv ta yikh asotsiatyvni zviazky z prozapalnymy tsytokinamy u khvorykh na heneralizovanyi parodontyt. Visnyk problem biolohii i medytsyny, Poltava, 2014;2: $62-65$ s.
4. M.F. Danylevskyi, A.V. Borysenko, A.M. Politun, M.lu. Antonenko, L.F. Sidelnikova, 0.F. Nesyn. Terapevtychna stomatolohiia. Kyiv: Medytsyna; 2008: 343-360s.

5. American Academy of Periodontology. Guidelines for the management of patientswith periodontal diseases J. Periodontol. - 2006; 77: 1607-1611.

6. Moskalenko V.F., Antonenko M.Iu. Naukove obgruntuvannia modeli dyspanseryzatsii dorosloho naselennia molodoho viku iz zakhvoriuvanniamy parodonta. Okhorona zdorovia Ukrainy. 2007;3:113-118s.

7. Shkrebniuk R. Yu. Zminy markeriv endotelialnoi dysfunktsii u syrovattsi krovi u patsiientiv z heneralizovanym parodontytom na tli tsukrovoho diabetu I typu z kardiomiopatiieiu Visnyk problem biolohii i medytsyny. 2016; 4(2): 282-285 s.

8. Ladich E. R. Atherosclerosis pathology [Electronic resource]. — http:// reference.medscape.com/article/1612610- overview.

9. Auer, J.W. , Berent R., Weber T., Eber B. Immunopathogenesis of atherosclerosis (Responce) Circulation. - 2002.105; 10:64.

10. Ross R. Atherosclerosis - an inflammatory disease. New Engl. J. Med. 1999; 340;115-126.

11. Lockhart P.B., Bolger A.F., Papapanou P.N., Osinbowale 0., Trevisan M., Levison M.E., Taubert K.A., Newburger J.W., Gornik H.L., Gewitz M.H., Wilson W.R., Smith S.C. Jr., Baddour L.M. Periodontal Disease and Atherosclerotic Vascular Disease: Does the Evidence Support an Independent Association: A Scientific Statement From the American Heart Association. Circulation 2012;125:2520-2544.

12. Tonetti M.S., Van Dyke T.E. Periodontitis and atherosclerotic cardiovascular disease: consensus report of the Joint EFP/ AAP Workshop on Periodontitis and Systemic Diseases. J Periodontol 2013;84: 24-29.

13. Rath M, L Pauling A. A unified Theory of Human Cardiovascular Disease Leading the Way to the Abolition of this Disease as a Cause for Human Mortality. Journal of Orthomolecular Medicine 1992; 7(1): 5-15.

14. Libby P., Ridker P.M. Inflammation and atherosclerosis: role of C-Reactive protein in risk assessment. Am. J. Med. 2004; 116: 9-16.

15. Mraz, M., Haluzik M. The role of adipose tissue immune cells in obesity and lowgrade inflammation. J. Endocrinol. 2014; 222;113-127.

16. Mya M., Aronow W. Subclinical hypothyroidism is associated with coronary arterial disease in older persons. J. Gerontol. Biol. Sci. Med. Sci. 2002;57: 658-659.

\section{Authors' contributions:}

According to the order of the Authorship.

\section{Conflict of interest:}

The Authors declare no conflict of interest.

\section{CORRESPONDING AUTHOR \\ Yurij L. Bandrivsky}

I. Horbachevsky Ternopil State Medical University

Brygadna, 14a/86, 46012, Ternopil, Ukraine

tel: +380973047399

e-mail: bandrivsky.83@gmail.com

Received: 12.09 .2018

Accepted: 21.02.2019 
PRACA POGLĄDOWA

REVIEW ARTICLE

\title{
MODERN APPROACH TO THE PROBLEM OF PERTUSSIS
}

\section{NOWOCZESNE PODEJŚCIE DO PROBLEMU KRZTUŚCA}

\author{
Valentyna I. Ilchenko, Liudmyla M. Sizova, Svitlana M. Tanianskaia, Inna N. Nesina, Kateryna V. Pikul \\ UKRAINIAN MEDICAL STOMATOLOGICAL ACADEMY, POLTAVA, UKRAINE
}

\begin{abstract}
Introduction: Recently, there has been a tendency to increase the incidence of pertussis in many countries of the world and this disease in these countries is among 10 most serious causes of death in young children.

The aim of the work - is to analyze specialized scientific literature for generalization of data and present a modern look at questions of etiology, epidemiology, pathogenesis, clinical manifestations, diagnosis, treatment and immunoprophylaxis of pertussis.

Materials and methods: Available scientific sources over the past years, devoted to the problem of pertussis are studied by the methods of overview, system and content analysis. Review and conclusions: The main questions of pertussis are outlined. Timely diagnosis, treatment and immunoprophylaxis allow adjusting the actions of doctors to solve the issues of the decrease of the incidence of pertussis. This is greatly helped by modern guidelines for the management of patients with this pathology.
\end{abstract}

KEY WORDS: pertussis, children, treatment, prevention

Wiad Lek 2019, 72, 3, 466-471

\section{INTRODUCTION}

Nowadays, the problem of a pertussis does not lose its relevance in the world. According to the WHO, every year in the world are sick with pertussis about 60 million people, and die - 1 million, mostly children under 1 year [1-2]. Recently, there has been a tendency to increase the incidence of pertussis in many countries of the world and this disease in these countries is among 10 most serious causes of death in young children [3-14]. The main risk factor for pertussis is insufficient immunological protection of children due to low immunization coverage, violations of schedules and timing of vaccination, unreasonable medical exclusions from vaccination.

Due to the deteriorating epidemiological situation regarding pertussis in Ukraine (an increase in the incidence of 10 times in the last 3 years in different age groups, as well as a decrease in the preventive vaccinations, due to the difficult economic situation and the refusal of parents), there is difficult task to use opportunities to stop this phenomenon [6, 15-19]. Timely diagnosis, treatment and, most importantly, prevention, allow adjusting the actions of doctors to solve the issues of the decrease of the incidence of pertussis.

\section{THE AIM}

The aim of the work is to analyze specialized scientific literature for generalization of data and present a modern look at questions of etiology, epidemiology, pathogenesis, clinical manifestations, diagnosis, treatment and immunoprophylaxis of pertussis.

\section{MATERIALS AND METHODS}

Available scientific sources over the past years, devoted to the problem of pertussis are studied by the methods of overview, system and content analysis. The data of world literature are presented and the results of modern research are analyzed.

\section{REVIEW AND DISCUSSION}

Pertussis is acute infectious disease which is caused by pertussis rod and it is transmitted through airborne and characterized by the damage of respiratory airways and spastic (convulsive) cough $[7,20]$.

\section{BRIEF HISTORY}

The burst of pertussis was described by G. de Baieu in Paris in 1578 , in the XVII century. The description of the epidemic in England was introduced by T. Sydenham, in the XVIII century. In XVIII Hoffman announced about pertussis. The first monograph about pertussis was created by A. Brendel and Bassiville. A detailed description of pertussis was made by N. F. Filatov. In 1900 and 1906 the pathogen was isolated from the mucus, which was isolated with cough and studied in detail by J. Bordet (Belgium) and O. Gengou (France). In 1957, the killed pertussis vaccine was created, and since 1965 vaccinations have been carried out by the associated vaccine. [7, 21-23].

\section{ETIOLOGY}

The causative agent of the disease is Bordetella pertussis, a gram-negative, immobile bacterium that has a rod-like 
shape and causes a specific damage of the bronchial epithelium. This microorganism produces a large range of toxins and biologically active substances (pertussis toxin, tracheal cytotoxin, adenylate cyclase, endotoxin, filamentous hemagglutinin, pertactin, dermo necrotic toxin, agglutinogens, lymphocyte-producing factor). Bordetella pertussis is not very stable in the environment, it dies under direct sunlight during the year, and at a temperature of $56^{\circ} \mathrm{C}-15-30$ minutes. It is quickly inactivated under the influence of disinfectants. In dry phlegm, it keeps the viability for several hours $[21-22,24]$.

\section{EPIDEMIOLOGY}

Pertussis presents the most contagious disease and can be presented in $97-100 \%$ of population. People of different age groups are ill with this disease. More than $50 \%$ of pertussis in children of infancy is associated with insufficiency of mother immunity and the absence of transplacental transmission of specific protective antibodies, so disease can occur from the first days of life. Major part of diseases can be present in children up to 2 years old who undergo this disease very bad $[3,25]$. Pertussis is epidemic worldwide. In each area the disease becomes epidemic at intervals of 2-4 years. The first case of pertussis usually does not have the natural life-span immunity, but repeated infection (if it occurs), passes easily and often does not differ.

The source of infection of pertussis is a sick person with any form of the infectious process: mild, moderate, severe, and especially with subclinical forms. The causative agent is contained in droplets of saliva released during coughing. The period of infectivity begins with the first day of the onset of clinical symptoms. The most contagious patients in the catarrhal period and the first week of spastic cough - in the $90-100 \%$ excreted pathogen. During the second week of spastic cough, infectivity decreases and the pathogen can be isolated in $60-70 \%$ of patients. The susceptibility to pertussis does not depend on age, but is due to the presence of immunity to it. The index of contagiousness is 0.7 , and with close contact - $0.9[4-5,17,21-22,24]$.

\section{PATHOGENESIS}

Bordetella pertussis produces several toxins, the main as pertussis toxin, which increases the sensitivity of tissues to histamine, leads to dysfunction of lymphocytes and stimulates insulin secretion. After fixation of the bacterium to the flashing airway epithelium (due to adenylate cyclase and pertussis toxin), epithelial cells are damaged, the drainage function of the epithelium of the respiratory tract is damaged, which prevents the rapid elimination of bacteria from the body. Tracheal cytotoxin and dermanecrotic factor increase the production of mucus and contribute to the absorption of pertussis toxin. Most clinical symptoms of pertussis are associated with damage to the epithelium cells of respiratory tract. Firstly, to suffer the drainage function of the mucous membranes, this leads to the accumulation of viscous mucus. The thick, viscous mucus reduces the permeability of small bronchi and bronchioles. This leads to the development of atelectasis, nonspecific bronchopneumonia, and emphysema. The mechanism of elimination of mucus is a cough, which becomes frequent, obsessive and paroxysmal. The accumulation of viscous secretion in the throat provokes vomiting. As a result of frequent cough attacks in the respiratory center, as an excitation center of the dominant type is formed, which can spread to other parts of the nervous system such as vascular, vomiting, and others. During an attack, spasm of the vessels, vomiting, and increased blood pressure may occur. In the future, attacks of spasmodic cough may occur when irritated receptive fields that are not associated with cough reflex (for example, with strong acoustic stimuli, throat examination, injections). The dominant hotbed is stored for a long time, so spastic cough can be observed after elimination of infection. However, in the emergence of stronger excitation centers, the dominant hotbed is braked-due to the cessation of attacks during an exciting game.

In general, in the pathogenesis of the pertussis, hypoxemia, hypoxia and the state of acidosis, which occur as a result from impaired of pulmonary ventilation, circulation and oxidative processes is important. Also, in the mechanism of spastic cough, the allergenic effect of Bordetella pertussis plays a role, while bacteremia does not have a significant effect $[7,21,24]$.

\section{CLINICAL MANIFESTATIONS}

The incubation period varies within 3-14 days, preferably it is about a week. During the course of the disease, there are three periods such as: catarrhal, spasmodic cough, and recovery.

The catarrhal period develops gradually. It manifests in moderately catarrhal phenomena in the form of dry cough, the body temperature remains normal, but more often increases to subfebrile values, the general state of patients remains satisfactory. Gradually, the cough intensifies, and becomes hard. At the end of this period, it can manifest itself in the form of attacks, especially at night, in spite of the treatment. This should cause a pediatrician or family doctor opinion about pertussis, but not an acute respiratory viral infection or bronchitis. In this case, it should be carefully collected the epidemiological history and assign or repeat a general blood test in which you can see the characteristic changes of the pertussis: high leukocytosis, lymphocytosis and normal erythrocyte sedimentation rate. The catarrhal period lasts 3-14 days, and the infant is reduced to 5-7 days.

The period of spasmodic cough (convulsive period) develops also gradually. Cough presents as an attack and develops more frequent, becomes convulsive. An attack of the cough can occur suddenly, but more often, patients are anticipating it: they have a tingling sensation, a feeling of pressure in the chest, anxiety. The attack begins with several coughing shocks during one breath. During the breath there is a whistling sound, which is the result of spastic narrowing of the vocal cavity. During one attack, coughing and reprises alternate and 
can be repeated several times. During an attack, the patient swells the cervical veins, the face becomes inflated, hyperemic, often cyanogenic, looks scared, tears flow, the mouth is open, the tongue is as much as possible protruding, it forms a «shuttle», the bridle can be damaged. In severe cases, there are nosebleeds, hemorrhages in the sclera, involuntary urination and defecation. The attack often ends with vomiting movements with the release of viscous mucus, sometimes actually vomiting, and in severe cases it is possible to stop breathing. In infants, cough attacks are not accompanied by reprisals and often cause apnea. Due to the lack of teeth in children of this age group, there is no damage to the tongue bridle. Body temperature is normal. Fever can be and indicates the possibility of complications. There are dry rales in the lungs and arterial pressure can be increased. Coughing attacks can provoke different external stimuli (oropharynx examination, breastfeeding, feeding, solid food, negative emotions). The period of coughing attack lasts 3-4 weeks and in children up 1 year old lasts to 6-8 weeks. Number of attacks gradually decreases and their intensity reduces.

There are three main types of pertussis: mild, moderate, severe. During the mild type, the frequency of attacks to 15 per day, the number of reprises is to 5, attacks are typical, short, vomiting is relatively rare, the general state of health of patients is not damaged. During the moderate type the number of attacks increases to 25 per day, the number of reprises includes 10, often at the end of the attack, vomiting occurs. General health status deteriorates. During the severe form of pertussis, the number of attacks increases to 30-50 per day or more, attacks is severe, can last up to 15 minutes, have more than 10 reprises and almost always end with vomiting, sleep disturbance, lack of appetite, lethargy, weight loss, prolonged fever. In newborn babies, even with moderate frequency and short duration of cough attacks, pertussis can be very difficult.

In addition to the main forms, there is often an eroded form of pertussis, characterized by the absence of typical cough attacks with reprisals and reduced flow. In such cases, tracheitis or tracheobronchitis is often diagnosed. Such forms are more commonly seen in vaccinated children. There is also an asymptomatic form of pertussis, in which there are no clinical manifestations, although in the body there are cyclic immunological and sometimes hematological changes; X-ray changes that are often detected, blood-filling of the lungs, changes in the capillary system are also described.

During the stage of reconvalescence, or even after the complete elimination of all the symptoms of pertussis, sometimes there is a recurrence of typical cough attacks - these are false relapses. They occur already after the body is released from the pertussis and is not accompanied by a typical reaction to pertussis. These «recurrence» occur in patients when they recover after any infectious disease (acute respiratory viral infection, tonsillitis) $[4,7,17,20-21,24]$.

\section{COMPLICATIONS}

Complications are connected mainly with the activation of secondary bacterial flora. Among these complications ones are dominated by pneumonia and less common diseases are presented by otitis, mastoiditis, pyelitis and other bacterial complications. The serious complication of this disease is the lesion of the central nervous system (seizures, fainting, paralysis) and encephalopathy. They are associated with a disturbance of the oxygenation of the brain tissue, dyscirculatory and dystrophic disorders in it. Often there are severe consequences such as paralysis, mental disorder, deafness, blindness.

Sometimes complications are associated with cough strength: pneumothorax, atelectasis, mediastinal and subcutaneous emphysema, umbilical and inguinal hernia, rectal incontinence, urinary incontinence, and complications of hemorrhagic nature: skin and subconjunctious hemorrhages, bleeding from the tympanic membrane and its rupture, brain hemorrhage. During the first months of life, pertussis passes badly and is accompanied by the number of complications. The most commonly used type of complication such as pneumonia, which is the main cause of death in the case of pertussis [20-21].

\section{DIAGNOSTICS}

There are bacteriological, serologic and PCR methods of pertussis diagnostics [4-5, 7, 20-21, 24, 26].

Bacteriological method (sowing the material from the nasopharynx and cultivating it on the nutrient medium) is informative at an early stage. The study is carried out on an empty stomach in 2-3 hours after drinking or eating. The material is taken from the oropharyngeal surface during 5-7 days of the disease twice. The preliminary result can usually be obtained in 3-5 days and the final one - in 5-7 days. The sensitivity of the test varies depending on the quality and terms of the study from 20 to $90 \%$. In the early days of the disease, it determines reliable result in 86-98\% of cases, but over time, the accuracy indicators are reduced to $15-20 \%$, especially with the use of antibiotics.

The «Gold Standard» for the diagnosis of pertussis is the reaction of the immunoassay. It allows detecting different classes of immunoglobulin's (Ig A, M, G) in the serum of blood, which helps the doctor to diagnose accurately and determine the stage of the infectious process and find out strong the immune system is to pertussis. The diagnostic sensitivity of this method is $66.6 \%$, the specificity is $100 \%$. Blood test is performed on an empty stomach, not earlier than 4 hours after the last meal. After that, serum is released from the blood, which is a material for the research. The research can be either qualitative (positive/negative result) or quantitative. IgM antibodies occur during the acute stage of pertussis during about 2 weeks of the disease. In 2-3 weeks IgA is detected. During the third week, IgG antibodies begin to occur - they are responsible for the formation of persistent immunity.

PCR testing can be done during the first 4 weeks of the disease. The sensitivity of this test exceeds bacteriological research. The specificity of the method is $100 \%$. The smear is taken from the nose or from the oropharynx. It should be taken to pick up the material on an empty stomach 
or 2-3 hours after drinking and eating, pre-rinse is not required. In the laboratory, in the recovered material, specific portions of the DNA of the bacteria causing pertussis are determined. The positive result determines disease or bacteriocarrier $[5,7,21]$.

The final diagnosis is determined:

- by the basis of characteristic symptoms of illness in the absence of the possibility of conducting laboratory diagnosis or with negative results of laboratory research;

- by the confirmation of the previous diagnosis by laboratory methods (isolation of culture or DNA of the pathogen or anti-infectious antibodies);

- by the basis of the characteristic symptoms of the disease, determining the presence of an epidemiological link with the source of the infection.

\section{TREATMENT}

The presence of Bordetella pertussis in the body defines either pertussis or asymptomatic course of disease. The treatment is required in any of these cases. Patients who are 1 year old, as well as patients with severe forms of pertussis and they had the presence of complications must be hospitalized. The bed regime is prescribed when there are fever and severe complications. All other patients show prolonged stay in the open air. It is very good for such patients to have cool and humid air - improves ventilation of the lungs, oxygen exchange and, possibly, reflexively affects the central nervous system and cough attacks are becoming rarer and weaker. The child should spend outdoors the most part of the day in the warmer days of the year, and in the cold - for several hours a day. During winter months walks should be carried out in closed areas from the drafts. Walking is allowed at air temperature not lower than $-10{ }^{\circ} \mathrm{C}$, however, overcooling is not allowed. It is also necessary to ensure continuous careful ventilation of the room in which the patient is located.

Much attention should be paid to educational work with children such as leisure activities, various activities, games, etc. It is necessary to exclude all sorts of stimuli such as emotional, physical which can provoke cough attacks.

Feeding should be complete. After feeding, you must especially protect the child from stimuli that provoke the development of cough attacks. If you have vomiting after eating, it should be repeated. There is a need for parenteral fluid administration when vomiting frequently presents.

To all patients in the first 3 weeks from the onset of the disease appoint erythromycin or other antibiotics from the group of macrolides in doses corresponding to the child's age within 14 days (for such antibiotic as Azithromycin the duration should be prescribed during 5 days). Trimethoprim (sulfamethoxazole) and ampicillin are used for intolerance to macrolides. These drugs are also prescribed for 14 days. However, from the perspective of evidence based medicine, optimal medications are Azithromycin and Clarithromycin. It should be noted that for the treatment of children during the first months of life, the administration of erythromycin is not recommended as the connection between its use and stenosis of the pyloric stomach is confirmed. The administration of an etiotropic therapy after 3 weeks from the onset of the disease pathogenetically unreasonable and is solved individually (in this period, antibiotic therapy should be prescribed to patients who may be in contact with non-immune individuals).

To prevent cough attacks $2.5 \%$ of Aminazine solution in $1-2.5 \mathrm{mg} / \mathrm{kg}$ is administered intramusculary twice a day (before the day and night sleep). In newborn babies solutions of Aminazine of $1.0 \mathrm{ml} * 3.0 \mathrm{ml}$ of Novocain solution is prescribed. Dosage calculation is done through Aminazine. Besides, Diazepam of $0.3 \mathrm{mg} / \mathrm{kg}$ can be used once a day. Elder children Diazepam is administered orally. There is experience with the use of salbutamol: for children 2-7 years - 1-2 mg 2-3 times a day, 8-14 years - 2 mg 3 times a day.

To decrease the intensity and frequency of cough, children at the age of 2 years can be prescribed antitussive drugs containing dextromethorphan hydrobromide, geyfenazine and on the basis of butamirati hydrocyterate.

According to evidence-based medicine, immunoglobulin's, corticosteroids, ß-adrenergic antagonists are not recommended for the treatment of pertussis.

Supervision of infants involves vital functions monitoring, episodes of apnea, frequent suction of mucus from the respiratory tract, providing adequate oxygenation, parenteral hydration, correction of hypoglycemia, parenteral nutrition.

When there is apnea it is necessary to restore respiratory tract as quickly as possible. Nose, oral cavity is kept from mucus and vomiting masses. Respiratory movements are restored by the rhythmic pressing of the hands on the chest of the child, using manual respirators, oxygen transport through the mask. During frequent, prolonged apnea, the child is transferred to the emergency department and intensive care unit, where the issues of the need for mechanical ventilation and correction of vital functions are solved $[4,7,17,20-21]$.

\section{HOSPITALIZATION}

A patient with pertussis is isolated in a hospital or at home for 30 days from the onset of the disease. Isolation should be carried out as early as possible. However, in practice, the diagnosis of pertussis is usually established during the period of spastic cough. Accordingly, isolation is postponed which greatly reduces its epidemiological efficiency. Hospitalization involves patients with a severe or complicated form of pertussis, children who are less than 2 years old, sick children from a family living in unfavorable living conditions, as well as from families with children who are less than 6 months who have not been ill with pertussis $[7,21]$.

\section{MEASURES}

Children who are 7 years old and were in contact with patients, they were previously not ill and were not vaccinated by pertussis vaccine, quarantine for 14 days from the 
time of isolation of the patient is determined. If the patient was not isolated and communication with him continued throughout the period of illness, quarantine is determined until the end of the period of contagion in the patient. The final disinfection in the hotbed of infection is not carried out (the causative agent quickly dies in the environment). When there is suspection of pertussis, a bacteriological examination is carried out.

Group of people who are at high risk of severe or complicated course of pertussis is established. People of this group are:

- children under 1 year old, especially the first four months;

- children with chronic pulmonary diseases which are accompanied with mucoviscidosis, diseases with respiratory failure;

- children with immunodeficiency status;

- pregnant women in the third trimester.

People from risk group should avoid patients with pertussis and people who cough. Patient from the group of risk should be administered antibacterial agents during the contact with the patient who is ill with pertussis.

Pregnant women are administered erythromycin or azithromycin if they were in contact with patients who were ill with pertussis $[4,20-21]$.

\section{PREVENTION}

According to the orders of the Ministry of Health of Ukraine № 551 dated August 11, 2014 and № 947 of May 18,2018 , acellular pertussis vaccine is used for active immunization, which is part of the combined vaccines (against diphtheria, tetanus and/or against poliomyelitis, hemophilic infection, viral hepatitis B) or adsorbed pertussis-diphtheria-tetanus vaccine. The next scheme of primary course of vaccination is used: the first dose is administered in 2 months of child's life, the second - in 4, the third - in 6. Revaccination should be done after the first course of vaccination in 18 months. The vaccination can't give life long immunity, disease can occur in late childhood and in adults. Experts recommend late re-vaccination to protect and prevent the spread of pertussis [16-17, 21].

\section{FURTHER PROSPECTS}

New strategies of pertussis are developed by scientists. In many countries the second revaccination is administered in pre-school age [4-5, 8-9, 11-12, 27-30]. Acellular pertussis vaccine is administered in the USA and in other countries of Europe, when children are more than 2 months old. The possibility of the first vaccine by newborn babies is proposed. Nowadays transplacental transmission of antipertussis antibodies to the fetus is effectively approved and their protective role is also detected. Efficacy of mother's vaccination contains $89 \%$ in order to prevent disease. Vaccination during pregnancy can decrease the mortality of newborn babies on $33 \%$, the hospitalization number on $38 \%$ and the morbidity - on $49 \%$. Acellular pertussis vaccine Tdap (27-36 weeks of gestation) is recommended for pregnant women nowadays. And to prevent infection of newborn child vaccination is necessary for all members of family. It allows protecting a child during the first 6 months before the formation of immunity [6]. However, in many countries Tdap vaccine is not licensed, that's why vaccination is impossible.

Nowadays scientists develop new effective pertussis vaccines. Live slight vaccine BPZE 1 is developed for intranasal injection. Results of the first stage of clinical identifications of the given vaccine demonstrated favorable advances. The increase of acellular pertussis vaccine efficacy is prognosed $[5,23]$.

\section{CONCLUSIONS}

Pertussis incidence does not leave its relevance, despite the possibility of effective prevention of this disease. Timely diagnosis, treatment and immunoprophylaxis allow adjusting the actions of doctors to solve the issues of the decrease of the incidence of pertussis. This is greatly helped by modern guidelines for the management of patients with this pathology. However, clinical experience matters the doctor and the individual data of a particular patient.

\section{REFERENCES}

1. Laboratory Manual for the diagnosis of whooping cough caused by bordetella pertussis. WHO [Internet] 2014. [cited 2018 Sep 19] 41 p. Available from: http://apps.who.int/iris/bitstream/ handle/10665/127891/WH0_IVB_14.03_eng.pdf?sequence=1

2. SAGE Working Group on Pertussis Vaccines. Background paper. 2014 WHO [Internet] 2014. [cited 2018 Sep 19] 82 p. Available from: http:// www.who.int/immunization/sage/meetings/2014/april/1_Pertussis_ background_FINAL4_web.pdf

3. Nadraha OB, Dybas IV. Kliniko-epidemiolohichni osoblyvosti perebihu kashliuka v ditei pershoho roku zhyttia [Clinical and epidemiologic peculiarities of pertussis in infants]. Zdorove rebenka. 2013;3(46): 131-135. [in Ukrainian].

4. Nikolaeva IV, Shaikhieva GS. Kokliush na sovremennom etape [Pertussis at the present stage]. Vestnik sovremennoi klinicheskoi meditsiny. 2016;9(2):25-29. doi: 10.20969/VSKM. [in Russian].

5. Nikolaeva IV, Tsaregorodtsev AD. Kokliush: aktualnye voprosy epidemiologii diagnostiki i profilaktiki [Pertussis: Topical issues of epidemiology, diagnosis, and prevention]. Rossiiskii vestnik perinatologii i pediatrii. 2015;60(5):162-167. [in Russian].

6. Tatochenko VK. Kokliush nedoupravliaemaia infektsiia [Pertussis Infection not under Complete Control]. Voprosy sovremennoi pediatrii. 2014;13(2);78-82. [in Russian].

7. Vasyunina AV, Krasnova El, Panasenko LM. Koklyush u detey. Lechaschiy vrach. 2011;10:18-23. [in Russian].

8. Greco D, Esposito S, Tozzi A, Pandolfi E, Icardi G, Giammanco A. Whooping cough, twenty years from acellular vaccines introduction. Annali di igiene: medicina preventiva e di comunita. 2015;27(2):415-431.doi: 10.7416/ai.2015.2029

9. Kiedrzynski T, Bissielo A, Suryaprakash M, Bandaranayake D. Whooping cough-where are we now? A review. NZ Med J. 2015;128(1416):21-27.

10. Manual for the Surveillance of Vaccine-Preventable Diseases: Chapter 10: Pertussis [Internet]. 2014 [cited 2018 Sep 19] Available from: https:// www.cdc.gov/vaccines/pubs/surv-manual/index.html 
11. McMahon G, Ring SM, Smith GD, Timpson NJ. Genome-wide association study identifies SNPs in the MHC class II loci that are associated with self-reported history of whooping cough. Hum Mol Genet. 2015;24(20);5930-5939.doi: 10.1093/hmg/ddv293

12. Nilsson L, Lepp T, von Segebaden K., Hallander H, Gustafsson L. Pertussis vaccination in infancy lowers the incidence of pertussis disease and the rate of hospitalisation after one and two doses: analyses of 10 years of pertussis surveillance. Vaccine. 2012;30(21):3239-3247.doi: 10.1016/j. vaccine.2011.10.089

13. van der Lee S, Stoof SP, van Ravenhorst MB, van Gageldonk PG, van der Maas NA, Sanders EA, et al. Enhanced Bordetella pertussis acquisition rate in adolescents during the 2012 epidemic in the Netherlands and evidence for prolonged antibody persistence after infection. Eurosurveillance. [Internet]. 2017 [cited 2018 Sep 19]; 22(47). doi: 10.2807/1560-7917.ES.2017.22.47.17-00011 Available from: https:// www.ncbi.nlm.nih.gov/pmc/articles/PMC5710659/

14. Yeung KHT, Duclos P, Nelson EAS, Hutubessy RCW. An update of the global burden of pertussis in children younger than 5 years: a modelling study. Lancet Infect Dis. 2017;17(9):974-980. doi: 10.1016/S1473-3099(17)30390-0

15. Bobrovitskaia Al, Golubova TF, Belomeria TA, Akulshina NV, Zakharova LA, Zaiats VYu. Kliniko-epidemiologicheskie osobennosti kokliusha u detei v usloviiakh nepolnogo okhvata vaktsinatsiei [Clinical and epidemiological features of pertussis in children at incomplete vaccination coverage]. Aktualna infektolohiia. 2015; 1(6):62-66. [in Russian].

16. Matvieieva OV, Moiseieva HV, Vasylieva VA, Bashkatova TI, Pavlenko KV. Rezultaty provedennia epidemiolohichnoho doslidzhennia shchodo vyvchennia stanu imunitetu proty kashliuku u ditei, yaki otrymaly shcheplennia vaktsynamy zatseliuliarnym kashliukovym komponentom ta zakhvoriuvanosti na kashliuk pislia otrymanykh shcheplen. Profilaktychna medytsyna. 2014;3-4:64. [in Ukrainian].

17. Mavrutenkov VV, Kramarev SA. Koklyush: celi-terapiii i vozmozhnosti profilaktiki [Pertussis: treatment goals and prevention options]. Aktualna infektolohiia. 2018;6(1):12-17. doi: 10.22141/2312413x.6.1.2018.125630 [in Russian].

18. Romanenko TA, Trunova OA, Bilomerya TA, Dumcheva TYu, Buhtiyarov EV, Podolyaka VL. Diahnostyka kashliuku za dopomohoiu IFA dlia vyiavlennia protykashliukovykh imunohlobuliniv [Pertussis diagnostics by means of eia for antipertussis immunoglobulins detection]. Zdorove rebenka. 2010;4(25): 104-108. [in Ukrainian].

19. Ilchenko VI, Syzova LM, Ananieva MM, Kotsiubailo LP, Duda OK. Analysis of pertussis incidence in the Poltava region. World of medicine and biology. 2018;3(65):71-74. doi: 10.26724/2079-8334-2018-3-65-71-74

20. Khlynina Yu0, Kramar LV, Arova AA, Nevinskij AB. Koklyush u detej: klinika, diagnostika, lechenie. Lekarstvennyj vestnik. 2017;11(4):34-39. [in Russian].

21. Duda OK, Vega AR. Kashliuk i parakashliuk: suchasni pidkhody do diahnostyky ta likuvannia (klinichna lektsiia). Mystetstvo likuvannia. 2016;3-4(129-130):43-45. [in Ukrainian].

22. Bouchez V, Guiso N. Bordetella pertussis, B. parapertussis, vaccines and cycles of whooping cough. Pathogens and Disease [Internet]. 2015 [cited 2018Sep 19];73(7). doi: 10.1093/femspd/ftv055 Available from: https://academic.oup.com/femspd/article/73/7/ftv055/580714
23. Cherry JD. The history of pertussis (whooping cough); 1906-2015: facts, myths, and misconceptions. Curr Epidemiol Rep. 2015;2(2):120-130. doi: 10.1007/s40471-015-0041-9

24. Tyukavkina SU, Kharseeva GG. Koklyush: epidemiologiya, biologicheskie svoystva Bordetella pertussis, printsipyi laboratornoy diagnostiki i spetsificheskoy profilaktiki. [Whooping cough: epidemiology, biological features of Bordetella Pertussis, laboratory diagnostics and specific prophylaxis]. Epidemiologiia i infektsionnye bolezni. 2014;19(4):50-59. [in Russian].

25. Petrova MS, Popova OP, Borisova OYu, Abramova EN, Vartanyan RV, Kell El. Kokliush u detei rannego vozrasta [Pertussis in children of early age]. Epidemiologiia i infektsionnye bolezni. 2012;6:19-24. [in Russian].

26. Romanenko TA. Rezultaty stezhennia za povnotoiu i svoiechasnistiu okhoplennia shcheplenniamy v systemi epidemiolohichnoho nahliadu za kashliukom [Observations of the completeness and timeliness of coverage immunization in system for epidemiological surveillance of pertussis]. Profilaktychna medytsyna. 2011;1(13):22-26. [in Ukrainian].

27. Brennan MJ. A new whooping cough vaccine that may prevent colonization and transmission. Vaccines [Internet]. 2017 [cited 2018 Sep 19];5(43). doi: 10.3390/vaccines5040043 Available from: http:// www.mdpi.com/2076-393X/5/4/43

28. Rigo-Medrano MV, Mendoza-García JL, Gimeno-Gascón A, Roda-Ramón J, Cremades-Bernabeú I, Antequera-Rodríguez P, Alcalá-Minagorre PJ, et al. Acellular vaccines (DTPa/dTpa) against whooping cough, protection duration. Enferm Infecc Microbiol Clin. 2016;34(1):23-28. doi: 10.1016/j. eimc.2015.01.014

29. Wiley E, Zuo Y, Macartney KK, McIntyre PB. Sources of pertussis infection in young infants: a review of key evidence informing targeting of the cocoon strategy. Vaccine. 2013;31:618-625. doi: 10.1016/j.vaccine.20

30. Zouari A, Smaoui H, Bousnina S, Menif K, Ben Jaballah N, Kechrid, A. The new health legacy: When pertussis becomes a heritage transmitted from mothers to infants. J. Med. Microbiol. 2011;60:1546-1549. doi: 10.1099/jmm.0.030809-0

Authors' contributions:

According to the order of the Authorship.

Conflict of interest:

The Authors declare no conflict of interest.

\section{CORRESPONDING AUTHOR Valentina I. Ilchenko}

Department of endocrinology with children's infectious diseases, Ukrainian Medical Stomatological Academy 26 Shevchenko St., 36011 Poltava, Ukraine tel: +380662544335 e-mail:val.ilch@ukr.net

Received: 05.10 .2018

Accepted: 21.02.2019 
PRACA POGLADOWA

REVIEW ARTICLE

\title{
KONTROLA CZYNNIKÓW RYZYKA SERCOWO-NACZYNIOWEGO U PACJENTÓW PO ZAWALE SERCA
}

\section{CONTROL OF CARDIOVASCULAR RISK FACTORS IN PATIENTS AFTER MYOCARDIAL INFARCTION}

\author{
Jan W. Pęksa, Piotr Jankowski, Danuta Czarnecka \\ I KLINIKA KARDIOLOGII I ELEKTROKARDIOLOGII INTERWENCYJNEJ ORAZ NADCIŚNIENIA TĘTNICZEGO, UNIWERSYTET JAGIELLOŃSKI W KRAKOWIE, \\ KRAKÓW, POLSKA
}

\begin{abstract}
STRESZCZENIE
Mimo znacznej poprawy w zakresie diagnostyki i leczenia chorób sercowo-naczyniowych, która nastąpiła w ostatnich latach, pozostają one nadal główną przyczyną chorobowości i śmiertelności w populacji. W wielu krajach Europy częstość występowania choroby wieńcowej jest aktualnie $050 \%$ niższa niż była na początku lat 80 . XX wieku, co wynika z podejmowanych działań w ramach prewencji sercowo-naczyniowej. Szczególną grupę pacjentów stanowią osoby po zawale mięśnia sercowego, czyli osoby z bardzo wysokim ryzykiem sercowo-naczyniowym. Należy u nich w zdecydowany sposób wdrażać działania na poziomie indywidualnym, czyli pracować nad poprawą w zakresie prowadzonego dotychczas niezdrowego stylu życia oraz kontrolować farmakologicznie inne czynniki ryzyka. Należy zalecać dietę ubogą w tłuszcze nasycone, czyli zawierającą głównie produkty pełnoziarniste, warzywa, owoce i ryby, zalecać regularny wysiłek fizyczny: 150 min/tydzień umiarkowanej, tlenowej aktywności fizycznej, także zmniejszenie podaży kalorii w celu pozbycia się nadwagi lub otyłości. Pomoc w rzuceniu nałogu palenia tytoniu powinna następować poprzez tzw. minimalną interwencję nikotynową oraz w razie konieczności terapię farmakologiczną. Kluczowa jest także kontrola pozostałych czynników ryzyka, czyli włáśiwe leczenie dyslipidemii (pierwszorzędowym celem jest poziom cholesterolu $L D L<1,8 \mathrm{mmol} / \mathrm{l}$ lub redukcja $0 \geq 50 \%$, jeśli wyjściowe stężenie wynosi między 1,8i3,5 mmol/), leczenie nadciśnienia tętniczego (docelowe ciśnienie tętnicze dla większości osób w wieku 18-65 lat znajduje się w przedziale: 120-130/70-79 mmHg, jeśli jest dobrze tolerowane, natomiast dla osób starszych wynosi: 130-139/70-79mmHg w przypadku dobrej tolerancji takiego ciśnienia), optymalna terapia cukrzycy (docelowa hemoglobina glikowana <7\%), a także właściwa terapia przeciwpłytkowa (u większości pacjentów zalecana jest podwójna terapia przeciwpłytkowa przez 12 miesięcy po ostrym zespole wieńcowym). Działania te powodują znaczącą poprawęjakości życia oraz spadek śmiertelności z powodu chorób sercowo-naczyniowych.
\end{abstract}

SŁOWA KLUCZOWE: zawał serca, czynniki ryzyka, nadciśnienie tętnicze, hypercholesterolemia, cukrzyca

\begin{abstract}
Despite significant improvements in the diagnosis and treatment of cardiovascular diseases that have occurred in recent years, they remain the main cause of morbidity and mortality in the population. In many European countries, the incidence of coronary heart disease is currently 50\% lower than it was in the early 1980s, which is the result of cardiovascular prevention. A special group of patients are people after myocardial infarction with very high cardiovascular risk. They should definitely implement activities at the individual level e. g. work on improving the unhealthy lifestyle and pharmacologically control other risk factors. A diet low in saturated fats should be recommended, i.e. mainly containing whole grains, vegetables, fruits and fish, recommend regular physical exercise: $150 \mathrm{~min} /$ week of moderate, aerobic physical activity, reducing the supply of calories in order to get rid of overweight or obesity. Help in quitting tobacco addiction should take place through the minimal nicotine intervention and, if necessary, pharmacological therapy. Another thing is the control of other risk factors, i. e. the appropriate treatment of dyslipidemia (the primary target is $L D L$ cholesterol $<1.8 \mathrm{mmol} / \mathrm{l}$ or reduction by $\geq 50 \%$, if the initial concentration is between 1.8 and $3.5 \mathrm{mmol} /$, treatment hypertension (target arterial pressure for most people aged $18-65$ is in the range: 120-130/70-79 $\mathrm{mmHg}$, if it is well tolerated, while for older people it is in the range: $130-139 / 70-79 \mathrm{mmHg}$, if it is well tolerated), optimal diabetes therapy (target glycated hemoglobin $<7 \%$ ) and appropriate antiplatelet therapy (in most patients double antiplatelet therapy is recommended for 12 months after acute coronary syndrome). These activities lead to a significant improvement in quality of life and a decrease in mortality due to cardiovascular diseases.
\end{abstract}

KEY WORDS; myocardial infarction, risk factors, hypertension, hypercholesterolemia, diabetes mellitus

Wiad Lek 2019, 72, 3, 472-483

\section{WSTĘP}

Mimo znacznej poprawy w zakresie diagnostyki i leczenia chorób sercowo-naczyniowych (CVD - cardiovascular diseases), która nastąpiła w ostatnich latach, pozostają one nadal główną przyczyną chorobowości i śmiertelności w populacji ludzkiej. W wielu krajach Europy częstość występowania choroby wieńcowej (CAD - coronary artery disease) jest aktualnie o 50\% niższa niż była na początku lat 80. XX wieku. Wynika to z podejmowanych działań prewencyjnych CVD, np. z wprowadzanych w wielu kra- 
jach w Europie ograniczeń palenia wyrobów tytoniowych w miejscach publicznych. Tym sukcesom należy przeciwstawić zjawiska powodujące zwiększenie zachorowalności na CVD, czyli wzrost częstości występowania w populacji otyłości i cukrzycy (DM - diabetes mellitus) [1-4].

U wszystkich pacjentów $z$ podejrzewaną lub rozpoznaną chorobą sercowo-naczyniową, aktualnie obowiązujące wytyczne zalecają ocenę całkowitego ryzyka CVD (wyróżniono 4 kategorie ryzyka: niskie, umiarkowane, wysokie lub bardzo wysokie) i w zależności od niego określenie celów terapii i sposobu dalszego postępowania niefarmakologicznego oraz farmakologicznego. Im wyższe jest ryzyko u danego pacjenta, tym bardziej intensywne i zdecydowane działania należy zastosować. Szczególną grupę stanowią osoby po zawale mięśnia sercowego będące pacjentami bardzo wysokiego ryzyka sercowo-naczyniowego. Należy u nich wdrażać prewencję CVD na poziomie indywidualnym: pracować nad poprawą w zakresie prowadzonego niezdrowego stylu życia (złej jakości dieta, brak regularnego wysiłku fizycznego, występowanie nadwagi lub otyłości, palenie tytoniu) oraz kontrolować czynniki ryzyka (właściwe leczenie dyslipidemii, nadciśnienia tętniczego, cukrzycy czy też właściwa terapia przeciwpłytkowa) $[1,5]$.

\section{CELE LECZENIA PACJENTÓW \\ Z BARDZO WYSOKIM RYZYKIEM SERCOWO-NACZYNIOWYM}

W Wytycznych Europejskiego Towarzystwa Kardiologicznego dotyczących prewencji chorób układu sercowo-naczyniowego z 2016 roku wyszczególniono, jakich pacjentów zalicza się do grupy bardzo wysokiego ryzyka CVD (kategoria ryzyka, do której zaliczani są m.in. pacjenci po zawale serca) oraz określono cele leczenia dla tych osób. Dane te przedstawiono, podążając za wytycznymi, w tabeli nr 1.

Omówienie kolejnych zaleceń prewencji wtórnej CVD u pacjentów po zawale serca wraz z podaniem kluczowych badań popierających te działania przedstawiono w kolejnych częściach pracy.

\section{KONTROLA CZYNNIKÓW PSYCHOSPOKECZNYCH}

W codziennej praktyce klinicznej psycholodzy i terapeuci odgrywają bardzo ważną rolę - wspierają pacjentów w zakresie radzenia sobie z psychospołecznymi czynnikami ryzyka. Jest to szczególnie ważne dla osób z wysokim lub bardzo wysokim ryzykiem sercowo-naczyniowym. Właściwa komunikacja z pacjentem jest źródłem wsparcia emocjonalnego i profesjonalnych wskazówek dotyczących postępowania z czynnikami stresowymi, depresją, lękiem oraz czynnikami ryzyka CVD. Oczywiście komunikacja skoncentrowana na potrzebach pacjenta, powinna występować nie tylko w relacji terapeuta - pacjent, ale również, w miarę możliwości, lekarz - pacjent $[1,6]$.

W 2014 r. Whalley B. i wsp. wykonali przegląd systematyczny i metaanalizę randomizowanych badań oce- niających leczenie psychologiczne przeprowadzone przez przeszkolony personel wśród pacjentów z rozpoznaną chorobą serca obejmujący prace z co najmniej 6-miesięcznym okresem obserwacji. Otrzymano wyniki wskazujące na to, że interwencje psychologiczne nie zmniejszyły całkowitej liczby zgonów, ryzyka rewaskularyzacji lub zawału niekończącego się śmiercią, ale spowodowały niewielką / umiarkowaną poprawę w zakresie odczuwanej depresji i lęku. Praca z psychologiem powodowała także niewielkie zmniejszenie całkowitej śmiertelności sercowo-naczyniowej. Można więc stwierdzić, że specjalistyczne terapie psychologiczne są skuteczne w leczeniu pacjentów z psychologicznymi objawami choroby niedokrwiennej serca (niepokój, zaburzenia depresyjne i lękowe) [7].

Jeśli chodzi o farmakoterapię depresji u pacjentów po zawale serca, to zaleca się stosowanie selektywnych inhibitorów wychwytu zwrotnego serotoniny (SSRI - Selective Serotonin Reuptake Inhibitors). Należy mieć jednak na uwadze, że SSRI wpływają na metabolizm serotoniny z płytek krwi i stosowanie tych substancji może prowadzić do zwiększonego ryzyka krwawienia. Szczególnie ważne jest to w omawianej grupie pacjentów, którzy przeważnie poddawani są terapii przeciwpłytkowej. Niemniej jednak wciąż nie jest jasne, czy ryzyko związane z użyciem SSRI u pacjentów po zawale serca jest rzeczywiście istotnie podwyższone, ponieważ opublikowano zarówno wyniki potwierdzające, jak i przeczące wpływowi tego działania. $\mathrm{Z}$ pewnością natomiast trójcykliczne leki przeciwdepresyjne nie powinny być stosowane w leczeniu farmakologicznym pacjentów po zawale serca, ponieważ ich użycie wiąże się z istotnymi działaniami niepożądanymi ze strony układu sercowo-naczyniowego. Można je wytłumaczyć znaczącymi efektami antycholinergicznymi oraz proarytmicznymi (wydłużenie odstępu QT). Każde ich zastosowanie powinna poprzedzić dokładna analiza ryzyka / korzyści dla pacjenta po zawale serca [7-10].

\section{KONTROLA AKTYWNOŚCI FIZYCZNEJ}

Wiele przeprowadzonych badań potwierdziło fakt, że regularna aktywność fizyczna jest jednym z podstawowych działań w prewencji chorób sercowo-naczyniowych i obniża ryzyko wielu niepożądanych zdarzeń zdrowotnych u osób z czynnikami ryzyka choroby wieńcowej oraz u pacjentów z przewlekłą niewydolnością serca [1].

W 2004 Piepoli i wsp. przeprowadzili metaanalizę badań mającą określić wpływ treningu fizycznego na przeżycie pacjentów z niewydolnością serca spowodowaną dysfunkcją skurczową lewej komory (często są to pacjenci po zawale mięśnia sercowego). Do metaanalizy włączano badania $\mathrm{z}$ randomizacją porównujące grupy pacjentów regularnie ćwiczących z nietrenującymi regularnie, czas interwencji we włączonych pracach wynosił co najmniej 8 tygodni, a obserwacja co najmniej 3 miesiące. Odnaleziono 9 badań liczących w sumie 801 pacjentów: 395 wykonywało trening fizyczny, a 406 stanowiło kontrolę. Średni czas obserwacji wynosił 705 dni: odnotowano 88 (22\%) zgonów w ramieniu osób ćwiczących i 105 (26\%) w ramieniu kontrolnym. Stwierdzono, że trening 
Tabela 1. Pacjenci z bardzo wysokim ryzykiem sercowo-naczyniowym - charakterystyka kliniczna oraz cele leczenia.

\begin{tabular}{|c|c|}
\hline \multicolumn{2}{|c|}{ Pacjenci z bardzo wysokim ryzykiem sercowo-naczyniowym } \\
\hline $\begin{array}{r}\text { Obciąż } \\
\text { - udokumentowana CVD - kliniczne lub } \\
\text { ostry zawał serca, ostry zespół wieńc } \\
\text { i przemijający napad niedokrwienny, } \\
\text { obrazowych: istotne blaszki miażdżyc } \\
\text { przyrost takich parametrów w obrazo } \\
\text {-DM z uszkodzeniami narządowymi, tak } \\
\text { hiperch }\end{array}$ & $\begin{array}{l}\text { em z niżej wymienionych: } \\
\text { ch obrazowych (udokumentowana kliniczna CVD: przebyty } \\
\text { obrębie tętnic wieńcowych i innych tętnic, udar mózgu } \\
\text { tnic obwodowych; udokumentowana CVD w badaniach } \\
\text { w ultrasonografii tętnic szyjnych; nie należy do tej grupy } \\
\text { ść kompleksu intima-media w obrębie tętnic szyjnych), } \\
\text { stotnymi czynnikami ryzyka, jak palenie tytoniu czy istotna } \\
\text { ące nadciśnienie tętnicze, } \\
\mathrm{nl} / \mathrm{min} / 1,73 \mathrm{~m}^{2} \text { ), } \\
\mathrm{RE} \geq 10 \%\end{array}$ \\
\hline \multicolumn{2}{|c|}{ Cele leczenia u pacjentów z bardzo wysokim ryzykiem sercowo-naczyniowym } \\
\hline 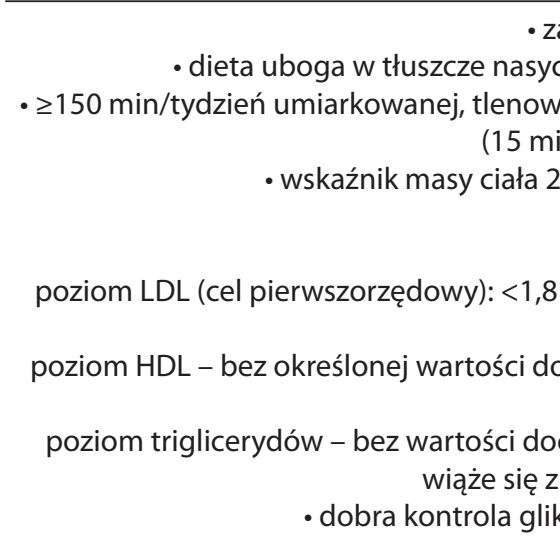 & $\begin{array}{l}\text { jakiejkolwiek formie, } \\
\text { produkty pełnoziarniste, warzywa, owoce i ryby, } \\
\text { w tygodniu) lub } 75 \mathrm{~min} / \text { tydzień energicznego, tlenowego PA } \\
\text { połączenie powyższych, } \\
<94 \mathrm{~cm} \text { (mężczyźni) lub <80 cm (kobiety), } \\
40 / 90 \mathrm{~mm} \mathrm{Hg} \text {, } \\
\text { lipidów: } \\
\text { edukcja o } \geq 50 \% \text {, jeśli wyjściowe stężenie wynosi między } 1,8 \\
\text { l } 35 \mathrm{mg} / \mathrm{dl}) \text {, } \\
\text { (>40 mg/dl) u mężczyzn i > 1,2 mmol/l (>45 mg/dl) u kobiet } \\
\text { ze ryzyko, } \\
<150 \mathrm{mg} / \mathrm{dl} \text { ) wskazuje na niższe ryzyko, a wysokie stężenie } \\
\text { nia innych czynników ryzyka, } \\
\text { obina glikowana }<7 \% \text { (<53 mmol/mol) }\end{array}$ \\
\hline $\begin{array}{l}\text { BP - ciśnienie tętnicze krwi; } \\
\text { CVD - choroba układu sercowo-naczyniowego; } \\
\text { HDL — lipoproteiny o wysokiej gęstości; } \\
\text { PA - aktywność fizyczna; }\end{array}$ & $\begin{array}{l}\text { CKD - przewlekła choroba nerek; } \\
\text { DM - cukrzyca; GFR - wskaźnik filtracji kłębuszkowej; } \\
\text { LDL — lipoproteiny o niskiej gęstości; } \\
\text { SCORE - systematic coronary risk estimation.; }\end{array}$ \\
\hline
\end{tabular}

znacząco obniżył śmiertelność (współczynnik ryzyka (HR hazard ratio $)=0,65 ; 95 \%$-przedział ufności (CI - confidence interwal: 0,46-0,92). Doszło także do redukcji w zakresie drugorzędowego punktu końcowego: zgonu lub przyjęcia do szpitala (HR=0,72; 95\% - CI: 0,56-0,93). Autorzy stwierdzili ponadto, że nadzorowany i właściwie prowadzony trening fizyczny nie niesie ze sobą zagrożeń dla zdrowia w populacji pacjentów $\mathrm{z}$ niewydolnością serca [11].

Regularna aktywność fizyczna powoduje zarówno podwyższenie poziomu cholesterolu frakcji HDL (high-density lipoproteins), jak i obniżenie poziomu trójglicerydów (TG - triglicerides) w surowicy krwi. Część badań wskazuje na fakt, że kobiety w mniejszym stopniu niż mężczyźni reagują, patrząc na lipidogram, na zmiany w aktywności fizycznej. Wynika to prawdopodobnie z faktu, że osoby z największymi zaburzeniami wyjściowymi lipidogramu (niższy poziom HDL i wyższy TG) odnoszą największe korzyści, a mężczyźni przeciętnie mają niższy poziom HDL i wyższy TG niż kobiety. Część badań podaje, że również cholesterol LDL (low-density lipoproteins), pozytywnie reaguje na na ćwiczenia fizyczne. W 2001 r. Leon i Sanchez przeprowadzili metaanalizę obejmującą 51 badań interwencyjnych - stwierdzili, że przez co najmniej 12 tygodni wykonywania umiarkowanych lub ciężkich ćwiczeń aerobowych $(n=4700)$ poziom cholesterolu HDL wzrósł o 4,6\%, podczas gdy poziom trójglicerydów spadł o 3,7\%, a cholesterolu LDL o 5\%. Poziom cholesterolu całkowitego pozostał niezmieniony, chociaż stosunek cholesterol HDL: LDL znacznie się poprawił $[1,12,13]$.

\section{INTERWENCJA W ZAKRESIE PALENIA TYTONIU}

Palenie tytoniu jest uznaną przyczyną wielu chorób, odpowiada za 50\% wszystkich, możliwych do uniknięcia, zgonów wśród palaczy, z których połowę stanowią zgony z powodu chorób sercowo-naczyniowych. W latach 1951-2001 przeprowadzono w Wielkiej Brytanii duże badanie prospektywne badające wpływ palenia papierosów na śmiertelność osób biorących w nim udział. Uczestnikami była populacja 34439 brytyjskich lekarzy płci męskiej. Informacje na temat ich zwyczajów palenia zostały uzyskane w 1951 r., a następnie okresowo monitorowane, badano również śmiertelność przez kolejnych 50 lat. Mężczyźni palący papierosy zmarli średnio o 10 lat wcześniej od osób niepalących przez całe życie. Głównymi przyczynami śmierci wśród palaczy były CVD, nowotwory oraz choroby układu oddechowego powiązane $\mathrm{z}$ nadużywaniem tytoniu. Zaprzestanie palenia w wieku 60, 50, 40 lub 30 lat pozwoliło odpowiednio uzyskać około 3, 6, 9lub 10 lat oczekiwanej długości życia $[1,14]$.

Odnosząc się do pacjentów po zawale serca, należy zauważyć, że w dużym przekrojowym badaniu EUROASPIRE 
Tabela 2. Charakterystyka zdrowej diety, w tym dla pacjentów po zawale serca

Nasycone kwasy tłuszczowe powinny stanowić <10\% całkowitej energii zawartej w pożywieniu w wyniku zastąpienia ich wielonienasyconymi kwasami tłuszczowymi

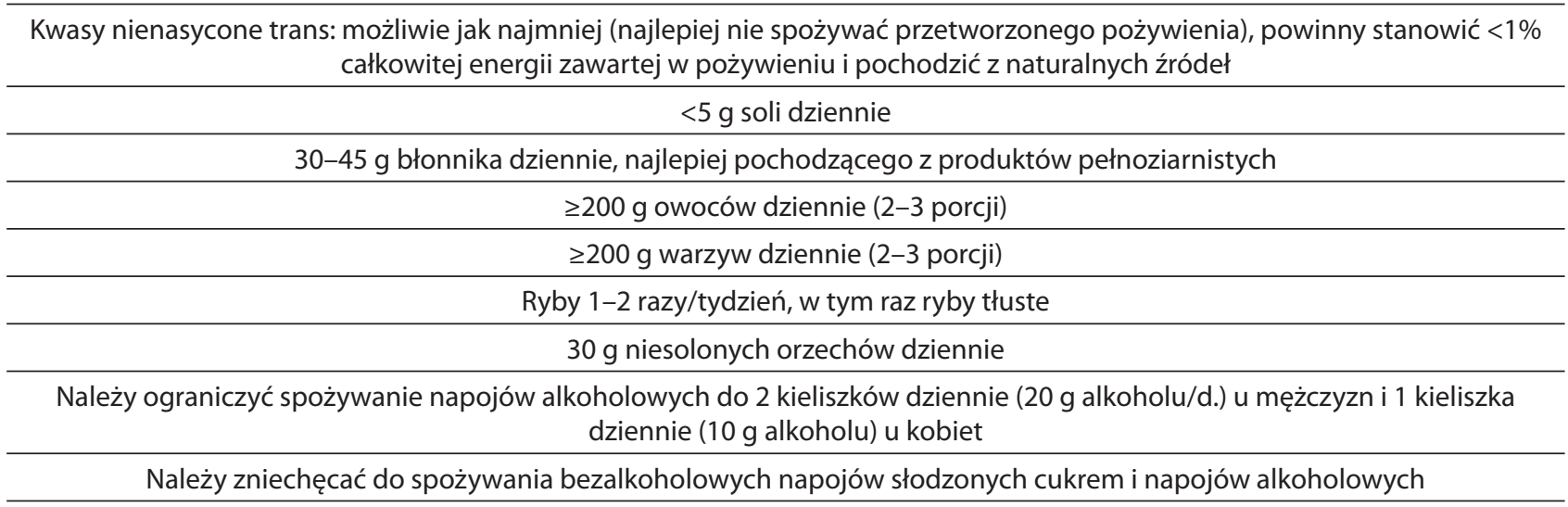

Opracowano na podstawie [1].

IV przeprowadzonym w 78 centrach z 24 krajów europejskich (populacja: pacjenci $\mathrm{w}$ wieku $<80$ lat $\mathrm{z}$ chorobą wieńcową, którzy przeszli pomostowanie tętnic wieńcowych, przezskórną interwencję wieńcową lub ostry zespół wieńcowy, $n=7998$ ), stwierdzono, że w czasie $\geq 6$ miesięcy od hospitalizacji aż $16,0 \%$ osób wciąż paliło papierosy, a 48,6\% osób było palaczami wcześniej, w czasie interwencji sercowo-naczyniowej lub ostrego zespołu wieńcowego. W badaniu tym wykazano również, że leczenie zgodne z zasadami medycyny opartej na faktach w zakresie zaprzestania palenia jest stosowane zbyt rzadko $[1,15]$.

Zaprzestanie palenia wyrobów tytoniowych przez osoby po zawale serca jest najskuteczniejszym ze wszystkich środków prewencyjnych CVD. W przeprowadzonym w $2010 \mathrm{r}$. badaniu OASIS 5 wykazano znaczące i duże zmniejszenie częstości występowania kolejnego zawału serca u osób, które zaprzestały palenia w porównaniu z osobami ciągle palącymi (iloraz szans, OR odds ratio $=0,57$; 95\% - CI: 0,36-0,89, czas obserwacji - 6 miesięcy) [16]. Wszystkie osoby palące, w tym oczywiście pacjentów po zawale serca, należy zachęcać do porzucenia tego nałogu. Przydatna jest $\mathrm{w}$ tym m.in. minimalna interwencja nikotynowa (Zasada 5 P: P - pytaj: systematycznie pytaj o nałóg palenia, $\mathrm{P}$ - poradź: nakłaniaj wszystkich palaczy do zaprzestania palenia, P - pozyskaj informacje: określ stopień uzależnienia od nikotyny i gotowość do zaprzestania palenia, $\mathrm{P}$ - pomagaj: ustal strategię zaprzestania palenia, obejmującą wyznaczenie daty zakończenia palenia, wsparcie behawioralne i farmakologiczne, $\mathrm{P}$ - poobserwuj: zaplanuj wizyty kontrolne), a także użycie środków farmakologicznych (nikotynowa terapia zastępcza, wareniklina lub bupropion) [1, 17-19].

\section{PRAWIDŁOWE ŻYWIENIE}

Nawyki żywieniowe ludzi wpływają na ryzyko sercowo-naczyniowe, oddziałując na poziom cholesterolu LDL i HDL w surowicy krwi, ciśnienie tętnicze (BP - blood pressure), masę ciała oraz kontrolę glikemii w cukrzycy. Najlepiej przebadaną i zalecaną dietą jest dieta śródziemnomorska składająca się w dużej mierze z ryb, jednonienasyconych tłuszczów z oliwy z oliwek, owoców, warzyw, produktów pełnoziarnistych, roślin strączkowych, orzechów i umiarkowanego spożycia alkoholu. Wykazano, że dieta śródziemnomorska zapobiega rozwojowi CVD, ale też raka piersi, depresji, raka jelita grubego, otyłości, cukrzycy, astmy, zaburzeń erekcji, zaburzeń poznawczych. Jest ona również znana z poprawy wskaźników dotyczących chorób sercowo-naczyniowych, jak stosunek talia-biodra, lipidów i markerów stanu zapalnego, ale również zgonów z powodu CVD $[1,20]$. Ponadto pacjenci kardiologiczni powinni starać się spożywać małą ilość soli (prowadzi to do obniżenia BP) i unikać spożywania bezalkoholowych napojów słodzonych cukrem [1]. Charakterystykę zdrowej diety, która może być zalecana większości pacjentów, w tym po zawale serca przedstawiono w tabeli 2 .

\section{KONTROLA MASY CIAŁA}

W ostatnich dekadach w krajach Europy BMI uległo znacznemu podwyższeniu i w konsekwencji doszło do wzrostu częstości występowania w populacji cukrzycy typu 2. W Stanach Zjednoczonych występuje podobne zjawisko; jeśli trend wzrostu występowania otyłości z lat 2005-2020 utrzyma się, to otyłość zrównoważy pozytywne efekty wynikające ze zmniejszenia częstości palenia tytoniu $[1,21]$. Do najważniejszych powikłań klinicznych otyłości należą: występowanie nadciśnienia tętniczego, zaburzeń lipidowych, insulinooporności, odczynu zapalnego i stanu prozakrzepowego, albuminurii, a także rozwój cukrzycy i występowanie zdarzeń sercowo-naczyniowych [1]. Tkanka tłuszczowa uwalnia prozapalną cytokinę: interleukinę 6, indukując układowe zapalenie niskiego stopnia. W 1999 roku opublikowano wyniki badania, do którego włączono 16616 mężczyzn i niebędących w ciąży kobiet w wieku co najmniej 17 lat określającego relację między nadwagą lub otyłością a podwyższonym poziomem markera stanu 
zapalnego: białka CRP (C-reactive protein). Po wyeliminowaniu czynników zakłócających, stwierdzono, że iloraz szans, OR, dla podwyższonego CRP wynosił 2,13 (95\%-CI: 1,56-2,91) dla otyłych mężczyzn i 6,21 (95\%-CI: 4,94-7,81) dla otyłych kobiet [22].

W 2014 r. Zhu J. i wsp. wykonali przegląd systematyczny i metaanalizę badające zawiązek nadwagi i otyłości z zawałami serca. Do metaanalizy włączono pięć badań pierwotnych (jedno badanie kohortowe i cztery badania kliniczno-kontrolne) z udziałem 36803 uczestników, spośród których u 14883 wystąpił zawał serca. Stwierdzono istotny statystycznie związek między nadwagą a zawałem mięśnia sercowego ( $\mathrm{OR}=1,27,95 \%$-CI: 1,21-1,33, p<0,001). Podobne wyniki były dla zależności między otyłością a zawałem mięśnia sercowego (OR =1,22, 95\% - CI: 1,07-1,40, $\mathrm{p}=0,003)$. Badanie pozwoliło więc potwierdzić, że zarówno nadwaga, jak i otyłość zwiększały częstość występowania zawału serca i jedną z metod zapobiegania wystąpieniu tego schorzenia jest kontrola wagi [23].

Interwencje prowadzące do zmniejszenia masy ciała, to oczywiście działania w zakresie zmiany stylu życia: modyfikacja diety, zwiększenie aktywności fizycznej. Ograniczenie podaży kalorii jest najważniejszym elementem w osiąganiu utraty wagi poprzez uzyskanie ujemnego bilansu energetycznego, podczas gdy utrzymująca się aktywność fizyczna jest ważna w utrzymywaniu utraty wagi. Istnieją również terapie uzupełniające w postaci farmakoterapii (np. preparaty orlistatu czy bupropionu / naltreksonu) i chirurgii bariatrycznej - skierowane do pacjentów, którzy nie osiągają zamierzonych efektów utraty wagi i celów zdrowotnych przy interwencjach związanych ze stylem życia [24].

\section{KONTROLA POZIOMU LIPIDÓW}

Hipercholesterolemia jest bardzo dobrze udokumentowanym czynnikiem ryzyka chorób sercowo-naczyniowych. Udowodniono to na podstawie licznych badań genetycznych, patologicznych, obserwacyjnych oraz interwencyjnych. Główny transporter cholesterolu w osoczu (cholesterol LDL - LDL-C) powoduje powstawanie blaszek miażdżycowych w ścianach naczyń krwionośnych (jest aterogenny) [1]. We wcześniej wspomnianym badaniu przekrojowym EUROASPIRE IV przedstawiającym dane z 24 krajów Europy wykazano, że aktualnie mniej niż $20 \%$ pacjentów z rozpoznaną chorobą wieńcową osiąga poziomy LDL-C wskazane w wytycznych europejskich. Wyniki te są zgodne z wcześniejszymi wielonarodowymi badaniami profilaktyki wtórnej przeprowadzanymi w Europie oraz innych częściach świata $[25,26]$.

Lekami z wyboru w terapii hipercholesterolemii są statyny (inhibitory reduktazy 3- hydroksy-3-metyloglutarylo-koenzymu A). W użyciu są również fibraty, leki wiążące kwasy tłuszczowe (żywice jonowymienne), niacyna (kwas nikotynowy), inhibitory wchłaniania cholesterolu (np. ezetimib) oraz nowoczesne, silnie działające inhibitory proproteinowej konwertazy subtylizyny/keksyny typu 9 (PCSK-9). U części pacjentów zaleca się podawanie połączeń wymienionych powyżej leków, np. inhibitorów wchła- niania cholesterolu w połączeniu ze statynami, gdy nie udaje się osiągnąć docelowego stężenia cholesterolu przy zastosowaniu maksymalnej, tolerowanej dawki statyny [1, 27]. Występują znaczne różnice w zakresie odpowiedzi na wyżej wymienione terapie, w związku z tym zalecane jest monitorowanie ich wpływu na poziom LDL-C. Statyny, poprzez redukcję LDL-C (pierwszorzędowy cel leczenia), powodują zmniejszenie chorobowości i śmiertelności z powodu CVD, a także obniżają częstość wykonywania interwencji w obrębie tętnic wieńcowych $[1,28]$.

Jeśli chodzi o pacjentów po zawale serca, to już w 2005 roku Ray i wsp. przeprowadzili wśród łącznie 4162 pacjentów badanie o akronimie PROVE IT-TIMI 22 porównujące intensywną terapię statynami (atorwastatyna w dawce $80 \mathrm{mg}$ ) z terapią standardową (prawastatyna, $40 \mathrm{mg}$ ). Złożony potrójny punkt końcowy (zgon, zawał serca lub ponowna hospitalizacja $\mathrm{z}$ powodu nawracającego ostrego zespołu wieńcowego) po 30 dniach wystąpił u 3,0\% pacjentów otrzymujących $80 \mathrm{mg}$ atorwastatyny w porównaniu z 4,2\% pacjentów otrzymujących prawastatynę w dawce $40 \mathrm{mg}$ (współczynnik ryzyka, $\mathrm{HR}=0,72,95 \%-\mathrm{CI}=0,52-0,99 ; \mathrm{p}=0,046)$. U stabilnych pacjentów atorwastatyna w dawce $80 \mathrm{mg}$ była związana $\mathrm{z}$ częstością występowania złożonego punktu końcowego wynoszącą 9,6\% w porównaniu z 13,1\% w grupie otrzymującej prawastatynę w dawce $40 \mathrm{mg}$ po średnim czasie obserwacji 24 miesiące ( $\mathrm{HR}=0,72,95 \%-\mathrm{CI}=0,58-0,89, \mathrm{p}=0,003)$. Już wtedy stało się więc jasne, że intensywna terapia statynami we wczesnym okresie po ostrym zespole wieńcowym prowadzi do zmniejszenia liczby zdarzeń klinicznych po 30 dniach, a u stabilnych pacjentów intensywna terapia statynami zapewnia długoterminową redukcję zdarzeń sercowo-naczyniowych w porównaniu ze standardową terapią. $Z$ tego powodu u pacjentów po zawale sera powinno się wdrożyć intensywne leczenie hipolipemizujące w szpitalu i kontynuować je długoterminowo po wypisie [29].

Należy pamiętać, że sporadycznie w trakcie terapii inhibitorami HMG-CoA może dojść do wystąpienia podwyższonego stężenia enzymów wątrobowych w osoczu - w większości przypadków jest to stan odwracalny. Nie jest więc wskazane rutynowe monitorowanie wartości enzymów wątrobowych. Ponadto u 5-10\% pacjentów leczonych statynami występują bóle mięśniowe. Rabdomioliza ze znacznym podniesieniem kinazy kreatynowej (CK - creatinine kinase) występuje niezwykle rzadko[1, 30].

Autorzy wytycznych ESC dotyczących leczenia zaburzeń lipidowych z 2016 roku szczegółowo opisują, jak postępować w przypadku stwierdzenia wzrostu aktywności enzymów wątrobowych w trakcie terapii statynami:

- jeżeli aktywność AlAT (aminotransferazy alaninowej) jest mniejsza niż 3-krotność górnej granicy zakresu wartości prawidłowych, zalecana jest kontynuacja terapii oraz ponowne oznaczenie aktywności enzymów wątrobowych po 4-6 tygodniach;

- jeżeli następuje wzrost AlAT do wartości $\geq 3$-krotnie wyższej od górnej granicy zakresu wartości prawidłowych, zalecane jest przerwanie leczenia statynami lub zmniejszenie dawki leku i ponowne oznaczenie aktywności enzymów wątrobowych po 4-6 tygodniach; jeżeli aktywność AlAT 


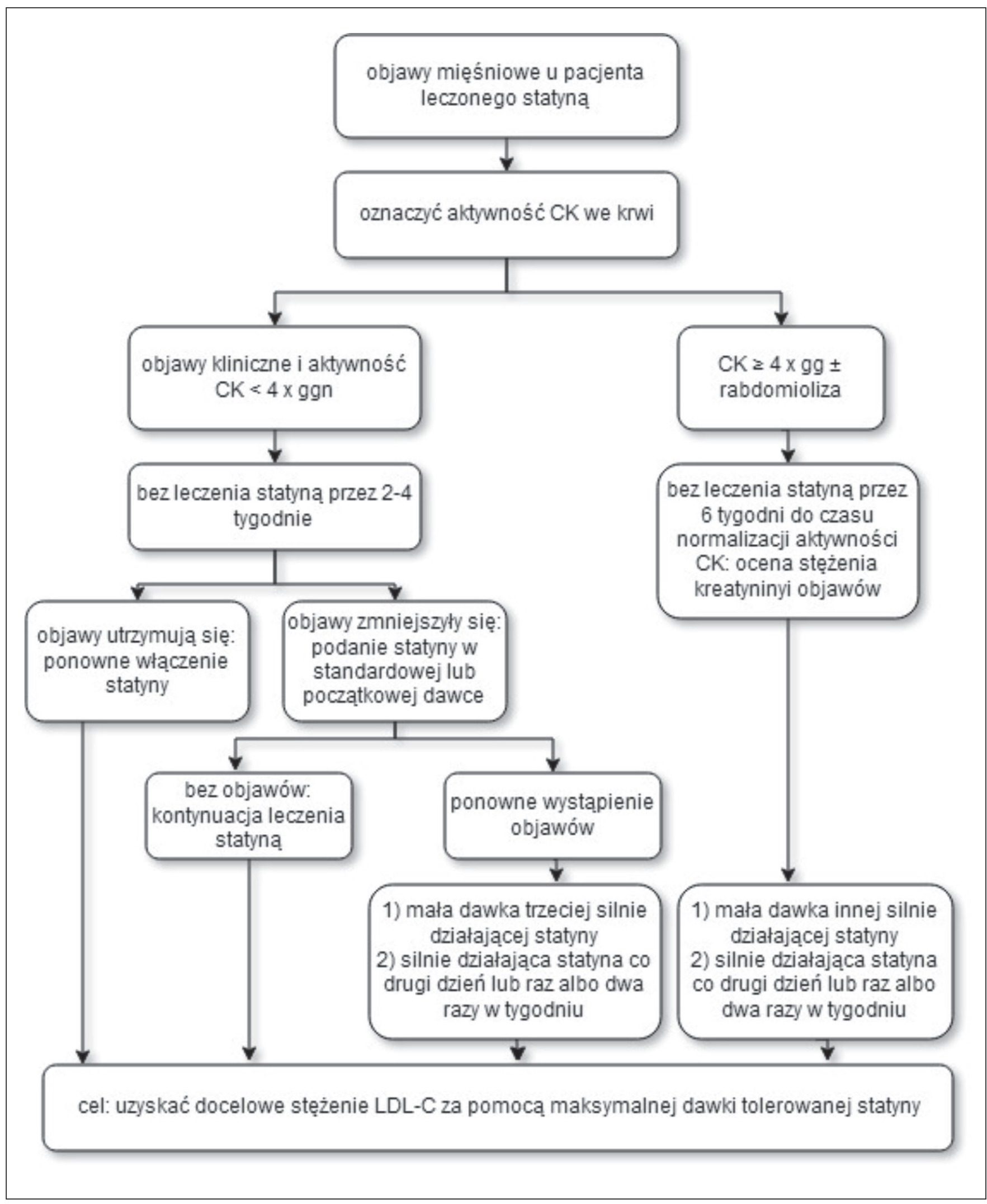

Ryc. 1. Postępowanie w przypadku stwierdzenia objawów mięśniowych u pacjenta leczonego statynami.

CK - kinaza kreatynowa, ggn - górna granica normy, LDL-C - cholesterol frakcji LDL. Opracowano na podstawie [31]. 
powróciła do normy, można rozważyć ostrożny powrót do stosowanego leczenia; jeżeli natomiast aktywność AlAT pozostaje zwiększona, należy poszukiwać innych przyczyn tego stanu [31].

W przywołanym dokumencie podano również bardziej złożony sposób postępowania w przypadku stwierdzenia podwyższenia aktywności enzymu świadczącego o uszkodzeniu mięśni - kinazy kreatynowej (CK). Postępowanie to przedstawiono na rycinie 1 .

\section{LECZENIE CUKRZYCY}

Choroba wieńcowa jest głównym czynnikiem warunkującym długoterminowe rokowanie u pacjentów z cukrzycą. Osoby chorujące na cukrzycę mają 2-krotnie zwiększone ryzyko zgonu z powodu chorób sercowo-naczyniowych. Ponadto występuje u nich zwiększona śmiertelność po zawale serca i gorsze ogólne rokowanie z powodu choroby wieńcowej. W ostatnich latach wystapiła wyraźna redukcja w zakresie wskaźników śmiertelności z powodu CVD w cukrzycy, która wynikała z lepszej kontroli czynników ryzyka. Należy jednak przeciwstawić temu fakt wzrastającej częstości występowania cukrzycy w większości krajów, co stanowi duże wyzwanie dla systemów opieki zdrowotnej $[1,32]$.

W 2010 roku Sarwar i wsp. z Emerging Risk Factors Collaboration przeprowadzili metaanalizę 102 badań prospektywnych badających związek między występowaniem cukrzycy, podwyższonego stężenia glukozy na czczo w surowicy krwi oraz innych czynników ryzyka u osób bez początkowej choroby naczyń krwionośnych. Analizy obejmowały dane dla bardzo dużej liczby 698 782 osób. W czasie tych badań wystąpiło łącznie 52765 zdarzeń sercowo-naczyniowych niepowodujących zgonu oraz zgonów z powodów naczyniowych. Iloraz ryzyka (HR) dla cukrzycy wynosił: 2,00 $(95 \%$ - CI=1,83-2,19) dla wystąpienia choroby wieńcowej, $2,27(1,95-2,65)$ dla udaru niedokrwiennego, 1,56 (1,19-2,05) dla udaru krwotocznego, 1,84 (1,59-2,13) dla niesklasyfikowanego udaru oraz 1,73 (1,51-1,98) dla agregatu zgonów z innych przyczyn naczyniowych. Stężenie glukozy we krwi na czczo było nieliniowo związane z ryzykiem naczyniowym. Nie wykazano znaczącego związku między wartościami glikemii w przedziale 3,90 - 5,59 mmol/l a wystąpieniem choroby wieńcowej. W porównaniu ze stężeniem glukozy na czczo wynoszącym 3,90-5,59 mmol/l, iloraz ryzyka (HR) wystąpienia choroby wieńcowej wynosił 1,07 (95\% $\mathrm{CI}=0,97-1,18)$ dla glikemii na czczo poniżej 3,90 mmol/l, $1,11(1,04-1,18)$ dla glikemii $5,60-6,09 \mathrm{mmol} / 1$ oraz 1,17 $(1,08-1,26)$ dla glikemii $6,10-6,99 \mathrm{mmol} / 1$ [1, 33, 34]. Przedstawione powyżej dane pozwalają uzmysłowić sobie, jak duże ryzyko zdrowotne niesie ze sobą zachorowanie na cukrzycę.

W leczeniu cukrzycy ważne jest osiąganie celów świadczących o wyrównaniu gospodarki węglowodanowej. Celem ogólnym jest uzyskanie stężenia hemoglobiny glikowanej $\mathrm{HbAlc} \leq 7 \%$ ( $\leq 53 \mathrm{mmol} / \mathrm{mol}$ ). Cele szczegółowe to m.in. dla chorych na cukrzycę typu 1 poziom $\mathrm{HbA} 1 \mathrm{c} \leq 6,5 \%$
( $\leq 48 \mathrm{mmol} / \mathrm{mol})$, dla chorych w zaawansowanym wieku i/lub cukrzycą z powikłaniami o charakterze makroangiopatii (przebyty zawał serca i/lub udar mózgu) i/lub licznymi chorobami towarzyszącymi: $\leq 8,0 \%$ ( $\leq 64 \mathrm{mmol} /$ mol). Cel glikemiczny dla kobiet z cukrzycą przedciążową planujących ciążę ma aktualnie wartość HbA1c <6,5\% ( $\leq 48 \mathrm{mmol} / \mathrm{mol})$. Jeżeli u chorego na cukrzycę w wieku $>65$. roku życia przewiduje się przeżycie dłuższe niż 10 lat przy realizacji ogólnych celów leczenia, należy dążyć do stopniowego wyrównania cukrzycy, przyjmując jako docelową wartość HbA1c $\leq 7 \%$. Poza postępowaniem związanym z kontrolą glikemii, podstawą prewencji CVD u osób z cukrzycą są te same zasady ogólne, co dla osób bez tej choroby. Szczególnie istotna jest dobra kontrola ciśnienia tętniczego oraz poziomu lipidów $[1,32,35]$.

W ostrym zespole wieńcowym zalecane jest odstawienie doustnych leków przeciwcukrzycowych, oznaczenie glikemii przy przyjęciu. Następnie zalecana jest normalizacja glikemii za pomocą dożylnego wlewu insuliny, gdy pacjent ma tzw. względną hiperglikemię (relative hyperglycemia). Za taki stan uznaje się glikemię powyżej $140 \mathrm{mg} / \mathrm{dl}$ (7,8 mmol/l) u osób z wcześniej rozpoznaną cukrzycą lub ponad $180 \mathrm{mg} / \mathrm{dl}$ (10,0 mmol/l) u pacjentów bez wcześniej rozpoznanej cukrzycy. Dożylne podanie insuliny jest jedynym sposobem szybkiej normalizacji glikemii oraz poprawy rokowania po przebyciu ostrego zespołu wieńcowego. Zalecana w wytycznych diabetologicznych częstość kontroli glikemii u pacjentów z wysokim poziomem cukru, to $\mathrm{w}$ ciągu pierwszej doby, w ciągu dnia: co 1 godzinę, a po uzyskaniu stabilizacji glikemii co 2 godziny Należy utrzymywać stężenie glukozy w granicach 100-180 mg/dl (5,6-10 mmol/l), odpowiednio regulując dożylny wlew insuliny. Leczenie choroby niedokrwiennej serca u osób, u których występują znaczne zaburzenia gospodarki węglowodanowej, powinno odbywać się korzystając z konsultacji specjalisty diabetologa (jeśli jest to możliwe) [35].

Jeśli chodzi o pacjentów po leczeniu z powodu ostrego zespołu wieńcowego, to poza chorymi z uprzednio rozpoznaną cukrzycą, przed wypisaniem ze szpitala należy wykonać doustny test tolerancji glukozy. U każdego chorego na cukrzycę typu 2 po przebytym ostrym zespole wieńcowym należy wdrożyć metforminę, o ile nie istnieją przeciwwskazania lub nietolerancja leku. W przypadku rozpoznania nietolerancji glukozy lub cukrzycy wskazane jest przeprowadzenie konsultacji diabetologicznej. Wytyczne diabetologiczne podkreślają również fakt, że przed planową koronarografią wykonywaną w celach diagnostycznych lub terapeutycznych należy odstawić metforminę co najmniej na 48 godzin przed zabiegiem, ponieważ u pacjentów leczonych tym lekiem, u których stosuje się jodowe środki kontrastowe, istnieje ryzyko wystąpienia kwasicy mleczanowej i pogorszenia czynności nerek). Można powrócić do jej stosowania po 24 godzinach po wykonaniu tego badania $[1,34]$. W wytycznych ESC / EACTS (Europejskie Stowarzyszenie Chirurgii Serca i Klatki Piersiowej - European Association for Cardio-Thoracic Surgery) dotyczących rewaskularyzacji mięśnia sercowego podkreślono jednak, że rzeczywiste 
ryzyko kwasicy mleczanowej jest bardzo niskie i dopuszczalnym postępowaniem alternatywnym może być ocena czynności nerek po koronarografii u pacjentów, którzy otrzymali bezpośrednio przed tym zabiegiem metforminę. Może być konieczne przerywanie podawania tego leku, jeżeli czynność nerek po koronarografii pogorszy się. Ten alternatywny sposób postępowania dotyczy pacjentów z prawidłową funkcją nerek, ponieważ wytyczne kardiologiczne zalecają przerwanie podawania metforminy przed koronarografią u pacjentów z niewydolnością nerek [36].

Dobrym sposobem na poprawienie rokowania pacjentów chorujących na cukrzycę oraz chorobę niedokrwienną serca jest włączenie do terapii przeciwcukrzycowej leków z grupy flozyn. W 2015 r. Zimman i wsp. z grupy EMPA-REG OUTCOME opublikowali wyniki badania, w którym losowo przydzielili 7020 pacjentów z cukrzycą typu 2 oraz wysokim ryzykiem sercowo-naczyniowym do 3 grup: otrzymującej $10 \mathrm{mg}$ emagliflozyny, $25 \mathrm{mg}$ tego leku lub placebo jeden raz dziennie (mediana czasu obserwacji wynosiła 3,1 roku). Pierwszorzędowy złożony punkt końcowy (zgon z przyczyn sercowo-naczyniowych, wystąpienie zawału serca niezakończonego zgonem lub udaru mózgu niedokrwiennego niezakończonego zgonem) wystąpił u 490 spośród 4687 pacjentów $(10,5 \%)$ w połączonej grupie pacjentów otrzymujących empagliflozynę oraz 282 z 2333 pacjentów (12,1\%) w grupie placebo (współczynnik ryzyka - HR w grupie empagliflozyny $=0,86,95,02 \%-\mathrm{CI}=0,74-0,99, \mathrm{p}=0,04$ ). $\mathrm{Nie}$ stwierdzono istotnych statycznie różnic między grupami pod względem częstości występowania zawału mięśnia sercowego lub udaru, ale w grupie otrzymującej empagliflozynę obserwowano istotnie niższy odsetek zgonów z przyczyn sercowo-naczyniowych (3,7\%, w porównaniu z 5,9\% w grupie placebo, względna redukcja ryzyka (RRR) wynosiła $38 \%$, HR=0,62 95\%-CI: 0,49-0,77). Hospitalizacji z powodu niewydolności serca wymagało 2,7\% osób w grupie empagliflozyny oraz $4,1 \%$ w grupie placebo $(R R R=35 \%)$, śmierć z dowolnej przyczyny wystąpiła u $5,7 \%$ pacjentów w grupie interwencyjnej oraz $8,3 \% \mathrm{w}$ grupie placebo $(\mathrm{RRR}=32 \%)$. Wśród osób otrzymujących empagliflozynę obserwowano większą częstość zakażenia narządów płciowych, nie obserwowano wzrostu częstości występowania innych zdarzeń niepożądanych [37]. Redukcja zgonów z przyczyn sercowo-naczyniowych w trakcie terapii empagliflozyną jest tłumaczona między innymi zmniejszeniem w porównaniu z placebo wskaźnika HbA1c, masy ciała, obwodu talii, stężenia kwasu moczowego w surowicy krwi oraz spadkiem ciśnienia tętniczego krwi [38].

Zwykle u pacjentów z cukrzycą typu 2 występują liczne czynniki ryzyka CVD, z których każdy wymaga leczenia zgodnego z istniejącymi zaleceniami. Długoterminowe postępowanie farmakologiczne u pacjentów z cukrzycą po zawale serca jest podobne, jak u pozostałych pacjentów $[1,34]$.

\section{LECZENIE NADCIŚNIENIA TĘTNICZEGO}

Według wytycznych ESC (European Society of Cardiology) i ESH (European Society of Hypertension) z 2018 roku za nad- ciśnienie tętnicze jest uważane, jak dotychczas, BP o wartości $>140 \mathrm{mmHg}$ i / lub rozkurczowe $>90 \mathrm{mmHg}$. Inną definicję nadciśnienia przyjęto $\mathrm{w}$ najnowszych zaleceniach amerykańskich: ACC (American College of Cardiology) i AHA (American Heart Association) z 2017 r., gdzie za nadciśnienie tętnicze uznano już wartości ciśnienia $>130 / 80 \mathrm{mmHg}$. Jednym z powodów utrzymania definicji i klasyfikacji w europejskich wytycznych była podnoszona przez specjalistów z Europy trudność w interpretacji wyników badania SPRINT (na którym w dużej mierze oparto wytyczne amerykańskie). Zostało ono przeprowadzone odmiennie metodologicznie $\mathrm{w}$ porównaniu do wcześniejszych badań $\mathrm{z}$ zakresu hipertensjologii: z powodu wykonywania nienadzorowanych pomiarów ciśnienia tętniczego w badaniu tym nie występowało nadciśnienie białego fartucha, skutkiem były również niższe mierzone wartości ciśnienia tętniczego [1,39].

Autorzy najnowszych wytycznych ESH i ESC podają wartości BP w pomiarach gabinetowych, które powinny być osiągnięte po zastosowaniu właściwego leczenia w zależności od wieku oraz chorób współistniejących:

- pacjenci w wieku 18-65 lat z nadciśnieniem tętniczym (w tym osoby z towarzyszącą DM, CAD lub po udarze mózgu / przemijającym ataku niedokrwiennym - TIA transient ischaemic attack) powinni mieć $\mathrm{BP}$ w przedziale: 120-130/70-79 mmHg, jeśli takie BP jest dobrze tolerowane (wyłączając pacjentów z przewlekłą chorobą nerek, u których dążymy do BP: 130-140 / 70-79 mmHg);

- pacjenci w wieku 65-79 lat z nadciśnieniem tętniczym (w tym osoby z towarzyszącą DM, przewlekłą chorobą nerek, CAD lub po udarze mózgu / TIA) powinni mieć BP w przedziale: 130-139/70-79 mmHg, jeśli takie BP jest dobrze tolerowane;

- pacjenci $\mathrm{w}$ wieku $\geq 80$ lat $\mathrm{z}$ nadciśnieniem tętniczym (w tym osoby z towarzyszącą DM, przewlekłą chorobą nerek, CAD lub po udarze mózgu / TIA), powinni mieć BP w przedziale: 130-139/70-79mmHg, jeśli takie BP jest dobrze tolerowane [39].

Należy mieć na uwadze, że nadciśnienie tętnicze jest bardzo dużym problemem populacyjnym: w Europie Środkowej i Wschodniej aż 150 milionów osób choruje na nadciśnienie tętnicze, w Polsce jest to 10,5 miliona osób (33\% ogółu osób dorosłych) [1,40].

Istnieje silny związek między nadciśnieniem tętniczym a występowaniem choroby niedokrwiennej serca. Badanie INTERHEART z 2004 roku wykazało, że około 50\% populacyjnego ryzyka związanego $\mathrm{z}$ wystąpieniem zawału mięśnia sercowego może być powiązane $\mathrm{z}$ dyslipidemią, $25 \%$ natomiast $\mathrm{z}$ nadciśnieniem tętniczym $[1,39,41]$. Niedawna metaanaliza 123 randomizowanych badań kontrolnych z udziałem 613815 uczestników wykazała, że każde obniżenie o $10 \mathrm{mmHg}$ skurczowego BP powodowało zmniejszenie ryzyka wystąpienia poważnych incydentów sercowo-naczyniowych o $20 \%$ (ryzyko względne, $R R=0,80$, 95\% - CI:0,77-0,83), zmniejszenie zachorowalności na chorobę wieńcową serca (RR=0,83, 95\% - CI:0,78-0,88), zmniejszenie częstości udarów mózgu ( $\mathrm{RR}=0,73,95 \%$ CI:0,68-0,77) i niewydolności serca ( $R R=0,72,95 \%$ CI:0,67-0,78), co w efekcie u badanych prowadziło do 
13\% zmniejszenia śmiertelności z wszystkich przyczyn $(\mathrm{RR}=0,87,95 \%$ - CI:0,84-0,9) [42].

Interwencje w zakresie modyfikacji stylu życia, kontrola masy ciała i regularna aktywność fizyczna mogą doprowadzić do normalizacji BP u pacjentów z nadciśnieniem tętniczym 1 stopnia lub obniżyć ciśnienie u pacjentów z wysokim prawidłowym ciśnieniem krwi. Należy podkreślić, że powyższe zalecenia niefarmakologiczne powinny być rekomendowane u wszystkich chorych otrzymujących leki hipotensyjne, ponieważ mogą one umożliwić redukcję dawek leków hipotensyjnych potrzebnych do uzyskania kontroli BP. Interwencją z zakresu modyfikacji stylu życia, specyficzną dla terapii nadciśnienia tętniczego, jest ograniczenie spożycia soli ( $<5 \mathrm{~g} /$ dzień) $[1,39]$.

W znacznej liczbie randomizowanych badań dotyczących leczenia hipotensyjnego, zarówno w badaniach porównujących aktywne leczenie z placebo, ale też w porównujących różne leki, stwierdzono, że główne korzyści z leczenia hipotensyjnego wynikają z samego obniżenia BP i w dużej mierze nie zależą od rodzaju zastosowanych leków. Według najnowszych europejskich wytycznych do leków pierwszego wyboru w leczeniu hipotensyjnym należą: inhibitory konwertazy angiotensyny (ACE-I - Angiotensin-Converting Enzyme Inhibitors), inhibitory receptora angiotensyny II (ARB - Angiotensin II Receptor Blockers), beta-blokery, blokery kanałów wapniowych i diuretyki (tiazydy i diuretyki tiazydopodobne: chlortalidon i indapamid). Są one zalecane do rozpoczęcia i leczenia podtrzymującego w celu kontroli ciśnienia tętniczego krwi, zarówno w monoterapii, jak i w leczeniu skojarzonym. Należy mieć na uwadze poszczególne wskazania dla konkretnych leków hipotensyjnych $[1,39]$

U pacjentów $\mathrm{z}$ nadciśnieniem tętniczym oraz chorobą niedokrwienną serca szczególnie wskazane są beta-blokery i leki działające na układ renina-angiotensyna-aldosteron (ACE-I lub ARB), które mogą poprawić wyniki po zawale mięśnia sercowego. U pacjentów $\mathrm{z}$ objawową dławicą, beta-blokery i antagoniści wapnia są preferowanymi składnikami strategii leczenia. U pacjentów z ostrym zespołem wieńcowym wytyczne europejskie zalecają szybkie obniżenie BP do wartości $<140 / 90$ mmHg, a jako leki pierwszego wyboru podają w tej sytuacji nitroglicerynę i labetalol, lekiem drugiego wyboru jest urapidyl [39].

Leczenie skojarzone jest wymagane do kontroli BP u większości pacjentów. Dodanie do leczenia substancji z innej klasy jest zalecaną strategią terapii, chyba że początkowo stosowany lek musi być odstawiony z powodu działań niepożądanych lub brak jest jakiegokolwiek działania obniżającego ciśnienie tętnicze po podaniu tej substancji. Warto podkreślić fakt, że dodatkowa redukcja BP, wynikająca z połączenia leków z 2 różnych klas, jest w przybliżeniu 5 razy większa niż po 2-krotnym zwiększeniu dawki jednego wcześniej stosowanego leku. Skojarzenie leków może ponadto powodować zmniejszenie działań niepożądanych związanych z użyciem każdej z substancji osobno, w większych dawkach. Łączne stosowanie 2 leków może również mieć zalety przy rozpoczęciu terapii hipotensyjnej, zwłaszcza u pacjentów obciążonych wysokim oraz bardzo wysokim ryzykiem sercowo-naczyniowym. U takich osób często pożądane jest wczesne uzyskanie kontroli BP $[1,43,44]$.

\section{LECZENIE PRZECIWPŁYTKOWE}

Po przebytym ostrym zespole wieńcowym standardem leczenia jest podwójne leczenie przeciwpłytkowe przez 12 miesięcy, co potwierdzono w wielu badaniach. W 2001 roku Yusuf i wsp. opublikowali wyniki badania CURE, w którym 12562 pacjentów z zawałem serca $\mathrm{z}$ uniesieniem odcinka ST zostało losowo przydzielonych do 2 grup. Pierwsza w ciągu 24 godzin od pojawienia się objawów otrzymywała oprócz kwasu acetylosalicylowego (ASA - acetylosalicylic acid) klopidogrel, czyli inhibitor receptora P2Y12 (natychmiast $300 \mathrm{mg}$, a następnie $75 \mathrm{mg}$ raz na dobę, 6259 pacjentów). Druga grupa otrzymywała oprócz ASA placebo (6303 pacjentów). Czas leczenia podwójną terapią przeciwpłytkową wynosił od 3 do 12 miesięcy. Pierwszorzędowy złożony punkt końcowy: zgon z przyczyn sercowo-naczyniowych, niezakończony zgonem zawał mięśnia sercowego lub udar wystąpił u 9,3\% pacjentów w grupie leczonych klopidogrelem vs. 11,4\% pacjentów w grupie placebo (ryzyko względne - RR związane $\mathrm{z}$ klopidogrelem $\mathrm{w}$ porównaniu z placebo wynosiło 0,80, 95\% - CI:0,72-0,90, p<0,001). Drugi złożony punkt końcowy: pierwszy złożony punkt końcowy lub wystąpienie opornego niedokrwienia mięśnia sercowego - wystąpił u 16,5\% pacjentów w grupie przyjmującej klopidogrel i $18,8 \%$ pacjentów w grupie placebo $(R R=0,86$, 95\% - CI:0,79-0,94; p<0,001). Odsetek pacjentów z nawracającym wewnątrzszpitalnym niedokrwieniem, niewydolnością serca i ponowną rewaskularyzacją był również znacząco niższy w przypadku klopidogrelu. W grupie klopidogrelu było więcej pacjentów z dużymi krwawieniami niż w grupie placebo (3,7\% vs. 2,7\%, ryzyko względne $R R=1,38, p=0,001$ ), ale nie było istotnie więcej pacjentów $\mathrm{z}$ epizodami krwawienia zagrażającego życiu $(2,2 \%$ vs. $1,8 \%, \mathrm{p}=0,13)$ lub krwotocznych udarów mózgu $(0,1 \%$ vs. $0,1 \%)[1,45]$.

W 2009 roku opublikowano natomiast wyniki badania PLATO, w którym porównywano tikagrelor - kolejny obok klopidogrelu inhibitor płytkowego receptora P2Y12 (dawka nasycająca $180 \mathrm{mg}$, następnie $90 \mathrm{mg}$ dwa razy na dobę) oraz klopidogrel (dawka wysycająca 300 do 600 mg, następnie $75 \mathrm{mg}$ raz na dobę) w celu zapobiegania zdarzeniom sercowo-naczyniowym w grupie 18624 pacjentów przyjmowanych do szpitala $z$ ostrym zespołem wieńcowym, z lub bez uniesienia odcinka ST. Po 12 miesiącach pierwotny złożony punkt końcowy: zgon z przyczyn naczyniowych, zawału mięśnia sercowego lub udaru wystąpił u 9,8\% pacjentów otrzymujących tikagrelor w porównaniu z 11,7\% pacjentów otrzymujących klopidogrel (współczynnik ryzyka, HR=0,84, 95\% - CI: 0,77-0,92, p<0,001). Istotne różnice wystąpiły ponadto jeśli chodzi o inne punkty końcowe: zawały mięśnia sercowego (5,8\% w grupie leczonej tikagrelorem w porównaniu z 6,9\% w grupie klopidogrelu, $\mathrm{p}=0,005)$ i zgon $\mathrm{z}$ przyczyn naczyniowych 
(4,0\% w porównaniu z 5,1\%,p=0,001). Częstość zgonu z jakiejkolwiek przyczyny była również mniejsza w przypadku tikagreloru $(4,5 \%$, w porównaniu do $5,9 \%$ w przypadku klopidogrelu, $\mathrm{p}<0,001)$. Nie stwierdzono istotnej różnicy w częstości występowania krwawień pomiędzy grupami tikagreloru i klopidogrelu (odpowiednio 11,6\% i 11,2\%, $\mathrm{p}=0,43$ ), ale tikagrelor był związany $\mathrm{z}$ większym odsetkiem dużych krwawień niezwiązanych z pomostowaniem tętnic wieńcowych (4,5\% w porównaniu $\mathrm{z} 3,8 \%, \mathrm{p}=0,03)$, w tym z większą liczbą przypadków śmiertelnego krwawienia wewnątrzczaszkowego i mniejszą śmiertelnych krwawień innych typów $[1,46]$.

Kwas acetylosalicylowy jest najlepiej przebadanym lekiem używanym w długoterminowej prewencji po zawale serca, udarze mózgu oraz w chorobach tętnic obwodowych. W przeprowadzonej w 2009 roku przez Antithrombotic Trialists' (ATT) Collaboration metaanalizie 16 badań obejmujących 17000 osób wykazano, że leczenie ASA $\mathrm{w}$ ramach prewencji wtórnej wiązało się z: poważnymi zdarzeniami naczyniowymi u 6,7\% pacjentów/rok vs. 8,2\% w grupie kontrolnej. Ryzyko udaru mózgu wynosiło 2,08\%/ rok w grupie leczonej aspiryną vs. 2,59\% w kontrolnej ( $\mathrm{p}=0,002)$, a zdarzeń wieńcowych: 4,3\%/rok vs. 5,3\% w grupie kontrolnej $(p=0,0001)$. Stosowanie aspiryny zwiększało częstość większych krwawień z przewodu pokarmowego i pozaczaszkowych $(0,10 \% \mathrm{w}$ porównaniu z $0,07 \%$ rocznie, p<0,0001), czynniki ryzyka choroby wieńcowej były również czynnikami ryzyka krwawienia [47]. W fazie przewlekłej po przebyciu zawału serca (>12 miesięcy) zaleca się stosowanie ASA. U osób bez stwierdzonej CVD nie zaleca się leczenia przeciwpłytkowego, gdyż zwiększa ono ryzyko wystąpienia poważnego krwawienia [1].

U pacjentów z ostrymi zespołami wieńcowymi poddawanymi przezskórnej interwencji wieńcowej, którym wszczepiono stent, autorzy wytycznych ESC / EACTS zalecają podwójną terapię przeciwpłytkową (DAPT dual antiplatelet therapy) obejmującą ASA w połączeniu $\mathrm{z}$ inhibitorem receptora P2Y12 przez 12 miesięcy, chyba że występują przeciwwskazania, takie jak nadmierne ryzyko krwawienia. U pacjentów z ostrym zespołem wieńcowym i wszczepionym stentem, u których ryzyko krwawienia jest wysokie (np. $\geq 25$ pkt w skali PRECISE-DAPT), należy rozważyć przerwanie leczenia inhibitorem receptora P2Y12 po upływie 6 miesięcy. U osób z ostrym zespołem wieńcowym, którym wszczepiono stent bioresorbowalny, należy rozważyć DAPT przez czas $\geq 12$ miesięcy, a nawet do końca przewidywanego okresu wchłaniania się stentu zależnie od indywidualnej oceny ryzyka krwawień i incydentów niedokrwiennych. U pacjentów z ostrym zespołem wieńcowym, którzy tolerowali DAPT bez powikłań krwotocznych, można rozważyć kontynuację DAPT przez czas >12 miesięcy. Warto podkreślić, że postępowanie dotyczące podtrzymującej DAPT jest takie samo $\mathrm{w}$ przypadku zawałów serca bez uniesienia odcinka ST, jak i w zawałach z uniesieniem odcinka ST [36]. Wspomniana powyżej skala PRECISE-DAPT pozwalająca ocenić ryzyko krwawienia u pacjentów leczonych DAPT jest wystandaryzowanym narzędziem korzystają- cym z pięciu parametrów: poziomu hemoglobiny, wieku, liczby białych krwinek, wskaźnika filtracji kłębuszkowej, obecności wcześniejszego krwawienia. Uzyskany wynik pozwala przewidzieć ryzyko krwawienia pozaszpitalnego podczas DAPT. Użycie skali wspiera podejmowanie decyzji klinicznych w czasie trwania leczenia (wynik $\geq 25$ pkt wskazuje na wysokie ryzyko krwawienia i należy w tej sytuacji rozważyć krótsze stosowanie DAPT). Skala jest ogólnodostępna w Internecie [48, 49].

Na podstawie wyników badania o akronimie ATLAS-ACS-2-TIMI-51 (Anti-Xa Therapy to Lower cardiovascular events in Addition to Standard therapy in subjects with Acute Coronary Syndromes - Thrombolysis In Myocardial Infarction 51) w wytycznych ESC / EACTS dotyczących rewasularyzacji autorzy podali zalecenie, że u pacjentów z ostrym zespołem wieńcowymi bez uniesienia odcinka ST lub z zawałem serca $\mathrm{z}$ uniesieniem odcinka ST poddawanych PCI, którzy nie przebyli udaru mózgu ani TIA i są obciążeni wysokim ryzykiem incydentów niedokrwiennych, a także cechują się niskim ryzykiem krwawienia i otrzymują ASA oraz klopidogrel, można rozważać małą dawkę riwaroksabanu $(2 \times 2,5 \mathrm{mg})$ po przerwaniu parenteralnego leczenia przeciwzakrzepowego (czas takiej terapii to około 1 rok). Należy zauważyć, że nie badano stosowania riwaroksabanu w połączeniu z silnymi inhibitorami receptora P2Y12 [36]. Ponadto w dużym badaniu COMPASS (Rivaroxaban for the Prevention of Major Cardiovascular Events in Coronary or Peripheral Artery Disease) wykazano wartość stosowania naczyniowej dawki riwaroksabanu (2,5 mg $2 \times$ /dzień.) w połączeniu z ASA w zakresie prewencji wtórnej u pacjentów z CAD [36].

\section{KONTROLA CZYNNIKÓW RYZYKA W POLSCE - DOTYCHCZASOWE WYNIKI}

W obserwacyjnym badaniu przeprowadzanym co kilka lat w południowej Polsce wśród pacjentów hospitalizowanych z powodu zawału serca lub planowej rewaskularyzacji naczyń wieńcowych $(\mathrm{n}=408 \mathrm{w}$ latach 1997-1998, $\mathrm{n}=600$ w latach 2011-2013) nie wykazano poprawy w zakresie kontroli czynników ryzyka na przestrzeni tych kilkunastu lat. Po 6-18 miesiącach od wypisu w latach 2011-2013 aż $18,3 \%$ pacjentów paliło papierosy $v s .15,7 \% \mathrm{w}$ latach 1997-1998 ( $\mathrm{p}<0,001) .43,3 \%$ pacjentów po wypisie w latach 2011-2013 miało $\mathrm{BP} \geq 140 / 90$ mm Hg vs. 45,9 w latach 1997-1998 ( $\mathrm{p}=0.06)$. Aż 72,1\% pacjentów nie uzyskało docelowego cholesterolu LDL po wypisie w latach 2011-2013 vs. 47,5\% w latach 1997-1998 ( $\mathrm{p}<0,001)$. Obserwowano również, że $34,0 \%$ pacjentów miało $\mathrm{BMI} \geq 30 \mathrm{~kg} / \mathrm{m}^{2}$ po wypisie w latach 2011-2013 vs. 24,9\% z takim BMI po wypisie w latach 1997-1998 (p<0.01), a także fakt, że aż 15,6\% miało stężenie glukozy na czczo $\geq 7.0 \mathrm{mmol} / \mathrm{l}$ po wypisie w latach 2011-2013 vs. 9,8\% w latach 1997-1998 ( $\mathrm{p}=0,09)$ $[50,51]$. Te dane utwierdzają w przekonaniu, że kontrola czynników ryzyka u pacjentów z chorobą niedokrwienną serca jest niedostateczna, a działania prewencyjne powinny być w przypadku tych osób rozpoczynane jak najszybciej i w zdecydowany sposób. 


\section{PODSUMOWANIE}

Kontrola czynników ryzyka sercowo-naczyniowego odgrywa kluczową rolę w osiąganiu wyników zdrowotnych krótko- i długoterminowych u pacjentów z chorobą niedokrwienną serca. Trzeba zdawać sobie sprawę z faktu, że mimo rosnącej świadomości dotyczącej prewencji chorób układu krążenia, w ostatnich latach nie nastąpiła spodziewana poprawa kontroli wyżej wymienionych czynników. Dobrym pomysłem jest z pewnością wprowadzenie odpowiedniego planu postępowania, którybędzie wdrażany po wypisaniu pacjenta ze szpitala i kontynuowany przez lekarzy pierwszego kontaktu. Zalecana jest kompleksowa i profesjonalna interwencja w zakresie modyfikacji stylu życia oraz występujących chorób współistniejących. Postępowanie polegające na skutecznej kontroli czynników ryzyka, poradach dotyczących aktywnościfizycznej, wsparciu psychospołecznym i właściwym użyciu leków hipotensyjnych, hipolipemizujących, kontrolujących glikemię oraz przeciwpłytkowych stanowi integralną część pomocy dla pacjentów, tak aby mogli powrócić po zawale serca do jak najpełniejszej aktywności i dobrego zdrowia.

\section{PIŚMENNICTWO}

1. Piepoli MF, Hoes AW, Agewall S et al. Wytyczne ESC dotyczące prewencji chorób układu sercowo-naczyniowego w praktyce kliniczej w 2016 roku. Kardiol Pol. 2016;74(9): 821-936. doi:10.5603/KP.2016.0120

2. Finucane MM, Stevens GA, Cowan MJ et al. National, regional, and global trends in body mass index since 1980: systematic analysis of health examination surveys and epidemiological studies with 960 country-years and 9.1 million participants. Lancet. 2011;377:557-567.

3. Danaei G, Finucane MM, Lu Y et al. National, regional, and global trends in fasting plasma glucose and diabetes prevalence since 1980: systematic analysis of health examination surveys and epidemiological studies with 370 country-years and 2.7 million participants. Lancet. 2011;378:31-40.

4. Nagelhout GE, de Vries H, Boudreau C. Comparative impact of smokefree legislation on smoking cessation in three European countries. Eur J Public Health. 2012 Feb; 22(Suppl 1):4-9. doi:10.1093/eurpub/ckr203.

5. Pascual FV. Pharmacological management of dyslipidemia in high and very high cardiovascular risk patients. Rev Esp Sanid Penit. 2016;18(3):95-108. doi:10.4321/S1575-06202016000300004.

6. Albus C, Ladwig KH, Herrmann-Lingen C. Psychocardiology: clinically relevant recommendations regarding selected cardiovascular diseases. Dtsch Med Wochenschr. 2014;139:596-601.

7. Whalley B, Thompson DR, Taylor RS. Psychological interventions for coronary heart disease: cochrane systematic review and meta-analysis. Int J Behav Med. 2014;21:109-121.

8. De Abajo FJ, García-Rodríguez LA. Risk of upper gastrointestinal tract bleeding associated with selective serotonin reuptake inhibitors and venlafaxine therapy: interaction with nonsteroidal anti-inflammatory drugs and effect of acid-suppressing agents. Arch Gen Psychiatry. 2008;65(7):795-803. doi: 10.1001/archpsyc.65.7.795.

9. Kim DH, Daskalakis C, Whellan DJ etal. Safety of selective serotonin reuptake inhibitor in adults undergoing coronary artery bypass grafting. Am J Cardiol. 2009;103(10):1391-1395. doi: 10.1016/j.amjcard.2009.01.348.

10. Roose SP, Laghrissi-Thode F, Kennedy JS et al. Comparison of paroxetine and nortriptyline in depressed patients with ischemic heart disease. JAMA. 1998;279(4):287-291. doi:10.1001/jama.279.4.287.

11. Piepoli MF, Davos C, Francis DP et al. Exercise training meta-analysis of trials in patients with chronic heart failure (ExTraMATCH). BMJ. 2004; 328: 189. doi:10.1136/bmj.37938.645220.EE.
12. Physical Activity Guidelines Advisory Committee. Physical Activity Guidelines Advisory Committee Report, 2008. Washington, DC: U.S. Department of Health and Human Services, 2008.

13. Leon $A$, Sanchez 0 . Response of blood lipids to exercise training alone or combined with dietary intervention. Med Sci Sports Exerc. 2001;33(6 Suppl):S502-15 (discussion S528-9).

14. Doll R, Peto R, Boreham J et al. Mortality in relation to smoking: 50 years' observations on male British doctors. BMJ. 2004; 328:1519.

15. Kotseva K, Wood D, De Bacquer D et al. EUROASPIRE IV: a European Society of Cardiology survey on the lifestyle, risk factor and therapeutic management of coronary patients from 24 European countries. Eur J Prev Cardiol. 2016;23:636-648. doi: 10.1177/2047487315569401.

16. Chow CK, Jolly S, Rao-Melacini P et al. Association of diet, exercise, and smoking modification with risk of early cardiovascular events after acute coronary syndromes. Circulation, 2010;121:750-758.

17. Górecka D, Bała M, Leczenie uzależnienia od tytoniu https://www.mp.pl/ poz/psychiatria/uzaleznienia/89907,leczenie-uzaleznienia-od-tytoniu.

18. Roberts NJ, Kerr SM, Smith SM. Behavioral Interventions Associated with Smoking Cessation in the Treatment of Tobacco Use. Health Serv Insights. 2013;6:79-85.

19. Jankowski P, Kawecka-JaszczK, KopećG et al. Polish Forum for Prevention Guidelines on Smoking: update 2017. doi:10.5603/KP.2017.0066

20. Widmer RJ, Flammer AJ, Lerman LO et al. The Mediterranean Diet, its Components, and Cardiovascular Disease Am J Med. 2015;128(3):229238. doi:10.1016/j.amjmed.2014.10.014

21. Stewart ST, Cutler DM, Rosen AB. Forecasting the effects of obesity and smoking on U.S. life expectancy. N Engl J Med. 2009; 361: 2252-2260. doi: 10.1056/NEJMsa0900459.

22. Visser M, Bouter LM, McQuillan GM et al. Elevated C-reactive protein levels in overweight and obese adults. JAMA. 1999 Dec 8;282(22):2131-5.

23. Jun Zhu, Xiaohua Su, Gang Li et. al. The incidence of acute myocardial infarction in relation to overweight and obesity: a meta-analysis Arch Med Sci. 2014 0ct 27; 10(5): 855-862. doi:10.5114/aoms.2014.46206

24. Shukla AP, Buniak WI, Aronne LJ. Treatment of obesity in 2015. Cardiopulm Rehabil Prev. 2015;35(2):81-92. doi:10.1097/ HCR.0000000000000112.

25. Rosei EA, Salvetti M. Management of Hypercholesterolemia, Appropriateness of Therapeutic Approaches and New Drugs in Patients with High Cardiovascular Risk High Blood Press Cardiovasc Prev. 2016; 23(3):217-230. doi:10.1007/s40292-016-0155-2

26. Teo K, Lear S, Islam $S$ et al. Prevalence of a healthy lifestyle among individuals with cardiovascular disease in high-, middle- and lowincome countries: the prospective urban rural epidemiology (PURE) study. JAMA. 2013;309:1613-1621. doi: 10.1001/jama.2013.3519.

27. Nelson RH. Hyperlipidemia as a Risk Factor for Cardiovascular Disease. Prim Care. 2013;40(1): 195-211. doi:10.1016/j.pop.2012.11.003

28. Colhoun HM, Betteridge DJ, Durrington PN et al. Primary prevention of cardiovascular disease with atorvastatin in type 2 diabetes in the Collaborative Atorvastatin Diabetes Study (CARDS): multicentre randomised placebo-controlled trial. Lancet. 2004;364:685-696

29. Ray KK, Cannon CP, McCabe CH. Early and late benefits of high-dose atorvastatin in patients with acute coronary syndromes: results from the PROVE IT-TIMI 22 trial. J Am Coll Cardiol. 2005;46(8):1405-1410. doi: 10.1016/j.jacc.2005.03.077

30. Stroes ES, Thompson PD, Corsini A et al. Statin-associated muscle symptoms: impact on statin therapy — European Atherosclerosis Society Consensus Panel Statement on Assessment, Aetiology and Management. Eur Heart J, 2015; 36:1012-1022. doi:10.1093/eurheartj/ehv043. 
31. Catapano AL, Graham I, De Backer G et al. Wytyczne ESC/EAS dotyczące leczenia zaburzeń lipidowych w 2016 roku. Kardiol Pol. 2016;74: 12341318. doi: 10.5603/KP.2016.0157

32. InzucchiSE, Bergenstal RM, Buse JB et al. Management of hyperglycemia in type 2 diabetes, 2015: a patient-centered approach: update to a position statement of the American Diabetes Association and the European Association for the Study of Diabetes. Diabetes Care. 2015;38:140-149.

33. Emerging Risk Factors Collaboration, Sarwar N, Gao P et al. Diabetes mellitus, fasting blood glucose concentration, and risk of vascular disease: a collaborative meta-analysis of 102 prospective studies. Lancet. 2010;375:2215-2222.

34. Leon BM, Maddox TM. Diabetes and cardiovascular disease: Epidemiology, biological mechanisms, treatment recommendations and future research. World J Diabetes. 2015 0ct 10; 6(13): 1246-1258. doi:10.4239/wjd.v6.i13.1246

35. 2017 Guidelines on the management of diabetic patients. A position of Diabetes Poland. Clin Diabet 2017; 6, Suppl. A: A1-A80. doi:10.5603/ DK.2017.0001.

36. Neumann F-J, Sousa-Uva M, Ahlsson A et al. Wytyczne ESC/EACTS dotyczące rewaskularyzacji mięśnia sercowego (2018). Kardiol Pol. 2018;76(12):1585-1664, doi: 10.5603/KP.2018.0228.

37. Zinman B, Wanner C, Lachin JM et al. Empagliflozin, Cardiovascular Outcomes, and Mortality in Type 2 Diabetes. N Engl J Med. 2015;373(22):2117-28. doi: 10.1056/NEJMoa1504720.

38. Inzucchi SE, Zinman B, Fitchett D et al. How Does Empagliflozin Reduce Cardiovascular Mortality? Insights From a Mediation Analysis of the EMPA-REG OUTCOME Trial. Diabetes Care. 2018;41(2):356-363. doi: 10.2337/dc17-1096.

39. Williams B, Mancia G, Spiering W. 2018 ESC/ESH Guidelines for the management of arterial hypertension. Eur Heart J.39(33):3021-3104, https://doi.org/10.1093/eurheartj/ehy339

40. Czarnecka D, Jankowski P, Kopeć $G$ et al. Polish Forum for Prevention Guidelines on Hypertension: update 2017. Kardiol Pol. 2017; 75(3):282285, doi:10.5603/KP.2017.0055.

41. Yusuf $S$, Hawken $S$, Ounpuu $S$ et al. Effect of potentially modifiable risk factors associated with myocardial infarction in 52 countries (the INTERHEART study): case-control study. Lancet. 2004;364(9438):937952. doi:10.1016/S0140-6736(04)17018-9
42. Ettehad D, Emdin CA, Kiran A et al. Blood pressure lowering for prevention of cardiovascular disease and death: a systematic review and meta-analysis. Lancet. 2016;387(10022):957-967. doi: 10.1016/ S0140-6736(15)01225-8

43. Wald DS, Law M, Morris JK et al. Combination therapy versus monotherapy in reducing blood pressure: meta-analysis on 11,000 participants from 42 trials. Am J Med. 2009;122:290-300. doi:10.1016/j. amjmed.2008.09.038

44. Jamerson K, Weber MA, Bakris GL et al. Benazepril plus amlodipine or hydrochlorothiazide for hypertension in high-risk patients. N Engl J Med. 2008;359:2417-2428. doi:10.1056/NEJMoa0806182

45. Yusuf S, Zhao F, Mehta SR et al. Effects of clopidogrel in addition to aspirin in patients with acute coronary syndromes without STsegment elevation. N Engl J Med. 2001;345:494-502. doi:10.1056/ NEJMoa010746

46. Wallentin L, Becker RC, Budaj A et al. Ticagrelor versus clopidogrel in patients with acute coronary syndromes. N Engl J Med. 2009;361:10451057. doi: $10.1056 /$ NEJMoa0904327

47. Antithrombotic Trialists'Collaboration, BaigentC, Blackwell Let al. Aspirin in the primary and secondary prevention of vascular disease: collaborative meta-analysis of individual participant data from randomised trials. Lancet. 2009; 373: 1849-1860. doi: 10.1016/S0140-6736(09)60503-1.

48. Costa F, van Klaveren D, James S et al. Derivation and validation of the predicting bleeding complications in patients undergoing stent implantation and subsequent dual antiplatelet therapy (PRECISE-DAPT) score: a pooled analysis of individual-patient datasets from clinical trials. Lancet. 2017;389(10073):1025-1034. doi: 10.1016/S01406736(17)30397-5.

49. PRECISE-DAPT Risk Calculator http://www.precisedaptscore.com/ predapt/webcalculator.html

50. Jankowski P, Czarnecka D, Badacz L et al. Practice setting and secondary prevention of coronary artery disease. Arch Med Sci. 2018;14(5):979987. doi: 10.5114/aoms.2017.65236

51. Banach M, Jankowski P, Jóźwiak J et. al. PoLA/CFPiP/PCS Guidelines for the Management of Dyslipidaemias for Family Physicians 2016. doi:10.5114/aoms.2017.64712

\section{Konflikt interesów}

Autorzy deklarują brak konfliktu interesów.

\author{
AUTOR KORESPONDUJĄCY \\ Jan W. Pęksa \\ I Klinika Kardiologii i Elektrokardiologii Interwencyjnej \\ oraz Nadciśnienia Tętniczego, \\ Uniwersytet Jagielloński w Krakowie \\ ul. Kopernika 17, 31-501 Kraków, Polska \\ tel. 124247300 \\ e-mail:janwpeksa@gmail.com
}

Nadesłano: 18.02.2019

Zaakceptowano: 03.03.2019 
PRACA POGLĄDOWA

REVIEW ARTICLE

\title{
LEGAL PROTECTION OF INVENTIONS WITHIN MEDICAL PRACTICE IN UKRAINE
}

\section{OCHRONA PRAWNA WYNALAZKÓW W MEDYCYNIE NA UKRAINIE}

\author{
Olha I. Bezpalova', Valeriy A. Yusupov' ${ }^{2}$, Olha Ye. Avramova', Tetyana V. Krasiuk ${ }^{3}$, Nataliia B. Larina ${ }^{4}$ \\ 'KHARKIV NATIONAL UNIVERSITY OF INTERNAL AFFAIRS, KHARKIV, UKRAINE \\ 2KRYVYI RIH NATIONAL UNIVERSITY, KRYVYI RIH, UKRAINE \\ ${ }^{3}$ YAROSLAV MUDRYI NATIONAL LAW UNIVERSITY, KHARKIV, UKRAINE \\ ${ }^{4}$ TAVRIDA NATIONAL V.I.VERNADSKY UNIVERSITY, KYIV, UKRAINE
}

\begin{abstract}
Introduction: There is a large number of patents registered in the field of medical practice in Ukraine. Despite this, the peculiarities of the legal protection of inventions within medical practice have not been researched in the modern legal doctrine of intellectual property.

The aim of this article is theoretical and practical study of the legal protection of medical inventions in Ukraine based on the analysis of Ukrainian patent law, issued patents for inventions applied within medical practice, as well as data from the State Expert Center of the Ministry of Health of Ukraine.

Materials and methods: The authors of the article have used methods of analysis and synthesis, as well as comparative and legal method. The analysis and further use of data from the State Expert Center of the Ministry of Health of Ukraine contributed to the definition of the problems of this publication, as well as the formulation of the authors' vision of the features of inventions within medical practice.

Review: Inventions within medical practice are the result of human intellectual activity in the field of medicine. The authors have offered to refer inventions within medical practice to a group of inventions with a possible risk. The risks of inventions within medical practice are divided into those that have a risk for people undergoing clinical trials and manufacturers who try to use these inventions.

Conclusions: The authors have grounded the expediency of supplementing the patent procedure with regard to inventions that can be applied within medical practice, with the rule of obligatory provision of documents on conducting clinical trials to the materials of the application for a patent on the invention, in cases of restrictions of the rights of a patent holder of medical and pharmaceutical inventions, by the provisions that would define the concepts and types of biotechnological inventions.
\end{abstract}

KEYWORDS: inventions within medical practice, legal protection of inventions, a patent and an invention, clinical trials, risks of inventions

Wiad Lek 2019, 72, 3, 484-488

\section{INTRODUCTION}

Chinese scholar, Jiang-ying He, in November 2018 made a statement on the birth of the first genetically "reformed" children in the world, which immediately caused international protest by geneticists [1]. This example proves that the problem of protecting inventions within medical practice is relevant, as it requires the development of new ethical standards and proper legal regulation. Inventions within medical practice can affect both the health of a person, and his life, which according to the Art. 3 of the Constitution of Ukraine is recognized as the highest social value in the state [2]. Such a constitutional approach to protecting a person requires a detailed elaboration of all actions that can affect human life, in particular the invention activities within medical practice.

Patentable inventions can be made during normal medical practice. For example, the development of new biocompatible polymers, the improvement of dental materials, new or modified catheters, new laboratory diagnostic tests and advanced medical devices [3]. But most of the inventions applied within medical practice are the result of many years research by individual scholars, groups of physicians or specialized medical research institutes. Despite the significant number of patents registered in Ukraine in the field of medical practice, the modern legal doctrine of intellectual property practically does not study the terms of legal protection of inventions within medical practice. Such an approach does not make it possible to determine the types of inventions within medical practice, the conditions for granting them legal protection, in particular taking into account the correlation of interests of a patent holder and patients, the ethics of medical invention activities. This problem for Ukraine is relevant because it has a practical and theoretical basis. Modern Ukrainian legislation is aimed at harmonization with European law, in particular in the field of intellectual property, and scientific research in this area began to correlate with the achievements of European, American and other leading foreign scholars. 
The common problem that is researched by intellectual property professionals in Ukraine, the EU, and the United States is inventions within medical practice, since the requirements of humanity and morals offered for these inventions should be understood in the same way. These inventions can be predominantly admitted industrially suitable only after clinical trials over a person, which leads to competition of human rights to safety, health care and the right to modern medical care, which may include experimental trials to facilitate human treatment.

\section{THE AIM}

The objective of this article is theoretical and practical study of the legal protection of medical inventions in Ukraine based on the analysis of Ukrainian patent law, issued patents for inventions applied within medical practice, as well as data from the State Expert Center of the Ministry of Health of Ukraine. The main task was to formulate propositions for improving the legislation of Ukraine in the field of protecting inventions within medical practice. The main task was to characterize the inventions applied in medical practice, to identify the risk of these inventions, to offer propositions for improving the Ukrainian legislation in the field of protection of inventions in medical practice.

Materials and Methods

Understanding the essence of the legal protection of inventions within medical practice was accomplished through the use of methods of analysis and synthesis that were applied to normative and legal acts, scientific publications in the field of invention activities within medical practice. The analysis and further use of data from the State Expert Center of the Ministry of Health of Ukraine contributed to the definition of the problems of this publication, as well as to the formulation of the authors' vision of the features of inventions within medical practice. The application of the comparative and legal method made it possible to formulate propositions aimed at bringing Ukrainian legislation in line with European standards in the field of inventions that can be applied in medicine.

The article of Zoran Miladinovis, Siniša Varga, Marija Radojkovi, "Patent law protection inventions in medicine and pharmaceutical industry" [4] is focused on studying inventions in the medical and pharmaceutical field. Scholars divide inventions within medical practice on the following groups: substances or compositions for diagnostic, surgical and other purposes; inventions associated with surgical, therapeutic and diagnostic methods; product inventions (for example, medicaments and medicines). They determine that inventions in the field of medicine are divided into medical products (medical equipment, diagnostic methods) and pharmaceuticals (medicines). This is a broad approach to understanding the inventions within medical practice, covering both inventions in the field of medicine and pharmacy.

The work "Personalized Medicine and Patent Law" of Zeynep Timocin Cantekin, addresses the scientific issue of personalized medicine that is associated with such medical inventions as an isolated DNA molecule, and the method for comparing the sequence of samples taken from a patient's DNA to the declared standard sequence. These are inventions that can be patented as inventions of biotechnology [5]. This research makes it possible to refer biotechnological inventions to inventions that are used within medical practice. The inclusion of such inventions to patentable leads to the need to apply ethical norms that have the priority over legal ones. This is due to the fact that the creation of any invention, in particular in the field of medicine, involves the experiments that are always interfering with the human right to life and the protection of his health. Therefore, the authors of this article relied on the research outlined in the scientific work of Benjamin Mason Meier entitled "International Protection of Persons Undergoing Medical Experimentation: Protecting the Right of Informed Consent" [6].

We note that the problem of the protection of medical inventions in the Ukrainian legal science was not almost considered. Some scholars (for example, O. M. Slobodian) only referred to the issues of protecting inventions of biotechnology [7].

\section{REVIEW AND DISCUSSION}

Inventions within medical practice are the result of human intellectual activity in the field of medicine, which has novelty, inventive level, industrial suitability and is protected by a patent. Types of inventions within medical practice are: methods of human treatment; devices for the treatment and diagnosis of a person; medicines; strains of microorganisms used to diagnose a person's disease or his treatment; biotechnological inventions. These inventions are divided into two groups: medical and pharmaceutical.

The peculiarity of medical inventions is in their risks, which can be manifested in human experiments during clinical trials and risks for future production. The process of their invention activities is obligatory linked to clinical trials. Passing successful experiments on animals necessarily passes to the stage of trials over humans. Most inventions within medical practice have risks for the application in industry, and therefore, before being passed on to commercial organizations, medical tests should be conducted to minimize the technical risks associated with the biology and peculiarities of a human body [8]. The presence of a risk in medical inventions distinguishes them from other inventions. The risks of inventions within medical practice should be divided into risks for people undergoing clinical trials and manufacturers trying to use such inventions. Therefore, these inventions should be considered to a group of inventions with a possible risk.

Each of these inventions must undergo clinical trials that are necessary to achieve the benefit for a patient [9]. All clinical trials in Ukraine are conducted in accordance with international ethical principles to ensure the protection of the rights, safety and well-being of those under study. Clinical trials can only be conducted, if the expected benefit justifies the risk, as well as with the informed consent of a 
patient to conduct a clinical trial [10]. Ukraine is an open country for carrying out clinical trials of medical inventions and medicines.

One should pay attention to such a specific feature of inventions that can be applied in medical practice, as their compliance with ethical standards, which is that their creation can not violate the natural development of a man. In the case of the violation of the norms of morals, humanism while creating a medical invention by an inventor, it will not obtain patent and legal protection.

Medical practice in Ukraine is considered as a professional activity of medical and pharmaceutical employees who carry it out as professionals and specialists in the field of health care [11]. Therefore, inventions within medical practice are divided into two groups: medical inventions (used in medicine) and pharmaceutical inventions (related to the invention of medicines). Medical inventions include methods for treating humans; devices for the treatment and diagnosis of a person; strains of microorganisms used to diagnose a person's disease or his treatment; biotechnological inventions. Pharmaceutical inventions include medicinal drugs.

Inventions within medical practice obligatory undergo clinical trials. Medical and biological experiments on humans are allowed in Ukraine. Such a conclusion follows from the fact that according to the Art. 45 of the Law of Ukraine "Fundamentals of the Legislation of Ukraine on Health Care", the use of medical and biological experiments on people in Ukraine is allowed with a socially beneficial purpose, in case if they are scientifically sound, the benefits of possible success in the risk of causing grave consequences for health or life, publicity of experiments' application, full awareness and free consent of an adult capable individual, which is subject to experiment, with regard to the requirements of its application, and also in terms of preserving medical secrecy in necessary cases. It is forbidden to conduct a research experiment on patients, prisoners or prisoners of war, as well as a therapeutic experiment on people, whose diseases do not have a direct connection with the purpose of an experiment [12]. Information on clinical trials of drugs obtained from the State Expert Center of the Ministry of Health of Ukraine indicates on the number of such experiments. While researching this information, the authors of this article selected the direction "Dermatology" and divided the data depending on the manufacturer of medicinal products (national or international company). In total, experiments related to 46 medicinal products, including 43 products from national producers and 3 from international ones. 27 national and 16 international sponsors were identified within national applicants for the clinical trial. In regard to the correlation of the number of experiments in Ukraine and in the world, we provide the following sample data: 1) 100\% international investment company "Quintiles Ukraine", as of June 30, 2017, plans to conduct 190 experiments in Ukraine out of the planned 240 experiments in the world; 2) the Swiss company AbbVie Biopharmaceutical Sciences GmbH as of August 14, 2017 planned 225 experiments in Ukraine, and 1640 in the world
[13]. The given data indicates that clinical trials in Ukraine are conducted with respect to national and international drug manufacturers. Therefore, Ukraine is included in the system of world clinical experiments. In this case, clinical experiments are not part of the system of legal protection of these inventions.

Clinical experiments in Ukrainian law fall into the sphere of regulation of medical law, and the legal protection of inventions within medical practice is regulated by the norms of intellectual property. This state indicates the imperfection of modern Ukrainian intellectual property legislation. The Law of Ukraine "On Protection of the Rights to Inventions and Utility Models" [14] does not specify the features of the protection and patent procedure of these inventions, and does not establish any restrictions on the verification of their industrial suitability. Herewith, there is a precedent, when the features of the patent procedure for strains of microorganisms were determined. It is about the Instruction on the procedure for the storage of microorganisms' strains in Ukraine for the purpose of conducting a patent procedure, which indicates that the storage of microorganisms strains must precede the filing of an application for an invention [15]. Therefore, it is necessary to establish the peculiarities of the patent procedure concerning inventions that can be applied within medical practice. These may be the rules on the obligation to add documents on conducting clinical trials to the materials of the application for a patent for an invention. Providing documents for carrying out clinical trials allows both to establish the industrial suitability of such an invention, and additional guarantees for the future manufacturer of such an invention, as this, for example, will reduce production risks.

While considering inventions within medical practice it is necessary to determine their risks. The risk is a justified necessity, grounded by the need to attract hazardous objects in a certain area of activity [16]. The use of inventions within medical practice is always associated with the risk of unknowing consequences for the human body, but this risk is justified by the need for the development of medicine in the.

The risks to humans in the inventions applied within medical practice are related to the fact that these inventions include biotechnological inventions that, for example, are related to a human biological material. As it was previously mentioned Chinese scholar, Jiang-ying He, stated on the possibility of modifying human DNA [1]. Can such experiments that have been actually introduced into public life, affect the future of mankind? It is probably difficult to provide a clear answer nowadays, because there is a risk that people along with positive changes will get a negative mutation. To prevent this, it is necessary to introduce a single standard for the legal protection of biotechnological inventions. Thus, one of the problematic issues of the legal protection of medical inventions in Ukraine is the protection of biotechnological inventions. There is no concept of this invention in the Ukrainian patent law, and therefore researchers of intellectual property use the norms of the 
Directive of the European Parliament and of the Council of 6 July 1998 on the Legal Protection of biotechnological inventions. According to the Art. 3 of this Directive, "inventions which are new, which involve an inventive step and which are susceptible of industrial application shall be patentable even if they concern a product consisting of or containing biological material or a process by means of which biological material is produced, processed or used. Biological material which is isolated from its natural environment or produced by means of a technical process may be the subject of an invention even if it previously occurred in nature" [20]. The absence of the norms in the Ukrainian legislation that would regulate the relations in the field of biotechnological inventions may have negative consequences (for example, the abuse or use of such a state in someone's interests). However we believe that the restrictive mechanism today is the provisions of Part 1 of the Art. 6 of the Law of Ukraine "On the Protection of the Rights to Inventions and Utility Models", according to which the legal protection is provided to an invention that does not contradict the public order, the principles of humanity and morals and corresponds to the requirements of patentability [2]. The problem of this norm is that it has not received a clear interpretation and a mechanism for its implementation at the subordinate level. Just the notion of public morality, which is the system of ethical norms, rules of conduct that have been developed in society on the basis of traditional spiritual and cultural values, ideas about goodness, honor, dignity, public duty, conscience, justice (paragraph 11 of the Art. 1 of the Law of Ukraine "On the Protection of Public Morality") is legally consolidated [21]. Therefore, the lack of a correlation of ethical and legal norms in the invention activities and application of biotechnological inventions in Ukraine is a legal gap.

The peculiarities of inventions within medical practice are not taken into account in the legal protection of these inventions, in particular, it is not defined in the patent procedure and restrictions of patent rights in the interests of society. The patent and legal protection of inventions involves the exclusive rights of a patent holder to the invention. It is a particular problem for inventions within medical practice, since a patent may be a limitation for the treatment of many people. For example, the state spends more than $50 \%$ of all funds allocated for purchasing antiretroviral drugs for the treatment of patients with HIV / AIDS in Ukraine, because of patenting a vital drug for the treatment of HIV / AIDS (a drug lopinavir / ritonavir). The indicated drug is protected in Ukraine by two secondary patents (on the derivative substance and method of treatment), which created an artificial monopoly in Ukraine until 2026 [22]. This example was the first in the history of patent law in Ukraine, which revealed a lack of a regulated balance of interests between patent holders of the invention that can be applied in medical practice, and society. Society while determining the exclusivity of the rights of patent holders has the right to reserve cases of restricting the rights of patent holders, if the use of the patented object is necessary for society's life-sustaining activity. In this case, private interests depart from broader public interests. In order private interests of patent holders are not violated by the interference with a public element, in particular in the form of abuse by public authorities, the patent law should clearly identify the cases of restricting the rights of patent holders of medical and pharmaceutical inventions.

\section{CONCLUSIONS}

Based on the conducted research it has been established that inventions within medical practice are the result of human intellectual activity in the field of medicine, which has novelty, inventive level, industrial suitability and is protected by a patent. These inventions are related to inventions having a risk. The risks of inventions within medical practice should be divided into risks for people going through clinical trials and manufacturers who try to use these inventions. The presence of risks in these inventions distinguishes them from other inventions and indicates on their specific features.

The legal protection of inventions in the medical practice of Ukraine consists of a complex of the norms of medical law and intellectual property right. These norms do not have a relationship that negatively may affect the level of their industrial suitability and the risks while using these inventions. This state of Ukrainian legislation indicates the expediency of further scientific research of the topic concerning legal protection of inventions within medical practice.

It is appropriate in the patent law of Ukraine: to establish the peculiarities of the patent procedure concerning inventions that can be applied within medical practice (for example, the rule on the obligation to add documents on conducting clinical trials to the materials of the application for obtaining a patent for an invention); to supplement the patent law of Ukraine with the provision on biotechnological inventions; to identify cases of restrictions on the rights of the patent holder of medical and pharmaceutical inventions.

\section{REFERENCES}

1. Regan $H$, Wright $R$, Field A. Chinese gene-editing scientist defends his research, raises possibility of third baby. CNN. 2018. Available from: https://edition.cnn.com/2018/11/28/health/genetic-editing-hespeaks-int/index.html (In Ukrainian).

2. Konstytutsiia Ukrainy [The Constitution of Ukraine]: zakon Ukrainy vid 28.06.1996 No. 254K/96-BP. Available from: http://zakon.rada.gov.ua/ laws/show/254\%D0\%BA/96-\%D0\%B2\%D1\%80 (In Ukrainian).

3. Schwertner H.A. Patenting medical inventions. Mil Med. 1994 Dec;159 (12): 729-32.

4. MiladinoviüZ, VargaS, Radojkoviü M. Patent law protection of inventions in medicine and pharmaceutical industry. Military Medical and Pharmaceutical Journal of Serbia. 2013;70(6):600-605. doi: 10.2298/ VSP1306600M.

5. Cantekin ZT. Personalised Medicine and Patent Law. An Overview of the Patenting of Genetic Inventions under United States and European Law in Relation to Genetic Diagnostic Tests. Thrusters. Ph.D. Thesis, European University Institute, Florence. 2017 September 30. Available from: http://cadmus.eui.eu/bitstream/handle/1814/49748/Timocin_ Cantekin_2017_LLM.pdf?sequence=1\&isAllowed=y (In Ukrainian). 
6. Meier BM. International Protection of Persons Undergoing Medical Experimentation: Protecting the Right of Informed Consent. Berkeley Journal of International Law. 2002;20(3):513-554. doi: 10.15779/ Z38693R.

7. Slobodian OM. Etyko-pravovi problemy zastosuvannia biotekhnolohii [Ethical and Legal Problems of Application of Biotechnologies]. Universytetski naukovi zapysky. 2011;1:56-63. (In Ukrainian).

8. Toner M, Tompkins RG. Invention, Innovation, Entrepreneurship in Academic Medical Centers. Surgery. 2008;143(2):168-171. doi: 10.1016/j.surg.2007.11.004.

9. Mehta H, Tidwell L, Liotta LA. Inventions and Patents: A Practical Tutorial; In: Espina V. (eds) Molecular profiling. Methods in Molecular Biology. 2017;1606:237-254. doi: 10.1007/978-1-4939-6990-6_25.

10. Poriadok provedennia klinichnykh vyprobuvan likarskykh zasobiv ta ekspertyzy materialiv klinichnykh vyprobuvan [Conduct clinical trials and expertise of clinical trials]: nakaz Ministerstva okhorony zdorovia Ukrainy vid 23.09.2009 No. 690. Available from: http://zakon.rada.gov. ua/laws/show/z1010-09 (In Ukrainian).

11. Zahynei Z, Shmal L. Medychna praktyka yak dozvolenyi vyd diialnosti v antykoruptsiinomu zakonodavstvi Ukrainy [Medicai practice as permitted activity in anti-corruption legislation Ukraine]. Naukovyi chasopys Natsionalnoi akademii prokuratury Ukrainy. 2017;2:51-67. Available from: http://www.chasopysnapu.gp.gov.ua/ua/pdf/2-2017/ zaginej.pdf (In Ukrainian).

12. Osnovy zakonodavstva Ukrainy pro okhoronu zdorovia (Fundamentals of the Legislation of Ukraine on Health (are): zakon Ukrainy vid 19.11.1992 No. 2801-XII. Available online: http://zakon.rada.gov.ua/ laws/show/2801-12 (In Ukrainian).

13. Informatsiia shchodo klinichnykh vyprobuvan v Ukraini. Profil vyprobuvannia: Dermatolohiia [Information on clinical trials in Ukraine. Test profile: Dermatology]. Derzhavnyi ekspertnyi tsentr Ministerstva okhorony zdorovia Ukrainy. Available from: https://clinicaltrials.dec. gov.ua/ (In Ukrainian).

14. Pro okhoronu prav na vynakhody i korysni modeli [0n the Protection of Rights to Inventions and Utility Models]: zakon Ukrainy vid 15.12.1993 No. 3687-XII. Available from: http://zakon5.rada.gov.ua/laws/ show/3687-12/page (In Ukrainian).

15. Instruktsiia pro poriadok deponuvannia v Ukraini shtamiv mikroorhanizmiv z metoiu zdiisnennia patentnoi protsedury [Instruction on the order of depositing in Ukraine strains of microorganisms for the purpose of carrying out a patent procedure]: nakaz Derzhpatentu Ukrainy ta Natsionalnoi akademii nauk Ukrainy vid 26.06.1995 No. 106/115. Available from: http://zakon.rada.gov.ua/laws/show/z028695 (In Ukrainian).

16. Petrytsyn NT. Ryzyk ta vidpovidalnist u tsyvilnomu prav [Risk and responsibility in civil law]. Chasopys Akademii advokatury Ukrainy. 2012;1(14):1-5. (In Ukrainian).
17. Seniuta IYa. Tsyvilni pravovidnosyny u sferi provedennia medychnykh doslidiv [Civil-Legal Relations in the Sphere of Carrying out Medical Experiments]. Medychne parvo. 2018;1(21):42-53. (In Ukrainian).

18. Juhn P, Phillips A, Buto K. Balancing Modern Medical Benefits And Risks. Health Affairs. 2007;26(3):647-652. doi:10.1377/hlthaff.26.3.647.

19. Thimbleby $H$. Technology and the future of healthcare. Journal of Public Health Research. 2013;2(3):28. doi:10.4081/jphr.2013.e28.

20. Directive 98/44/EC of the European Parliament and of the Council of 6 July 1998 on the Legal Protection of biotechnological inventions. Available from: http://www.wipo.int/wipolex/ru/text.jsp?file_id=126957.

21. Pro zakhyst suspilnoi morali [0n the Protection of Public Morality]: zakon Ukrainy vid 20.11.2003 No. 296-IV. Available from: http://zakon.rada. gov.ua/laws/show/1296-15 (accessed on 10 December 2018).

22. Demetska 0 . Reformuvannia sfery okhorony zdorovia mekhanizmamy prava intelektualnoi vlasnosti [Reformation of healthcare by mechanisms of intellectual property rights]. Farmatsevt Praktik. 2017;7-8:39-47. Available from: http://nbuv.gov.ua/UJRN/farmpr_2017_7-8_4 (In Ukrainian).

\section{Author Contributions:}

Conceptualization, Valeriy Yusupov and Olga Avramova; Formal analysis, Valeriy Yusupov and Nataliia Larina; Methodology, Olga Bespalova and Tetyana Krasiuk; Validation, Olga Bespalova, Nataliia Larina and Olga Avramova;

Visualization, Nataliia Larina and Tetyana Krasiuk; Writing - original draft, Valeriy Yusupov, Olga Bespalova and Olga Avramova;

Writing - review and editing, Valeriy Yusupov, Tetyana Krasiuk and Olga Avramova.

\section{Conflict of interest:}

The Authors declare no conflict of interest.

\section{CORRESPONDING AUTHOR}

\section{Olha Ye. Avramova}

Kharkiv National University of Internal Affairs

L. Landau avenue, 27, 61080 Kharkiv, Ukraine

tel: +380686057321

e-mail:avramova.o.y@ukr.net

Received: 20.12 .2018

Accepted: 27.02 .2019 
OPIS PRZYPADKU

CASE REPORT

\title{
BAKTERIEMIA WYWOŁANA PRZEZ OCHROBACTRUM ANTHROPI - NIETYPOWE POSTĘPOWANIE
}

\section{BACTERIA CAUSED BY OCHROBACTRUM ANTHROPI - UNUSUAL BEHAVIOR}

\author{
Jolanta Grabowska-Markowska' ${ }^{1}$, Iwona Pawłowska' ${ }^{2}$, Grzegorz Ziółkowski ${ }^{3}$, Jadwiga Wójkowska-Mach ${ }^{4}$ \\ 'SPOŁECZNE TOWARZYSTWO HOSPICJUM CORDIS, KATOWICE, POLSKA \\ ${ }^{2}$ WOJEWÓDZKI SZPITAL SPECJALISTYCZNY NR 5 IM. ŚW. BARBARYW SOSNOWCU, SOSNOWIEC, POLSKA \\ ${ }^{3}$ WYŻSZA SZKOŁA MEDYCZNA W SOSNOWCU, SOSNOWIEC, POLSKA \\ 4KATEDRA MIKROBIOLOGII, COLLEGIUM MEDIUM, UNIWERSYTET JAGIELLOŃSKI, KRAKÓW, POLSKA
}

\begin{abstract}
STRESZCZENIE
0. anthropi, dawniej znany jako Achromobacter jest tlenową, Gram-ujemną pałeczką, szeroko rozpowszechnioną w środowisku, w różnych niszach ekologicznych. Obecnie jest to pojawiający się drobnoustrój oportunistyczny związany z opieką zdrowotną, a także infekcjami u osób z upośledzoną odpornością, głównie u dzieci i noworodków. Autorzy prezentowanej pracy przedstawiają przypadek 13-letniej pacjentkiz chorobą neurodegeneracyjną, u której z posiewu krwi izolowano 0 . anthropi. Chora była hospitalizowana w Społecznym Towarzystwie Hospicjum Cordis w Katowicach, a po wypisie z hospicjum została objęta domową opieką długoterminowa pod nadzorem lekarza rodzinnego. Obraz kliniczny 0 . anthropi może być bardzo różny, powoduje ciężkie zakażenia, jak np. zakażenia krwi. Z powodu trudności w identyfikacji Ochrobactrum anthropi może stanowić wyzwanie diagnostyczne i terapeutyczne. Trudność w różnicowaniu Ochrobactrum spp. jest związana również z brakiem jednoznacznego obrazu klinicznego zakażenia przebiegającego z bakteriemią 0 . anthropi. Ponadto drobnoustrój ten jest trudny do leczenia, ze względu na naturalne szerokie spektrum oporności na antybiotyki.
\end{abstract}

SŁOWA KLUCZOWE: Ochrobactrum anthropi, diagnoza, sepsa

\begin{abstract}
0. anthropi, formerly known as Achromobacter, is an aerobic, Gram-negative bacillus, widespread in the environment, in various ecological niches. Currently, it is an emerging opportunistic microorganism associated with health care, as well as infections in people with immunodeficiency, mainly in children and newborns. The authors of the presented work present a case of a 13-year-old female patient with a neurodegenerative disorder in which 0 . anthropi was isolated from blood cultures. She was hospitalized in the Social Society of the Cordis Hospice in Katowice, and after discharge from the hospice she was covered by long-term home care under the supervision of a family doctor. Clinical picture 0 . anthropi can be very different, causes serious infections, such as blood infections. Due to difficulties in identification, Ochrobactrum anthropi can be a diagnostic and therapeutic challenge. The difficulty in differentiating Ochrobactrum spp. Is also related to the lack of a clear clinical picture of infection with bactera 0 .anthropi. In addition, this microorganism is difficult to treat due to the natural broad spectrum of antibiotic resistance.
\end{abstract}

KEY WORDS: Ochrobactrum anthropi, diagnosis, sepsis

Wiad Lek 2019, 72, 3, 489-492

\section{WSTĘP}

Ochrobactrum anthropi jest tlenową, Gram-ujemną pałeczką, szeroko rozpowszechnioną w środowisku, w różnych niszach ekologicznych: roślinnych i zwierzęcych oraz w glebie. Zakażenia pałeczką O. anthropi dotyczą głównie osób z upośledzoną odpornością, w tym dzieci i noworodków, pacjentów dializowanych czy pacjentów z mukowiscydozą oraz zazwyczaj są związane ze stosowaniem linii donaczyniowych - szczególnie cewnika centralnego [1-3]. Pałeczka ta należy do rodziny Brucellacae i rodzaju Ochrobacterium, dotychczas potwierdzono, że przyczyną zakażeń u ludzi, oprócz O. anthropi, są jeszcze O. intermedium i O.pseudointermedium [4].
Obraz kliniczny O. anthropi może być bardzo różny, powoduje ciężkie zakażenia, jak ropne martwicze zapalenie powięzi, septyczne zapalenie stawów, zapalenie otrzewnej, zapalenie płuc, zapalenie kości, gałki ocznej czy zakażenia krwi związane $\mathrm{Z}$ cewnikiem (catheter-related bloodstream infections) [5-14]. O. anthropi ma bardzo szerokie spektrum oporności na antybiotyki, w tym na antybiotyki $\beta$-laktamowe, co sprawia, że zakażenia wywołane przez ten drobnoustrój są trudne do leczenia $[2,3,11]$.

\section{OPIS PRZYPADKU}

13-letnie dziecko płci żeńskiej z chorobą neurodegeneracyjną - postępujące porażenie nadjądrowe, związaną 
z zanikiem komórek nerwowych, zostało przyjęte w dniu 20.07.2018 r. do Społecznego Towarzystwa Hospicjum Cordis w Katowicach. W leczeniu steroidy były stosowane sporadycznie, najczęściej w postaci nebulizacji w trakcie infekcji z występującą dusznością oddechową (ostatnio w marcu 2018 r). Ze względu na obraz kliniczny w zakresie rozpoznania infekcji podano również antybiotyk ceftriakson.

Powodem przyjęcia były występujące od dnia 18.07.2018 r. objawy infekcji, tj.: temperatura ciała powyżej $39,5^{\circ} \mathrm{C}$, trudności w oddawaniu moczu, obrzęki stóp, luźne stolce, znaczne osłabienie i apatia, a wyniki badań z dnia 19.07.2018 r. wskazywały na poważny stan kliniczny: leukocytoza wynosiła $11,11\left(10^{\star} / 3 \mathrm{uL}\right)$, hemoglobina 9,5 g/dL, CRP 91,91 mg/l, Ca 8,4 (mg/dl).

W dniu przyjęcia pobrano m.in mocz na posiew oraz rozpoczęto dożylną terapię ceftriaksonem i leczenie wspomagające: leki przeciwgorączkowe, przeciwbiegunkowe Smekta, Hidrasec, Furosemid, dożylne uzupełnienie zaburzeń gospodarki wodnej i kwasowo-zasadowej.

Pacjentka była przyjęta $\mathrm{z}$ założonym cewnikiem centralnym CVC (central venous catheters), który ani w chwili przyjęcia, ani w trakcie pobytu nie został usunięty w związku z klinicznymi wskazanymi do do stosowania CVC, nie był też wymieniany - codzienna kontrola nie wykazywała zmian miejscowych. Sylikonowy cewnik do pęcherza moczowego wymieniano regularnie, co 21 dni. W trakcie hospitalizacji u pacjentki stosowano również okresowo tlenoterapię z zastosowaniem koncentratora tlenu w celu zmniejszenia duszności po rozważeniu i wykluczeniu zaburzeń nerwicowych i adaptacyjnych.

W dniu 24 lipca 2018 r. poziom CRP (C Reactive Protein) wynosił 56,93 mg/l, leukocytoza 11,29 (10*/3uL), a hemoglobina $10,00(\mathrm{~g} / \mathrm{dL})$, a z posiewu moczu uzyskano znamienną bakteriurię o etiologii Pseudomonas aeruginosa i wdrożono terapię celowaną z zastosowaniem piperacyliny z tazobaktamem do dnia 07.08.2018 roku.

W dniu 30.07.2018 roku stwierdzono spadek poziomu CRP do $25,6 \mathrm{mg} / \mathrm{l}$, leukocytozy $8,93\left(10^{\star} / 3 \mathrm{uL}\right)$ oraz hemoglobiny 9,6 g/dL, podwyższeniu uległ poziom Ca całk. 9,3 mg/dl oraz zaobserwowano stopniowe ustępowanie objawów klinicznych, tj. normalizację temperatury, stolców, poprawę diurezy, stopniowe ustępowanie obrzęków. W dniu 03.08.2018 roku poziom CRP wyniósł 22,2 mg/l.

Niestety w dniu 6.08.2018 r. nastąpiło pogorszenie i obserwowano zmianę obrazu klinicznego choroby, u dziecka wystąpiły wymioty, dwukrotnie luźne stolce, stan podgorączkowy. Wyniki przeprowadzonych badań: leukocytoza 9,8 (10*/3uL), hemoglobina 9,3 (g/dL), Ca całk. 8,9 (mg/ dl), a CRP 52,44 (mg/l). Pobrano krew na posiew, z której izolowano pałeczki Klebsiella pneumoniae o fenotypie oporności typu ESBL (Extended-Spectrum Beta-lactamases) wrażliwe na piperacylinę $\mathrm{z}$ tazobaktamem, ale oporną na ceftazydym. Równolegle wykonano posiew moczu, który dał identyczny wynik jak wykonany wcześniej, tj. w dniu 24.07.2018 i był to ponownie Pseudomonas aeruginosa wrażliwy na piperacylinę $\mathrm{z}$ tazobactamem, ceftazydym, tobramycynę, a oporny na gentamycynę.
Wbrew wynikowi uzyskanemu z krwi podjęto decyzję o kontynuacji leczenia w kierunku zakażenia układu moczowego i w dniu 07.08.2018 r. zmieniono antybiotyk na ceftazydym, a terapię kontynuowano do 15.08.2018 r. Uzyskano poprawę stanu klinicznego pacjentki potwierdzoną wynikami badań analitycznych, w dniu 13.08.2018 r. poziom CRP wyniósł $8,67 \mathrm{mg} / \mathrm{l}$, leukocytoza 7,3 (10*/3uL), hemoglobina $10,3 \mathrm{~g} / \mathrm{dL}$, Ca całk 10,4mg/dl, kreatynina $0,32 \mathrm{mg} / \mathrm{dl}$.

$\mathrm{Z}$ powodu podwyższonego CRP oraz utrzymujących się stanów podgorączkowych, w dniu 13.08 .18 r. pobrano krew na posiew. Nie dokonano oznaczenia prokalcytoniny z powodu braku odczynnika. Z krwi pobranej na posiew izolowano pałeczki $O$. anthropi oporne na piperacylinę z tazobactamem (minimalne stężenie hamujące wzrost drobnoustroju, MIC $64 \mu \mathrm{g} / \mathrm{ml}$ ) i ceftazydym (MIC $64 \mu \mathrm{g} / \mathrm{ml}$ ) oraz wszystkie pozostałe testowane antybiotyki, $\mathrm{z}$ wyjątkiem imipenemu (MIC 0,25 $\mu \mathrm{g} / \mathrm{ml}$ ) i meropenemu (MIC $0,12 \mu \mathrm{g} / \mathrm{ml}$ ). Ze względu na to, że pacjentka nie miała gorączki (powyżej $38^{\circ} \mathrm{C}$, dreszczy oraz hipotencji) nie wdrożono celowanej antybiotykoterapii, pomimo dodatniego posiewu krwi. W tym przypadku należało dążyć do poszerzenia diagnostyki mikrobiologicznej o badanie cewnika naczyniowego celem potwierdzenia obecności drobnoustroju w cewniku i jego okresowego wysiewu do łożyska naczyniowego, co skutkowałoby ewentualną zmianą zastosowanego schematu leczenia przeciwdrobnoustrojowego.

W dniu wypisu 15.08.2018 r. na życzenie opiekunów, pacjentka została wypisana $\mathrm{z}$ hospicjum do domu w stanie ogólnym dobrym, stabilnym. Domowa opieka długoterminowa była kontynuowana pod nadzorem lekarza rodzinnego w odległości około $60 \mathrm{~km}$ i nie była powiązana z pierwotnym miejscem hospitalizacji.

W dniu 19.08.2018 r. lekarz rodzinny opiekujący się pacjentką stwierdził u dziecka stany podgorączkowe, wymioty i biegunki. W dniu 22.08.2018 r. bez pobrania materiałów do badań mikrobiologicznych wdrożono empiryczną terapię amikacyną $15 \mathrm{mg} / \mathrm{kg} 1 \mathrm{x}$ dziennie $i v$, zmienioną w dniu 29.08.2018 na tobramycynę $3 \mathrm{mg} / \mathrm{kg} 1$ $\mathrm{x}$ dziennie $i v$. W drugiej połowie września i w pierwszej połowie października 2018 r., a następnie w drugiej połowie października 2018 r. przy stabilnym stanie klinicznym dziecko było ponownie poddane empirycznej dożylnej antybiotykoterapii aminoglikozydami realizowanej do końca listopada 2018 roku, kiedy też usunięto cewnik centralny, który nie został przesłany do badania mikrobiologicznego, z powodu brak zmian zapalnych w miejscu wkłucia. Jednak pomimo braku zmian miejscowych, w przypadku izolacji z krwi rzadkiego czynnika etiologicznego, należałoby również wykluczyć kontaminację cewnika.

Należy w tym miejscu zauważyć, że aminoglikozydy stosowane w monoterapii innych zakażeniach niż zakażenia układu moczowego są mniej skuteczne niż antybiotyki $\beta$-laktamowe i ich stosowanie w dłuższym okresie czasowym może zwiększać ryzyko działań niepożądanych, jak i wyższej śmiertelności. Stosowanie tych antybiotyków nie zwalnia lekarza od wykonywania badań mikrobiolo- 
gicznych jako konsultacji medycznej. W tym przypadku takiej konsultacji medycznej nie przeprowadzono. Terapię antybiotykami aminoglikozydowymi należy przerywać po uzyskaniu poprawy klinicznej lub po otrzymaniu wyniku badania mikrobiologicznego. Jednak dłuższe stosowanie antybiotyków aminoglikozydowych jest zalecane w infekcyjnym zapaleniu wsierdzia. Autorzy pracy nie potrafią powiedzieć, czy lekarz rodzinny takie rozpoznanie postawił, można jedynie przypuszczać po długości stosowanie tych preparatów, że takie rozpoznacie było brane pod uwagę. Infekcyjne zapalenie wsierdzia jest bowiem schorzeniem o zróżnicowanym obrazie klinicznym i uzewnętrznia się szeregiem nieswoistych objawów.

Identyfikację wszystkich izolowanych szczepów wykonano z zastosowaniem systemu automatycznego Phoenix 100 (Becton Dickinson). Identyfikację O.anthropi potwierdzono techniką MALDI-TOF MS-Matrix Assisted Laser Desorption/Ionization Time-of-Flight Mass Spektrometry (Bruker Daltonik, Germany). Do identyfikacji i określania lekowrażliwości zastosowano panele combo NMIC/ ID-204. Testy lekowrażliwości interpretowano zgodnie z zaleceniami EUCAST, http://www.eucast.org/.

\section{OMÓWIENIE}

Chociaż przypadki patogeniczności O. anthropi są rzadkie, istnieje kilka udokumentowanych przypadków pokazujących, że zakażenia o tej etiologii dotyczą głównie osób z obniżoną odpornością, z wyniszczającymi chorobami lub nowotworami złośliwymi, chociaż Rastogi opisał zapalenie opon mózgowych $O$. anthropi u immunokompetentnego pacjenta chirurgicznego [15]. Zakażenia O. anthropi były opisywane przez autorów $\mathrm{z}$ różnych części świata $[3,16$, 17], ale najwięcej doniesień dotyczących zakażeń krwi pochodzi z Indii i były to sepsy noworodkowe $[2,11]$ oraz u osób dorosłych $[9,10,18]$. Większość opisanych przypadków zakażeń była związana ze stosowaniem cewników naczyniowych, co wskazuje że prawdopodobnie podstawowym patomechanizmem tych zakażeń jest wcześniejsza kontaminacja cewnika donaczyniowego $[3,5,6,8,10,11]$.

W przypadku opisanej pacjentki najważniejszym czynnikiem rozwoju zakażenia o tak rzadkiej etiologii była choroba podstawowa, stosowanie steroidów, antybiotyków wpływających na upośledzenie układu immunologicznego oraz na pewno unieruchomienie dziecka i nie doleczone infekcje, a także brak stałej kontroli mikrobiologicznej związanej z ordynowanymi antybiotykami.

Ochrobactrum anthropi może stanowić wyzwanie diagnostyczne i terapeutyczne, głównie z powodu trudności w identyfikacji, np. opisywano mylne oznaczenie jako wielooporny niefermentujący oksydazododatni szczep Pseudomonas, Burkholderia, Sphingomonas, Sphingobacterium, Elizabethkingia, Alcaligenes, Agrobacterium czy Empedobacter [9, 10]. Trudność w różnicowaniu Ochrobactrum spp. jest związana również z brakiem jednoznacznego obrazu klinicznego zakażenia przebiegającego z bakteriemią O. anthropi [4]. Dlatego w ocenie autorów identyfikacja zakażenia $O$. anthropi na podstawie posiewu krwi u pacjenta z obniżoną odpornością była możliwa nawet przy braku pełnoobjawowego zakażenia krwi, tj. ze skąpymi objawami klinicznymi ze względu na wyciszoną odpowiedź immunologiczną i trudnością w klinicznej interpretacji reakcji zapalnych monitorowanych za pomocą np. nieswoistego białka CRP $[2-4,18,19]$.

Oporność pałeczek $O$. anthropi na antybiotyki $\beta$-laktamowe, w tym oporność na inhibitory $\beta$-laktamazy $\mathrm{z}$ wyjątkiem karbapenemów, związana jest $\mathrm{z}$ wytwarzaniem $\beta$-laktamaz typu AmpC, OCH-1 [9, 10, 14]. W naszym przypadku izolowany szczep O. anthropi był wrażliwy tylko na karbapenemy, tj. imipenem i meropenem, co znalazło potwierdzenie $\mathrm{w}$ innych doniesieniach $[2,9,10]$.

W opisywanym przypadku dziecko było leczone początkowo piperacyliną z tazobaktamem, a następnie ceftazydymem, chociaż O. anthropi in vivo wykazywał oporność na te antybiotyki. Pacjentka jednak dobrze zareagowała na leczenie, a antybiotyk nie wymagał zmiany, co ma głównie związek z prawdopodobną stosunkową niską jego wirulencję. Potwierdzają to wcześniejsze doniesienia, które wskazują na dobre rokowania, zarówno u pacjentów immunokompetentnych [17, 19], jak i w neutropenii (biorców przeszczepów), u których opisuje się ustąpienie bakteriemii nawet bez podawania antybiotyków [20].

Przypisywanie patogeniczności pojawiającemu się oportunistycznemu patogenowi, jakim jest O. anthropi pozostaje zagadką kliniczną, ponieważ z jednej strony może on nie pasować do objawów klinicznych, stosowanej terapii drobnoustrojowej i rokowania pacjenta, chociaż z drugiej strony może odgrywać rolę w zaostrzeniu innych chorób współistniejących. Powyższy problem dotyczy szczególnie pacjentów nieimmunokompetentnych, bez względu na wiek i chorobę podstawową.

\section{PODSUMOWANIE}

Leczenie każdego przypadku zakażenia wymaga staranności, szczególnie w zakresie korzystania ze źródeł informacji: wywiad, dane kliniczne, wyniki badań analitycznych i równolegle, kiedy wymaga tego sytuacja, również badań mikrobiologicznych. Badania mikrobiologiczne są rodzajem specyficznej konsultacji medycznej mającej na celu ustalenie czynnika etiologicznego zakażenia, jak i jego wzoru oporności, a następnie współpracy w zakresie stosowanej antybiotykoterapii. Nie każdy pacjent wymaga leczenia przeciwdrobnoustrojowego, ale każde leczenie przeciwdrobnoustrojowe wymaga rzetelnej analizy danych: klinicznych dotyczących przede wszystkim stanu pacjenta i jego obciążeń oraz mikrobiologicznych dotyczących wyników badań różnych materiałów pobranych w różnym czasie, w tym cewnika donaczyniowego w celu wykluczenia jego kontaminacji przy braku cech zakażenia odecewnikowego. Prezentowany przypadek pokazuje, że pomimo obrazu klinicznego i wykonanych badań diagnostycznych, w tym mikrobiologicznych, stosowano preparaty przeciwbakteryjne niezgodnie z otrzymanymi wynikami badań mikrobiologicznych. Należy również zauważyć, że podanie antybiotyków w terapii empirycznej nie zwalnia lekarza 
z obowiązku wykonywania badań mikrobiologicznych, jak i też oceny farmakodynamicznej i farmakokinetycznej stosowanych antybiotyków. Stosowanie aminoglikozydów w monoterapii, oprócz zakażeń układu moczowego, nie jest zalecane. Zalecane jest w przypadku podejrzenia lub rozpoznania infekcyjnego zapalenia wsierdzia. Równocześnie przy stosowaniu tego typu antybiotyków wymagane jest określanie stężenia leku w surowicy.

\section{PIŚMIENNICTWO}

1. Bizet C, Bizet J. Comparative susceptibility of Ochrobactrum anthropi, Agrobacterium tumefaciens, Alcaligenes faecalis, Alcaligenes denitrificans subsp. denitrificans, Alcaligenes denitrificans subsp. xylosidans and Bordetella bronchiseptica against 35 antibiotics including 17 beta-lactams. Pathol Biol (Paris). 1995;43(4):258-263.

2. Gupta A, Chauhan K, Pandy A. Neonatal Septisemia by 0.anthropi: A Missed Pathogen. Int Curr Microbiol App Sci. 2018;7(05):1651-1654.

3. Kettaneh A, Weill F, Poilane let al. Septic Shock Caused by Ochrobactrum anthropi in an Otherwise Healthy Host. J. Clin Microbiol. 2003. J Clin Microbiol. 2003; 41(3): 1339-1341.

4. Hagiya H, OhnishiK, Maki M et al. Clinical characteristics of Ochrobactrum anthropi bacteremia. J ClinMicrobiol. 2013;51:1330-1333.

5. Graham RLJ, Sharma MK, Ternan NG et al. A semi-quantitative GeLC-MS analysis of temporal proteome expression in the emerging nosocomial pathogen Ochrobactrum anthropi. Genome Biol. 2007;8(6):R110.

6. Mrozek S, Dupuy M, Hoarau L. Brain empyema due to Ochrobactrum anthropi. Med Mal Infect. 2014;44(3):128-129.

7. Chiu LQ, Wang W. A case of unusual Gram-negative bacilli septic arthritis in an immunocompetent patient. Singapore Med J. 2013;54(8):e164-168.

8. Naik C, Kulkarni H, Darabi A et al. Ochrobactrum anthropi: a rare cause of pneumonia. J Infect Chemother. 2013;19(1):162-165.

9. Khan ID, Mukherjee T, Gupta S et al. Ochrobactrum anthropi sepsis in Intensive Tertiary Care. J Basic Clinical Med. 2014, 3(1):18-20.
10. Khan ID, Sahni AK, Sharma UK et al. Bacterial infections and emerging resistance in renal transplant recipients. Bangladesh J Med Sci. 2015;14:14-21 doi: http://dx.doi.org/10.3329/bjms.v14i1.16306

11. MudshingkarSS, Chore AC, PalewarMSetal. O.anthropi:An unsual pathogen: Are we misssing them?. Indian J Med Mikrobiol. 2013;31:306-308;

12. Song S, Ahn JK, Lee GH et al. An epidemic of chronic pseudophakic endophthalmitis due to 0 chrobactrum anthropi: clinical findings and managements of nine consecutive cases. Ocul Immunol Inflamm. 2007; 15(6):429-434.

13. Mattos FB, Saraiva FP, Angotti-Neto H et al. Outbreak of Ochrobactrum anthropi endophthalmitis following cataract surgery. J Hosp Infect. 2013;83(4):337-340.

14. Romero Gómez MP, Peinado Esteban AM, Sobrino Daza JA et al.. Prosthetic mitral valve endocarditis due to 0chrobactrum anthropi: case report. J Clin Microbiol . 2004;42(7):3371-3373.

15. Rastogi N, Mathur P. Ochrobactrum anthropi: An emerging pathogen causing meningitis with sepsis in a neurotrauma patient. J Infect Dev Ctries. 2017;11(9): 733-735.

16. CieslakTJ, Robb ML, Drabick CJ et al. Catheter-associated sepsis caused by 0 chrobactrum anthropi: report of a case and review of related nonfermentative bacteria. Clin Infect Dis. 1992;14:902-907.

17. Vaidya SA, Citron DM, Fine MB et al. Pelvic abscess due to 0 chrobactrum intermedium corrected in an immunocompetent host: Case report and review of the literature. J Clin Microbiol. 2006;44:1184-1186.

18. Arora U, Kaur S, Devi P. Ochrobactrum anthropi septicaemia. Indian J Med Microbiol.2008;26:81-83.

19. Yu WL, Lin CW, Wang DY. Clinical and microbiologic characteristics of Ochrobactrum anthropibacteremia.J Formos Med Assoc. 1998;97:106-112.

20. Ezzedine H, Mourad M, Van Ossel C et al. An outbreak of Ochrobactrum anthropi bacteraemia in five organ transplant patients. J Hosp Infect. 1994;27:35- 42

Konflikt interesów:

Autorzy deklarują brak konfliktu interesów.

\section{AUTOR KORESPONDUJĄCY Grzegorz Ziółkowski \\ Wyższa Szkoła Medyczna w Sosnowcu, Wojska Polskiego 6, 41-200 Sosnowiec, Polska tel. (32) 2911019, fax. (32)2634013 wew,219 e-mail:nc3@wp.pl.}

Nadesłano: 01.02.2019

Zaakceptowano: 04.03.2019 
OPIS PRZYPADKU

CASE REPORT

\title{
POWIKŁANIA LECZENIA IMMUNOSUPRESYJNEGO W PRZEBIEGU CIĘŻKIEJ POSTACI ATOPOWEGO ZAPALENIA SKÓRY - OPIS PRZYPADKU
}

\section{COMPLICATIONS OF IMMUNOSOPRESSION TREATMENT IN HEAVY THERAPY FOR ATOPIC SKIN - CASE DISCUSSION}

\author{
Joanna Zajączkowska' , Jadwiga Korzeniowska² \\ 'WYDZIAŁ HUMANISTYCZNY, AKADEMIA HUMANISTYCZNO-EKONOMICZNA W ŁODZI, ŁÓDŹ, POLSKA \\ 2ZAKŁAD MEDYCYNY RATUNKOWEJ I MEDYCYNY KATASTROF UNIWERSYTET MEDYCZNY W ŁODZI, ŁÓDŹ, POLSKA
}

\begin{abstract}
STRESZCZENIE
Atopowe zapalenie skóry (AZS) jest schorzeniem o zróżnicowanym i nieprzewidywalnym przebiegu klinicznym. Może występować u chorych w każdym wieku, niezależnie od płci. Etiologia schorzenia oraz jego patomechanizm nie zostały dokładnie wyjaśnione. W przebiegu AZS występuje różnorodność objawów chorobowych, co stwarza częste problemy diagnostyczne. Wśród objawów dominują świąd i suchość skóry, z towarzyszącymi zmianami wypryskowymi. Leczenie jest trudne i długotrwałe, zarówno miejscowe, jak i ogólne. U chorych z ciężkim przebiegiem schorzenia stosuje się również leczenie immunosupresyjne, obarczone jednak występowaniem groźnych działán niepożądanych. W przedstawionym przypadku klinicznym potwierdzono złożoność obrazu klinicznego choroby oraz jego zróżnicowanie. Opisano występujące powikłania leczenia, wśród nich wystąpienie skrajnej leukopenii po wdrożeniu azatiopryny.
\end{abstract}

SŁOWA KLUCZOWE: atopowe zapalenie skóry, świąd, zmiany skórne, immunosupresja, powikłania

\begin{abstract}
Atopic dermatitis (AD) is a disorder with a diverse and unpredictable clinical course. It can occur in patients of all ages, regardless of gender. The aetiology of the disease and its pathomechanism have not been clearly explained. In the course of ad, there is a variety of disease symptoms, which causes frequent diagnostic problems. Symptoms are pruritus and dry skin with accompanying eczema. Treatment is difficult and long-lasting, both local and general. In patients with severe course of the disease, immunosuppressive treatment is also applied, however, it is burdened with dangerous side effects. In the presented clinical case, the complexity of the clinical picture of the disease and its differentiation were confirmed. Complications of treatment have been described, including the occurrence of extreme leukopenia after the implementation of azathioprine.
\end{abstract}

KEY WORDS: atopic dermatitis, pruritus, skin changes, immunosuppression, complications

Wiad Lek 2019, 72, 3, 493-499

\section{WSTĘP}

Atopowe zapalenie skóry (AZS) jest schorzeniem o zróżnicowanym i nieprzewidywalnym przebiegu klinicznym, zakwalifikowanym do grupy chorób cywilizacyjnych. W ciągu ostatnich kilkudziesięciu lat, liczba chorych na świecie zwiększyła się blisko dwukrotnie. Jej średnia częstość występowania szacowana jest w granicach 1-20\% w całej populacji ludzkiej, a zróżnicowanie to jest zależne od regionu świata. Może występować u chorych w każdym wieku, niezależnie od płci [1]. Istotą choroby są zaburzenia w układzie immunologicznym. Na etiologię choroby znaczny wpływ mają różne czynniki alergizujące. Istotne są też czynniki genetyczne i środowiskowe, uwarunkowane rozwojem gospodarczym i związanym z nim zanieczyszczeniem środowiska, na które w sposób bezpośredni jest narażona skóra. Współistniejące zaburzenia ze strony układu immunologicznego predysponują do rozwinięcia się atopowego zapalenia skóry [2]. Obserwuje się podwyższone poziomy immunoglobulin klasy E, które uznano za istotny element atopii. Wykazano związek mutacji genu kodującego białko filagrynę z nieprawidłową budową bariery naskórka, czego konsekwencją jest zaburzenie funkcji ochronnej skóry. Niedobór filagryny prowadzi do niedoboru NMF (Natural Moisturizing Factor - czynnik nawilżający, który naturalnie występuje w skórze), a to z kolei powoduje wzrost pH skóry i jej nadmierną kolonizację przez gronkowca złocistego. Czynniki te prowadzą do wysuszenia skóry i potęgują świąd [3]. Patomechanizm choroby nie został do końca wyjaśniony, a podstawą rozpoznania są kryteria kliniczne [4]. U chorych na AZS występują receptory charakteryzujące się wysokim powinowactwem do immunoglobulin E. Wiążą one antygeny i prezentują je limfocytom T pomocniczym. Pobudzony limfocyt różnicuje się $\mathrm{w}$ kierunku limfocytu $\mathrm{T}_{\mathrm{H}} 1$ lub 
$\mathrm{T}_{\mathrm{H}}$ 2. Różnią się one od siebie profilem produkcji cytokin i wykazują wzajemne, hamujące na siebie działanie. Zachowanie równowagi pomiędzy nimi warunkuje prawidłową odpowiedź immunologiczną, a jej zaburzenie jest charakterystyczne dla AZS. W badaniach potwierdzono przewagę $\mathrm{T}_{\mathrm{H}} 2$ we wczesnej fazie odpowiedzi immunologicznej i przewagę $\mathrm{T}_{\mathrm{H}} 1 \mathrm{w}$ fazie późnej [5]. Uznano, że AZS jest wynikiem złożonych reakcji genetycznych i epigenetycznych, w odniesieniu do czynników środowiskowych, w oparciu o procesy immunologiczne, ze wspólistniejącym defektem bariery naskórkowej [6].

Różnorodność objawów choroby wynika ze specyficznych zmian w genotypie oraz heterogeniczności alergenów. AZS uznano za chorobę przewlekłą i nawrotową, w przebiegu której mogą współistnieć inne IgE zależne choroby atopowe, np. astma oskrzelowa, alergie pokarmowe. Wśród najczęstszych objawów występują właśnie suchość i świąd skóry, z towarzyszącymi wielopostaciowymi zmianami skórnymi, z przewagą występowania wyprysku. Obraz kliniczny może być bardzo zróżnicowany. Wśród objawów skórnych dominują rumień oraz grudki i pęcherzyki wysiękowe. Wraz z rozwojem choroby pojawia się lichenifikacja skóry oraz przebarwienia. Świąd jest określany przez pacjentów jako objaw najbardziej uciążliwy i w sposób znaczny obniżający jakość źycia, jest determinantem zdrowia psychicznego w tej grupie chorych. Efektem świądu jest drapanie i występowanie wtórnych zmian w postaci łusek i strupów. Usytuowanie zmian skórnych w miejscach widocznych dodatkowo stygmatyzuje te osoby w ich środowiskach [7].

$\mathrm{W}$ rozpoznaniu atopowego zapalenia skóry bierze się pod uwagę obraz kliniczny pacjenta, w którym należy zidentyfikować przynajmniej trzy z czterech głównych objawów sklasyfikowanych przez Hanifina i Rajka oraz co najmniej trzy objawy mniejsze. Klasyfikację Hanifina i Rajka prezentuje tabela I [7].

Złożoność obrazu klinicznego stwarza pewne problemy diagnostyczne. Rozpoznanie opiera się głównie na badaniu podmiotowym i przedmiotowym. W diagnostyce wykorzystuje się testy punktowe $\mathrm{z}$ alergenami pokarmowymi i powietrzno-pochodnymi, testy naskórkowe alergii kontaktowej na związki chemiczne oraz oznaczenie całkowitych i antygenowo swoistych IgE w surowicy krwi. Wskazuje się na zasadność dodatkowego wykonania atopowych testów płatkowych z typowymi atopenami [8] oraz badanie histopatologiczne wycinków skóry, w których stwierdza się obecność cząsteczek adhezyjnych typowo niewystępujących w skórze bez atopii [5].

Leczenie AZS jest terapią trudną z uwagi na wieloczynnikowy patomechanizm zmian. Wykorzystuje się głównie metody leczenia objawowego i miejscowego (glikokortykosteroidy - GSK, inhibitory kalcyneuryny, leki przeciwhistaminowe, cyklosporyna - lek II rzutu) oraz tzw. leczenie uzupełniające (fototerapia, suplementacja preparatami roślinnymi zawierającymi kwas $\gamma$-linolenowy). W obszarze obserwacji klinicznych znajdują się leki antyleukotrienowe, immunoterapia alergenowa (swoista), interferon- $\gamma$, blokery aktywności limfocytów T [5]. W przebiegu choroby częstym zjawiskiem jest występowanie zakażeń wtórnych (bakteryjnych, grzybiczych, wirusowych lub mieszanych). Najczęściej wywołanych przez gronkowca złocistego, Trichophyton rubrum, Malassezia spp i Candida spp. W leczeniu stosuje się wówczas miejscową lub ogólną antybiotykoterapię. Nowatorską metodą leczenia jest stosowanie jedwabnej odzieży, która zawiera czynnik AEM 5772/5 (czynnik przeciwdrobnoustrojowy) redukujący obecność gronkowca na skórze [9].

Schorzenie jest obecnie nieuleczalne. Choroba ta jest niezwykle uciążliwa, wkraczająca w każda sferę życia pacjenta, przez co wymagająca holistycznego podejścia do procesu leczenia i pielęgnowania. Wielofunkcyjność skóry i jej wielozadaniowość ma duży wpływ na utrzymanie homeostazy organizmu, a wszelkie procesy patologiczne toczące się w jej obrębie stanowić mogą istotne zagrożenie zdrowotne dla pacjenta. Leczenie i pielęgnacja mają na celu poprawę jakości życia chorego w zakresie łagodzenia objawów i zapobieganiu okresom zaostrzeń. Jako działania profilaktyczne zaleca się stosowanie preparatów wzmacniających barierę naskórka.

\section{OPIS PRZYPADKU}

Pacjentka lat 42, od 8 lat leczona z powodu ciężkiej, lekoopornej postaci atopowego zapalenia skóry, zakwalifikowana do leczenia biologicznego. Choroby współistniejące: - depresja - ponad 20-letni wywiad chorobowy, dwukrotne próby samobójcze, myśli suicydalne;

- pourazowe zmiany zwyrodnieniowe obu stawów kolanowych;

- zmiany zwyrodnieniowe kręgosłupa w każdym z odcinków;

- zespół PCOS (Polycystic Ovary Syndrom - zespół policystycznych jajników) - stan po usunięciu pękniętej torbieli z wtórnym zapaleniem jamy otrzewnej;

- zespół jelita drażliwego;

- przepuklina rozworu przełykowego;

- obustronna tonsilektomia.

W chwili przeprowadzenia wywiadu:

- depresja w fazie remisji, bez leczenia farmakologicznego;

- stałe dolegliwości bólowe kręgosłupa;

- uporczywy świąd skóry dłoni, stóp, przewodów słuchowych, owłosionej skóry głowy, okolicy prawej pachwiny, obu dołów pachowych;

- zmiany skórne o charakterze wysypki pęcherzowej, z miejscowym wysiękiem płynu surowiczego na palcach I, II i III obu dłoni oraz palców I, II stopy lewej z zajęciem stawu śródstopno-paliczkowego palucha oraz te same zmiany w okolicy stawu śródstopno-paliczkowego palucha prawego;

- uszkodzone płytki paznokciowe placów I, II i III dłoni lewej oraz palców II i III dłoni prawej, uszkodzona płytka paznokciowa lewego palucha.

Wywiad rodzinny w kierunku chorób skóry, astmy oraz chorób alergicznych ujemny do drugiego pokolenia, zarówno ze strony matki, jak i ze strony ojca. We wczesnym dzieciństwie występowała nietolerancja białka krowiego 
POWIKŁANIA LECZENIA IMMUNOSUPRESYJNEGO W PRZEBIEGU CIĘŻKIEJ POSTACI ATOPOWEGO ZAPALENIA SKÓRY...

Tabela I. Kryteria większe i mniejsze atopowego zapalenia skóry wg Hanifina i Rajka.

KRYTERIA WIĘKSZE

$$
\text { ŚWIĄD }
$$

PRZEWLEKŁY I NAWROTOWY PRZEBIEG

\section{CHARAKTERYSTYCZNA MOFROLOGIA ZMIAN I ICH LOKALIZACJA}

OSOBNICZY LUB RODZINNY WYWIAD ATOPOWY

\section{KRYTERIA MNIEJSZE}

Suchość skóry, rybia łuska, natychmiastowe reakcje skórne, podwyższony poziom lgE, wczesny wiek wystąpienia zmian, skłonność do nawrotowych zakażeń skóry, nieswoisty wyprysk rąk i/lub stóp, wyprysk sutków, zapalenie czerwieni warg, nawrotowe zapalenie spojówek, fałd Dennie-Morgana, stożek rogówki, zaćma, zacienienie wokół oczu, fałd szyjny, świąd po spoceniu, nietolerancja pokarmów, nietolerancja wełny, zaostrzenie po zdenerwowaniu, biały dermografizm, rumień twarzy, akcentacja mieszków włosowych

Źródło: Wanat-Krzak M, Kurzawa R. Diagnostyka i leczenie wyprysku atopowego. Alerg Astma Immunolog 2006; 11 (1):12

w postaci silnej reakcji ze strony układu pokarmowego. $\mathrm{Z}$ opowiadań matki wynika, że były to obfite, chlustające wymioty i intensywna biegunka. Pacjentka była karmiona mlekiem specjalnym. W wieku przedszkolnym i później, spożywała w codziennej diecie mleko krowie oraz jego przetwory, bez efektów nietolerancji czy alergizacji. W okresie nastoletnim, jedyną reakcją uczuleniową, która wystąpiła, był wstrząs anafilaktyczny po podaniu Pyralginy.

Pierwsze objawy choroby pojawiły się w roku 2009. Był to uporczywy świąd wewnętrznych powierzchni dłoni, bez widocznych zmian skórnych. Świąd przemieścił się w okolice palców obu dłoni, pojawiły się drobne pojedyncze wypryski sugerujące wyprysk potnicowy, z uwagi na współistniejącą nadmierną potliwość dłoni i stóp. Ówczesna diagnoza dermatologiczna - wyprysk atopowy. Zalecono miejscowe stosowanie steroidów.

W roku 2010, u pacjentki wykonano zabieg obustronnej tonsilektomii z powodu przewlekłego stanu zapalnego. W badaniu histopatologicznym rozpoznano zakażenie Staphylococcus aureus.

Przez kolejne lata zmiany wypryskowe ulegały stopniowej intensyfikacji. Pojawiły się również zmiany na palcach obu stóp. Wykonano badanie bakteriologiczne zmian z prawej dłoni, w którym nie stwierdzono obecności patogenów chorobotwórczych.

W roku 2014, na przełomie lipca i sierpnia, pojawiła się grudkowa wysypka początkowo w okolicy pomiędzy piersiami, a następnie objęła ona obie piersi, by w ciągu kilku dni rozprzestrzenić się na całą klatkę piersiową (Ryc. 1). Chora została skierowana do leczenia na oddziale dermatologicznym w trybie pilnym. Wdrożono wówczas następujące leczenie: cefotaxime, dexamethasonum $\mathrm{w}$ dawkach zmniejszających, klemastyna, ranitidine, venlafaxine, metformina oraz leczenie miejscowe: hydrocortisone butyrate, dexamethasonum, okłady z soli fizjologicznej, maść chłodząca z fluocinolone acetonide + neomycin, maść chłodząca $\mathrm{z}$ hydrocortisone butyrate, hydrocortisone + natamycin + neomycin, maść cynkowa. Wyniki badań dodatkowych (VDRL, kał pasożyty i G.lamblie) były prawidłowe.

Do stosowania ogólnego zalecono przyjmowanie bilastine 2 x 1 tbl., zewnętrznie: maść chłodzącą z hydrocortisone na całe ciało oraz erythromycin na okolicę dekoltu. Bezpośrednio po wypisaniu z oddziału objawy skórne powróciły, jednak znacznie zaostrzone. Wysypka obejmowała całe ciało, z wyjątkiem twarzy. Na skórze pośladków pojawiły się ponadto wilgotne, sączące rany przypominające II $^{\circ}$ ran odleżynowych, dodatkowym objawem był miejscowy ból (Ryc. 2). Chora została skierowana do leczenia w klinice dermatologii, z zaleceniem przyjmowania do czasu ustalonego terminu przyjęcia cyklosporyny w dawce $200 \mathrm{mg} /$ dobę. W okresie poprzedzającym hospitalizację wykonano oznaczenia przeciwciał w grupach IgE, IgG, IgA i IgM, które nie odbiegały od ustalonych norm. Oznaczenie ANA1 dało wynik graniczny ze wskazaniem ponownej kontroli po 6 miesiącach.

W trakcie hospitalizacji w klinice podwyższono dawkę cyklosporyny do $300 \mathrm{mg} /$ dobę. Zastosowano glikokortykosteroidy ogólnie, acyclovirum, antybiotykoterapię ogólną oraz leczenie miejscowe. Zmiany skórne ustąpiły z pozostawieniem przebarwień, świąd również ustąpił. $\mathrm{W}$ warunkach domowych kontynuowano leczenie w sposób następujący: cyklosporyna $200 \mathrm{mg}$ rano $+100 \mathrm{mg}$ wieczorem, feksofenadyna 180mg $2 \times 1$ tbl./dobe, hydroxyzinum $10 \mathrm{mg}$ doraźnie, przy wystąpieniu nasilonego świądu (1 tbl. rano, 2 tbl. wieczorem), miejscowo: maść parafinowa, mediderm krem, clotrimazolum + tormentillae unguentum compositum na zmiany na sromie. W trakcie hospitalizacji, pacjentka została zakwalifikowana do projektu badania klinicznego, w trakcie którego wykonano u niej TEST ALERGIE EUROLINE ATOPIE, w którym ujawniono niskie miano przeciwciał w odniesieniu do soji $(0,47 \mathrm{kU} / \mathrm{l})$, w pozostałych typach alergenów nie ujawniono specyficznych przeciwciał.

Ze względu na nagłe pojawienie się zmian o charakterze rogowca, w obrębie wewnętrznych powierzchni obu dłoni oraz na powierzchni podeszwowej obu stóp, pacjentkę skierowano na diagnostykę w kierunku obecności choroby nowotworowej, która została wykluczona. W badaniach obrazowych stwierdzono przepuklinę wślizgową rozworu przełykowego przepony, powiększone guzki krwawnicze, stłuszczenie wątroby. W badaniach laboratoryjnych przesunięcie $\mathrm{w}$ prawo $\mathrm{w}$ rozmazie morfologii, które miało najpewniej związek z przyjmowaną cyklosporyną.

W kolejnym roku, na przełomie listopada i grudnia, wystąipiły dodatkowe objawy w postaci bólu w okolicy szyi z towarzyszącym powiększeniem węzłów chłonnych oraz wyciekiem surowiczo-ropnym $\mathrm{z}$ obu przewodów słuchowych, $\mathrm{z}$ wtórnym pogorszeniem słuchu. W badaniu 
ultrasonograficznym (USG) stwierdzono powiększenie węzłów chłonnych, zalecono kontrolę u lekarza prowadzącego chorobę podstawową.

W wieloletnim przebiegu choroby, objawami dominującymi są zmiany skórne palców stóp i dłoni. Ze względu na uporczywy świąd, zmianom tym towarzyszą przeczosy wywołane drapaniem. Zmiany te często ulegają wtórnym zakażeniom o zróżnicowanym, zmiennym i/lub mieszanym podłożu patogennym grzybiczo-bakteryjnym (Ryc. 3 i 4).

W roku 2016, od lutego, nastąpiło znaczne pogorszenie się stanu skóry. Pojawiły się rozległe zmiany zapalne w postaci wysypki grudkowej z miejscowymi zmianami liszajowatymi. Objawy te zdominowały okolicę klatki piersiowej i szyi, z następowym kierunkiem wstępującym na okolicę żuchwy. Najsilniej prezentowały się w okolicach dołów pachowych. Zmianom tym towarzyszył silny świąd (Ryc. 5 i 6). Pacjentka została skierowana na leczenie szpitalne. W trakcie pobytu włączono leczenie steroidami oraz antybiotykoterapię, prowadzono również intensywne leczenie miejscowe. Włączono ponownie cyklosporynę w dawce $200 \mathrm{mg} /$ dobę, jednak z uwagi na wzrost poziomu kreatyniny w surowicy, dawkę tę zredukowano do $100 \mathrm{mg} /$ dobę. Uzyskano względną stabilizację i poprawę stanu klinicznego w zakresie zmian skórnych. Pacjentka została wypisana do domu z zaleceniem dalszego leczenia w warunkach ambulatoryjnych. Z uwagi na pojawienie się granicznych wartości ciśnienia tętniczego obserwowanych w trakcie wdrożenia cyklosporyny zalecono codzienną kontrolę tych wartości oraz wykonywanie $1 \mathrm{x}$ w tygodniu oznaczenia poziomu kreatyniny w surowicy. Po miesiącu nastąpiło kolejne, jeszcze silniejsze zaostrzenie choroby, w obrazie klinicznym jak dotychczas z tym, że zmiany objęły również twarz i skórę głowy (Ryc. 7). Dodatkowo pojawiła się duszność spoczynkowa, znacznie nasilająca się w trakcie minimalnego wysiłku fizycznego, z towarzyszącymi umiarkowanymi obrzękami kończyn dolnych. Ze względu na wystąpienie niepożądanych efektów leczenia cyklosporyną, w trakcie kolejnej hospitalizacji, podjęto decyzję o wdrożeniu azatiopryny do leczenia podstawowego. Wdrożono również fototerapię UVB-NB, uzyskując tylko częściową poprawę stanu miejscowego oraz zmniejszenie nasilenia świądu. Pacjentka została wypisana w stanie ogólnym dobrym z zaleceniami, jak dotychczas. W siedemnastej dobie leczenia azatiopryną stan chorej zaczął się stopniowo pogarszać. Pojawiły się uogólnione obrzęki całego ciała, które w ciągu dwóch dni przybrały postać obrzęków masywnych. Wśród zmian skórnych dominowały plackowate zmiany liszajowe z nadmiernym łuszczeniem się skóry całego ciała. Pojawiło się znaczne osłabienie, dreszcze z wieczornymi rzutami gorączki powyżej $40^{\circ} \mathrm{C}$. Pacjentka została przetransportowana przez zespół ratownictwa medycznego na szpitalny oddział ratunkowy, gdzie została zakwalifikowana do leczenia na oddziale dermatologii. Brak uchwytnej przyczyny tak gwałtownego pogorszenia się stanu chorej utrudniał diagnozę i leczenie. Stan pacjentki, pomimo podjętego leczenia objawowego pogarszał się, jednak już nie tak intensywnie. W drugiej dobie zalecono, aby pacjentka odstawiła wszystkie leki, które miała zalecone w dotychczasowym leczeniu ambulatoryjnym, pozostając wyłącznie na wdrożonym leczeniu szpitalnym. W ciągu kilku godzin stan chorej wyraźnie się poprawił. Przy próbie ponownego włączenia azatiopryny wystąpiła skrajna leukopenia oraz gwałtowne zaostrzenie zmian skórnych z towarzyszącymi objawami ogólnymi (duszność, temperatura do $39^{\circ} \mathrm{C}$, dreszcze). Wdrożono intensywne leczenie objawowe, uzyskano stabilizację stanu chorej. Podano 1 ampułkę Tevagrastimu ze względu na leukopenię WBC $1,4 \mathrm{~K} / \mu \mathrm{l}$ (zakres normy 4,0-10,0). W badaniach dodatkowych wysoki poziom wskaźników zapalnych: białka ostrej fazy (CRP) i prokalcytoniny (PCT). Stwierdzono zakażenie skóry Staphylococcus aureus MSSA wrażliwym na metycylline, cefalosporyny I i II generacji oraz penicyliny $z$ inhibitorami. Badanie krwi na posiew dało wynik jałowy. Ryciny 8 i 9 zostały wykonane w trzeciej dobie pobytu na oddziale, obrzęki nie były już tak zaawansowane, jak pierwotnie, jednak nadal były masywne. Doszło do przezskórnego sączenia się płynu obrzękowego przez uszkodzoną skórę w okolicy obu podudzi. Wdrożone leczenie i odstawienie azatiopryny przyniosły znaczącą poprawę stanu zdrowia i w 10. dobie wypisano pacjentkę z zaleceniem kontroli w macierzystej klinice dermatologii.

Po dwóch tygodniach, nastąpiło kolejne zaostrzenie stanu zapalnego skóry. Pacjentka ponownie hospitalizowana. Poza uogólnionym zaostrzeniem zmian skórnych, w badaniach laboratoryjnych stwierdzono niedokrwistość i nadpłytkowość, przesunięcie w obrazie białokrwinkowym oraz podwyższony poziom glukozy we krwi, odnotowano również podwyższone wartości OB. Wdrożono leczenie steroidami uzyskując stabilizację stanu ogólnego oraz wycofanie się zmian zapalnych skóry.

Z uwagi na zmiany skórne w okolicy sromu i krocza pobrano wycinki do badania histopatologicznego, w którym stwierdzono dystrofię hyperplastyczną.

Ostatnia hospitalizacja miała miejsce w 2017 roku z powodu niejednoznacznego obrazu klinicznego, w trakcie której wykonano badanie histopatologiczne i immunologiczne w kierunku choroby Hailey-Hayley - wynik negatywny. Zmniejszono wówczas dawkę cyklosporyny do $200 \mathrm{mg} /$ dobę. Kontynuowano leczenie miejscowe jak dotychczas.

Wdrożona terapia kontynuowana była do dnia przeprowadzenia niniejszego badania.

\section{DYSKUSJA}

Leczenie immunosupresyjne jest obarczone występowaniem działań niepożądanych. W opisie profesjonalnym cyclosporyny wskazuje się na zwiększone ryzyko rozwoju nowotworów. Z tego powodu, gdy u pacjentki pojawił się rogowiec, została ona skierowana do dalszej diagnostyki w kierunku choroby nowotworowej, bowiem jest on jednym $\mathrm{z}$ objawów skórnych zespołów paraneoplastycznych [10]. W przebiegu leczenia dawką 200mg/dobę, u pacjentki stwierdzono wzrost poziomu kreatyniny do wartości granicznych, który obniżył się po zmniejszeniu dawki do 100 mg/dobę. Dysfunkcja nerek w krótkotrwałym leczeniu 


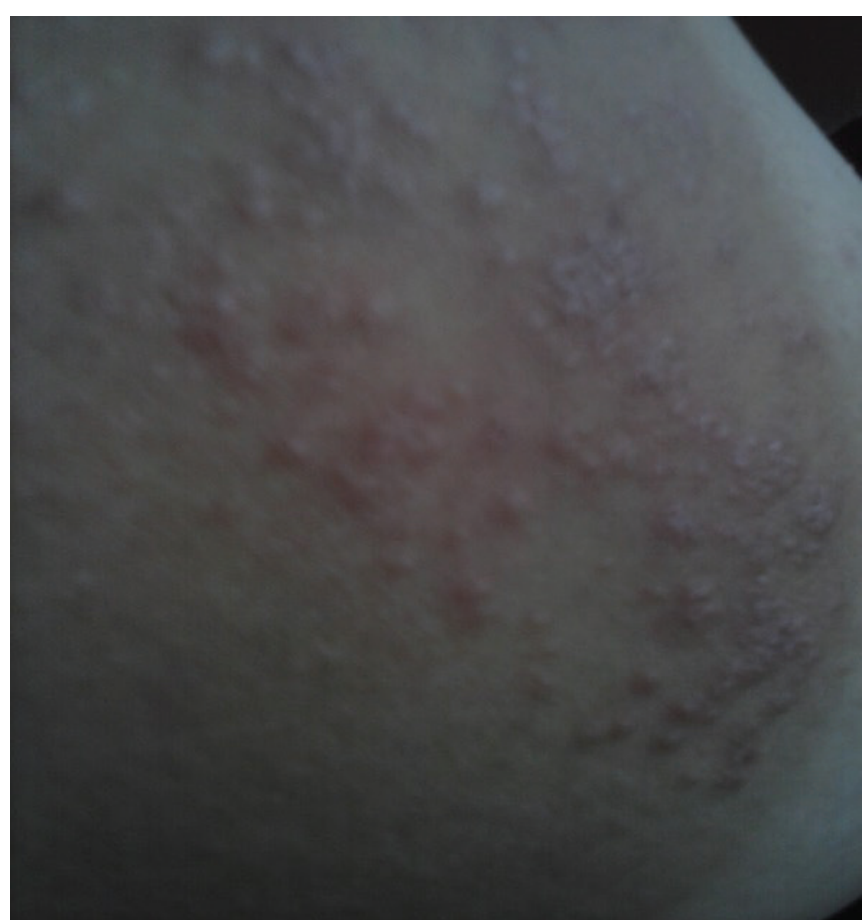

Ryc. 1. Wyprysk pęcherzowy na skórze piersi.

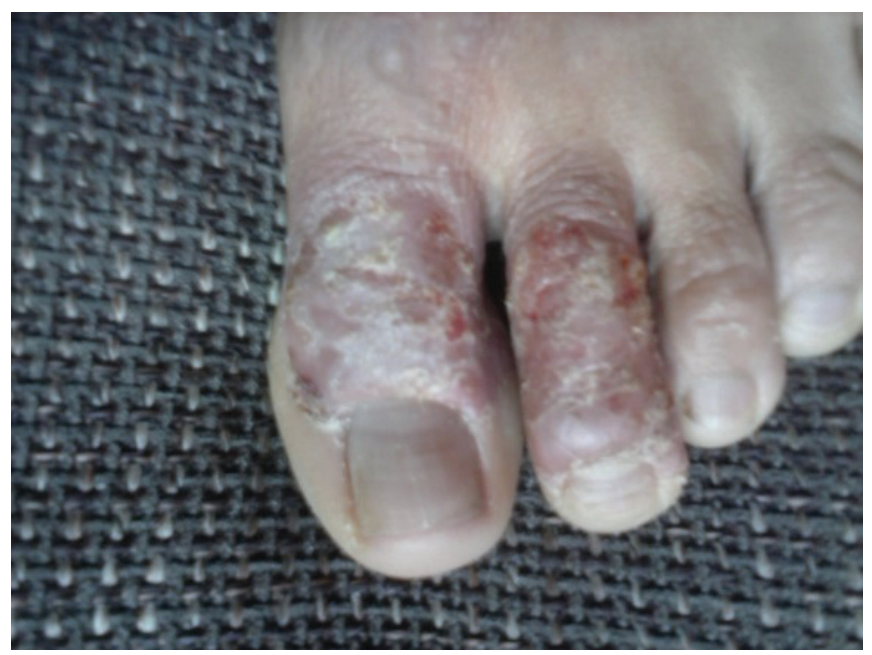

Ryc. 3. Sączące, wtórnie nadkażone grzybiczo zmiany skórne palców I, II i III stopy lewej.

cyklosporyną jest $\mathrm{z}$ reguły przejściowa. W leczeniu przewlekłym, trwającym co najmniej dwa lata, może jednak prowadzić do uszkodzeń strukturalnych w nerkach $\mathrm{z}$ następowa niewydolnością nerek [13]. Wskazuje się również na możliwość wystąpienia nadciśnienia tętniczego, którego etiologia związana jest ze skurczem naczyń krwionośnych, pobudzeniem układu renina-angiotensyna-aldosteron oraz pobudzeniem aktywności współczulnego układu nerwowego. W badanym przypadku, w pierwszym okresie leczenia wystąpiło nadciśnienie tętnicze wymagające zastosowania leków hipotensyjnych. Objawami towarzyszącymi były szybkie męczenie się i duszność. Po upływie 3 miesięcy leki te zostały odstawione, a wartości ciśnienia utrzymywały się w granicach normy [11]. W jednym z badań dotyczącym

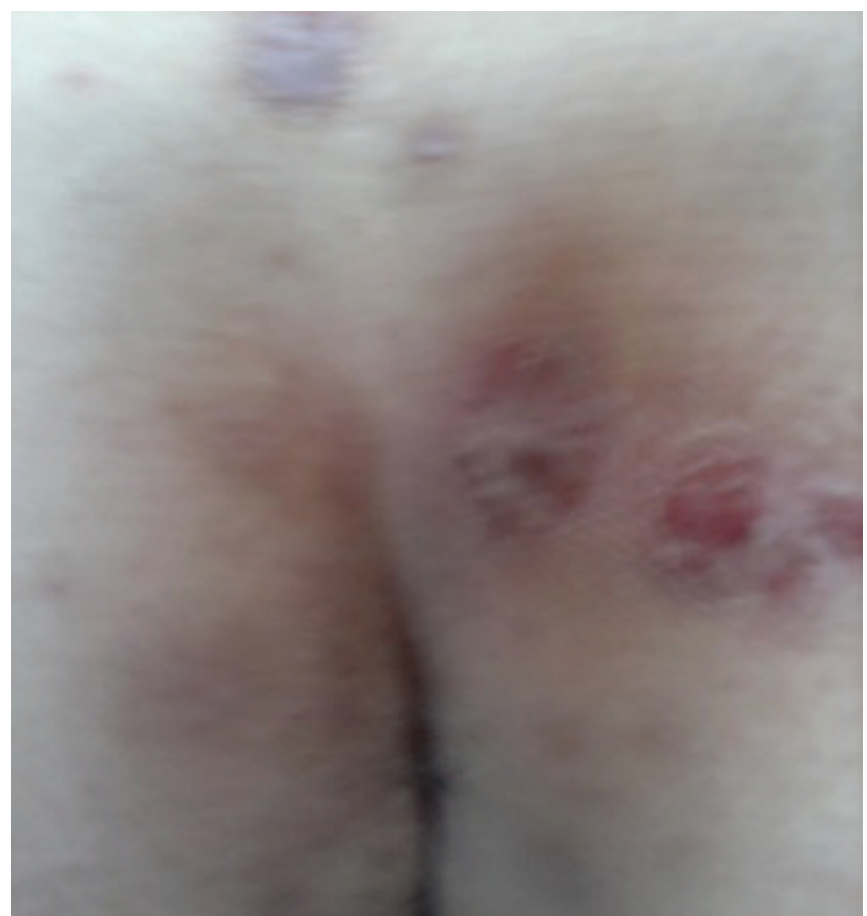

Ryc. 2. Zmiany skórne w okolicy szpary pośladkowej.

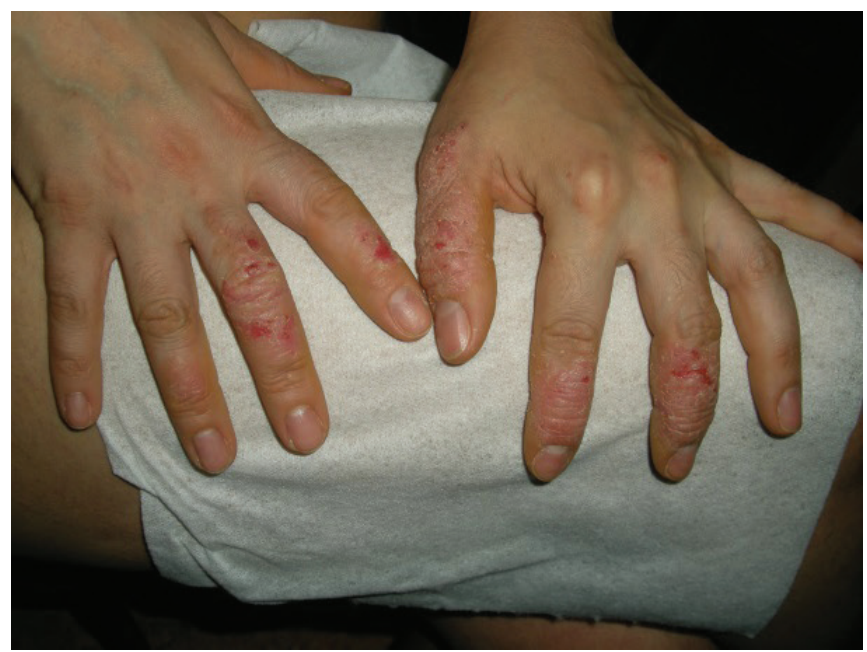

Ryc. 4. Zmiany skórne w obrębie obu dłoni.

wybranych parametrów jakości życia chorych z łuszczycą, leczonych cyklosporyną stwierdzono występowanie różnych działań niepożądanych u $6,4 \%$ chorych poddanych badaniu, najczęstszym było właśnie nadciśnienie tętnicze [12]. W badanym przypadku obserwowano zwiększone wartości glikemii, co może być wynikiem długotrwałego stosowania cyklosporyny [17].

W opisywanym przypadku, po zastąpieniu cyklosporyny azatiopryną wystąpiło gwałtowne pogorszenie się stanu ogólnego w postaci masywnych, uogólnionych obrzęków całego ciała, $z$ intensyfikacją zmian skórnych. W obrazie klinicznym pojawiła się gorączka $\left(>40^{\circ} \mathrm{C}\right)$ i silna duszność oraz znaczne osłabienie organizmu. W badaniach laboratoryjnych stwierdzono skrajną leukopenię, która wskazywana jest 


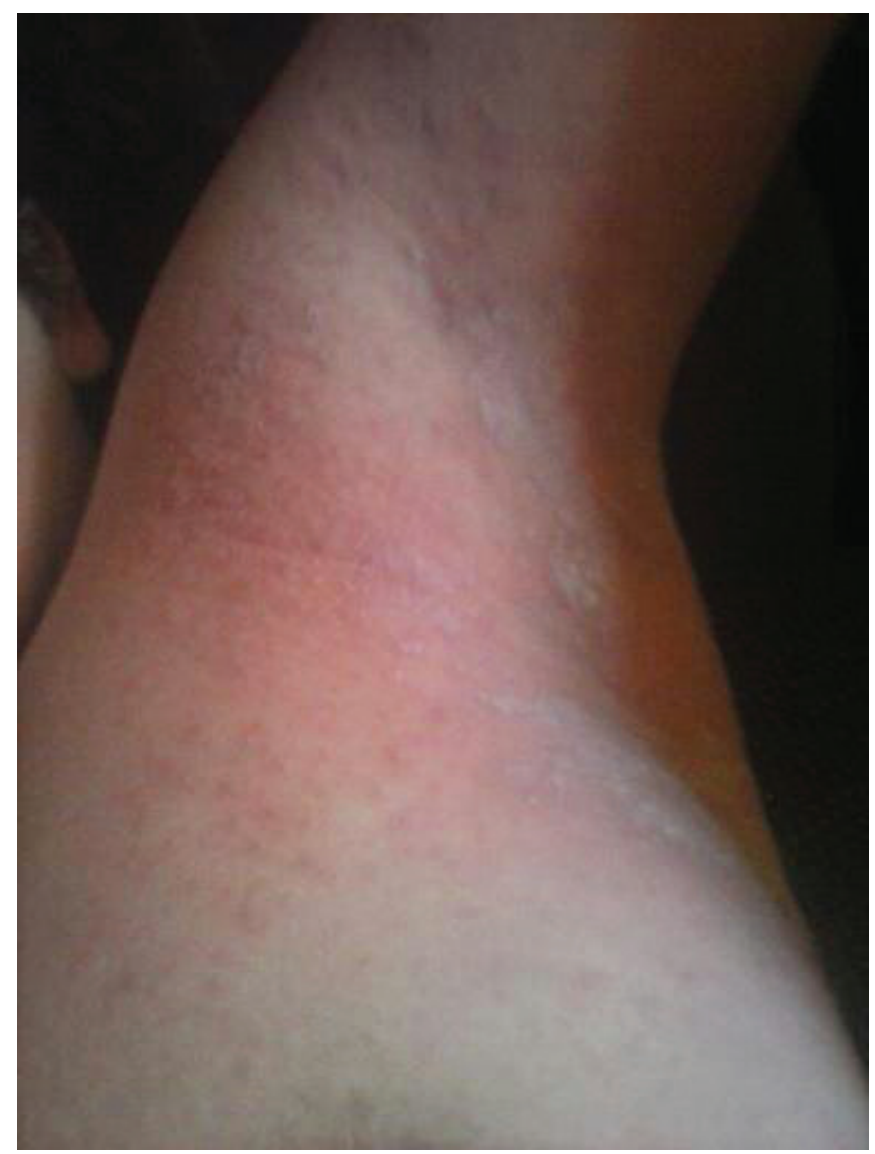

Ryc. 5. Wysypka rumieniowo-grudkowa z nadkażeniem grzybiczym w okolicy dołu pachowego lewego.

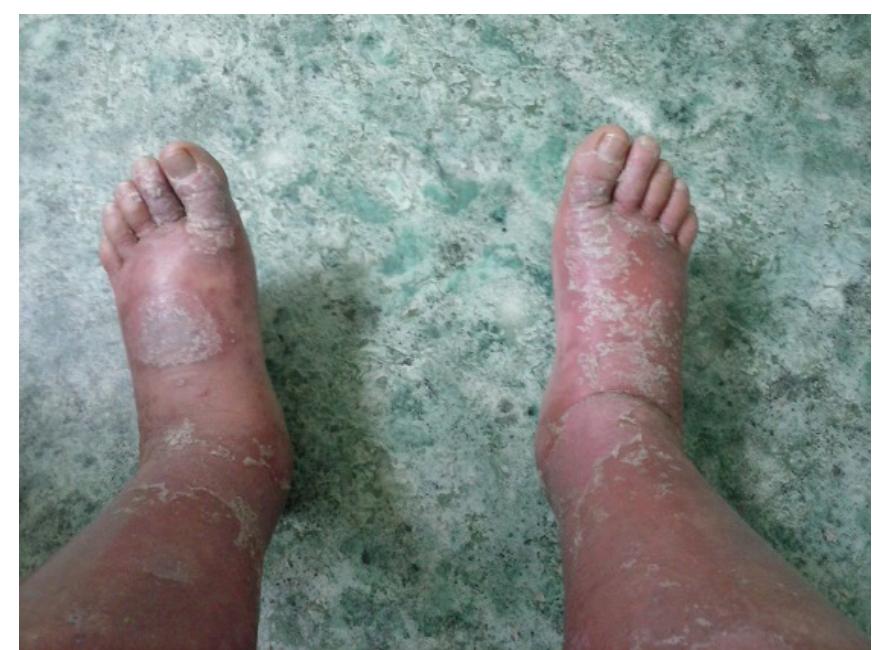

Ryc. 8. Masywne obrzęki z ciężkim przebiegiem zapalenia skóry.

w piśmennictwie jako jeden z możliwych skutków ubocznych leczenia [14]. Wśród zaburzeń hematologicznych, które mogą również wystąpić w trakcie leczenia azatiopryną jest megaloblastoza, aplazja układu czerwonokrwinkowego i limfadenopatia [16]. W przebiegu atopowego zapalenia

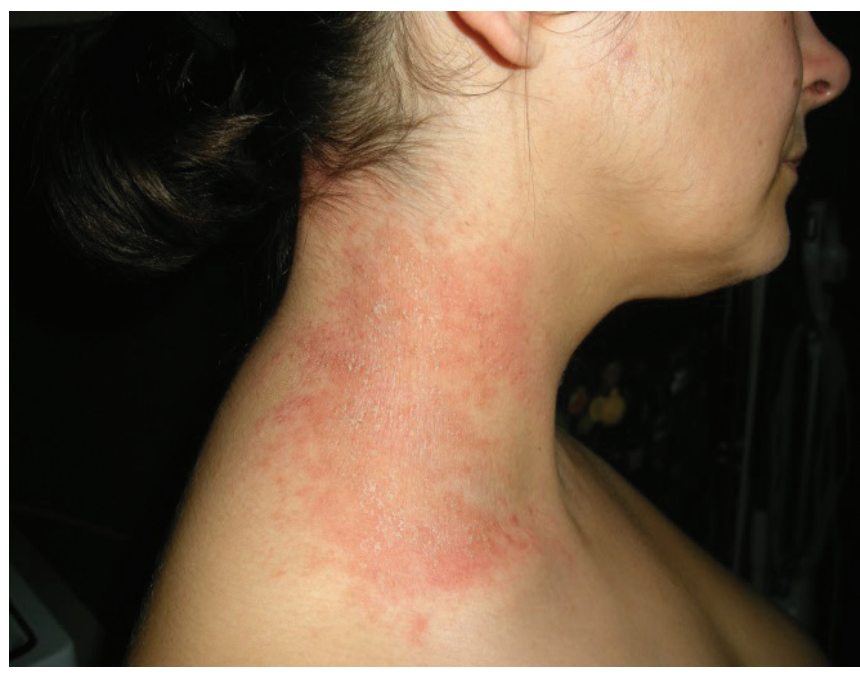

Ryc. 6. Wysypka rumieniowo-grudkowa ze zmianami liszajowatymi w okolicy szyi.

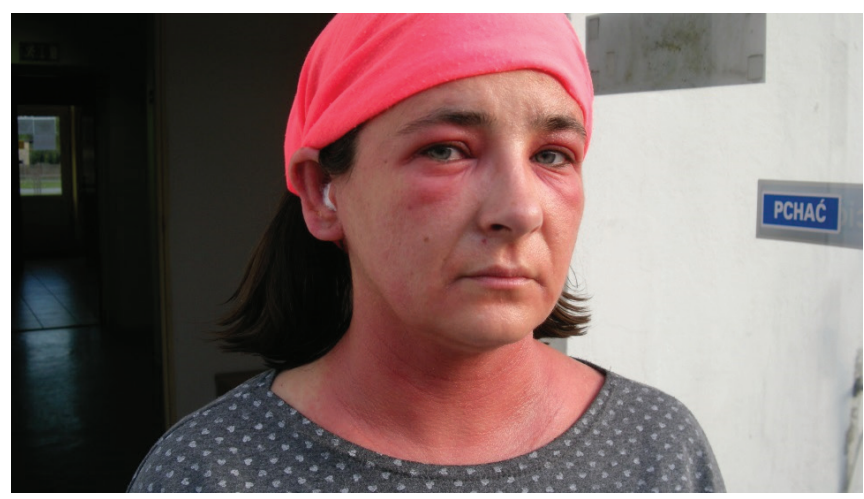

Ryc. 7.Zmianyzapalneskórytwarzyw okresiezaostrzeniachoroby.Widoczny obrzęk izaczerwienienie oczuztowarzyszącymzapaleniem spojówek. Wspótistniejący ropny wysiękz obu przewodów stuchowych - ze zbiorów pacjentki.

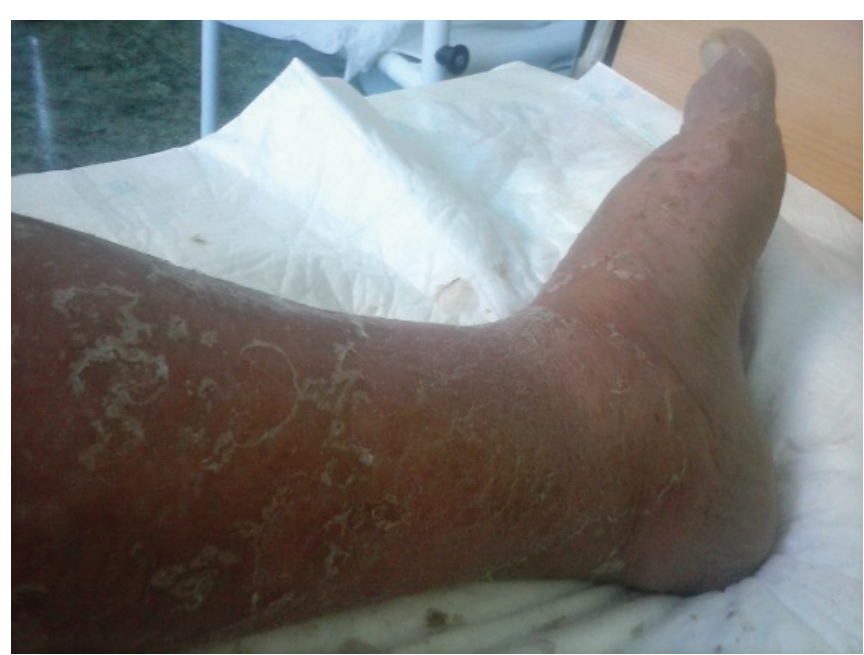

Ryc. 9. Sączące rany podudzi w przebiegu masywnych obrzęków.

skóry, częstym zjawiskiem są wtórne zakażenia bakteryjne Staphylococcus Aureus, które występują u około 90\% chorych. U pacjentki również potwierdzono obecność zakażenia skóry tym patogenem. Kolonizacja tego patogenu odgrywa znaczącą rolę w patogenezie AZS. W wywiadzie pacjentka 
wskazywała na konieczność poddania się obustronnej tonsillektomii właśnie z powodu zakażenia Stapfylococcus Aureus, które miało miejsce w okresie po wystąpieniu pierwszych objawów atopowego zapalenia skóry [15].

Leczenie immunosupresyjne jest wykorzystywane w wielu dziedzinach medycyny, głównie w transplantologii, alergologii, w leczeniu chorób autoimmunizacyjnych i onkologicznych. Dotyczy zatem chorych obciążonych różnymi schorzeniami współistniejącymi, co przekłada się również na możliwość występowania odmiennych działań niepożądanych. Do najczęstszych zalicza się zakażenia o różnym podłożu patogennym (szczególnie niebezpieczne są drobnoustroje oportunistyczne). Niebezpieczne są również powikłania wynikające z toksyczności tych leków, np. nefrotoksyczność, hapatotoksyczność i kardiotoksyczność. Objawy niepożądane występują częściej u osób, których leczenie immunosupresyjne jest długotrwałe z zastosowaniem wysokich dawek preparatów [18].

\section{WNIOSKI}

Przedstawiony przypadek kliniczny potwierdza, że atopowe zapalenie skóry ma złożony obraz kliniczny oraz zróżnicowany i zmienny charakter. Przeprowadzony z pacjentką wywiad potwierdził, że występujące w przebiegu choroby objawy kliniczne znacznie obniżają jakość życia pacjenta. Powikłania leczenia immunosupresyjnego mogą wystąpić w każdym momencie leczenia i mogą stanowić zagrożenie dla zdrowia i życia pacjenta, o czym świadczy poważny przebieg obrazu klinicznego chorej po wdrożeniu azatiopryny. Działania niepożądane leczenia immunosupresyjnego zależą w głównej mierze od zastosowanych dawek leków, od długości trwania leczenia oraz od występowania schorzeń współistniejących.

\section{PIŚMIENNICTWO}

1. Sybilski AJ, Raciborski F, Lipiec A, Tomaszewska A et al. Atopic dermatitis is a serious health problem in Poland. Epidemiology studies based on ECAP study. Postep Derm Alergol. 2015;32(1):1-10.

2. Gołąb J, Jakóbisiak M, Lasek W, Stokłosa T. Immunologia. Warszawa: PWN 2012

3. Polańska A, Jenerowicz D. Rys historyczny wybranych zagadnień związanych z etiopatogenezą i leczeniem atopowego zapalenia skóry. Now Lek 2008;77;5:382-384

4. Waszczykowska E. Atopowe zapalenie skóry - postępowanie lecznicze. Przegl Alergol 2004;1:24-29

5. Woldan-Tambor A, Zawilska J. Atopowe zapalenie skóry (AZS) - problem XXI wieku. Farmakologia Polska 2009;65 (11);804-811

6. NowickiR, TrzeciakM,Wilkowska A etal. Atopowezapalenieskóry-aktualne wytyczne terapeutyczne. Stanowisko ekspertów Sekcji Dermatologicznej Polskiego Towarzystwa Alergologicznego i Sekcji Alergologicznej Polskiego Towarzystwa Dermatologicznego. Lekarz P0Z 2015;1:39
7. Wanat-Krzak M, Kurzawa R. Diagnostyka i leczenie wyprysku atopowego. Alerg Astma Immunolog 2006;11(1):13

8. Silny W, Czarnecka-Operacz M, Gliński W, Samochocki Z, Jenerowicz D. Atopowe zapalenie skóry - współczesne poglądy na patomechanizm oraz metody postepowania diagnostyczno-leczniczego. Stanowisko grupy specjalistów Polskiego Towarzystwa Dermatologicznego. Postep Derm Alergolog 2010;27(5):365-383

9. Nowicki R. Leczenie infekcji skóry w atopowym zapaleniu skóry. Forum Med Rodz 2010;4(5):323-329

10. Kamińska-Winciorek G, Brzezińska-Wcisło L. The most common selected acquired cutaneous paraneoplastic syndromes in internal malignancy. Postep Derm Alergolog 2004;21(3):136-143

11. Adamczak M, Więcek A. Leki immunosupresyjne a nadciśnienie tętnicze. Nadcisn Tetn 2011;15(4):263-268

12. Narbutt J. Ocena wybranych parametrów jakości życia u chorych na łuszczycę leczonych cyklosporyną (preparatem Sandimmun Neoral ${ }^{\circledR}$ ) - 12-tygodniowe obserwacje w warunkach ambulatoryjnych praktyki medycznej. Raport z badania; Derm Klin 2012;14(4):165-169

13. Michalewska A, Bręborowicz A. Leczenie systemowe w atopowym zapaleniu skóry; Alerg Astma Immunolog 2013;18(1):14-20

14. Bożek A, Dzienniak A, Foks A, Kucharczyk J, Maciejiczek J, Marcak M, Więckiewicz G. Metody leczenia atopowego zapalenia skóry. Med Rodz 2014:4:170-176

15. Ong PY, Leung DYM. Rola zakażeń w atopowym zapaleniu skóry. Derm Dypl 2011;2(2):17-26

16. Maj S. Polekowe powikłania hematologiczne. Postep Nauk Med 2000;4:17-28

17. Rehman A, Setter SM, Vue MH. Zaburzenia stężenia glukozy związane ze stosowaniem leków Część 2: hiperglikemia związana ze stosowaniem leków. Diabetolog Dypl 2012;9(1):39-42

18. OgarczykE, Kowalewicz-Kulbat M, WawrockiS, Fol M. Immunosupresja wymagający sprzymierzeniec na trudne czasy. Postep Hig Med Doswiad 2015;69;1299-1312

\section{Konflikt interesów:}

Autorzy deklaruja brak konfliktu interesów

Opis przypadku byt wykorzystany w pracy dyplomowej pierwszego autora

Pacjentka wyraziła zgodę na wykorzystanie danych.

\section{AUTOR KORESPONDUJĄCY Jadwiga Korzeniowska}

Zakład Medycyny Ratunkowe i Medycyny Katastrof

Uniwersytet Medyczny w Łodzi, Łódź, Polska

e-mail:jagoda17@interia.eu

Nadesłano: 19.12.2018

Zaakceptowano: 12.02.2019 
ORIGINAL ARTICLE

PRACA ORYGINALNA

\title{
BURNS IN PRACTICE OF HELICOPTER EMERGENCY MEDICAL SERVICE IN POLAND. RETROSPECTIVE ANALYSIS
}

\author{
OPARZENIA CIAŁA W PRAKTYCE ZAŁÓG ŚMIGŁOWCOWE」 \\ SŁUŻBY RATOWNICTWA MEDYCZNEGO W POLSCE. \\ ANALIZA RETROSPEKTYWNA
}

\author{
Patryk Rzońca ${ }^{1}$, Piotr Tomaka ${ }^{2}$, Robert Gałązkowski ${ }^{3}$ \\ 'DEPARTMENT OF EMERGRNCY MEDICINE, FACULTY OF HEALTH SCIENCES, MEDICAL UNIVERSITY OF LUBLIN, LUBLIN, POLAND \\ ${ }^{2}$ ANAESTHESIOLOGY AND INTENSIVE CARE UNIT, LECZNA, POLAND \\ 3DEPARTMENT OF EMERGENCY MEDICAL SERVICES, FACULTY OF HEALTH SCIENCE, MEDICAL UNIVERSITY OF WARSAW, WARSAW, POLAND
}

\begin{abstract}
Introduction: Burns are a huge problem for public health and a challenge for healthcare systems all around the world. They are responsible for 180.000 deaths worldwide each year. In order to ensure high quality treatment and rehabilitation of these patients burn centres are established in many countries. Another vital factor influencing the prognosis of patients with burns is quick transport that in many countries, including Poland is carried out by Helicopter Emergency Medical Service (HEMS).

The aim: To describe the operations carried out by HEMS with particular stress put on the target medical facility.

Materials and methods: The research was conducted with the method of retrospective analysis of operations performed by HEMS crews. All missions from January 2011 to December 2018 were included in the study and 2534 cases were qualified for the final analysis.

Results: The study group was predominantly male (72.72\%) aged 18 years old and less (36.65\%). Nearly two thirds of the patients were transported to hospitals with a burn ward (61.88\%). Opioid analgesics as well as crystalloids were the most commonly administered drugs (respectively 68.55\% and 64.76\%). Statistical analysis showed that HEMS arrival time (20.77 minutes vs 18.60 minutes) and duration of the transport to designated hospital (40.11 minutes vs 19.66 minutes) were significantly higher in the cases of deciding to transport the patient to the hospital with the burns department $(p<0.001)$.

Conclusions: Presented results showed that HEMS crews are more often assigned to help ground-based Medical Rescue Teams in case of patients who required treatment in burn centres. Moreover, the time and distance to the hospital with burn ward was significantly longer compared to other healthcare facilities. This confirms that the assigning of HEMS crews for the patients with severe burns was reasonable.
\end{abstract}

KEY WORDS: burn, Helicopter Emergency Medical Service, prehospital care, burn centres

\section{STRESZCZENIE}

Wstęp: Oparzenia ciała stanowią ogromny problem dla zdrowia publicznego i wyzwanie dla systemów opieki zdrowotnej na świecie. Każdego roku odpowiedzialne są za 180 tysięcy zgonów na świecie. W celu zapewnienia wysokiej jakości leczenia i rehabilitacji pacjentów z oparzeniami ciała w wielu krajach tworzone są centra leczenia oparzeń. Kolejnym kluczowym elementem wpływającym na rokowanie pacjentów z oparzeniami ciała jest szybki transport, który w wielu krajach, w tym również w Polsce realizowany jest przez załogi Śmigłowcowej Służby Ratownictwa Medycznego (HEMS).

Cel pracy: Charakterystyka misji załóg HEMS realizowanych do pacjentów z oparzeniami ciała, ze szczególnym zwróceniem uwagi na miejsce transportu poszkodowanych. Materiał i metody: Badania przeprowadzono metodą analizy retrospektywnej interwencji wykonanych przez załogi Śmigłowcowej Służby Ratownictwa Medycznego Lotniczego Pogotowia Ratunkowego. Do badania włączono wszystkie misje z okresu od stycznia 2011 roku do grudnia 2018 roku, w których załogi HEMS były dysponowane do pacjentów z oparzeniami ciała. Do ostatecznej analizy zakwalifikowano 2534 przypadków interwencji załóg HEMS.

Wyniki: W badanej grupie dominowali mężzyźni (72,72\%), pacjenci w przedziale wiekowym 18 i mniej lat (36,65\%). Blisko dwie trzecie pacjentów transportowana była do szpitali z oddziałem oparzeniowym (61,88\%). Najczęściej podawanymi lekami były opioidowe leki przeciwbólowe (68,55\%) i krystaloidy (64,76\%).Z analizy statystycznej wynika, że czas dolotu (20,77 min vs 18,60 min) i czas transportu do szpitala (40,11 min vs 19,66 min) były istotnie wyższe w przypadku decyzji o transporcie pacjenta do oddziału leczenia oparzeń $(p<0,001)$.

Wnioski: Przedstawione wyniki badań wykazały, że załogi HEMS częściej są dysponowane do pomocy Zespołom Ratownictwa Medycznego w przypadku pacjentów, którzy wymagali leczenia w centrum leczenia oparzeń. Ponadto czas transportu i dystans do szpitala z oddziałem oparzeniowym jest istotnie dłuższy w porównaniu do szpitali bez oddziału oparzeniowego. Potwierdza to zasadność dysponowania załóg HEMS do pacjentów z ciężkimi oparzeniami ciała.

SŁOWA KLUCZOWE: oparzenia, Śmigłowcowa Służba Ratownictwa Medycznego, opieka przedszpitalna, centrum oparzeniowe 


\section{INTRODUCTION}

A burn is a damage to the skin or other tissue of an organism resulting mainly from heat or radiation but also from biological, chemical, physical and electrical factors whose effect may be local or systemic. Ultraviolet radiation radioactivity, electrical or chemical skin damage as well as smoke inhalation are also considered as burns. Globally burns are a serious problem for healthcare systems and are responsible for 180.000 deaths per year. The majority of these deaths occur in low and middle-income countries with nearly two thirds of the deaths reported in the Africa and Southeast Asia. Non-lethal burns are the main reason of prolonged hospitalisation, high morbidity, body disfiguration and disability resulting in reduced self-esteem and social exclusion [1-5].

About $1 \%$ of the Polish population suffer from burns every year. Children and elderly are particularly exposed to this kind of stress. Estimations show that burns among children up to age of seven represent a quarter of all burns. They are mainly the result of contact with hot liquids. Among adults burns are most often related to accidents at work or at home $[6,7]$.

Burns constitute a serious problem but the continuous development and progress of medicine promotes the development of modern medical techniques and procedures that allow to treat effectively patients with severe burns. In many countries burns centres and wards are being established as in the case of multiple trauma centres. There are seven highly specialised burn centres in Poland. Through coordinated efforts they enable treatment and rehabilitation of patients with severe burns. The rapid transport of such patient to specialised facility is crucial for the prognosis of survival [8]. Therefore in Poland as in many countries including Austria, Denmark and the USA the Helicopter Emergency Medical Service (HEMS) has been established and used to provide transport of patients with severe injuries, acute heart attacks, and burns to the suitable, specialised hospitals [9-12].

The aim of the research was to describe the characteristics of Helicopter Emergency Medical Service missions carried out for burn patients with a highlight to the target medical facility.

\section{MATERIALS AND METHODS}

The research was conducted using the method of retrospective analysis of operations performed by Helicopter Emergency Medical Services crews. All missions concerning burn patients from January 2011 to December 2018 were included in the study. Cases of cancellation, interruption of the missions as well as lack of casualties were excluded. Ultimately, 2534 cases were qualified for the final analysis. The study did not require the consent of the bioethics committee.

The research was carried out based on medical and operational documentation of Helicopter Emergency Medical Service. Under the consent of the Director of Medical Air Rescue Service. During the analysis of HEMS medical records the following data was obtained and used to complete the research: gender and age of the patients, date of intervention, clinical status parameters of patients (based on symptoms and three scales: Glasgow Coma Scale - GCS, Revised Trauma Score - RTS, National Advisory Committee for Aeronautics - NACA), medical actions undertaken during the mission and information related to the description of the HEMS mission.

Data obtained from medical records was subjected to statistical analysis using STATISTICA 13 program (StatSoft, Cracow, Poland). In the description of qualitative data the quantity (n) and percentage (\%) were used whereas

Table 1. Characteristics of the test group.

\begin{tabular}{|c|c|}
\hline \multicolumn{2}{|c|}{ Sex - n (\%) } \\
\hline Female & $691(27.28)$ \\
\hline Male & $1842(72.72)$ \\
\hline \multicolumn{2}{|c|}{ Age - n (\%) } \\
\hline$\leq 18$ years & $927(36.65)$ \\
\hline $19-34$ years & $354(14.00)$ \\
\hline $35-49$ years & $427(16.88)$ \\
\hline $50-64$ years & $482(19.26)$ \\
\hline $65-79$ years & $210(8.30)$ \\
\hline$\geq 80$ years & $124(4.90)$ \\
\hline Age (years) M (SD) & $32.80(27.03)$ \\
\hline \multicolumn{2}{|c|}{ Type of burn - n (\%) } \\
\hline Thermal & $2285(90.21)$ \\
\hline Chemical & $248(9.79)$ \\
\hline \multicolumn{2}{|c|}{ Burn location - n (\%) } \\
\hline Head and neck & $344(13.58)$ \\
\hline Trunk & $337(13.30)$ \\
\hline Limbs & $142(5.61)$ \\
\hline Airways & $97(3.83)$ \\
\hline Multiple body area & $1613(63.68)$ \\
\hline \multicolumn{2}{|c|}{ Endotracheal intubation - $\mathbf{n}(\%)$} \\
\hline Yes & $702(27.70)$ \\
\hline No & $1832(72.30)$ \\
\hline \multicolumn{2}{|c|}{ Mechanical ventilation - $\mathbf{n}(\%)$} \\
\hline Yes & $683(26.95)$ \\
\hline No & $1851(73.05)$ \\
\hline \multicolumn{2}{|c|}{ Medication - n (\%) } \\
\hline Benzodiazepines & $877(34.61)$ \\
\hline Anaesthetics & $674(26.60)$ \\
\hline Crystalloids & $1641(64.76)$ \\
\hline Opioids & $1737(68.55)$ \\
\hline Muscle relaxants & $344(13.58)$ \\
\hline GCS M (SD) & $13.24(3.86)$ \\
\hline RTS M (SD) & $11.14(2.24)$ \\
\hline NACA scale M (SD) & $4.00(1.28)$ \\
\hline
\end{tabular}


Patryk Rzońca et al.

Table 2. HEMS mission characteristics.

\begin{tabular}{|c|c|}
\hline \multicolumn{2}{|l|}{ Event location - n (\%) } \\
\hline Urban & $1266(53.02)$ \\
\hline Rural & $1122(46.98)$ \\
\hline \multicolumn{2}{|l|}{ Season - n (\%) } \\
\hline Spring & $766(30.24)$ \\
\hline Summer & $888(35.06)$ \\
\hline Autumn & $517(20.41)$ \\
\hline Winter & $362(14.29)$ \\
\hline \multicolumn{2}{|l|}{ Type of mission - $\mathbf{n}(\%)$} \\
\hline Emergency flight & $773(30.52)$ \\
\hline Inter-hospital medical transport & $1760(69.48)$ \\
\hline \multicolumn{2}{|c|}{ Transport to burn centre or burn ward - $\mathbf{n}(\%)$} \\
\hline Yes & $1568(61.88)$ \\
\hline No & $966(38.12)$ \\
\hline \multicolumn{2}{|l|}{ First on site $-\mathbf{n}(\%)$} \\
\hline Ground-based EMS & $2316(91.54)$ \\
\hline HEMS & $214(8.46)$ \\
\hline Response time (min) M(SD) & $8.68(8.36)$ \\
\hline Time to reach the place of call (min) $M(S D)$ & $19.90(9.49)$ \\
\hline Duration of action at the place of call $(\mathrm{min}) \mathrm{M}(\mathrm{SD})$ & $24.77(13.19)$ \\
\hline To hospital transport time $(\min ) \mathrm{M}(\mathrm{SD})$ & $32.71(24.94)$ \\
\hline Overall time of patient supervision $\mathrm{M}(\mathrm{SD})$ & $56.53(31.83)$ \\
\hline Distance from the place of call $(\mathrm{km}) \mathrm{M}(\mathrm{SD})$ & $55.59(33.10)$ \\
\hline Distance to hospital (km) M(SD) & $96.58(70.55)$ \\
\hline
\end{tabular}

the mean (M) and standard deviation (SD) were used to describe quantitative data. To check the normal distribution of quantitative variables the Shapiro-Wilk normality test was used. The Chi-suqre test was used to statistically assess significant differences between quantitative variables. Non-parametric U Mann-Whitney test was used to examine the differences between the two groups. The significance level was considered $\mathrm{p}<0.05$.

\section{RESULTS}

The study group was predominantly male (72.72\%). The widest age range was eighteen years or younger $(36.65 \%)$ and the average age for the whole group was 32.80 . The vast majority of patients suffered from thermal burns (90.21\%) which mostly involved multiple body regions (63.69\%). In the analysed group $27.70 \%$ of the patients required endotracheal intubation and $26.95 \%$ of them required mechanical ventilation. Opioids as well as crystalloids were the most commonly administered drugs (respectively $68.55 \%$ and $64.76 \%$ ). The mean GCS score for the whole group of patients was 13.24 points, RTS - 11.14 points while on the NACA scale patients were assigned to the $4^{\text {th }}$ category (Table 1 ).

Interventions of HEMS were most frequent in urban areas $(53.02 \%)$, in summer (35.06\%), as part of inter-hospital medical transport (69.48\%) and to provide the support to the ground-based medical rescue teams (91.54\%). Nearly two thirds of patients were transported to hospitals with burn ward (61.88\%). The average HEMS time response was 8.68 minutes (8.36). Average HEMS arrival time at the scene was 19.90 minutes (SD 9.49), with mean distance of 55.59 kilometres (SD 33.10). On-site proceedings took 24.77 minutes on average (SD 13.19) and overall time of patient supervision was 56.53 minutes (SD 31.83). Transportation to hospital lasted 32.71 minutes on average (SD 24.94) with a mean distance of 96.58 kilometres (SD 70.55) (Table 2).

The statistical analysis showed that women were significantly more frequently transported to the hospital with the burn ward (63.90\% vs. 56.58\%). Additionally, the mean age was higher in patients who were admitted to the burn ward (41.18 years $v s .19 .19$ years). The analysis shows that burn ward was more often reached by patients in the urban area (69.04\% vs. 50.00\%) and by those eligible for inter-hospital medical transfer (51.14\% vs $8.41 \%$ ) as well as when HEMS provide assistance for ground-based medical rescue teams (63.17 vs $48.13 \%)$. Patients with airways thermal injury (67.01\%) and multiple body area burns (68.82\%) were significantly more often transported to the burn ward. The analysis of the clinical status of the patients showed that those transported to burn wards were significantly more severely 
Table 3. Relationship between the place of transport, sociodemographic data, type of mission, clinical condition and treatment.

\begin{tabular}{|c|c|c|c|}
\hline Variables & Burn unit hospital & Non-Burn unit hospital & p-value \\
\hline \multicolumn{3}{|c|}{ Sex - n (\%) } & \multirow{3}{*}{0.0008} \\
\hline Female & $391(56.58)$ & $300(43.42)$ & \\
\hline Male & $1177(63.90)$ & $665(36.10)$ & \\
\hline \multicolumn{3}{|c|}{ Age - n (\%) } & \multirow{7}{*}{0.0000} \\
\hline$\leq 18$ years & $304(32.79)$ & $623(67.21)$ & \\
\hline $19-34$ years & $275(77.68)$ & $79(22.32)$ & \\
\hline $35-49$ years & $330(77.28)$ & $97(22.72)$ & \\
\hline $50-64$ years & $392(80.49)$ & $95(19.51)$ & \\
\hline $65-79$ years & $162(77.14)$ & $48(22.86)$ & \\
\hline 80 and more years & $103(83.06)$ & $21(16.94)$ & \\
\hline Age average $M(S D)$ & $41.18(24.82)$ & $19.19(24.85)$ & 0.0000 \\
\hline \multicolumn{3}{|c|}{ Event location - n (\%) } & \multirow{3}{*}{0.0000} \\
\hline Urban & $874(69.04)$ & $392(30.96)$ & \\
\hline Rural & $561(50.00)$ & $561(50.00)$ & \\
\hline \multicolumn{3}{|c|}{ Type of mission n (\%) } & \multirow{3}{*}{0.0000} \\
\hline Inter-hospital medical transport & $900(51.14)$ & $860(48.86)$ & \\
\hline Emergency flight & $65(8.41)$ & $708(91.59)$ & \\
\hline \multicolumn{3}{|c|}{ Burn location - n (\%) } & \multirow{6}{*}{0.0000} \\
\hline Head and neck & $179(52.03)$ & $165(47.97)$ & \\
\hline Trunk & $142(42.14)$ & $195(57.86)$ & \\
\hline Limbs & $72(50.70)$ & $70(49.30)$ & \\
\hline Airways & $65(67.01)$ & $32(32.99)$ & \\
\hline Multiple body area & $1110(68.82)$ & $503(31.18)$ & \\
\hline \multicolumn{3}{|c|}{ First on site $-\mathrm{n}(\%)$} & \multirow{3}{*}{0.0000} \\
\hline HEMS & $103(48.13)$ & $111(51.87)$ & \\
\hline Ground-based EMS & $1463(63.17)$ & $853(36.83)$ & \\
\hline Endotracheal intubation - n (\%) & $599(85.33)$ & $103(14.67)$ & 0.0000 \\
\hline Mechanical ventilation - $\mathrm{n}(\%)$ & $580(84.92)$ & $103(15.08)$ & 0.0000 \\
\hline \multicolumn{4}{|c|}{ Medication - n (\%) } \\
\hline Benzodiazepines & $595(67.84)$ & $282(32.16)$ & 0.0000 \\
\hline Anaesthetics & $443(65.73)$ & $231(34.27)$ & 0.0163 \\
\hline Crystalloids & $1114(67.89)$ & $527(32.11)$ & 0.0000 \\
\hline Opioids & $1132(65.17)$ & $605(34.83)$ & 0.0000 \\
\hline Muscle relaxants & $288(83.72)$ & $56(16.28)$ & 0.0000 \\
\hline GCS M (SD) & $12.73(4.30)$ & $13.99(2.90)$ & 0.0000 \\
\hline RTS M (SD) & $10.89(2.46)$ & $11.52(1.80)$ & 0.0000 \\
\hline NACA scale M (SD) & $4.21(1.22)$ & $3.67(1.29)$ & 0.0000 \\
\hline Time to reach the place of call ( $\mathrm{min}$ ) M (SD) & $20.77(10.59)$ & $18.60(7.35)$ & 0.0000 \\
\hline On-site proceedings (min) M (SD) & $26.37(13.64)$ & $22.12(11.95)$ & 0.0000 \\
\hline Duration of transport (min) M (SD) & $40.11(27.35)$ & $19.66(11.54)$ & 0.0000 \\
\hline $\begin{array}{l}\text { Overall time of patient supervision (min) } \\
\text { M (SD) }\end{array}$ & $65.70(34.85)$ & $41.55(17.98)$ & 0.0000 \\
\hline $\begin{array}{l}\text { Distance from the destination to the } \\
\text { hospital (km) M (SD) }\end{array}$ & $58.80(37.08)$ & $50.77(25.25)$ & 0.0000 \\
\hline Transport distance (km) M (SD) & $120.01(74.37)$ & $54.83(35.67)$ & 0.0000 \\
\hline
\end{tabular}


affected which is reflected in GCS (12.73 vs 13.99), RTS (10.89 vs 11.52 ) and NACA scale (4 vs 3.67$)$. In the same time these patients were more likely to require endotracheal intubation, mechanical ventilation and medication.

The analysis of the time and distance covered during missions concerning burn patients shows that the time of arrival (20.77 minutes vs 18.60 minutes), on-site proceedings (26.37 minutes vs 22.12 minutes), the time of transport to hospital (40.11 minutes vs 19.66 minutes), the distance to the place of the event ( 58.80 kilometres vs 50.77 kilometres ) as well as transport to the hospital (120.01 vs 54.83 kilometres) were significantly higher when the patient was transported to the burns department $(\mathrm{p}<0.0001)$. Detailed statistical analysis is presented in Table 3.

\section{DISCUSSION}

Ubiquitous prevalence of the problem of burns led the authors to undertake the research on the HEMS missions concerning burned patients with stressing the target medial facility. Data of our research showed that the study group was predominantly male aged eighteen years old and younger (mean age 32.80). A study by Wejnarowski et al. on the optimising the transport duration of burned patients by HEMS showed that man were the main group of patients, while the children under the age of five and the adults between the age of fifty and sixty were the most numerous groups [13]. Chrzanowska-Wąsik et al. performed an analysis of burned adults hospitalized in the Eastern Burns Treatment and Reconstructive Surgery Centre in Łęczna which shows that again were a dominant group and the average age of patients was 48.5 years [8]. Similarly the analysis by Nadolny et al. for medical emergency operations performed by Emergency Medical Rescue Teams on burned patients shows that main victims are adult men [14]. Men and adults were also the main victims of severe body burns in a study carried out by Lam et al. [15]. On the other hand, the Newberry et al. study on patients access to healthcare in India showed that women and people aged 25-34 were the dominant group of respondents [16].

Nadolny et al showed that the following drugs were successively used in burned patients: analgesics, crystalloids and sedatives. In adult patients morphine and $0.9 \%$ solution of natrium chloride was used most frequently, while in children paracetamol and morphine appeared to be most common [14]. On the other hand, the analysis of our studies shows that the burned patients received mainly opioids and crystalloids from HEMS crews.

This analysis showed that HEMS crews treated patients with multiple burns more frequently. Due to their severe clinical condition, the analysed group of patients was most often transported to centres with burn wards. Sheridan et al., who analysed the cases of burns in the USA, confirmed the legitimacy of transporting patients with severe body burns in their studies. The authors proved that delayed transport of the burned patient to the burns centre adversely affects the improvement of the outcome, which results, among other things, from prolonged transport time [17].
The retrospective analysis shows that women, patients over the age of 18, patients from rural areas and patients with multiple burns were more likely to be transported to burns wards. Furthermore, they required more frequent endotracheal intubation and mechanical ventilation. Clinical status analysis based on GCS, RTS and the NACA scale showed that patients who were transported to burns treatment centres were in a worse clinical condition. Bell et al. (2012) conducted an analysis of patients with burns transported to burn centres in Canada. He discovered that these were predominantly men whose average age was lower. The analysed group of patients required tracheal intubation and air transport more often [18].

The next part of this retrospective analysis compared the duration of the helicopter mission and the distance travelled to the place of the incident and the distance to the hospital. The time of arrival at the scene (20.77 minutes vs. 18.60 minutes), duration of transport to hospital (40.11 minutes vs. 19.66 minutes), distance to site (58.80 kilometres vs. 50.77 kilometres) and distance to hospital (120.01 kilometres vs. 54.83 kilometres) were significantly greater when the patient was transported to a burns treatment facility. Similar results were obtained by Bell et al. In his study, the time of transport to the burn centre exceeded 4 hours in $70 \%$ of the cases. His and our results confirm that HEMS missions to patients with severe burns are justifiable. This reduces both the time it takes for the patient to reach the patient and the time it takes for the patient to reach the selected hospital. This is also confirmed by studies by Moens et al. and Chen et al.. They show that both the time of reaching the burned patient and the time of transport to the hospital are shorter if they are carried out by the HEMS crew $[19,20]$.

\section{CONCLUSIONS}

Burns are a significant reason for calling the Helicopter Medical Rescue Service. Commonly they concern men and young people. Patients treated by HEMS crews most often suffer from thermal burns, affecting multiple body regions, and consequently they are transported to burns treatment centres. Our research shows that both the time and distance to a unit specialised in the treatment of burns are significantly longer. Therefore, it appears to be appropriate to call HEMS for burns, especially for those requiring treatment in a burn centre. Shortening the time of reaching the patient to hospital improves outcome of prognosis, which has been confirmed by numerous authors.

\section{REFERENCES}

1. Garcia-Espinoza JA, Aguilar-Aragon VB, Ortiz-Villalobos EH, Garcia-Manzano RA, Antonio BA. Burns: Definition, Classification, Pathophysiology and Initial Approach. Gen Med 2017;5:5. doi: 10.4172/2327-5146.1000298.

2. Peck MD. Epidemiology of burns throughout the World. Part II: intentional burns in adults. Burns. 2012; 38(5):630-7. doi: 10.1016/j. burns.2011.12.028.

3. Hettiaratchy S, Dziewulski P. $A B C$ of burns: pathophysiology and types of burns. BMJ. 2004; 328(7453):1427-1429. doi: 10.1136/ bmj.328.7453.1427. 
4. Peck MD, Kruger GE, van der Merwe AE, Godakumbura W, Ahuja RB. Burns and fires from non-electric domestic appliances in low and middle income countries Part I. The scope of the problem. Burns. 2008;34(3):303. doi: 10.1016/j.burns.2007.08.014.

5. Mock C, Peck M, Peden M et al. A WHO plan for burn prevention and care. World Health Organization 2008. https://apps.who. int/iris/bitstream/handle/10665/97852/9789241596299_eng. pdf;jsessionid=B7FA6E2874399624B57F57446DAD6CAA?sequence $=1$ (accessed on 24 February 2019).

6. Topczewska-Cabanek A, Pernach A, Nitsch-Osuch A et al. Burns as a cause of hospitalising children in one of Warsaw's hospitals in 2008-2012. Fam Med Prim Care Rev 2014;16(3):297-299.

7. Chrapusta A, Jędrys J, Budzyńska A et al. The analysis of death rate among burn victims and difficulties with interpretation of epidemiological data. Leczenie Ran 2014;11(2):79-83. doi: dx.doi.org/10.15374/LR2014010.

8. Chrzanowska-WąsikM, ChemperekE, Sokołowski D, Goniewicz M, Bednarz K, Rzońca P. Burn analysis in adult patients hospitalized in the EastCentre of Burn Treatment and Reconstructive Surgery in Łęczna.J Jdu Health Sport. 2017;7(4):410-419. doi: http://dx.doi.org/10.5281/zenod0.495655.

9. Rzońca P, Gałązowski R, Podgórski M. Role of Polish Medical Air Rescue in National Medical Rescue System. Disaster Emerg Med J 2017;2:64-68.

10. Osler M,Mårtensson S, PrescottE, Carlsen K. Impact of gender, co-morbidity and social factors on labour market affiliation after first admission for acute coronary syndrome. A cohort study of Danish patients 2001-2009. PLoS One 2014;9:e86758. doi: 10.1371/journal.pone.0086758.

11. Gunnarsson SI, Mitchell J, Busch MS, Larson B, Gharacholou SM, Li Z et al. Outcomes of Physician-Staffed Versus Non-Physician-Staffed Helicopter Transport for ST-Elevation Myocardial Infarction. J Am Heart Assoc. 2017;6:e004936. doi: 10.1161/JAHA.116.004936.

12. Řsterís Ǩ, Heltne JK, Vikenes BC, Assmus J, Brattebř G. Factors influencing on-scene time in a rural Norwegian helicopter emergency medical service: a retrospective observational study. Scand J Trauma Resusc Emerg Med. 2017;25:97. doi: 10.1186/s13049-017-0442-5.
13. Wejnarski A, Podgórski M, Kamecki A, Świeżewski SP. Rola Lotniczego Pogotowia Ratunkowego w optymalizacji czasu transportu pacjentów oparzonych. [The role of the Polish Medical Air Rescue in optimization of transport time of patients with burns]. Anest Rat 2016;10:34-45.

14. Nadolny K, Ładny JR, Ślęzak D, Komza M, Gałązkowski R. Analiza medycznych czynności ratunkowych wykonywanych przez zespoły ratownictwa medycznego z całej Polski u pacjentów z ranami oparzeniowymi. [Analysis of medical rescue operations performed by medical rescue teams from all over Poland in patients with burn wounds]. Wiad Lek. 2019;72(1):26-30.

15. Lam NN, Huong HTX, Tuan CA. Mass burn injuries: an analysis of characteristics and outcomes in a developing country. Ann Burns Fire Disasters. 2017;30(3):210-213.

16. Newberry JA, Bills CB, Pirrotta EA et al. Emerg Med J 2019;36:176-182. doi:10.1136/emermed-2018-207900.

17. Sheridan R, Weber J, Prelack K et al. Early burn center transfer shortens the length of hospitalization and reduces complications in children with serious burn injuries. J Burn Care Rehabil 1999;20:347-50.

18. Bell N, Simons R, Hameed SM, Schuurman N, Wheeler S. Does direct transport to provincial burn centres improve outcomes? A spatial epidemiology of severe burn injury in British Columbia, 2001-2006. Can J Surg. 2012;55(2):110-116. doi: 10.1503/cjs.014708.

19. Moens D, Stipulante S, Donneau AF, Hartstein G, Pirotte O, D'orio V et al. Air versus ground transport of patients with acute myocardial infarction: experience in a rural-based helicopter medical service. Eur J Emerg Med. 2015; 22(4): 273-8.

20. Chen X, Gestring ML, Rosengart MR, Peitzman AB, Billiar TR, Sperry JL, et al. Logistics of air medical transport:When and where does helicopter transport reduce prehospital time for trauma? J Trauma Acute Care Surg. 2018;85(1):174-181.

\section{Conflict of interest:}

The Authors declare no conflict of interest.

\section{CORRESPONDIG AUTHOR Patryk Rzońca}

Department of Emergency Medicine, Faculty of Health Sciences, Medical University of Lublin, 4-6 Staszica St., 20-081 Lublin, Poland e-mail: patryk.rzonca@gmail.com

Received: 20.02 .2019

Accepted: 15.03 .2019 


\section{KONSULTANCI KRAJOWI W DZIEDZINACH KARDIOLOGII I MEDYCYNY RATUNKOWEJ PODPISALI LIST INTENCYJNY W ZAKRESIE WSPÓŁPRACY I PRZEKAZALI GO MINISTROWI ZDROWIA}

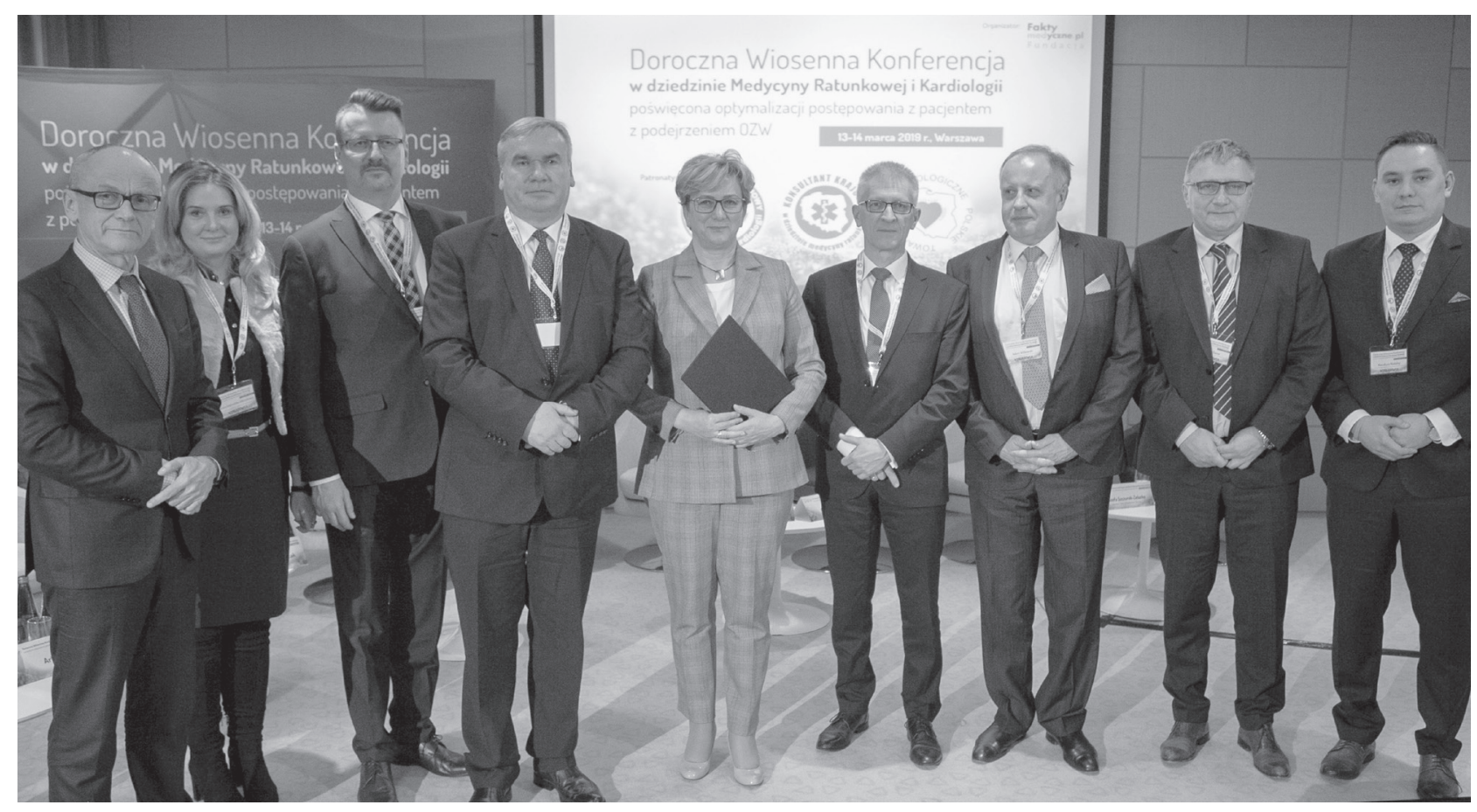

Podczas dorocznej Wiosennej Konferencji w dziedzinie Medycyny Ratunkowej i Kardiologii, która odbyła się w dniach 13-14 marca w Warszawie, konsultanci krajowi w dziedzinach kardiologii i medycyny ratunkowej podpisali list intencyjny w zakresie współpracy obydwu środowisk i przekazali go Ministrowi Zdrowia. Celem inicjatywy jest optymalizacja postępowania z pacjentami ze schorzeniami kardiologicznymi, w tym w podejrzeniu Ostrego Zespołu Wieńcowego, na który zapada rocznie nawet 130 tysięcy pacjentów.

- Pacjenci z problemami kardiologicznymi są dziś w znacznej mierze leczeni zgodnie z aktualną wiedzą medyczną, ale poprawy i doskonalenia wymaga współpraca środowisk: medycyny ratunkowej i kardiologii między innymi w zakresie zapewnienia pacjentom z podejrzeniem Ostrego Zespołu Wieńcowego odpowiedniej opieki przedszpitalnej i jak najszybszego przekazania chorych pod opiekę właściwego szpitala - mówi prof. Piotr Ponikowski, prezes Polskiego Towarzystwa Kardiologicznego.

Jak podkreślali eksperci Wiosennej Konferencji w dziedzinie Medycyny Ratunkowej i Kardiologii, ostry zespół wieńcowy to obszar, który mimo opieki i terapii na najwyższym światowym poziomie, trzeba i warto doskonalić.

- Polski system leczenia Ostrych Zespołów Wieńcowych w ostrej fazie znajduje się w światowej czołówce. Obecnie w Polsce jest 156 ośrodków kardiologicznych, podejmujących leczenie interwencyjne OZW. Leczenie za pomocą zabiegów przezskórnej interwencji wieńcowej (PCI), podejmowane w zawałach STEMI ( z uniesieniem odcinka ST), osiągnęło poziom 93\%. To wynik bardzo zadowalający. Mimo wspaniałych wskaźników dotyczących leczenia interwencyjnego OZW, poprawy wymaga rokowanie odległe pacjentów z OZW związane ze stosowaniem odpowiedniej terapii (między innymi leczenia przeciwpłytkowego i terapii hipolipemizującej) po wyjściu pacjenta ze szpitala w ciągu tygodni, miesięcy i lat po przebytym zawale serca, a optymalizacji - etap opieki przedszpitalnej i skrócenie czasu przekazania pacjenta do pracowni hemodynamicznej - mówi prof. Jarosław Kaźmierczak, konsultant krajowy w dziedzinie kardiologii. Odnośnie do pierwszego etapu postępowania w podejrzeniu OZW zgromadzeni na konferencji konsultanci krajowi i wojewódzcy w dziedzinie medycyny ratunkowej i kardiologii zdefiniowali wspólne stanowisko w kierunku wdrożenia postępowania dyspozytorów medycznych i zespołów ratownictwa medycznego wobec pacjentów ze schorzeniami kardiologicznymi. List intencyjny w zakresie nawiązania i zacieśnienia współpracy pomiędzy środowiskiem medycyny ratunkowej i środowiskiem kardiologicznym w Polsce podpisali: prof. Jarosław Kaźmierczak, konsultant krajowy w dziedzinie kardiologii, prof. Jerzy Robert Ładny, konsultant krajowy z dziedzinie medycyny ratunkowej oraz prof. Piotr Ponikowski, prezes Polskiego Towarzystwa Kardiologicznego. Dokument został przekazany Ministrowi Zdrowia.

- Jesteśmy przekonani, że nasza międzyśrodowiskowa inicjatywa idealnie wpisuje się w ministerialny projekt Dobrych Praktyk - rekomendacji postępowania zespołów ratownictwa medycznego, sygnowany przez konsultantów krajowych w dziedzinach medycyny ratunkowej i kardiologii. Jako konsultanci krajowi przy wsparciu i za pośrednictwem konsultantów wojewódzkich dołożymy wszelkich starań, aby Dobre Praktyki były jak najszerzej rozpropagowane wśród personelu medycznego oraz realizowane w jak największym zakresie. Na praktyczne rozwiązania oczekują pacjenci wymagający specjalistycznej interdyscyplinarnej pomocy a także zespoły terapeutyczne podejmujące optymalne decyzje w codziennej pracy - mówi prof. Jerzy Robert Ładny, konsultant krajowy w dziedzinie medycyny ratunkowej. 